\title{
MASTER
}

EXTERNAL TRANSMITTAL AUTHORIZED

ORNL

Central Files Number

$60-7 \cdot 65$

\section{ENGINEERING EVALUATION OF}

\section{VOLATILITY PILOT PLANT EQUIPMENT}

F. W. Miles

W. H. Corr

\section{NOTICE}

This doctunent cantains information al a proliminary nature and was prapored primarily lor iniernat ase of the Oak Ridgo Notional Laberotory. It is subject to revision or correction and therefore does nat reprtatent a final report. The information is not to be abstracted, reprinted or otherwise given public disemination withoul the approval af the ORNL patent brench, Legal and Intormation Contral Departmemt.

OAK RIDGE NATIONAL LABORATORY

$$
\text { operated by }
$$

UNION CARBIDE CORPORATION

for tho

\section{U. S. ATOMIC ENERGY COMMISSION}




\section{DISCLAIMER}

This report was prepared as an account of work sponsored by an agency of the United States Government. Neither the United States Government nor any agency Thereot, nor any of their employees, makes any warranty, express or implied, or assumes any legal liability or responsibility for the accuracy, completeness, or usefulness of any information, apparatus, product, or process disclosed, or represents that its use would not infringe privately owned rights. Reference herein to any specific commercial product, process, or service by trade name, trademark, manufacturer, or otherwise does not necessarily constitute or imply its endorsement, recommendation, or favoring by the United States Government or any agency thereof. The views and opinions of authors expressed herein do not necessarlly state or reflect those of the United States Government or any agency thereof. 


\section{DISCLAIMER}

Portions of this document may be illegible in electronic image products. Images are produced from the best available original document. 


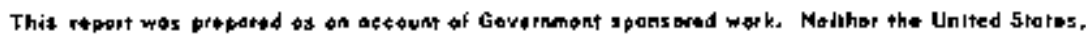

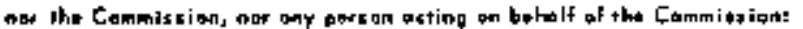

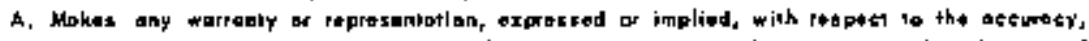

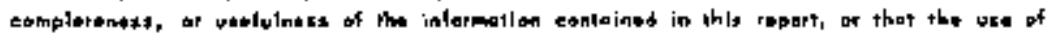

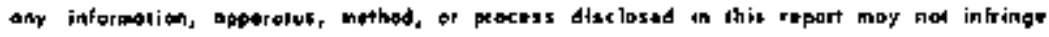
priyelely awned' raghte; or

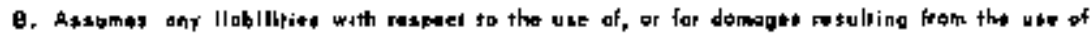

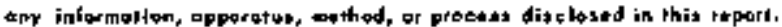

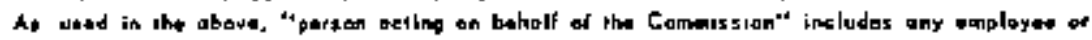

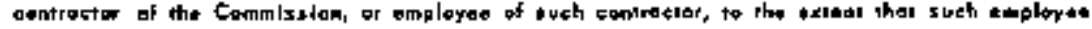

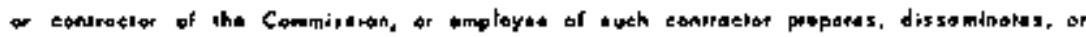

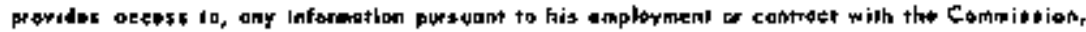
or kit implayment with weh aentrostar. 
Fxtemal Transmittal Authorized

ORHL-CF-60-7-65

CAEMICAL TECENOLOCY DIVISION

EIFOTREGRING BVAUUATIOW OF VOLATILITY PILOT PLAFT EQUIPMBNT

F. W. MHles and W. H. Carr

DATE ISSUED

SEP $501960^{\circ}$

OAK RIDGE NATTONAL IABORATORY

Oak RIdge, Tennessee

Operated by

UNTON CARBIDE CORPORATIOK

for the

U. S. ATOHIC BHEETY COMASSION 


\section{ABSTRACT}

The ORIL Volatility PIlot Plant engineering experience and operating techniques are compiled for reference. Different systems within the plent are presented separately. For each systen, equ1pment and operating details, evaluations, and recomendations are given. The report covers all operations up to Auguat, 1958. 
1.0 Summary $\ldots \ldots \ldots \ldots \ldots \ldots \ldots \ldots \ldots \ldots \ldots \ldots \ldots \ldots \ldots \ldots \ldots \ldots \ldots \ldots \ldots \ldots$

2.0 Introduction $\ldots \ldots \ldots \ldots \ldots \ldots \ldots \ldots \ldots \ldots \ldots \ldots \ldots \ldots \ldots \ldots \ldots \ldots \ldots$

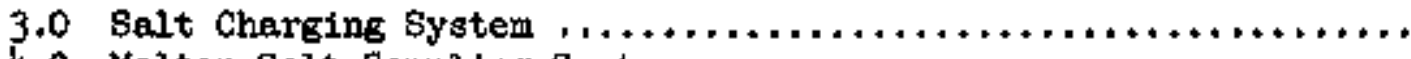

4 .0 Nolten Salt Sampling Syster $\ldots \ldots \ldots \ldots \ldots \ldots \ldots \ldots \ldots \ldots \ldots \ldots \ldots$

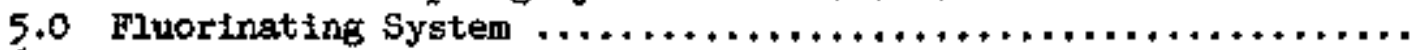

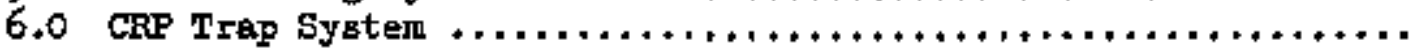

7.0 Heated Duct System $\ldots \ldots \ldots \ldots \ldots \ldots \ldots \ldots \ldots \ldots \ldots \ldots \ldots \ldots \ldots \ldots \ldots$

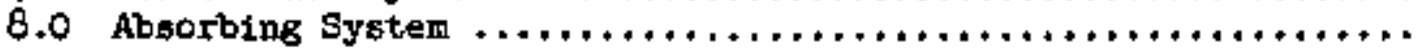

9.0 Cold Trapping system $\ldots \ldots \ldots \ldots \ldots \ldots \ldots \ldots \ldots \ldots \ldots \ldots \ldots \ldots \ldots \ldots$

10.0 Product collectling System $\ldots \ldots \ldots \ldots \ldots \ldots \ldots \ldots \ldots \ldots \ldots \ldots \ldots \ldots$

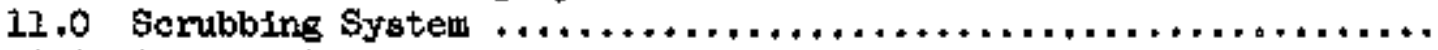

12.0 Product Samplins System $\ldots \ldots \ldots \ldots \ldots \ldots \ldots \ldots \ldots \ldots \ldots \ldots \ldots \ldots \ldots \ldots \ldots$

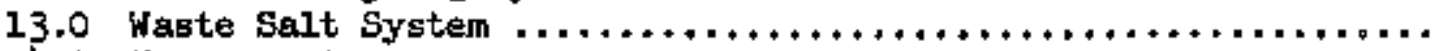

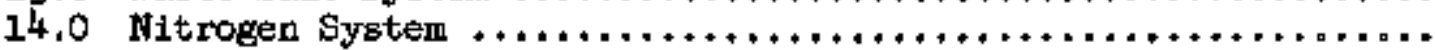

15.0 Fluorine System $\ldots \ldots \ldots \ldots \ldots \ldots \ldots \ldots \ldots \ldots \ldots \ldots \ldots \ldots \ldots \ldots \ldots \ldots \ldots$

16.0 ARE Charging System $\ldots \ldots \ldots \ldots \ldots \ldots \ldots \ldots \ldots \ldots \ldots \ldots \ldots \ldots \ldots \ldots$

Valves

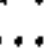

18.0

Flange Leak-Detecting arsten

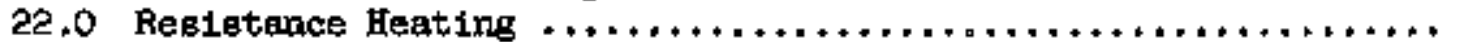

23.0 Radiation Safety Including Criticelity ................ 
3.1 List of Sslt charging System Componenta...............

4.1 List of Molten Salt Sampling System Components $\ldots \ldots \ldots \ldots \ldots \ldots \ldots$

5.1 List of Fuorinating System Componenta.................

5.2 Interlocks Affecting Fluorinetion and/or Fluorine Fior, .....

6.1 List of GRP prap System Components...................

7.1 List of Heated Duct System Components..................

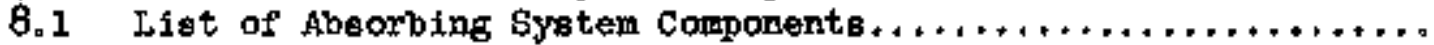

9.1 List of Cold Trapping System Componenta.................

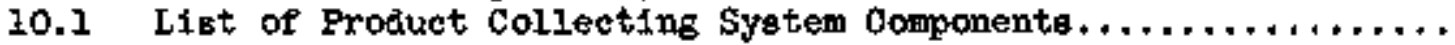

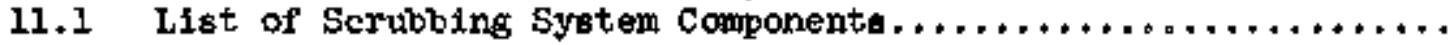

12.1 List of Produet Sempling System Components...............

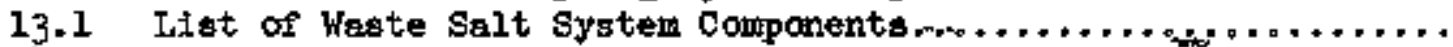

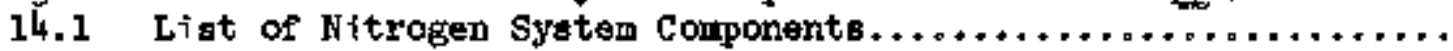

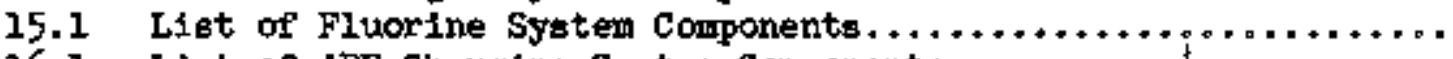

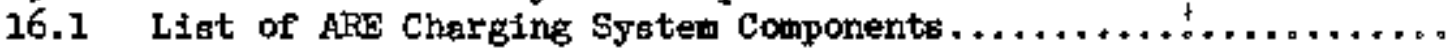

17.1 Manually Opereted Valves Used In VPP Process Work...........

17.2 Flow Rate through 1/2-in. and 1-in. HCV 's with a 1/2-pst Pres-

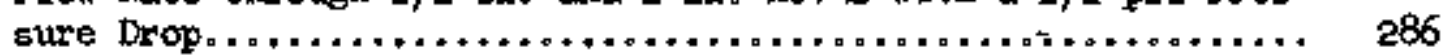

17.3 Endurance Tests of Unconditioned Kel-F Disks at Room Temperature 293

17. 4 Endurance Tests of Unconditioned Kel-F Disks at Normal Heated Duct Temperatures.....................................

17.5 Endurance Teat of Preconditioned Kel-F Disks at Normel Hested Duct Tenperature ....................................

17.6 Self-Heailng Lata at Room Tempereture on Leaking HCV'B Fitted

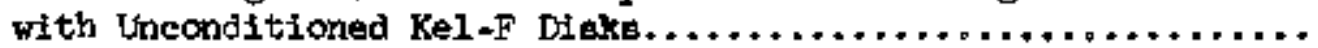

17.7 Remotely Operated Control Valve Data and Required Operational Attention........................................ 304

17.8 Pertjnent Date for Fressure Reducing Valves UBed in the VPF Sitrogen Syatem.................................... 310

17.9 Reconmended Valves for Various Service Conditioni in the VPP.

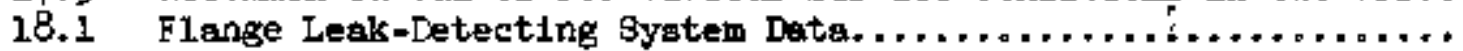

21.1 Date for Autoresistunce-Heeted Molten Salt Lines.............

22.1 Veasel or Pipe not in Contact with Heater: Operiating Tempera-

ture $=400-6500 . . \ldots \ldots \ldots \ldots \ldots \ldots \ldots \ldots \ldots \ldots \ldots \ldots \ldots \ldots \ldots$
Veseel or Pipe In Contact with Heater: Opereting Temperature

22.2 Vesel or Pipe in Contact with Heater: Operating Temperature

22. 3 Veseel or Pipe in Contact with Heater: Operating Temperature

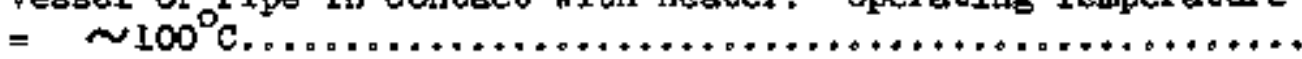

23.1 Radioactively Hazardous Operations in the VPP.............

23.2 List of Equipment and Moans for Detecting Radiation.........

23.3 Protective Devices, Decontamination, and Waste Diaposal In-

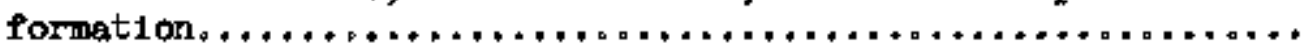


2.1 Flowsheet for ORdL Fluoride Volatility Płlot Plant, ORNL-LR- DNg.

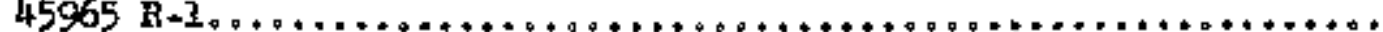

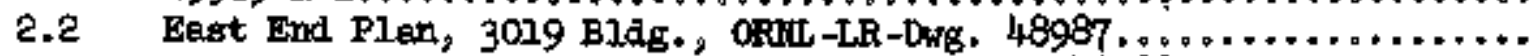

2.3 Typicel Sect1 on, 3019 Bldg., ORtL-LR - Dwg. 48988..............

3.1 Equipment Arrengement for Salt Charging System................

"Cold" Balt Charge Can...... ................................

4.1

Equipment Arrangement of Molten Balt Bampling System. . .........

5.1

Equipment Arrangement in the Fltorinating Syatem (Mark I FV-100),

5.2

Arrangement of HCV -7 , ECV -8 and Related Fluorinator end Fluorine

6.1

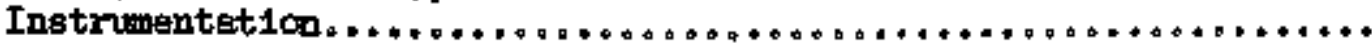

6.2

6.3

Equipwent Arrengewent in the CRP Trap System..................

7.1

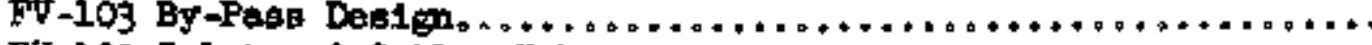

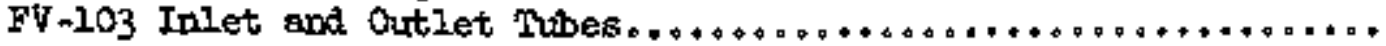

squipinent Arrangement in the Heated Duct System, ORiL-IR-Drg.

8.1 5004 .

9.1

Equiposnt Arrangement in the Absorbing system $\ldots \ldots \ldots \ldots \ldots \ldots \ldots$

9.2

Bquip.ment Axrangement in the Cold Trapping Byaten............

Batch-Type UF 6 Detector, FV-123........................

Equipment Arrangement in the Product Collecting syatem. .........

10.1

II.1

Equipment Arrangement in the Serubbing System................

II. 2

11.3

11.4

11.5

Dupl

Schematic Diegrem of Mark II PCV $-39 . \ldots \ldots \ldots \ldots \ldots \ldots \ldots \ldots \ldots \ldots \ldots \ldots \ldots$

Ends of Comecting Rod for Noyno Pung after is 7,000-hr Service

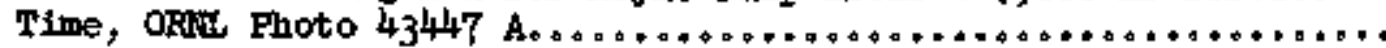

11.6

Comparisons of Hew and Used Moyno Pump Parts: Rotor-End and

Corresponding Pin of comnecting Rods, ORiL Photo 48455 A.........

12.1

12.2

12.3

12.4

Fquipment Arrangement in the Protuct Bempling System (K-25 sampler)

Equipqent Arrangement in the Product Bampling Syetem (Minisampler)

Vies of Minisampler as Used in cell e, ofuL Photo 44993 A........

Close-Up Vlew of Mnisanpler Nanifold Connected to a Froiuct

Cylinder, ORRL Photo 43438 A....

12.5

13.1

13.2

$13 \cdot 3$

$13.4 \mathrm{~A}$

$13.4 \mathrm{~B}$

13.5

13.6

14.1

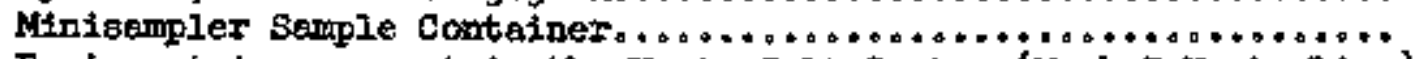

Equipment Arrangement in the Waste Balt System (Mark I Waste Line)

Equipment Arrangement in the Waste salt system (vark II Waste Line) Mark II IStrogen Supplies to Waste Freeze Valve (FV-106) Vent Iines Mark I Waste Hozzle and Heater.

Wark II Waste Nozzle and Heater.

$\mathrm{Al}_{3} \mathrm{O}$, Trap (FV-127)。

Before-end After-the-Incident V1ers of the Weste Carrier Door

Becuring Device.......... o. ..........................

14.2

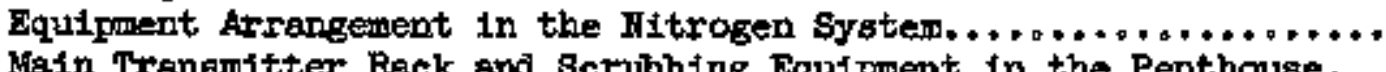

Main Tranemitter Rack and Scrubbing Equipment in the Penthouse, OFIL Photo 45045 A 
15.1 Equipent Arrangement in the Fluorine system...............

15.2 Fluo:ine Tank Trallers Showins Manifold Valves, Ofoll Photo 18063 A.

15.3 Fluorine Tank Trailer, FV-161, Gas Mentfold Showlng High $F_{2}$ Flow

15.4 Shut - off Bquipment, ofirL Photo 44869 A.....................

Schenlet1c Dlagram for $\mathrm{N}_{2}=\mathrm{F}_{2}$ Interlock..................

Equipment Arrangement if the ${ }^{2}$ ARE Charging system............... Comparison Between Original and Altered Component Arrangements in the ARE Cherging Syoten. ............................. AFE Dump Tank, Fv-110,0kRL Photo 15043 A.................... AFS Dump Tenk Being Lowered into the Retort and Fuxnace, ORnL Photo

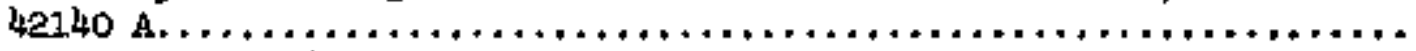
ARE Drmp Tank-Retart-Furnace Assembly. . . . . . . . . . . . . . . . Placement of $\mathrm{FV}-515,-515 \mathrm{~A}$, and $-115 \ldots \ldots \ldots \ldots \ldots \ldots \ldots \ldots \ldots$ Detals of Fv-104 Vent Line and Heaters Placement.............. Fent Line Heaters for SV-10k and Other ARE Bquipment in Cell 1, oful Photo 43448 Cross-Section of $1 / 2-1$. Hemote-Operated Palve (HCV) and a $1-i n$. HCV Disagrembled, OFNL Photo $50913 \ldots \ldots \ldots \ldots \ldots \ldots \ldots \ldots \ldots \ldots \ldots \ldots \ldots$ HCV Disks, ORHL Photo 43441 A Eefect of Preheating Conditions on the Reaction of Kel-F Disks with

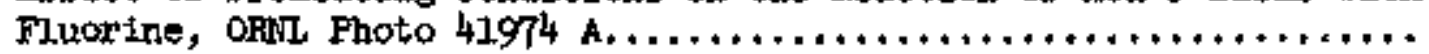
Four Freeze Velve Designs with Approximate Reglons of Sealing.... Equipment Arrangement in the Flange ieak-Detecting syoter......... Detalis for Incorporating the First Flange in ine H-103-1 into the Flange Leak-1)tecting system...........................

20,1 Portion of VPP Equipment Bged in Systen Leak-Detecting. . .........

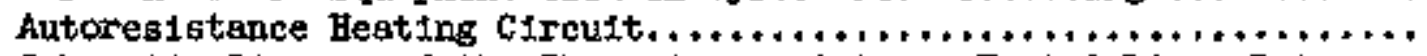
Schemat1c Diagram of the Three Autoresistance-Heated Iines Between

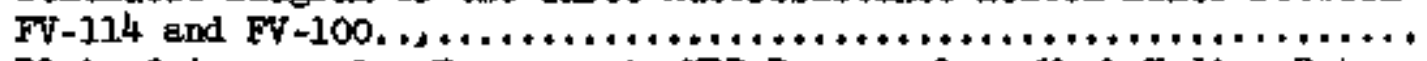
Plot 


\section{$-1-$ \\ 2.0 SUMARY}

The Oak Ridge fiationel Laboratory Voletility Pilot Plant was operated from 1956 to 1958 studying the decontamination and recovery of uranium from molten salt reactor fuels. Engineering experience and operating techniques developed during this period of operations are compiled to serve as a reference source.

The salt charging system (a charge melt vessel, heated by an electric fumace, and associated equipment) was used to trangfer fuel from small shipping cans into the fluorinator. The princlpel difficulty encountered was plugging due to inadequate heating.

Molten salt in the fluorinator was sampled with ladles. Even though many modifications were made, the sampling system was never entireis satisfactory: sempling itself was difficult; removal of the sample from the ladie was a problem; dissolution of the sample was difficult; and the samples were not always truly representative of the entire melt.

In the fluorinating system (an I-nlckel vessel, electric firnace, and auxiliaries such $\mathrm{as}_{\mathrm{s}}$ instrmentation), uranium was fluorineted to $\mathrm{UF}_{6}$ and separated from non-volatile fission products and the salt mixture witch constituted the bulk of the fuel. Numerous operational diffieulties (such as plugglng) were encountered, but most of these were, or could be, allevsated by relatively minor design changes and/or revised cperating methods. Even though there were shortcomings in the detajled design of the syrtem, the basic design was satissactory.

The Complextble Radioactive Products (CRP) trap was designed to, remove sone of the contaminants (stich as zirconium, niobium, and chromsum fluorides) from the $\mathrm{UF}_{6}$ stream leaving the fluorinator. The last design used (a bed of NaF pelleta et $400 \mathrm{c}$ ) worked vell except that the necessary uniform temperature was hard to obtain and the problem of rewoval and disposition of the contaminated pelleta had not been solved.

All UF 6 plping was encloged in a heated duct to prevent UF 6 condensation and to contain esceping $U_{6}$ in the event of a leak. In spite of nonuniform temperature distribution, 8 peration of the aystem was satisfactory.

An absorption system utilizing $\mathrm{KaF}$ pellets (absorptiog of UF 6 and fisaion products at $\sim 100^{\circ} \mathrm{C}$ followed by desorption of $\mathrm{WF}_{6}$ at $\geq 390^{\circ} \mathrm{C}$ ) wes used for final decontemination of the $\mathrm{UF}_{6}$ streem. The system was generally satisfactory for the program in which it was used, but the long heating and cooling times required and the difficulty of handling contaminated NaF would necessitate redesign of the equipwent for more efficient scheduling and/or processing of higher activity fuels.

Decontaminated $\mathrm{UF}_{6}$ was condensed in the cold trapping ayatem. This system included two cold trapg in series ( $-40^{\circ}$ and $-55^{\circ} \mathrm{C}$ ) and a chemical trap (HaF at room temperature) to ensure against loss of the UF $6^{*}$. The cold traps had bulltin heaters for product transfer. In spite of the inability to reach the design temperature of $-6 \mathrm{e}^{\circ} \mathrm{C}$ in the second cold trap and of occasional Freon vepor iocks caused by heating the traps, operation of the systen wes eatisfactory. 
Product UF wes collected by evacuating inerts from the cold traps, heating the cold treps to liquefy the IF $_{6}$, and transferring the product to a 5-in. shipplng cyllnder. The operation required about twelve hours, and the portion of product which hed to be recondensed in the cold traps and held until the next run was extremely erratic; other than this, the system vas satisfactory.

In the scrubbing system, excess fluorine in the off-gas atream was neutralized witb $\mathrm{KOH}$ solution in a spray tower before the inert geses were discharged through the building off-gas header to the ateck. The only algniffcent diff1culty encountered was occosional plusging of the gas inlet line, believed to have been caused by eveporation of KOH-KF solution adhering to the gas Inlet pipe.

Product tF $_{6}$ was aempled by melting the content; of a shipping cylinder and draining a portion Into ample tube (or tubes) wounted on a special apparatue. The necessary sanples were obtained, but the operational difficulties in obtaining a sample and the alr activity resulting from the sempling made the systen barely adequate rather than truly aatisfactory.

After completion of fluorination, the salt remaining in the fluorinator was disposed of through the waste salt system. Waste salt wes transferred by pressure through a transfer line into a disposable waste can, where It froze. Th1s can, In its shielded carrier, was transported to the buriel ground for permanent buriel. Difflculties were encountered whth plugs in the trenafer line (primarily at the fluorinator, in the freeze valve vents, and at the exit nozzle) and with salt splatter from the spece between the exit nozzle and the waste can, but operations were improved by modiflcations. The system was satisfactory for the activity levels involved, but would be Inedequate for high activity levels.

Nitrogen was used as the inert gas, and fluorine vas the fluorinating agent. The aupply systems for these two gases incomporated several special feetures, such as a dryer in the $H_{2}$ system, and $H F t_{x a p}$ in the $F_{p}$ systers, and extensive instrumentation. In prifr work with fused salt fuels, helium had been specteled as an inert gas; however, no difficulties were encountered with nitrogen. With proper materials, equipment, and operating techniques, both gas syatems could be operated with no major difficulties.

The ARE system was designed speciflcally for removing the Aircraft Reactor Experiment fuel from its dump tank, transferxing it in a single batch to a hold tank, and then transferxing the fuel in $s 1 x$ batches to the fluorinator. It was necessary to maintain fuel in the hold tank in a molten state for about half a year. There were no mafor diffleulties with this systerr.

Valves used in gas Iines were commerciel untts; those used in molten Balt lines were line plugs formed by freeztng a reservolr of selt. An extensive development program was necessary to improve some valve destghs to the point where they met operating requirements. For future program, the air operated on-off valves should be completely redeaigned; all other types of valves (both commerciel and "freeze" valves) were satisfactory. 
A flange leak-detecting system, basically a pressure-monitored nitrogen buffer at the ring joint, was 1nstalled on some of the flanges. This system identified leaking flanges and ensured that any leakage was njtrogen rather than direct leakage between the prosess and atmosphere. The system worked very well and, in the future, will be extended to all other critical flanges.

All joints (except the above flanges) were tested by fluorine pressure with KI-starch to indicate leaking fluorine. After repalr of all leaks dibcovered by this method, the over-all system was tested by pressure drop. This test showed that the leakage was no greater than $0.035 \% / \mathrm{min}$ at $20 \mathrm{psig}$, and was probably much less.

All heating in VPP was electrical. Autoresistance heating was used for molten salt trangfer lines. For this, low-voltage $(\sim 7 v)$ high-amperage $(\sim 435$ amp) power is put directly on the pipe itself; the electrical resistance of the pipe results in the pipe serving as heeting elewent. The only major difficulty wos in attaining uniform temperature distribution. All heating requirements other than for molten salt lines were met by conventional resistance heaters elther as commercial heaters or furnaces or as commercial heating elements locally formed into heaters. All electrical heating was quite dependable and satisfactory.

Radistion safety required continuous vigilance. The most gerious problem encountered was air borne $\alpha$ contamination, which perialically necessitated the use of masks. The highest average exposure reported for any week was less than $50 \mathrm{mrem} / \mathrm{man}$, and there were no over exposures. 


\subsection{INTROCACHIOA}

The Oas Ridge Nationsl Laboratory Volatility Pilot Plant was constracted in 1955 and 1956 (1) to aid in developing the Fluoride Volatility Process (2) and to decontaminete and recover the uranium in the Aircraft Reactor Experinent (ARE) (3) fuel. The pilot plant waa operated intermittently from 1956 to 1958. The resulta obtained during this pertod of operation have been reported from a process standpoint $(\underline{4}, 2,6)$. Corrosion experience 1 ts the subject of a separate report (7). These reports sumarize all date which are pertinent from either a process or a corrosion atsondpoint, and thus present soure equipment performance and engineering data. however, there is no previous publication reporting the engineering experience in any complete form.

This report is a compiletion of all aveilable engineering experience gained in operating the ORNL Volatility Pllot Plant, Data have been extracted from topical reports, status and progress reports, log booke, unrecorded observations of operating personnel, etc. It is intended primar $11 y$ as an equipinent reference Bource.

In formst, the equipment is divided into twenty-one logical systems. The eleven sections from the salt charging system (Bection 3) through the waste system (Section 13) parallel the flow of material through the plant. Subsequent sections cover service and special equipment such as the Hitrogen Systers (Section 14) and Rediation Sefety Incliding Criticality (Section 23). For each system a table of contenta is presented, deteils of the equipment pleces are recorded in a table, and the operating procedure is given along with oritical operating steps. Hext, each component is thoroughly evaluated with pertinent crosinreferencing in the equipment table. Then the equipment evaluation if bummarized, conclusions are dram, and recommendations are recorded. And fingliy, essentlal appendices are included.

It is expected that this report will be the initial reference in any search for engineering experience on all operationg to date in the Volatility Pilot Plant, that at leset ninety per cent of such aearches ean be completed with no additional reference needed, and that references will be given for all others.

Basically, the OHW Fluoride Volatility Procesa Involves contacting a uranium-bearing molten solt fuel vith elemental fluorine, further deconteminating the evolved TF $_{6}$ by an absorption-desorption cycle in godium flucride, and cold-trapplng and Fecorering the UF ${ }_{6}$. Through all runs, the usual batch weighed $\sim 150 \mathrm{~kg}$, hed a volume of $\sim 52$ liters, and contained $\sim 10 \mathrm{~kg}$ of uranium. A flowsheet of the process is shown in Fig. 2.1,

The GRil Volatility Pilot Plant is located in Cells 1 and 2 of Building 3019 and in adjacent areas. The physical layout 1s shom in Figs. 2.2 and 2.3. Buslding 3019 was originally constructed for the blesith phosphate process for

For simplicity, trade names are used for equipwent pleses where these are better knom than the generic terms. Bxamples are: (a) Varing or Pcrerstat instead of autotransformer and (b) Pyrovane or theeleo zather than tempexature controller. The equipment numbering system is delineated elsewhere. $(B, 9)$. 


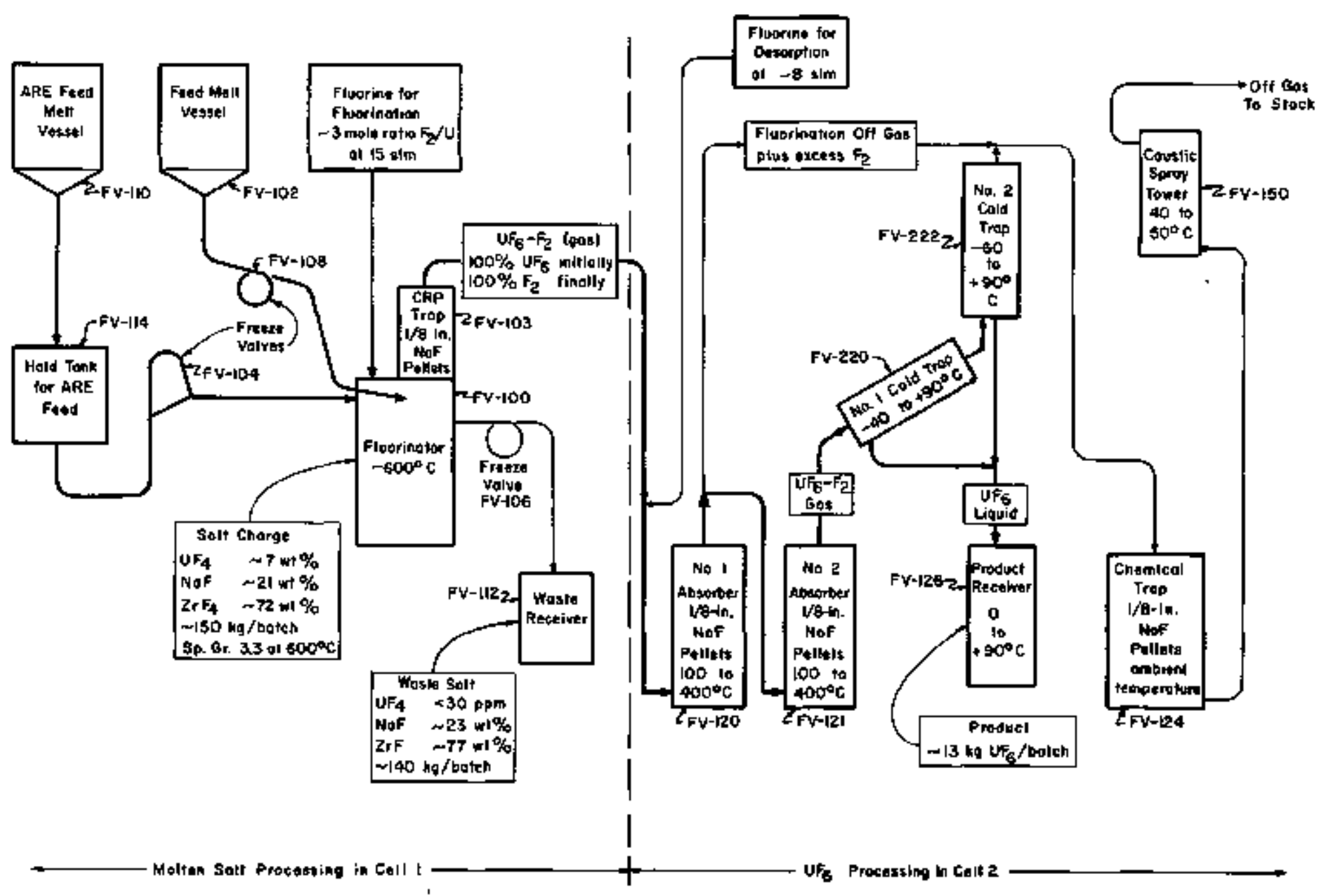

Fig. 2.1. Flowsheet for ORNL Fluoride Volatility Pilat Plant. 


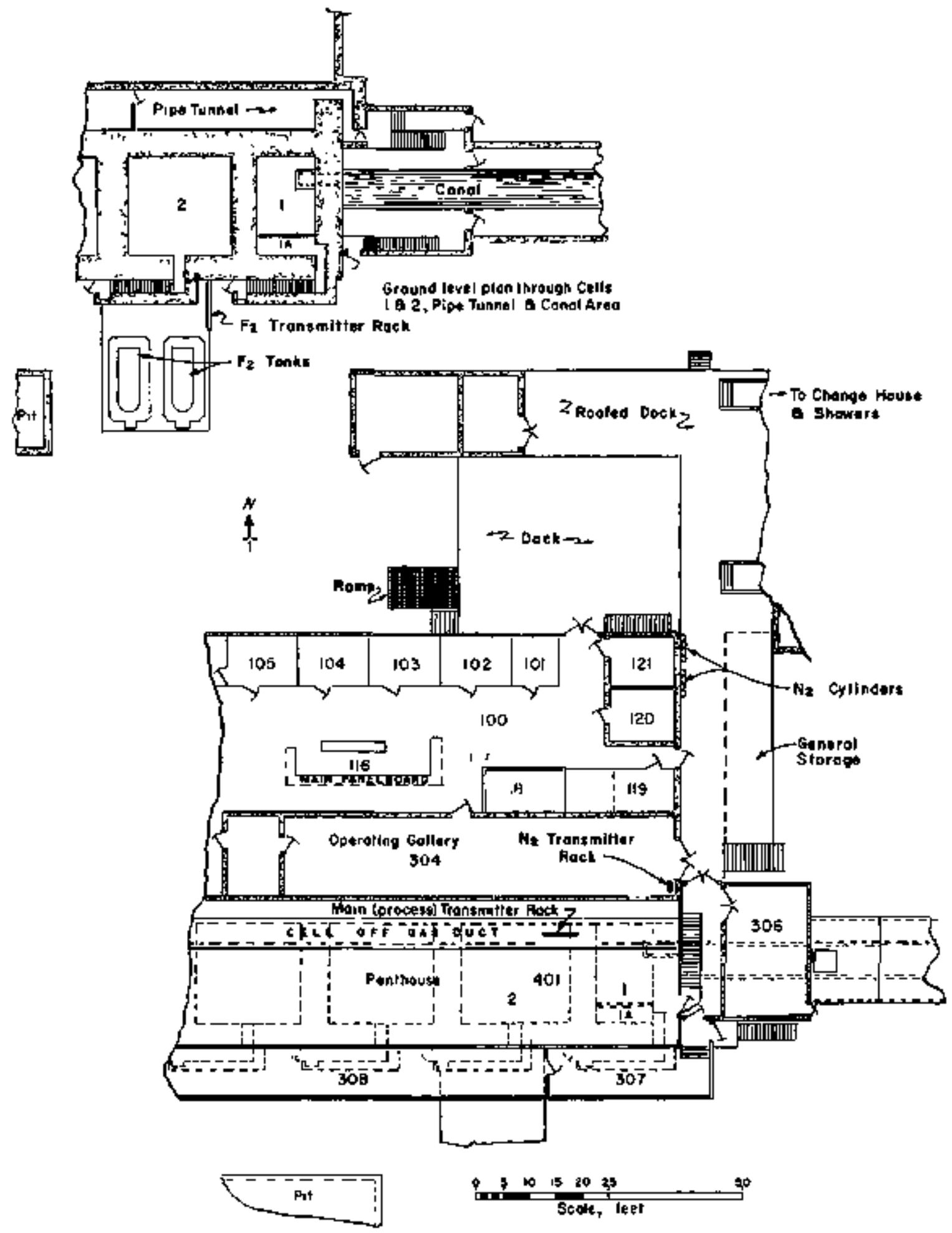

Fig. 2.2. East End Plan, 30l9 Bidg. 


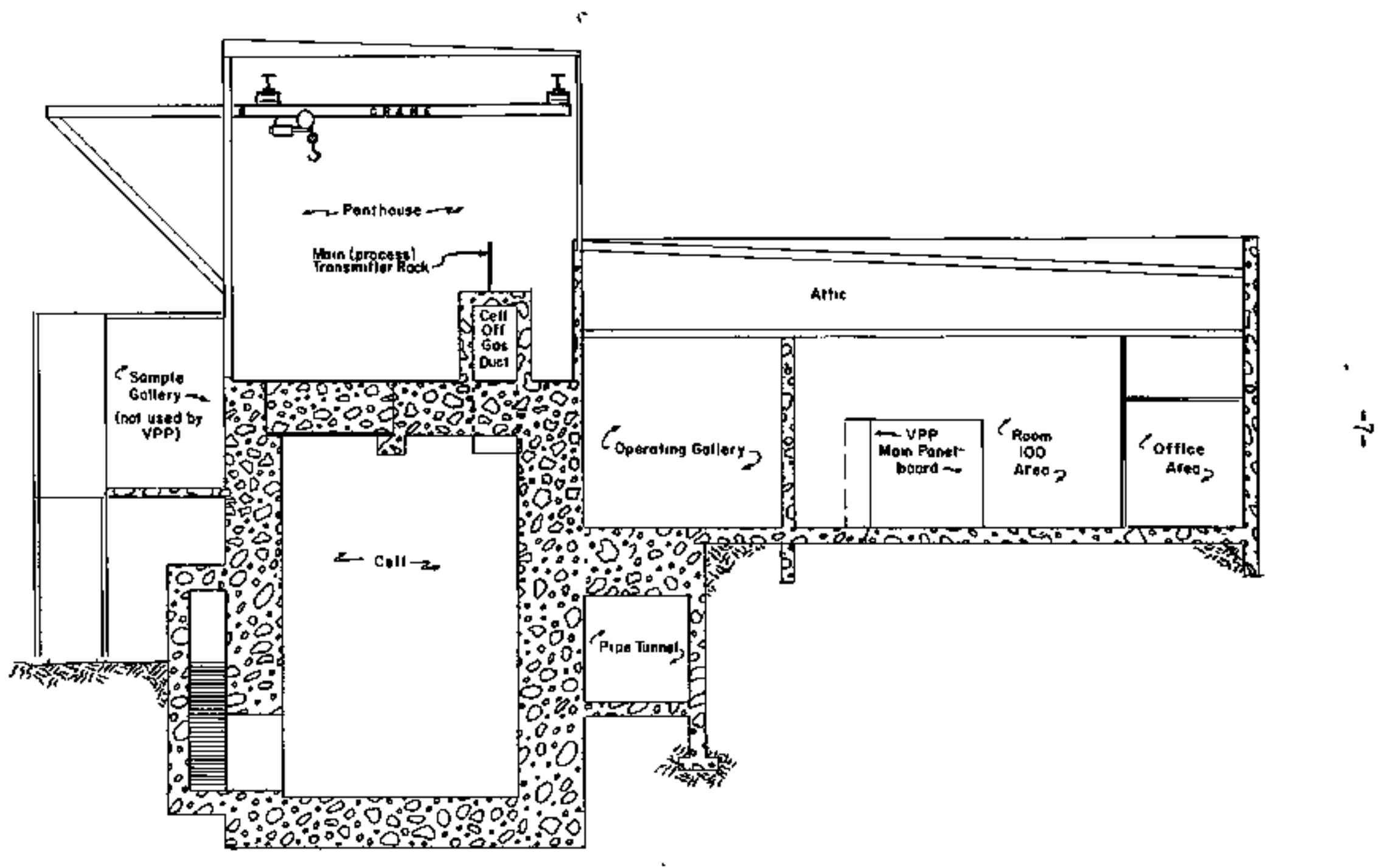

Fig. 2.3. Typical Section, 3019 Eldg. 
plutonium recovery. The building has since been used as a pilot plant for several fuel processing progrems. Durins the period of volatility operations In the eagt end of the butlding, the Thorex P1ilot Plant was operated in the remainder of the cells.

Cells I and 2 are $27 \mathrm{ft}$ high by $19 \mathrm{ft}$ north-5outh. Cell I $1 \mathrm{~s}$ il ft eastwest, Cell $220 \mathrm{ft}$ east-west. Shielding la provided by concrete, North walls are 5 ft thick, south walla 4 ft tuick, east and west walls $5 \mathrm{ft}$ thick, and the roof of each cell. $4^{+}$ft thick. Bach cell hes a roof hateh $9 \mathrm{ft}$ by $9 \mathrm{ft}$ and a gtalrway and lobreinth entrance from ground level dom to cell floor level. In addition, Cell 1 has o $1^{+}$ft thick wall running east-west, forming what is sajled cell 1-A.(3-1/2 ft by $1,1 \mathrm{ft})$ in the south portion of Cell 1 . The south wall of the cells forms most of the south wall of the building while the north face is adjacent to the "Operating Gallery". The area over the cello IB enclosed, formings the "Penthouse", and is used for some nonrediogetive operations as well as for access to the ceile through the cell hatch covers (or roof plugs). The Operating Gellery is at a level approximately that of the upper thiri of the cells; directly beneath the operating level 1s the "P1pe Tunnel" used for equipment which must be close to the cells, $1_{s}$ nonredioactive, and needs little attention.

Inttial operations of the pilot plant ware in september, 1956. From this date unt11 Hovember, 1957, operations consisted of mechanleal check-out of equipment (" $M$ " rums) and "cold" operations (" $C$ " runs) in partions or all of the plant vith non-imadiated meterial. The AFS fuel vas processed (" $\mathrm{B}^{+}$runs) from Horember, 1957, unt1l Narch, 1958. Following the "E" rums, another reactor charge was processed ("L" rung); gome of these "L" rums were "spiked" with plutonium $(20,6)$ and/or fuel material from in-pile loops in order to make additionel decontamination stulies. In August, 1958, the p1lot plant was shut dorn for modiftcations wich would permit the processing of heterogenerous fuels with higher levels of rediaactivity. This report covers ali operations up to August, 1958 . 
3.0 Salt Charging system . . . . . . . . . . . . . 9

3.1. Introduction. . . . . . . . . ......... 10

3.2 Equipment ......................... 10

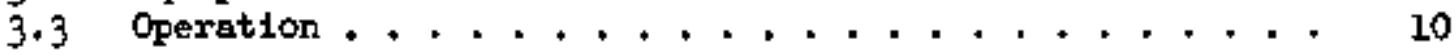

3.3.1 Operating Procedure ............... 10

3.3.2 Critical Operating Steps ........... 14

3.4 Equipment Ferformance .................. 14

3.4.1 Charge Line, MS-102-1 to MS-108-1........ 14

3.4.2 Charge Melt vegael, FV-102 ......... 16

3.4.3 Charge Melt Furnace, FV-502........... 18

3.4.4 Outlet Pipe Heater, FV-502A .......... 28

3.4.5 Vent LInes Heaters, FV-508 and FV-509...... 18

3.4 .6 Manipulator, FV $-908 \ldots 20$

3.4 .7 Fuel Carrier, Fv $-950 \ldots 20$

3.5 Summary and Conclusions................ 20

3.6 Fecomendations ..................... 21

3.7 Appendix ........................

3.7.1 Operating Procedure: Loeding Melt Vesse1. . . .27

3.7.2 Operating Procedure; Charge Salt Transfer ... 24 


\subsection{SALT CHAFGING SYSTEM}

\subsection{Introduction}

The salt charging system was used to feed the molten fluorlde salt into the fluorinator. This system hamiled salt batches varying in size from two to ten gallons and was different from the ARE charging systen." The principal steps in operating this systen were:

e. Placing the aolid fluoride salt in the cherge melt vessel.

b. Melting the aglt in a nitrogen atmosphere and allowing it to drain to the fluorinator.

fiadlation exposure was reduced by using a shielded charge carxier and by performing the operation remotely.

\subsection{Equituent}

F1g. 3.1 gives the equipment arrangement in the salt charging system. To eliminate difficulties, Beveral changes in components vere made during the " $\mathrm{C}$ " runs. The components of this syatem and major changes made in them are listed and described In Table 3.1.

\subsection{Operation}

\section{3 .1 Operating Frocedure ${ }^{\text {b }}$}

Major steps in operating the aelt chsrging system were:

a. Preparing the salt charge which included putting the salt into the charge cans or crushing the material and basging.

b. Loeding the salt charge into charge melt vessel and closing the furnace 1id.

c. Purging cherge welt vessel and setting other nitrogen purges.

d. Setting the necessary valves.

e. Putting the required instruments (including temperatiure controllers, autoresistance transformers, PC-45, PR-45, LR-2, PR-33, TR-1A, TR-L, and TI-4) in service and symchrondeing the charts.

1. Heating: (a) the charge melt vessel (to be held at $600^{\circ} \mathrm{c}_{0}$ ); (b) the seit transfer line and freeze valve (to be kept $z 570^{\circ} \mathrm{C}$ ); and (c) the fluorinator (to be malntalned at $600^{\circ} \mathrm{c}$ ).

a sec. 16.4.1 through 16.4.14.

"Charging a normel batch ( 252 1) required w12 hx from "heat-on" FV-102 until the entire charge was in FV-100. 


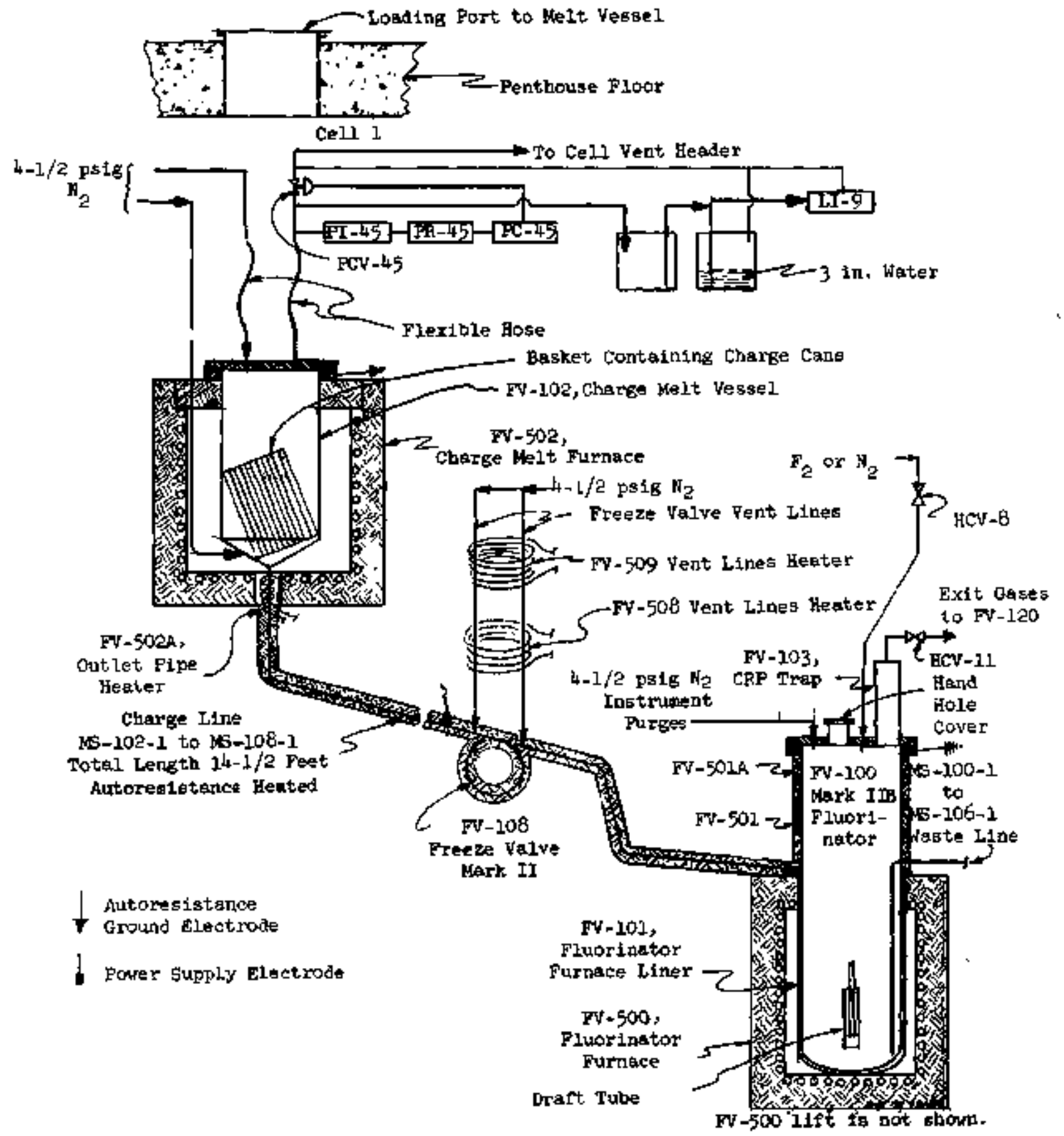

Fig. 3.ג. Equipment Arrangement for Salt Charging system 
Toble 3.1

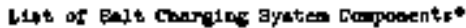

\begin{tabular}{|c|c|c|c|c|}
\hline Goporsts & 7n: & thos matehes & 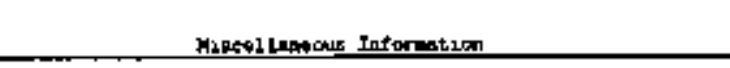 & Buftringent \\
\hline 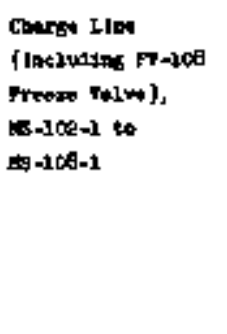 & 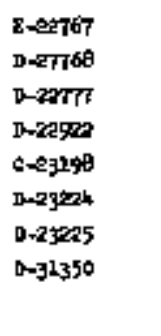 & 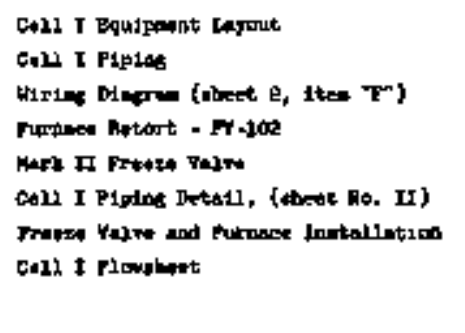 & 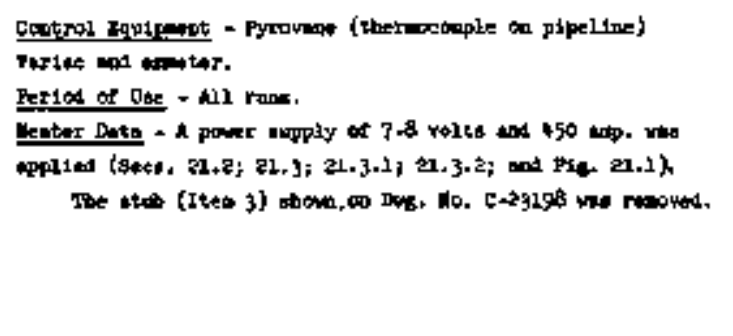 & 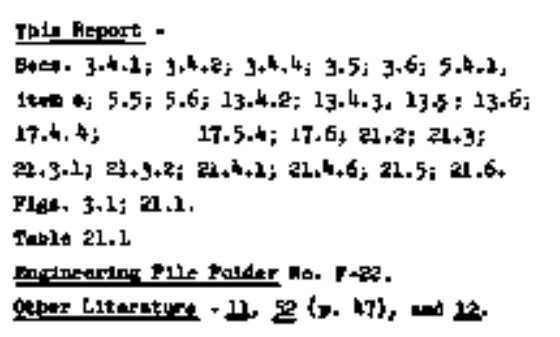 \\
\hline 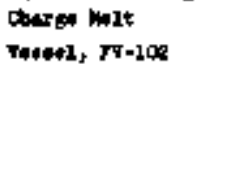 & 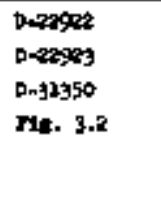 & 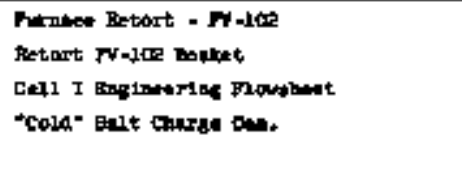 & 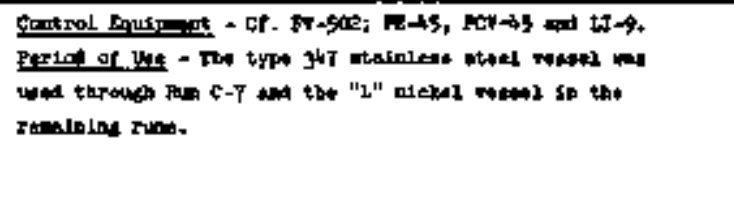 & 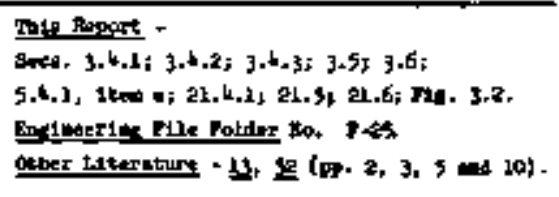 \\
\hline 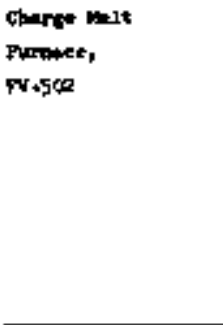 & 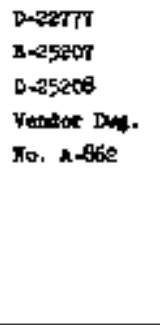 & 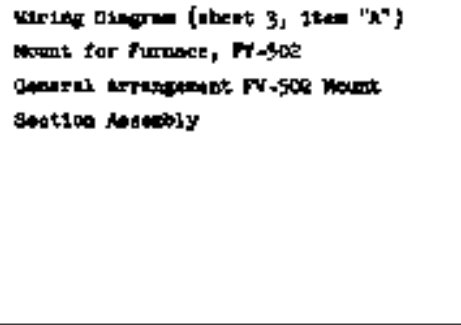 & 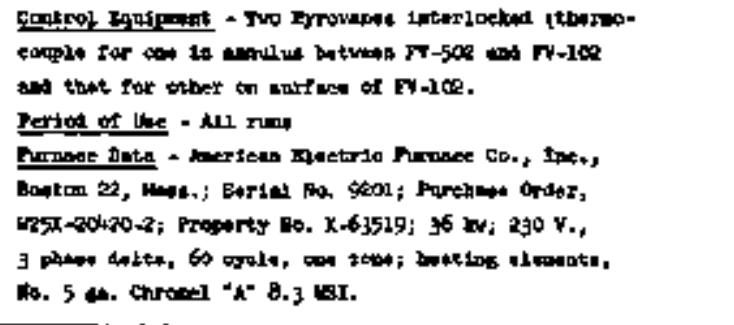 & 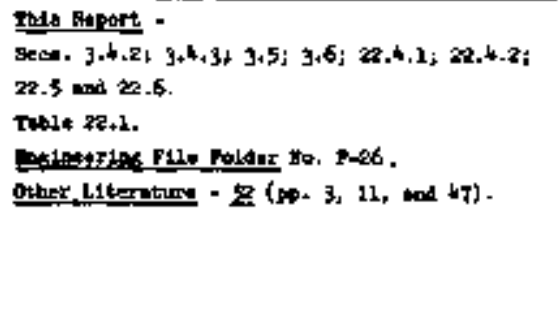 \\
\hline 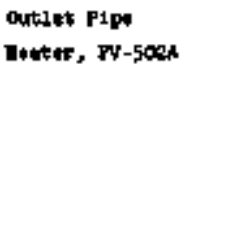 & 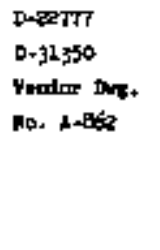 & 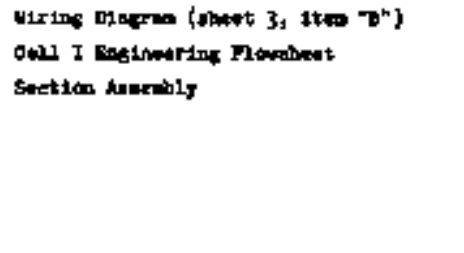 & 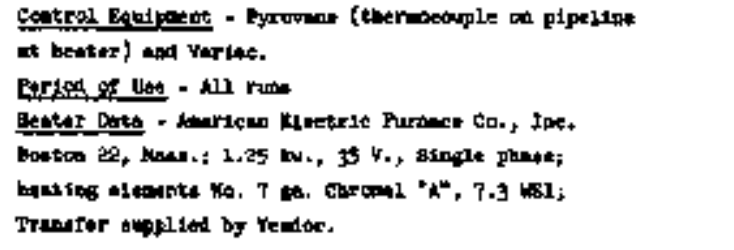 & 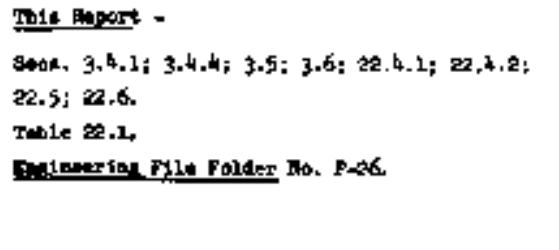 \\
\hline
\end{tabular}

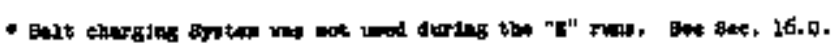


Table 3.1 (cant inme)

\begin{tabular}{|c|c|c|c|c|}
\hline 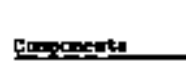 & Ther & 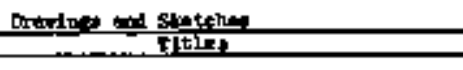 & 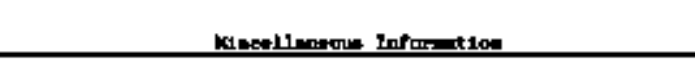 & 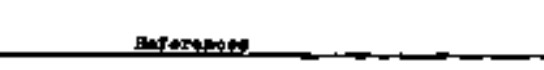 \\
\hline 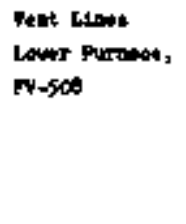 & $\begin{array}{l}0 \times \operatorname{sen} 8 \\
0+31350\end{array}$ & 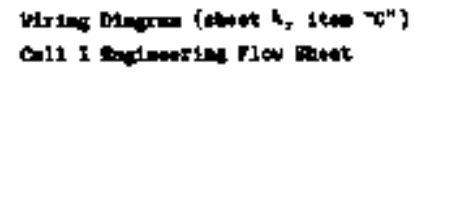 & 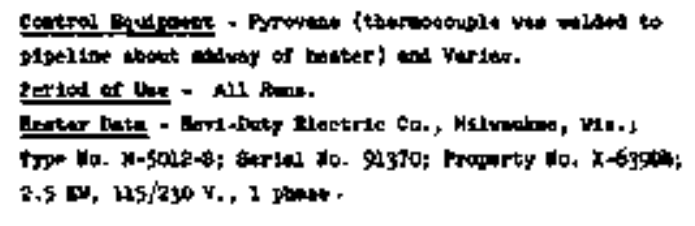 & 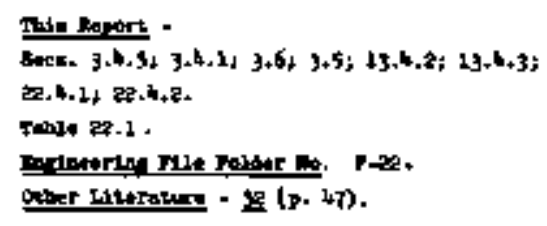 \\
\hline 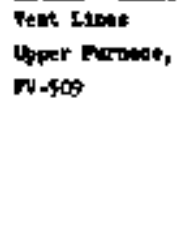 & $\begin{array}{l}\text { D-2emb } \\
0,31350\end{array}$ & 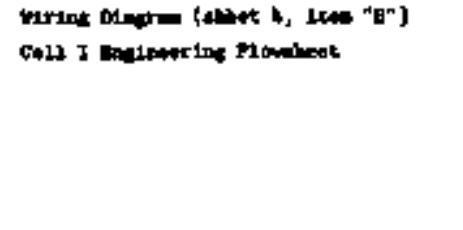 & 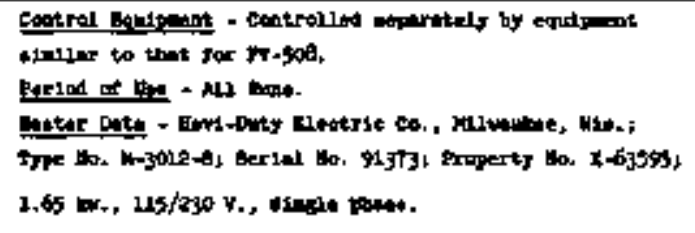 & $9 \mathrm{~km}$ is for $\mathrm{N}+306$ nower. \\
\hline Noripolatar, & 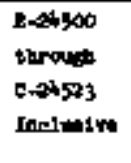 & 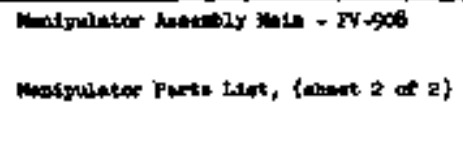 & Forted of lut - 111 mon. & 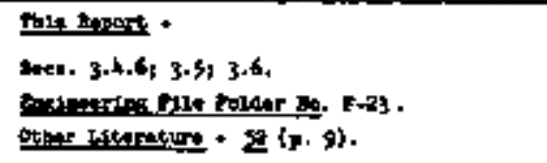 \\
\hline $\begin{array}{l}\text { Fond Cartier: } \\
\text { Fisso }\end{array}$ & 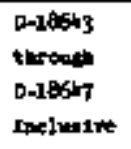 & 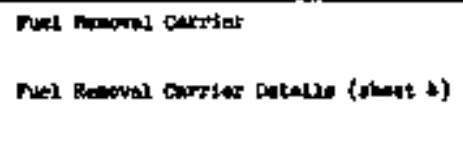 & 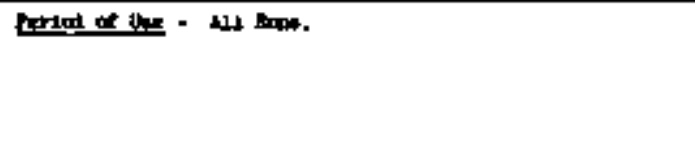 & 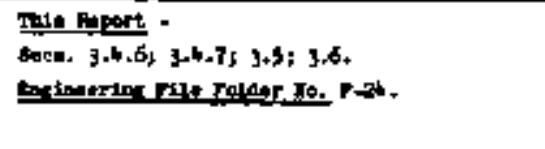 \\
\hline
\end{tabular}


8. Watching LR-2 for indication of feed selt fioring linto the fluorinator ent mainteining the $\mathrm{PR}-45$ reading at 1 in. of $\mathrm{H}_{2} \mathrm{O}$ pressure diring the transfer.

h. After all the selt had transferred, keeping the vent lines funnaces at $650^{\circ} \mathrm{C}$ to melt any salt freeztng in these lines during trensfer.

1. Cutting off the power to the charge melt vessel, the molten salt line, and treeze valve.

3. During atop $1 .$, malntainting $P R-45$ at 1 in. of $\mathrm{y}_{2} 0$ pressure while the equipment cooled.

NOIJ: When the selt charge was bulky such as crushed salt, it was necessary to perform more than one selt charging operetion to obtain a normal batch of w150 kg (52 itters).

Syatem modiflcations necessitsted editional minor steps in the procedure. For the complete salt charsing procedure, see Becs. 3.7.1 and 3.7.2.

\section{3 .2 Critical Operating Steps}

e. Avoiding blowing sand seal when placing the cberge melt furnoce lid to prevent losing sand seal and/or sucking send into Fv-102.

b. Purging all the air out of FV-10e inftially and then maintalning a nitrogen atmosphere in the vessel during the rest of the charging operation by keeping $\mathrm{FR}-45$ at one $1 \mathrm{n}$. of $\mathrm{H}_{2} \mathrm{O}$ pressure to avoid losing the sand seal and/or sucking air into the syrstem. (To remove all afr the vessel was purged for $16 \mathrm{hr}$ before starting to heat the equipment.)

c. Having the vessels and entire charge line not enough (FV-102 at $600^{\circ} \mathrm{C}, \quad F-100$ at $600^{\circ} \mathrm{C}$, and charge line Including freezs ralve FV- 108 at $\geqslant 570^{\circ} \mathrm{C}$ ) to melt salt in FV -102 or to maintain the salt flutd in the charge line and $F Y-100$.

d. Sealing FV-LOS before fluorination of the batch.

\subsection{Equipment Performance $^{\text {a }}$}

3.4 .1 Charge I.ine, MS-102-1 to $15-108-2^{b}$

The charge line included the molten salt line between FV-102 and FV-100 and also the Kark II Ireeze valfe, FV-108. This 1.ine ves aimilar structurally to the Maxk I waste line of Sec. 13.4.2. Operstionaily, however, there was a difference, that is, oravity transfers were used in the

a Ater the "I" runs, the charging line was dismantled and moved to Burial Groumd Ho. 3 (Sec. 23.4.16b). The remalning equipment was retalned for future processing. b Sec. 21.4.1 and Table 21.1.

c The Mark I (pot-type) freeze valve design tested in the ufoP section was never used in the VPP (Sec. $17,4,4$ ). 
charge line and elther pressure or siphon trensfers in the waste 1ine. The gravity transfer usulliy occurred at one of thice rates. These rates with accompenying items of equipment behavior were:

a. Moderate (most common) - trangfer required about_one hour; little extre effort involved in maintaining the $\mathrm{PR}-45$ reading at one inch of water pressure; no tendency to blow the sand seal.

b. Slow transfer required several hours probably becauge of a partial plug somewhere in the 11ne; no trouble met with keeping the PR-45 reading at one inch of water pressure; no tendency to blow the sand seell.

c. Fast transfer required 1ess than one-balf hour probably becayse nearly all of the charge was molten in FV-102 before transfer started; much trouble encountered with keeping the FR-45 reading at one inch of veter pressure; merked tendency to blow send seal. There wes no "sure-flre" way of obtaining a moderate trensfer rate although this was approsched by having all of the charge line $2570^{\circ} \mathrm{C}$ when the charge started melting. In some eases, a very slow or a "no-flow" transfer rate was increaged by blowing nitrogen through FV-108 and by pressurizing FV-lo0 with nitrogen. Although this practice was successfully used at times, it cannot be recommended for two reasons: (a) danger of blowing sand seal and (b) possibllity of plugging the waste line or instrument dip lines of FV-100. The preferred glternate to this method was having the entire charge itne $z 570^{\circ} \mathrm{C}$ (Sec. 21.3.2).

Charge line plugs most commonly formed in these places:

a. Adjacent to FV-502A. Plugs negr this heater reaulted from cold spots in the line ceused by openings in the insulation. Such plugs were eliminated by stuffing Fiberfrax in crevices in the insulation. Sotnetimes such openings in the insulation formed while beating the line to temperature. Consequently, inspection and some petching with the line at temperature were required at times.

b. Freeze-velve-to-vent lines joints. These plugs were similar to those discussed in Secs. 13.4.2 and 13.4.3.

Eerly in the pilot plant work the autoresistance ground lug on the FV-102 end of the charge line was welded to the charge line e few inches below FV-502. In such an arrangenent, the length of pipe between FV-502A and the autoresistance

a Ine temperatures were measured with themocouples placed as described in Sec. 21.4 .6 .

b Aluminum silicate vitreous ceramic fiber - OFH stores Cat. No. 15-00e-3000. 
Fround lug was too cold to keep the sait flutd. The situation was aimilar to that creeted at the fluorinator by putting the lug on the charge line near the vessel. The firat remedy in which a tubular heater was added was unsatisfactory. Finally, after other Ineffective efforts were mode, the nickel autaresistance ground ing was welded to the FV-102 flange si for FV-100. "This solution was effective and relatively simple to perform.

\section{c. FV- 100 wall. These plugs disappeared after the nickel auto- reasatance electrode was welded to the FV-100 flange (Sec. 5.4.1e and 1tem b. above).}

Although most of the plugs were caused by inadequate hesting revulting from misplacing the ground electrode, the plug in Run c-6 evidently was a mixture of composition 108 (56 wole per cent $\mathrm{HaF}-37.5 \mathrm{zrF}_{4}-6.5 \mathrm{UF}$ ) and Zircon ore. VIsual observation work gerforned on such mixtures indicated that

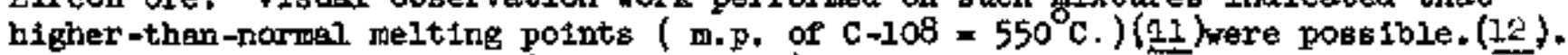
In addition, gas formation (probably $\mathrm{SiF}_{4}$ ) and higher than-pormal viscosities were noticed. It was presuwed that other fused salt mixtures would be affected similarly by zircon ore. Finally, higher-than-normal melting points and viscosities were observed with $C-108$ and corrosion seale mixtures. IIhls corrosion scale was that formed in the type 347 stainless steel PV-loc in early runs (Sec. 3.4.2).

Although a 3/8-in. Wes charge line was never tried, experience with a $3 / 8$ in. IPS charge line should parallel that with the Mark II waste line (Sec. 13.4.2).

The Ireeze valve loop did not tend to "blow" or lose 1ts seal despite the "swallowing" phenomenon (Sec. 3.4.2). The nitrogen purge ines were apparently effective siphon breaters. The vent line on the FV-100 side of the loop was repleced with a nitrogen purge line to achleve better control of the inert atmosphere in the systew. ThIB change also allowed a more positive UF 6 shut-off by a menual valve $(V-74 c)$ in the Gallery which replaced Ecv-3 in the freeze valve vent.

Prior to the "C" runs, a hole wa burned in FV-108 by attempting to weld an autoresistance lus to the plpe containing anl. The selt evidently melted because of local heating and expanded until it ruptured the pipe. Attempts to repair the hole only increased the demage thereby necesaltating the febrication of e new freeze valte.

\section{4 .2 Charge Melt Vessel, FV-102}

The yessel fitted anugly into the charge melt furnace and was 1ts 11ner (retort). The originel vessel made of type 347 stainless steel suffered severe scaling (oxidetion) in the presence of heat, atr and fluoride fumes from melting salt because of poor sealing of the furnace

"The lug was moved to the FV-102 flenge after Run c-2. Also cf. item c. below, 
lid to the retort (See Vendor's draving on asbestos strip seal.). Although the scaling was eliminated when 8 tight closure was achleved with the and seal, the vessel was replaced after fim $c-7$ by one wade of " $\mathrm{L}$ " nickel having

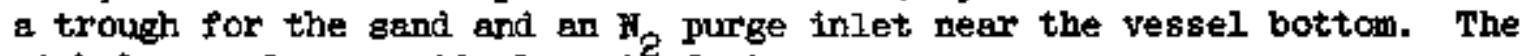
nickel vesgel was entirely satisfactory.

The sand seal wes satisfactory but hed geveral disadvantages. First, it was rathex delicate, cepable only of rithstanding gas pressure (or vacum) of $<4$ in. water. After chrome ore, Zircon ore, and ordinery sana vexe tried as sealing materials, a mixture of half zircon ore and half clean sand was found to be the most satisfactory seal. It afforded fatr reststance to rupture and fair "self healing" after rupture.

To avoid rupturing the sand seal by pressture surges during operation, $a$ 1-1/2 in. IPS vent with a pressure control valve (PCV-45) actuated by PE- 45 was installed between FV-102 and the cell off-gas duct. A bypess around the control valve provided emergency venting in case the valve ection was too Blow. Two agall pots were installed in the bypass. The one facther away from FV-102 contalned water in which the vent bypess pipe was submerged about three inches to preserve the seal with LF-9 Indicating the water level. The pot nearer FV-102 served to cateh this vater in the event of a negative pressure surge in FV-1C2. The arrangement was reasonably satisfactory, since the sand seal did not "blow" because of presarre surges during operation and no water got into FV-102. On several occasions vacuum surges in FV-102 were indicated on PR-45 when the salt started to melt and drain by gravity from the vessel. Theae aurges were especially pronounced when the salt began to drain suddenly after the transfer had been dellayed by a cold spot in the FV-102 charge line to the fluorinator. This "swallowing" effect could usually be anticipated and counteracted by increasing the $\mathrm{H}_{2}$ purge rate to FV-102 when the gal, transfer was expected to start.

The mein difficulty with the sand seal occurred during lifting and lowering of the furnace lid. The lid acted as a large piston, moving the FV-102 atmosphere in the direction the 110 was moved. Because of this, the lid had to be set very carefully into the and geal to avoid blowing sand outward from FV-102 as the lid came to rest. Conversely, the lid hed to be lifted very carefully to prevent suching sand into the vessel. The small capactty of valve PCV 45 to pass gas was responsible for much of this difficuty. zircon ore wes sucked into the vessel in Run C-6 resulting in a high melting plus in the FV-102 drain. The drain pipe had to be sawed open and the plug drilled through from below (Sec. 3.4.1). Although only one such incident occurred during the entire VPP operation, a repetition during an extremely "hot" run would present a very difflcult repas problem. Despite the dellcate nature of the sand seal, it effectively prevented entry of air into $\mathrm{FV}-102$ aince no diffieulty from $\mathrm{O}_{2}$ or water vapor was experienced after it was installed.

acf. Ref. No. 13 for details of instruments (Table 17.7 and Secs. $14.4 .5,16.4 .3$, 16.4.4, and 17.4.3). 
The bagket and charge cans for FV-102 were astisfectory for "cold" rums, Several modifications of the charge cans were made before the final design shown in Fig. 3.2. was developed to eult $\mathrm{X}-12$ selt filling requirementi. The lids were used to retaja an inert atmogphere in the cags during filling. At the VPP, the lids were removed, and 4 cans were loaded upside down in the basket for 3owering Into FV-1.\%. Bcale on the charge cans indicated that the $\mathrm{F}_{\mathrm{g}}$ purging in FV-lOe did not remeve all the eir from the inverted cans, elthough no serfous difficulties occurred because of this. Durfing "hot" runs, the begket became highly contaminated from aalt that accumlated on $t$.

\subsubsection{Charge Melt Furnace, FV $-50 e^{a}$}

The furnace performed satisfactorfly throughout the pilot plent runs, heating to the desired temperatures (600 $\mathrm{C}$. nommal, $700^{\circ} \mathrm{C}$. maximum) without a failure. Time to reach $600^{\circ} \mathrm{C}$ from rocm temperature was $3-1 / \mathrm{h} \mathrm{hr}$; time to cool from $600^{\circ} \mathrm{C}$. to room temperature was $20 \mathrm{hr}$. The original asbestos tape seal for the ild was not satisfactory, ellowing afr to enter the retort as the furnace cooled. Vent and purge connections of $1 / 2-1$. IFS were provided to the lid originaliy; these were later replaced with 1-1/2-in. INP fittings (Sec, 3.4.2).

The wount for FV-502, supported on a pivot for swinging the furnace under the hatch, worked well the only time it was needed, that is, when the stainless steel FV-102 wss replaced by the nickel vessel.

\section{4 .4 Outlet P1pe Heater, FV-502A}

The outlat heater performed satisfagtorily without a failure throughout the pllot plent runs. The time-to-600 $\mathrm{C}$. gf the pipeline was $5 \mathrm{br}$. At times, the plpeline was heated higher than $600^{\circ} \mathrm{c}$. with $700^{\circ} \mathrm{c}$. being the mexinum.

Care was required to maintain thermel insulation around the base of FV-502A beeause the jotnt where the out,let pipe insulation ended at the furnace base tended to open vhen the pipe insulation shrenk or altd down. werd from the furnace. Af delineeted in Sec. 3.4.1, Fiberfrax was packed in such cracks.

\subsubsection{Vent IInes Heaters, FV-506 and FV-509}

The two vent lines heaters performed satisfactor 1 ly without failure. cold spots tended to occur at the points where the $H_{2}$ purge lines joined the freeze valve because furnace FV -508 was orlginaliy installed too high above the freeze valve. The situation here roughly paralleled that for FV -506 and FV -507 in Secs. 33.4 .2 and 13.4 .3 (Cf. also Sec. 3.4.1).

Table 22.1 and Secs. 22.4.1, 22.4.2; 22.5, and 22.6. 
1/8-in. d1a, 5.5. ra removable handle
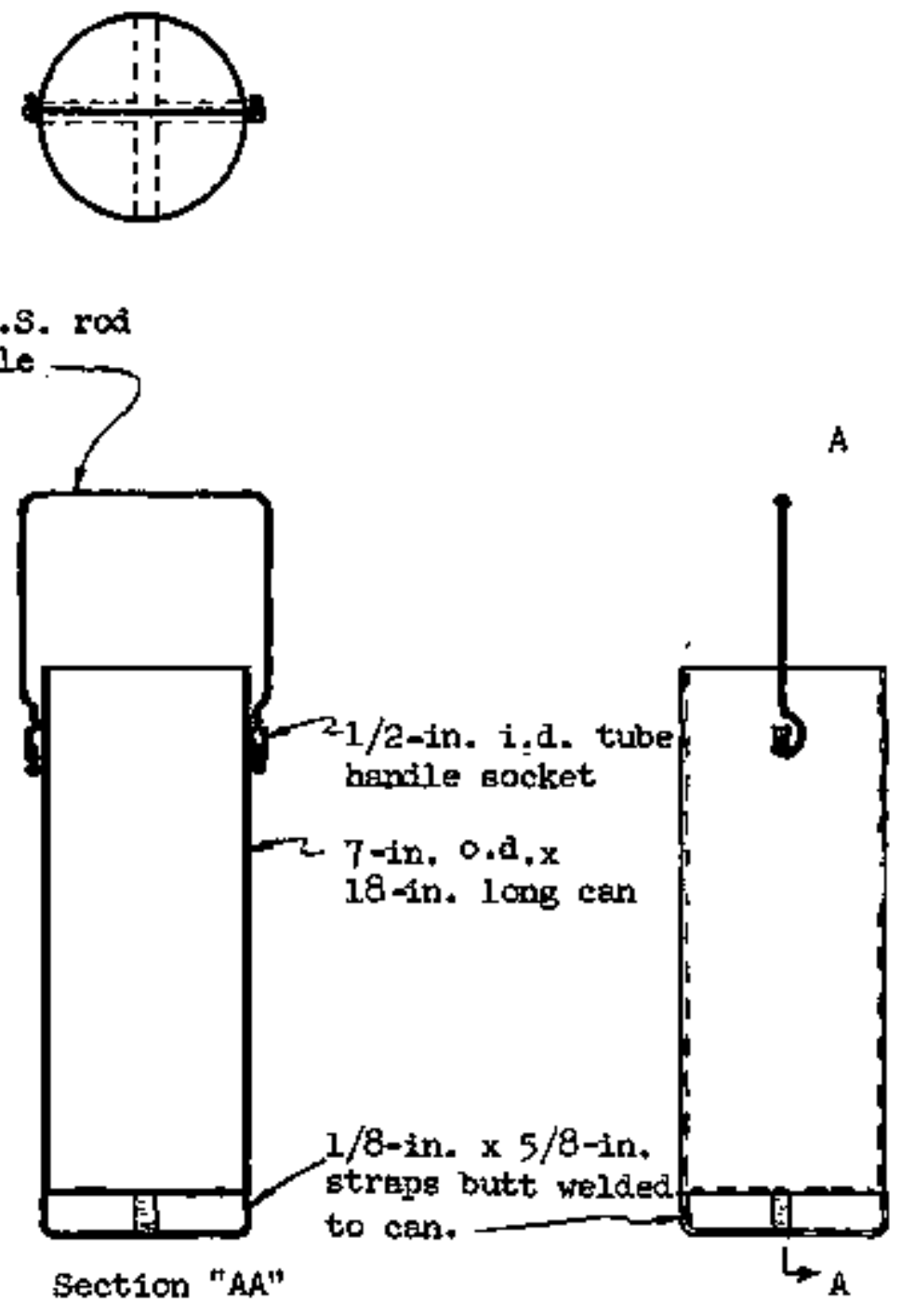

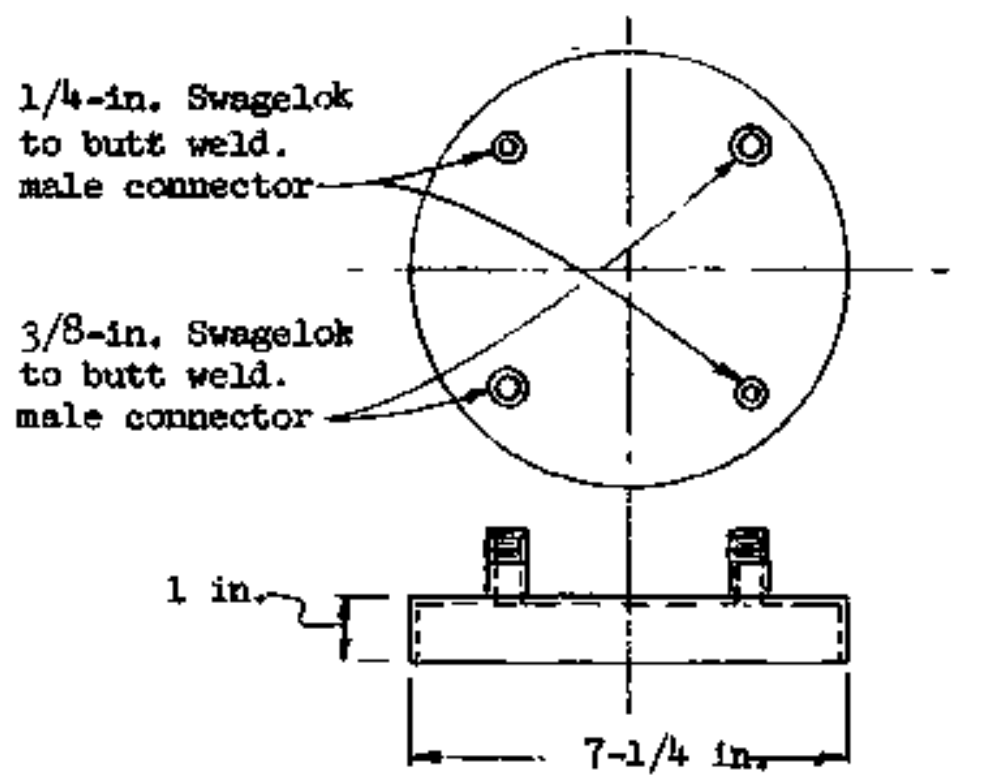

Can Lid

(used only while filting)

Note: All material 1/8-in. nickel except as noted. 


\subsubsection{Mantpulator, FV -908}

The manlpuiator in conjunction with the ruel carrier fry-950 was intended to prov1de remote charging of small cans of radioactive salt. Because of a misumderstanding in the design phase, the manipulator was built to hardile a amaller welght then a single charge can filled with salt $(\sim 75 \mathrm{lb})$. Thus, it could not invert the cans and lower them into the melt vessel as 1ntended. Consequently, th1s operstion hed to be performed by hand. The manipulator was uged to lift and lower the lid of the charge melt furnece and it performed this operation satisfactorily, al.though the arrangement of the manipulator craink handles were awkiard and experience was required to operate them,

A closed-circutt television system was orlginaliy purchased to essist the remote charging but was not installed because the activity level $B$ were never bigh enough to requife its use, and because the manipulator coldi not perform the matn operations which were to be observed by $T V$. The Ty would have been helpful in meneuvering the furnace lid, since the manipulator had no index to indteate where its book engaged the lid handle and eince this was not directly vistble to the operator when the lid was sumg away from the furnace.

\subsubsection{Fuel Carrier, Fy -950}

The carrier was originally designed to handle the aluminum eans into which the ARS fuel vas to be poured, although it was never used for that purpose. In the VPP, it was used to transport redioective loop salt and fragments of ARS components (pusp parts and piping) in nickel cans from the Gamma Gardens storege area (southeast corner of Building 3550) to Bullaling 3019 Penthouse, where the cans vere lowered into the charge melt resse, Although it proved akkward to invert the cang before placing them in the fuel carrier (This had to be done manually and required personnel exposure to radiation.), no parts or crumbs of salt fell through the rethining screen in the inverted cans. This operation was intended to be performed by the menlpulator orer the open charge melt ressel so that crumbs of "hot" salt would fall into FV -102 . The carrier handled the cans sat1sfactorily deapite the lack of a convenlent means to handie the wires by which the Inverted cans were lowered into FV-1,02 from the carrier.

\subsection{Sumary and Conclusions}

In general, the charge salt system operated successfully and fulfilled its designed function. Some changes were required to correct original flaws, but the over-all design and construction were satisfactory. Time required was $12 \mathrm{hr}$.

The grapity tranefer ordinarily required about an hour although sometimes 1t was much slower or faster. Having the entire charge line $\geq 570^{\circ} \mathrm{C}$. was usually reagonable assurence of transferring at the one-hour rate.

Charge Ifne plugs uoually resulted from inedequate neating et: (a) the freeze-valve-to-vent-line joints, (b) the outlet pipe heater, or (c) the fluorinator wall. The remedy for each of these plugs is discussed. Plugs in b. and c, wore largely ellminated by welding electrodes to the Fv-100 and -102 flanges. 
Although most charge iine piugs were caused by inedequate heating, the plug in Run C-6 apparently was a composition 106:Zircon ore mixture having a bigher melting point than $c-108$.

The freeze valve loop did not "blow" or lose 1ts seal despite the "swallowing" phenomenon during transfers presumably because the nitrogen purge lines were effecm tive aiphon breakers.

An attempt to veld an autoresistance lug to a plpe containfng salt resulted in burning a hole in the pipe.

The orlginal type 347 stainless steel charge melt pessel corroded and ws replaced after Run $C-7$ wth one mede of "L" nickel. The nickel vessel was satisfactory.

The sand seal and PCV 45 comhination was superior to the asbestos gasket originally used to seal the charge melt vessel. The main trouble witb the sand senl occurred while lifting and lowering the furnace lid. But a "swallowing" effect during the transfer was potentially troublesome. This effect could waldily be anticipated and counteracted by increasing the nitrogen purge rate when the sajt transfer started. The sand seal apparently caused one plug when Zircon ore wes pulled into the vessel as discussed.

The basket and charge cans were less satisfactory for "hot" than for "cold" runs. This occurred because, through a misunderstanding in the design phase, the manipulator was bullt to handle a smeller weight then the 75-lb charge can. Consequently, the manipulator was used only to lift and lower the furnace lid. It required experience to operate the manipulator because of the awkward arrangement of the handies.

The fuel carrier handlea cans sat1sfactorily in apite of the two alfficulties discussed.

The furnace and heaters were aatiofactory and required the following times to heat their respective components to temperature: (a) furnace $=3-1 / 2 \mathrm{hr}$, (b) outlet pipe $=5 \mathrm{hr}$, and (c) vent lines $=3 \mathrm{hr}$. After flowing the charge to the fluorinator, it required $20 \mathrm{hr}$ to cool the charge vessel to room temperature.

\subsection{Recommendations.}

It Is recoimended that the selt cherging system be used "ss-1s" unless the activity of the charge sazt approaches that for the "hottest" " $\mathrm{L}$ " rums in which case an Improved meens for remotely putting the salt into the charge melt vessel would be needed. Further, the following are recommended:

a. That the operating procedure should: (a) emphasize having the entire cherge line $=570^{\circ} \mathrm{C}$ by the time the charge starts to melt and (b) mention the two most inkely cold spots - at the outlet pipe heater and at the freeze-valve-to-vent-lines joints.

b. That nickel autoresistance ground lugs such as on the fluorinator and the charge melt vessel continue to be put on the vessels. 
c. That welding not be done on plpelines contalining salt.

d. That any future charge nelt veseel be made of "L" atckel or a material of equal or better corrosion resiatance in fused fluoride salts.

\subsection{Appendix}

3.7.I Operating Procedure: Loading Melt Vessel

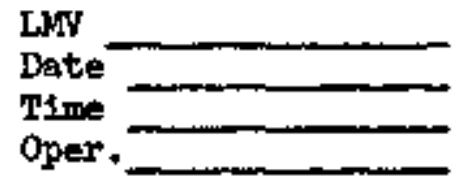

\section{PARP I: PRELIMTNARY CEFBCK}

1. Open or adjuat PV -4 to give 4.5 pais on PI-32 on control panel.

2. Record FI-3. scim.

3. Check that TR-IA and TR-1B are "on" and operating properly, and that cherts are aynchronized.

4. Record the following temperatures:

$T R-1 A-1$

TR- MA-2

TR-1B-1

TR- $\mathrm{AB}-3 \mathrm{~B}$

TR- $3 \mathrm{~B}-\mathrm{SB}$

TR- 1 B -9

(If any of the above temperatures are above $100^{\circ} \mathrm{C}$, check with supervigor before proceeding to next step.)

5. Cheek that TIC-IB-9

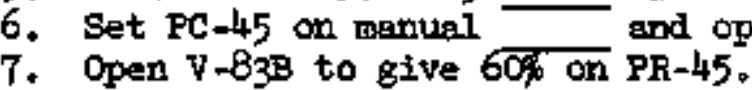
and TIC-1A-1 5 are "ofe".

7. Open $V-838$ to give $60 \%$ on PR -45 .

8. Remove cover by raising it elowly streight up with the manipulator.

9. Set cover to one side and check to see that the regiel 18 empty and ready to recelve feed.

10. Cloge V-B3B.

Checked by

Time

Date

MOFE: Get oupervigor's approval before proceeding to Part II, "Loeding Salt."

Approved

Time

Date

PART II: LOADIHG SALT

11. If loose material is to be charged, place it in the charge melt veseel first, and record the weight in step 14 below,

12. Turn each of the cans to be loaded upside dom and lower it carefully 1nto the charge melt vessel. 
13. Record the following data:

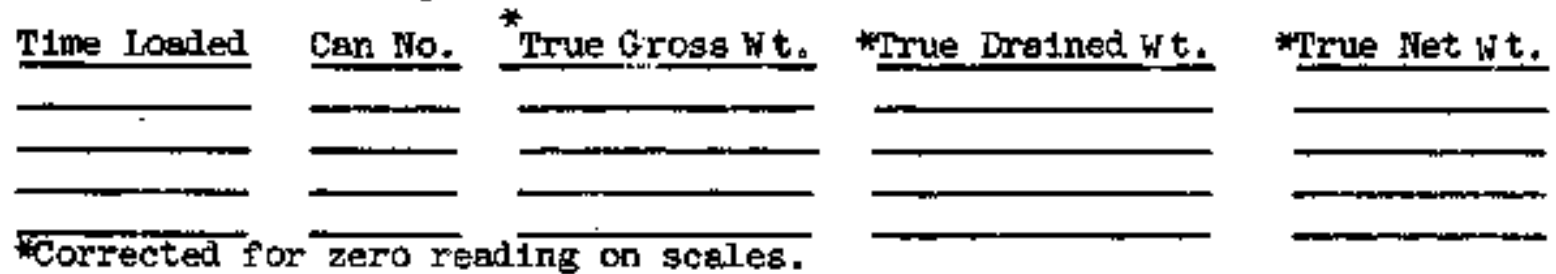

14. Set PC-45 on manual and adjust PCV -45 to $15 \mathrm{ps}$

15. Read the following instruments: PR-45 LI -9 In.

16. Add of renove water from seal pot intil II-9 reads 3 in.

17. Replace FV-lO2 cover carefuly, using the followlog procedure:

a. Make sure plenty of 2 ireon sand is unformly distributed around the periphery of the seal.

b. Raise the cover off the rack with the manipulator, sulng the-cover around and center it over the charge melt ressel, and then slowly lower the cover down into the seal.

c. Tamp the cover to make a good seal, making certain the corer ts level.

d. Clean oft (and save) the excess and on the top of the charge melt veriel.

18. Open $\mathrm{v}-73 \mathrm{~A}$ $v-80$ and $V-8 j A$

During the following operation recond the requested numbers on data sheet.

19. Open V-83C until FI-35 reeds approxisately $6 \%$. Time open

20. Open V-B3B unt1l FI-35 incresses to approximetely 12\%. T1me done

21. Open 73B until FI-35 increases to approximately $20 \%$. Time done

22. Approximately 1 ho later close $\mathrm{V}-73 \mathrm{~B}$

23. Set FI-13 and FI-C5

to 1 efh erach. - Time done

24. Set PC-45 on "auto" and adjust set point to $60 \%$ ( 1 in. H 0 pressure).

25. Slowly close V-83C until FC 45 is controlling at setpoint.?

26. Recond FI-3__ BIm, PI-32 By PBIE, PR- 45 \%. Time completed

NOTE: Check with supervisor before proceeding to "Charge Salt Transfer." Upon completion of this, retirn to Part III of "Loading Melt Vessel," "Retrieving Charge Cans."

PART III: RETRIEVING CHARGE CANS

27. When TR-LA-2 falls below $200^{\circ} \mathrm{C}$, open $\mathrm{V}-83 \mathrm{~B}$ umt11 FI-35 reads $10 \%$

28. Set PC-45 on manual, and open PCV-45 to $15 \mathrm{psig}$

29. Remove cover by reising it slowly straight up with the manipulator. Tyme

30. Sving cover avay from operator and set it on platform provided.

31. Close V-83B.

32. Pull out cans waing crane and place them on blotter paper on the Penthouse floor. 
33. Rewelgh cans and record weights under "Drained wt" in step 13 above. Time completed By

3.7.2 Operating Procedure: Charge Salt Transfer

Approved by:

$$
\text { Shift Superviaor }
$$

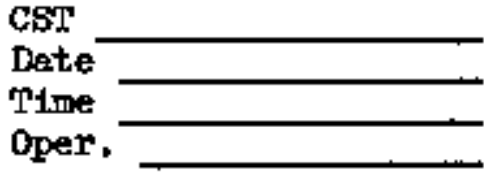

1. The following velves on the penelboard should be closed:
$\mathrm{HX}-8$
$\mathrm{HX}-12$
$\mathrm{FX}-32$
and $\mathrm{HX}-34$

2. The following valves on the panellboard should be open:

HX -6 $\mathrm{HX}-11$ IXX -35 and $\mathrm{EX}-36$

3. The following valves in the galiery should be open:

$\mathrm{V}-78$

$V-79$ $\mathrm{V}-80$

4. Adjust PVIh to read 4.5 psig and $V-81$ and PV-4 to 4.5 psis

5. The following velves in the gallery should be closed: $\mathrm{V}-90 \mathrm{~A}$ $V-90 B$ $v-92$

6. The following valves in the Penthouse should be open:
$\mathrm{v}-27$ $\mathrm{V}-72$ and V-112 (or 173 )

7. Set the following purges :

\begin{tabular}{|c|c|c|c|c|}
\hline Valve Ho. & FI-N⿴囗. & Lbcation & Flow Rete & Purge Point \\
\hline & $=-\infty$ & Penthouse & I cfh (ea. side) & $\overline{\mathrm{LE}-2}$ \\
\hline & - & Penthouse & $1 \mathrm{cfb}$ & $\mathrm{IE}-2$ \\
\hline & 27 & Penthouse & $150 \mathrm{ec} / \mathrm{msn}$ & S-100-1 \\
\hline & 13 & Gallexy & 1 efh & LN-108-1 \\
\hline 641 & 14 & Gadlery & $1 \mathrm{cth}$ & INV -1 \\
\hline 75 & 15 & Gallery & $1 \mathrm{cfh}$ & $1 \mathrm{~N}-104-1$ \\
\hline & 25 & Gallery & 1 cfb & $L N-102-1$ \\
\hline & 26 & Gallery & $150 \mathrm{cc} / \mathrm{min}$ & LN-106-1. \\
\hline$-91 A$ & 31 & Gallery & 1 cfh & $13-1,03-1$ \\
\hline
\end{tabular}

8. Set PC -45 on "auto" and adjust setpoint to +1 in. He $(60 \%)$.
Read PR 45
क. $1 \mathrm{I}=9$
Record FI-3 sctm, PI-32 (In gellery.). psig.

1.1. The following 1nstruments shoild be in service and charts syachronized:

DR -2

TI 4 LR $=2$ PR -33 TR-LA TR=1B and

12. Switch TX-1B, $\mathrm{XX}-\mathrm{-1B}-4$, and $T \mathrm{TX}-1 \mathrm{~B}-7$ to position "B."

13. Twrn the following controllers on, and adjust the set points as indicated:

$\begin{array}{lc}\text { Controller } & \text { Setpoint, }{ }^{\circ} \mathrm{C} . \\ \text { TIC-1A-5 } & 650 \\ \text { TIC-1A-6 } & 610 \\ \text { TIC-1A-8 } & 650 \\ \text { TIC-1B-3B } & 500 \\ \text { TIC-3B-LB } & 650^{*} \\ \text { TIC-1B-11 } & 700\end{array}$

Time Set

NOTE: If necesatry, reise the get point of TIC-1B-4B unt11 TR-1B-I Is equal to or greater than $550^{\circ} \mathrm{C}$. 
14. Adjust the folloring Vartacs:

$\begin{array}{ll}\text { Var1as } & \text { Setting } \\ \text { TC-1B- } & (140) 145 * \text { volts } \\ \mathrm{TC}-1 \mathrm{~B}-11 & (190) \text { volts }\end{array}$

*Ad fust unt1l El-1B-4 reads 435 emps.

15. When above controllers are controlling at the set point, proceed to step 16 .

16. Turn the rollowing controllers on, and adjugt the set points as indicated:

$\begin{array}{lcl}\text { Controllex } & \text { Set Point, } \mathrm{C} & \text { Time Set } \\ \text { TIC-1A-1 } & 660 & \\ \text { TIC-1A-2 } & 640 & \end{array}$

17. Adjust the following Variacs
Variac
Setting volts
Time Set

18. T1me then TR-LA-C reachea $500^{\circ} \mathrm{C}$

When TR-1A-2 reaches $500^{\circ} \mathrm{C}$, observe closely TI-i4-43. If an abrupt rise in temperature occurs, notify supervisor immediately. Also observe LR-2 for buildup of salt in the fluorinetor. Record initial reading of IR-2

19. Record the time of the following events, 1 noted:

a. Salt begins to melt

b. LR+2 shơns a buildup

c. LR-2 stops rising

Final leyel

d. TR-LA-2 atops rising

Finel Temperature

发。 c.

20. Check FI-13 and FI-14 for flow at 1 cfh each. If etther line is plusged, proceed to stop 22 - Otherwise, proceed to step 25

21. Turn the following controllers on and or adust the set points as indicated:

$\begin{array}{lcl}\text { Controller } & \text { Set Foint, }{ }^{\circ} \mathrm{C} \\ \text { TIC-TB-3B } & 650 \\ \text { TIC-1B-TB } & 650 & \\ \text { TIC- } 1 \mathrm{~B}-\mathrm{TH} & 650 & \end{array}$

22. Time when TR- $3 B-3 B$ and $T R-7 B-T B$ levels of

23. After 15 min record LR-2 reading

24. Shut off TIC-1A-1

TIC-IB-TB , and TIC-1B-9, Thas off

TIC- $1 \mathrm{~B}-\overline{3 \mathrm{~B}}$

g, and proceed to step 25

25. Lower VariscB TC-1Bd4 and $\overline{\mathrm{TC}-\overline{\mathrm{IB}}-9}$

to zero volts.

26. Check PR-45 while FV-IOE 18 cooling to see that 1 in. $\mathrm{H}_{2} \mathrm{O}$ pressure is maintained.

27. When TR-3B-1 falls below $450^{\circ} \mathrm{C}$, and the freeze valve $1 \mathrm{~s}$ sealect, proceed to "Feed Salt Fluorination," subject to approval by supervisor. Time reached

28. When TR-1A-2 falls below $200^{\circ} \mathrm{C}$ return to Pert III of "Loadins Melt Vessel" to retrleve the cherge cans. 
COATENTS

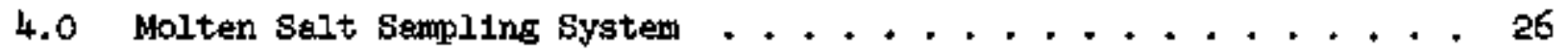

4.1 Introduction ....................... 27

4.2 Bquipment ....................... 27

4.3 Operetion ..................... 27

4.3.1 Opereting Procedure .................. 27

4.3.2 Critical Operating Steps............. 3l

4.4 Equipment Evaluation ................ 31

4.4.1 Sampler Assembly, FV-900 ............. 3l

a. Sempler Reel and Pedestal ........... 31

b. Jadle Guide Pipe ................. 31

c. Ledle-to-Wire connector . . . ........32

a. teadle ................... 32

e. Sarpler Carrier ............... 32

f. Discussion ............... 32

4.4 .2 Sampler Hood, FV-995 .............. 34

4.5 Sumbry and Conclusions............... 34

4.6 Recommendations................... 35

4.7 Operating Procedure: Molten Salt Sampling . . . . . . . 35 


\subsection{MOLIFN SAIT SAMPLIHG SYSTEM}

\subsection{Introduction}

Both the feed and waste salt mixtures were sampled while molten in the fluorinator using the molten salt sampling system. The principel steps in this sampling operation were:

a. Lowering a weighted ladle into the molt and allowing it to remain long enough to fill with salt.

b. Withdrawing the filled ladle and processing the sample for analysea.

Rediation exposure was reduced by lead shielding and renting the fluorinator vapors.

\subsection{Equipment}

The general arrangement of the molten galt sampling equipment was as shown in Fig. 4.1 for ald pilot plant rork. This figure also shows the latest wodel of each individusi component. The various component models are listed and described in Table 4.1 .

\subsection{Operation}

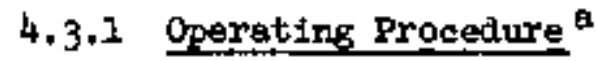

Steps in operating the molten salt sampling system were:

e. Sparging FV-100 w1th $20 \mathrm{slm}$ of $\mathrm{N}_{2}$ for 45 min (feed salt) or 30 min (waste salt) through line $X-100-1$.

b. Uaing liquid level (LR-2) and density (DR-2) date to compute the depth to lower the aample ladle.

c. Plecing empty ladle on end of reel wire.

d. Making cextain that the ampler hood was aecurely in place, and thet both air-lock doors were closed.

e. Setting $N_{0}$ purge for the ladle guide pipe to FV-100 and malntaining the pressure in the hood (PI-5I) at one Inch of water wile taksing the sample.

f. Opening $V-88$; lowering ladle to the predetermined depth; letting ladle stay at this position for $\sim 20$ seconds; then lifting ladle to the sampler hood.

B. Closirg V-8B and opening V-129 to a vacuum reading of 2 to 3 inches of water on PI-5I.

\footnotetext{
asapling required $\sim 2$ hr inclualng 45 -min melt sparge time.
} 


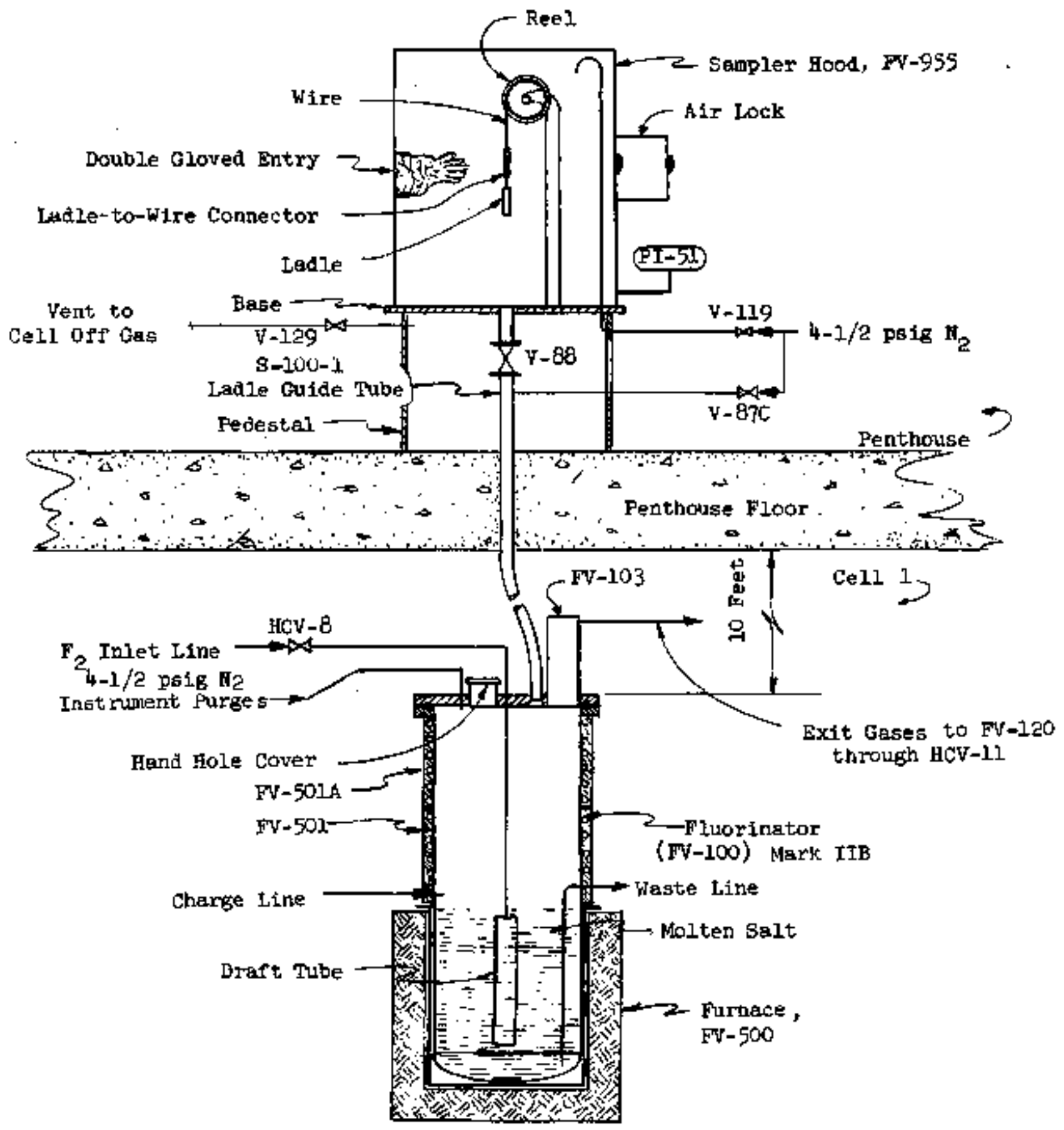

FV-500 11't is not shown.

Fig. 4.1. Equipment Arrangement or Molten Salt Sampling System 
tanke th1

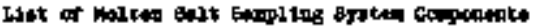

\begin{tabular}{|c|c|c|c|c|}
\hline Geresenter & Then & 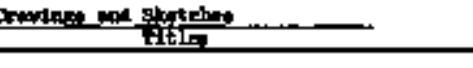 & 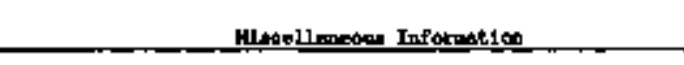 & Meterensen \\
\hline 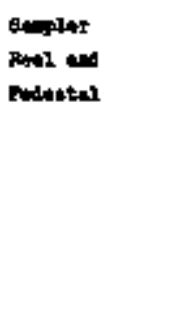 & 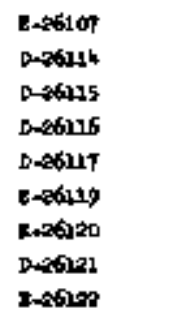 & 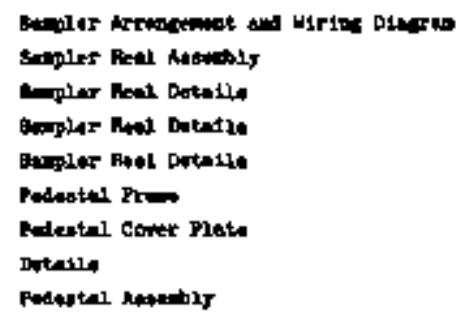 & 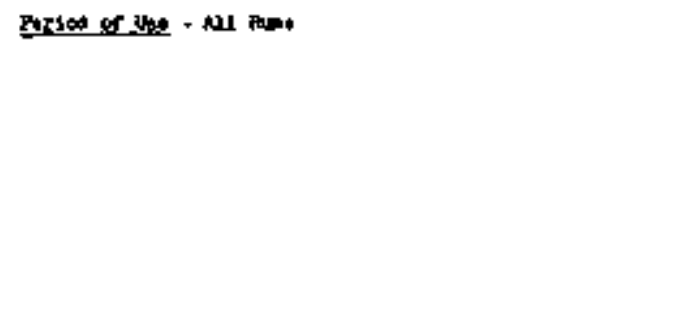 & 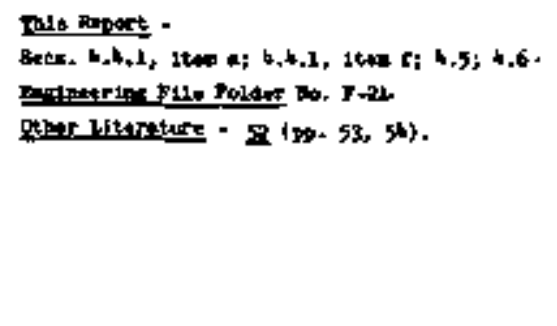 \\
\hline \multirow[t]{2}{*}{ 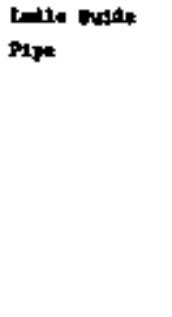 } & 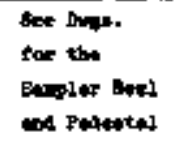 & & 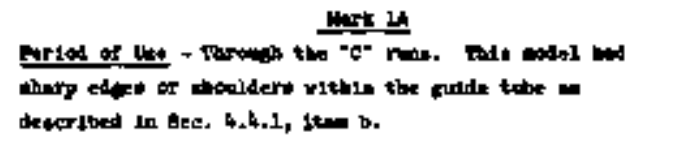 & 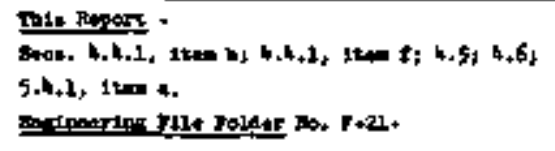 \\
\hline & 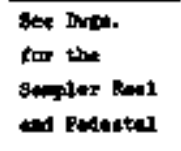 & & 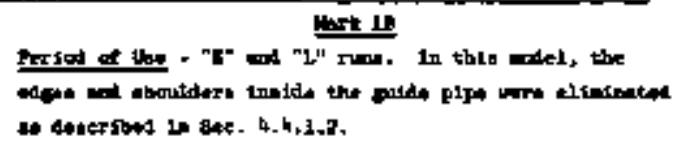 & \\
\hline 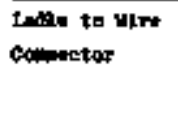 & $0-86113$ & 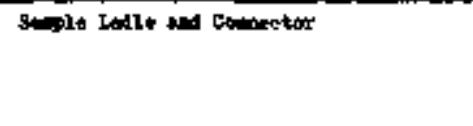 & 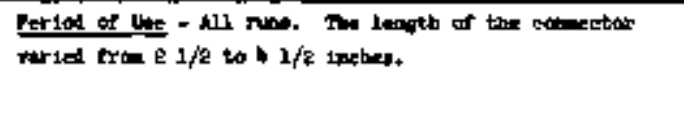 & 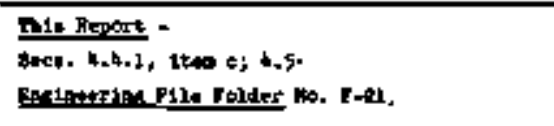 \\
\hline mente & 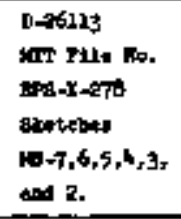 & 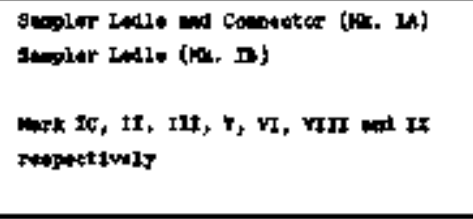 & 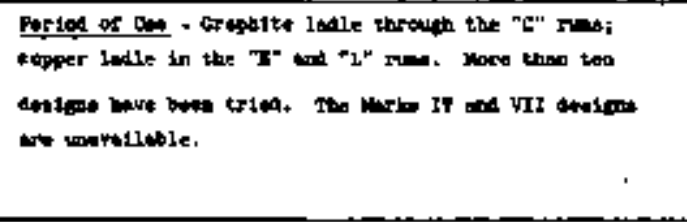 & 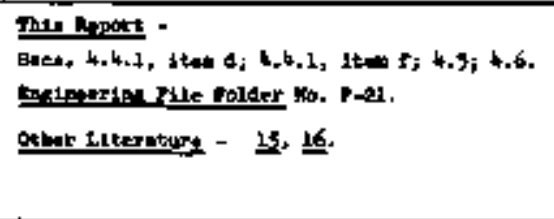 \\
\hline $\begin{array}{l}\text { corrster, } \\
\text { r-sto }\end{array}$ & $\begin{array}{l}0-26107 \\
0-26100 \\
0-36109 \\
0-36110 \\
0.35111 \\
0-66121\end{array}$ & 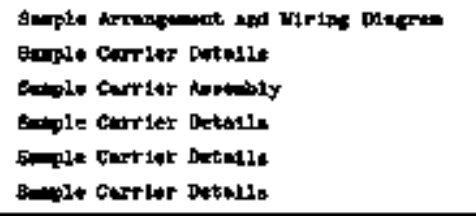 & 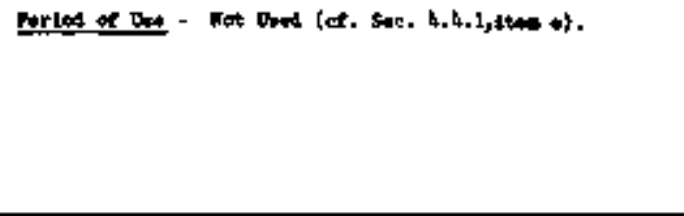 & 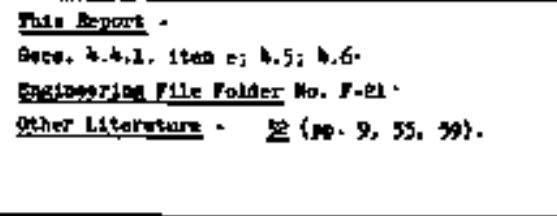 \\
\hline
\end{tabular}


Table +11 (Coutions)

\begin{tabular}{|c|c|c|c|c|c|}
\hline \multirow{3}{*}{ 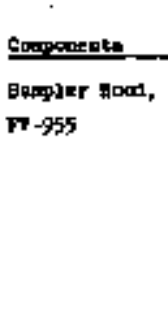 } & \multicolumn{2}{|c|}{ 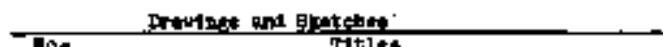 } & 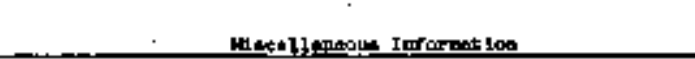 & 'syrefencest & \\
\hline & 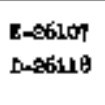 & 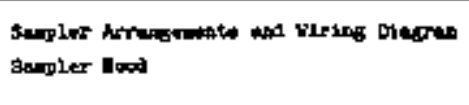 & 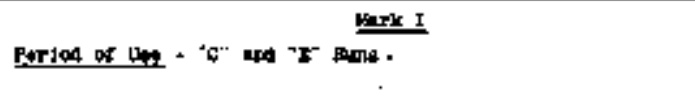 & 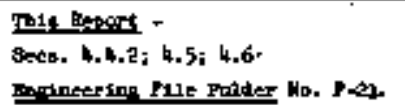 & \\
\hline & $0-20118$ & 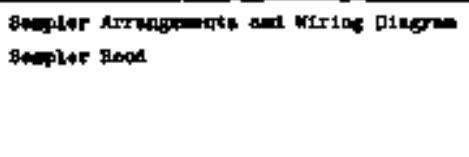 & 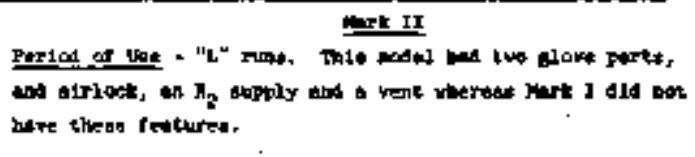 & . & \\
\hline
\end{tabular}


h. Discomecting ladle from reel wire; removing sauple from ledle; subultting sample for analyses.

Equipment modificet1ong necessitated minor changes in the procedure. For the complete procedure, see Sec, 4.?.

\subsubsection{Critical Operating Stepg}

a. Determining accurately the depth to lower the ladle.

b. Leaving the ladie in the molten salt long enough ( 20 seconds) to collect the semple.

c. Being careful not to kink the reel wire.

d. Being certain that the combination of excessive FV-100 vapor apace pressure and HCV-8 open would not cause a plus to form in the FV-100 $\mathrm{F}_{2}$ inlet line. (Sec. 5.4.18).

e. Agitating the melt adequately to ensure collecting a representative molten salt sample,

\subsection{Equiment Eveluation}

4.4 .1 Sampler Assembly, FV-900'

a. Sampier Reel and Pedestal

The sempler reel and pedestal were satiafactory an orloinally designed, and no change in them was made.

The reel wire was made of nickel. It was very sugceptible to kiniking unless great care was exercised in winding it on the reel. When kinked, even to a small extent, it was necessary to replace the entire length of wire to operate the gaxpler.

b. Iadle Guide Pipe

Model differences were:

Mark IA - Threaded joints in sulde pipe and urtapered shoulder at entrance to guide pipe from the fluorinator vapor space.

a Sec, 4.4,2e.

b sec. $4,4,1 f$.

c After the " $\mathrm{L}$ "rums, the sampling equipment was moted to Burial Ground No. 3 (Sec. $23.4 .16 \mathrm{~b}$ ). 
Mark IB - Butt-relded jolntg with grinding of welds where possible to eliminate internal shoulders (especially at $v-88$ and the adjacent tee) and tapered shoulder at gatde pipe entrance from the fluorinator vapor space.

These refinements reduced hang-ups of the ladie in the guide tube. Previously hang-ups consumed considerable time, especially at times when attempting to pull the filled ledle from the fluorinator vapor space into the guide tube (Sec. 5.4.1e).

\section{c. Ladle-to-fire Connector}

The connector cauned the ledle to sink in the melt. While imbersed, the ladle filled with salt. The overwall length of the connector was varied between $2-1 / 2$ in. and $4-1 / 2$ in. Generelly, the longer heatler lengths were preferred because these caused the ladle to $\mathbf{s i n k}$ more quickly and presumably nore completely.

d. Ledle

More than ten ladle derigns described in Teble 4.1 were tried. The f1rst few deglgns were made of high-density graphite end the later ones of thin-wall copper tubing. The graphite ledles were very expensive because of the great amount of machinIng required. In addition, it was difficult to remove nolten salt samples from eraphite ladles without contandnatins the sample with graphite and spreading radtoactivity. The copper ladies were relatively inexpensive, and it was easier to remove samples from the copper ledles as well as to prevent sample contamination andor the spreading of radioactivity. The ladle in use when the plant was shut down after the " $L$ " runs was Mark IX (6, FIg. 9.1, p. 40). Although this ledle was the most satisfactory of all designs to date, removing the molten salt required careful handling and resulted in some personnel exposure to radiation as described in sec. 4.4.1r.

e. Sample Carrier

The semple carrier was not used because: (a) the radioactivity of the samples handled cound be successfully sttenueted using lead bricks inside the hood; (b) the Mark II hood design would not accomodate the semple carrier (This occurred because of the limited time evallable for designing the Mark II hood.); and

(c) the carrier did not contain a wire-cutting mechanisw.

f. Discussion

The MIT practice school at Oak Ridge conducted a sampling study using a graphite ladie whlch was helpful, but the sample contalned graphite from the ladie. (14). 
The changes made in the sampler assembly improved its operability. However, these shortcomings were retained:

(1) Two men were required to operate the sampler beceuse of the necessity for carefully threading the ladle into the gutde tube from point of entry until the ladle passed through $\mathrm{V}-88$, Whereas it was physicaliy possible for one man to operate the molten salt sampler, this constituted a difficult and time-consuring task because of the position of the reel toggle switch relative to the gloved entry into the sampler hood. A ginor redesion could heve remedied this situstion.

(2) One-hslf hour was consumed per semple, princlpally because of the slow speed of the reel. Providing a twospeed reel could reduce the time per somple considerably. The fast speed would be used while the ladle was in the guide tube except near V-88. However, using the fast speed would accentuate the wire-kinking problem at the reel.

In a technique used to reduce the sampling time, nore than one ladle was atteched to the reel wire. Although this scheme has been used successfully, it was subject to these troubles: (a) jamming of the ladleg in the guide tube and (b) incompletely filling the ladiles with salt. Therefore, this technique was never widely practiced。

(3) Some trouble was sttll experienced with the ladle hanging in $\mathrm{V}-88$ despite uring a gete valve and providing as mucb open area as posetble in the ladle gutde tube. Mast of the hang-upg were apparently within the valve body which probably could have been reduced by using a larger valve.

(4) Removing the salt sanple from the ladie was not only t1me consuming but also a radiation hazera to personnel. In the best method found, the ladie was hammered while contained within a piece of Tygom tubing closed at the ends, The powdered salt formed was poured as accumulated into the plestic bottle in which the semple was submitted for analysis. The sdvantage of the simplicity of this method was reduced by the rediation exposure recelved by the personnel. In one of the other methods tried, the entire copper ladle and sample were dissolved. Although this method was the simplest for pilot plant persomel and colld be used with little radiation expostre, the entire sample was difficult to dissolve. 
(5) The nickel reel wire tended to kink unless handled very cerefully.

Whether representative samples were obtained with the molten salt sempler was questionable. In a waste salt sampling gtudy, differences in analyses among three kinds of semples ( $(\mathrm{c})$ sempler, (b) flowing stream, and (c) waste can half-section indicated that the sempler results were low in urantum (15). This finding Initiated fluorinetor mixing study which showed that conical bottom with center-spaced draft tube should produce adequate agitat1on (16). Ho comparative sample work has been performed on feed salt samples.

Dupl1cate feed salt samples varied $\sim \pm 1 \phi(\sim \pm 0.05 \mathrm{mg} / \mathrm{g})$ and waste salt samples $\sim \pm 20 \%(\sim \pm 0.001 \mathrm{mg} / \mathrm{g})$. The high percentage deriation for the weste semples was attributed to the very low $J$ concentration and to the method of enalysia (15).

\section{4 .2 Sampler Hood, FV +995}

Nodel differences Were:

Mark $I$ - No $N_{2}$ supply, rent, a1r-lock, or glove ports。

Mark II - $\mathrm{H}_{2}$ supply, vent, air-lock, and glove port $\mathrm{B}$.

These refinements to the sempler hood reduced not only the time required to take samples in the " $\mathrm{B}$ " and "L" runs but also the radioactivity received by personnel and the release of $\alpha$ contamination in the Penthouse. The sources of air-bourne $\alpha$ were: (a) Fu added to runs $L-3$ and $-4, I-6$, and $I-8$ and (b) residual $U_{6}$ in the ladie gutde tube.

\subsection{Surmary and Conciusions}

The assemblage of the followine components produced a molten salt aampler which was suitable for taking feed salt and waste salt samples in the " $L^{\text {" }}$ runs: (a) pedestal and reel, (b) Mark IB ladle guide pipe, (c) 4-1/2in, ladle-towre connector, (d) Mark IX ladle, and (e) Mark II saupler hood. Its chief disadvantages were: (a) it required two men to operate and (b) one-half hour was consumed per sample. This high unit sample time could be reduced by filling more than one ladje at a time, a technique which was not entirely satisfactory. The time required for sampline was $w 2 \mathrm{hr}$.

Eliminating shoulders in the gutde pipe at the valve ( $V-88$ ) and at the fluorinator end of the guide plpe retuced hang-ups of the ledle.

The sample carrlex was not used because it contained no wire-cutting device and because there wes 1nsufficlent time to fit it into the Mark II bood design. Actually, the carrier was not needed to reduce personnel exposure to rediation since this was done with lead bricks.

Analyses of waste salt samples taken in different ways left doubt as to the validity of ladle-arawn samples. No such work was done with feed salt samplea. 
The variability of auplicate feed salt samples was $\pm 1 \%(n \pm 0.05 \mathrm{mg} / \mathrm{g})$ and of duplicate waste salt amples $v \pm 20 \%(\sim \pm 0.001 \mathrm{mg} / \mathrm{s})$.

\subsection{Recormendations}

It is recomended that:

a. Any new design using the ladie sampling method require only one operator ano include: (a) a lerger velve in the ladle guide pipe, (b) a means for remote renoval of the sample from the ladle, $\langle c\rangle$ a two-speed ladle trevel as described to reduce the untt sample time, and (d) shielding otber than by lead bricks to enable handing samples of higher activity.

b. Further stury be done on the validity of waste salt samples taken by the ladle method and study also be done on the validity of feed salt samples taken by this method.

c. A study be performed to see whether the method of molten salt sampling should be changed.

4.7 Pperating Procedure: Molten Salt Sampling

FSP

Date

T1me

Operator

\begin{tabular}{l} 
2. Recond LR-2 reading \\
2. Compute density of liquid: $\$$, DR-2 reading \\
\hline
\end{tabular} 0.005 .

$$
(\mathrm{DR}-2 \text { reading })(0.005)=(\ldots)(.005)
$$

II

3. Add 3,0 to answer in (2) to give actual dengity. $3.0+\quad=\quad$ (Should be between 3.0 and 3.5).

4. To correct tR-2 liquid level for this density, divide the of reading on $L R+2$ by the answer in (3).

Corrected level $=\frac{(\text { LR - 2\$) }}{\text { Density from }(3)}+($ - $)=$

5. To obtain cil of salt multiply answer in (4) by 2.03 . ( ) $2.03=$ sm of salt.

6. Obtain sampler counter correction by subtracting "cm of Balt" from 708.

$708-(\mathrm{cm}$ of salt $)=708-(\quad)=$ is counter correction

7. Fise toggle switch of fluorinator sampler pedestal unt1l connector bits the stop.

$$
\text { Counter reading }=
$$
cm.

8. To celculate counter reading when leale is 1muersed, subtract counter correction calculated in step (6) fron counter reading in step (7).

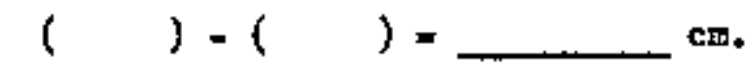


9. Set $\mathrm{FV}-50$ on 2 polg. Close V-129

10. Check that hood is securely in place and both doors of air-1ock are closed.

11. Open V-8TC and partially open $V-87 B$ unt11 PI -52 reads $1-1.5$ inches of water.

12. Open V-119 until PI-51 reads about 1 inch of water.

13. O en V-88__. Regulete V-87B to matrtein 1 inch of water on PI-51.

14. Depress toggle switch to lower sample ledje.

15. When coumter reass the number in $(\vec{B})$, release the toggle switch.

16. Wait 20 seconds, then rajse toggle stritch to retrieve sample ladle.

17. Close $\mathrm{V}-86,-87 \mathrm{~B}$

18. Partially open V-li29 and-119 vacutm.

19. Disconnect wite and place ladle and whe In air-lock. Close Inner door

20. Open outer dow and retrieve sample.

21. Attach $14-1 / 2$ in. of 20 -gauge nickel wire to ladle ans place in air lock

close outer door into connector and tighten set screws

22. Repeat sampling as per runsheet - record data below:

Date

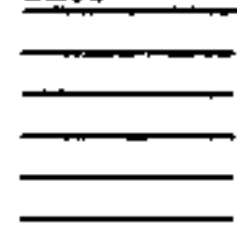

Tyme

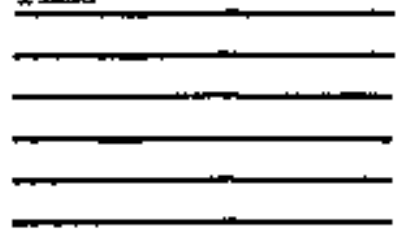


5.0 Fluorinating system $\ldots \ldots 37$

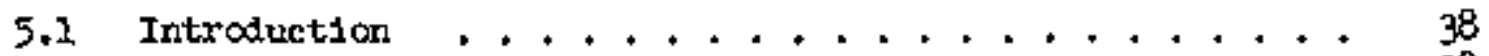

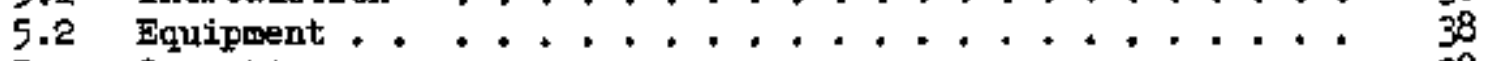

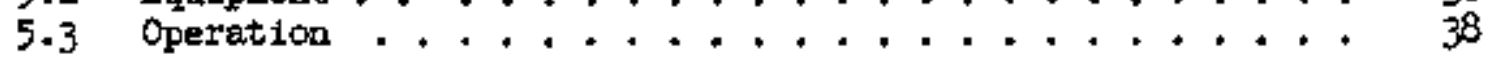

5.3.1 Operating Procedure. . . . ........ 38

5.3 .2 critical Operating steps .......... 42

5.4 Equipment Evaluation ................ 43

5.4 .1 Fluorinator, $5 v-100 \ldots 4 . \ldots . \ldots 4$

a. Model Differences - Mark I and II .... 43

b. Model Differences - Mark IIA and III .... 45

c. Plug Formetion ............ 45

d. Corroston Detk ............ 47

5.4.2 Fluorinator Furnace Lines, Fv-101 ........ 48

5.4 .3 Fluorinator Furnsce, Fv-500 ......... 48

5.4 .4 Fluorinator Furnace Lift, Fv-910 ...... 49

5.4 .5 Fluor inator Lower Mantle Heater, FV $-501 \ldots 49$

a. Model Differences - Mark I and II ..... 49

b. Discusston ................... 49

5.4.6 Fluorinator Upper Mantle Heater, FV-501A . . . 50

5.4 .7 Fluorinator Instrumentation ......... 50

5.4 .8 Interlocks .................. 51

5.5 Summary and Conclustong ................ 55

5.6 Recorimendations .................... 56

5.7 Opersting Procedure; Feed Salt Fluorination ..... 57 


\subsection{FLUORINATTIG SYSTEM}

\subsection{Introduction}

In the fluorinating system, the urenium wes separeted from the nonvolat1le fission products and alt mixture congtituenta by volatilization as W. Some of the volatile fluorties of flation products and melt ingredients - $\mathrm{HF}_{4}$, $\mathrm{NbF}_{5}$,

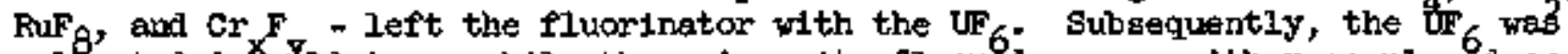
collected in cbid traps while these impurity fluorides were elther complexed on NeF beds or retained in the tail gas atream. The princlpal step in the operation of the fluoringting aystem was bubbling $F_{\text {e }}$ into the molten sait to effect the reaction, $\mathrm{UF}_{4}+\mathrm{F}_{2} \longrightarrow \mathrm{UF}_{6}$, until the urenim content of the salt was < 20 ppm. The operation was performed remotely.

\subsection{Equipment}

Figure 5.1. is the equipment arrangewent of the fluorinating oystem with the Mark I fluorinator. Two other vesgel designs (Marke IIA and IIB) have al been used. The princtpal differences awong the three models are recorded in Secs.5.4.1a and b. Details relative to the fluorinator and its auxillary components are listed and described in Table 5.1.

\subsection{Qperation}

5.3.1 Operating Procedure

Steps in operating the fluorinating ayatem were:

a. Maintaining the temperatures of the feed salt $(\sim 150 \mathrm{~kg}$ of $\sim 50$ $\mathrm{M}$ \& $\mathrm{Nar}-46 \mathrm{ZrF}_{4}-4 \mathrm{t}_{4}$ ) in the Pluorinator at $-600^{\circ} \mathrm{C}$, the CRF trap at $\sim 400^{\circ} \mathrm{C}$, the heated duct at slightly $>65^{\circ} \mathrm{C}$, and both absorbers at $65-75^{\circ} \mathrm{C}$.

b. Putting the necessary instrumenta and charta in service and establishing all $\mathrm{k}_{2}$ purges uging 4-1/2 paig $\mathrm{N}_{2}$.

c. Sampling the feed galt (Sec, 4).

d. Setting ralves as required and seeing that the cold traps were at operating temperatures.

e. Aacertalning that Ff -124 end FV-158 were fllled with NaF pellets and that FV 650 vas running.

f. Makins certain that the scrubber vas operating normally, and that there was adequate scrubbins sapacity for a normal fluorination (sec, 11.3.1).

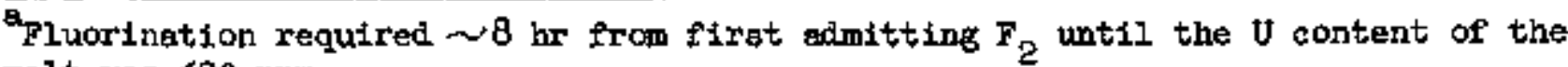
melt was <20 ppm.

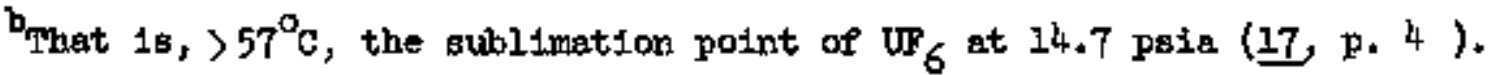




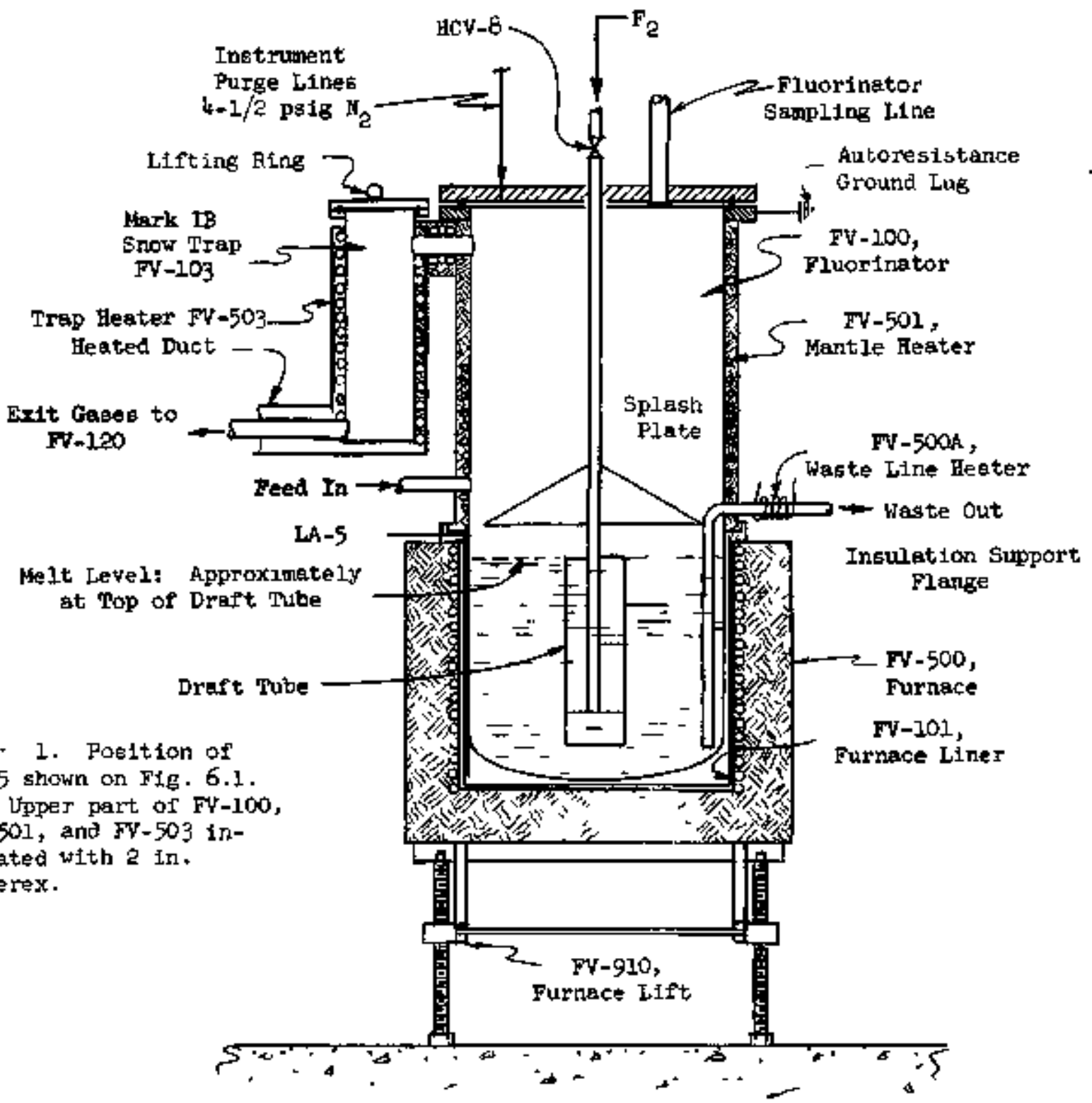

Fig. 5.1. Equipment Arrangement in the Fluorlobting System (Mark I FV-100) 
Thes 5 20 5

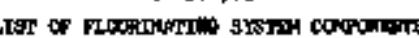

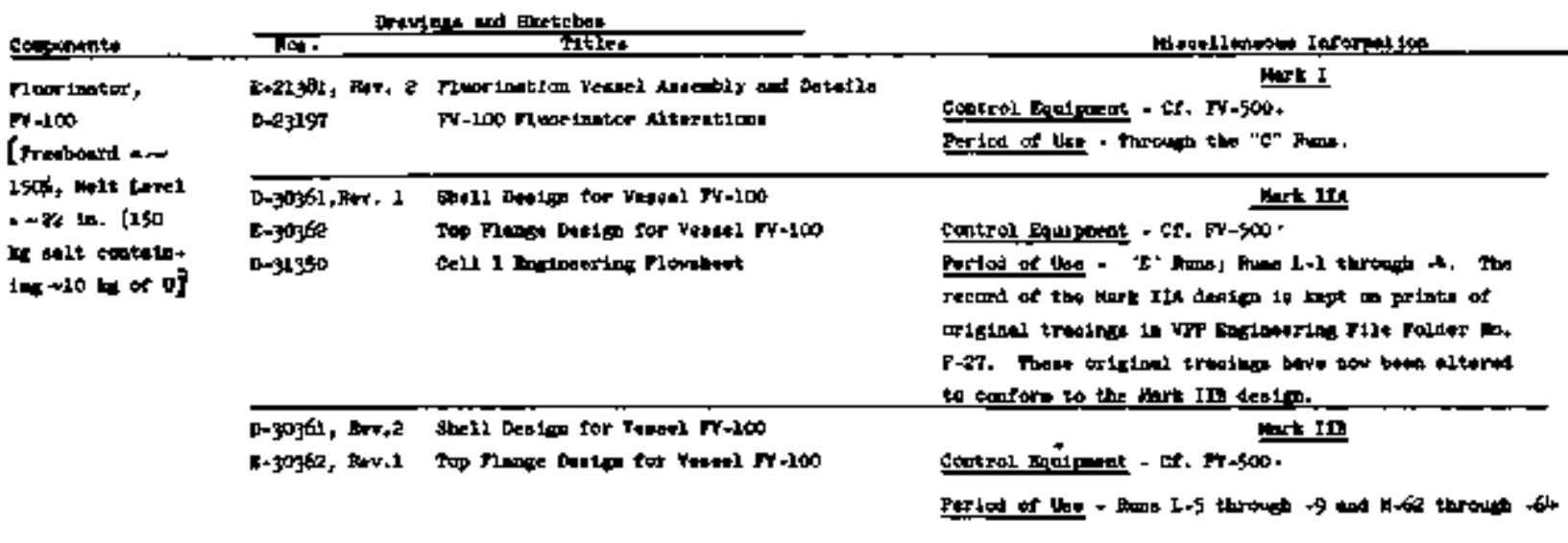

\begin{tabular}{|c|c|c|c|c|}
\hline 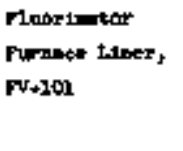 & D-19703 & 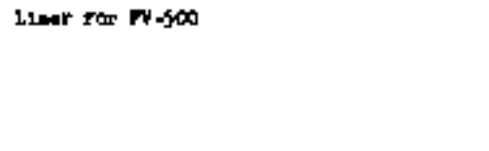 & 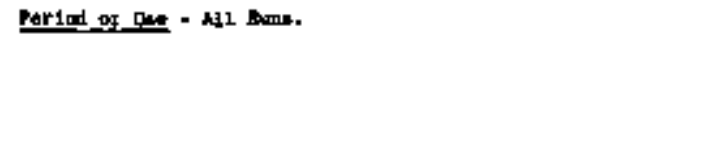 & 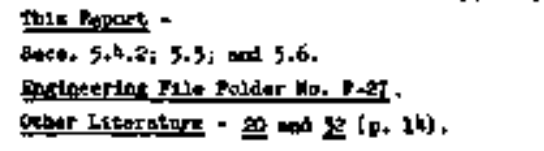 \\
\hline $\begin{array}{l}\text { Purters } \\
\text { Ft-900 }\end{array}$ & 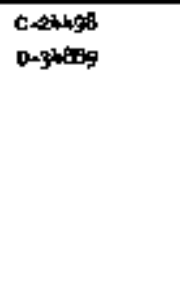 & 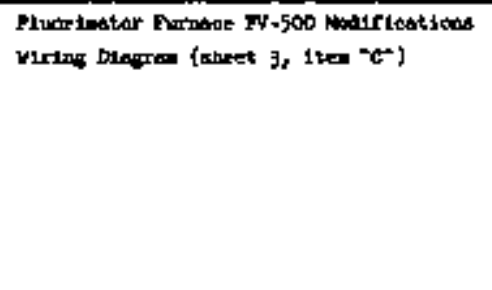 & 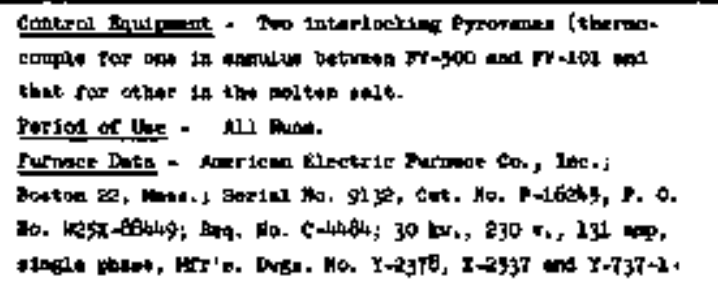 & 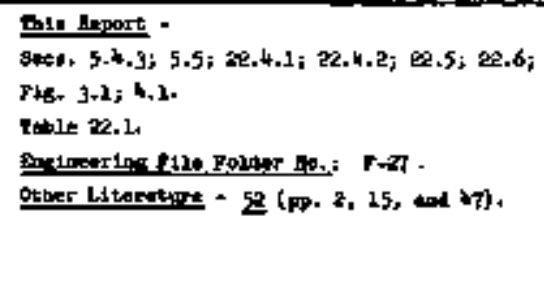 \\
\hline \multirow[t]{2}{*}{ 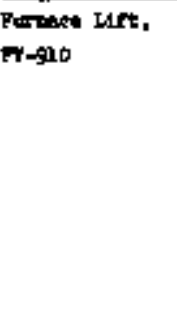 } & 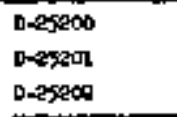 & 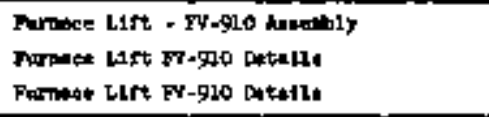 & 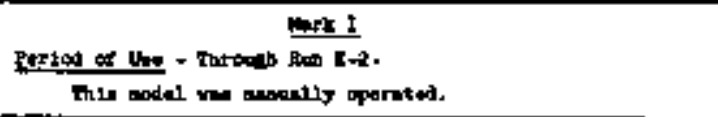 & \multirow{2}{*}{ 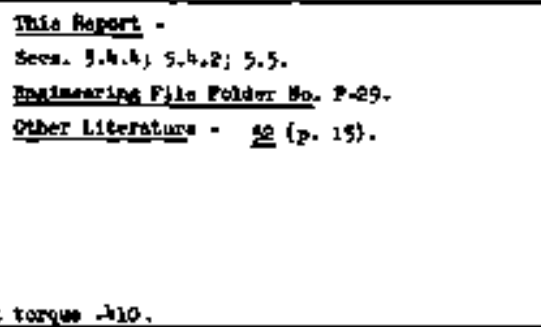 } \\
\hline & 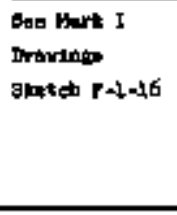 & 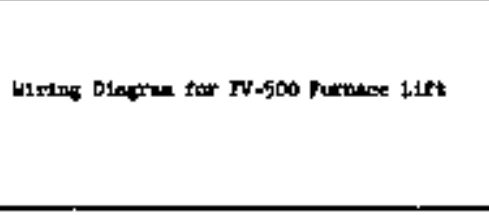 & 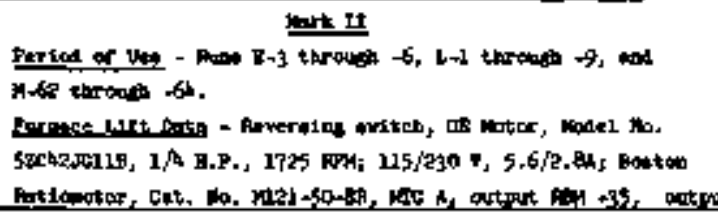 & \\
\hline
\end{tabular}

Thes Amport

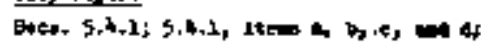
5.6.7; 5.4.5, 1taw b; 5.5; 5.6; 3.4.1; 3.5;

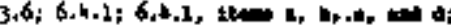
$6.4 .4 ; 13+4.2,13.5 ; 13.6 ; 15.4 .4 ; 15.5$ $16,4,16,26.5,1931$ 21.4.4, 20.4.5, al .4.6. P195. 3+1 and 4,1 .

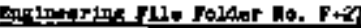

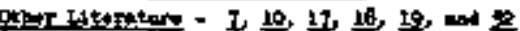
(19, 2, 14) 
Fable 3.1 (cantimund)

\begin{tabular}{|c|c|c|c|c|c|}
\hline \multirow{3}{*}{ 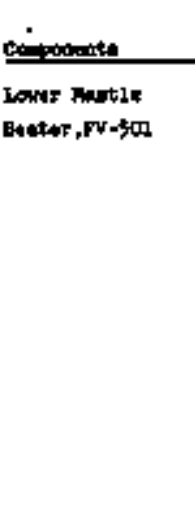 } & \multicolumn{2}{|c|}{ Draypes wa batabes } & \multicolumn{2}{|c|}{ 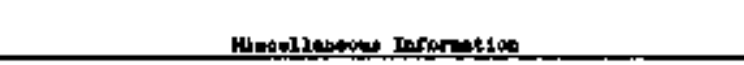 } & \multirow{3}{*}{ 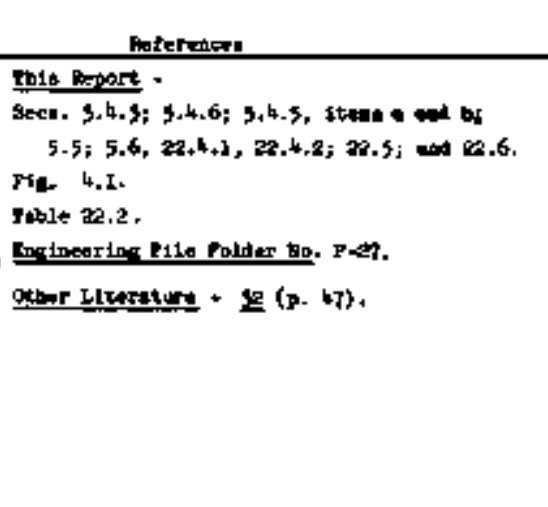 } \\
\hline & $\begin{array}{l}\text { D-ёतTा } \\
\text { D-2279s, Nor.1 }\end{array}$ & 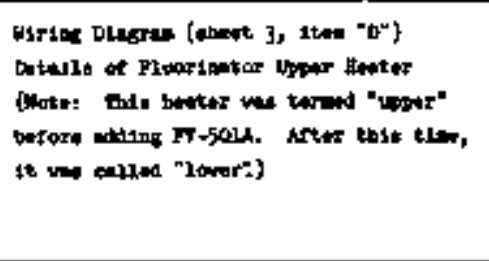 & \multicolumn{2}{|c|}{ 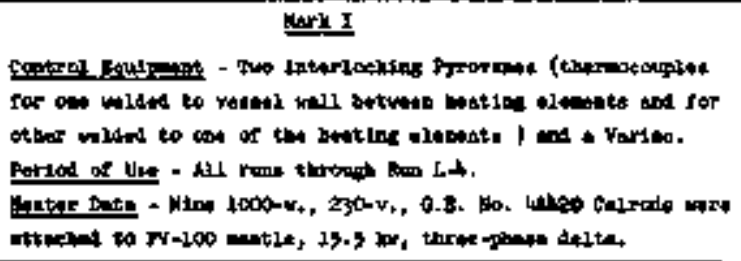 } & \\
\hline & D-36899 & 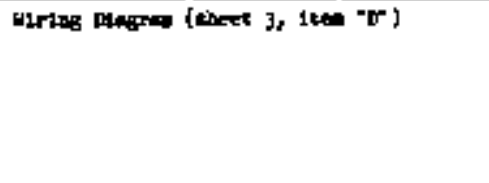 & \multicolumn{2}{|c|}{ 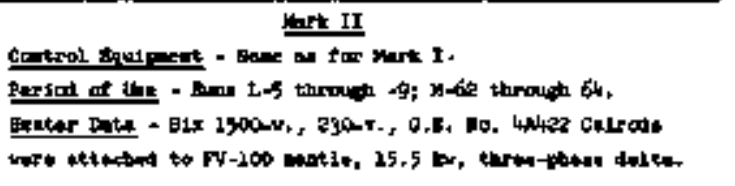 } & \\
\hline lootet, ro-sols & $0-3409$ & 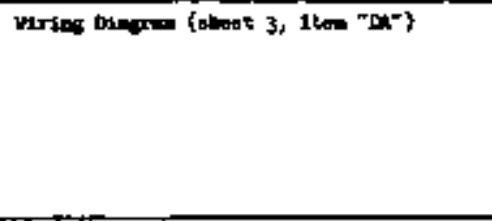 & \multicolumn{2}{|c|}{ 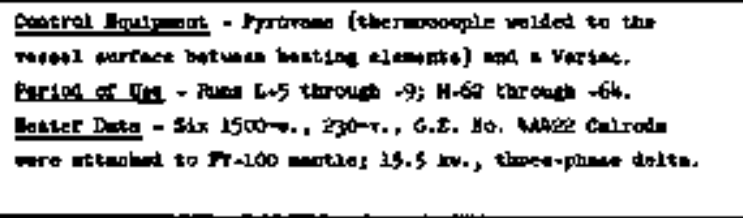 } & 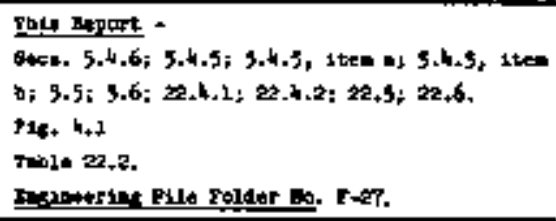 \\
\hline 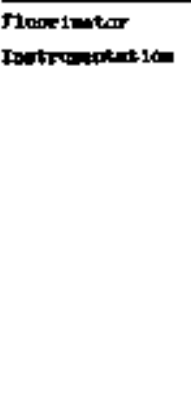 & $D-31350$ & Dell so. I meisenries howbiant & 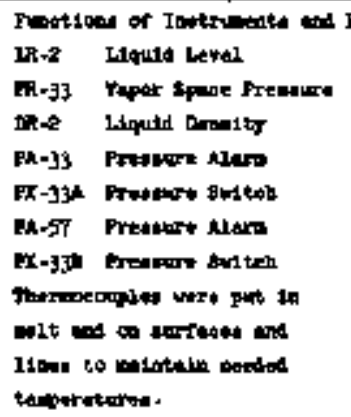 & 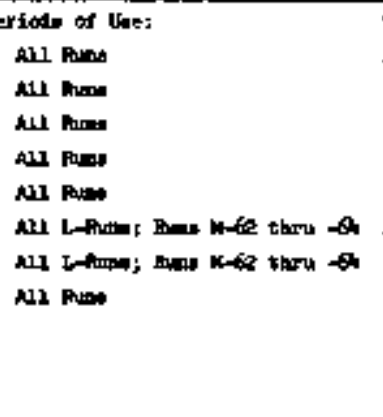 & 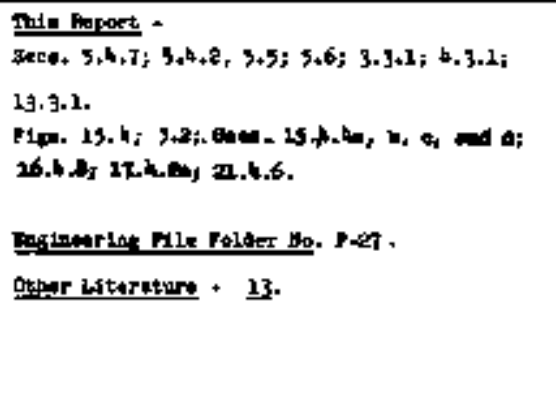 \\
\hline
\end{tabular}


8. Setting the $F_{2}$ flow rate to bubble $20 \mathrm{slm}$ of $F_{2}$ into the feed sa.l.t.

h. Cooling the first absoziber with compressed atr wen the temperature in that vessel increased. (A tempersture increase indicated that UF 6 was being sorbed by the NaF, Usually cooling the second absorber was unnecessary because easentially no $\mathrm{UF}_{6}$ passed through the IIrst absorber.)

1. Continuing to fluorinate unt1) the galt level recorder (IR-2) indicated a decrease of 6.5 chart divisions. (Thia desrease in liquid level occurred while $\mathrm{tP}_{6}$ was being volatilized from the salt, reflecting a change in density rather than in melt level.)

j. Sampling the wate salt. (Sec. 4).

k. Refluorinating at 20 elm for one hour.

1. Sanpling the vaste salt.

m. Fiepeating atepa $\mathrm{j}$. and $\mathrm{k}$. until the $\mathrm{U}$ content of the waste aalt wes approximately $20 \mathrm{ppm}$.

System modificetione necesaitated only minor changes in the procedure. For the complete procedure, see Spc. 5.7.1.

\section{3 .2 Critical Operating Stepe}

e. Keeping the fluorinstor pressume below $\times 3$ psig to reduce the tendericy to form plugs in the $F_{2}$ inlet ilne.

b. Maintaining the heated duct temperatures $265^{\circ} \mathrm{C}$. to avoid condensing $\mathrm{UF}_{6}$ in line $\mathrm{B}-103-1$.

c. Holding the $\mathrm{OH}^{-}$and the $\mathrm{F}^{\boldsymbol{}}$ concentrations in the serubber at $\geq 1.0$ molar and $\leq 1.0$ molar, respectively, to aroid pasaing $F_{2}$

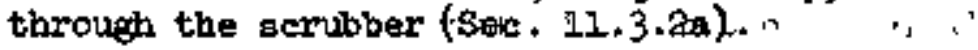

d. Making certain that the U content of the waste salt was <20 ppm before finlshing the fluorination step.

e. Cooling the first absorber with air to keep itg temperature below $120^{\circ}$ to $150^{\circ} \mathrm{c}$. and, therefore, winimize the tendency to decompose the UF $6 \cdot 3$ HaF complex.

f. Holding the CRP trap temperature at $\sim 400^{\circ} \mathrm{C}$. to reduce $\mathrm{UF}_{6}$ absorption and/or $\mathrm{UF}_{5}$ formation.

g. Keeping cold trapg at operating temperatures. 
5.4 Equipment Braluation

5.4 .1 Fluorinator, FV-100"

a. Model Differences - Mark I and II

1. Positions of off-gas line and CRP trap.

Mark I: Off-gas line was on the northwestern side of the vessel near the top of the vessel.

Wark II: In the northwestern quandrant of the top flange.

In both cases, the CRP trap was located in the off-gas line within a few inches of the vessel. In Mark I, the aide position of the CRP trep offered no possibility of dumping 1t; contents into the molten salt vithout physically handing the trap packing material. In Mark II, CRP trap dumping, although physically posalble, failed because of two factors: (a) the NeF pellets agglomerated, and (b) the dumping and/or bed vibrating mechanlin (Syntron) was inadequete.

2. Vesael wall thicknesses at the supports.

Hark I: $1 / 4 \mathrm{in}$.

Mark II: $1 / 2$ in.*

During the "c" mus, the metal cross-section of the Mark I vessel uarped, becoming slightly elliptical. This condition was most severe at the aupport ears where internally the major diameter (on egst-west line) was $13.513 \mathrm{in}$. and the minor diameter was 13.217 1n. In Mark II, increasing the wall thickness at the support eara to $1 / 2-i n$. evidently eliminated the vessel warpage since the metal cross-section remained circuler.

3. Locations of the autores1atance ground lugs for anlt transfer lines.

Mark I: Individual ground lugg were placed near the vessel wall on each salt line.

Mark II: Common ground lug wes placed on the lower veagel flange.

Placing the autoresiatance ground luge on the molten salt lines adfacent to the vegael wall effected cold apots

after use, all equipment exeept the furnace lift was moved to Burial Ground No. 3 (sec. $23,4.16 \mathrm{~b}$ ). The furmace lift was retained for future processing. 


\section{$-4+$}

at these locattons and, therefore, interfered with salt transfers in the feed and waste lines. In kark Ir, a common gxound electrode for all tranter lines welded to the lower vessel flange apparently corrected this trouble."

4. Hickel pipe stub lengths in waste and tranafer line at the fluorinator wall.

Mark I: 2 -in. long.

Mark II: 1/2-in. long.

For botb Mark I and II, the nickel pipe stub in the waste salt trangfer line at the FV-100 wall created a cold spot whlch was heated to the desired temperature with FV-500A as described in Sec. 13.4.2.

5. Spleah plate and draft tube.

In Mark IIA, the aplash plate was ralsed 5 In. and the draft tube shortened 4 in. with the total diatance between the botton of the splash plate and the top of the araft tube belng 9 1n. Greater than in Mark $I$. Changing the relative locetions of the splash plate and draft tube produced no known effect on fluorine constmption, fluorination time, CRP trep plugging, or vessel vall encrustations.

6. Vessel accesges,

Mark I: Accesa was obtained only by removing the top llange.

Mark II: Ijw1ted access was possible through the band-hole incorporated in the top flenge.

7. Lower end of molten salt sampler guide pipe (at bottor of FV-100 top flange, Sec. 4,4,1b).

Mark I: Square end caused ladje to hong on escent.

Mark II: Tepered end eliminated hanging of the ledle at this point.

a Secs. 3.4.1, 13.4.2, 21.4.1, 21.4.3, 23.4.4, 21.4.5, and 21.4.6.

b The Mark I dispersion nozzle show on DMg. E-2l381 was a UNOP model and was never used at the Pllot Plant. The draft tube of Dwg. D-23197 was the Nerk II design of the gas atspersion device. 
b. Model Differences - Mark IIA and IIB

1. Splash plate and draft tube.

Mark IIA: Splash plate; 4-1n. NPS draft tibe,

Mark IIB: No splash plate; 3-1n. NPS draft tube.

Th1s change produced no known effect on $F_{2}$ consumption, fluorsnation time, CRP trap plugging, or veseel wall deposits.

2. Instrument purge line tips.

Mark IIA: Line cut $15^{\circ}$ to the horlzontal per Dwg. E-30362. Mark ITB: Internally tapered end per ${ }^{1}$ wg. B-30362, Rev. 1.

The tapered tips of Mark III apparently reduced salt pluge in instrumeut purse ines.

3. Corrosion spectuten nipple lensths were:

Hark IIA: 2-1/e-in. long.

Wark IIB: 7-1/2-to 9-1/2-in. 10mg.

Increasing the distance of the swagelois threed from the top flange virtually eliminated thread galling.

4. Top flange and hand-hole cover flange leak detector connections.

Mark IIA: Fone

Mark IIB: Comnections were alded.

Incorporating the FV-100 top flange and the tand-hole cover flange in the leak detector system enabled continuousisy monitoring the top flange for leaks. See Bec. 1.8.3, Ftg. 18.l, and Table 18.1 for further detalls.

c. Plug Formation.

1. The fluorine inlet line.

Most of the inlet line plugs apparently. stemmed from inaloperetion and from the faulty design of other aystem components instead of from inedequate fluorinator design. Therefore, attempted remedies involved improving operating techniques and altering the destons of other systems rather then that of the fluorinating system. Examples of this were:

a For the Nark II vessel, a aeveral in. bed of loose asbestos cement was placed

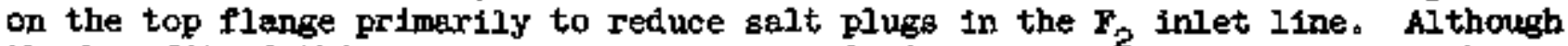
the benefit of this measure was not assessed, it was apparently much less than that atteinable by eliminating maloperation. 
(a) the HCV -7 and -8 interlock switch-over at $\sim 8 \mathrm{psig}$ as discussed in Sec. 5.4.7 and (b) the $\mathrm{N}_{2}-\mathrm{F}_{2}$ dnterlock described In sec. 15.4 .4 . The inlet line plugs resulting fron the $\mathrm{H} 1 \mathrm{~F}_{2}$ prec1pitation during Run $\mathrm{I}-4$ vere exceptions to the above coment sbout inlet line plugs. At thst time, plugs also occurred in the fluorinator instrument probes, the CRP trap, and the wate line ag mentioned in Sec. 13.4.2. This material wes difficult to remove from the fluorinator. In fact, removel required transferming through an instrument probe as much as possible; freezing the salt; remoring the top flange after cutting the dip tubes; and chlpping out the herd mass with a hand chisel and tack hammer. While thus removins the selt, dished head scars $\sim 125$ milg deep with external bulges of $\sim 1 / 16 \mathrm{in}$. maxtmum were made. This damege did not affect the utility of the vessel during the five remaining "L" runs and Runs $\mathrm{M}-62,-63$ and -64 .

2. The fluorinator ingtrument probes.

Instrument probe plags were belleved to be elonificantly reduced by using the tapered tips referred to in Sec. 5.4.1e. .

3. The CRP trap.

The inlet and outlet tubes uged in the Mark II CRP trap were erroneously thought to have eliminated CRP trap plugging in the last four " " runs becauge CRP trap plugging again became chronic during the first four "L" mms (Sec.6.4.1e). In addition to the inlet and outlet tubes, a CKP trap bypass line (wIth heeter FV-500B) was Installed between Rums E-2 and -3 (Sec. 6.4,4).

Gas entrainment studies (Runs $\mathrm{H}-62$ through -64 ) in the Mark II fluorinator Indteated that: (a) the upper section showld be at a temperature of $400^{\circ} \mathrm{C}$ or lower to minimize entrainment (18), (b) similar studles should be mede in a new-design vessel ( 18$)$, and (c) freezing and remelting a fuil salt charge ( w150 kg) produced no know vessel damage.

Attempts at fluorinating through the waste line have not been entirely satisfactory. In fur $L \mathscr{L}$, for example, the entire fluorination was performed through the waste ilne with ifttle difflculty and with no apparent ohange in eluorine consumption. In Run L-9, however, fluorinating through the

a Only about $1 / 4$ of the salt wes removed in this way because a hole in the purge Ine several inches below the orlginal salt level stopped the transfer. 
waste line was unsuccessful beceuse the desired fluorine flow rate could not be maintained. Although no known differences in the condition of the waste line for the two runs existed, a plug was believed to have formed in the unheated section of the waste line above the melt level as mentioned In Sec. 13.4.2. In both the Harke I and II vessels, a ris of salt solidified internally a few inches above the melt level. This solidifled salt probably contributed to the plugs in the waste line above the melt level which were mentioned above in this section and in Sec. 13.4.2. Such a situation could present a serlous problem during decontaminetion after processing highly radioactive salt mixtures. In the Mark I design, this was not deemed of major concern because of the low activity of foreseesble feed selts. Consequently, no effort was expended to eliminate this rim. In the Mark II design, however, the mantle hester was redeslgned, this measure being partially effective es delineated in sec. 5.4.5b.

\section{d. Corrosion data.}

Fluorinator corrosion data vere (7):

1. Mark I Vessel.

Service conditions (all work through " $\mathrm{C}^{1 /}$ runs): Totel time, $\sim 1160 \mathrm{hr}$ including $\sim 61 \mathrm{hr}$ w1th $\mathrm{F}_{2}$; temperature range, 600 to $725^{\circ} \mathrm{C}$; selt, $\mathrm{NaF}-2 \mathrm{xF}_{4}-\mathrm{UF}_{4}$.

\section{Findings:}

(a) Maximum attack was in the vapor phase.

(b) Maximum thiclmess affected was 73 tills of which 47 mils was metal loss, 21 mils was intergranular penetration of the interior surface, and 5 mils was intergranular axtdation of the exterior surface.

2. Mark II Vessel and Internsl Fipes and Tubes.

Rather severe corrosion occurred on the intermel well of the Mark II fluorinator and on its internal components. The attack was mostly intergranular in nature and was considerably more severe where the metal was contected by the molten selt. It was thought that sulfur, occurring as a contaminant in the molten salt, was responstble por the intergranular penetration. In the three phases of experiments

${ }^{\text {a }}$ A record of docontaminating practices is in Seca. 23.4.15b and 23.4.150. 
conducted with the Mark II vessel, the two most significant factors corrostonwise seemed to be: (a) the time of exposure at temperature to walten selts, and (b) the amount of fluorine sparged through the salt. Further detail is available elsewhere (19).

The stainless steel sheathed thermocouples used during the gas entrainment studies (Rums M-62 through -64 ) corroded badly both in the aalt and vapor apace. Although gevere corrosion was anticipated, stainless steel sheathed thermocouples were used because those with Inconel sheaths were unsvailable.

\section{Corrosion Specimens in Mark I and II Vesaels.}

A wide divergence in process conditions occurred. In general, corrosion was greatest at the alt-vapor interface. ITOR-2, IHOR -8 , Hydh -80 , Waapalloy, Hastelloy w, and 90 Ni-10 Co have shown promlse in individual teats and will be atudied further.

\subsubsection{Fluorinator Furnace Liner, FV-101}

The fluorinator furnace liner was never tested for its primary purpose, that is, to contain the fluorinator charge in case of resiel failure. Such a fallure did not occur. -

At times the liner shorted out $L A-5$ thereby falsely indicating a fluorinstor failure. Uaually this happened when the liquid temperature vas greater than the normal tetperature of $600 \mathrm{c}$. Consequently, lowering the fluorinetor temperature generally atopped the alarm.

Miasligmment of the liner with reepect to the furnace caused the lifer to contact the Mark II vessel in the southeastem quadrant. This fect probsbly caused the vessel to be hottest in that region, thereby explating why the greeteat corrosive attack on the Mark ITs ressel Was in that vicinity $(20,7)$.

\section{4 .3 Fluorinator Furmace, FV $-500^{9}$}

Th1s furnace was agtiefactory. The time-to $-600^{\circ} \mathrm{C}$, of the ressel was either $\sim 7 \mathrm{hr}$ in normal operation, thet is, wh the vessel expty, or $\sim 8 \mathrm{hr}$ starting with a $150 \mathrm{ks}$ charge of equimolar $\mathrm{NaF}-\mathrm{ZNF}_{4}$ at room tempereture.

In eooling the vessel, the furnace was lowered in five or more atepe to hasten cooling. The rapidity of furmece lowering was governed, however, by the appearance of the vessel. That 1s, lowering in each step was done only as long as the visible part of the surfece of the vessel wes at bleck

a

Table 2. 1 and 3eca. 22.4.1 and 22.4.2. 
heat. This limit on furnace lowering was necessery to avold undue thermel shock. In this way, the vessel temperature was reduced to esgentilelly room temperetire in $\sim 30 \mathrm{hr}$.

\subsubsection{Fluorinetor Furnace Lift, FV-910}

Both the Mark I (hand-operated) and II (power-operated) designs of the furnace ifft were setisfectory for raising and lowering $\mathrm{FV}-500$. Although the Mark II design eljminated the hard menuel work of Mark I, operating Mark II also necessitated entering the cell.

Cell entrance requiretwent in the Nark II design was deened necessary to adequately follow the ascent of FV -500 whereas remote operation might have resulted in equipment danege had the vessel contacted the liner. In the Mark IIB fluorinator, misal gnment occurred as delineated in Sec. 5.4.2. Later, however, when processing materlals of higher activity, remote operation w111 be mondatory.

5.4 .5 Fluorinator Lower Mantle Heater, FV-501

a. Model Differences - Mark I and II

The Nark I design is shown on Dwg. D-22785. In the Mark II design the heated portion of the vessel was effectively lowered a few inches from that achieved in the Mark I design, by bending the Cairods symotrically as ecoupered with the unsymmetrically bent Calrods in Mark I and then placing the bend against the FV-100 insulation support as compared with the "up" pasition of bends in Mark I. This arrangement lowered the hot portions of the Calrods to the vesael insulation support whereas in Mark I the necessity for bringing the celrod terminals away from the vessel for electrical, connections left geveral inches of the vessel surface above the inaulation support untouched by the hot Calrod surfaces. A compromise was mede in Calrod posttioning for the Mark II design. That is, the bottoms of the bends were put at the insulation support instead of a few inches lower as desired. This compromise was mede becaluse of the difriculty In removiag on slotting the aupport and the need for an insulation support.

b. Discussion

Both Maxk I and II were capable of heating the fluorinator well to $600^{\circ} \mathrm{C}$. The Mark II design heated a greater portion of the vessel surface to $600 \mathrm{C}$, thereby reducing the size of the rin of salt sbove the melt level. The time required to heat the vessel wall to $600^{\circ} \mathrm{C}$ was $3 \mathrm{hr}$. Thls time could be reduced by 
setting TIC-LA-11 oomewhat higher than the customary $650^{\circ} \mathrm{C}$. Eet point because of the 1nterlocking arrangement of this Pyrovane wth TIC-1A-8. Two thermocouples were used: one welded to the vessel surface at the Calrods and the other welded to one of the Calrods (Secs. 5.4.7 and 22.4.2).

\section{4 .6 Fluorlnator Upper Mantle Heater, FV-501A}

This heater was installed after Rin $\mathrm{L}-4$ to keep the upper 15 inchee of the fluorinator vessel at $450^{\circ} \mathrm{C}$. to reduce the emount of $\mathrm{ZrP}_{4}$ entering the CRP trap and prerent UF 6 sorption by salt spatterings on this section of the fluorinator. This heater was not needed, however, since the upper 15 inches of FV-1,00 could be kept at $450^{\circ} \mathrm{C}$. Without using FV-50LA. In addition, no heavy aalt or $\mathrm{ZrF}_{4}$ depostis collected on the upper portion of FV-100 nor on the top flange. Whether the antount of $2 \mathrm{FF}_{4}$ entering the CRP trap decreased was not ascertained.

\section{4 .7 Fluorinator Instrumentation}

LR-2, a pdematic-type instrument, monitored the liquid level in the fluorinator. The liquid level data were used for: (a) charging the fluoxinator, (b) celculeting the ladle depth ${ }^{\prime} g x$ molten salt sampling, (c) 'termsnating the first fluorination of a batch, and (d) Btopping the veste sal.t transfer. $\mathrm{f}$ LR-2 was almoat indispensable for both operations and data work.

LR-2 was relatively gatisfactory although it was out-of-service about one-tenth of the time. These operational difficulties occurred:

a. The high-pressure purge line plusged. The tapered tipe added to the sukmerged purge lines in the Mark IIB vegsel apparently reduced the number of ingtrument purge line plugs.

a Table 22.2 and Sece, 22,4.1 and 22,4.2.

$b$ Ref. 23 for details of Inatrument components (Sec. 14.4.5).

c

Sec. $3 \cdot 3 \cdot 1$.

d

Secs. $3 \cdot 3 \cdot 1$ and $4 \cdot 3 \cdot 1$.

e The flrst fluorination for each batch was stopped when the LR-2 resding decreesed 6.5 chart divisions (Sec. 5.3.11).

1

Sec. $23 \cdot 3 \cdot 1$. 
b. The calibration vas changed by both vessel and purge line corrosion. An example of such a change in calibration oceurred with Merk I vessel during the " $C$ " runs.

c. At times during meloperation, $F_{2}$ and/or $\mathrm{F}_{6}$ flowed through the low-pressure purge line to the fuin Transmitter Rack. This occurred when the presaure in the rapor space was greater then that of the purge nitrogen.

d. The reding was spurlous wh vapor space pressures greater than \%-l/2 psig because thie nltrogen purge flow was intexrupted.

PR-33, a pneumatic-type instrument, reconted the pressure in the FV-10O vapor space and wea necessary both for operetions and data work. Little trouble wth it occurred although it was possible for $\mathrm{F}_{2}$ end/or $\mathrm{UF}_{6}$ to flow through the purge line to the Main Transmittêr Rack as for IR-2. Its "down-time" was pract1celly nil.

$\mathrm{DR}-2$, a penumatic-type instrument, recorded the density of the molten salt. It was used for: (a) calculeting the ladie depth for molten salt sampling (Secs. 3.3.1 and 4.3.1) and (b) determining the terminetion of the first fluorlnation for eech batch (Sec. 5.3.1). DR-2 was more troublesome than IR-2, having been out-of -aervice about half-time. The operational troubles with DR-2 were similar, however to those with LR-2. In addition, melt solidffication could effect the rupture of the DT-2 bellows umless the instrument equalizing valve was open (Sec. 16.4.8). The 1mportance of removing a density instrument from service when the high-pressure probe wes thought to be plugged, and also when sait was frozen in that vesael 1s mentiomed in Socs. 14.4.5 and 16.14.16. Generajly, instriment purge line plugging with If -2 was more frequent than with tR-2 since DR-2 had two submerged purge lines to one for $I R-2$. The $h 1 \mathrm{gh}$ "down-time" of $\mathrm{DR}-2$ necessitated learning bow to operate without 1t. Even though the Iluorination could be performed without it, density data wexe helptul in deta-work.

\section{4 .8 Interlocks}

Interlock date are given in Table 5.2. Prior to interlocking HCY-7 and -8 , these valves were opereted Independentiy and plugging of line $X-100-1$ was more frequent. $P A-33$ and $P X-33 A$ were helpful sefety features on the fluorinator during the pilot plant work to date. In the future, however, when the CRP trap plugging problem is solved, these instruments thay not be needed.

As for PA-33 and PX-33A, FA-57 and FX-33B may not be needed when CRP trap plugging is eliminated. In one or two runs, PX-33B was disconnected 
Table 5.2

INTERLOCKS AFFECTING FLUORTMATTON ARD/OR FUUORTRE FLOW

\begin{tabular}{|c|c|c|c|}
\hline Valve or Instrument & Action & Purpose & $\begin{array}{l}\text { Operditonal } \\
\text { Phase Used }\end{array}$ \\
\hline HCV -7 and $-8^{2}$ (See FIg. 5.2) & $\begin{array}{l}\text { HCV }-7 \text { was closed when }-8 \\
\text { was open and vice versa; } \\
\text { operated either manually } \\
\text { at Wain Panelboard or by } \\
\text { FX-33A. }\end{array}$ & $\begin{array}{l}\text { To enable fluorinating and } \\
\text { to reduce line } X-100-1 \text { salt } \\
\text { plugs stemming from high } \\
\text { Fv-100 vapor space pressure. }\end{array}$ & $\begin{array}{l}\text { Waste salt transfer } \\
\text { Fluorination }\end{array}$ \\
\hline$P A-33$ & $\begin{array}{l}\text { Sounded when FV-100 vapor } \\
\text { space pressure rose to } 8 \\
\text { palg; reset then pressure } \\
\text { agata fell to } 8 \text { psig. }\end{array}$ & $\begin{array}{l}\text { To warn of high pressure in } \\
\text { vapor spece. } \\
\text {. }\end{array}$ & Waste salt transfer \\
\hline $\mathrm{PX}=33 \mathrm{~A}$ & $\begin{array}{l}\text { Overrode panelboard control } \\
\text { of BCV-7 and -8 by closing } \\
-8 \text { and opening }-7 \text { when vapor } \\
\text { space pressure reached } 8-1 / 2 \\
\text { psig; then prespure again } \\
\text { fell to } 8 \text { palg, swltch reget. }\end{array}$ & $\begin{array}{l}\text { 'To reduce line } X-100-1 \text { salt } \\
\text { plugs steming frojn bigh } \\
\text { FV-100 vapor space pressure. } \\
\text { ' }\end{array}$ & Waste galt transfer \\
\hline PX-33B & $\begin{array}{l}\text { Cutoff } F_{2} \text { flow when the } \\
\text { Fv-100 vapor space pressure } \\
\text { rose to } 4-1 / 2 \text { psig; when } \\
\text { this pressure again fell to } \\
4 \text { psig, reget. }\end{array}$ & $\begin{array}{l}\text { To reduce line } X-100-1 \\
\text { pluge stemming from bigh } \\
\text { FV-100 vapor space pressure. } \\
\text { ' }\end{array}$ & Fluorination \\
\hline $\mathrm{PA}=57^{\mathrm{b}}$ & $\begin{array}{l}\text { Sounded when PX- } 333 \text {, FX-57, } \\
\text { PX-58, PX-59, or PX- } 60 \text { cut- } \\
\text { off F flow; reset when } F_{2} \\
\text { flow started again. }\end{array}$ & To warn of $F_{2}$ flow cutoff. & $\begin{array}{l}\text { Fluorination or any } \\
\text { other operation } \\
\text { while } F_{2} \text { was flowing }\end{array}$ \\
\hline$P X-5 ?^{b}$ & $\begin{array}{l}\text { Cutoff } \mathrm{F}_{2} \text { flow when } \Delta \mathrm{P}_{1} \\
\text { ( } \mathrm{PE}-6 \text { reading minus } \mathrm{PE}=10 \\
\text { reading) decreased to } 0.5 \\
\text { psi; when } \Delta \mathrm{P}_{1} \text { exceeded } 0.5 \\
\text { psi, reset. }\end{array}$ & $\begin{array}{l}\text { To keep } \mathrm{F}_{2} \text { out of the } \\
\mathrm{N}_{2} \text { system. }\end{array}$ & Same as for PA- 57 \\
\hline
\end{tabular}

a See Sec. $17.4,2$, 1ten $\mathbf{b}$ for a degcription of HCV's.

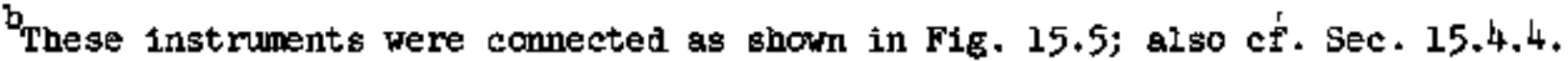


Table 5.2 (Contimued)

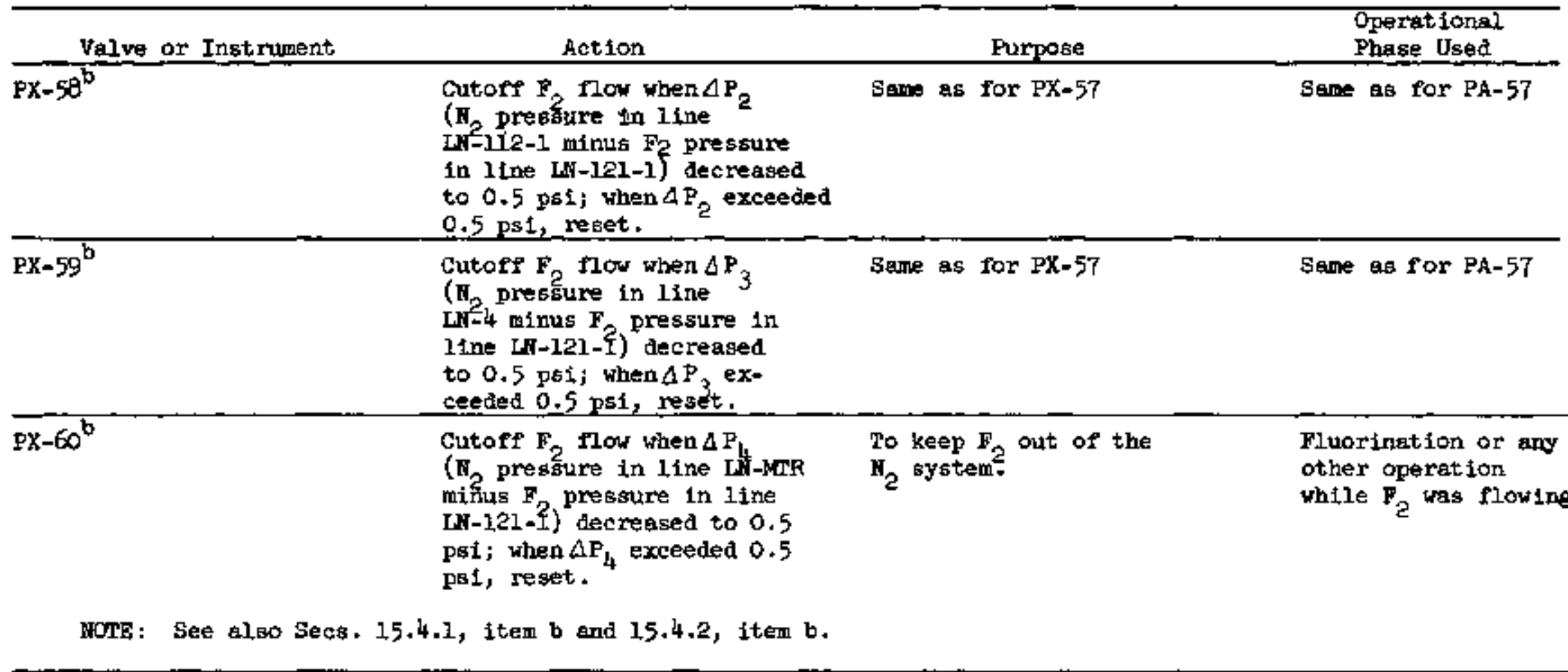

These instruments were connected as Bhown in F1g. 15.5; also cf. 8ec. 15.4.4. 


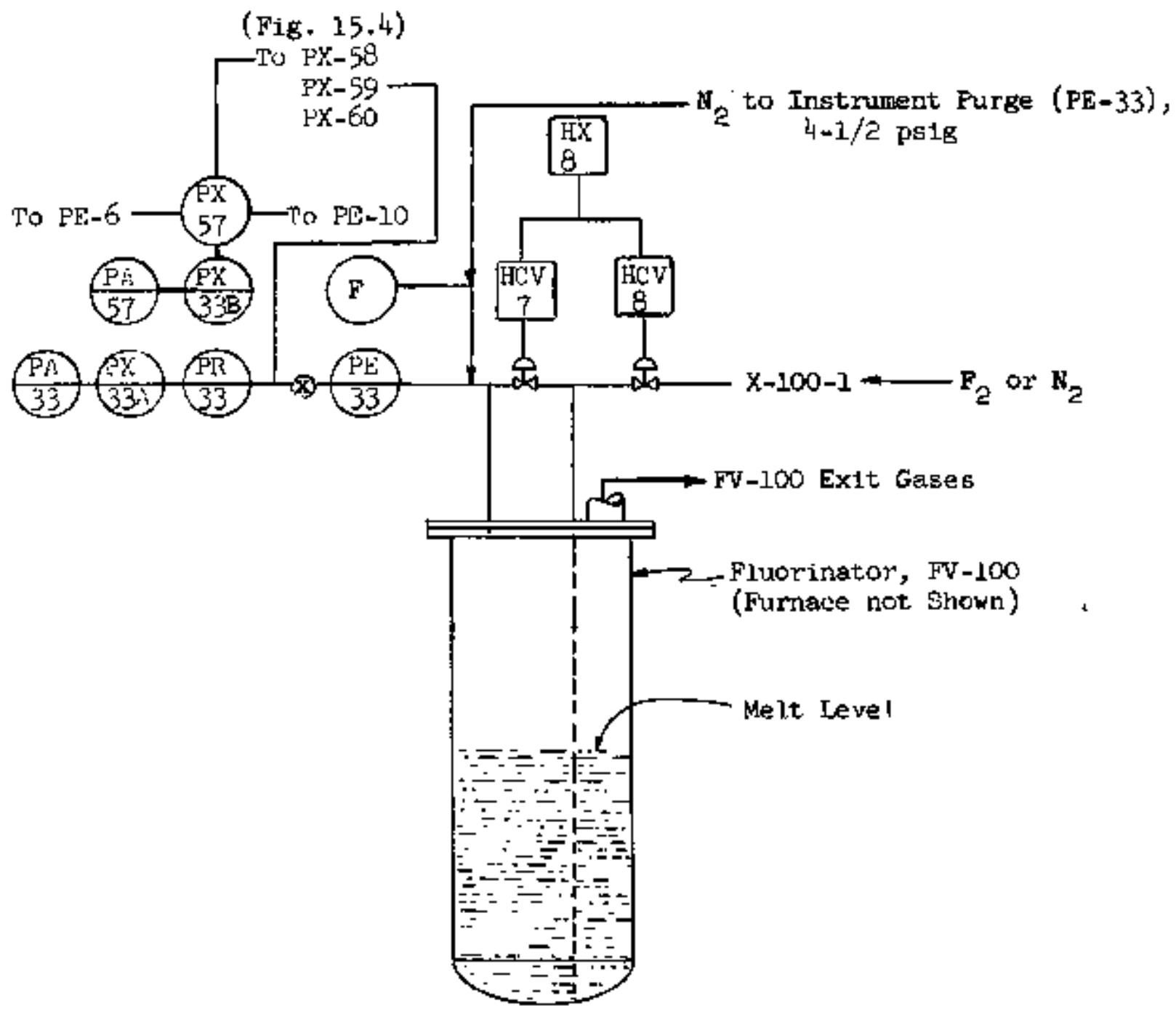

Actions of HCV -7 and -8 :

1. HCV-7 opened when -8 closed to equelize pressare in the dip tube of line $X-100-1$ and in the FV- 100 vapor space; HCV 7 closed when -8 opened to allow gas to flow through the dip tube.

2. Pressure switch (PX-33A) closed HCV-8 and opened HCV-7 when pressure in the vapor space rose to $8-1 / 2$ psig to reduce dip tube pluss reaulting from high presiures in the rapor space.

3. The actions of PX-33B, PA-57, and PX-57 had no effect on HCV-7 and -8 . See section 5.4.7 for these actions.

F's. 5.2. Arrangement of HCV -7 , HCV -8 , and Related Fluorinator and Fluorine Instrumentation 
to enable completing the fluorination since its removal permitted sufficient $F_{2}$ Plow at higher than 4-1/a paig. Generaliy, hovever, if $F_{2}$ woula not flow below 4-I/2 psig, increasing the $F_{2}$ pressiure was far less benteficial than eliminating the plug causing the high Fv-100 pressure.

Whether the PA-57 and PX-33B combination as connected served a useful purpose is debateble. FA-5T probably did since dt made operating personnel cognizant or a 4 psig rapor space pressure. PX-33B, however, contributed little by shutting off the $F_{2}$ flow. Instead of being helpful, it probably vas detrinentel. For example, when FX-33B shut off the $F_{2}$ flow, it left HCV -8 open and HCV -7 cloged thereby not alioring the pressure to equalize between line $X-100-1$ and the vapor space. Then, unless HCV 8 wis closed and -7 opened manually, an increase in vapor space pressure by the instrument purges without a corresponding increase in 1 ine $X-100-1$ pressure would force salt into this line with a plug as a likely result. Because of this possibllity of plug formation, it woold have been better to uBe FX-33B as a differential pressure switch operating as reconmended.

Several combinations of $\mathrm{BCV}-7,-8, \mathrm{PA}-33, \mathrm{PX}-33 \mathrm{~A}, \mathrm{PA}-57$, and $\mathrm{PX}-33 \mathrm{~B}$ have been used. The one discussed above was the most satisfactory despite the fact that when $P X-33 B$ ahut off the $F_{2}$ flow It was esaential to manualiy switch HCV -7 and -8 to avold $F_{2}$ inlet lifie plugs.

Thermocouples were used for tempereture measurement and control in sultable thermowelis, on vessel surfaces, and on pipelines (Secs.21.4.6 and 22.4.2).

\subsection{Stumany and Conclusions}

The fluorination equipment operated relatively satisfectorily. Heating-up and cooling-down times are given in previous sections for the funace and heaters, and the equipment troubles encountered are highilghted. Time required wes $8 \mathrm{hr}$.

All three FV-1OO designs were operable. Increasing the wall thiciness at the vessel supports ellminated vessel warpage occurring with a thinner-wall Fluorinator.

Locating the autoresistence ground lug on the vessel flange apparently eliminated cold spots on the salt transfer lines near the FV-100 veseel wall.

Removing the splash plate had no known effect on fluorination time, fluorine consumption, CRP trep plugging, or wall deposits on the upper Fr-100 wall.

Galling of swagelok threads on corrosion tubes was decreased by lengthenting these tubes from $2-1 / 2$ in. to $\sim 7-1 / 2$ to $9-1 / 2$ in。

Fluorine inlet line plugs resulted primarily from maloperation.

Whether fluorinating through the vaste line is feasible was not determined from the limited work done. 
Results of gas entrainment atudies indicated the desirgblilty of keeping the upper section of the ressel at a texperature of $\leq 400^{\circ} \mathrm{c}$. to minimize entralnment. In addition, similar studies on a new vessel would be beneficial.

Redes1gning the lower mentle beater reduced the rim of aalt in FV-100 bbove the melt level whereas the upper mantle heater was not needed to keep the upper vessel wall at $450^{\circ} \mathrm{C}$.

Severe corrosion occurred on both ressels. In both ceses, the attack was mostly intergrabular on the internal walls. In Mark I, the metal in the vepor phase was more severely attacked. In Mark II, corrosion was most severe where the metel was contected by the molten solt. Apparent factors were: (a) presence of sulfur, (b) the time of exposure at telmperature to molten salts, and (c) the amount of fluorine sparged through the salt.

The furnece liner, the furnece, and the furnace lift were satisfaction.

t.R-2, PR-33, and $\mathrm{RR}-2$ were useful instruments, LR-2 and PR-33 gave nearly full-time service, but $D R-2$ was avallable about half-time because of dip-tube plugs. Frow an operational vienpolnt, the need for LR-2 and PR-33 was clearly estabilshed whereas the need for DR-2 was questionable since Beveral runs were wade without 1t. For report Information, hovevex, data from all three inetrumente were benericial. The tapered tipe on instrument purge lines introduced In the " $\mathrm{L}$ " runs apparently reduced purge line plugs.

The fluorinator velve and pressure (BCV-7, HCV-8, PA-33, PX-33A, PA-57, and PX-33B) 1nstrumentetion discussed was the best errengement which has been tried. But the PA-57 and PX-33B combination would heve been more ugeful connected differently as recormended.

LA-5 was not evaluated aince a fluorinator failure did not occur. system,

Thermocouples enabled maintalining the necessary temperature throughout the

\subsection{Recommendations}

It is recanmended that: ${ }^{\mathrm{a}}$

a. The splasih plate be eliminated in future designs of fluorinators.

b. The use of tapered tips on Fluorinator ingtrument purge lines be continued.

c. The use of the common vessel ground lug for autoresistance heated salt transfer lines on the fluorinator be continued.

${ }^{a} \mathrm{Cf}$. Sec, 13.6 relative to recommendations on eliminating cold spots: (a) in waste line Inside of fluorinstor vessel and (b) at nickel pipe stub between the fluorinator wall and the Inconel waste line. 
d. The corrosion opectmen entry tubes be so designed that the tubing threads (Swagelok) on corrosion specimen asiembliea be kept a avfficient diatance from the adjecent high-temperature surface to avoid galling.

e. The new tluorinator be so designed as to eliminate any cold section of the vessel well on whlch a rim of salt wight form.

f. A feabibility atudy be made before deciding to fevelop a new alloy to replace nickel, as the fluorinator meterial of construction.

8. The new fuorinator desiga Include an upper section operated at $\leq 400^{\circ} \mathrm{C}$. to minimize entreinment.

h. The need for a flyorinator furnace liner and LA-5 be re-evaluated.

1. LR-2, PR-33, DR-2 be incorporated in the nef fluorinator design.

j. The Ingtrumentation of a new-design fluorinator provide for interlocking BCV -7 and -8 Buch that the latter would close and the former open when the $4 \mathrm{P}$ (11ne X-100-1 pressure minus vapor space pressure) decreases to $1 . / 2$ psi and then reverse then the $4 \mathrm{P}$ increases to one psi (An alarm would soumd at a $\Delta \mathrm{P}$ of $1 / 2 \mathrm{ps} 1$ and stop and reset at one psi.); further the $N_{\rho}-F_{2}$ interlock showld be changed so that HCV.8 would close and -7 open then the $F_{0}$ flow was cutorf, and these valves would reverse when $F_{2}$ flow was resimed.

$k_{\text {b }}$ The need for any additional safety instrumentation to that mentioned above in 1tem $j$. Bhould be thoroughty studied before installation.

5.7 Operating Procedure: Feed Balt Fluorlnation (Rev。 April 1, 2958)

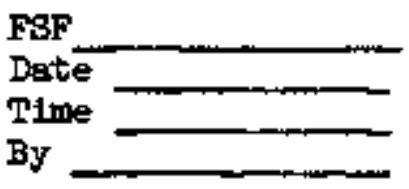

PART I - PRELIMITARY OPBRATIOAS

1. Tuxn on $\mathrm{Ex}-\mathrm{sv}-522$

and $\mathrm{EX}-\mathrm{EV}-650$. Time

2. Check that the following instruments are in service, their charts symchronized, and their purge rotameters set: DR-1

DR-2

$\mathrm{FR}-5$

PR-11

FI -38

3. Open $\mathrm{EX}-11$ PR-2 FR-6

1 $P R-12$ $T R-2 A$

Adjugt PI-6 to 4.5 paig. $\mathrm{T} R-2$ $F R=8$ , $\mathrm{PR}-\overline{\mathrm{I} 6}$ TR-2B , $F \mathbf{R}-4$ LR-8 , $\mathrm{PR}-33$ , IA -5 N'R-9 $\mathbf{P R}=34$ FR-1

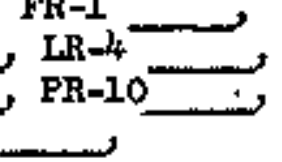

3.
$\square$
-6. Adjust FR-1 to $20 \mathrm{sim}$ ( $80 \%$ of full scale). Time on Check that TIC-1A-5 is net on $660^{\circ} \mathrm{C}$ and that TR-1A- 6 reads at leest $600^{\circ} \mathrm{C}$.

7. Set controller TIC-1A-3 on $400 \mathrm{c}$. desired heating $1 \mathrm{~A}-6 \mathrm{~cm} 6 \overline{10} \mathrm{c}$. $\therefore$ If not, adjust TIC-1A-5, 6 . and ad just $T C-1 A-3$ to give the 
8. Then $\mathrm{PIC}-1 \mathrm{~A}-3$ attains $400^{\circ} \mathrm{C}$. check $T R-1 \mathrm{C}-1 \mathrm{I}$ If TR-1C-11 i.6 less than $340^{\circ} \mathrm{C}$, increase setpoint on TIC-IA-3

9. Record readings on proper date sheet.

10. Approximately 45 minutes after step 5, close FCV-1

\section{Time}

11. Close $\overline{\mathrm{HX}}-8$.

12. Sample fluorinstor times; use runsheet FSP-1:

Code Samples FS la to Lamib FS 16 to lamb FS le to Laing Fs 1d to Laing Fs le to Feldrien Fs lt to

12a. Supervisor sign for samplins

13. When Tik-lB $4 \mathrm{~B}$ and TR-1B-5B drop to $150^{\circ} \mathrm{C}$, proceed to step 14. $T R-J B-4 B$ reeding

14 Close v-88

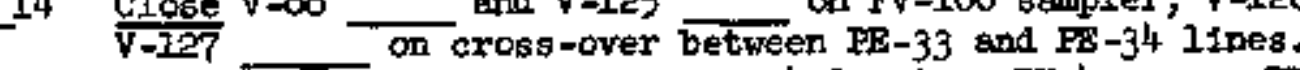
and $v-125$ - TR-1B-5B reading

25. Adjust thege regulators to read 4.5 poig. PV-4, PV 8

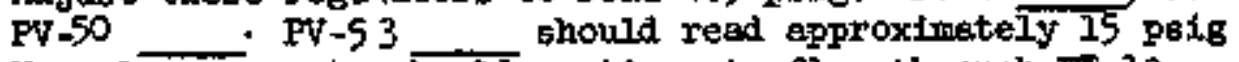

16. Normal purge rate should continue to flow through $\mathrm{FI}-13$

FI -15

FI-31 FI-25 , FI-26 - (FI-e7 is on FV-100 sampler) $\mathrm{FI}-3 \bar{O}$

\section{PART IT - FLUORTHARION}

17. Gpen the following valves: $\mathrm{Ex}-11$
$\mathrm{EX}-14$ $\mathrm{EX}-15$ EXX-16 HX -13

18. Close the following valves:

$\mathrm{HX}-8$ HX -25

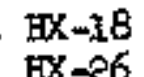
, $\frac{\mathrm{BX}-19}{\mathrm{HX}-27}$ $\mathrm{EX}-26 \longrightarrow \mathrm{BX}-27 \longrightarrow \mathrm{HX}-32$ $\operatorname{Fx}_{\mathrm{HX}-35}$ $\mathrm{HX}-12$ $\mathbf{H X}-30$ and $\mathbf{4} \times-34$

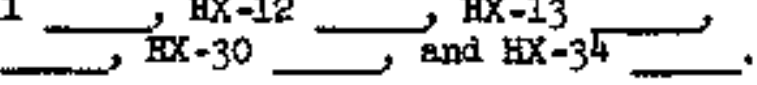
PV-44

19. The folloning controllers should be set:

TIC

2A-B

2A-11

2A-22

सB-9

2B-10
Recorder Reading

75

75

120

120

120

120
Trise Set

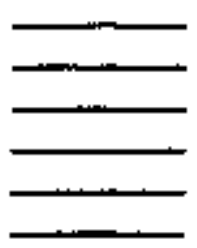

20. Adfut the following Variacs:

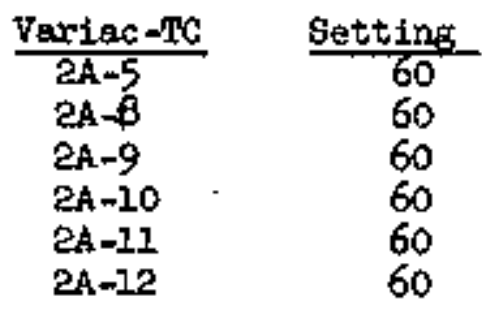

Time Set

60

60

Wait for all duct temperatures on TI-4, 5 to attain $65^{\circ} \mathrm{C}$. before contiruing 
22. After TR-2A-6 start up scrubber

and $T R-2 A-7$

$\cos$ (or heat) to $65-75^{\circ} \mathrm{C}$,

23. Take scrubber inlet sample ${ }^{\circ}$ sI for $\mathrm{OH}^{-}$and $\mathrm{u}^{16}$.

24. Set PC-10 on "auto" and adjust setpoint to 4 psig (ao\% full scale).

25. Set $\mathrm{XC}-2$ on manual and $\mathrm{HX}-1$ on h1gh range

26. Turn on fluorine supply cut-off switeh. Depress enerigizer button on trailer flow device to inltiate flow, then adjust Fi-2 to $20 \mathrm{slm}$ ( $80 \%$ of full scale).

The time fluorine was turned on

27. When flow 1s steady, open $\mathrm{HX}-8$

28. Close $\mathrm{HX}-12$.Time close

29. Switch controller FR-2 to "auto."

30. When $\mathrm{UF}_{6}$ begins to appear in the first absorber (temperatures rise on TR-2A-7), turn off TIC-2A-5 and TIC-2A-8

31. Turn on air sparger to FV-520. Thime on

32. Record pertinent data on sheets proplded.

If this is the first fluorination on the feed charge, go to steps $33-40$.

33. First Fluorination

Continue fluorination until the ilquid level decreased $6.5 \%$.

Initial liquia level LR-2

Final liquid level should be

$-6.5$

34. Time $F_{2}$ flow stopped

35. Reise the output pressure to flull scale on PG-10 (manual)

36. Adjust FR-1 to 20 slin ( $80 \%$ of full scale)

37. Thirty minutes after step 36, close FCV-1. T1me

38. Close HX-8.

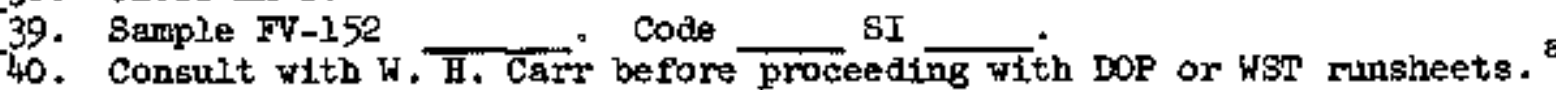

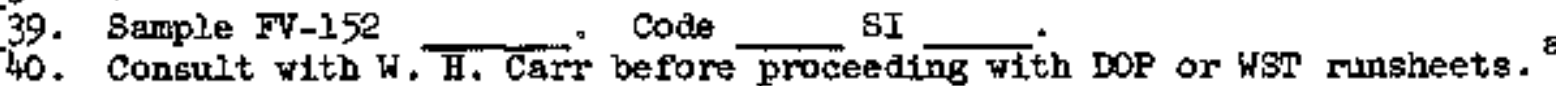

41. As soon as DR-2 and IR-Z Level off for 30 minutes, shut of fluorine Slow Time

42. Turn off alr flos to FV-520 when TR-2A-6 and -7 fall to $80^{\circ} \mathrm{C}$. Time off

43. Ralse the output pressure to full scale on FC-10 (manual)

Lower the output pressure to zero on FR-2

44. Adjust FR-1 to $20 \mathrm{slm}$ ( $80 \mathrm{~g}$ of full scale)

45. Thirty minutes after step 36, close FCV-1. Tine

46. Close HX-8.

47. Sample fluorintor 2 times: Code samples

WS-1b. If extra samples pulled: Code

48. Sample FV-152 - Code SI फ़-1c, WS-Ia,

49. Open $\mathrm{HX}-12$

50. Set PC-10 on "auto" gcale).

51. Set FC-2 on mamual and adjust setpoint to $4 \mathrm{psig}$ ( $20 \%$ of foll

52. Turn on fluorine supply cut-off swtch and depress energizer button on fow device at trailers - Adjust FR-2 to $20 \mathrm{slm}$ ( $80 \%$ of fill acale). The time fluorine was turned on

If this is a continuation fluorination on the feed charge, go to steps $41-65$. 
53. When flow is steady, open HX-8

54. Close $\mathrm{HX}-12$ . Time closed

55. Sw1tch controller FR-2 to "auto.

56. When UF, reappears in the first absorber (temperature rise on TR-2A-7) turn of TIC-2A-S and TIC-2A-8.

57. Turn on atr sparge $\overline{\text { to } \overline{\mathrm{FW}}-\mathrm{Sz}}$. Time

58. Stxty mfnutes after time in (54) smut off fivorine flow. Due off at - Actually shut off at

59. Raise the output pressure to furi scale on PC-10 (manual) Lower the output pressure to zero on FR-2

60. Adjust FR-1 to 20 sim ( $80 \%$ of full scale).

61. Thirty minutes after atep 60 , close FCV-1. Time

62. Sample fluorinator 4 times. Code

$$
\begin{array}{r}
\text { WS-2a } \\
\text { WS-2b } \\
\text { WS-2c } \\
\text { wS-2d }
\end{array}
$$

If more samples are pulled code Wh WS WS

64. Wa1t for U analysia. Consult with W. H. Garr before proceeding with DOP or WST runsheets.

65. Sample FV-152. Cose sI - Time

$\mathrm{By}$ 
$6.0 \mathrm{CRP} \operatorname{Trap} \mathrm{system} \ldots \ldots . . \ldots \ldots$

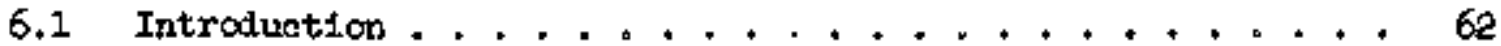

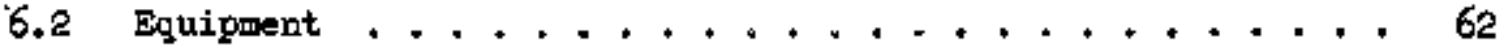

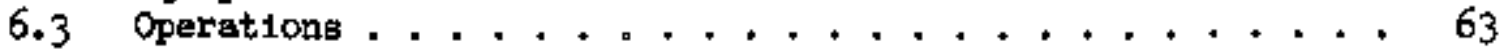

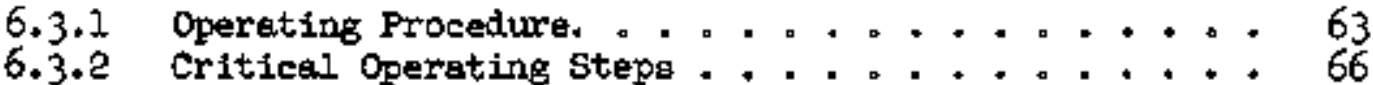

6.4 Equipment Evaluation ................ 66

6.4 .1 CRP (SnOr) Prap, FV 103 . . . . . . . . 66

a. Model Differences - Mark IA and IB ..... 66

b. Model Differences - Mark IB and IIA ..... 67

c. Model Differences - Mark IIA and IIB ..... 68

d. Add1t1onal Remarks, Fv-103 ........ 70

6.4 .2 CRP (Snon) Thap Heater, Fv -503 . ....... 73

6.4 .3 FV-103 Exit Line Heater, FV -503A ....... 73

6.4 .4 FV-103 Bypass Heater, FV -500B ........ 74

6.5 Surmary and Concluations ............... 74

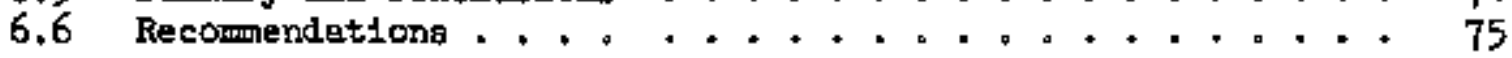




\subsection{Introduction}

During fluorinetion, the Complezible Redioactive Products (CFP) trap sorbed some of the volatile fluorides $\left(\mathrm{ZrF}_{4}, \mathrm{NbF}_{4}\right.$, and $\left.\mathrm{Cr}_{\mathbf{X}} \mathrm{F}_{\mathrm{Y}}\right)$ from the fluorInator exit gases strean whlle others includin $\mathrm{UF}_{6}$ passed through and flowed to the absorbers. The sorbed volatile fluorides were impuritles and were, therefore, subsequently discarded whth the NaF sorbent. Operation of the trap was performed remotely. The major operational step vas maintaining the NaF pecking at $\mu^{4} 100^{\circ} \mathrm{C}$ to prevent $\mathrm{UF}_{6}$ sorption.

\subsection{Equirment}

All tour models of FV-102 (Merk Hos. IA, IB, IIA, and IIB), provided the flow path for fluorinator exit gases to the heated duct. For Mark IIB, the equipment arrangement was as shown in Fig. 6.1. Differences among the various models are described in sec. 6.4.1a, $b$ and $c$.

The Mark IA vessel was termed "snow trap" because $i t$ was deslgned to remove $\mathrm{ZrF}_{4}$ and $\mathrm{MbF}_{4}$ "snow" from the extt fluorinator gasea." In the early pilot plant work, chromium Iluorides were also found in these gases. This fact inftiated the ettempt to remove chroufun fluorides as well \&s $\mathrm{ZrF}_{4}$ with the Mark IA vessel by alterlns the design. The altered trap (Mark IB) was proved inadequate in subsequent pilot plant runs. After this, the Mark IIA model was built and used starting with the " $\mathrm{E}$ " runs. Still later (after Rum E-2), atnor alterations proâced the Mark IIB design. The Mark IIA and In vegsels were termed Conplexible Radioactive Products (CFP) traps beceuse they were destgned to remove chromium fluortdes and $2 \mathrm{rF}$. Detalls of the components for the four FV-103 nodels are listed in Table 6.1.

\subsection{Operetion}

\subsubsection{Operating Procedure}

Steps in operating the CRP trap system were:

a. Havdng the CRP trap packed wtth $7.0 \mathrm{~kg}$ of $1 / 8-\mathrm{in}$. HaF pellets and assemibled leak-tight.

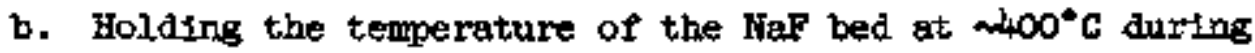
fluorination to prevent sorption of $\mathrm{UF}_{6}$.

\footnotetext{
$\mathrm{zrF}_{4}$ and $\mathrm{hbF}_{4}$ are subsequently referred to as $2 \mathrm{rF}_{4}$.
} 


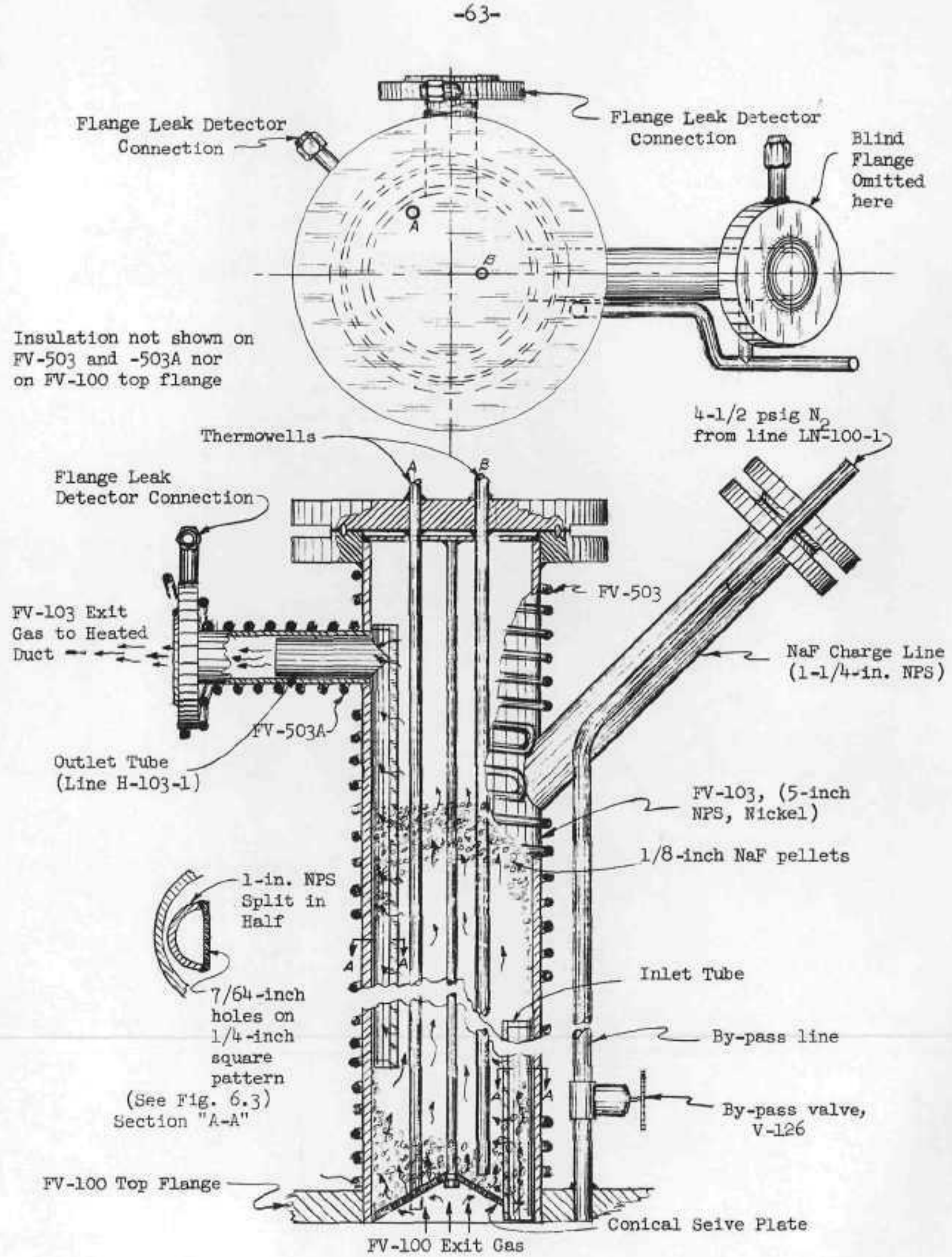

Fig. 6.1. Equipment Arrangement in the CRP Trep System 


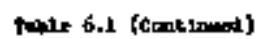

\begin{tabular}{|c|c|c|c|c|}
\hline cen & 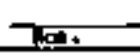 & 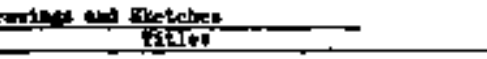 & 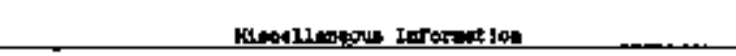 & Rofuratate \\
\hline 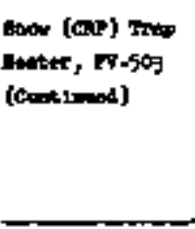 & 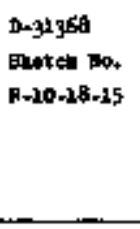 & 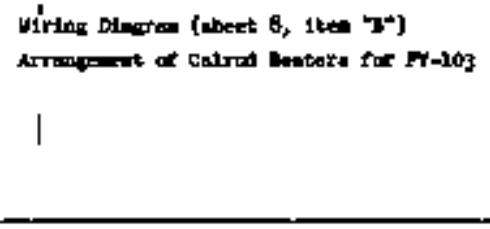 & 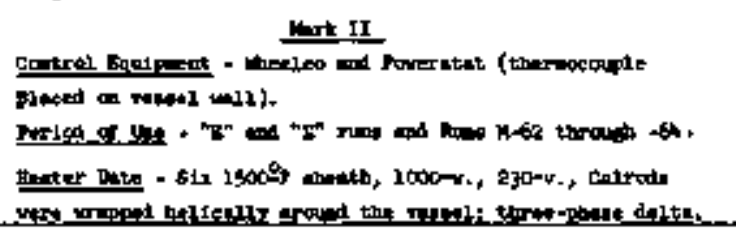 & 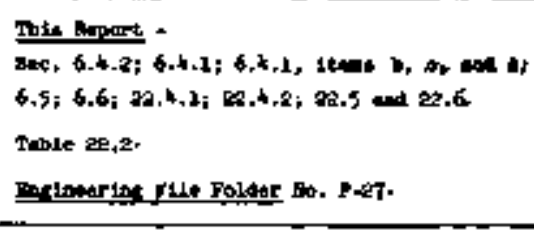 \\
\hline 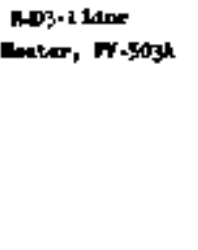 & Destege & 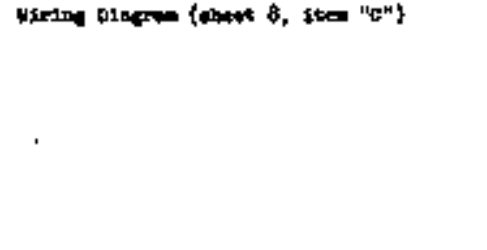 & 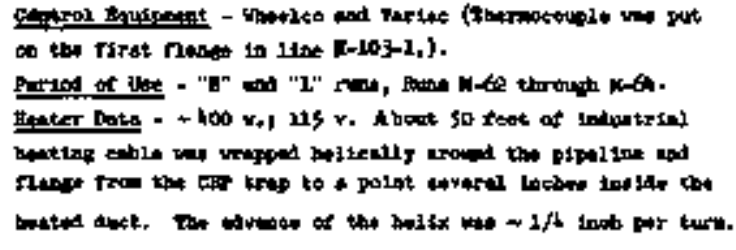 & 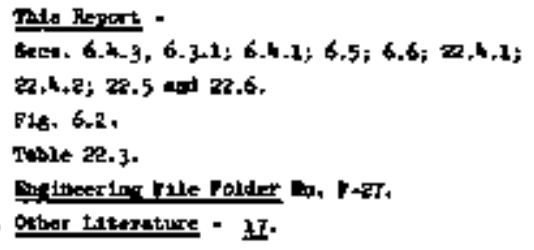 \\
\hline 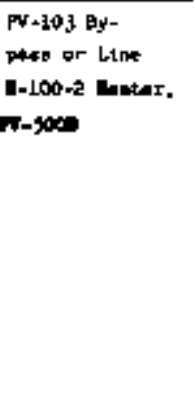 & $D+34698$ & 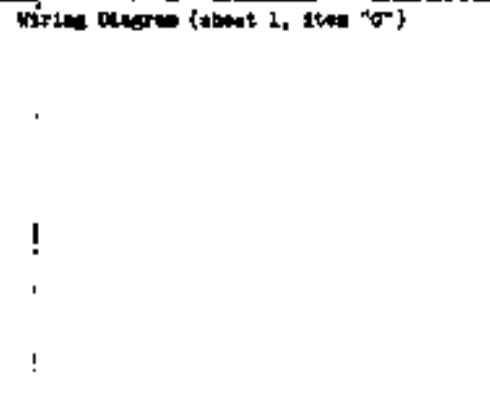 & 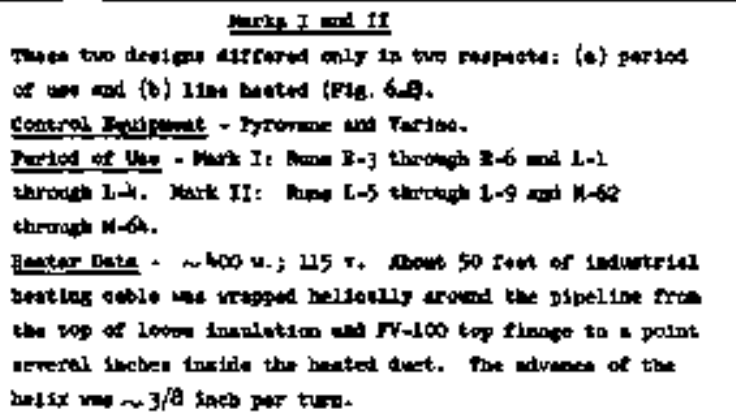 & 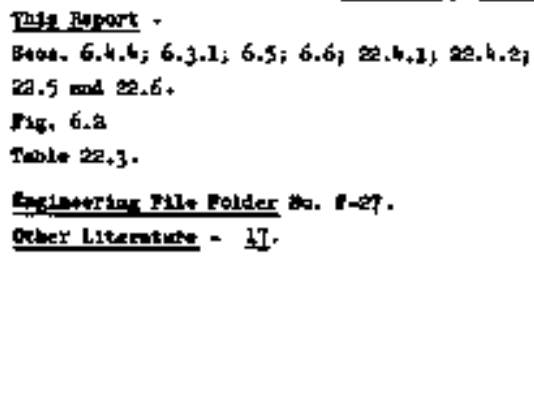 \\
\hline
\end{tabular}


c. Majntaining the nitrogen purge on the HaF fill line at one efl to prevent $\mathrm{UF}_{6}$ condensation in this line.

d. Keeping the exit gases line $\mathrm{H}-103-1$ at a temperature $>65^{\circ} \mathrm{C}$ to prevent condensing UF $_{6} ;$ or keeping bypass line H-100-2 at a temperature $>65^{\circ} \mathrm{C}$ when using the FV-103 bypass.

e. Changing the NaF in the trap as required.

System changes necessitated alterations in the procedure from time to t tre. Since the CRP trap eystem operating procedure was part of that for the fluorination systen, see Sec. 5.7.1 for the complete procedure.

\subsubsection{Critical Operating Steps}

a. Maintaining the temperature of the $\mathrm{Mar}$ bed at $\sim 400^{\circ} \mathrm{C}$.

Higher temperatures than $400^{\circ} \mathrm{C}$. celdsed UF to form which was permanently corsplexed by the NaF whereas lower temperatures required CRP trap desorption to prevent $\mathrm{UF}_{6}$ loss.

b. Keeping a clear flow-path through Fv-103 upon vhloh pontinuing the fluorination depended.

\subsection{Equipment Evaluation}

\section{$6.4 .1 \mathrm{GRP}$ (Snow) Trap, Fr-103 ${ }^{\mathrm{C}}$}

a. Model Differences - Mark IA and IB

Differences between Mark IA and IB were:

1. Packing

Mark IA - Nickel Mesh

Mark IB - 1/8-in. MaF pellets

The nickel mesh in the Kark IA model was supposed to remove $\mathrm{ZrF}_{4}$ "snow" from the FV-100 extt gaaes. The study (Rune M-2l through -48 ) indicated that: (a) nickel meah removed a small portion $(\mathrm{kl} / 10)$ of $2 \mathrm{rF}_{\mathrm{t}}$ "snow" from the extt gases; (b) sintered nickel disks plugged and, therefore, could not be used; (6) chromium fluorides as well as $\mathrm{ZrF}_{4}$ were present in the FV-100 exit gases; (d) NaF was a promisting FV-103 packing since it sorbed chromiun fluoridess as well as $\mathrm{ZrF}_{4}$, and since it would not sorb $\mathrm{UF}_{6}$ at $\sim 390^{\circ} \mathrm{C}$.

\footnotetext{
The tenperature of $\sim 65^{\circ} \mathrm{C}$. was safely above the sublination point of $\mathrm{UF}_{6}\left[\sim 57^{\circ} \mathrm{C}\right.$. at 14.7 psia $(\underline{17}, \mathrm{p} .4)]$.

b In pilot plant work through the "t" runs, the frequency of NeF bed changing wag unpredictable because of operational troubles.

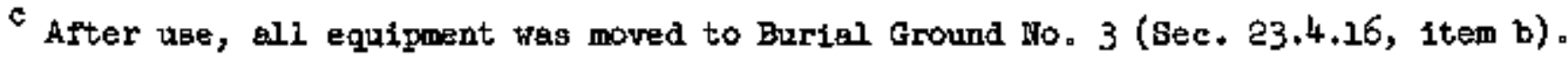

a Desorption of $\mathrm{UF}_{6}$ from the absorbers was performed at $\sim 390^{\circ} \mathrm{C}$. as delineated in Sec. 8.3.1.
} 
As a result of this study, 1/8-1n. NaF pellets were used as the bed in the Mark IF and all subsequent FV-103 designs. In eddition, the Mark IB vessel was heated with Calrods to reduce $\mathrm{UF}_{6}$ sorption.

2. Heater

Mark IA - No heater.

Mark IB - Calrod heater, Mark I FV-503.

See Sec. 6.4.2 for details and under "Mark IB and IIA Differences" in this section.

b. Hodel DIfferences - Mark IB and IIA

1. Gas Flow Scheme

Mark IP - Downflow

Mark IIA - Upflow

The gas downflow through Mark IB resulted in plugs of NaF pellets in line H-103-l. The pellets were generally blown into this line by high fluorinator pressures accompanying $F_{2}$ Inlet line plugs. Plugs evidently resulted because of (a) the packing of pellets and/or (b) the sorption of $\mathrm{UF}_{6}$ by the HaF. With the upflow pattern in Msrk IIA, the plugs formed by iten (a) and not form but those resulting from 1ten (b) did.

2. Fosition Relative to $F v-100$

Mark IB - On the s1de of FV-100

Mark IIA - Above FV-100

Placing the trap above the top flange made it phystcaily posstble to dung the FV-103 contents into the fluorinator, Despite this possibility of duatping, however, the scheme never worked elther because of faulty equipment design and/or the agglomeration of the $\mathrm{HaF}$ pellets.

3. Vessel Heater

Mark IB - Calrods placed along cylindrical elements and bent under the vessel bottom heated neither cylindr1cal surface nor bottom of the vessel adequately (Mark I FV-503\}.

Mark IIA and IJB - Calrods wrapped helicelly around the vessel heated the cylindrical vessel surface to $400^{\circ} \mathrm{C}$ as desired. Since the trap was welded to the FV-100 top flange, there was no trap bottom to heat (Mark II FV-503).

See Sec. 6.4 .2 for further details. 
4. Exit Gases Line Heater

Mark IB - Without an elxillary heater, the terperature of the jolnt between FV-103 and Itne H-103-1 was believed to be $465^{\circ} \mathrm{C}$.

Mark IIA - W1,th heater FV-503A, 11ne B-103-1 and the flange out 31 de of the heated duct were kept above $65^{\circ} \mathrm{C}$ with no $\mathrm{UP}_{6}$ condensing.

c. Model Differences - Mark IIA and IIP

I. Flange Leak Detector

Mark IIA - No flange leak detector.

Mark IIB - The FV-103 top flange, the flange on line H-103-1, and the flange on the HaF fill line were added to the rlange leak detector system, Having these fllanges connected to the flange leak detector systen was belpful in leak testing as discussed In Sec. 18.3, see also Fig. 18.1 and Table 18.1 .

2. Thermowells

Mark IIA - Conteined no internal thermowell for monitoring the NaF bed temperature because a thernowell would have conflicted with the NaF dumping mechentsm.

Mark IIB - Two thermowells running the length of the trap were instelled, one near the axis of the bed and the other $1 / 8$ in. from the trap fnner surface. The thermowelly thede it possjble to measure temperature profiles of the bed.

3. CRP Trap Bypass

Mark IIA - No bypass for filuorinator exit gases was provided.

Mark IIB - A bypass (11ne H-100-2) was installed so that the fluorination could be continued if the CFP trap plugged. Freviously, a CRP trap plug stopped the fluorination unt 11 the plug could be elfminated.

The two CRP bypess desiens installed are shown in Fig. 6.2.

The Mark I model wes unsat isfactory because of plugs developing In V-126 (Eoke No. 413) as delineated in Sec. 17.4.1, item $\mathbf{s}$. The Mark II model was never used and, therefore, cannot be evaluated. Its deslen appeared to be superior, however, to the Hark I design because the $1 / 4-i n$. SMMD valve has a larger port than the Hoke No. 413 valve, and because the line size was larger throughout. 


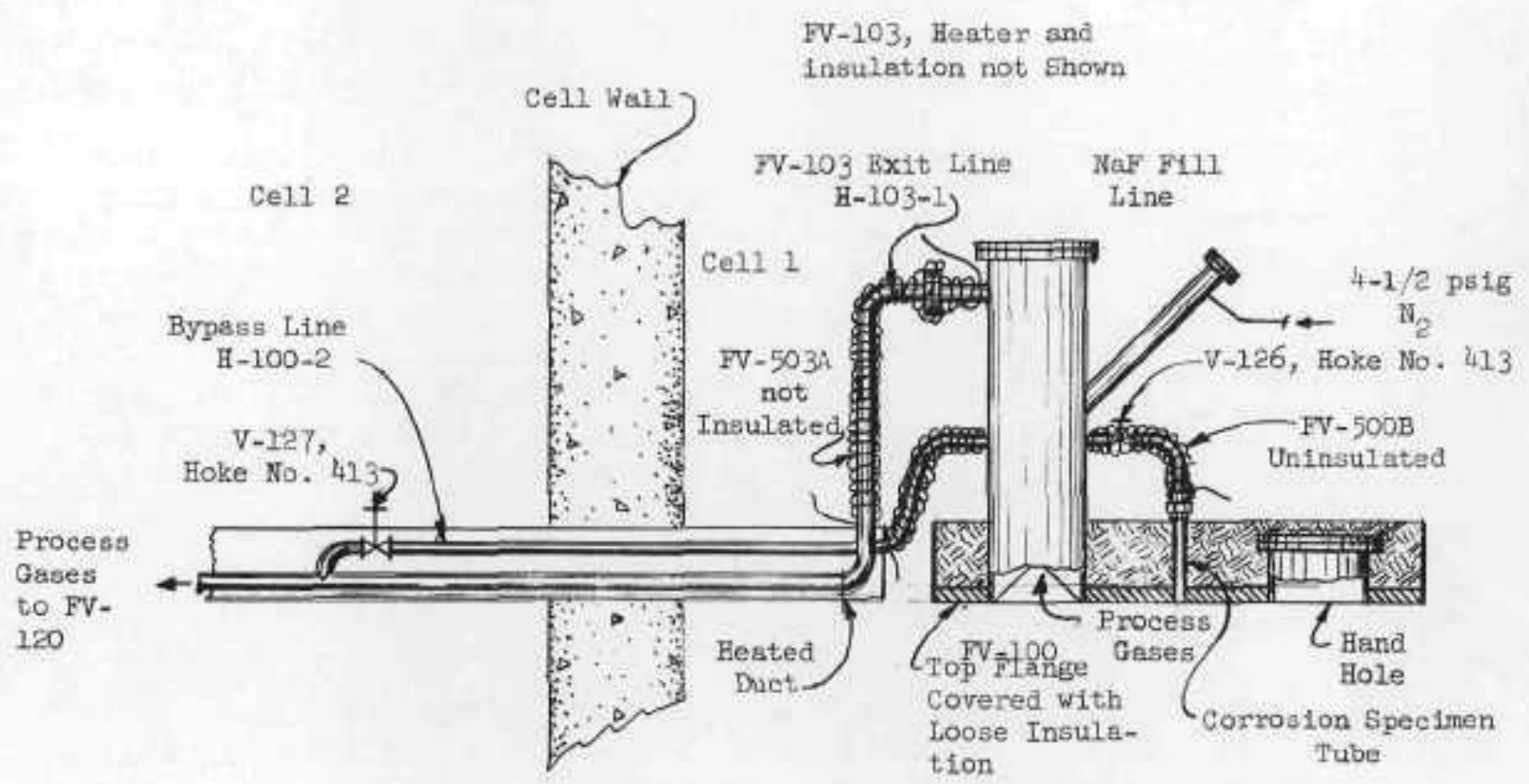

Mark I

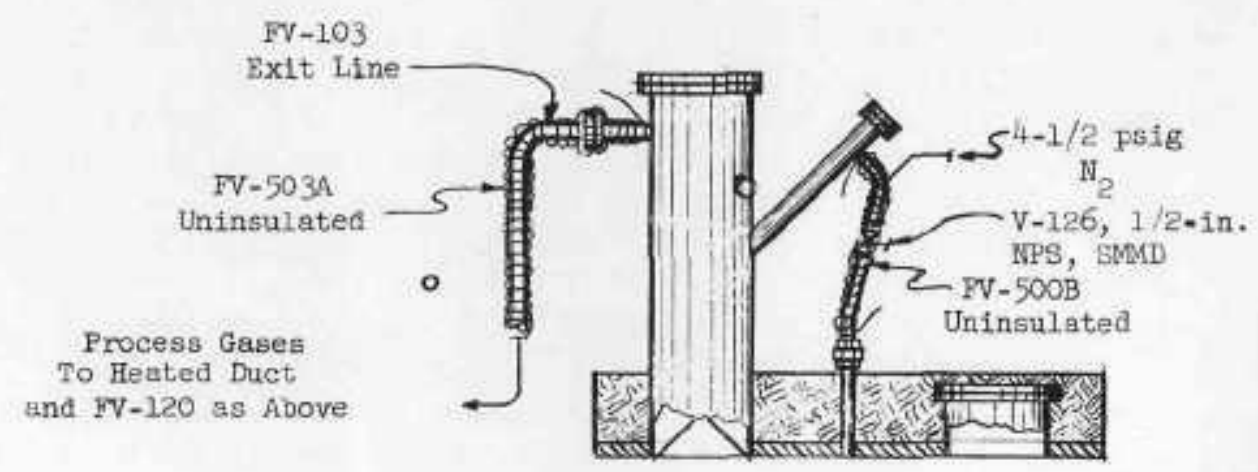

Mark II

F1g. 6.2. FV-103 By-Pass Designs 
4. Inlet and Outlet Tubes

Mark IIA - No inlet and outlet tubes. The depth of bed sinterIng at which no $F_{2}$ would flow was around 4 to 5 inches. It was felt that the addition of an inlet tube to disperse the gas vertically in the bed would reduce the shutdowns caused by sintering. In addition, an outlet tube would provide additional outlet area if the top of the NaF bed crusted over.

Mark IIB - Inlet and outlet tubes were provided to increase the effective flowpaths into and out of the trap as shown in Figs. 6.1 and 6.3 . Operating experience while using these tubes indicated that the tendency to form plugs during maloperation outweighed the advantage offered by the tubes. For example, CRP trap plugs were numerous during Runs $L-1$ through -4 with the tubes in place. In addition to this experience, whether the tubes were needed in periods of smooth operation (Runs E-3 through -6 and I-5 through -9) was not ascertained.

\section{d. Additional Remarks, FV-103}

$\mathrm{ZrF}_{4}$ "snow" removal by the Mark IA trap mesh was unsat1sfactory. More "snow" deposited on the vessel surfaces upstream from the nickel mesh than on the mesh. In addition, relatively large amounts of material passed through the trap and deposited in the pipeline between the trap and the flrst absorber as vell as probably in the first absorber. This pipe deposit apparently aggravated the tendency of $\mathrm{FCV}-11$ to leak and, during decontaminating, necessitated water-washing this portion of the system. The apparent effects of this material on the first absorber are delineated in Sec. 8.4.1, 1tem b.

The series of developmental runs (M-2l through -48) referred to under "Mark IA and IB Differences" Initlated the heated trap packed with NaF to remove both ZrF "snow" and chromium fluorides. Although the Mark IB trap was difficult to heat evenly and inadequately retained $\mathrm{NaF}$, the additional data obtained with it were valuable in designing the Mark IIA trap.

Despite the superiority of Mark IIA to Marik IB, Mark IIA was not satisfactory because:

1. The vibrator and remote discharging device which utilized a remote valve operator to move the trap sieve plate did not work satisfactorily. The two princlpal reasons for its failure were (a) insufficient movement of the sieve plate and (b) agglomeration of the NaF bed. 

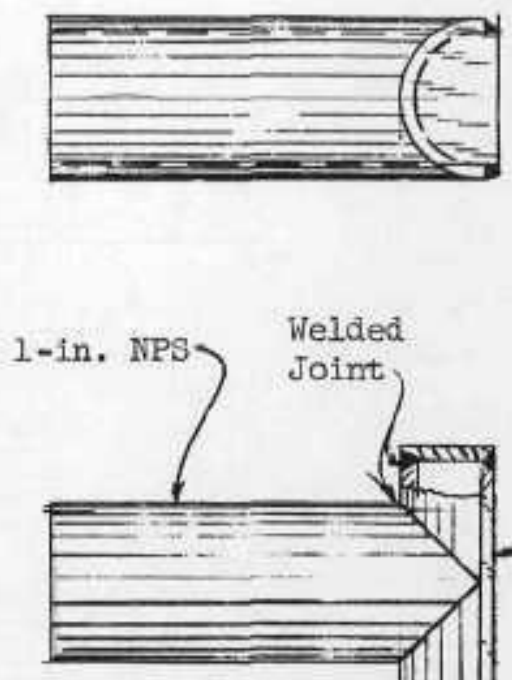

Welded

Joint

2-1/8-in. plates welded to split

Weld Cap

on end
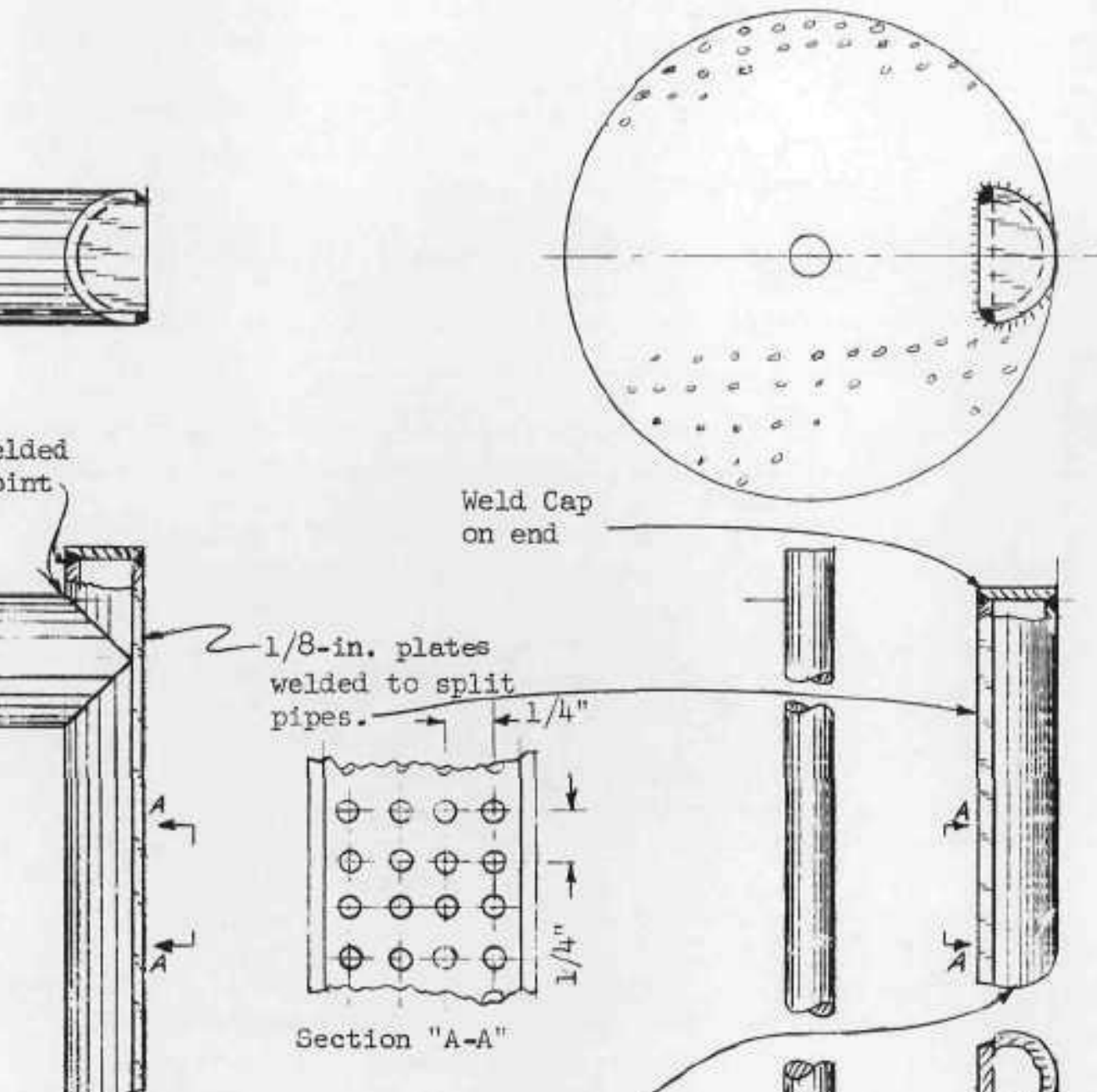

A mand

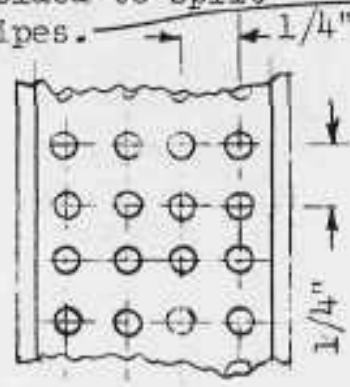

Section "A-A"

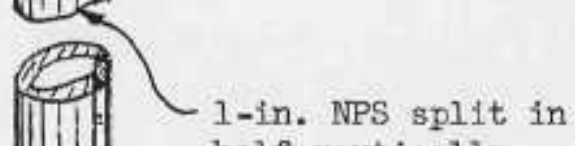
half vertically
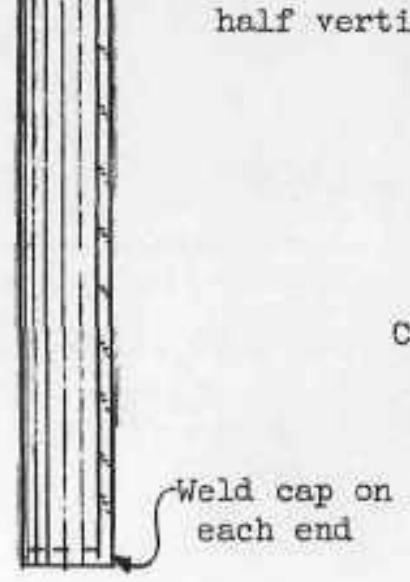

Outlet Tube
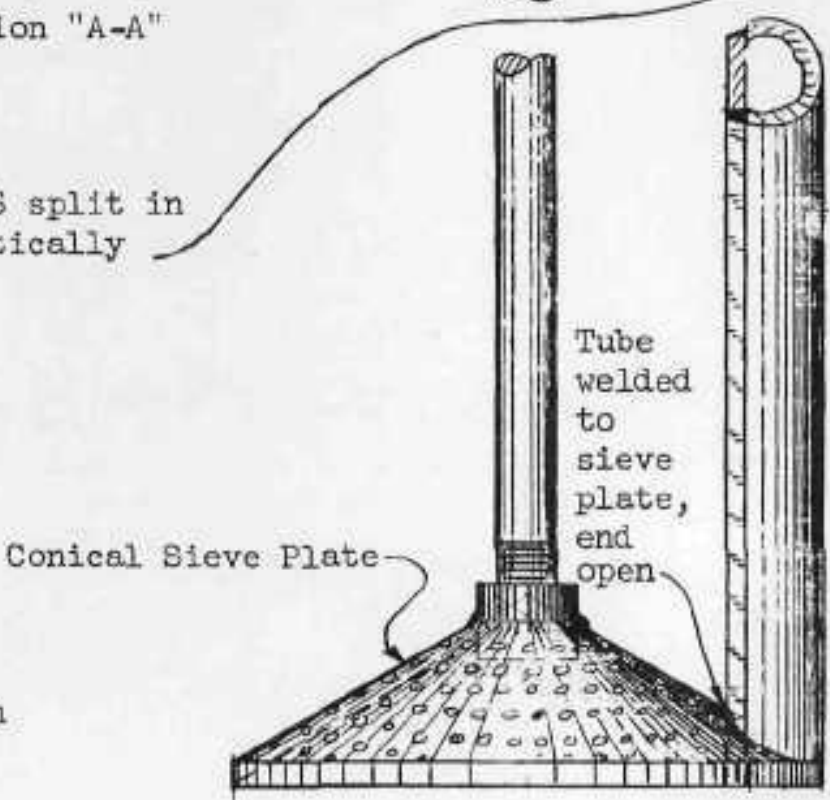

Inlet Tube

Fig. 6.3. FV-103 Inlet and Outlet Tubes 
2. The temperature profile of the NaF bed could not be determined without thermowells in the $\mathrm{NaF}$ bed.

3. The uranium retention was $>100$ grams. Inab1lity to determine $\mathrm{NaF}$ bed temperatures probably contributed to the high uranium retention. The thermowells installed in Mark IIB helped to correct this situation.

4. The trap plugged frequently. Although the mechanisms causing CRP trap plugs are not understood, two observations were made: (a) a relationship seemed to exist between maloperation and FV-103 plugging, (Maloperation usually involved higher-thannormal FV-100 melt temperatures and pressures and excessive time-at-temperature.); (b) plugs formed by NaF particle agglomeration and/or plugging of the holes in the sleve plate. (Some NaF agglomerates were rather soft, i.e., could be easily crushed by hand, and resembled poly-fluorides. "Others were yellowish possibly indicating the presence of $\mathrm{U}$ or $\mathrm{Cr} .{ }^{\mathrm{b}}$ Sleve plate plugs were very hard and had to be drilled out.)

Although the Mark IIB model showed the same tendency to plug as did Mark IIA, it did enable temperature profile determination in the $\mathrm{NaF}$ bed. The temperature gradient could be reduced from $\sim 100^{\circ} \mathrm{C}$. to $\sim 80^{\circ} \mathrm{C}$ by decreasing the upper fluorinator mantle temperature in zone No. I from 550 to $450^{\circ} \mathrm{C}$. In addition, uranium retention in Mark IIB was reduced from $>100 \mathrm{~g}$ to $\angle 10 \mathrm{~g}$ by desorbing the NeF at a minimum temperature of $400^{\circ} \mathrm{C}$. after fluorination.

The Mark II FV-103 showed significant corrosive attack, particularly nearest the fluorinator where intergranular penetration occurred (19, 7).

The highest bed activities occurred after Run L-7 and were gross $\beta-160$ counts/min/ing U and gross $\gamma-3.4 \times 10^{3}$ counts $/ \mathrm{min} / \mathrm{mg}$. U. No 95 was the chief $\gamma$ emitter (2i). Bed activities during the " $\mathrm{E}$ " runs were lower (2, 23$)$.

Unloading FV-103 wad done either with a portable vacuum cleaner or with FV-420 (Sec. 10.4.12).

a If the agglomerates contained polyfluorides, HF was probably present in the gases leaving the fluorinator. Before the " $\mathrm{E}$ " runs, the HF trap (FV-163) was installed to remove HF from the $F_{2}$ to the plant as described in Secs. 15.4.1a and 15.4.3. The effect of the $\mathrm{HF}^{2}$ trap addition on CRP trap plugging has not been assessed.

b

Sec. 8,4.1b. 
A gas sampler for use between the fluorinator and absorber was reconmended in the study made by the M.I.T. practlce school in Oak Ridge (14). This sampler was never used because ( $\mathrm{a}$ ) the need for such a sample never arose and (b) the difficulty of taking an uncontaminated sample and analyzing it was oo great.

\section{$6.4 .2 \mathrm{CRP}$ (Snow) Trap Heater, $\mathrm{FY}-503$}

Mark I heated the bottom of the $\mathrm{NaF}$ bed to $\sim 300^{\circ} \mathrm{C}$, and the top (external cylindrical surfece) of the trap to $\sim 200^{\circ} \mathrm{C}$. In $\sim 4$ hours. Cooling deta to room temperature are not available." This heater was inadequate beceuse each of the three $J$-bent calrods was intended to heat two perpendicular surfaces, thet is, both the cylindrical and bottom surfaces of the trap. Instead of such an arrangement, it would have been better to use four calrods, three equally placed circumferentially along cylinder elements and the other on the bottom surface of the trap.

Mark II heated the $\mathrm{HaF}$ bed to $400^{\circ} \mathrm{C}$. In $2-1 / 2 \mathrm{hr}$ with TC-1A-3 get on 35\%. The temperature profile range from bottont to top of trap was $-80^{\circ} \mathrm{C}_{s}$ The $400^{\circ} \mathrm{C}$. bed could be cooled to essentialiy roor temperature in $12 \mathrm{hr}$. Although the sheath-to-electrode resistance of the Calrods was reduced to 5,000 ohms during decontamination after Run $\mathrm{L}-4$, a subsequent repeated slow "baking out" at successively bigher temperatures increased the resiatence to 20,000 ohms. Then the heater was used as before without further incident.

\section{$6.4 .3 \quad \mathrm{FV}-103$ ExIt Line Heater, EV-503A}

This heater was satisfactory for keeping the temperature of line H-103-1 and the 1-1/4 NFS flange above $65^{\circ} \mathrm{C}$. The time-to-temperature for line E-103-1 was 3/4 hr wth Variac TC-1B-12 set at $60 \mathrm{v}$. The cooling time to roon temperature was $1 / 4 \mathrm{hr}$. $^{\mathrm{I}}$

a Schematically shown In Fig. 5.1, F18. 22.2 and Secs, 22.4.1 and 22.4.2.

b sec. 8.4.1, iten b. The Calrod around the line between FV-100 and FW-103 is not mentioned here, but it was used as indicated in Table 6.1.

C Schematically shown in F1g. 6.1 (F1g. 22.3 and Secs. 22.4.1 and 22.4.2).

d This decontamination was performed very carefully to avoid ruining the calrods; that is, the FV-103 and -503 surfaces were wiped with the aqueous HHO and Tide solution instead of belng soaked therein. Normally the sheath-to-elettorde resiatance is $>1$ megohm.

e Thls line was kept at $\sim 115^{\circ} \mathrm{C}$. during fluorination. Also ef. Sec, 6.3.1 and 6.4.1. f With a roon temperature of $75^{\circ} \mathrm{C}$ at times in this vicinity. 
6.4 .4 F-103 Eypess Heater, FV-5008

This heater kept line H-100-2 above $65^{\circ} \mathrm{C} .^{b}$ The time-to-temperature was $3 / 4 \mathrm{hr}$ with TC-108 set at $100 \mathrm{v}$. The cooling time to room temperature vas $\sim \mathrm{l} / 2 \mathrm{hr}$.

Plugs in the FV-103 bypass were mentioned in Sec. 6.4.1a.

\subsection{Summary and Conclusions}

Although the Hark IIB trap was the best of the "snow" and CFP traps, there were still improvenents needed. Difficulties and changes in the models are highlighted in the foregoing sections, and hester data and times-to-temperature are given.

The Mark IA "snow" trap packed with nickel mesh renoved a small percentage of the $\mathrm{ZrF}_{\mathrm{h}}$ and none of the chromsum fluorides from the FV-100 exit gases. The Mark IB trap packed with NaF was Inoperable beceuse of inadequate heating and plug formation. Corresponding urantum retention wis $\sim 500 \mathrm{~g}$. The Mark IIA trap was still unsatisfectory because of plug formstion although the uranium retained $(\sim 100 \mathrm{~g}$ ) was lowes than for Mark IA. One-elght in. Bodium fluoride pellets was the most satisfactory CRP trap packing used. Other anaterlals tested were nickel wesh and sintered nickel dikks.

The Mark IIB trep enebled reducing the uranium retention to < $10 \mathrm{~g}$ but was extremely susceptible to plugging during maloperat ion wille fluorineting. With this trap, the desired $400^{\circ} \mathrm{C}$. NaF bed temperature could be malntained during fluorinetion with a miniming temperature proftle range of $\sim 80^{\circ} \mathrm{C}$. Although the temperature performance was better than for Mark $\mathrm{B}$, the $80^{\circ} \mathrm{C}$. range was $\mathrm{greater}$ than destred.

The Haf dumping scheme incorporated in the Mark IIA trap design did not work.

The Mark I FV-103 bypass was inoperable because of a plugsed Hoke No. 413 valve $(v-126)$. The kark II model was never trled.

The inlet and outlet tubes Incorporated in the Mark IIB trap did not solve the plugging problen as wes first supposed. The only generalization valid for plugg was that they were present during maloperation.

The effect of the HF trap (FV-163) addition on the CRP trap plugging has not been determined.

\footnotetext{
a F18. 22.3; Secs. 22.4.1. and 22.4.2.

Sec. 6.3.1, 1tend.
} 
The uranium retention was reduced from $>100 \mathrm{~g}$ to $<10 \mathrm{~g}$ with the Mark IIB trap by desorbing the KaF bed at $m 400^{\circ} \mathrm{C}$. following the fluortantion.

Lines $\mathrm{H}-103-1$ and $\mathrm{H}-100-2$ we re maintained as desired at $\sim 100^{\circ} \mathrm{C}$. with Industrial heating cable. Despite the fact that the FV-503 Calrods were successfully used after decontamination, the decontamination procedure used did reduce the sheath-to-electrode resistence appreciably.

\subsection{Recountandations}

It is recominended that:

a. A NaP-packed, Galrod-heated, trap continue to be used between the fluorinator and the absorber to reduce depostts in line H-103-1 and agglomeration in the first absorber.

b. A higher heater watt density be used at the top of the trap than at the bottom of the trap to inintinize the range of the temperature profile.

c. The FV-103 top flange and any rlange in line H-103-1 be 1ncorporated Into the flange leak detector system.

d. Themowelis similar to those in the Mark IIB trap be included in any new destgn.

e. Additional work be done on durping the CRP trap contents alrectly into the Pluorinator.

f. The HF trap continue to be used, and an HF analyzer be Incorporated in the $F_{2}$ line from the iff trap.

B. Desorbing the CRP trap following fluorination and prior to absorber desorption be contimued.

h. Using industrial heating cable be cont Inued on UF 6 Ines such as H-103-1 and H-100-2.

1. A UF 6 bypass around the new CRF trap aimilar to the Mark II design be provided.

j. Extreme care be exercised in decontaminating veasel surfaces containjig tubular heaters such as calrods to avoid "shorting out" the elements. 
7.0 Heated Duct system . . . . . . . . . . . . . 76

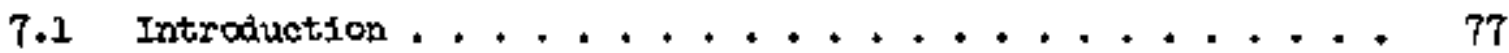

7.2 Equipment ............................ 77

7 .3 Operation . . . . . . . ............... 77

7.3 .1 Operating Procedure .............. 77

a. Bquipment Shakedown .............. 77

b. Operation ................ 77

7.3.2 Critical Operating Steps.............80

7.4 Equjpment Evaluetion . . . . . . . . . . . . . 80

7.4.I Shakedorm Experiences ............... 80

a. Air Flow Belance ............... 80

b. Moving FV-158 and 5 -650 to the Pentbouse. . . 80

c. Celrod Additions and Rearrangement ...... 81

d. Heat Lanps................. 81

7.4 .2 Bested Duct . . . . . . . . . . . . . . 81

7.4 .3 Heated Duct Hesters, FV-522 ........... 82

7.4 .4 Heated Duct Blower, FV 650 . . . . . . . . . . 83

7.4 .5 Heated Duct Chemical Trep, FV-158 ........ 83

7.5 Sumery and conclusions .................. . . 84

7.6 Reconnendations .................... 85 


\subsection{Introduction}

The process piping between the fluorinator and the main process chemical trap ( $\mathrm{FV}-1 \mathrm{CH}$ ) was maintained at a temperature of $>65^{\circ} \mathrm{C}$. by the heated duct system to prevent the deposition of $\mathrm{UF}_{6}{ }^{*}$ In addition, the flow of air within the beated duct made it possible to recover urentum from UF 6 leaks in this process piping and to reduce cell contemination resulting from such leaks.

\subsection{Equinment}

Fis. 7.1 is a schematic arrangenent of the equipment in the heated duct aystem. Details of the individual components are listed in Table 7.1 .

\section{3 operation}

\subsubsection{Operating Procedure}

a. Equipment Shakedown

Mejor steps in equipient shakedown were:

1. Iriliing holes in the duct walls as indicated at " $\mathrm{x}$ " notations on Fig. 7.1 to roughly belance the air flow through the heated auct.

2. Adjusting the Mercoid Ductatherme and rearranging or adding Calrods to obtain a nearly constant temperature throughout the beated cuct.

HOTE: See Sec. 7.4.1 for equipment shakedown details.

\section{b. Operation}

The steps involved in putting the heated duct in operation were incorporated in the operating procedures of other VPP systems. These steps were required:

1. Futting all the lid sections on the beated duct.

2. Having FV-158 filled with $11 \mathrm{~kg}$ of 1/8-in. NaF pellets.

3. Turning on both the blower sw1tch (EX-FV-650) and the heated duct wwitch (EX-FV-522).

The temperature of $65^{\circ} \mathrm{C}$ is above the sublination temperature $\left[\sim 57^{\circ} \mathrm{C}\right.$. at 14.7 psia $(1 \underline{7}, p .4)]$. 


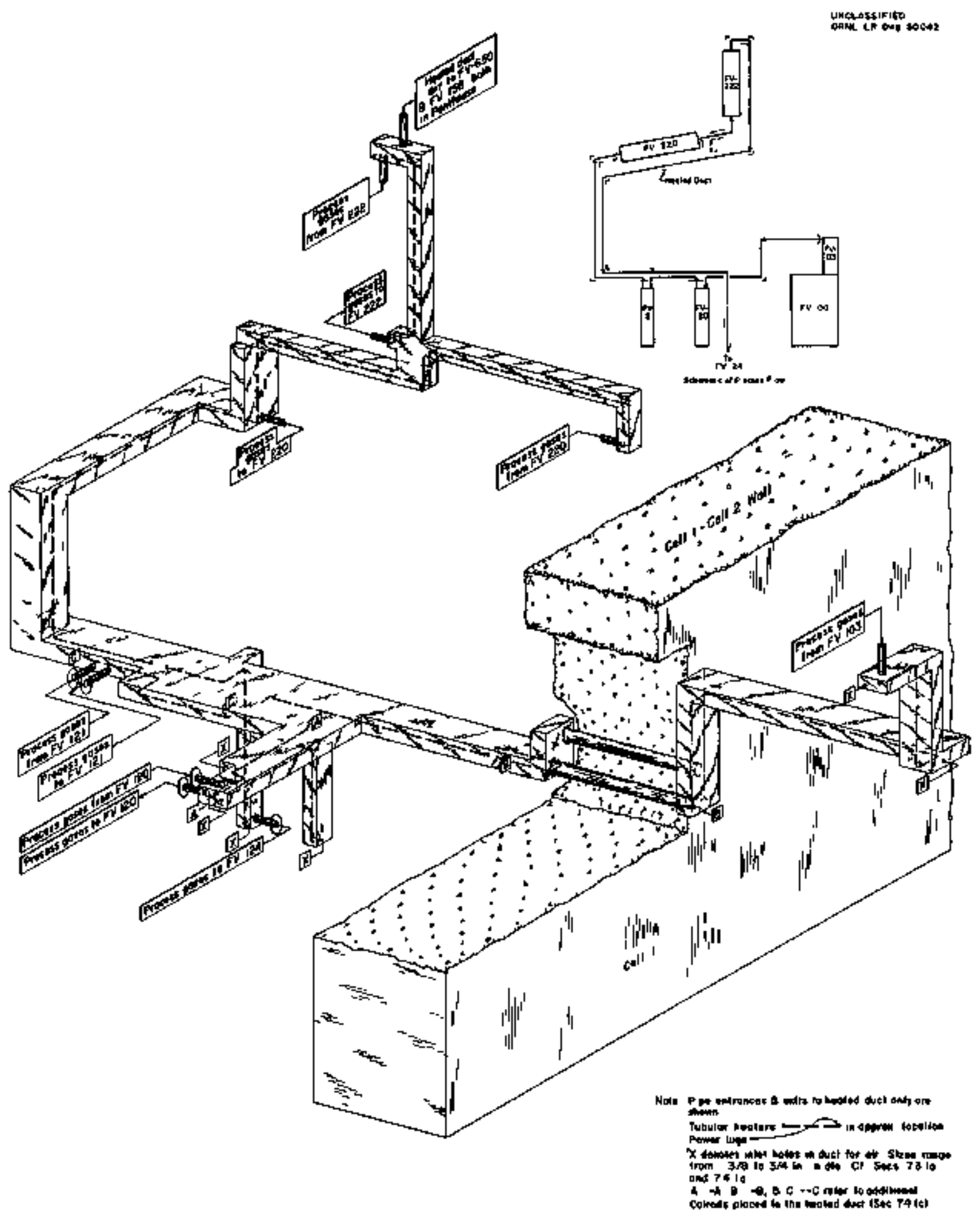

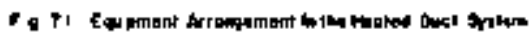


Thele $T .1$

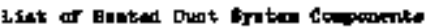

\begin{tabular}{|c|c|c|c|c|}
\hline contanente & 7कार & 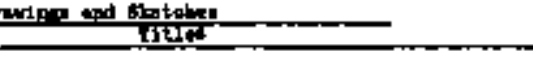 & 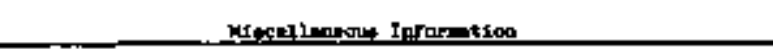 & Beference: \\
\hline Beeted buet & 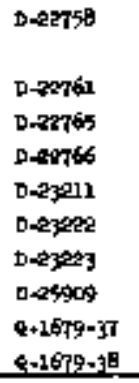 & 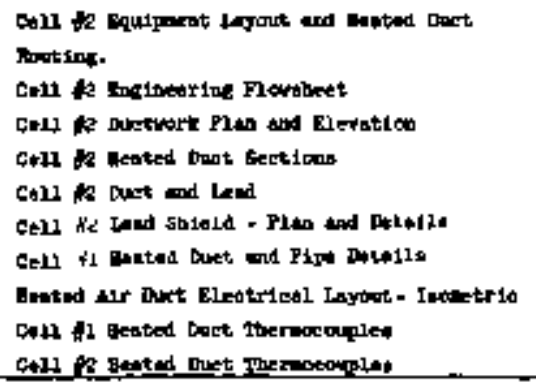 & 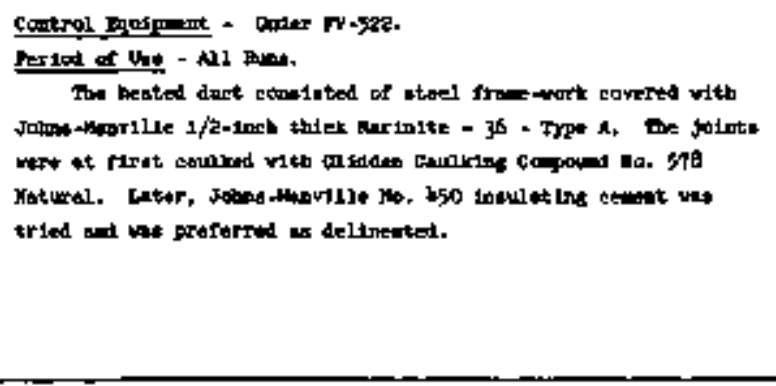 & 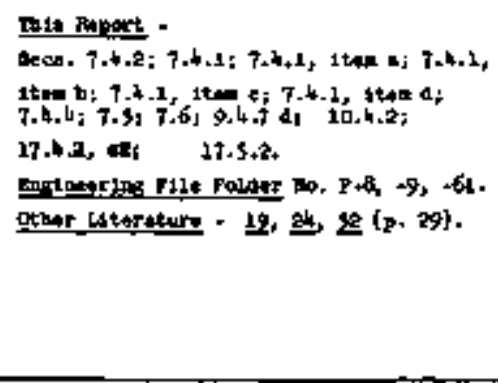 \\
\hline 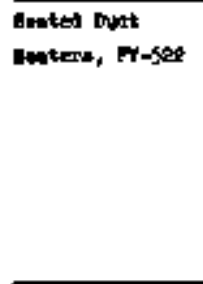 & $0-25909$ & 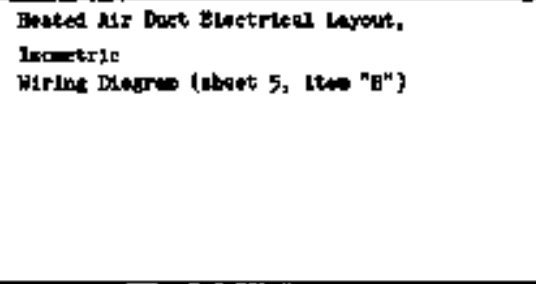 & 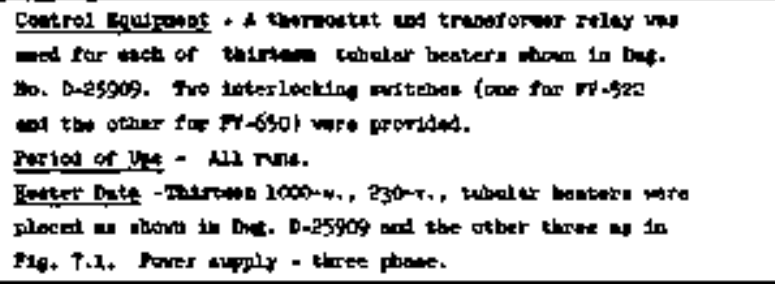 & 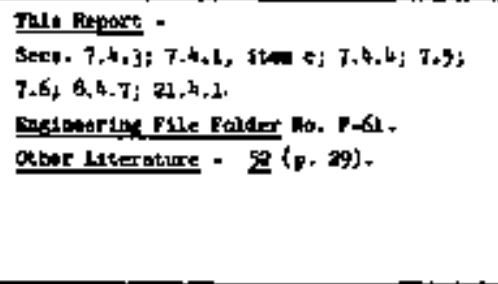 \\
\hline 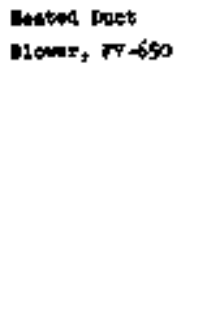 & 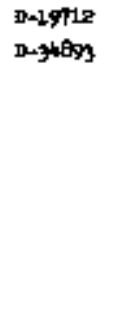 & 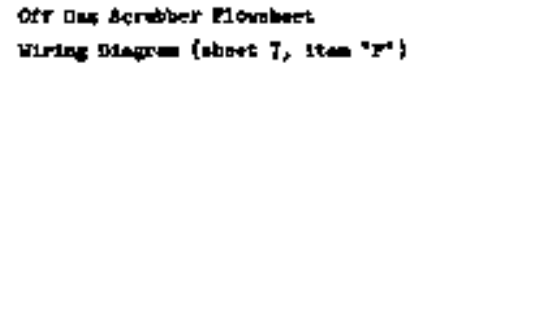 & 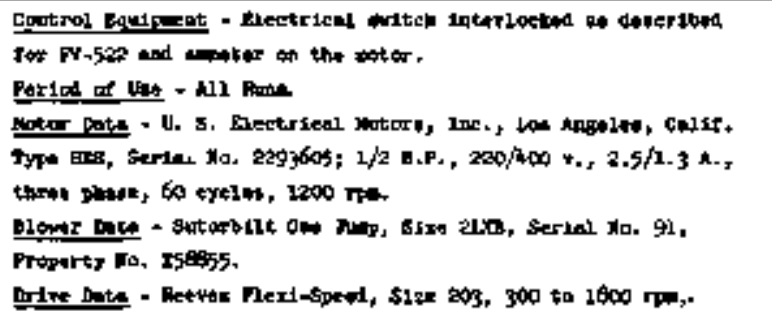 & 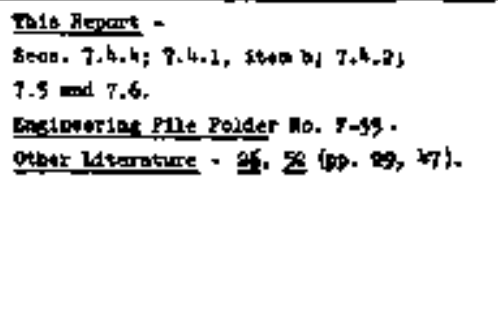 \\
\hline 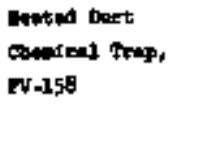 & $0-19712$ & 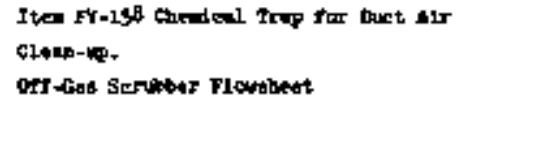 & 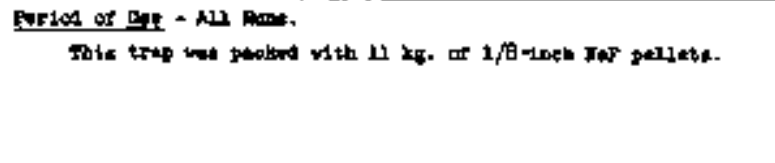 & 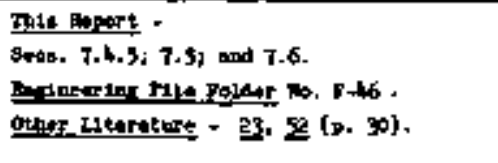 \\
\hline
\end{tabular}




\section{$-80=$}

\subsubsection{Critical Operating Stepg}

a. Having a nearly constant temperature tbroughout the duct of $\geq 65^{\circ} \mathrm{C}$. to arold depositing UF $6^{\circ}$

b. Making certaln that all lid sections were placed on the heated duct.

c. Turning on both $\mathrm{EX}-\mathrm{FV}-650$ and EX-FV-52e. (The heaters could not be turned on with EX-FV-522 unless EX-FV-650 was "on.")

\subsection{Equipment Bvgluation}

\subsubsection{Shakedown Expertences}

Shakedown items are discussed below. The effect of each independently was not assessed. After shakedoim, however, heated duct operation was satisfactory. No run dom-tive ras caused by UF 6 depasiting in the heated duct piping.

\section{a. Air-Flow Belance}

In making the holes in the duct well as mentioned in Sec. 7.3.1a, the hole sizes and number of holes were roughly detenmined depending on the distance atray from the blower and the duct crosssection. "Despite the fact that the determination was only approximate and that no distribution of air flows was later ineasured, the temperatures in the tuct were edequate to prevent $\mathrm{UP}_{6}$ from depostting after the shakedown chenges were made. After equipment shakedown, however, it was questionable whether the air flow rate in the duct was great enough to transfer $U_{6}$ leaks to FV-158 as discussed in Sec. 7.4.4.

b. Moving FV-158 and FV-650 to the Penthouse

The chinney effect which occurred in the heated duct at the cold traps wth FV-150 and $F-650$ in Cell 2 resulted in moving these components to the Fenthouse. The cold lines in the vieinity of IV-222 caused by the chimney effect were warmer efter the change. The Persthouge locetion chosen was adjacent to the cell offgas duct to make a short exit gases run ( 5 to $10 \mathrm{ft}$ ) from the blower to the duct. This desion essured a better gas flow rate through the heated duct than did the cell a location with a $\sim 60$-ft exit line to the duct, an arrangement which seriously reduced the mount of gas moved by the blower. 
c. Calrod Adaltions and Rearrangement

Three 1000-w Calrods were added to the original heated duct electrical system, Increasing the number of tubular heaters to sixteen. One of the additignal calrods was added to each phase of the three-phase elrout. These beaters were placed adjacent to the piping as follows: (a) in the duct at the FV-leo extremity (line A-A in Fig. 7.1 ), (b) in the sleeve of Cell 1-2 vall along the side of the process piping (11ne B-B in Fig. 7.1), and (c) in the duct rear the FV-12l lines (1ine C-C in Fig. 7.1). These additions Increased the temperatures in these locations as desired.

The heating element nearest $\mathrm{FV}-124$ was moved closer to line $\mathrm{X}-222-1$, and this section of the duct was altered to contain the pipeline and heate $r$ and also to afford easier access to the inlet line flange of FV-124. These two changes along with adding heat lamps mentioned in item $d$. below afforded better heating of this line.

\section{d. Hest tamos}

Two 250-w heat lamps were directed on the section of bare Iine between the end of the heated duct and FV-I24 to avold IF/6 deposition in this portion of line X-2Ee-1 (cf. Fis. 9.1).

\subsubsection{Eested Duat}

The heated duct was satisfactory although the initial lida were not strong enough to support a men. Because the section of the heated duct near FE-26 wes a convenlent walk-way, steel supports were added to prevent danage to the duet lid in this vicinity.

For the first half of the VPP work, the walls and lids of the heated duct were made of Marinite, and the lid foints (Marinite-to-angle Iron) were made with Glidden caulking compound No. 578 Natural. Short-time tests indicated that such joints would be satisfectory at expected tenperatures of $110^{\circ} \mathrm{C} .(24)$. Subsequent use of these joints corroborated the result from the tests. In fact, the bond between the Marinite and angle iron was so strong that breaking the joint usually required destroylng the Harinite. Since several occasions arose which neceasitated opening sections of the duct and since each of these openings necessitated replacing a substantial portion of

a The three-phase delta heating arrangement shown as item "H" In Drawing No. D-22779, Rev. I did not include any of the three Calrods added. As revised, therefore, this drawing should have shown six 1000-w tubulex heaters in one phase and flve in each of the other two phases.

b

After uae, equipment was moved to Buriel Ground No. 3 (Sec. 23.4.16b) except for the heated duct blower and chemteal trap.

C Johns-Manville 1/2-in. Marintte-36-Type A. This was chosen for 1ts relatively low thermel conductivity of 0.77 (BTJ) (in.) $\left./\left(\mathrm{ft}^{2}\right)^{\circ} \mathrm{F}\right)(\mathrm{hr})$ at $200^{\circ} \mathrm{F}$ ( $1, p, 6$ ). 
the Narinite, asbestos cement ${ }^{\mathrm{a}}$ was successfully substituted for the caulking compound. Using asbestos cement, the joint between Marinite and angle iron was adequate, and breaking this joint did not destroy the Marinite.

The high cost and special orderting of Martintte probably w111 lead in the future to the substitution of Flextboerd. Flextboerd is cheaper and is stocked in ORHL stores. Flextboard was used successfully in the new lid for Fv-526 (Sec. 10.4.2).

Prior to Run E-2, the HCV-z2 bonnet leaked UF 6 troto the heated duct (Sec. 17.4.2,e.2). Most of this $\mathrm{UF}_{6}$ remained in the vicinity of HCV-22, aome of it coloring the Marinite yellow. Other $\mathrm{UF}_{6}$ leaks at PE-14 and -15 in the " $\mathrm{C}$ " runs left $\mathrm{UF}_{6}$ in the heated duct near the top of FV-222, (25, p.21). Although the UF from these leaks was evidently not sWept to FV-158 $\overline{a s}$ desired, little cell contamination resulted because most remained inside the duct (Secs. $7.4 .4 ; 9.4 .7$, item a).

Corrosion in the Monel piptng in Cell 2 appeared Insignificant on saxples from piping instie the heated tuct (19).

Afr temperatures were measured with bare thermocouples having hot surctions extending inside the duct. These thermocouples were purposely placed antay from heating elements and pipelines to avold being overly influenced by them (Sec. 2 F.4.2). Temperatures of resistance-heated equipment were determined with thermocouples ad delinested in Sec. 22.4.2.

\section{4 .3 Heated Duct Heaters, FV-522}

After the heater additions, heater rearrangement, and heated duct alteration near $\mathrm{FV}-124$ discussed in Sec. $7.4 .1 \mathrm{c}$, the neated duct temperatures were sat1sfactory (range: $\sim 60^{\circ}$ to $135^{\circ} \mathrm{C}$.).

The FV-522 system and FV-650 were interlocked so that the heaters could not be turned on unless the blower was on (Sec. 7.4.4), a safety masure to avold high local temperatures in the auct with the blower not running.

A ninor gmount of trouble was met with cold lines caused by the chinney effect in the vertical section of the heated auct in Cell 1 . Any opening in the horizontal section of the duct adjacent to the fluorinator accentuated this trouble.

It required $\sim 2$ hours for the heated duct to heat from room teruperature to the normal ope rating temperature range of $\sim 60$ to $135^{\circ} \mathrm{C}$. This wide temperature range was probably the chief disadvantage to tubular heaters because of the high wattage per unit length ( 40 watts per inch for the heaters used). The low temperature extreme was on line $5-103-1$ (in area denoted by item $a$. below). Evidently thls thermocouple resd silghtly low; otberwise, more

\footnotetext{
Johns- Manville Ho. 450 insulating cement.

b Sec. 8.4.7.
} 
trouble wth UF condensing in this line during desorption would have probably occurred. Other cold axeas in the heated duct included:

a. The ares where the plping left the duct going to and from FV-120. This area was espectally cold when the Cell 2 door was open during cold weather. The remedy Included adding the hester mentioned in Sec. $7.4 .1 \mathrm{c}$ as well an ceulking the asmular holes around lines H-103-1 and B-120-I as these Ifnes passed through the duct wall.

b. The duct extreaity at $\mathrm{FV}-124$. This area wes heated adequately after moving the heater closer to line $x-222-1$ and rebullding this section of auctwork (Sec. 7.4 .1 , 1tera b).

No trouble with tubular beaters has occurred. Both THK's and Calrods have been used in the heated duct (3ec. 21.4.1).

\section{4 .4 Heated Duct Blower, Fiv-650}

The operation of this blower had been satisfactory. As stated in Sec. 7.4.1b, the cell 2 location seriously rediced the amount of air handled. Even in the Penthouse location, there was some doubt whether the pumping rate of the blower was adequate to pull UF vapor from piping leaks into FV-158 for subsequent recovery. This doubt arose from the fact that very little $\mathrm{VF}_{6}$ was collected in FV-158 when the two UF 6 leaks mentioned in Sec. 7.4.9 occurred. In each case, considerable yellowing of the Mariaite in the vicinity of the leak indicated that uF $_{6}$ sorbed on the Marinite Instead of being swept to Fr-158.

The blower lubricating schedule formulated earlier vas followed although radioactite operation was a deterrent to routine lubrication (26).

\subsubsection{Hested Duct Chemical Trap, FV-15B}

This trap containing $11 \mathrm{~kg}$ of $1 / 8-i n$. NaF pellets operated satis. factorily. With the air inlet at the top, whether any UF had been sorbdi could be determined qualitatively by removing its lid and observing the color of the HaF bed. In this way, the presence of $\mathrm{UF}_{6}$ could be detected Wthout renoving the trap contents. This arrangement saved operating tima because little $\mathrm{UF}_{6}$ ever reached this trap. The heaviest loading of this trap was 7 grams of of which was < one of of its capacity (23). Because so little of its capacity was used at the highest loading, no $\mathrm{OF}_{6}$ ever passed through the trap. The trap bed vas generally used for a number of runs without changing. The frequency of ehanging was sporadic. Unloading was done vith a portable racuun eleaner.

${ }_{\text {A yellorish coloration indicated the presence of UF }}$ (Sec. 10.4.9). 


\subsection{Sumary and Conclusions}

After equipment shakedown, heated anct operation wes aatisfactory. No run dom-time was caused by UF $_{6}$ depositing in the heated duct piping.

Shakedown activities described included: (a) making an a1r-flow balance to evenly distribute heat and to provide movement of vapors to the chemical trap for sorbing any UF 6 in the heated duct; (b) moving the chemical trap and blower from Cell 2 to the Penthouse to eliminate cold areas near FV-2a2 caused by the chimney effect and to increase the blower throughput; (c) adiing three adiftional heaters to Increase duct temperature in certain areas; (d) moving the heater nearest IV- 124 adjacent to the pipeline to better heat this line and altering this section of the duct to accomodate the relocated heater; and (e) adding two heat lamps to heat the bare section of pipeline between that extremity of the auct and FV-124.

Marinite was autable for the walls and lids of the heated duct. Bowever, Flexiboard vould be e good substitute because it is cheaper and is stocked in ORAL Stores whereas Merinite must be specially requisitioned.

Glidden caulkting compound No. 578 Natural has been successfully used on Harinite-to-angle iron joints. Its extremely strong bond, however, necessitated destroying the Karinite to open the duct. Therefore, abestos cement Which forms a weaker but adequate bond was substituted for the caulking compound.

UF 6 leake in the heated duct have occurred: (a) near ACV-2a in the early "F" rung and (b) near the top of FV-2e? in the "c" runs. These leaks were easily Identified by the yellowish coloration of the Marinite. Since no uranium was found in FV-158 in either case and considerable yellowing of the Marinite occurred, these leaks raise the question of whether the alr flow rate in the heated duct systen was adequate to pull UF vapor into FV-158 for subsequent recovery.

The extreme temperatures in the heated duct were $\sim 60$ and $135^{\circ} \mathrm{C}$. under normal operating conditions. This wide temperature range was evidently caused by the high wattage per unit length ( 40 watts per inch) of the heaters. Some trouble with cold areas occurred. It required $\approx 2$ howrs to hest the duct from room temperature to operatins temperature. Ho trouble with the tubular heaters occurred.

Ho difficulty was experienced with the blower after it wes moved to the Penthouse although 1ts inability to transfer UF 6 rapor to fV-158 indiceted low pumping rate. The lubricating achedule was followed although redioactive operation was a deterrent to following this schedule.

The operation of FV-158 wes setisfectory. Its maximum uraniun loading was $<$ one $\phi$ of capacity; therefore, no UF 6 pessed through $1 t$. The unloading schedule was aporadic. The top gas inlet fecilitated detecting whether any UF 6 bad been collected.

Corrosion of the Monel ptping in Cell 2 appeared Inslenificant. 


\subsection{Recommendat ions}

It is recormended that the heated auct be used in its latest state of development except that:

a. If tubuler heeters continue to be used in the heeted duct, ThK's or GE Calrods be used without substituting other brands because of the success with these hesters in the past.

b. The punping capacity of FV- 650 be determined an compared with its rated capscity.

c. F-650 and its motor be lubricated before subsequent operat 1ons.

d. Studies be made on the advisability of using a heating element with a lower wattage per inch and of substituting Flextboent for Marinite. 
8.0 Absorbing system . . . . . . . . . . . . . 86

8.1 Introduction . . . . . . . . . . . . 87

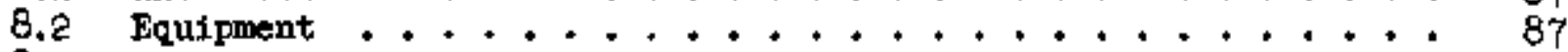

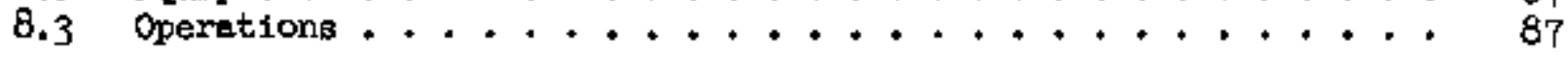

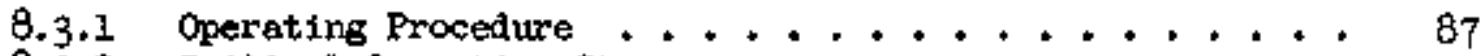

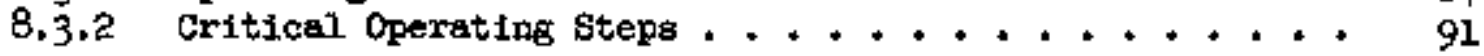

8.4 Equipment Evaluation .................. 92

8.4.1 Absorbers, FV-120 and $-1,21 \ldots . . \ldots 9$

a. Model Differences - Mark IA and IB ...... 92

b. Absorber Evaluation ............ 92

8.4.2 Absorber Furnaces, FV-520 and -521 . . . . . . . 99 96

8.4.3 Inlet P1pe Heaters, FV-520A and $-522 \mathrm{~A} \ldots \ldots . . . . .97$

8.4.4 Outlet P1pe Heaters, FV-520B and $-521 \mathrm{~B} . \ldots . . . . .97$

8.4.5 Gas Preheaters, FV-520C and -521C ......... 97

8.4 .6 Heat Lamps for Flanges ............... 97

8.4.7 Absorber Instrumentation ............. 97

8.5 Stmory and conclusions ................. 98

8.6 Recondendations . . . . . . . ....... 99

8.7 Operating Procedure: Desorption of Product ......... 100 


\subsection{ARSORBIIC SYSTEM}

\subsection{Introduction}

In the absorbing system, $\mathrm{UF}_{6}$ was separated from volatile fluorides of fission

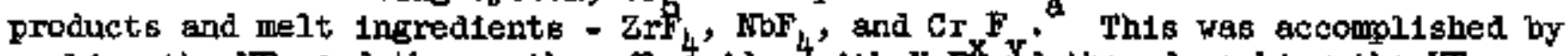
sorbing the $\mathrm{UF}_{6}$ and these other fluortdes w1th $\mathrm{KaF}^{4} \mathrm{X}_{\mathrm{d}}$ then desorbing the UF 6 preferentially while the other fluorides remalned on the sorbent. The chlef ${ }^{6}$ teps in the operation of the absorbing system vere: (a) sorbing the subject fluorides from the fluorinator exit gases on HaF and (b) desorbing the UF by beating the NaF bed in a stream of $F_{2}$ which swept the $\mathrm{UF}_{6}$ to the cold treps.

\subsection{Equiment}

Two absorbers alike in design and cornected in serles were used in the Yolatility Pilot Plant. F1gure 8.1 shows an assembled absorber. Since model differences in the absorber do not show in this sketch, these are delineated in Sec. 8.4.1a. Details relative to the vessel and Its auxiliary components are liated in Table 8.1 .

Some therrocouples were placed in the thernowells of the ebsorbers; others were welded to the external surfaces of the absorbers (Sec. 22.4.2).

\subsection{Operation}

\subsubsection{Operating Procedure}

Steps in operating the absorbing system vere:
Sorption
a. Maintaining the temperatures of both absorbers at $\sim 80^{\circ} \mathrm{C}$ (Compressed air for cooling during borption vas rewoved.); the heated duct at $\geq 65^{\circ} \mathrm{C}$ (Sec. $7 \cdot 4 \cdot 3$ ); and the cold traps at $-40^{\circ} \mathrm{C}$ and $-55^{\circ} \mathrm{C}$ respectively.

\footnotetext{
The reaction mechanism of UF with NaF is unknown and 18 , therefore, termed "sorption" while the ressel 1 called "absorber" and the aystem "absorbing" (르).

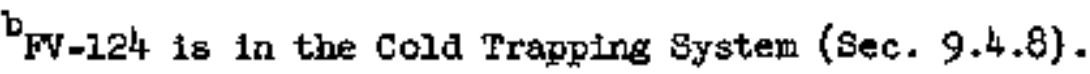

The warm part of the system was kept at a temperature slightly above the aubl1mation point of $\mathrm{UF}_{6}\left[57^{\circ} \mathrm{C}\right.$ at 14.7 psia, $(17, \mathrm{p} .4)$, with the HaF beds held only slightly $>65^{\circ} \mathrm{C}$ to avold a teaperature rise to $>150$ to $200^{\circ} \mathrm{C}$ during sorption. The cold traps were kept cold to prevent $\mathrm{WF}_{6}$ loss [vapor pressure of VF 6 at $-40^{\circ} \mathrm{C}$ was $8.5 \times 10^{3} \mathrm{pila}$ (17). Cf. Sec. 8.4.7.
} 
Logend and Wotes:

1. Flange leak detection designated as "LD-

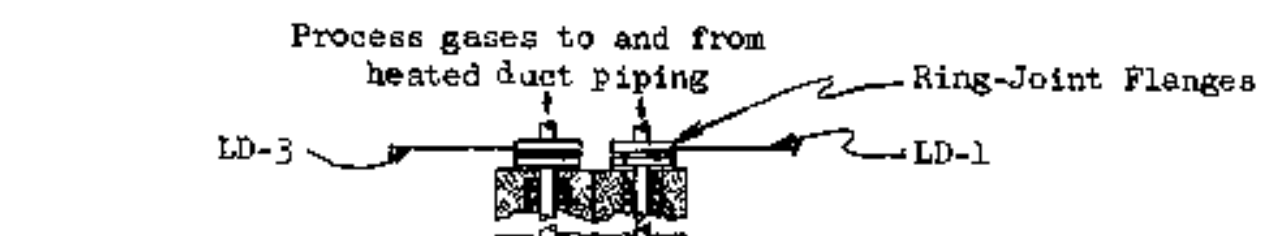

2. Gas preheater not shown

3. Thertacouples:

$\mathrm{T}_{1}$-Inlet ges $\mathrm{T}_{2}$-Lower bed $\mathrm{T}_{3}$-Center of bed $\mathrm{T}_{4}$-Upper bed $T_{5}$-Exit $\operatorname{sa}^{\mathbf{a}}$

aell not show

ID.

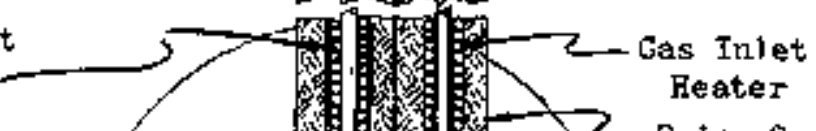
Heater

ID.
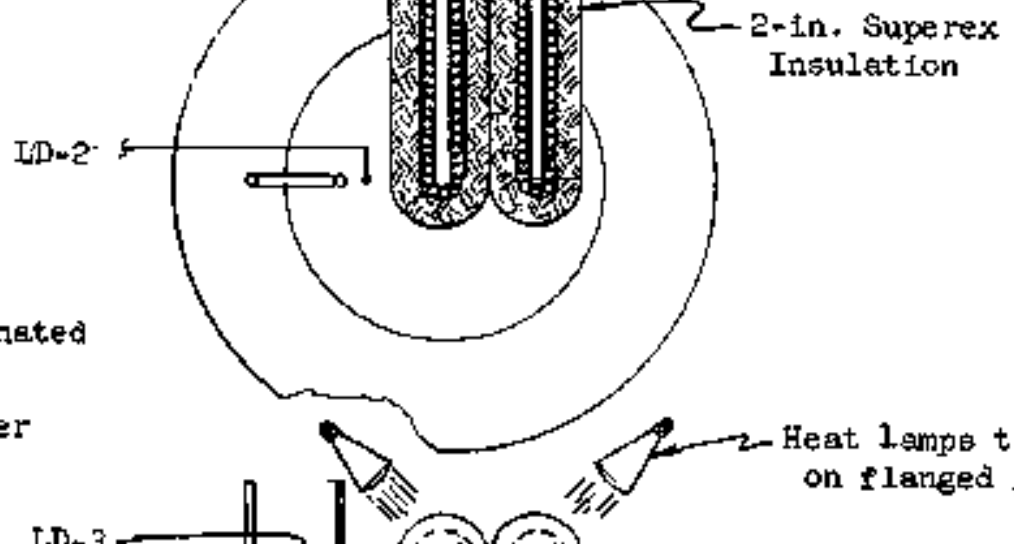

LD.

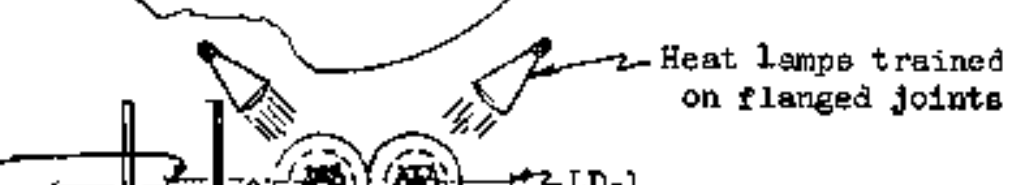


Talde 8.1

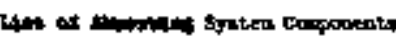

\begin{tabular}{|c|c|c|}
\hline \multirow[b]{2}{*}{ 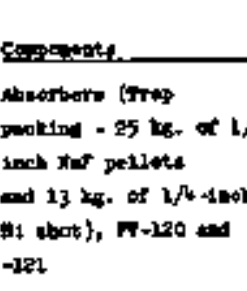 } & \multicolumn{2}{|c|}{ 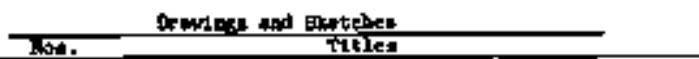 } \\
\hline & 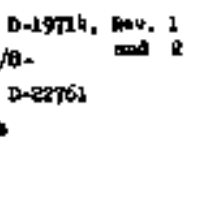 & 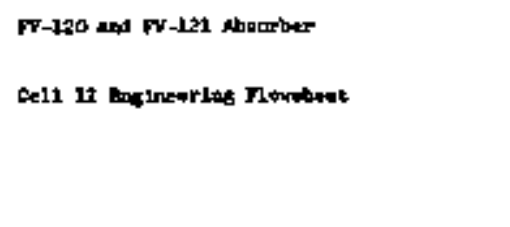 \\
\hline 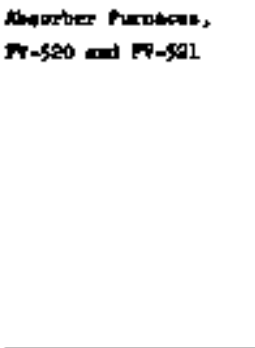 & 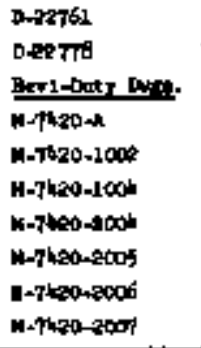 & 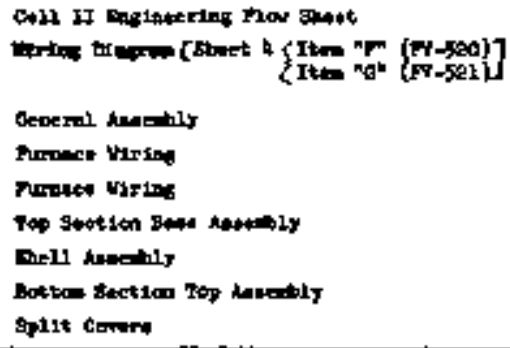 \\
\hline 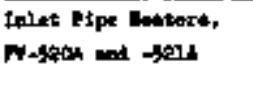 & $\begin{array}{l}\frac{\pi-\sin m}{0-82761} \\
0-2360\end{array}$ & 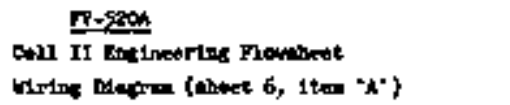 \\
\hline
\end{tabular}

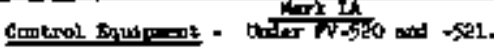

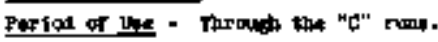

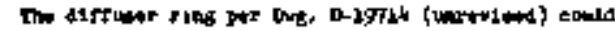

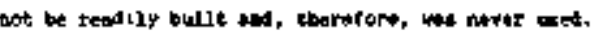

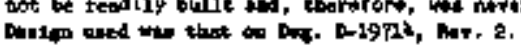

$$
\text { 눈도 }
$$

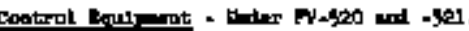

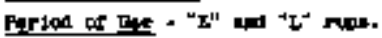

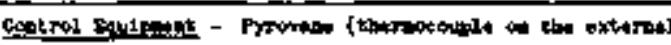

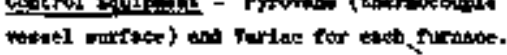

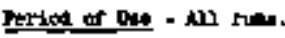

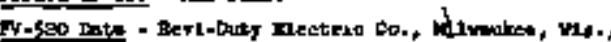

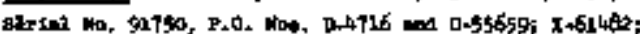

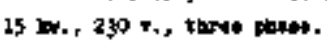

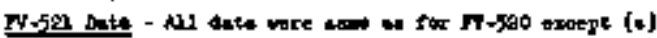

Ger1al Ho. 91Tk9 and (t) $x-63540$.

Aotoroseat

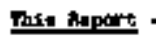

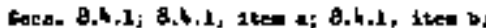

8. 3.1: 8.4.5, 0.4.7: 8.5; 8.6: 9.4.6;

15,4.5, 1ten b; 13.5; 18,4+2; and 18,4+2.

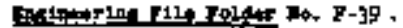

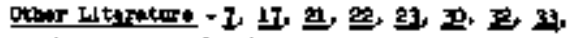

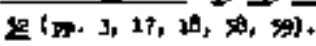

\section{Th1s txport -}

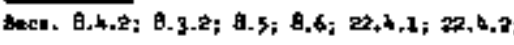

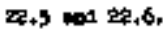

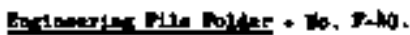

\section{rision}

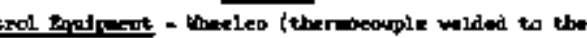

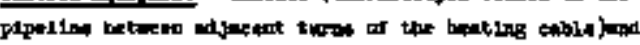
Varies.

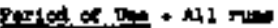

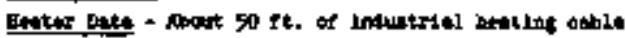

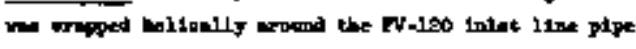

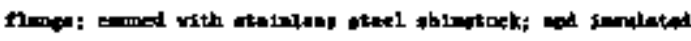

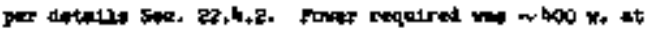

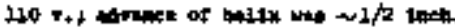

Biniler to thent sor roxom.

\section{Fr-5ent}

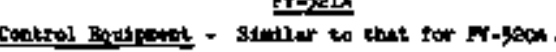

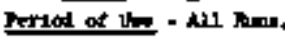

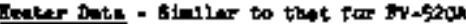

\section{Finc Ringt -}

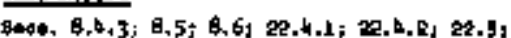
a4d 22.6 .

Th1s $2.3+$

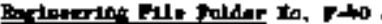

C.


Tobld 6.1 (Comtioned)

\begin{tabular}{|c|c|c|c|c|}
\hline 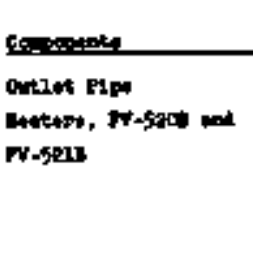 & 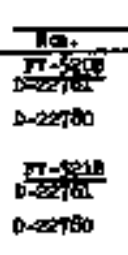 & 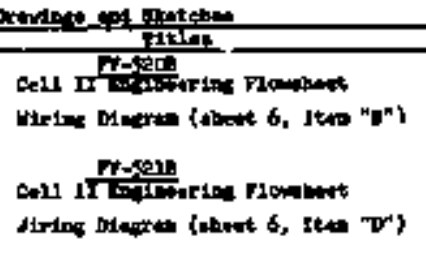 & 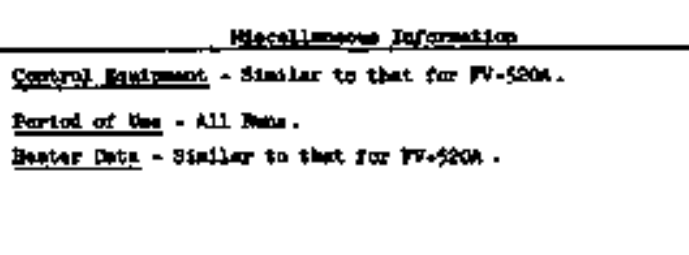 & 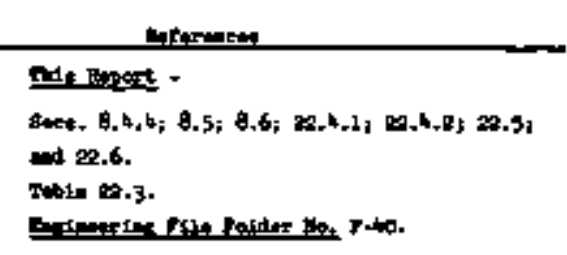 \\
\hline 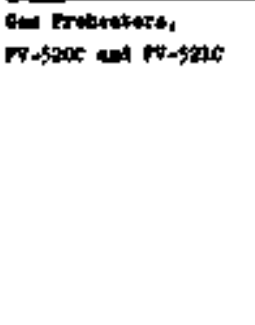 & D-astail & 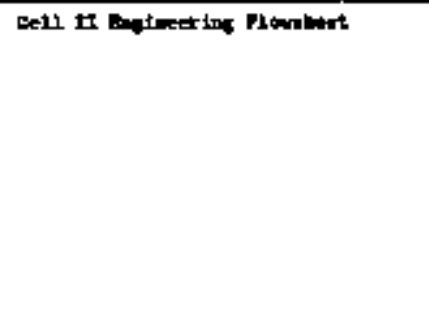 & 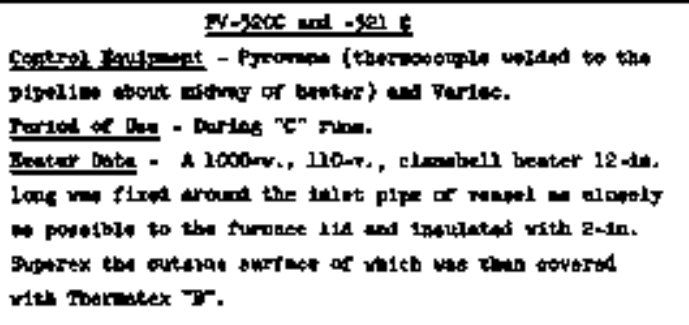 & 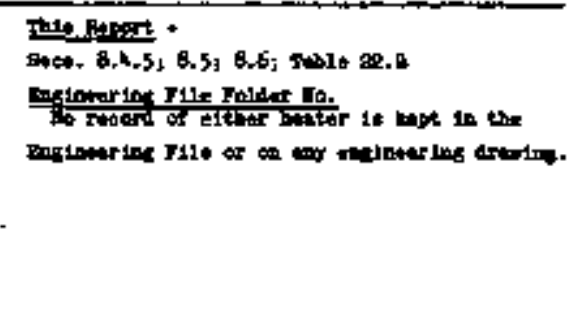 \\
\hline 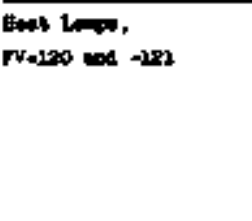 & D-expil & 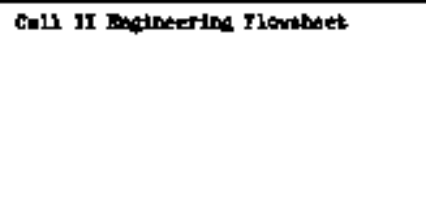 & 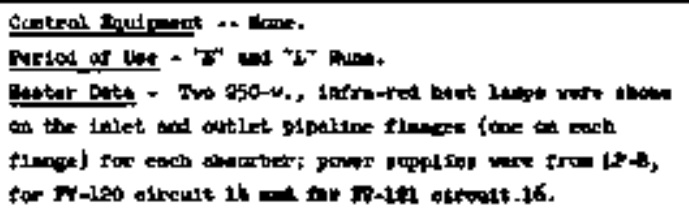 & 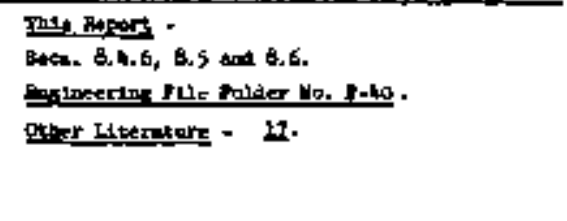 \\
\hline 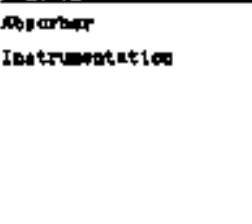 & & & & 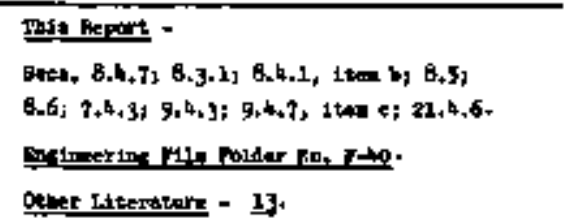 \\
\hline
\end{tabular}


b. Futting the necessary instruments and charts in service and establishing all $\mathrm{N}_{2}$ purges using $4=\mathrm{I} / 2 \mathrm{ps} 1 \mathrm{~g} \mathrm{~N}_{2}$.

c. Setting valves as requitred.

a. Controlling at Indicated set points heaters on FV-220 inlet pipe, absorber falet and outlet pipes, and absorber Inlet and outlet flenges (heat lamps).

e. Making certein that the scrubber was operating norally, and thet there was edequate scrubbing capacity for a normal sorption and desorption.

f. Heving $\mathrm{FV}-124$ and -158 packed w1th $\mathrm{NaF}$ and $\mathrm{FV}-650$ ruming.

\section{Desorption}

g. Adjusting the $F_{2}$ flow rate through the absorbers to 8 sim and continning steps a - I as needed.

h. Turning on absorber furnaces and setting the1r controllers at $-400^{\circ} \mathrm{C}$.

1. Continuing to heat the absorbers until the upper and lower temperatures in both absorbers exceeded $390^{\circ} \mathrm{C}$.

J. Turning off the absorber furnaces and the heaters referred to in item $d$.

$k$. Shutting off the $F_{2}$ flow 15 minutes after doing item $\mathrm{g}$.

1. Purgins absorbers with $\mathrm{N}_{2}$ for 40 minutes.

m. Sampling the absorber beda in segments as required to obtatn pertinent anslytical data (27, p. 37). (Such sarmplins was done once at the end of Run E-6 and once at the end of Fun L-9. In prior runs, sampling was done at odd intervals because of the developmental nature of those runs.)

System changes necessftated only minor alterations in the procedure. The sorption procedure was part of the fluorinetion procedure given in Sec. 5.7. For the complete desorption procedure, see Sec. 8.7.1.

\subsubsection{Critical Operating Steps}

a. Malntaining the bested duct temperatures and the FV-220 inlet (heated by FV-527) $\geq 65^{\circ} \mathrm{C}$ to prevent depositing UF $_{6}$ in the piping.

b. Holding the $\mathrm{OH}^{-}$concentration in the serubber solution at $\geq 1.0 \mathrm{~W}$ to avoid passing $\mathrm{F}_{2}$ through the scrubber.

c. Having the absorbers at $65^{\circ}-75^{\circ} \mathrm{C}$, before absorption to evold operating time lose (Sec. 8.4 .2 ). 
d. Heving both absorbers at $280^{\circ} \mathrm{C}$ before desorption to avoid depositing UF 6 on the cold surfaces of the second absorber and to reduce the time required to heat the HeF to $80^{\circ} \mathrm{C}$. (About four hours could be consumed in heating the cold absorbers to $80^{\circ} \mathrm{C}$ following excessive cooling during sorption.) See Sec. 8.4.2.

e. Holding cold traps at operating temperatures to minimize the amount of $\mathrm{UF}_{6}$ passing through them.

f. Having FV-124 and -158 in service to sorb any UF in gases passing through the cold traps or Wf leaking out of the system piping, respectively.

g. Maintaining $F_{2}$ flow and not exceeding a temperature of $400^{\circ} \mathrm{C}$ In the absorbers to recuace the formation of $\mathrm{UF}_{5}$. (Honvolatile $\mathrm{UF}_{5}$ represented a uranium loss.)

\subsection{Eculoment Evaluation}

\subsubsection{Absorbers, FV-220 and $-121^{a}$}

a. Model Differences - Merk IA and IB

Mark IA contained thermowells as shown on ORWL Dwg. D-19714, Rev. 1 and kerk IB as shown on ORNL DWg. D-19714, Rev. 2 .

The thermowells in Mark ID were superior to those in Mark IA in these ways: (a) enabled measuring inlet and outlet ges temperatures as well as the bed temperature at a point higher in the bed than beforehand, (b) used structurelly stronger thertiowella in the NaF bed (1/4-in. NFS Sch. 40 Inconel vs. 1/8-in. MPs Sch. 40 nickel), and (o) facilitated the installation of thermocouples because of the larger 1.d. of the 1/4-In. WFS.

The Mark Is design was al.6o superior because flanges were incorporated in flange leak-detector system (ef. Secs. 18.3, 18.4.1, 19.4.2; F1E. 18.1; Table 28.1).

b. Absorber Bvaluation

Charge for an absorber was $25 \mathrm{~kg}$ of $1 / 8-\mathrm{in}$. NaF pelilets, $b, c$ with $13 \mathrm{~kg}$ of 1/4-in. nickel shot placed as bhown in Fig. 8.1.

Absorber capactty was nominaliy $10 \mathrm{~kg}$ of U as UF 6 . Theoretical cepecity $(0.9 \mathrm{~g} \mathrm{U} / \mathrm{g} \mathrm{NaF})$ was $22.5 \mathrm{~kg}(\underline{28}, \mathrm{p} .33)$.

\footnotetext{
after use, the absorbers and assoctated equipment were moved to Burial Ground No. 3 (Sec. 23.4.16, 1tem b).

b Attenpts to reduce processing costs by usting less expensive $\mathrm{NaHF}_{2}$ instead of NaF falled because of polyfluoride formation in domstream NaF beds and condensation of HF in unbeated sections of the system piping (29). The economic justification was shown (30, 3l, p.9). Also cf. 5ec. 9.4.8.

"Using mimas 20-mesh HaF instead of the more expensive $1 / 8-1 n$. pellets was not feasible because of difficulties encountered with fines.
} 
Absorber losses on the everage were:

1. One absorber passed $\sim 25$ to $30 \mathrm{~g}$ of $\mathrm{U}$ in the exit gases.

2. Two absorbers and cold traps in serfes as in most runs passed $\sim 11 \mathrm{~B}$ of $\mathrm{J}$ out in tail gases.

3. After desorption at $400^{\circ} \mathrm{C}$., I4 of of remaiped equally distributed verticaliy on the absorbex bed.

Experiences with the ebsorbers were:

1. Difficult to unload because of the small neck. D1scharging was done by vacum in a manner described elsewhere to deterwine the distribution of uranium and/or impurities in the bed (ol) . It was difficult to remove the absorber bed without spreading $\mathrm{NaF}$ dust.

2. Uneven gas distribution in gas diffuser ring. A rough qualitative test performed by bubbling aix through the affuser ring while the ring was under water showed that about two-thirds of the alr was discharged adjecent to the ges Inlet pipe. Consequently to prevent UP 6 from heevily loading the liaF above this region the absorber sas filled to the botton of the diffuser ring with $13 \mathrm{~kg}$ of nickel ahot. Then, the Nar pellets were charged on top of the nickel shot. Although the efficacy of this scheme was not fully determined, less caking of NaF in the bottom of the absorber occurred after this change then beforeband.

3. Iong time (e.g., $12 \mathrm{hrs}$ ) required to hat the center of the bed to $390^{\circ} \mathrm{C}$. Two means of shortening the heat-up time of the center of the absorber bed have been tried. First, the gas preheater mentioned in Sec. 8.4.5 was added. Second, the distance from the outer circuanference to the center of the bed was reduced from $5^{* \prime}$ to $4^{*}$ by axial, placement of a plece of $2-i n$. NPS (31, p. 26). Thia reduced by one 1nch the dietance through which heat from the absorber furnace flowed to reach the mostdistant NaF pelleta. Some reduction in heat-up time was realized, but the improvement was slight. In addition, exact axial plecement of the center pipe was extremely diffloult because of the small neek and geometry of the alosorber design. Consequentiy, using this axial plpe technique for reducing heat-up time was discontinued.

a The U passing the absorbers and cold traps was collected on NaF in Fr-124. The U collected In FV-124 and that remaining In the absorber bed after desorption was reclaimed by dissolution (Sec. $9.4 .8 ; 32$ )

$b$ In the " $\mathrm{F}$ " and " $\mathrm{L}$ " runs, the desorption in the final run of each series was performed at $600^{\circ} \mathrm{C}$. With no marked decrease in the U retention of the bed. cf. footmote above.

C Sec. 8.3.1. 
4. Preasure build-up before FV-120. In the pre-CRP trap pertod, conalderable trouble with pressure butldup before Fv-loo was experienced. This apparently atd not occur in post-cRP trap work. Generally, thwee observations were made churing the period of time that FV-120 plugsing was prevalent:

(a) Sintering and/or agsiomerating of NaF pellets occurred. The first of the two series-connected NeF beds was yery susceptible to plugeing. Plugging did not occur, however, In the last four " $\mathrm{E}$ " runs or the last five " $\mathrm{L}$ " runs. And the reel reason(s) for these exceptions cannot yet be formulated. One possiblilty is that maloperation during fluorination was essociated with plugging because maloperation wes absent in these above mentioned " $\mathrm{E}$ " runs and present in elmost every other run. "Maloperation" here is defined as embracing the following out-of-theordinary fluorination conditions: (1) Dressure rises in the fluorinator, (2) excessive fluorination tire, and (3) higher-than-normal fluorination temperaturea.

The second possibility is that the HF in the $F_{\text {a }}$ reacted with the MaF to form polyfluorides (Sec. 15.4.19). An 日F trap (Sec. $15.4,3$ ) was installed prior to the " $\mathrm{E}$ "rung to remove the Ell from the $F_{2}$.

(b) Colortng of some Har pellets took place, the colors belng yellow, brown and pink (31, p.28). Analyses of the colored pellets disproved the bellef that all yellowlsh MaF pellets are high in uranlum content. Por instence, many of the yellowisb pellets contained substantial percentages of chromium and little uranium. Along with these findings, the brown and pink pellets vere alao found to contain bigh percentages of chromium. Apparently the differently colored $\mathrm{Cr}-\mathrm{rlch}$ pellets represented chromium In different valence states.

(c) More than three-fourths of the holes in the diffuser rings of both absorbers were plugged. The holes in the FV-I2O diffuser ring plugged with this vessel in the FV-120 position (first absorber in series). After the FV-120 diffuser ring disintegration (1tem 5 following), the vessels were exchanged. Then, after the FV-12l vessel was uned for several rung in the FV-120 position, examination of its diffuser ring revealed atmilar plugging. FV-l21 was restored with a circumferential weld as was $F V-120$, efter drilling out the plugs.

a Pressure bulld-up was noted on PG-12 and PE-38 (Sec. 8.4.7). 
5. Disintegration of FV-120 diffuser ring ${ }^{a}$ The cauge of this Incident was not definitely known. But three out-of-theordinary precticea might have contributed to it elther indivichally or collectively:

(a) Ho $F_{\text {a }}$ conditioning of $F-120$ prior to the sodium fluoride preparation. $F_{p}$ conditioning was not indicated in the sodium fluoride preparetion procedure because the conditioning with HF was thought to be adequate al,though not as effective as that with $\mathrm{F}_{2}$.

(b) Fure $F_{\text {g }}$ being fed to the vesgel with the bed at $\sim 600^{\circ} \mathrm{C}$ instead of at $375^{\circ} \mathrm{C}$. as indiceted by the sodium fluoride preparation procedure. Heating the bed to this higher temperature before adding $F$ was intentional rather than accidental. Reasons for this were: (e) to minimize the HF relessed from the Naf during desorption by flnishing the NeHF to HaF conversion at $\sim 200^{\circ} \mathrm{C}$. above the normal

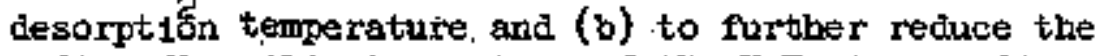
sodium fluosilleate content of the NaF since sodium fluosilicate reacts irreversibly with $\mathrm{UF}_{6}{ }^{\circ}$

(c) The accelerated cooling technique used on FV-120 after desorption. In this technique, FV-120 was isolated from the system by valving after desorption. Then, the inlet and outlet flanges were uncoupled and blenked off. Hext, the vessel was lifted out of the furnace to hasten cooling. The furnace was left open vith a spall flow of alr to it to cool more repidiy. After the vessel and furnace had cooled to the desired temperatures, the vessel was lowered into the furnace and recoupled to the system (33). Whether the vessel was then conditioned with $F_{2}$ before being used again for the absorption-desorption ofole is unknown. Although the mechantsm causing the diffueer ring fallure is uninown, sufficlent heat was released to partially melt the Inconel ring. It is rather probable that the heat came from a localized highly exothermic reaction like that of fluorine with organic material(s) such as dirt, grease, or a rag which might have been accidentally left in the absorber after cherging with NaHF. Repalr of the diffuser ring was accomplished by: (1) cutting the vessel cireumferentially in a plane normal to its axis and 12 to 15 in. above the botton of the vessel; (2) dressing up the melted edges of the diffuser ring and welding on plates to seal the ring, this operation reducing the ring to about two-thirds its orlgtnal size; (3) removing the plugs from about three-fourths of the diffuser ring holes; and (4) restoring the vessel with a 
circumferential wold. After FV-120 was so repaired, the original FV-120 wes benceforth uaed in the FV-12l position and vice verse. This exchange vas made because of the reduced size of the FW-120 ges diffuser ring.

6. Shielding. The lead shielding around the FV-lizo inlet line H-103-1 and the concrete-block wall around the FV-120 and -520 assembly were adequate shields for the radiation levels encountered in Cell 2. The highest bed sctivities which occurred curing the "I" runs were: gross $\beta$ - 51 counta/min/mg U and gross $\gamma-220$ counts/min/mg U. Csl37 was the principal $\gamma$

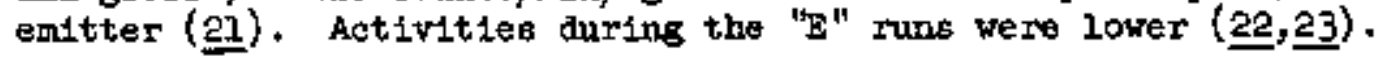

7. Flange leak-detector connections. The top flanges and the inlet and outlet lines flanges of both absorbers tere incorporated into the flange leak-detector system before Run E-3. Daring subsequent runs, leaks vere detected by this system in the top flanges to both vesgels whereas no leak was found at the inlet and outlet flanges. In each case, the leak was greatest with the vessel at $\sim 100^{\circ} \mathrm{C}$ and least at $\sim 400^{\circ} \mathrm{C}$ (during desorption). Since the system pressure was about atmospheric, applying 30 piig If dynamically to the leak-detector connections at the absorber top flanges eliminated any alr-leakage Into the vessels through the Ilange leaks. Attemptis to stop the leak by draning the flange bolts tighter with the veseel at $\sim 100^{\circ} \mathrm{C}$ fatled. The bolt nats would not move at the 175 ft-lb. limit of the torque wrench used. Trying to tighten the bolts with the vessel at $400^{\circ} \mathrm{C}$ was not feasible.

The NeF sampler for the abosthers recommended in the study made by M.I.T. practice school at Oak Ridge was never used because larger samples then could be taken with it were desired (14). Usually the bed was sampled in gegmenta as mentioned in Sec. 8.3 .1 .

8.4.2 Absorber Furnaceg, rv-520 and $-521^{b}$

To secure proper furnace $11 \mathrm{~d}$ closure, it was necessary to "hot-rod" both lids to accommodate the Mark IB themocouple wells and the top flange leak-detector plumbing.

Signiflcant time-lags were encountered vhile heating and cooling in the $<100^{\circ} \mathrm{C}$ range. For example, assunting the absorbers vere at $90^{\circ} \mathrm{C}$ thile preparing for fluorination, it required 3 to 4 hours to reach the destred $65-75^{\circ} \mathrm{C}$ range. In the same way, if the absorbers were at $50^{\circ} \mathrm{C}$ whlle preparing for fluorination, 3 or

Secs. 18.3, 18.4.1, 18.4.2; F1g. 18.1; Table 18.1.

bable 22.1 and Secs. 22.4.1, 22.4.2, 22.5, and 22.6. 
4 hours were required to heat to the required temperature range. The full 1upact of this time-lag was felt when the fluorination was delayed by operating error.

Absorber cooling was hastened by applying a compressed alr strean to the vessels; otherwise, the cooling time-lag mentioned above would have been much greater.

It. required about 14 hours to cool the absorbers to $<100^{\circ} \mathrm{C}$. following the desorption step. In this case also, coupressed air was blown on the vessel after it had cooled to $m 300^{\circ} \mathrm{C}$. This cooling step was not usually critical titee-wise, however, becanse subsequent parts of the run could be carried on whlle the absorbers were cooling.

The absorbex heat-rp time arring desorption tas 12 hours. The IF 6 -bearing vessel (FV-120) required about two hours longer than did the second absolber because of the hedt required to decompose the Uf 6 . $3 \mathrm{MaF}$ complex (23).

\subsubsection{Inlet Pipe Heaters, FV $-520 \mathrm{~A}$ and $-521 \mathrm{~A}$}

These heaters were satisfactory. The heat-up tinfe to $100^{\circ} \mathrm{C}$. was 2 hours. See Table 22.3, and Secs. 22.4.1, 22.4.2, 22.5 and 22.6 .

\subsubsection{Outlet Pipe Heaters, FV-520B and -5218}

These heaters were satisfactory. The heat -up time to $100^{\circ} \mathrm{C}$. was 2 hours. See Table 22.3, and Secs. 22.4.1, 22.4.2, 22.5, and 22.6.

\subsubsection{Gas Preheaters, FV -5900 and $-521 \mathrm{C}$}

These heaters were removed during the " $\mathrm{C}$ " runs after demonstrating b their ineffectiveness in reducing the tine-to-temperature of the absorbers. Their failure resulted from: (a) the small surface areas of the neated surfaces, (b) the low contect timeg between the bas and the heated surfaces, and (s) the presumably low over-all heat transfer coefficient.

\subsubsection{Heat Lamps for Flanges}

These heat lamps were effectively used to keep the absorber inlet and outlet pipe tianges (shown in Fig. 8.1) at $>65^{\circ} \mathrm{C}$. Without them the flanges wete cold gnough $\left(i e_{y},{ }^{\prime \prime}<57^{\circ} \mathrm{C}\right.$ ) to condense $\mathrm{UF}_{6}(17, \mathrm{p}, 4)$. The heat-up time to> $65^{\circ} \mathrm{C}$ was about one hour.

\subsubsection{Absorber Instrumentation (Sec. 14.4.5; 13)}

PE-38 indicated the pressure of the gases lesving FV-103 in line Ei-103-1. This instrument satisfactorily indicated plugs in the aystem piping to the scrubber, especially in FV-1FO (Sec. $8.4 . \mathrm{Jb}$ ). But, in the effort to reduce the probability of $\mathrm{UF}_{6}$ leaks in the system duxing Fun $\mathrm{E}-3$, the PE-38 connection was capped off ( $\mathrm{sec}, 9.4,7 \mathrm{c}$ ).

\footnotetext{
This is the reason for liating items $c$. and d. es critical operating steps in Sec. 8.3.2. 
Experience w1th instruments $\mathrm{FE}-5$ and $\mathrm{PS}-12$ paralleled that with FE-6 and PE-13 (Sec. 9.4.7c). Prior to capping off these connections as for PE-38 and other's durlug Run E-3, however, PE-12 also indicated plus formation in FV-120.

PE-34 Indicated the pressure of the gases in 11ne H-12O-1 between FY-120 and -121. Th1s 1nstrument enabled detecting plugs in FV-121. and downstresm of th1s vessel throughout the VPP work. The plug in the FV-220 inlet during fou I-7, for example, was found with PE-34 (Sec.9.4.3).

The rarious thermocouples used in this system vere indispensable for monitoring these temperatures: (a) absorber beda and gas inlets and outlets (as shown on Fig. 8.1), (b) external surfeces of the vesiels, and (c) heated duct (Bes. $7 \cdot 4 \cdot 3)$.

\subsection{Summary and Conclusions}

Bech absorber was capable of sorbing $10 \mathrm{~kg}$ of $\mathrm{v}$ as $\mathrm{VP}_{6}$ (< $50 \%$ theoretical capecity) when packed with $13 \mathrm{~kg}$ of nickel ohot and $\hat{2} 5 \mathrm{~kg}$ of 1/8-1n. NaF pellets. About 25 to $30 \mathrm{~g}$ of $\mathrm{U}$ pessed through one such absorber while only $\sim 11 \mathrm{~B}$ of $\mathrm{U}$ passed through four vessels in series (FV-120, FV-12l, FV-220, and FV-222 in that order) as normsily used in the Volatility Pilot Plant. After a normal desorption at $\sim 400^{\circ} \mathrm{C}$, about $14 \mathrm{~g}$ of $\mathrm{U}$ remained equally distributed on the absorber bed.

$U_{6}$ in the tail gea strean did not represent a procesa loss. This meterial was soxbed on MaF in FV-124 and was leter reclatined by aqueous processing.

Attempti to use either crushed MaF or MaHF 2 instead of $1 / 8-12$. NaP peliets met with diffleulties as outlined earlier.

Operational experfences with the absorber vessels 1ncluded;

a. Mark IB thermowells were superior to those in Mark IA.

b. The gall necks made unloading the NaF from the absorbers difficult.

c. The uneven gas distribution of the diffuser rings was probably turproved by using nickel shot.

d. The 10-1n. diameter of the Ner bed made it difficult aither to heat or cool the center of the bed.

e. Dlffuser ring hole plugs and bed agglomeration were significantly lower in post-CRP t rap runs.

f. Coloration of $\mathrm{MaF}$ pellets gualitetively showed the presence of both $U$ and $\mathrm{Cr}$.

g. The mechenism causing the disintegration of the FV-l20 diffuser ring is unknown although three out-of-the-ordinary practices were performed durting the sispociated runs. 
h. Absorber shielding vas adequate for the activity of the material handied.

i. Leaks in both vessel top flanges were found with the flange leak detector system.

The absorber furnaces were adequate although 12 to 14 hours were required for desorption. Cooling the absorbers efter desorption by blowing compressed atr on the vessela required $\sim 14$ hours.

Prior to sorption, it required $\sim 4$ hours efther to heat a cold absorber or cool a warn absorber to the desired $65-75^{\circ} \mathrm{C}$. temperature range. Th1s resulted in an operating time loss unless done simultaneously with other preparations for fluorinetion. Prolonged cooling after sorption also ceused time loss in desorption.

The performances of auxiliary heaters were:

a. Inlet and outlet line beaters were satisfectory and required $\sim 2$ bours to reach the operating temperature of $100^{\circ} \mathrm{C}$.

b. Heat lamps requiring a one-hour heet-up time were adequate for maintaining the inlet and outlet pipe flanges at $>65^{\circ} \mathrm{C}$.

c. Gas preheaters were unsstisfactory.

The instrumentation was partially getisfectory. All pressure instruments ( $\mathrm{PE}-12,-34$, and -38 ) successfully indicated downstream plug formation. But PE-12 and -38 were removed from service in Run E-3 to reduce the probebility of having $\mathrm{UF}_{6}$ leaks, $\mathrm{kE}-5$ was never used because of the improper range. Thermocouples we uged to medsure temperatures.

\subsection{Recommendations}

It is recommended thet:

a. The aboorber be redesigned with at least these features: (a) shorter heating and cooling times, easier unioading, and more uniform gas dis. tribution than in Mark I; (b) adequate provision for unit shielding besed on the material to be processed; (c) incorporation into a flange leak detection system; and (d) provision for inlet and outlet line heaters and flange heat lemps $8 \mathrm{~s}$ before if these ere needed.

b. Two absorbers be used packed with $1 / 8-1$. NaF pellets in series as before with some form of CRP trap upatream of the first ebsorber to reduce plugging in the first absorber.

e. Nons of the three extraordinary practices associated with the FV-120 diffuser ring fallure be used.

a. Operating procechures be altered to enaure baving the absorbers in the designated temperature range $\left(65-75^{\circ} \mathrm{C}\right.$.) when reedy for fluorination and also then ready for desorption to avota a loss of operating time. 
e. The use of gas preheeters similar to those ( $F-520$ and -5210 ) used during early absorber work be discontinued.

f. Pressure instrument $(s)$ contimue to be used to indicate dorn-ptrean plus formation.

8.7 Operating Procedure: Desorption of Product (Revised November 1, 1957)

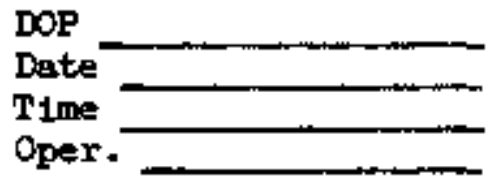

1. Close the following velves on the panel:

EX-8

$\mathrm{HX}-25$ , $\mathrm{EX}-18$ HX-26 , HX-19 , $3 x-32$ , $\mathrm{HX}-22$ , $\mathrm{HX}-35$ , $\mathrm{Hx}-23$ , $\mathrm{HX}-36$ $\mathrm{HX}-24$

2. Open the following valvee on the penel:

BX-12 and $\mathrm{HX}-34$ , $\mathrm{HX}-13$ , $\mathrm{HX}-14$ , $\mathrm{HX}-15$ , $\mathrm{HX}-16$ , HX- 30

3. Open $\mathrm{V}-27$ - Keep EX-11 open when fluorinetor requires venting. and $v-72$ on roof. Close V-126 close $V-127$ $\left(\begin{array}{l}\text { Cell one } \\ \text { Cell two }\end{array}\right)$

4. The following instruments should be in service and charts syachronized:

LR-4

TR- $2 B$ , FR-B TR- $\overline{\mathrm{CC}}$ , $P R-34$

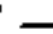
following controllexs:

\begin{tabular}{c} 
Controller - TIC \\
\hline $2 A-11$ \\
$2 A-12$ \\
$2 B-2$ \\
$2 B-9$ \\
$2 B-10$ \\
$F V-527$
\end{tabular}

\begin{tabular}{c} 
TIC Set Point* \\
\hline 130 \\
145 \\
58 \\
135 \\
135 \\
100
\end{tabular}

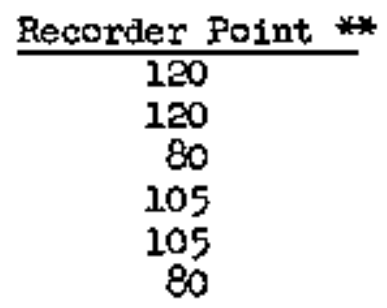

Time Set

6. Adjust the settings on the following Varlecs:

\begin{tabular}{l} 
Yariac - TC \\
\hline $2 A-11$ \\
$2 A-12$ \\
$2 B-2$ \\
$2 B-9$ \\
$2 B-70$ \\
$T C-527$
\end{tabular}

\begin{tabular}{c} 
Settings \\
\hline 60 \\
60 \\
90 \\
60 \\
60 \\
80
\end{tabular}

Time Set

7. Record pertodic data on sheets provtded.

F Set polnt is setting on controller.

* Control point is reading on recorder. 
8. Turn on brine switches in pipe tumnel brine reservolir at $10-15 \mathrm{ps} 1 \mathrm{~s}$. - Set pressure on each

FV -830 $\mathrm{FV}-832$ FV -832 Tine - Start compressors on $\mathrm{Fv}-830$

9. Thirn on FV-35e agrtator in FV-152 and start FV-450 Recirculate $\mathrm{KOF}_{\mathrm{H}}$ through velves $4,8,10$ into tower. Use (toB side) fluorine inlet line 10. Sample $\mathrm{FV}-152$. Coded "SI".

11 . Set PC-10 on "auto" and adjust set point to 4 psig (20\% full scale). 12 . Set $\mathrm{PC}-2$ on manual

13. Turn on Muorine supply and adjust FR-2 to 8 SIM ( $18 \%$ full scale). Time fluorine on

24. When nows have levelled out, switch controliers to "euto". 15. Set these controllers:

\begin{tabular}{|c|c|c|}
\hline$\frac{\text { Controller }- \text { TIC }}{2 A=5}$ & $\frac{\text { Set Point }}{\mathrm{b}}$ & $\frac{\text { Control. Point }}{400}$ \\
\hline
\end{tabular}

a) Adjust so TR-2R-3 is maintained at $420^{\circ} \mathrm{C}$. (Maximam).

b) Adjust so TR-2:-9 1s maintained at $420^{\circ} \mathrm{C}$. (Maximfm).

16. - Adjust the settings on these Variacs:

$\begin{array}{lc}\text { Variac } & \text { Original Setting } \\ -2 A-5 & \text { Reduce (When Controllins) Time Bet } \\ \text { TC-2A-8 } & 220\end{array}$

17. Record data on sheets provided.

18. Continue operation until TR-2A-6, -7, -9 , and-10 and TR-2E-5, TR-2E-11, each exceeds $390^{\circ} \mathrm{C}$.

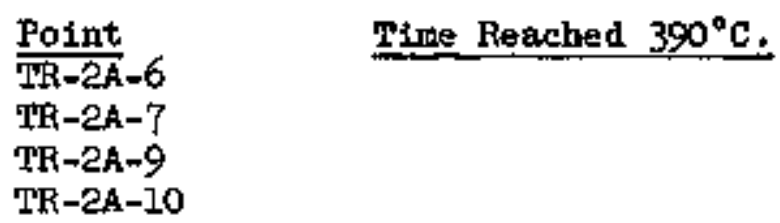

19. When all above points reach $390^{\circ} \mathrm{C}$, shut off these controllers:

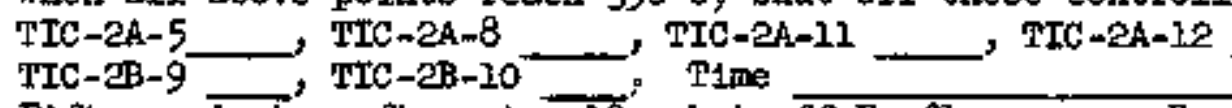

20. Fifteen minutes after step 19, shut off $F_{f}$ flow $\ldots$. Feset $\mathrm{FR}-2$ and FC-10 to zero output pressure

21. Set FR-1 at $50 \%$.

22. Set PI-6 on 4.5 psis 2 . The

24. Close: $\mathrm{EX}-12, \mathrm{HX}-13, \mathrm{HX}-14$

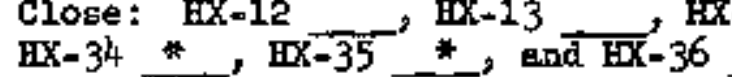

Femove FV-120 FV-121 and Fv-124 Sample FV-152, Code $S I$ - TIme .

As soon as FV-124 is reloeded and replaced, open $\mathrm{HX}-34$ FX-36 - Time $+$ By 
9.0 cold Trapping systen . . . . . . . . . . . . . 102

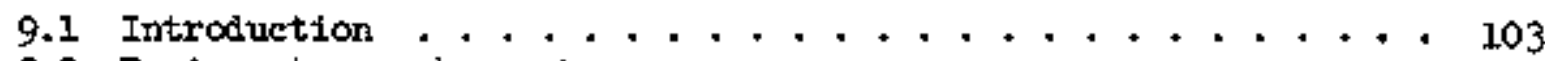

9.2 Equipment . . . . . . . . .......... 103

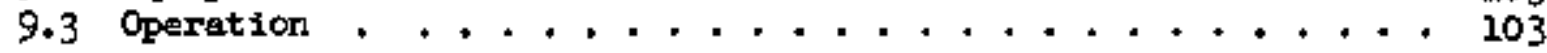

9.3.1 Operating Procedure ............. 103

a. Cooling Procedure ............. 103

๖. Heating Procedure ............ 107

9.3 .2 Critical Operating Steps........... 107

9.4 Equipment Eveluation . . . . . . . . . . . . 108

9.4.1 5-In. Cold Trap, Fv-220 . . . . . . . . 108

9.4.2 Refrigeration unit for FV-220, FV $-830 \ldots . . . . .109$

$9.4 .3 \mathrm{FV}-220$ Heater6 . . . . . . . . . . 109

9.4.4 6-In. Cold Trap, Fv-2e2 .................... 110

9.4.5 Refrigeration Un1t for FV-222, Fv-832 ....... 110

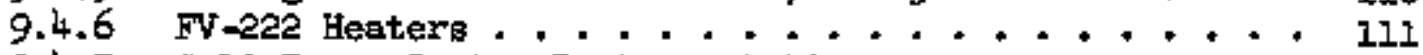

9.4 .7 Cold Traps System Instrmentation . . . . . . . . 111

a. FE-11 (FV-830, and FE-12 (FV-832) ...... 117

b. PA-36, PX-36 and PI-36 (FV-220); PA-37, PX-37,

and PI-37 (FV-222) . . . . . . . . 111

c. $\mathrm{FE}-6$ and $\mathrm{PZ}-13 \ldots . . . . . . . .1112$

d. FE-7, $\mathrm{PE}-14$ and $-15 \ldots \ldots \ldots . . \ldots 113$

e. $\mathrm{FE}-\mathrm{B}$ and $\mathrm{PE}-16 \ldots \ldots \ldots \ldots . \ldots . \ldots . \ldots 13$

f. Thermocouples .................... 114

9.4.8 Main Procese Chemical Trap, Fv-124 ........ 114

9.4.9 Batch-Type $\mathrm{UF}_{6}$ Detector, $\mathrm{Fv}-123 \ldots \ldots . . . . .24$

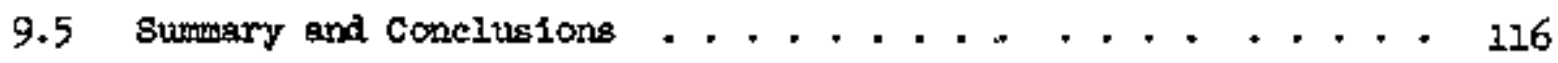

9.5.1 Entire Cold Traps Systemn .............. 116

9.5.2 5-In. Cold Trap and FV-830, FV-220 . . . . . 116

9.5 .3 6-In. Cold Trap and $\mathrm{FV}_{-832}, \mathrm{FV}-222 \ldots \ldots . . . .116$

9.5 .4 Instrumentation ..................... 117

9.5 .5 Main Process Chemlcal Trap, Fv-124 . . . . . . 117

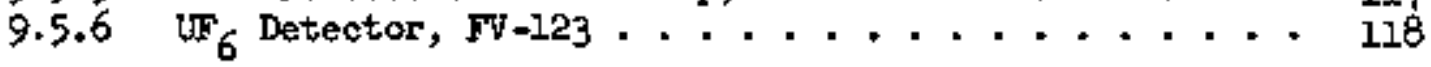

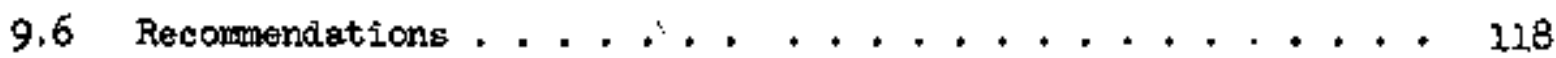

9.7 Operating Frocedure: Operation of Refrigeration Systems ... 118 


\subsection{Intraduction}

In the cold trapping system, the $\mathrm{UF}_{6}$ desorbed from the absorbers ras collected frow the $F_{,}$-bearing sweep gas by freezing it out on two series-connected cold traps. To aroid $\mathrm{tF}_{6} \mathrm{~L}_{\mathrm{s}}$, the exit sweep gas from the cold traps pasaed through a chemical trap before being serubbed in the caust ic scrubbing tower. Major steps in operating this system were:

a. Keeping the two cold trapa at $-40^{\circ} \mathrm{c}$. and $-55^{\circ} \mathrm{C}$. respectively, and having the chemical trap and acrubber operating noxmally.

b. D1recting the appropriate $\mathrm{UF}_{6}$-bearing gas stream through the two cold traps, the chemical trap, and caustle scrubber in that order.

\subsection{Equipment}

The general arrangement of the equipment in the cold traps system is shown in Fig. 9.1. The measured volumes of the cold traps are gtven. Detalls of individual, components are recorded in Table 9.1 .

\subsection{Operation}

\subsubsection{Operating Procedure}

Steps in the operating procedure for the cold treps systen were:

\section{a. Cooling Procedure}

1. Havlug the $F-11,-13$, and -22 eireults filled with their respective Freons, the cooling water turned on, the thermostat set at the desired operating temperature for each unt $\left(-40^{\circ} \mathrm{F}\right.$ for FV -830 and $-60^{\circ} \mathrm{F}$ for FV-832), and the brine cooler switch at each unit turned on.

2. Making certain that the presure in each cold trap vacuum jacket was $<3$ in. of Hg. [PA-36 and -37 sounded then the vacuum jacket pressures vere $>3$ in. of Hg. When thls happened, the pressure switches (PX-36 and -37) could be reset by pumping down the jackets to an absolute pressure below one tm. of He.

3. Turnting on the refrigerating units switches at the kain Panelboard.

4. Setting the r-ll flow rate in each circuit at about $4-1 / 2$ gpin by adjusting valves $\mathrm{V}-60$ and -61 .

5. Performing the desired operational step, $i, e$, the feed salt fluorination (Sec. 5.3.1), the desorption of product (Sec. 8.3.1), or the collection of residual $\mathrm{UF}_{6}$ vapar th product collection 
folumes of cold Trape as Inetalled in VPP (measured by $R$. G. N1eol) Fv-220 (Bounded by HCY's 13,15 , and 19)---12.9 liters. Fq-22e (Bounded by HCV's 14, 15, 18, and 22) ---50.0 liters .

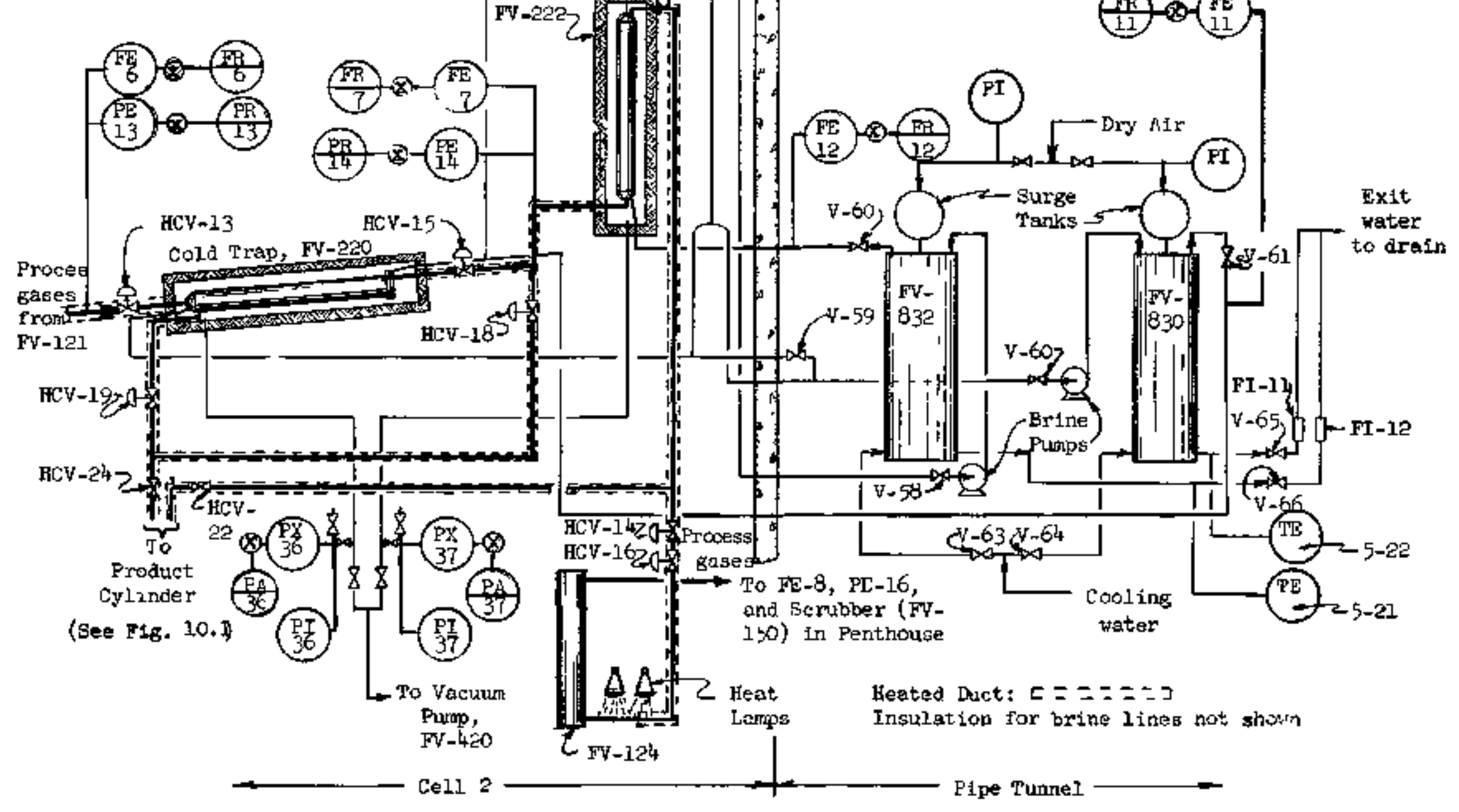


Table 9.2

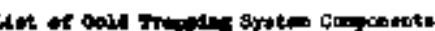

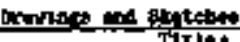

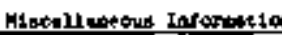

\begin{tabular}{|c|c|c|c|c|}
\hline 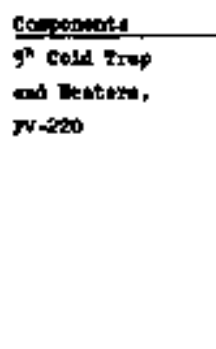 & 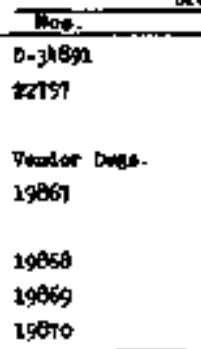 & 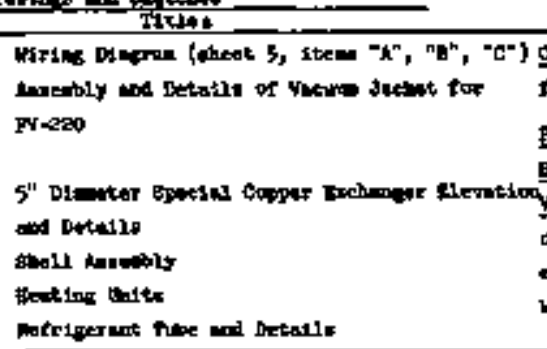 & 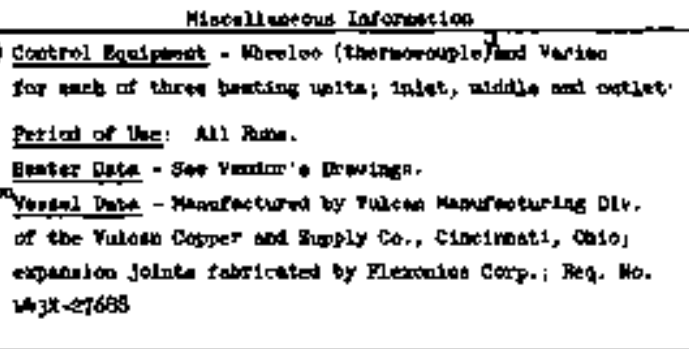 & 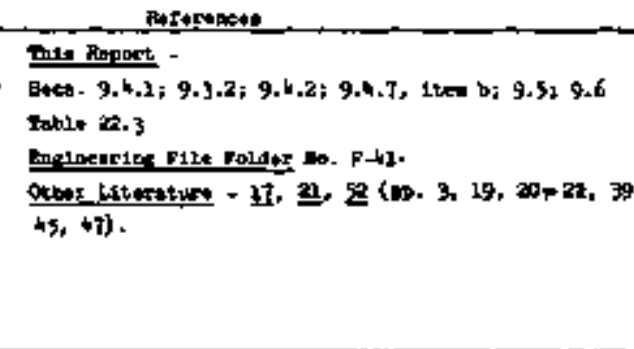 \\
\hline 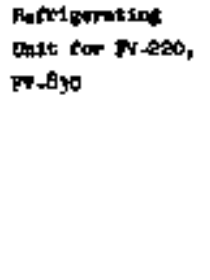 & 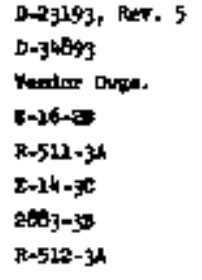 & 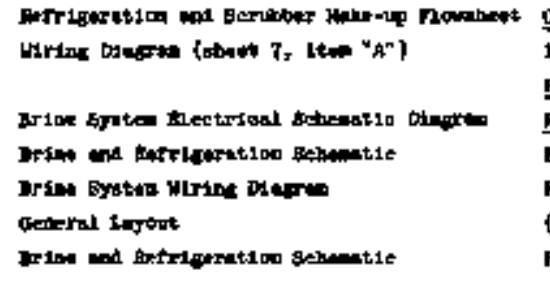 & 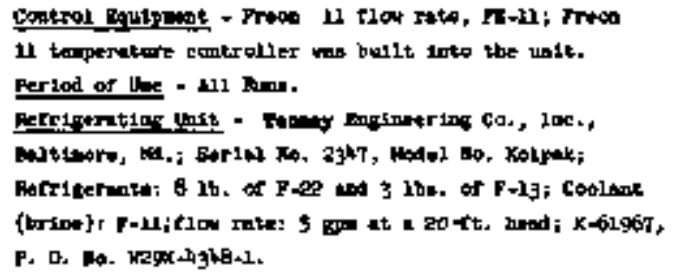 & 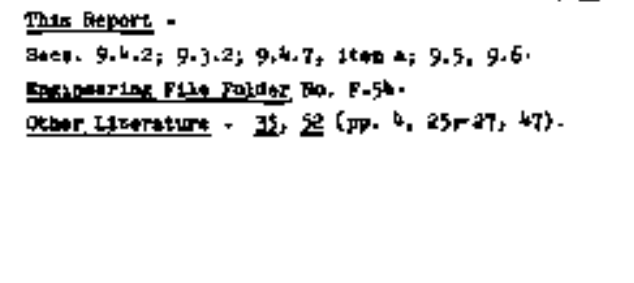 \\
\hline 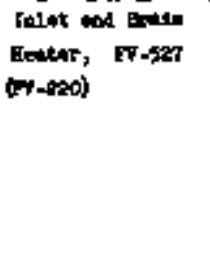 & $\begin{array}{l}p<2761 \\
0<36095\end{array}$ & 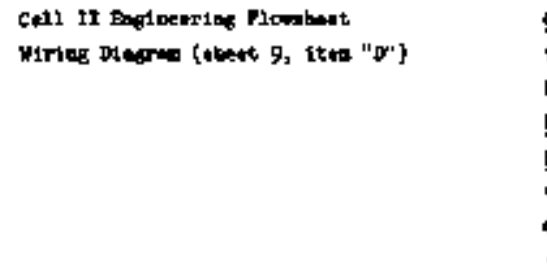 & 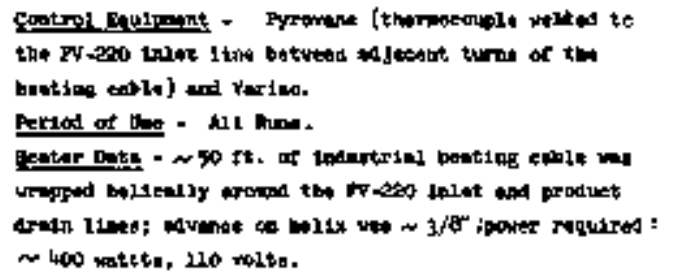 & 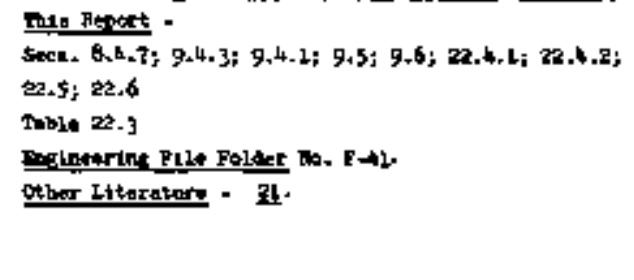 \\
\hline 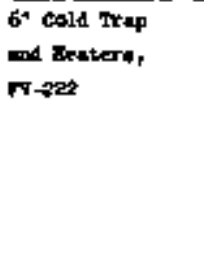 & 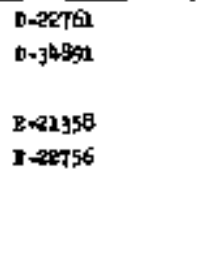 & 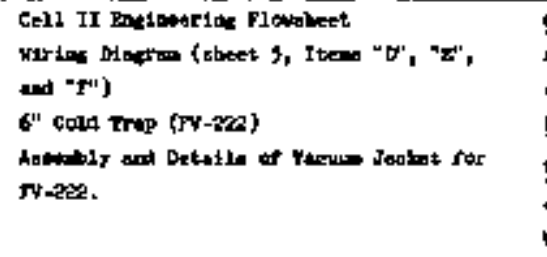 & 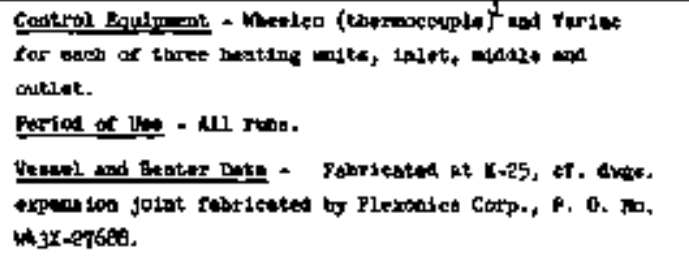 & 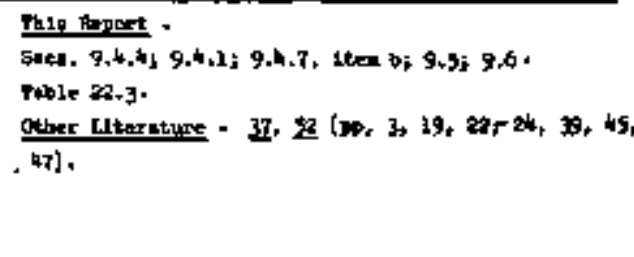 \\
\hline
\end{tabular}

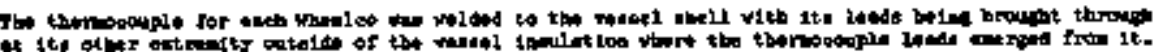




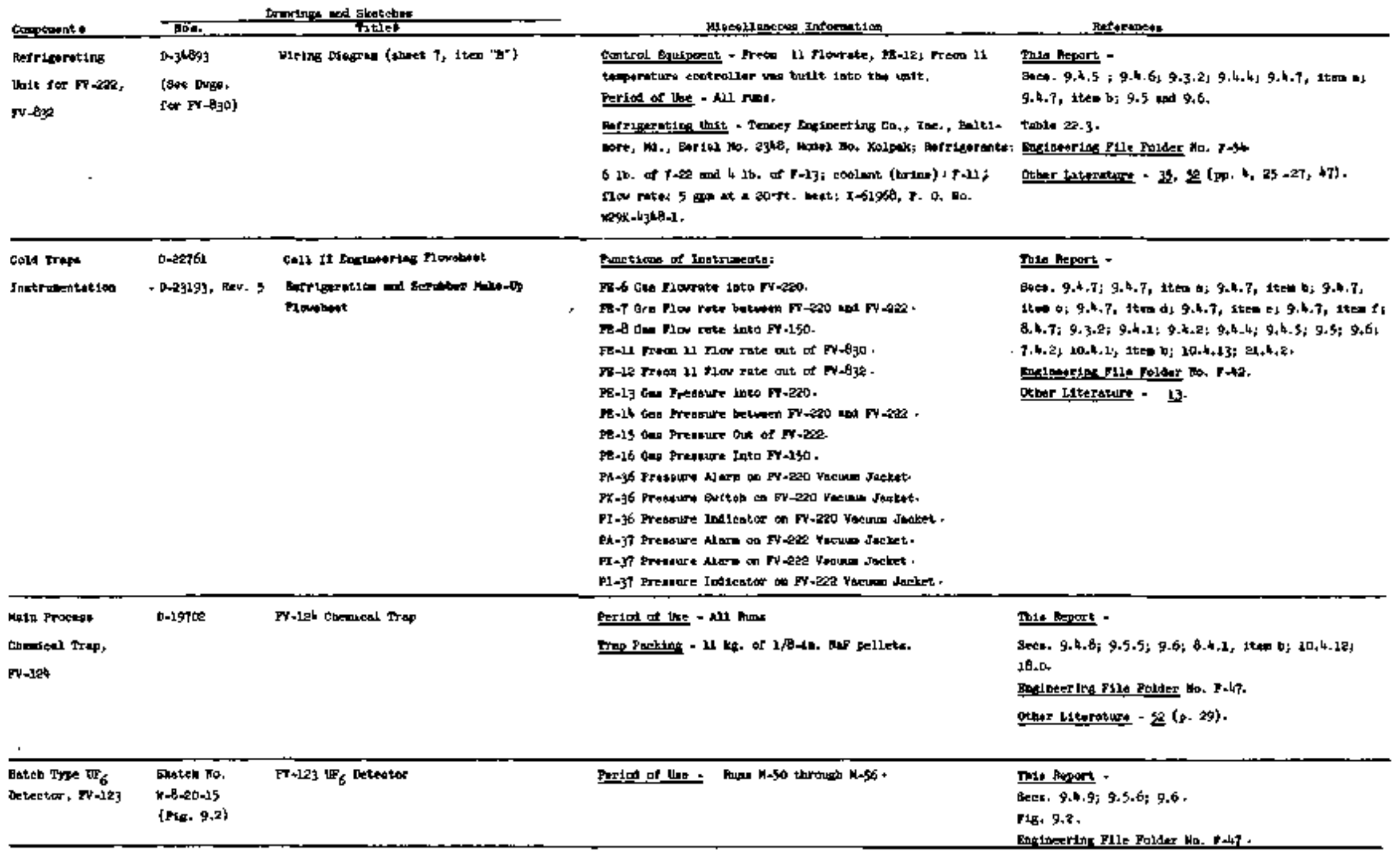


(Sec. 10.3.1). (Making certain that the maln chemical trap was filled with Nar, and that the acrubber was operating properly were parts of these operationd steps.)

6. After step (5) was pinished, sbutting off the refriberating units by atting off both the brine cooler switches at the units and the refrlgerating units switches on the Main Panelboard. (E1ther one of the two switches for a given unit would eut off the unit whe reas both had to be "on" to start 1t. But both awitehes should be turned off efter use to prevent starting

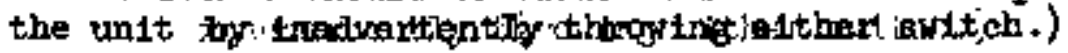

\section{b. Hesting Procedure}

2. After step (6) in Sec. 9.3.1a, the 1nlet, middle, and outlet heaters of both cold traps were used to heat the cold traps to $\sim 80^{\circ} \mathrm{C}$. (ThIs was done only during product colkection as descrlbed 1n Sec. 20.3.1\%)

Q. Pertodically bleeding both Full reservotrs as necessary to keep the pressure at 10 to $15 \mathrm{psig}$.

\section{3 .2 Critical Operating Steps}

a. Maintaining the level of F-2l in each reservolr at about mid-way in the stght glass. (Because F-ll was vented during interinttently bleeding repor from the brine clrcult, F-ll additions were necessery at times.)

b. Maintaining the F-13 and F-22 c1rcults of each refrigerating unit filied. (The frequency of replentshing these circuits rarled. The inability of the units to attatn the noral operating temperatures usvaliy indicated the need for replentshing the F-13 and/or $\mathrm{F}-22$.

c. Keeping $10 \mathrm{psig}$ of axy instrument alr pressure above the liquid in each F-11 reservolr. (This was specified in the Tenney opereting instructions. The low head developed by the F-1, purp apparently necessitated this surge tank over-presare.)

d. Eleving cooling water flowing to each unft, (The cooling vater was needed in the 8-13 circult. Since water was drawn to each unit extometically, the vater supply was left on continuously. Ho cooling water flowed when the unit was "off".)

e. Reading temperatures of the cold traps from recorders instead of from temperature controllers. (S1nce the temperature controllers had been caltbrated in a different temperature range from that reached furing product collection, the controller reading was nisleading.) 
f. Having both the brine cooler switch at the unit and the switch on the panelboard "on" we required before elther refrigerating unit would start.

B. Bleeding off F-1l vapor was essential at times before F-11 could be pumped.

Starting F-11 to purpins was always difficult after having had the cold traps hot during product collection. Since the bojling point of F-11 was $74.7^{\circ} \mathrm{F}$, the vapor pressure of F-1I w1th the cold trapg hot was considerably above atmospherle pressure. F-21 vapor vapor-locked the brine purm. Unt1l F-1l flow could be established, actions taken were: (1) to start the refrigerating unit, (2) to bleed off vapor from the syatem through the surge tank valve or the $F-11$ bleed valve $(T-55$ and/or -57 for $F V-830$ and $\nabla-56$ for $F V+832)$, and (3) to increase the dry instrument air pressure in the surge tank to $\sim 20 \mathrm{ps} I \mathrm{~s}$. Since $1 \mathrm{t}$ was not ascertained which of these actions was most beneficial, the three were usuelly tried simultaneously. The time required to atart F-ll fllow in FV-830 with FV-220 hot was about one and one-half hours. The tine required in FV-832 was uswally about one-half hour.

At times this same trouble was encountered, although to a lesser degree, when sterting the units in hot veather.

Detalled operating procedures are given in Bec. 9.7.1, eppropriate parts of secs. 5.7.1, 8.7 .1 , and 10.7 .2 , and the Tenney bolletin (34).

9.4 Equipment Evaluation

\section{4 .1 5-1n. Cold Trap, FV-220}

The operation of $\mathrm{FV}-220$ was sat1afactory with no maintenance betng required. But two changes in the original design were needed:

a. An additional heater was required to heat simultaneously the trap inlet line and product drain line adjacent to the trap. (For more detatl, see sec. 9.4 .3$)$.

b. A means should have been provided to reduce the time required to stajt the F-ll flowing in the brine system. Th1s change was never made. See Secs. $9.3 .2,9.4 .2$, and 9.6 .

See Sec. 9.4.70 relative to evacuating the FV-200 vacum jacket.

a After the "L" mus, most of the equipment was dismantled and Joved to Burial Ground No. 3 (Sec. 23.4.16b). However, the cold traps were left in place for future processing. 


\section{4 .2 Refrigerstion Undt for Fv-220, $\mathrm{Fr}-830$}

The design operating temperature of $=40^{\circ} \mathrm{C}$. in $\mathrm{FV}-220$ was attained. The IV-220 Inlet and outlet heaters had little effect on the $-40^{\circ} \mathrm{C}$. operating temperature (35). Only one part replacement and minor miscellaneous malntenance were needed. After approximately 2500 hours of service, the thermal overload on the F-13 compressor burned out and vas replaced. The three Freon systems needed replenjahing intermittent $1 \mathrm{y}$. The F-ll clrcuit was reftlled nost frequently because atarting the F-ll flow necessitated bleeding off F-ll vapor to eliminate vapor locks in the pump as delineated in sec. 9.3.z.

Characteristic operating data of this unlt for cooling Fv-220 to $-40^{\circ} \mathrm{C}$. with the F-li flow set at $\sim 4-1 / 2 \sin$ were:

a. With FV-220 Initielly at room temperature $=\sim 2-1 / 4$ hours.

b. With FV-220 inftialiy at $\sim 80^{\circ} \mathrm{C}$. Aurting product collection $-\sim 3-1 / 2$ hours. (Th1s did not include the $1-1 / 2$ hours nomelly required to start the brine flow; Sec. 9.3.2.)

see sec. 9.4.7a for information on $\mathrm{FH}-11$.

\section{4 .3 FV-220 Hesters ${ }^{a}$}

The inlet, midjle, and outlet heaters were satisfactory. Heating characteriatics were:

e. Tyme required to heat $F V-220$ from $-40^{\circ} \mathrm{C}$, to $\sim 80^{\circ} \mathrm{C}$, was $3-1 / 2$ hours.

b. Controller settings at operating temperature $\left(\sim 80^{\circ} \mathrm{C}+\right)$ :

$\begin{array}{lcc}\cdots+ & \text { Eyrovane, }{ }^{\circ} \mathrm{C} . & \text { Variac, volta } \\ \text { Inlet } & 58 & * \\ \text { Hiddie } & 70 & 80 \\ \text { Outlet } & 190 & \end{array}$

* Hot available

In the early " $M$ " runs, Insufficlent heating of both $F-220$ and -222 inlet lines to keep these lines above $65^{\circ} \mathrm{C}$. was discovered (35). Weither the heated duct nor the cold treps inlet heaters adequately heated these lines. The satiafactory remedies were: (a) FV-527 for the FV-220 inlet and (b) insuletion for the FV-222 inlet. FV-527 was wrapped around both the FV-220 inlet line and the product drain line adjacent to the cold trap because this arain line was alao too cold.

a Table 20.3.

b That 1B, above the triple point of $64^{\circ} \mathrm{c}$ at 22 psis (17, p.4). 
The need for FV-527 was denonstrated later in kun $4-7$ (21, pp. $\left.33,3^{4}\right) . \mathbf{a}$ During the desorption of product in this run, this heater was left off accidentally. Melting the $\mathrm{UF}_{6}$ plug which had formed deleyed the desorption. step several hours. The heating characteristics were: (a) rime from room tempersture to operating temperature $\left(\sim 80^{\circ} \mathrm{C}\right.$.) was approximately one hour. (b) Pyrovane and Variac aettings to maintain operating temperatare were $120^{\circ} \mathrm{C}$. and $50 v$, respectively.

\section{4 .4 6-In. Cold Trag, FV-222}

The operation of this trap was successful. In the "c" runs, normally $<58$ of $\mathrm{U}$ as $\mathrm{UF}_{6}$ passed through $\mathrm{FV}-222$ and was collected on FV-124 (36, 31, 29). A cest brass coupling fallure resulted in a UF 6 leak in Run $\mathrm{C}-7$ ceusing a low recovery in that run $(37, p+31)$. This coupling formed the closure for the TE-2C-6 themocouple well. The alphe radioactivity released caused more concerm then the loss of product because the product contained nommal

uranium. In the subsequent repair, an Inconel adapter with welded joints was used. At the same time, a similar change wes made in the TE-2C-4 thermocouple well. No further trouble hes been experienced vith either thernocouple well.

The comment in sec. 9.4.1 regarding reducing the time required to start F-1) flowing in the FV-830 brine system also applies here.

See Sec. 9.4.70 relative to evacuating the FV-2e? racum jacket.

\section{4 .5 Refrigeration untt for $\mathrm{FV}-222, \mathrm{FV}-832$}

The operation of this refrigerating unit was satisfactory although the $-62^{\circ} \mathrm{C}$. desigm tentperature in $\mathrm{FV}-222$ could not be reached. Consequently, $\mathrm{FV}$-2es was operated with no known deleterdous effect at a temperature of $-55^{\circ} \mathrm{C}$. The FV-ze inlet and outlet heaters had a pronounced effect on the trap temperature (35). Only minor miscellaneous maintenance involving the interinitient replenishing of Freons-11, 13 and 22 was required. As for Fr-830, F-1I replenishing was togt frequent.

Characteristic operating data of thls untt for cooling FV-222 to $-55^{\circ} \mathrm{C}$. with the $F-1]$ flow rate set at $\sim 4-1 / 2$ gam were:

$$
\begin{aligned}
& \text { a. W1th Fv-22C initially at roon temperature }=\sim 3-1 / 2 \text { hours. } \\
& \text { b. W1th Fv-222 initially at } \sim 80^{\circ} \mathrm{C} \text {. during product collection }=\sim 6-1 / 2 \\
& \text { hours. }
\end{aligned}
$$

Th1s time did not include the half-hour usually needed to start the brine flow (Sec. 9.3.2). The reason why the brine Mlow in FV-83e was started more qulckly than in FV-830 was not ascertajned.

See Sec. 9.4.7e for information on $\mathrm{FE}-12$.

\footnotetext{
Table 22.3 and Secs. 9.4.1, 9.4.7, 22.4.1, 22.4.2, 22.5 and 22.6. $\mathrm{b}^{+}$Alpha radioact1vity was monitored with a portable disk sempler (Sec. 23.4.3); $\gamma-\beta$ smears (sec. 23.4.8) and urine samples (Sec. 23.4.13) were taken; and masks and other protective devices were worn as needed (sec. 23.4.14).
} 
9.4 .6 FV-2C2 Heaters $^{\mathrm{a}}$

The inlet, Ifiddle, and outlet neaters were satiafactory. ${ }^{b}$ Heating characteristics were:

a. Time required to heat FV-222 from $-55^{\circ} \mathrm{C}$. to $\sim 60^{\circ} \mathrm{C}$. Was $2-3 / 4$ hour.

b. Controller settings at operating temperature $\left(\sim 80^{\circ} \mathrm{C}.\right)$ :

$\begin{array}{lcc} & \text { Fyrovane, }{ }^{\circ} \mathrm{C}, & \text { Vardac, volts } \\ \text { Inlet } & 75 & * \\ \text { Middle } & 85 & * \\ \text { Outlet } & 95 & 170\end{array}$

* Lot srailable

9.4.7 Cold Traps Bystem Instrumentation (1 13 )

8. FE-11 (FV-830) and FE-12 (FV-832)

These orfices measured the Freon -ll flow rates in the brine circuits. After the injtial leaks were elfminated, these flow meters were sat 1sfactory. Generaliy, the flow rates were set at $\sim 4-1 / 2$ Bpm by adjusting $\nabla-61$ for FT-11 and $\nabla-60$ for FE-22. Since the flow retes tended to increase alightly with time, intermittent adjustments were required to malntain the destred values.

b. $\mathrm{PA}-36, \mathrm{PX}-36$, and PI-36 (FV-220); PA-37, PX-37 and PI-37 (FV-22R)

The inner liner of each cold trap was surrounded by a racuum jacket serving two purposes: (a) primarlly to detect a leak in the inner liner and (b) secondarily to gid in lnsulating the inner liner. A pressure alarm, a presaure switch, and a mercury manometer monttored the preaaure in each vacuum jacket. The pressure alarm and preseure sultch worked as follows:

1. Contactis on the pressure switch closed when the absolute presaure fell to $l \mathrm{in}$. of $\mathrm{Hg}$. Thle get the pressure awitch for actuation described in 1 tem 2 .

\footnotetext{
Table 22.3 .

b Comment on heating FV-222 inlet line in Sec. 9.4.4.

Secs. 9.4.2 and 9.4 .5 .

a secs, 9.4.1 and 9.4 .4 .
} 
2. Contacts on the pressure switch opened when the absolute pressure rose to three in. of Hg. thereby setting off the pressure alarm on the Main Panelboard.

IOW: After the alarm sownded following the rise of the pressure to 3 in. of Hg (abs.), it was necessgry then to evecuate the jacket to a pressure of $1 \mathrm{in}$. of $\mathrm{Hg}$ (abs.) to set the pressure sottch for another ectuation (1tem 1 ).

The mercury manometer could be used as desired to determine the pressure in the vacution jacket.

This instrumentation vas sat1sfactory. Ho known leaks to the racuim jacket of either cold trap occurred. The pressure elerms did soumd a few times during the two and one half year period in which the " $\mathrm{C}^{+r}$, " $\mathrm{E}$ ", and "L" russ-we made. These alarm actuations were attributed to rexy slon leaks in the vacuum jeckets and shoved thet the instrumentation worked properly. In eech case, the vacum jacket was evacuated to an absolute pressure below one $1 \mathrm{~h}$. of $\mathrm{Hg}$ to reget the pressure, switch by opening the approprlate valve, V-51 for FV-200 and $\mathrm{V}-52$ for FV-222, The frequency of occurrence was approxtmetely semiennualiy or eninully.

Although the mercury manometers were adequate for intermittently checking the presaure in the jackets, they had these disedvantages:

(a) Required too much space in the cell.

(b) could be blown free of mercury by pressurizing.

(c) Had glasp soverg which were eastly broken. sutitable.

Another type of pressure Instriment would have been more

c. $\mathrm{FE}-6$ and $\mathrm{PE}-13^{\mathrm{b}}$

These pneumatic-type instruments monitored flow rate and pressure at the inlet to Fv-220. In early work, neivner of these Instrments was ugeful because: (1) the range of FE-6 was too great to maasice VPP flow rates and (2) the renge of PR-13 (0-1 psig)

a The vacurum pump used was FV 420 (Sec. 10.4.1.2).

b

Sec. 14.4 .5 . 
wag too amelil for the line pressures encountered about haif the time. Changing the ranges to watch VPP conditions approximately coincided with the deciston made in Run E-3 to reduce the probability of leaks by capping off some instrument connections. Congequently, little subsequent work was done with FB -6 and FE-13.

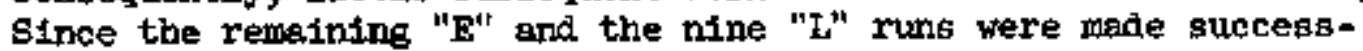
fully without them, these instmments were not needed to operate the plant. But flow rate and preasure data at this point would have been helpful to operating as well as to data processing persounel.

a. FE-7, $\mathrm{FE}-14$ and $-25^{\mathrm{b}}$

The experiences with these Instruments paralleled that with $\mathrm{FE}-6$ and FE-13. One difference was that $\mathrm{PE}-14$ and -15 were uged in the high-pressure portion of VPP whereas PE-1.3 was not. Because the pressure in this portion of VPY was $50 \mathrm{pgig}$ auring prokuct collection an $\mathrm{N}_{2}$ purge of $\sim 4-1 / 2$ to 10 psig could not be used. In adittion, bleeding $\mathrm{H}_{\text {, }}$ into the cold traps while draining product would have increased the quantity of inert gases therein, and $\mathrm{UF}_{6}$ could have collected in the cold purge lines between the cold traps and the Main Transmitter Rack. Because of these three objections to using the customary preumatic-type instrument with an $\mathrm{H}_{2}$ purge, two other schenes were tried:

14) Valving ofe the purge lines during product colfection and not using these Inotruments in that operational step.

Scheme 1. was beset with UF leeks: (a) at tuoing and pipe joints and $(b)$ at the three-tay solenoid wed in one design at PE-15 because of a mistake in connecting lines to its ports (Bec, 7.4.2).

2. Putting the pressure transmitter in the heated duct with no $\mathrm{N}_{2}$ purge as for PR-26 (Bec, 10.4.13).

Scheme 2, was preferable to gcheme i. But this was never tried because these 1ristmments were put out of service along vith others after Rin $\mathrm{E}-3$ (Sec. 9.4.7c).

e. FE-8 and PE-16

As for $\mathrm{FE}-6$ and $\mathrm{PE}-13$, the or $1 \mathrm{~g} 1 \mathrm{nal}$-iestign instruments had inadequate ranges. The subsequent instruments (FI- 6 with a renge of $0-35$ literg/min. and $\mathrm{PE}-16$ with a range of -0.5 to +4.5 psig) were satisfactory. In addition to monitoring the gas flow

a Besides FE 6 and FE-13, other instruments teken out of service at that t1me were $\mathrm{FE}-5,-7$; $\mathrm{PE}-12,-14,-15$, and -38 . (Sec。 8.4 .7 ).

b

Sec. 14.4 .5 


\section{$-214-$}

to the caustic scrubber, $\mathrm{FZ}-8$ varned operating personnel of any umususlly high gas flow wich might indicate that a ralve in the system had been inadvertently left open. One of the nost helpfur. uses of PE-16 was its pressure rise occurring when the scrubber Inlet line plugged. One disadvantage was that leaks in this victinty were hard to find because of the large number of jolnts,

\section{Thermocouples}

The thermocouples used to measure temperatures vere satisfactory and gave Indiapensable operating data. As steted in Sec. 9.3 .2 , felying on temperature controllers for temperatures instead of temperature recorders was poor practice. Thermocouples were placed as described in sec. 22,4.2.

\subsubsection{Hain Process Chemical Trag, FV-124}

The operation of this trap was relatively aatiafectory. ${ }^{\text {a }}$ Iranium retentions have varled frcm zero to $5,334 \mathrm{~g}$ wth essentially po uranim passing through the trap (27, 25, 36, 37, 39, 23, 25, and 23). Retained uranium did not represent $\mathrm{a}$ loss because it was recoverable (3is) An upper Nar retainer screen was added after pressure surges from 50 psig to etmospheric pressure forced FeF pellets up to V-72 in the Fenthouse. Two other changes as yet not made are desirable:

a. Incorporating the top flange in the flange leak-detector system (Bec. 18).

b. Altering the trep design to facilltate losding and unloading.

The normal FV-l24 charge was il kg of 1/8-1n. NeF pellets. NaF pellets were preferable to the minus 20 -mesh HaF particles tried because of the absence of fines. Ulading FV-124 was done efther with a portable vacuus cleaner or with FV-420 (Bec. 10.4.12).

In the early VPP work when $\mathrm{HaHF}_{\text {, was }}$ converted to the NaF in the alosorbers, FV-124 was lert empty to prevent the formation of NeHF, therein (Sec. 8.4.1b).

\section{4 .9 Batch-Type UT, Detector, FV-123}

During the "c" runs, a batch-type UF 6 detector was butlt and used in the inlet line to sV-124. The operating oninclple of tbis detector was that the increase in temperature occurring when a small quantity or Nar sorbed $\mathrm{UF}_{6}$ could be detected with a thersiocouple. The design of the device is shown in Fig. 9.2. It woriked satisfectorily but was not used in enriched-uranium rums because of the frequent changing requitred.

s. Sec. 8.4 .10 . 


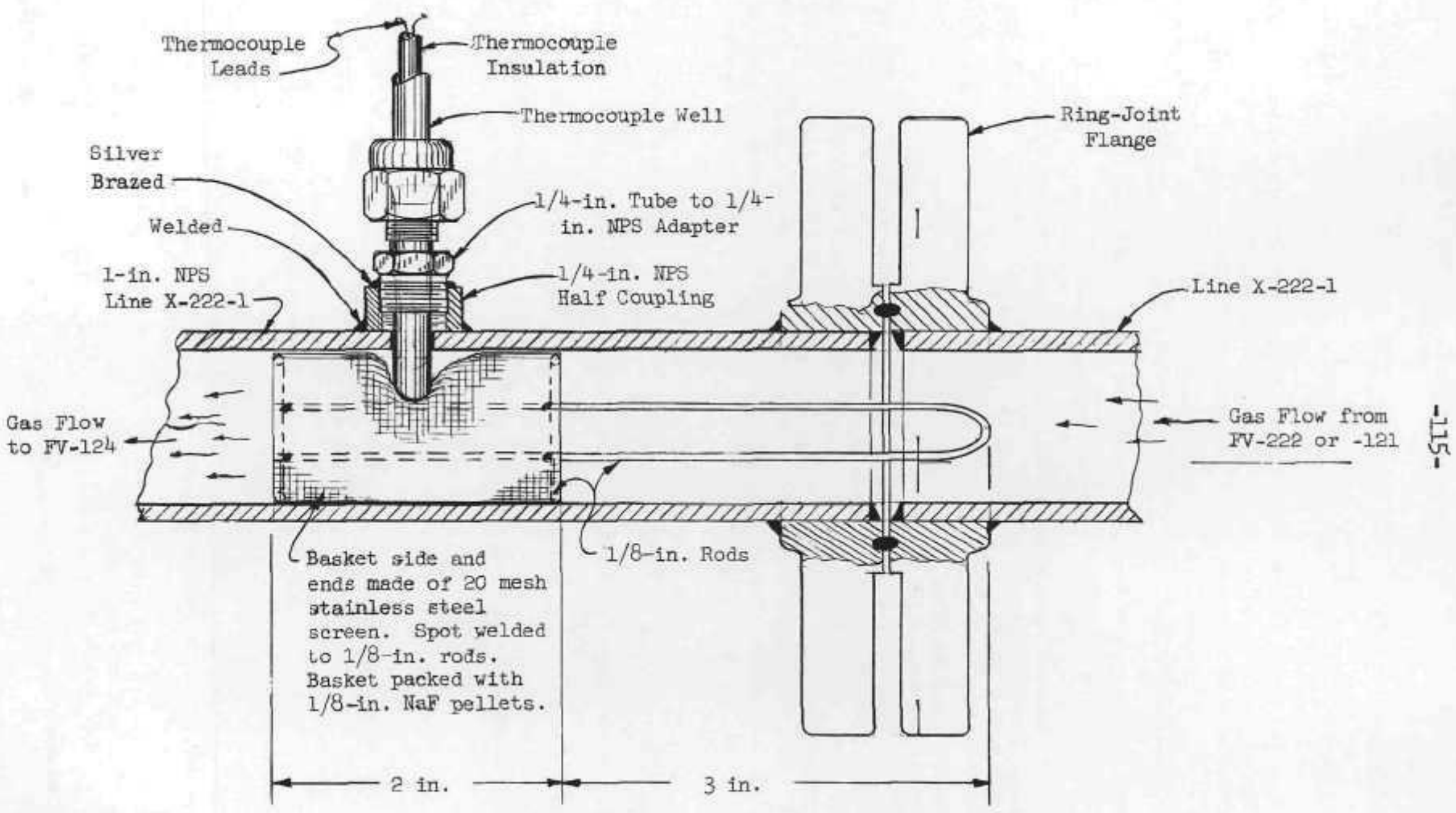

Fis. 9.2. Batch-Type UF 6 Detector, FV-123 


\subsection{Summary and Conclusions}

\subsubsection{Entire Cold Traps System}

The operation of the cold traps system was satisfactory. Some minor design changes were made while a few needed design changes have not yet been done. Heating characteristics of the various-heaters are recorded.

\subsubsection{FV-220 (5-in. Cold Trap) and FV -830}

The design operating temperature of $-40^{\circ} \mathrm{C}$. was attained. Since the temperatures of the inlet and product drain lines were $\left\langle 65^{\circ} \mathrm{C}\right.$. while the trap was cold, FV-527 was added to prevent UF from solidifying in these lines. One $\mathrm{UF}_{6}$ plug in the inlet line during Fun L-7 when FV-527 was inadvertently left off confirmed the need for this heater. The inlet and outlet heaters had little effect on trap cooling.

Maintenance on FV-830 included replacing a thermal overload after about 2500 hours of service and intermittently replenishing the three Freon circuits.

At a 4-1/2 gpm flow rate of F-11, the time required to cool FV-220 from rogm temperature to $-40^{\circ} \mathrm{C}$. was $2-1 / 4$ hours. With the trap initially at $\sim 80^{\circ} \mathrm{C}$. after product draining, the cooling time under similar conditions was $3-1 / 2$ hours, this time excluding the $1-1 / 2$ hours required to start $F-11$ flowing. A way to decrease the time to start F-11 flowing was needed but never received any design attention.

\subsubsection{FV-222 (6-in. Cold Trap) and FV-832}

The 6-in. cold trap attained only $-55^{\circ} \mathrm{C}$. Instead of the design value of $-62^{\circ} \mathrm{C}$. However, this fact had no known deleterious effect on plant operation. Since the FV-222 inlet line could not initially be heated to $>65^{\circ} \mathrm{C}$. while the trap was cold, this line was insulated. The inlet and outlet hesters had a pronounced effect on trap cooling.

A cast brass coupling on a thermowell failed in Run C-7 releasing a quantity of normal $\mathrm{UF}_{6}$ in Cell 2. The $\alpha$ radioectivity released was of more concern than the loss of the normal uranium. In the repair, an Inconel adapter with welded joints was used. Another thermowell of similar design was changed in the same way.

In the " $\mathrm{C}$ " runs, normally $<5 \mathrm{~g}$ of $\mathrm{U}$ as $\mathrm{UF}_{6}$ passed through both FV-220 and -222 in series.

The only maintenance work on FV -832 was intermittently replenishing the Freons in its three circuits.

At the 4-1/2 gpm flow rate of F-11, the time required to cool FV-222 from room temperature to $-55^{\circ} \mathrm{C}$. was $3-1 / 2$ hours. With the cold trap initially at $\sim 80^{\circ} \mathrm{C}$. after product draining, the cooling time was $6-1 / 2$ hours, this 
the being exclusive of the half-hour needed to start the F-ll flow. Why It took three times as long to atert the $F-11$ flow in $5 \mathrm{~V}-830$ as in FV-832 was not ascerteined. At any rate, the need for a means of reducing such time losses was evident.

\subsubsection{Instrumentation}

FE-1l and -12 were batisfactory as 1nstalled. Usually the F-11 flow rates on both FV $-830 \mathrm{and}-832$ were set at about $4-1 / 2 \mathrm{spm}$. To maintain thege flov rates, intermittent valve adjustments were required.

$\mathrm{PA}-36$, PX-36, and PI-36; PA-37, PX-37, and PI-37 performed satisfactorily, although no UF 6 leak apparently occurred to detect with them. PA-36 and PX-36; PA-37 and PX-37 actusted at sensannual or annual frequencies. Such actuations were attributed to slow leaks in the vacuun jackets. When this occurred, normel operating conditions were restored by agein evacuating the vacuum jacket to $<1$ in. of $\mathrm{Hg}$ (abs.). The mercury manometers were space consumers and subject to mercury bl buing and glass breakage. Another type of pressure instrument would have been more eppropriate.

FE -6 and -7 ; PE-13, -14 , and -15 were initlayly installed with inproper ranges for VPP. Obtaining instruments with sultable ranges and the decision to ellminete these instruments to reduce the leek probeb1lity in VPP occurred almost simulaneously. Consequentily, these instruments were no longer used, and the purge lines were cepped 1n Cell 2. The experiences encountered with $\mathrm{FF}-14$ and -15 are recouled as e matter of record because these instmments were in the bigh-pressure portion of VPP during product collection. Pressires could kave been satisfactorily measured at these points with arrangements aimilar to that for PE-26. (Sec, 10.4.13).

FE-8 and PE-16 initialiy also heving had unguttable ranges were setisfactory after the ranges were changed. These instrunents were useful in norminl operations, in trouble-shooting, and in data work.

Thermocouples were successfulty used and found to be indispensable.

\section{$9.5 .5 \mathrm{FV}-124$}

This trap was relatively satisfactory, passing little or no UF $_{6}$ at loadings up to $\sim 5,000$ of of $t$.

An NaF retaining screen at the top of the trap bed was added to prevent the blowing arowid of lial pellets in the system.

Two needed items not yet dome are: (a) adding the top flange to the flange leak-detector system and (b) altering the trep design to facilitate loading and unloading.

The normal trep eharge was $11 \mathrm{~kg}$ of $1 / 8-i n$. NaF pellets. 


\section{$9.5 .6 \quad \mathrm{EV}-123$}

This UF 6 detector worked aatisfactorily but was not needed in the "L" and "L" ruis.

\subsection{Recommendations}

It is recommended that the cold traps system be operated in the future witb the equipment as described herein except for the following chenges:
a.
A meens of reducing the time required to atart $F-11$ flowing in the brine circuits after product araining be provided, expecially for the FV-220 and -830 combination.
b. A now design FV-124 be bullt to factlitate loeding and unloeding.
c. The mercury mancmeters (PI-36 and -37 ) be replaced with more suitable pressure instrumenta.
d. Ang ruture PE placed in the high-pressure portion of VPP be installed similerly to $\mathrm{Pz}-26$.
e. Ho more cast brass fittings be used in the VPP (Bec. 15.6).

\subsection{Operating Procedure: Operation of Refrigeration Syztems}

Preliminary to startup, the three circuits of each bystem $w$ ill have been filizd with Freon-22 (high stage), 13 (low stage) and 11 (brine clrcuit). The power circuit to the compressors vill be "on", and the brjne cooler awitch will be closed.

NOTE: Vent ralves 55,56 , and 57 should not be opened as this would bleed off Freon gas.)

1. Open these valves to provide cooling water to the first stage:
63 65 and 66

2. Open these valvea on refrigeration I1nes neer FV-830 and FV-832; Turn on FV $-83 \overline{0 \text { and }}$ FV $-8 \overline{32}$ at the Main Fanelibord,

A temperature controller is provided at FV-B3O and another at FV-83a which sean be set to give a desired temperature. The temperature is indicated on TE- $\mathrm{TD}-2$ and $\mathrm{TE}-2 \mathrm{D}-3$, respectively.

To Shutdown:

5. Close $\mathrm{V}-60$ Turn off Fv'B30 board. and $V-61$ and $\overline{\mathrm{FH}-832}$

on outlets from refrigeration syatem. control circuits on Main Panel; 
10.0 Froduct Collecting System . . . . . . . . . . . . 119

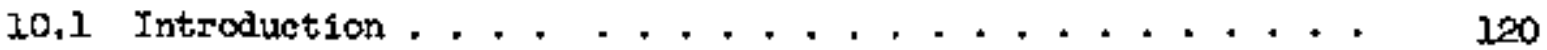

10.2 Equipment .......................... 120

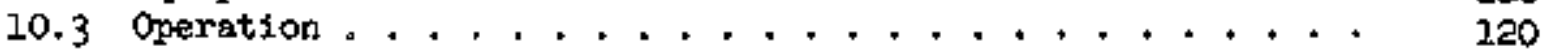

10.3.1 Operating Procedure ............ 120

10.3.2 Critical Operating stepa .......... 126

10.4 Equipment Performance . . . . . . . . . . . . . 126

10.4.1 Product Cylinder, Fv-126 ......... 126

10.4.2 Product Cylinder Heater, FV-526 ........ 127

10.4.3 Product Cylinder Inlet and outlet Lines Heater, ... 128

10.4.4 Product Pigtails Heater, FV-5268 . . . . . . 128

10.4.5 Product Weigh Station, FV-922 ......... 228

10.4.6 Product Cooling Coil, FV-226 ......... 129

10.4.7 Product Cooler Blover, FV-622 . . . . . . . . 129

10.4.8 Product Cooler Refrigersting Unit, FV -820 . . . . 129

10.4.9 Product Purge Chemical Trap, Fv-122 ........ 130

10.4.10 Product Purge Cold Trap, Fv-224 ........ 131

10.4.11 Coolant Conta1ner for FV-224, FV-924 ...... 131

10.4.12 Vacum Punp, Fv-1420 ............ 131

10.4 .13 Instrumentation . . . . . . . . . . . 132

10.5 Sumbary and Conclusiona . . . . . . . . . . . 133

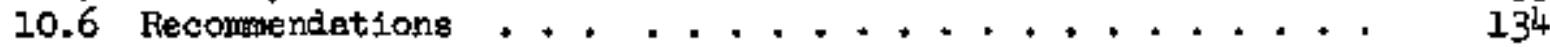

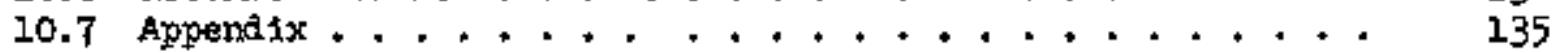

10.7.1 Operating Procedure: Product Cyllnder Handling . . 135

10.7.2 Operating Frocedure: Product Removal Operation . . 136 


\subsection{PRODUCT COLIECTINO SYSTYM}

\subsection{Introduetion}

The $\mathrm{IF}_{6}$ product having been previously frozen out in the cold traps after desorbing was heated and then collected in the product eyiner. The product was transferred in both the liquid and geseous states, 11naliy being frozen out in the product cylinder. The principal steps in the operation of this aystem vere:
a. Drainting liquid $\mathrm{UF}_{6}$ to the product eylinier.
b. Thermally transferring $\mathrm{UF}_{6}$ vapor to the chilled product recelver.
c. Purging reatdial $\mathrm{WF}_{6}$ out of the lines.

\subsection{Equipment}

The general arrangement of the product collecting syatem is show in Fig. 10.1. Descriptions of the components are given in Table 10.1.

\subsection{Operation}

10.3.1 Operating Procedure

Stepg in the operation of the product collecting system were:

a. Having $10 \mathrm{~kg}$ of $\mathrm{U}$ as $\mathrm{IF}_{6}$ frozen out on the cold traps; 11 tg of $1 / 8$-in. HaF pellets in FV-124; $3 \mathrm{~kg}$ of HaF pellets in FV-202; FV 420 operating; and joint B at FV-122 and -124 leaktight (as determined by the KI-sterch leak-test described in Sec. 17.4 .2$, e.)

b. Taring and connecting the product oylinder to the pigtails; putting has in service.

c. Conditioning the product cylinder and leak-tepting (KI-starch method) the pigtail connections and ralves. Conditioning was completed at $\sim 5$ to 10 palg $F_{2}$ pressure (Sec. 15.4.5a) and then the kI-starch leak-testing was dome yth the system filled with $F_{2}$ at this pressure (Sec. 17.4.2, e2)].

d. Heating the product oylinder to $\sim 80^{\circ} \mathrm{C}$.

\footnotetext{
Product collecting required 10 to $12 \mathrm{hr}$ from system eracuation to closing the cylinder valves.

$b$ While draining the liquid $U_{6}$, the sygtem was kept at a temperature of $\sim 80^{\circ} \mathrm{C}$, i.e., safely ebove the triple point ( $64^{\circ} \mathrm{C}$. at $22 \mathrm{psia}$ ) but not high enough to veporize all of the $\mathrm{DF}_{6}(\underline{17}, \mathrm{p}, 4)$.
} 


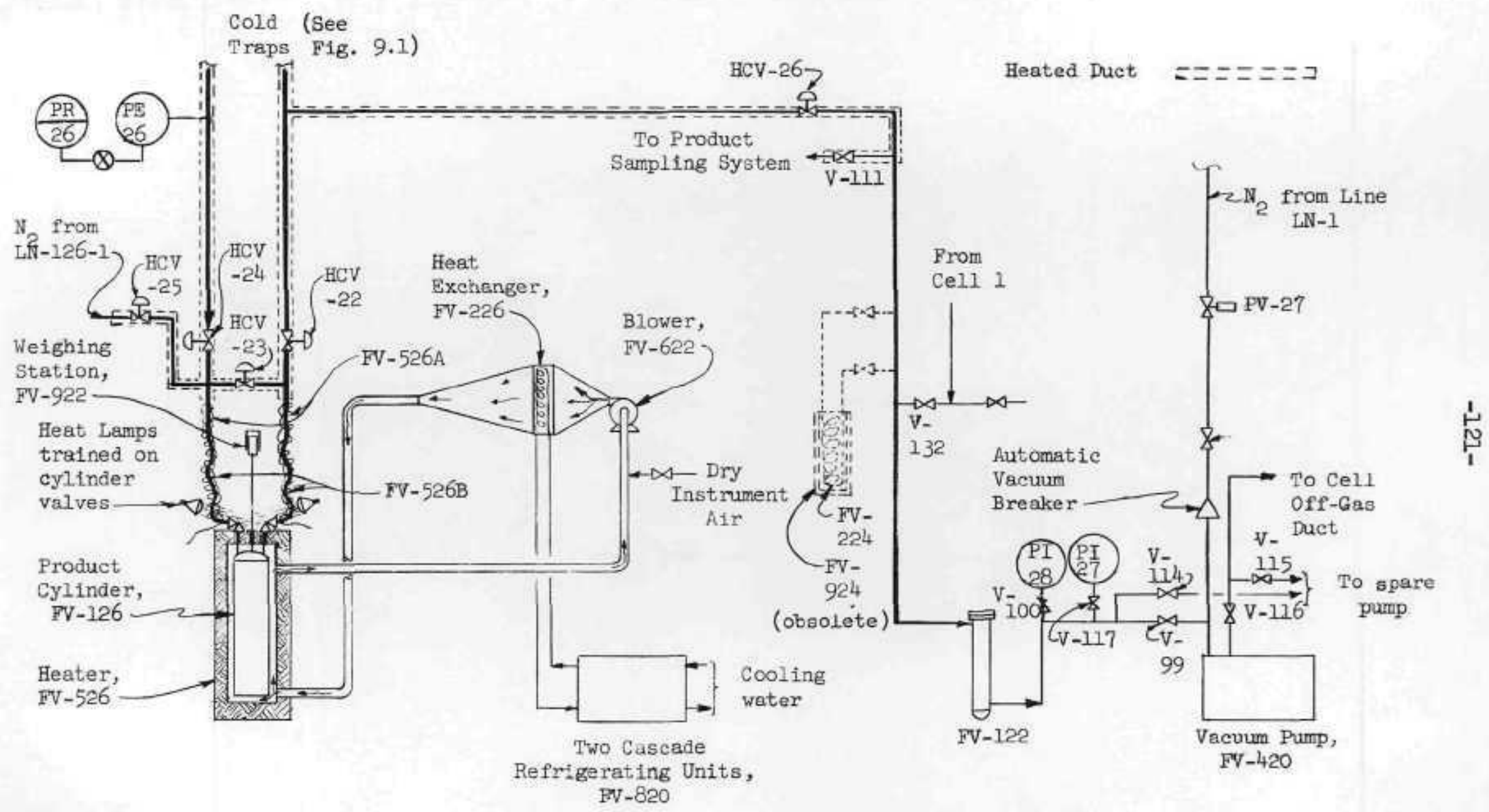

Fig. 10.1. Equipment Arrangement in the Froduct Collecting System 
2014 10.1

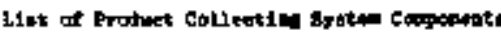

\begin{tabular}{|c|c|c|c|c|}
\hline Gopomenter & \multicolumn{2}{|r|}{ 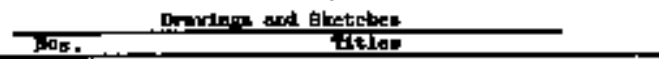 } & 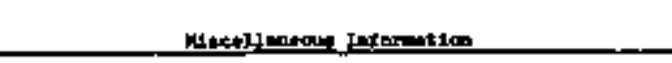 & 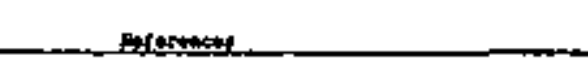 \\
\hline 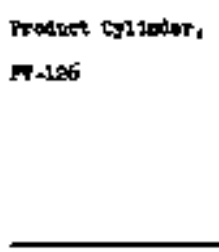 & 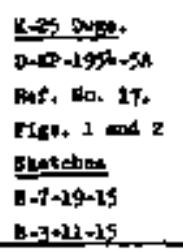 & 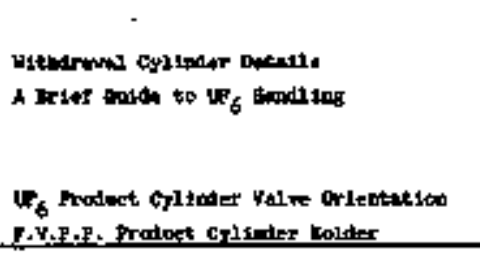 & 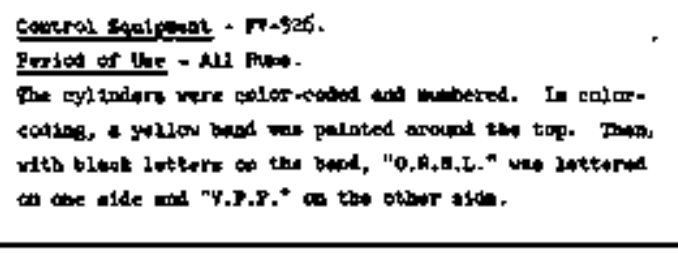 & 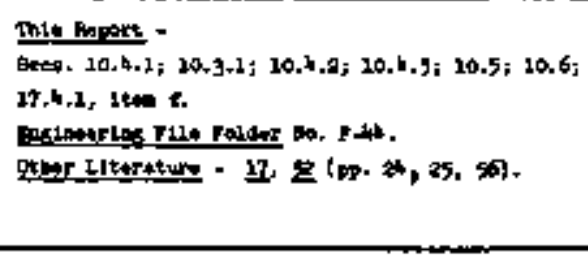 \\
\hline 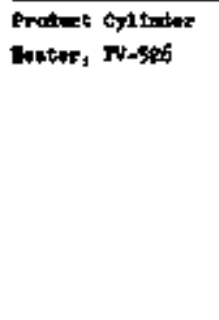 & 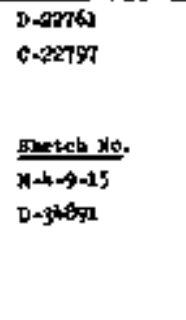 & 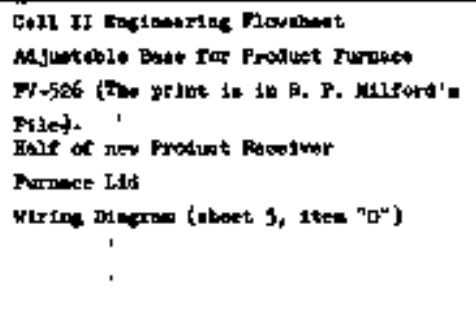 & 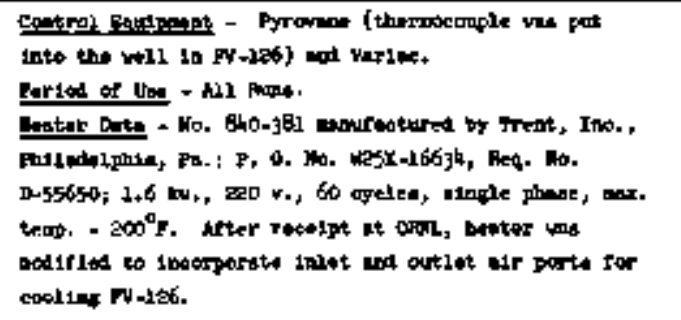 & 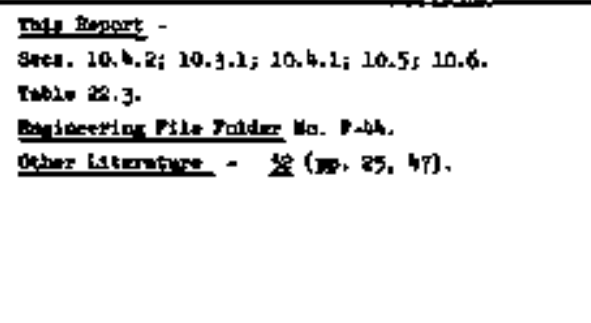 \\
\hline 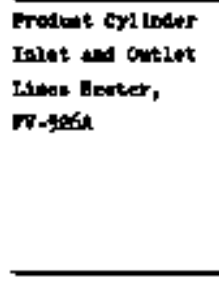 & $\begin{array}{l}0-20761 \\
0-2 x>00\end{array}$ & 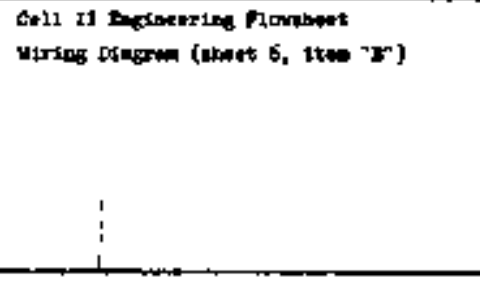 & 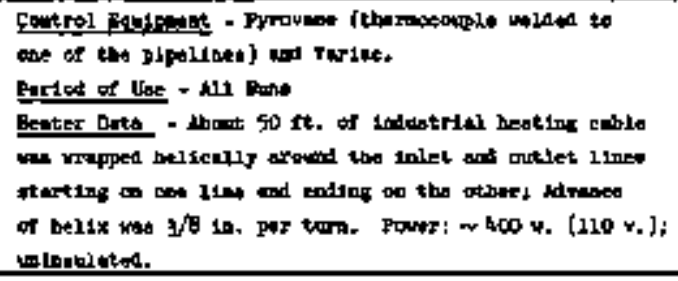 & 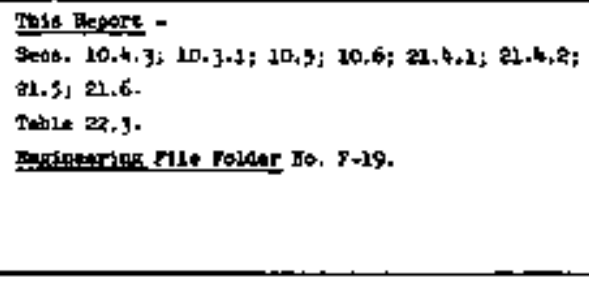 \\
\hline 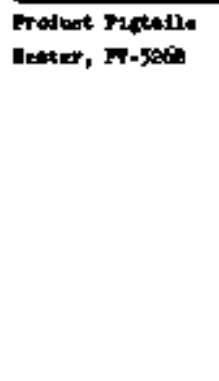 & D-1468p5 & 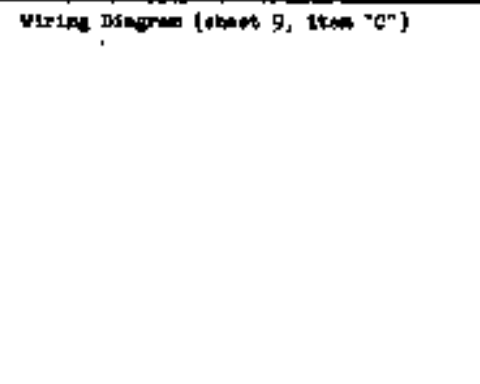 & 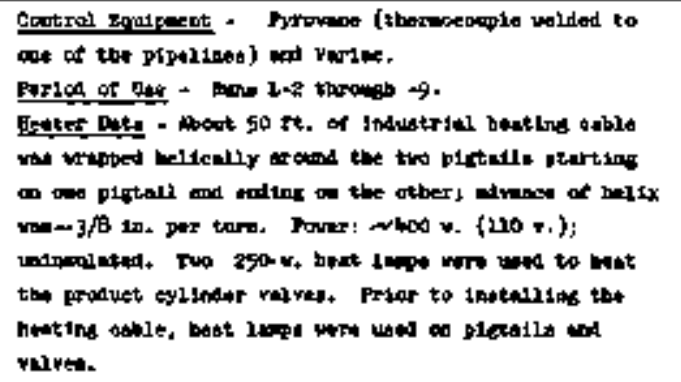 & 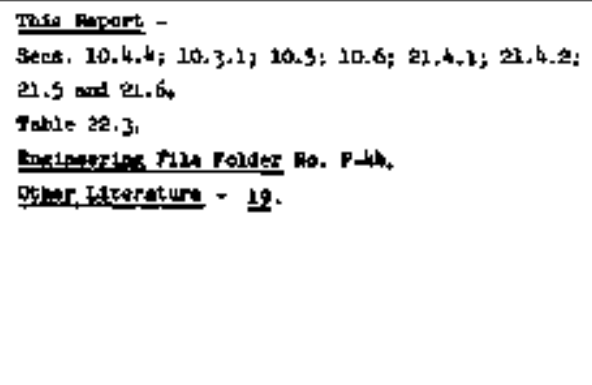 \\
\hline
\end{tabular}


S4bL 20,1 (cabt1 ment)

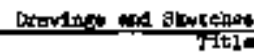

\begin{tabular}{|c|c|c|c|c|}
\hline cerosostits. & Fon: & 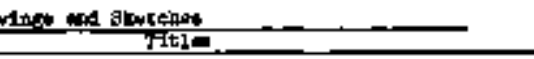 & 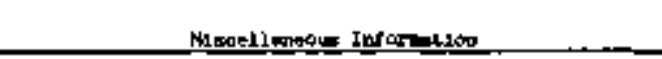 & Boperepoes \\
\hline 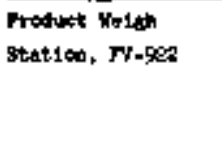 & 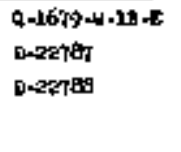 & 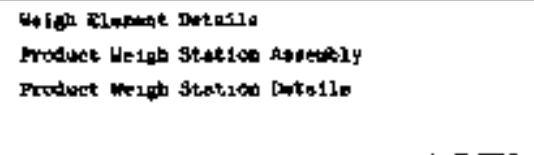 & 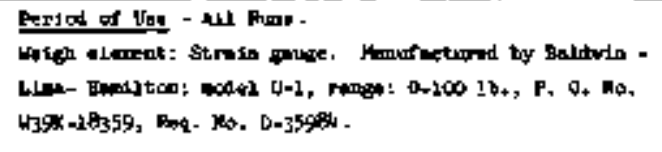 & 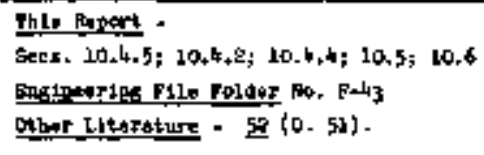 \\
\hline $\begin{array}{l}\text { Praduet coonlind } \\
\text { tod1, Wress }\end{array}$ & 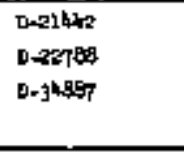 & 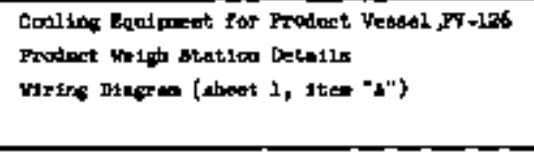 & 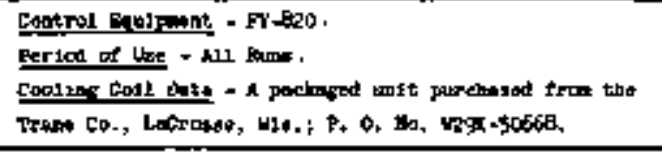 & 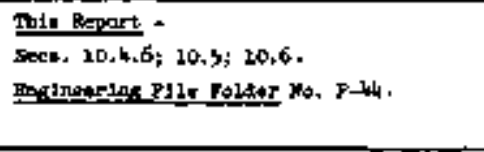 \\
\hline 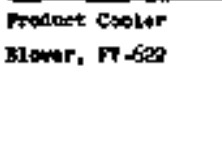 & $\begin{array}{l}0.20142 \\
0-32+59 \\
0-7400 \%\end{array}$ & 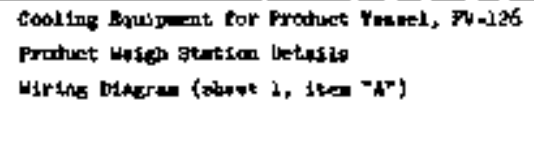 & 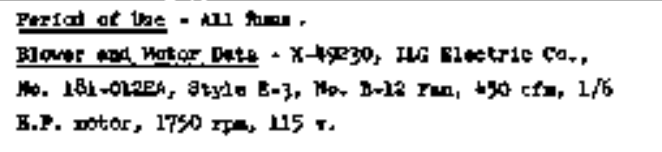 & 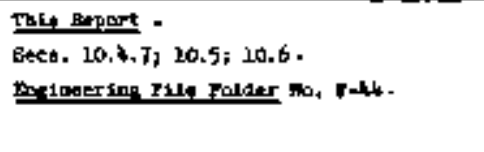 \\
\hline 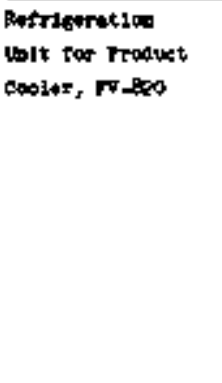 & 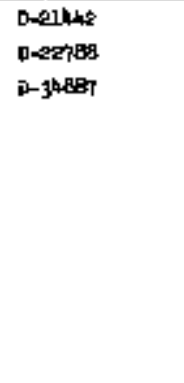 & 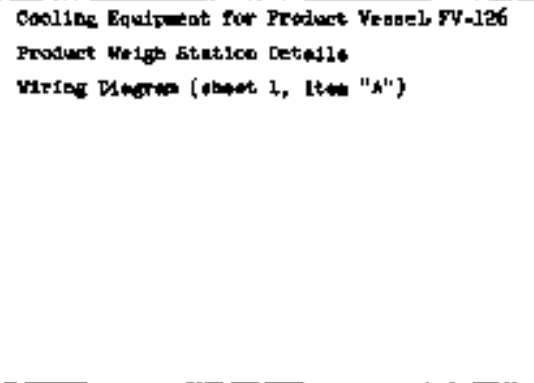 & 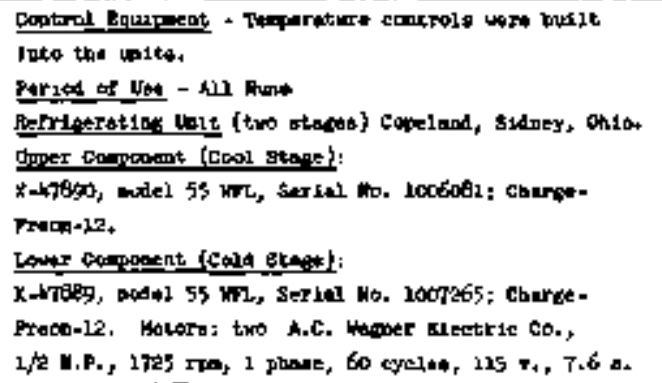 & 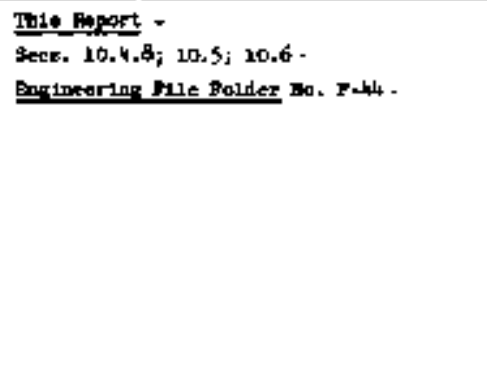 \\
\hline 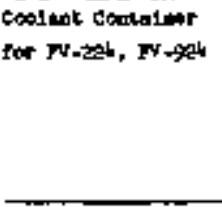 & Tatror & Ine & 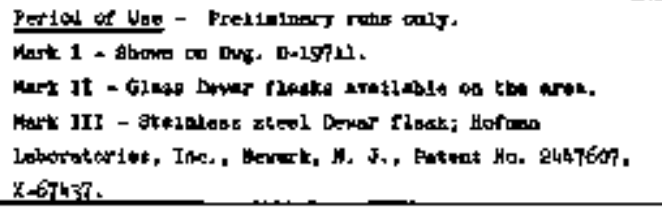 & 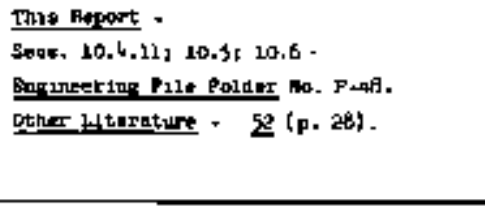 \\
\hline
\end{tabular}


Table 10.1 (fontinet)

\begin{tabular}{|c|c|c|c|c|}
\hline \multirow{2}{*}{ 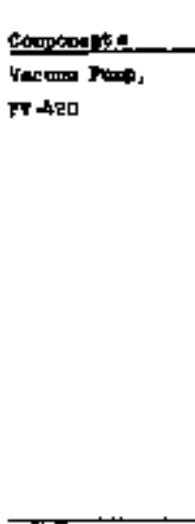 } & \multicolumn{2}{|c|}{ 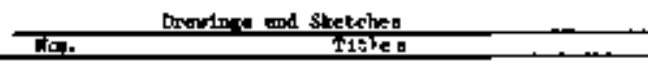 } & 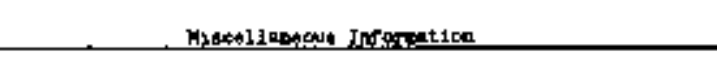 & \multirow[b]{2}{*}{ 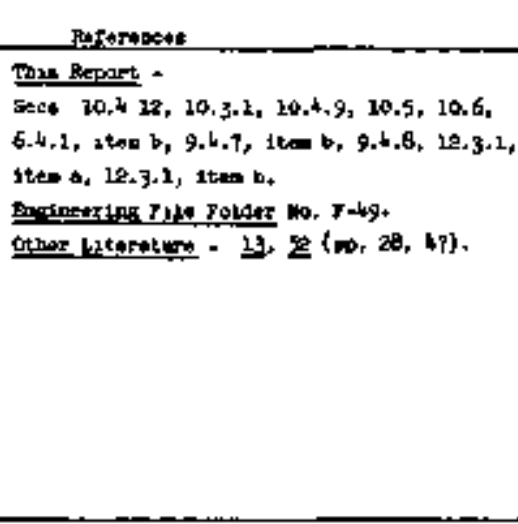 } \\
\hline & 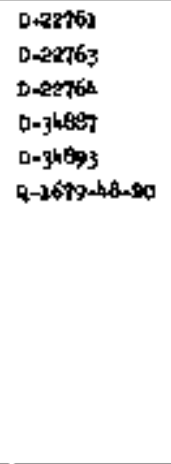 & 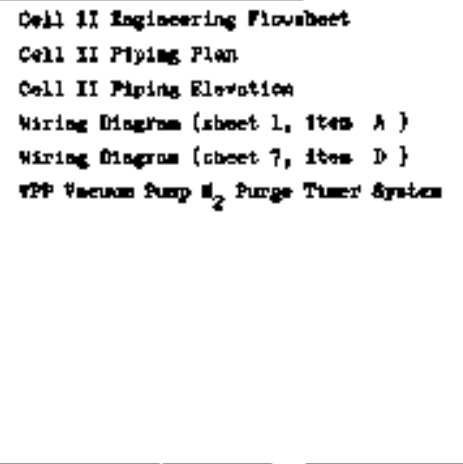 & 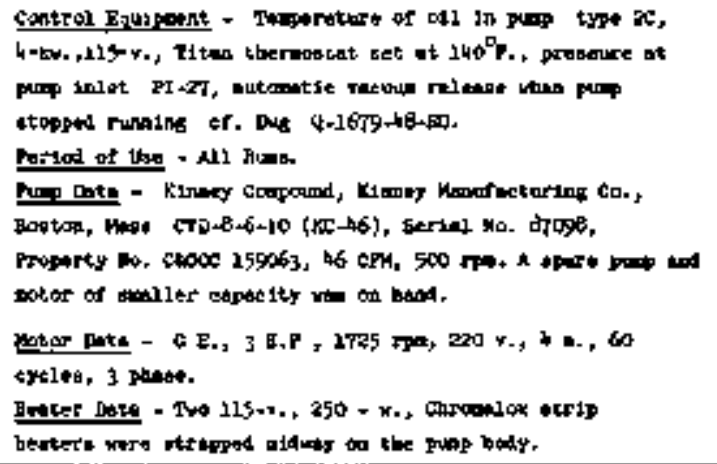 & \\
\hline 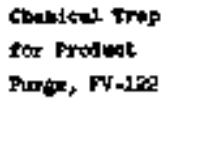 & $0-19709-\mathrm{Re}$ & Fr-122, thealoel Trup & 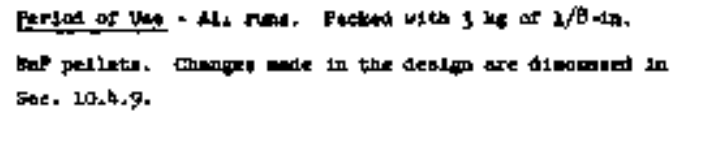 & 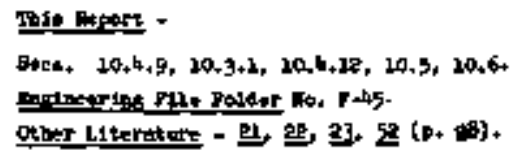 \\
\hline 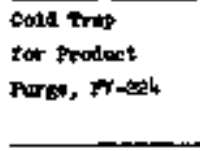 & D-19T10 & Fy-esth cold Trep & 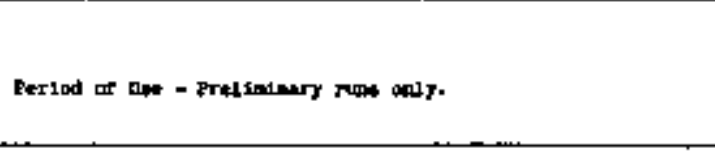 & 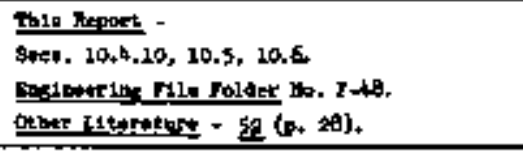 \\
\hline 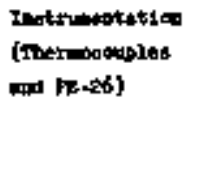 & D-क्षा5] & 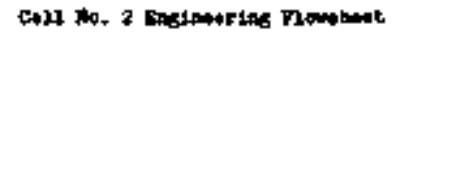 & 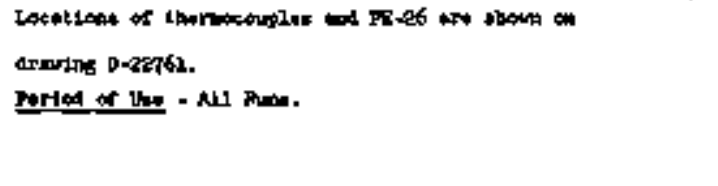 & 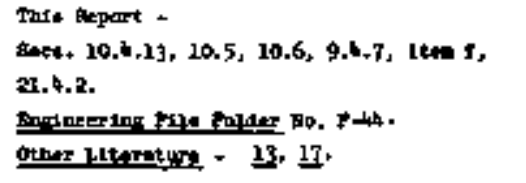 \\
\hline
\end{tabular}


e. Setting valves as needed to evacuate the cold traps and product recelver to 0.3 mins of $\mathrm{Hg}$ as determined by PI-27. This was the reasonable pressure linit in cold trap evacuation, A higher pressure left inext gases in the syratem; a lower pressure resulted in excessIve $\mathrm{UF}_{6}$ logs to FV-122 via the exit gases , (36, j. 28 ).

f. Isolating the cold trapa and product eglinder from the rest of the VPP.

8. Feating to and leeping at $\sim 80^{\circ} \mathrm{c}$ the cold traps and piping of the evacuated portion of VPP using heaters IV-527, FV-526A, and FV-526B, the inlet, middle, and outlet heaters on both cola trape; and the heat lampe for the product cylindex valves.

h. Draining the Iiquid $\mathrm{UF}_{6}$ Into the product csilinder by opening $\mathrm{ECV}-18$ and HCV -19 .

i. After the 11 quid $\mathrm{UF}_{6}$ hed drained or when PR-26 reading exceeded $130 \%$ of that before aterting the liquid to drain, $b$ starting FV-820 and -6e2, and bleeding dry instrument exr into the FV-126 cooling system to prevent molsture from collecting on the cylinder.

j. One hour after the product receiver temperature (TR-ac, 6 ) reached $O^{\circ} \mathrm{C}$ and leveled off end the WR-IB reading leveled off, closing the product recelver velves and shutting off FV-820 and -622 .

k. Shutting off the heat to the cold traps and cooling them to $-40 \mathrm{C}$ (FV-ZCO) and $-55^{\circ} \mathrm{C}(\mathrm{FV}-222)$ using FV-830 and -832 , respectively.

1. Evacuating the two cold traps by purping for 5 minutes and then filling with $\mathbb{N}_{2}$ to atmospheric pressure and repeating this step two more times.

m. Barpling FV-15e and oubsitting for $\mathrm{U}^{+6}$ and $\mathrm{OH}^{-}$analyses.

n. Turning off FV-526A, FV-526B, and the heat lange on the product recelver.

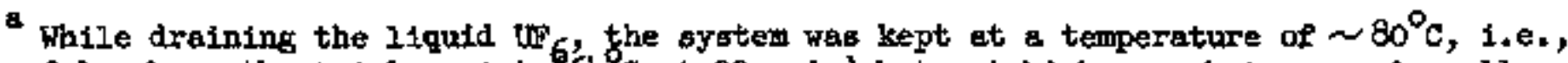
asfely above the triple point ( $64^{\circ} \mathrm{C}$ at $22 \mathrm{psia}$ ) but not high enough to vaporize all of the Uf 6 (17, p. 4 ).

b Fv-526 was shut off during liquid dratning period.

c Starting FV -830 and -832 was usually a tine-conswaing operation as aelineated in Sec. 9.4.2. 
o. While chilling the pigteils with ary ice, disconnecting the product receiver; plugring the ends of the plgtails; and capping the ends of the product cylinder ralves.

p. Weighing the proiuct cylinder and storing it safiely in $a$ criticality drum.

q. Emptying and refilling FV-122 and -12l as needed.

Sygtem modifications necessitated additional minor steps in the procedure. For the complete procedure, see Becs. 10.7.1 and 10.7.2.

10.3.2 Grit1cal Operating Steps

a. Makting certain that all product cylinder weighing was done in the prescribed fashion using the designated scales and standard welghts.

b. Assuring that the system prifor to product removel contained no leak detectable by the KI-atarch method.

c. Making certain that the 0.3 sm of Hg pressure was attained on evacuation vithout extended pumping. (An extended pumping period indicated a leak which showld be eliminated and an unaue loas of $\mathrm{UP}_{6}$ to Fi-122 vis the exit geses.)

d. Hariog all of the pipelines and valves at $\sim 80^{\circ} \mathrm{C}$ which eliminated the depostition of $\mathrm{JF}_{6}$ in cold places.

e. Assuring optimum UF collection by the one.hours waitingsperfod after $\mathrm{TR}-2 \mathrm{C}-6$ reached $0^{\circ} \mathrm{C}$ and $\mathrm{WR}-1 \mathrm{~B}$ leveled off.

f. Cooling the cold traps to operating temperatures and then eracuating the residual gases through FV-122 and ehilling and eappling the pigtails to minisize UF 6 losses.

g. Continuously watching in Cell 2 for $\mathrm{UF}_{6}$ leaks ("whtte smoke") while PR-26 read ebove atmospheric pressure.

10.4 Equjpment Performence

\subsubsection{Froduct Cylinder, Fv-126}

Three alterations to the standard 5-1n. product cyllnier used by K-25 produced a gatiafectory product recelver for VFP: first, numbering and sdentifying for VPF; second, adalng the centrel thermowell for monitoring the

\footnotetext{
after the " $\mathrm{L}$ " rums, most of the equipment was dismentled and moved to Burial Ground Ho. 3 (Sec. $23.4 .16 \mathrm{~b}$ ). Howevex, the product cylinders, the cylinder heating and cooling equipoent, the chemical trap, and vaculm pusp were retatned for future processing.
} 
$\mathrm{UF}_{6}$ temperature, and finally, changing the valves and valve orientation. Two valve troubles were experienced:

a. Soltd UF $_{6}$ condensing in valves and preventing closure. This situation was remedied by: (1) wrapping pigtails all along and close to the valves with Mark II FV-526B jnsteed of heeting pigtalls wth Mark I FV-526B (heat lamps) and retaining one heat lamp from Marl I FV-526B for heating each valve, (2) redesignIng the FV-526 11a (Mark II) as described in Sec. 10.4.2, end (3) altering the FV-9e2 cyltider supporting device as delinented In Sec. 10.4.5.

b. Valve leaking through the pecking. This valve was repacked without further trouble as described in Sec. 17.4.1f.

The criticality containers for storing $\mathrm{WF}_{6}$-bearing cylinders were satisfactory.

The product cylinder wes kept at $\sim 80^{\circ} \mathrm{C}$ during the l1quid $\mathrm{UF}_{6}$ trangfer (Sec, 10,3.1).

In the " $\mathrm{C}^{\text {t }}$ man product trannfers, about $25 \mathrm{~g}$ of $\mathrm{U}$ as $\mathrm{UF}_{6}$ was normally purged to FV-124 (25, 27, 36, 37, 29). This

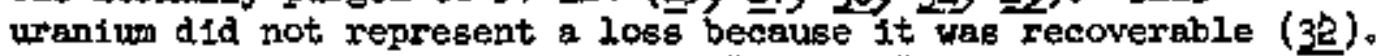
No such data were obtained in the " $\mathrm{E}$ " and " $L$ " runs.

\subsubsection{Product Cylinder Heater, FV-526}

This heater operated successfuliy. The onjy necessary cinange was an altered lid mede of Flexiboard which served two murposes: first, it ainimized the drag of the cylinder on the lit thereby greatly reducing the effect of this drag on tbe cylinder welghing monitor, and second, it raseed the sylinder valves out of the furmace so that UF 6 pluge could be eliminated by externel heating (heat lamps).

The heating cheracteriatics of FV-526 vere:

a. Time to heat enpty cylinder from room temperature to $\sim 80^{\circ} \mathrm{C}$ : one hour.

\footnotetext{
Teble 22.3 and Secs, 21.4.1, 21.4.2,

See footnote for 1tems d. and 8 . in Sec, 10.3.1.
}

b 
b. To keep cylinder at $\sim 80^{\circ} \mathrm{c}^{\circ}$, P yrovane and Vartac settings were $85^{\circ} \mathrm{C}$ and $120 \mathrm{v}$, respectively (Bec. 10.4.1).

c. Time to heat a product cylinder conteingng $\sim 10 \mathrm{~kg}$ of $\mathrm{U}$ as $\mathrm{IF}_{6}$ from roon temperature to silghtly $>100^{\circ} \mathrm{C}$ (for sampling): $6^{\prime} 6^{6}$ 8 hours.

10.4.3 Product Cylinder Inlet and Outlet Lines Heater, FV $-526 \mathrm{~A}^{\mathrm{b}}$

This neater worked satisfactorily. Performance data were:

a. Time to hent lines from room temperatume to $\sim 80^{\circ} \mathrm{C}=\sim 1 / 2$ hour.

v. Pyrovene and Variac settings to maintain $\sim 80^{\circ} \mathrm{C}$ were $120^{\circ} \mathrm{C}$ and $50 \mathrm{v}$, respectively.

10.4.4 Product P1gteils Hegter, FV-526B b

Th1s heater whs satisfactory. The only difficulty was that heat lamps were also necessary to keep the product cylinder valves hot enough to prevent $\mathrm{JF}_{6}$ deposition wille collecting product. Instead of being a rauit in the heater, this technique was an expedient. Using the Industriel heating cable for pigtalls and euxillary heat lamps for valves was less complicated than using industrial heating ceble for both pigtails and. valves. The resson was that the hesting cable would have required rewrapping every time a cylinder was connected.

Prior to instaling the hedting cable, the pistails and valves were heated entirely with heat lamps. In this arrangewent, the pigtails were not heated as uniformly and considerable time was spent ad fusting heat lamps.

Heater performance data were:

a. Time to temperature $\left(\sim 80^{\circ} \mathrm{C}\right)-\sim 2-1 / 2$ hours.

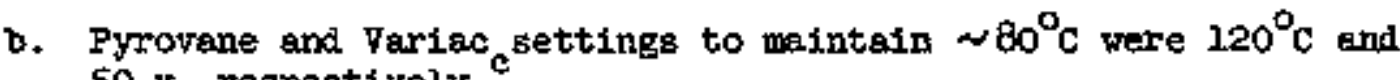
$50 \mathrm{v}$, respectively.

corrosion of the pigtalls and Honel piping in the product collecting system vas insigntficant ( $(19)$.

10.4.5 Product Weigh Station, FV-922

The product weigh station gave a rough record of the cylinder weight ville collecting $U_{6}{ }_{6}$. This record was very valuable in charting the progress

\footnotetext{
See footrote for items d, and g. In Sec. 10.3.1.

beble 22.3 and secs. 21.4.1, 21.4.2. Three valves, one in a temporary line connectine the pigtails and the other two in a temporary ${ }^{2} F_{6}$ supply line to the pigtails, plugsed in early work (Sec. 17.4.16),

ccontroller themocouples were silver brazed to the plgtails.
} 
of this step in the process ard, in addition, wes normally within a kilogrem of the actual cylinder welght as determined bo Toledo seales checked by ss Meteriel Accountability.

The operation of the product welgh station was beset with three atffeurties:

a. The drag occurring when the product cyinder andor valves rubbed ageinit the fumace lid. This drag which cavsed the weight recond to be low vas greatly reduced by the new-design lid mentioned in Sec. 10.4.2 and by suspending the cylinder from its thermowedl. Freviously, the cylinder was slung from the weigh element by an awkward circumferentiol clamp wich accentuated the dres egelnst the furnace Ild.

b. The drag resulting from the flexing of the pigteils. This drag could not be elimfnated, but its effect on the weight record was compensated for whle zeroing the recorter.

c. The wetgh element absorbing some of the heat rrom the beat lamps. This sttuation caused concern because black material dripped from the element at times. Actually, however, no specific damage to the element was appsrent. This situation wes largely corrected when nost of the lamps were dispensed with in favor of industriel heating cable (sec, 10.4.4).

10.4.6 Product Cooling Co17, FV-226

This cooling coil performed well throughout all runs.

\subsubsection{Froduct Cooler Blower, FV-622}

This blower was satisfectory.

\subsubsection{Product Cooler Refriserating Unit, FV-O2O}

The operation of this refrigerating unt was satisfactory. Three commentis are pertinent:

a. The unit required msintenance about every 6 months.

b. It wss necessery to rum both units to obtain cooling because of the cescede hook-up.

c. Mrouble wag experienced with the overlaad on the lower unit which presumatiy wes ceused by starting the lower untt less than $\sim 15$ minutes after the uyper unit wes started.

The combination of FV-226, -622 , end -820 was egpable gi cooling the product cylinder contalning $\sim 10 \mathrm{~kg}$ of $\mathrm{U}$ es $\mathrm{UF}_{6}$ from $\sim 80^{\circ} \mathrm{C}$ to $0^{\circ} \mathrm{C}$ in $\sim 3-1 / 2$ hours.

\footnotetext{
Aluis unit appetrs in Fig. Ig.3.
} 
10.4.9 Product Purge Chemical Trep, Fv-122

The operation of this trap (ahown on Dug. Ko. D-19709-Fe) was unsatisfactory. Consequently, the following changes were nepessary:

a. The flow scheme tas reversed. Two disadvantages were met in the original flow scheme: (a) the qualitative test, $t_{\phi} e$, yellow sh coloration of KaF, for uranium could not be used to till whether IJ had been pjeked up by merely observing the top of the HaF (Sec. $7,4,5)$ and (b) the arrangement made it possible to pull far into the racuum pturip.

b. A apring-loaded alntered nickel alak wes placed on top of the HaF bed to elimlnate blowing NaF around in the syotem.

c. The resael was realigned and made more accessible by welding to a nearby ateel col.umom.

The original placement resulted in improper alignment of the veseel relative to 1ta pipelines as well as the inaccessibility of the inlet and outlet flange bolts. Both of these factors made it aifficult to change the Hap in the trap as well as to make the rlanged joints leak-tight. After this change, the situation was improved although the filenge bolta were atill somewhat ineccessible. Whether the difficulty of rendering the flanged joints leak-tight resulted from the trouble in tightening the difficult-toget-at bolta or the use of a flat-gasketed joint instead of a ring joint was never ascertained. At any rate, the result was either incomplete evacuation of the cold traps in atepa $e_{\text {and }} l_{0}$ of the Operating Procedure (8ec. 10.3.1) or prol,onged puwping with an acccompanying high piek-up of $\mathrm{UF}_{6}$ in FV-122.

It was felt that the proper solution to this altuation was to replace the flat-gagketed top flange of FV-1.22 with a ring-joint flange and to make oome of the bolts even more accessible. Th1s change vas not made withe operating and should, therefore, be made before another processing period begins.

Urentum normally sorbed in FV-122 wes reduced by better opereting technique from $\sim 25 \mathrm{~g}$ per ros in the " $\mathrm{C}^{t}$ runs to a total of $15 \mathrm{~g}$ in the lagt

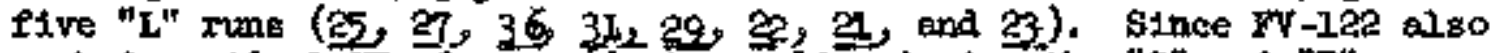
sorbed res1dual UF 6 frow prouct sampling during the "C" and " $\mathrm{E}$ " runs, horever, only the uranlum trapged during the "I" runs ceme from the product transfer step (Secs. 12.3.1e, 12.3.1b and 12.4.2c). The uranium did not Fepresent a losa because it was recoverable (32).

This trap was packed with $3 \mathrm{~kg}$ of $\lambda / 8-1 \mathrm{n}$. HaF pellets. Unloeding FV-122 was done either whth a porteble vacuim cleaner or whth Fv-420 (Sec. 10.4.12). 
10.4.10 Product Purge Cold Trap, Fv-224

This cold trap used in Rona $c-3$ through -8 was unnecessary because the product purge chemical trap was capable or collecting the Uf 6 evacuated during product collection $(\underline{25}, 27,36,21)$. In addition, this trap was awkward to handle.

\subsubsection{Coolant Container of $2 \mathrm{~V}-224, \mathrm{FV}-924$}

The most auitable coolant container (Mark III) was the stainless steel Dewar flask. The oritinal container (Merk I) was unsultable because of its size and shape. The glass Devar Flask (Mark II) available at OKHL was too fragile.

In the early WPP work, both FV-224 and FV-924 were found to be nonessential equipuent,

\subsection{I2 Vecurm Fure, Fv-420}

The vacuum purp was used as follows:

a. To evecuate cold trepe during product collection. The pump was adequate for this service, Difficultieg were met in achievIng the desired pressure (0.3 rm of Hof, ef. Sec. 10.3.1) faly when leaks were present in the systen. Leeks giving the most trouble were those in the FV-1ae top flange and valve $v-114$,

b. To evacuate the $\mathrm{UF}_{6}$ eampler (Sec, 12.3.1a and 12.3.1b). The vacurm pump was satisfactorily used in $\mathrm{UF}_{6}$ sampling.

c. To evecuete the cold trap jackets (Bec. 9.4.7b). The racuum pup was satiafactory for thia aervice. No difficulty was experienced.

a. To empty chemical treps Fv-103, t122, and -124 (Secs. 6.4.1b, 9.4.8, 10.4.9). Using the vacum pump to empty chemicel traps was preferred over using a portable vacum cleaner beceuse it was more conventent and because it presented no exheust ges problem. But in this service fines were bled to the vacuum pump which apparently increased the frequency of overhauling.

Specific troubles met vere:

a. It was necessary to use MIFL (Miller's Fluorinated Lubricant) ofl which was very viscous at room temperature and, therefore, required heating to $\sim 140^{\circ} \mathrm{F}$ either to fill the punp or to atart It. This heating preparatory to sterting the pusp was done both with heat lampe and with two atrip heaters fastened to the prup body. A thermostat set at $140^{\circ} \mathrm{F}$ and tumered in the oil was incorporated in the strip heaters cireuit. The strip heaters method was preferxed. 
b. A gluey mass which clogged the pump lubricetion ports formed in the pump. Formation of this material was presumed to sten from: (a) heating the ofl, (b) pessing $F_{\text {f }}$ through the o1l, and (c) the accumulation of NaF fines. Its formation necessitated this approximate meintenance schedule: (a) changing oll quarterly and (b) orerhauling pump semi-annually or annually." The accumulation of $\mathrm{HaF}$ fines was believed to be the most damaging. This gluey mass affected the pumping capacity, although to an unknown degree.

c. NaF" pellets from FV-222 were sueked into the pump. This trouble wes encoumtered only in early VPP work and resulted both from sudienly openting $V-99$ and from inadequately retaining the NaF in FV-lec (29, p.27). Later both of these difficulties were elininated.

d. A vacuum-break on the upstream side of the pump was necessary when ahutting down the vacuum punp. The consequence of not breaking the vacum was the possiblilty of sucking oil into the system. Since there was angeat likellhood of this, an autcmatic racuum-breaktng device was installed. This device was actuated when the purp motor power supply shut off." This actuation would occur from a power shut off occurring manualiy or by the ciscult breaker but not from a power failure.

e. The racum pump originally discharged exit gases to the cell. In early VPP work, the Jrup exhaust was plped to the cell offgas duct.

Since the vacuum pimp was indispensable during product collection, a spare purp of smaller capactty and suiteble nipples for connecting it to the aystem were provided in the event of Ktnney pump breek dow. This spare pump was used when HaF pellets vere accidentally pulled into the kimney pump during Rim C-10 (29, p.27). Its pumplag capacity was inbdequate, how ever.

\section{4,13 Instrumentetion}

FE-26 (13) and thermocouples were Indispensebie in following the product collection operation. PE-26 monitoring the system pressure indicated the movement of the Uf 6 from the cold traps to the product cyllader. For exacple, at the maximuin pressure of $\sim 50$ psie, the Uf 6 was a mixture of liquid and vapor. The subsequent decrease in pressure reading 1ndicated the collection of $\mathrm{UF}_{6}$ in the product receiver. Finally, when product collection was over, the FE-26 reading was nearly zero psia as it had been previously after system evacustion.

\footnotetext{
"Overhauling was done at the $K-25$ Vacum Fump shop in Building 1401 under ' . R. L. Leinart's supervision。

bTh1s systeri conteined a solenoid and a timer so that $\mathrm{N}_{\mathrm{s}}$ flowed for one minute only. Complete operational information is given in Engineering File Folder No. 49.
} 
After PT-26 was placed inside the heated duct to keep it above $65^{\circ} \mathrm{C}$, 11ttle trouble with it arose. Previously, it was essential to replace the Bourdon spring on two occasions because of $\mathrm{UF}_{6}$ condensation.

Some trouble was experlenced with PI -27, the pressure gage used to determlne the extent of evacuation (0.3 m $\mathrm{mg}$ as in step a, Sec. 10.3.1) of the product collecting syatem. Although the reasons for the trouble were not fuliy ascertained, exposure to $U F_{6}, F_{2}$, and NaF fines wes evidently a contributing factor.

\subsection{Summary and Conclusions}

Most of the components of the product collecting system gave little trouble. Principal difficulties were met with the product cylinder valves, the product purge chentcal trap, and the vacum pump. The characteriatics of the heating equipment are recorded. The product collecting operation required 10 to 12 houre.

The atandard 5-1n. $\mathbf{H F}_{6}$ eylinder was altered to identify w1th VPP and to adapt to the operation. Adaptation constituted inatalling central thermowell and changing and reorienting the ralves. Plugs occurring in cylinder valves were ellminated by redesigning the FV 526 lid and by heating each valve with a heat lamp. The packing in one valve on a cylinder containing if 6 was replaced vithout incident se deseribed. Criticality conteiners for the cyllidiers were successfully used.

The cylinder furnace lid was changed to minirize drag and to ralse the valves out of the furnace for proper heating.

Pigtails heated edequately with industrial heating cable vere unevenly heated with heat lamps. In addition, considerable time tas consumed by odjusting the heat lamps. Corrosion of the product pigtails and Monel piping in the product collecting system appeared insignificent.

The product weigh station worked better when the cylinder was suspended by the thertatiell than when suppended by a circumerential clamp. The reason was that less drag occurred from the thermowell suspension. The weight element exuded a black material as a result of heat ebsorption, but tbis caused no known damege to the element. The weighing device was sulteble for monstoring the change in cylinder weight while collecting UF ${ }_{6}$. Usually the finel weight indiceted by the device was within ebout one kllogram of the true ur' weight determined with Toledo scales checked by ss Material Accountability.

The product oylinder cooling system cooled a product cylinder with $\sim 10 \mathrm{~kg}$ of $\mathrm{U}$ as $\mathrm{UF}_{6}$ from $80^{\circ} \mathrm{C}$ to $0^{\circ} \mathrm{C}$ in $3-1 / 2$ hours. Cooling was obtained only when both refrigerating units were running. Maintenence on the refrigerating unite was required about semi-amnully.

That 1s, above the triple point of UF 6 (See Step $a$, Sec. 10.3.1). 
The product purge chemical trep required these changes:

a. Reversed flow scheme to enable detecting J pick-up without enptying the trap.

b. Reaesigned for adequate retention of NaF pellets without the possibility of pellet movement.

c. Realigned vessel to alter 1 ts position relative to its pipelines and to Inprove accessibility to the flanges bolts.

Because of the Inaccessibility of the flanges bolts and presumably because of the flat-gasketed flanged joints, leake were difficult to eliminate. such leaks e1ther resulted in incouplete evacuation in froduct collection or a pro* longed "pumping-down" tiore. Incomplete evacuation increased the partial pressure of inert gases during product collection. Prolinged pumping eugmented the plckup of $\mathrm{UF}_{6}$ in FV-122. Improvements in operating technique enabled reducing the uranium gormally sorbed by this trap to a total of $15 \mathrm{~g}$ in the last f1ve "L" runs. Uranium so collected was recovereble.

The product purge cold trap and tts coolant container were used only through Run c-8.

The vacum puimp was used to: (a) evacuste the cold traps, cold trap jackets, and $\mathrm{UF}_{6}$ sampler and (b) empty the chemical traps. At times, attalning a pressure of $0.3^{6 m}$ of $\mathrm{Hg}$ during product collection was difficult, this difficulty usuelly stemming from leaks. The other evacuations presented no trouble. Buptying the chemical traps with the pump resulted in getting NaF fines in the vacum punp oil. Specific troubles vith the pump were: (a) the necesstey for using kFL ofl requiring heat $1 \mathrm{ng}$, (b) the formation of a gluey mass in the pump lubrication ports, (c) $\mathrm{NaF}$ pellets inadrertentiy being sucked 1nto the pump, (d) the necessity to break the vacuun when pump was shut off, and (e) release of exit gases in cell 2 In the eariy design. The spare jump was ingdequate for product collection. Reasong for the trouble with PI-27 were never fully ascextained. PE-26 and thermocouples vere indispensable in following the product collection operation.

\subsection{Recominendations}

It is recollonented that:

a. The components of the product collecting systern not mentioned belos be used in the latest stage of development in future processing.

b. The 15-minute waiting perfod between starting the first and second product cylinder cooling system refrigereting units be adhered to more closely: these units should be checked oemi-annually.

c. The product purge chemical trep be rebullt with the following deafgn features: (a) gas inlet at the top for esse in qualitatively detecting $\mathrm{UF}_{6}$ pick-up, (b) adequate $\mathrm{HaF}$ pellet retention without pellet movenent, and (c) flanged joints whteh are easy to make leak-free as determined by the KI-aterch method. (Th1s change includer naluting the bolts for rlenges accessible.) 
a. Nar fines be kept out of the vacuun pump by: (a) screening Nef for use in the product purge chemical trap and (b) emptying chemical treps some way other then wlth the racula pump.

e. An adequate spare for the vacuim pump be obtained and kept ready for service.

f. The following maintenance schedule for the vacuum pump be adhered to until proven unnecessery: (a) chasge oil quereterly and (b) overhaul semitannually or annually.

\subsection{Appendix}

g. A reliable, accurete low-pressure gage be installed instead of PI-27.

10.7.1 Operating Procedure: Product Cylinder Handling (Fevised Feb. 7, 1958

$\underline{\text { PART A }}$

PRH

Date

Time

Oper.

1. Select a conditioned $5 " \mathrm{UF}_{6}$ cyilinder for use as a product recelver. Cylinder Number

2. Carefully weigh the cylfnder (with the valve capa on, but with all other attachments removed) on Toledo Scale No. X-26515. Wt $=$

3. Zero reading of scele kg.

4. Wetgh the $25 \mathrm{~kg}$ check-weight. wt $=$ kg.

5. If this number $3 \mathrm{~s}$ not between 24.95 and $25.05 \mathrm{~kg}$, have the scales checked, then repeat steps 2,3 , and 4 .

6. Place the product recelver in the fuxnace (FV-526).

7. Attach the lifting lug to the cylinder.

8. Connect the pigtalis to the cylinder using new alwinum gaskets. Be Bure to use a back - up wrench.

9. Attach the lifting lug to the weighing assembly, malcing sure the cyllnder is centered in the furmece.

10. Install lids on furnace, then make final check that the cylinder hanga freely from the weighing element. Time done

11. Close $\mathrm{V}-53 \quad \mathrm{~V}-99, \mathrm{~V}-114$ $\mathrm{v}-1.15$ on discharese side, and $\mathrm{v}-111$ on suction side of Fv-420, and

12. Open $V-714$

14. close $\mathrm{EX}-2 \mathrm{2}$

15. Turn on $\mathrm{FV}-420$.

17. Punp system down for 5 minutes.

18. ciose $\mathrm{HX}-26$.

19. Open $\mathrm{HX}-25$ unt11 $\mathrm{H}_{2}$ flow stops. (Watch FI-3.)

20. cloge $\mathrm{kx}-25$.

21. Open EX-26 for 5 minutes.

22. close $\mathrm{nx}-26$.

23. Open HX-25 as in step 19.

24. close EX-25. 
25. Open $\mathrm{Ex}-26$ for 5 minutea.

26. close $\mathrm{kX}-26$.

27. Open $\mathrm{HX}-25$. When flow levels out record FI-3

28. Clone $\mathrm{EX}-25$, When flow levels out record FI-3

29. Froceed to IFS rumsheet.

PI-32

PI-32

PAFT B

30. After product has been collected in the cylinder, and the pistails purged, daconnect pigtalls from the cylinder.

31. Replece valve caps on aylinder and pluss in the pigtails

32. Remove the lifting lug, and take the cylinder out of the furnace.

33. When cylinder has warmed to room temperature, welgh on Toledo scale $\mathrm{x}-26515$. $\mathrm{Wt}=$

34. Zero reading of acale $\mathrm{kg}$.

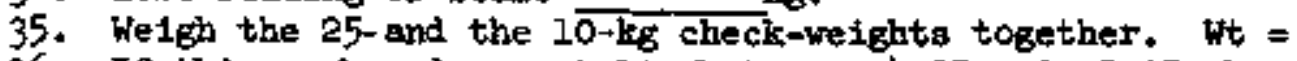

36. If thje number does not lie between 34.95 and 35.05 , have the scales checked, then repeat steps 33 and 34 .

37. Return the cylinder to Cell 2 for sampling.

38. After product ampling operation, rewelgh cylinder as abore.

Cylinder welght

Check welghts

Zero realing of ecile _L kg.

k.g.

kg.

39. Store cylinder in VPP storase cage.

10.7.2 Operating Procedure: Product Removal Operation (Revised May 1, 1958)

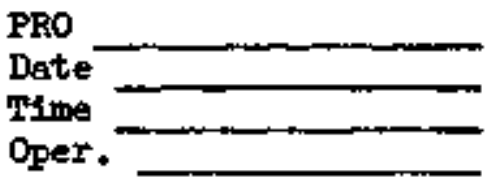

1. Begin this procedure after the installation of the cylinder according to Part A, PCH rinsheet. Cylinder Number

2. Close $\mathrm{V}-53$

$-99$ $-100$

3. Open eylinder valves.

4. Conation ejlinder and pigtalls with $F_{2}$. (See FCP rumbeet).

5. Switch $\mathrm{kX}-1$ to point $B$. WR-1B reading

6. Cloge $\mathrm{Ex}-13$

7. Open $\mathrm{kx}-15$

26 , 14 , 16 Time 18

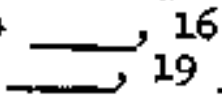

$\longrightarrow$ दे $22 \longrightarrow 30$ kg

8. Set the following controllers. Record informetion on appropriete dets sheet.

Controller Set Point Time Set Time Reached

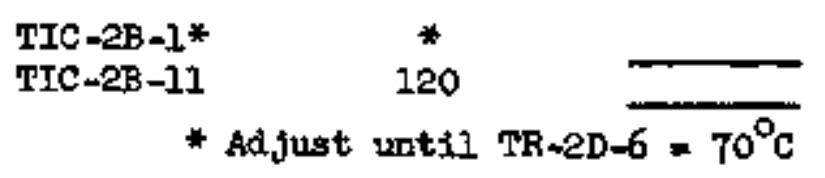


9. Adjust heat lamps on pigtails until $66^{\circ}$ Tenpilgtik melts along entire length of pigtatls.

10. Adjust $T C-2 B-11$ to $50 \mathrm{v}$ after reeching temperature in step 8 .

11. Check that Fv -420 is running.

12. Open V-99 slowly. Tfme open

13. When PI-27 falls to $0.3 \mathrm{~mm} \mathrm{H8}$, close $\mathrm{Ex}-26$ and V-99

Tine closed (If mintinum vacuum is pumping for 5 tilnutes, close $\mathrm{FX}-26$ source of inleakage.)

14. Close Hx.18 and $V \cdot 99$ and look for Bleed air from Freon reservoirs (if necessary) to keep pressure at 10-15 peig

16. Set the foliowing controllers:

\begin{tabular}{lcccc} 
Controller & Set Point & Control Point & Time Set & Time Rigached \\
\cline { 2 - 2 } & 58 & 80 & \\
TIC-2B-3 & 70 & 80 & \\
TIC-2B-4. & 130 & 80 & \\
TIC-2B-5 & 75 & 80 & \\
TIC-2B-6 & 85 & 80 & \\
TIC-2B-7 & 95 & 80 &
\end{tabular}

17. The Variacs should be adjusted to give, as neerly as possible, Identical temperature records on $\mathrm{TR}-\mathrm{2C}-1,2,4,5,6$. Then,
a) Set TC-a-2, 3, 4, 5, 6, 7 on 50\% of fult seale
b) Make adjustments on individual Varsacs to keep temperature records close together
c) Then increase each Variac as the slope of the temperature curves begin to decrease (Curves flatten.)
d) Finally, maintaln $\mathrm{TR}-\mathrm{CC}-1,2,4,5,6$, at $80^{\circ} \mathrm{C} \pm 5^{\circ} \mathrm{C}$.

18. Observe PR-26. When PR-26 reads equivalent of atmospheric pressure, stetion a man at entrance to eell 2 to observe any leakage from the system, Reading on PR-26 \$.

19. When PR-26 1ncreased $15 \%$ above the reading in step 18 , open $18 x-18$ Shut off TIC-2B-1

20. Watch WR-1B. When reading is increasing less than 1 division in five miuttes, open $\mathrm{BX}-19$

21. When wi -j stops increseing 1 division in 5 minutes (or any time the presgure on PR-26 exceeds $30 \%$ above reading in step i8) start the product coolers.

22. To start coolers: Turn on dry air supply to blower air to produce s slight hisiing sound).

23. Turn on blower.

24. Allow 5 minutes to dry out system, then turn on cooler il.

25. Approximately 10 to 20 minutes later, turn on cooler fa.

26. Meintein these conditions until TR-2D-6 and WR-1B both level off.

$\begin{array}{lll}\text { InBtrument } & \text { Time Levelled orf } \\ \text { TR-2D-6 } & \text { Reading } \\ \text { WR-1B } & \end{array}$


27. Wait 60 minutes then close the product cylinder valves. Time closed

28. Turn off TIC-2E-2 $3,3,5$

29. Turn on brine pusps in pipe tunnel $\longrightarrow$. Reduce pressure on each brine reservolr to $10-15 \mathrm{psig}$ Q32 Time

30. After TR-2D-1 and -24 - Start compressors FV -830 and

NOTE: Detween steps 30 and 37, while $\mathrm{BX}-14$ and -16 are closed, close EX -35 and -36 , then pull and ref11I FV-124*. (Yea

No T Trime pulled . Fill in card Eile on $\mathrm{FV}-125$

31. Open HX-25 until pigtanis are pressurized indication of pressurizing.)

32. Close $\mathrm{BX}-25$ and open $\mathrm{EX}-24$

33. After 15 seconds, close $\mathrm{kX}-24$.

34. Repeat steps 31,32 , and 33

35. Repeat steps 31, 32, and 33 sisain

36. Close $\mathrm{EX}-18$ ani -19

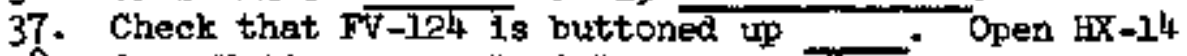

38. Open V-99_. Resd PI-27, or-28, min Hg. and -16

39. Check that FV 420 is running.

40. Open $\mathrm{HX}-23$ and $\mathrm{EX}-26$

41. Punp down for 5 minutes.

42. Close $\mathrm{HX}-26$.

43. Open $\mathrm{HX}-25$

(Watch $\mathrm{FI}-3$. ) , V-7LA and $v-73 B$ until $\mathrm{N}_{2}$ stops flowing.

44. Close $\mathrm{HX}-25$.

45. Open $\mathrm{HX}-26$, purap down for 5 minutes.

46. Ciose $\mathrm{EX}-26$.

47. Open $\mathrm{HX}-25$ unt $11 \mathrm{H}_{2}$ stops flowing.

48. Close $\mathrm{HX}-25$.

49. Open $\mathrm{BX}-26$, pump down for 5 minutes.

50. close $\mathrm{EX}-26$.

51. Open $\mathrm{HX}-25$, until $\mathrm{N}_{2}$ stops flowing.

52. close $\mathrm{HX}-25$.

53. Turn off TIC-2B-11

5i. Sample FV-152, Code SI . Submit for Ut and oH".

and pigtail heat lapps

Return to PCH rumbheet Part B, for removal of product cylinder. Record cylinder weight bere as well as in FCA rumsheet.

cylinder weight

Check-weights

Zero reading —

ks.

ke.

56. Bmpty and refill fiv-122 and FV-158 only if requested. FV-122 Yes No _... FV -158 Yes ; No

Time Completed

Operator

* only if requested to refill. 
11.0 Serubbing system . . . . . . . . . . . . . . . . . 139

11.1 Introduct1on. . . . . . . . . . . . . . . . 140

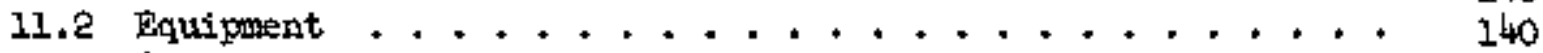

11.3 Operation .................... 140

11.3.1 0perating Procedure. . . . . . . . . . . . 140

11.3.2 Critical Opereting Steps............. 144

11.4 Equipment Evaluation . . . . . . . . . . . . . . 144

11.4.1 Serubbing Tower, FV-150 ............ 144

A. Genersl Information ............ . 144

b. Model Differences ............. 145

11.4 .2 Surge Tank, FV-152 . . . . . . . . . . . 150

11.4 .3 Surge Tank Agitator, FV-352 . . . . . . . . 150

11.4 .4 Clrculating Pum, FV $-450 \ldots . . . . . . . .150$

11.4.5 Caustic Make-up Tank, FV-140; Caustic Make-Up
Agitator, FV-340; Caustic Transfer Pump, FV-440; 154

and Cauktic Drum L1ft, FV-940..........

11.5 Shmmery and Conclusions................ . . 154

11.6 Reconmendations................... . . 155

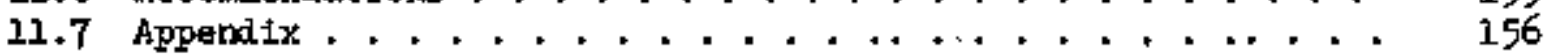

11.7.1 Operating Procedure: Scrubber Make-lp Procedure . . 156

11.7.2 Operating Procedure: Development Operations of

Serubber . . . . . . . . . . . . 157 


\section{1.1.1 Introduction}

In the scrubbing system, fluorine and a small amoumt of HF in the VPP tail gases were reacted with an aqueous KOH solution. The inert gases were subsequently exhausted to either the vessel or cell off-gas system in Building 3019. Principal ateps 1, the operation of this system were:

a. Maintaining adequate scrubbing capacity.

b. Keeping the scrubber pumg ruming and the inlet line to the scrubber unplugged.

\subsection{Equipment}

The general arrangement of the equipment in the scrubbing system is show in Fig. 1l.1. Detalls of the individual components are recorded in Table 11.1."

\subsection{Operation}

\subsubsection{Operating Procedure}

Steps in operating the scrubbing aystem were:

a. Determining whether the serubbing capacity in the surge tank was adequate for the operation to be done. (Th1s wes done by comparing the est1mated moles of scrubbing capacity needed with the poles of oH ${ }^{-}$ion in excess of 0.5 molar in the surge tank.)

b. Providing the necessary koH solution by the scrubber make-up procedure shown in Sec. 11.7.1.

c. Setting the necessary valves (Gec. 11.7.2, Part B.), and starting the agitator, Fv-352. (The top three spreys only were used.)

a. Putting the PCV-39, FE-9, and LE-4 instrumentation in service.

e. Turning on the scrubber pusm, EY-450.

WOTE: The scrubber was shut dom by turning off the scrubber pump and setting valves as necessary.

Altering the design of the VPP Irom time to tire required minor changes in the scrubbing operating procedure. Detalls of the operating procedures for the scrubbing system are given in Secs. 11.7.1 and 11.7.2.

\footnotetext{
The scmbbing tower, surge tank, and circulating puxp are shown In Fig. 14.2.
} 


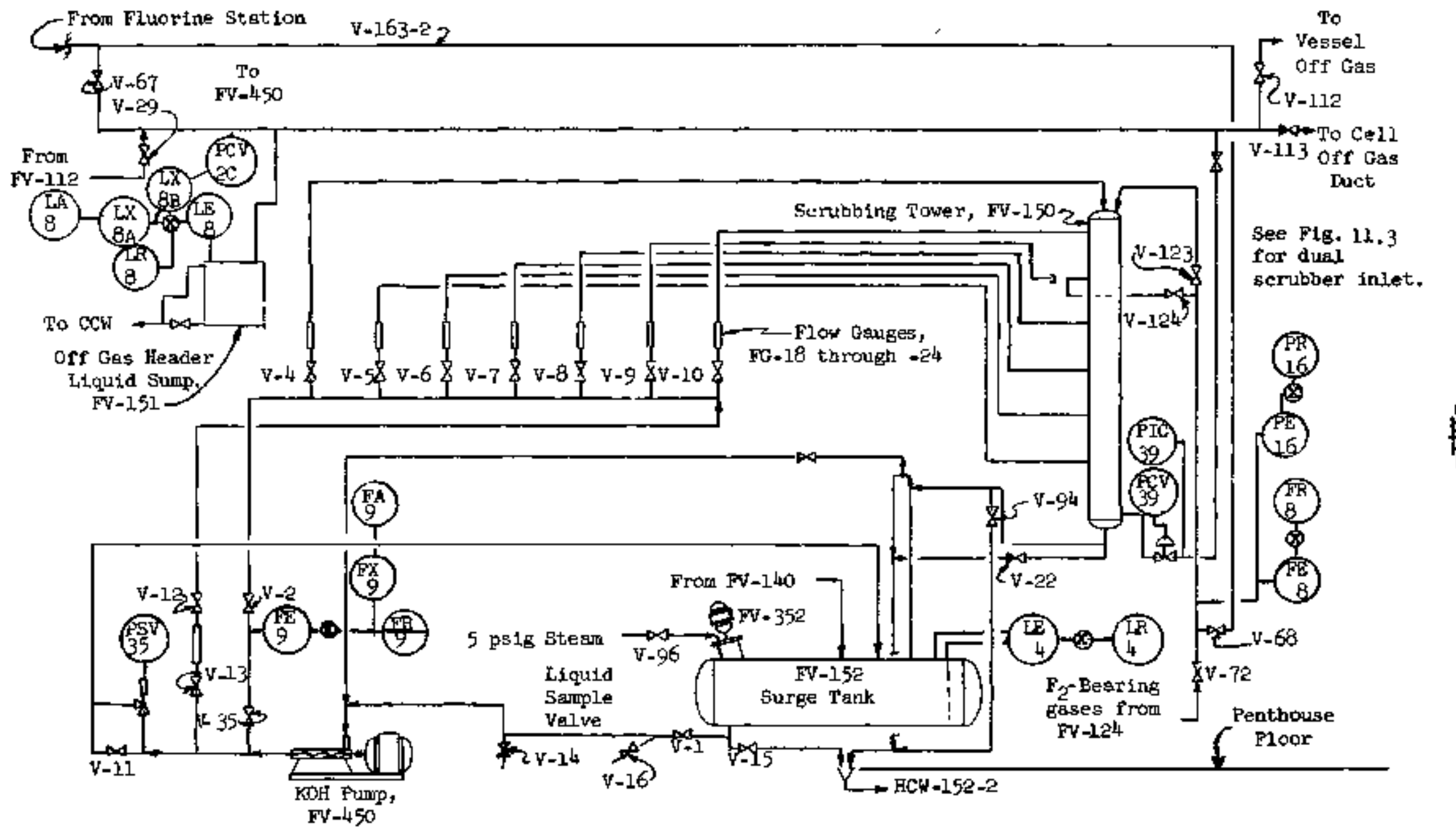

F1g. 11.1. Equipment Arrangement in the Scrubbing System 


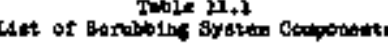

\begin{tabular}{|c|c|c|c|c|}
\hline \multirow{4}{*}{ 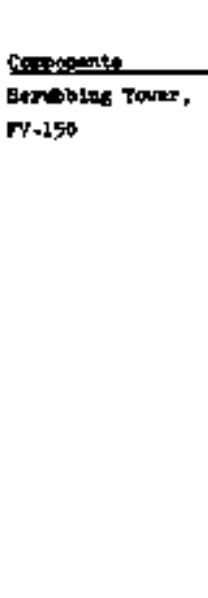 } & \multicolumn{3}{|r|}{ 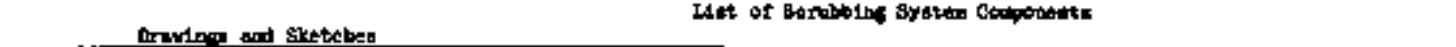 } & \multirow[b]{2}{*}{ Referetives: } \\
\hline & 7 & 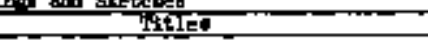 & 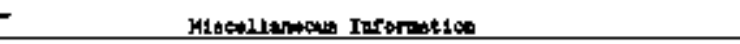 & \\
\hline & 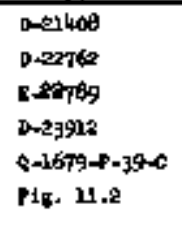 & 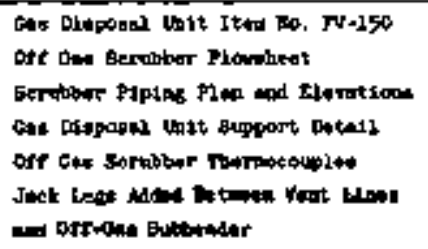 & 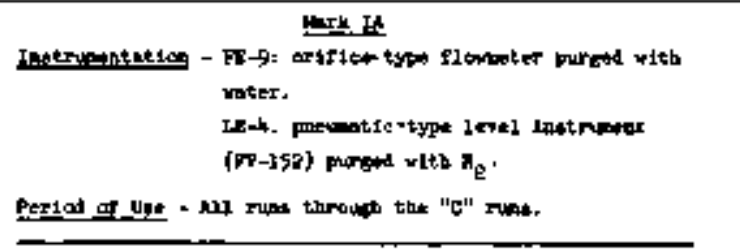 & 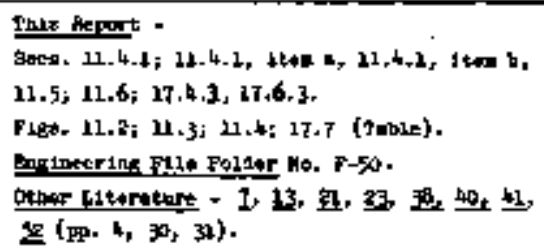 \\
\hline & Fit. 11.3 & 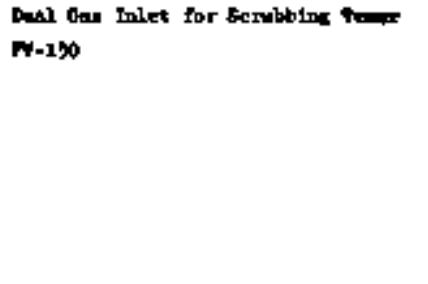 & 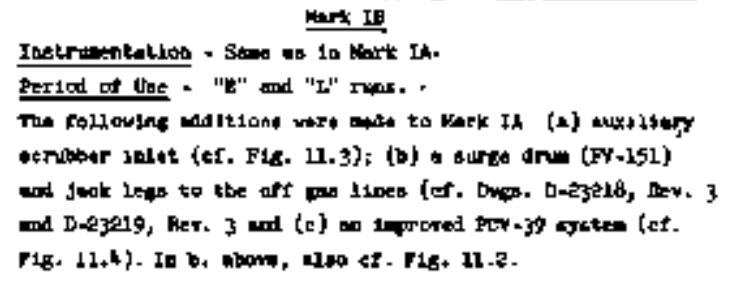 & \\
\hline $\begin{array}{l}\text { swise Tank, } \\
\text { Ft-15s }\end{array}$ & $\begin{array}{l}\text { b-19701 } \\
\text { to-2e789 }\end{array}$ & 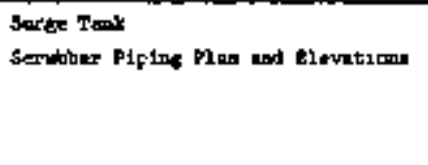 & 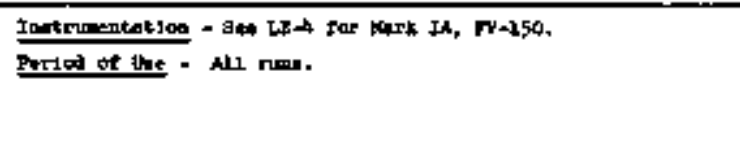 & 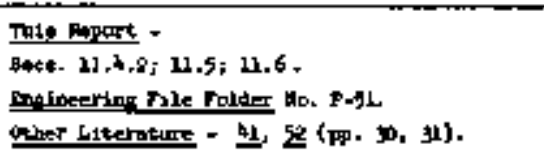 \\
\hline puree Thenk & 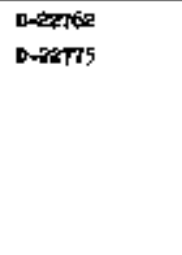 & 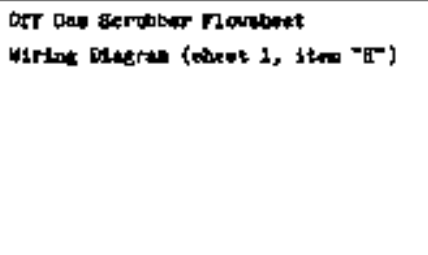 & 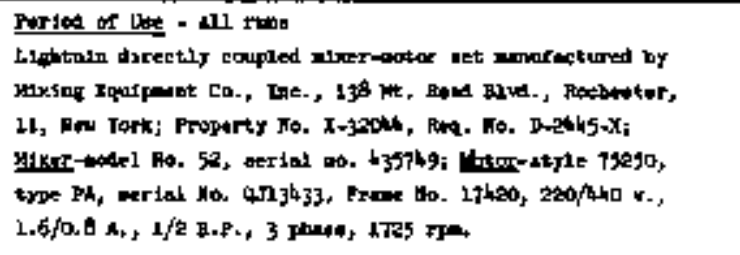 & 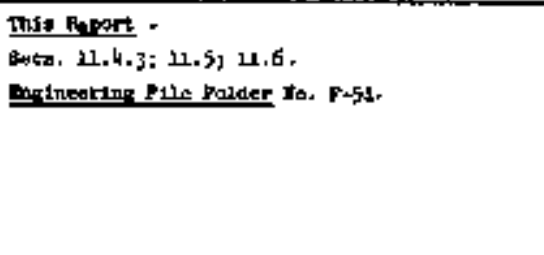 \\
\hline 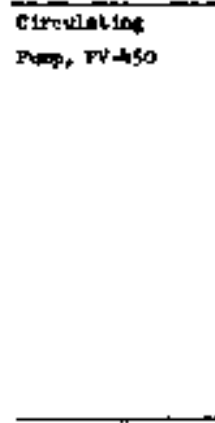 & 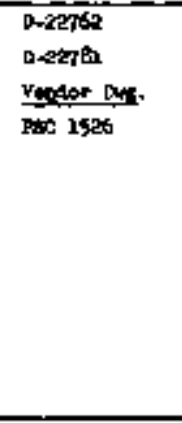 & 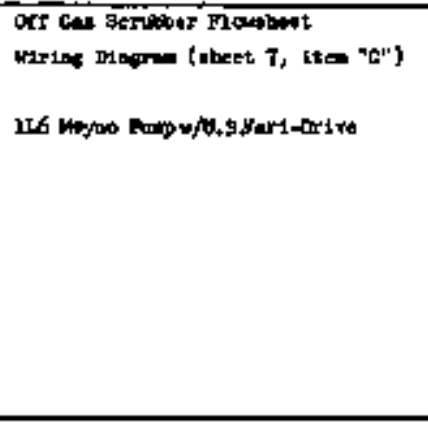 & 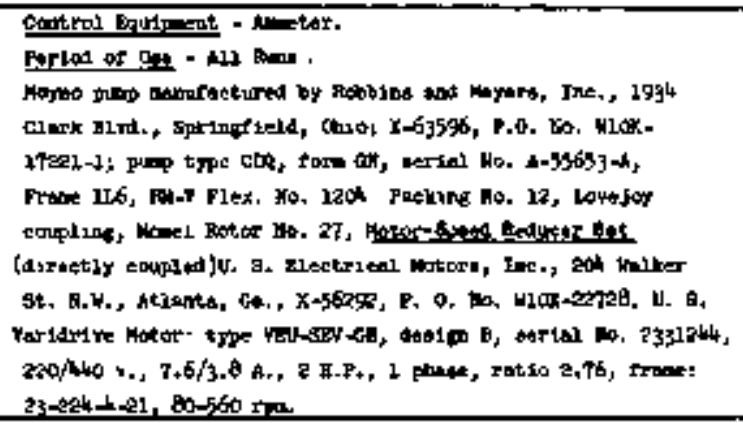 & 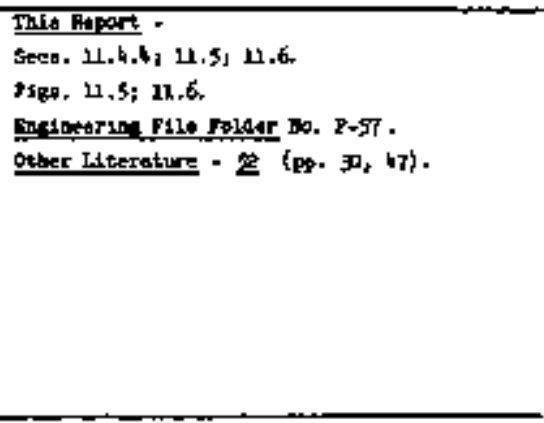 \\
\hline
\end{tabular}


table 21.1 [cootinnare)

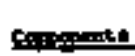

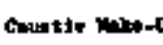
Twat, $\mathbf{w}-2$ ho

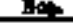
cumep D-23293

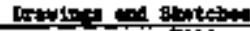
Fites

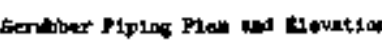

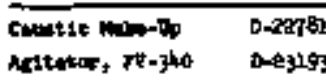

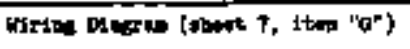

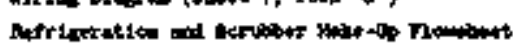

Burtal of the - N11 has.

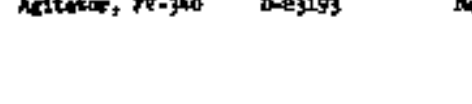

\section{cimele trengter}

$0-20 \pi t$

043199

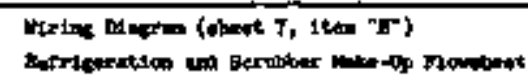

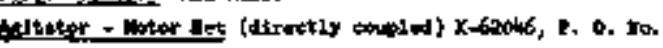

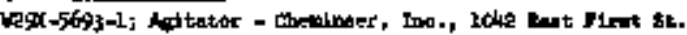

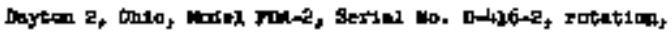

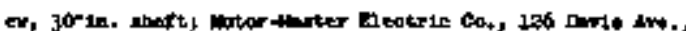

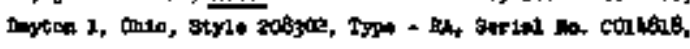

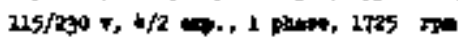

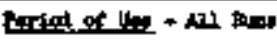

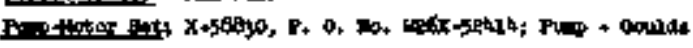

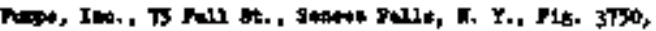

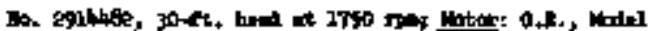

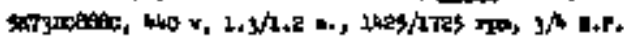

3 sher.

\begin{tabular}{|c|c|c|c|}
\hline 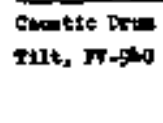 & 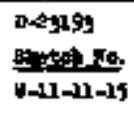 & 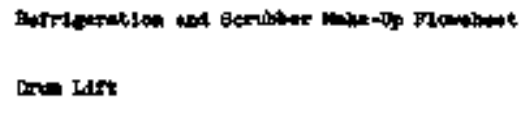 & 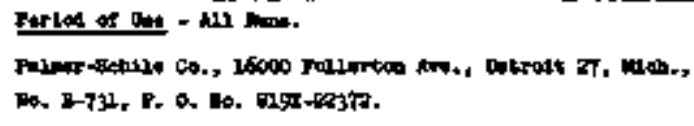 \\
\hline
\end{tabular}

Bareromet

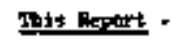

Beck. 11.4.5; $12.3+21.6$

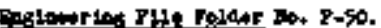

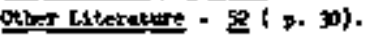

\section{nin, spats: -}

Sece. 21.4.6; 22.5; 23.6.

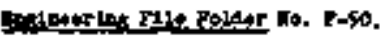

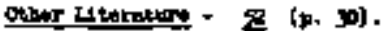

mite seom -

Ses. 11.4.7, 11.5511 .6

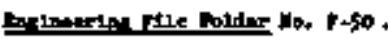

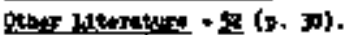

\section{Haxp}

8eos. $11.4 .85,22.3121 .6 \%$

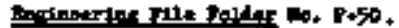

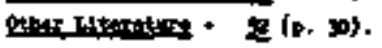




\subsubsection{Critical Operating Steps}

a. Keeping the serubber solution within (ar ${ }^{+}$) 11mitr of 0.5 and $2 M(10 \mathrm{wt} \$)$. The lower limit was insed to avald exheust 倍, $F_{2}$ in the exit gases. At times in the " $\mathrm{E}$ " and "L" mins, however, the (OH) wes $\mathrm{rm}$ as low as $0.2 \mathrm{M}$. Whether apprec1able $F_{2}$ passed out in the exit gases during such operation was not escertained. Although the upper limit of $2 . \mathrm{M}\left(\mathrm{OH}^{-}\right)$in the atarting solution was exceeded at times, thi $\bar{B}$ represented a conventent concentration based on the $45 \% \mathrm{kmH}$ purchesed and on the aize of the scmuber make-up solution equipment. Becense of the high solubility (107 g/ $100 \mathrm{ml}$ of water or $18.4 \mathrm{M}$ ) of $\mathrm{KF}$ in water at $30^{\circ} \mathrm{c}$, the $\left(F^{-}\right)$wes of small reletive laportance unless the same colution wes used and strengthened repeatedy.

b. Keeping the acmibber gea inlet line unplugged. (A ges inlet line plug necessitated shutting off the $\mathrm{F}_{2}{ }^{*}$ )

c. Contimuing to operate the scrubber as long as $F_{2}$ vas flowing to evold pessing $\mathrm{F}_{2}$ into the off-gas systems.

\subsection{Equipment Eraluation \\ b}

11.4 .1 Scrubbing Tover, FV-150

a. General Informeticion

Scrubber performance tests were run in October end Notember of 1956 (38). When $B$ total of 2.74 cu ft of $F_{2}$ wes contgcted with 6 gPI of $\sim 2$ M KCH (two Schutte and Koerting Fig. 62zc-30 coarse spray nozzles) at a solution tempereture $>30$ to $35^{\circ} \mathrm{C}$, the $\mathrm{F}_{2}$ concentration in the off-gas was $<100$ pgm. Temperatire was proposed as an important factor in the reaction:

$$
\mathrm{F}_{2}+2 \mathrm{KOH} \longrightarrow 2 \mathrm{HF}+\mathrm{H}_{2} \mathrm{O}+1 / 2 \mathrm{O}_{2}
$$

In VPP operations, the scrubber performance data were:

1. Aftequately handled $\mathrm{F}_{2}$ flow rates up to 30 ilterg/nin with $\sim 10$ gpin of $\mathrm{KOH}$ flowing through only the top three spray nozzles.

2. The uranium normally collected in the Kotl solution wis 1nsigaficant (27, 25, 36, 31, 29, 22, 23, 21).

3. Fission product activity in the KOH solution was low (2], 23 ). KOH solution concentration lintts established are given in Sec. $1,3.2$

This solubility figure was interpolated from data in (39) The minimim temperature in the scrubbing solution was $30^{\circ} \mathrm{C}$ in the " ${ }^{\prime \prime}$ runs (2l).

bafter the "L" Funs, the scrubbing equipment was retained for ruture processing. 
The only serious corrosion observed occurred on the gas 1nlet : liner. During eerly work, the corrosion noted on the Mark IA gas inlet liner was very severe 8.5 described elsewhere (40). In later work, corrosion on the Mark LA liner was less severe presimbly because the $\mathrm{KOH}$ temperatyre at the top of the scrubuing tower was lowered Pron $\sim 100$ to $50 \mathrm{c}$ (7). However, two localized highattack reglons were found. Corrosion of the small ges inlet liner (Mark IB, Sec. 11.4.1b) produced only surface roughening (7). Vidigage data revealed only alight corrosion on the scrubbing tower sholl (41).

Once while cleaning out the gas 1nlet liner, the flange of that assembly alipped off the pipe. Whether this was a weld failure or the separation of a poorly velded joint could not be determined. At any rate, to prevent a recurrence posstbily followed by dropning the pipe inside the scrubber, the foint vas remode using a heary veld es show on OFWL Dwg. D-2l 408 , Rev. 2. Since that time, no similar trouble has occurred.

FE-9 and LE-4 monitored the flow rate of the KOH solution and the liquid level in the aurge tank (Sec, 14.4.5). Both of these instrumenta were satisfactory. $L B-4$ was essentially trouble-free. However, the weter purges of FE-9 were difficult to galntaln because of: (a) rust in the water clogging up the purige ines ami (b) the fact that the purge pressure needed to be high enough to overcome the 65 psig pressure in the KOH line.

b. Hodel Differences

Differences in Mark IA and IP were:

1. Vent line piping.

(a) Mark IA piping design did not prevent KOH from flowing into the vent line plping. Although the gas exit ine of the scrubber wes $10 \mathrm{in}$. above the liquor exit line, the KOH solution in the Mark IA design floved into the exhaust gases hegier and thence into lines $v-172-1, v-161-1$, and $v-$ 162-1. This wes first discovered in Rum M-9 (between Runs C-2 and C-3) when solution dripped from en opening of zine $V-112-1$ in Cell 1 . A survey of the vent-line piping revealed the presence of $\mathrm{kOH}$ solution also in lines $\mathrm{V}-16 \mathrm{l}-1$ and $V-162-1$ at the Fluorine Pransmitter Rack. No reaction of $F_{3}$ whth the solution apparentiy occurred although the fact that such a happening was possible accelerated making the design change discussed under Wark IB.

\footnotetext{
a "LeBs severe" here means that the frequency of replacenent might be once every year or two.
} 


$$
-146 .
$$

(b) Mark IB - (L) eight foot Jack-legs shown In Fig. 11.2 were added to prevent any llquid in the off-gas subheader from entering lines $\mathrm{V}-112-1, \mathrm{FV}-128, \mathrm{a}$ and $\mathrm{V}-163-2 ;$ (2) the congtant+level arum FV-151 shown in FIg. 11.1 toward which the off-gas subheader sloped was also added to allow liquid in the off-ges subheader to drain and to autcmatically ahut off the elrculating pump if the KOH level in FV151 became too great. As far as is known, no occasiog has arised in which the jack-legs and FV-15I were needed. If so, however, the syatem worked since no further trouble with liquid in the vent piping has occurred.

2. Plugs in gas 1nlet line.

(a) Mark IA - The exlstence of only one gas Inlet necessitated shutting off the $F_{2}$ when this line plugged.

(b) Mark IB - A second scrubber inlet line was installed as shown in Fit. 11.3.

The dditionel scrubber 1nlet was useful in that its presence avoided having to shut down when the gas inlet line plugged. But the new inlet line, being of smaller diameter, plusged more rapidly than the original inlet iine. Consequently, the new gas inlet line could not be used for more than a few hours because of plugging.

3. PCV-39 design.

(a) Nark IA - PCV-39 designc appsrently allowed pressure-vacuum surges in the scrubber.

(b) Mark IB - PCV-39 design shown in Fig. 11.4 maintained the pressure differential across FCV -39 between slightly less than $1 / 2$ in. and $21 n$. of water. $d$ Maintaining the pressure differential between these limits asaured that the exit gases would continuously $f l o w$ in a direction away from the scrubber. This was a safety measure to prevent vapors in the off-gas line from entering the scrubber. At times, the off-gas line contained organic materials from the golvent extraction portion of the pilot plant. These, if present in the scrubber along whth $\mathrm{F}_{2}$, might explade. The 2-1n.

That is, the line to FV-128 prior to changing FV-128 to FV-158.

It is definttely known that FV 450 was never shut off automatically because of too great a liquid level in FValsl.

OFWL Dwg. Q-1679-P-39-CV.

Pressure differential = pressure on scrubber side of velve - pressure on off-gas side of valve (13). 

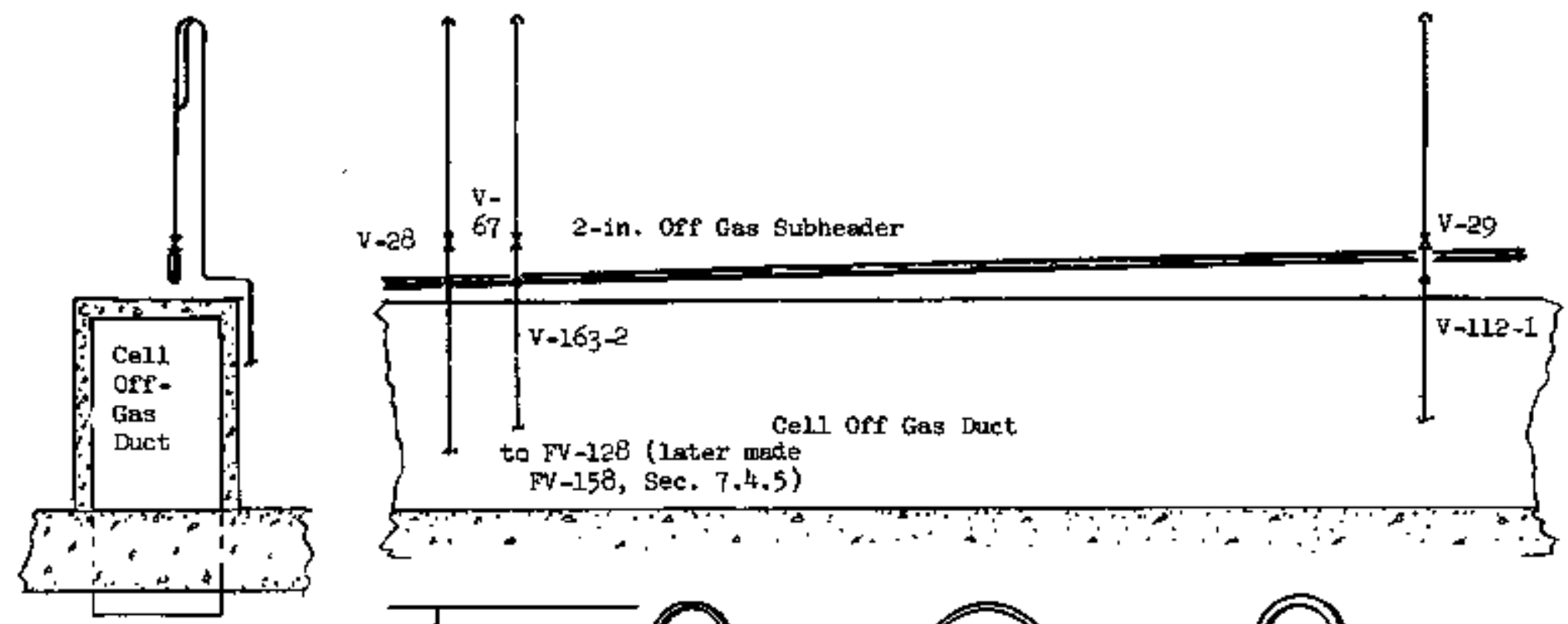

2-in. Off Gas Subhegder

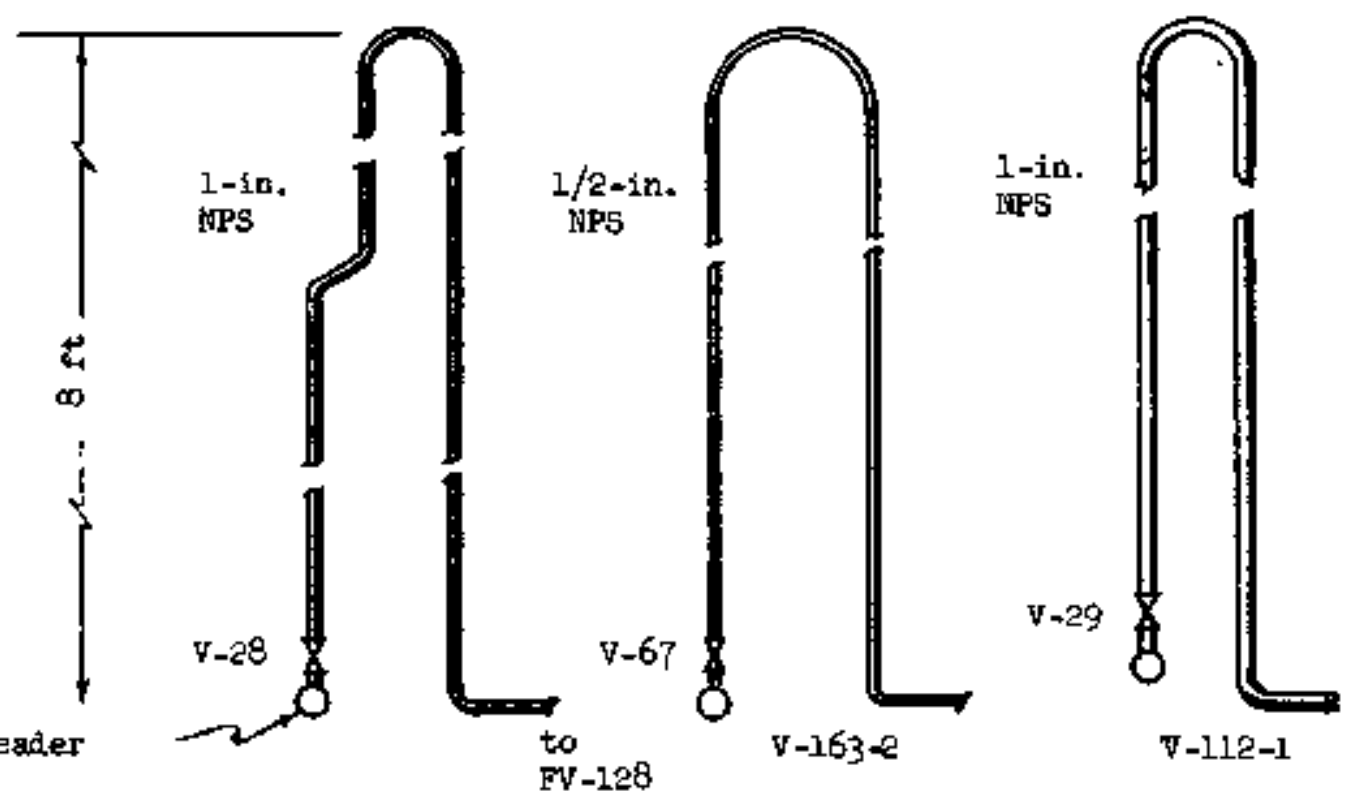

Figs. 11.2. Jack-Legs Added Between Vent Lines and orf Ges Subhesder 


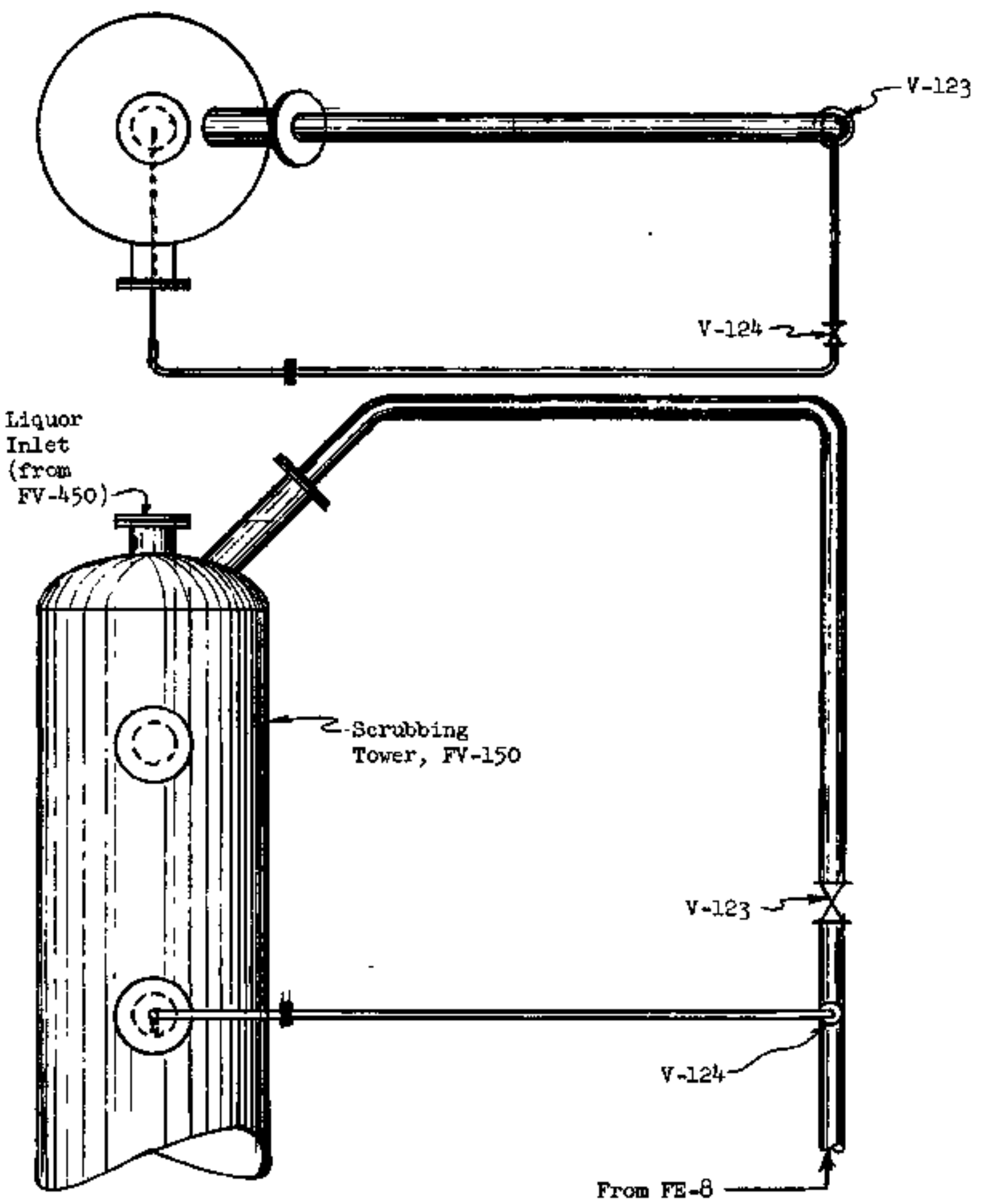

Fig. 11.3. Dual Gak Inlet for Scrubbing Power, FV-150 


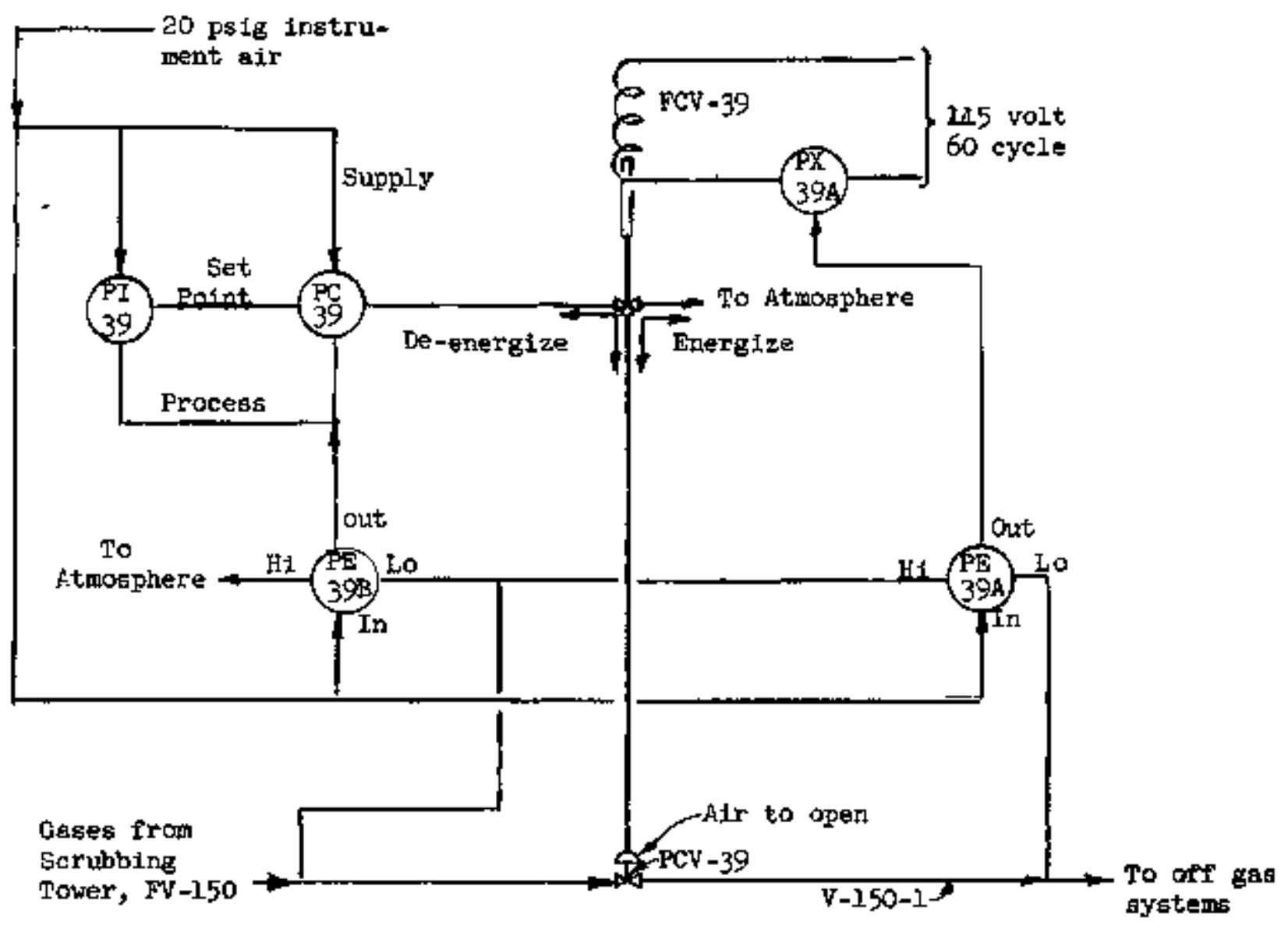

\begin{tabular}{|c|c|c|c|}
\hline Inst. No. & Make - Model & Renge - Type & Set to - \\
\hline $\mathrm{PE}-39 \mathrm{~A}$ & Taylor 339 RF-5 & $2-8-$ in. $\mathbf{H}_{2} \mathrm{O}$ & $0.2 \mathrm{in}, \mathrm{H}_{2} \mathrm{O}$ \\
\hline$P X-39 A$ & M. H. Prese. Su. & $0=15$ PSIG & Closes At 4.5 pari \\
\hline$P E-39 \mathrm{~B}$ & Tayior $339 \mathrm{RF}-5$ & $2-8$ In. $\mathrm{H}_{2} \mathrm{O}$ & $0-2$ fn. $\mathrm{H}_{2} \mathrm{O}$ \\
\hline$F C-39$ & Foxboro Model $58 \mathrm{PA}$ & --- & Reverge Action \\
\hline PI-39 & Moore MP Station & -- & -- \\
\hline $\mathrm{PCV}-39$ & Existing Valve & $\boldsymbol{m}$ & 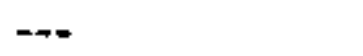 \\
\hline $\begin{array}{l}\text { FCV-39 } \\
\text { Sol.Valve }\end{array}$ & Skinner $1 / 8 ", 3$ tay & $\cdots$ & $m$ \\
\hline
\end{tabular}

F1g. 11.4. Schematic Dlagram of Mark II PCV-39 
of water maximm pressure differential was adequate for exhansting the Inert gases from the VPP operations.

\section{4 .2 Surcte Tank, FV-152}

$\operatorname{sil}(\underline{41})$.

Th1s 275-gallon tank was satisfactory. The gasount of corroston was

11.4.3 Surge Tank Agitator, FV-352

This agitator was suitable. As initially installed, the temporary arrangetient with the dangling switch-box was urisafe. Leter a safe installation was made.

\section{4 .4 Circalating Pump, Fr-450}

The Moyno pump was adequate for pumping the $\mathrm{xOH}$ solution over the scrubber. Two troubles were experienced:

a. The packing glend overheated in early work, apperentiy from the corrosive action of aqueous $\mathrm{KOB}$ on the rubber connecting rod washers as well as the backward installation of a grease seal. The remedy consisted of using Teflon washers, correctly plecing the grease seal, and replacing the chevron-type packing with 3/8-in. square graphite-impregrated asbestos which required no lubrication.

Within a year after this packing gland trouble waa resolved, a slow drip from the packing started which could not be eliminated by tightening the packing gland. Actually, howeter, a slow drip from the packing was preferable to pecking failure with no drlp because the solution would provide some lubrication and reduce scoring of the shaft by the packing. Therefore, the best solution was to operate with the leak and collect it in a drain pan.

b. The knuckle joint on the rotor-end of the connecting rod was worn severely. Others at Oak Ridge who have operated Moyno pumps thought that severe wear on the rotor-end knuckle joint of the connecting rod may be inherent in Moymo pumps.

To prolong the iffe of the knuckle foint, the consengus favored lubricating the jolnt as follows: (I) coating the contact surfaces with molybdenum disulfide and (2) then applying

H. T. Kite and D. T. Martin of Y-12; R. J. DeBakker and S. M. DeCamp of ORML,

b Applied as Lubri-Bona "A" (manufactured by Electrofilm, Inc., Tl6 Laurel Canyon Blvd., North Hollywood, Caifformia; Btodked at Y-12 under Catalog No. 11-435-9606). 
a caustic-resistant Dow-Corning stopcock grease. These lubricants were applied to both knuckle joints although no way was found for determining how much this treatment increased the life of either joint. It was presumed, however, that the life of the rotor-end knuckle joint is $\sim 7000$ hours, the service time at inspection (Fig. 11.5). Pertinent data were: (a) symptoms - intermittent squeak occurred in the pump with no apparent change in its performance; (b) condition of parts - the knuckle-joint pin was sheared; the pin severely enlarged the hole in the rotor-end of the connecting rod; and the packing scored the drive shaft slightly; and (c) repair - replaced the connecting rod and pins lubricating as described ebove; replaced the drive shaft, packing, washers and grease seals.

Although a routine lubrication schedule for the pump and motor was drawn up (26), the high radioactive background from other nearby equipment was a deterrent to following this schedule. No known damage occurred, however, to the pump or motor because of this lack of routine lubrication.

Before the start of cold runs in the fuel element dissolution program, the Moyno pump was disassembled for observation and repair. The operating time between this work and the prior work mentioned. above was $\sim 1200 \mathrm{hr}$. The observations made were: (a) the rotorend knuckle joint had again worn severely (Fig. 11.6); (b) wear on the other parts was slight with the drive shaft being slightly scored.

Repaix included:

1. Changing the stator (The stator had been used $\sim 8,200 \mathrm{hr}$ ) and the connecting rod and its two pins.

2. Reusing the other parts including the packing.

3. Not lubricating the rotor-end knuckle joint because the worst problem is evidently not lack of lubrication but rather stress concentration along a line tending to shear the pin on both ends. (Ald in arriving at this conclusion came from $T$. S. Mackey of ORIL, )

The scoring was so slight that the shaft could have been metallized and machined to size had a spare shaft not been available.

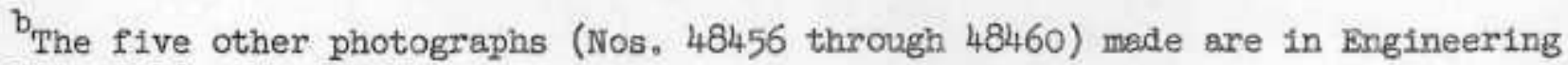
File Folder No. F-57.

cAlthough this work was scheduled, it hed not been done as of June 13,1960 . 


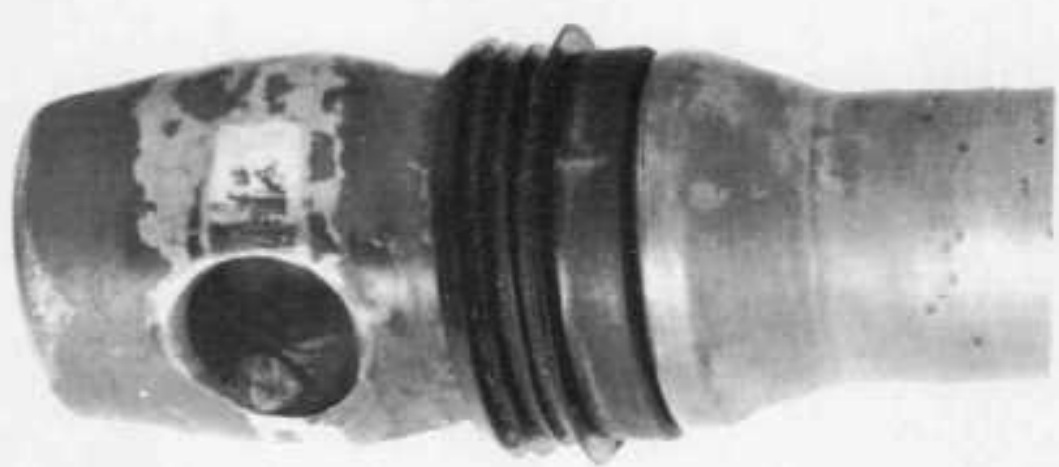

Drive-Shaft End
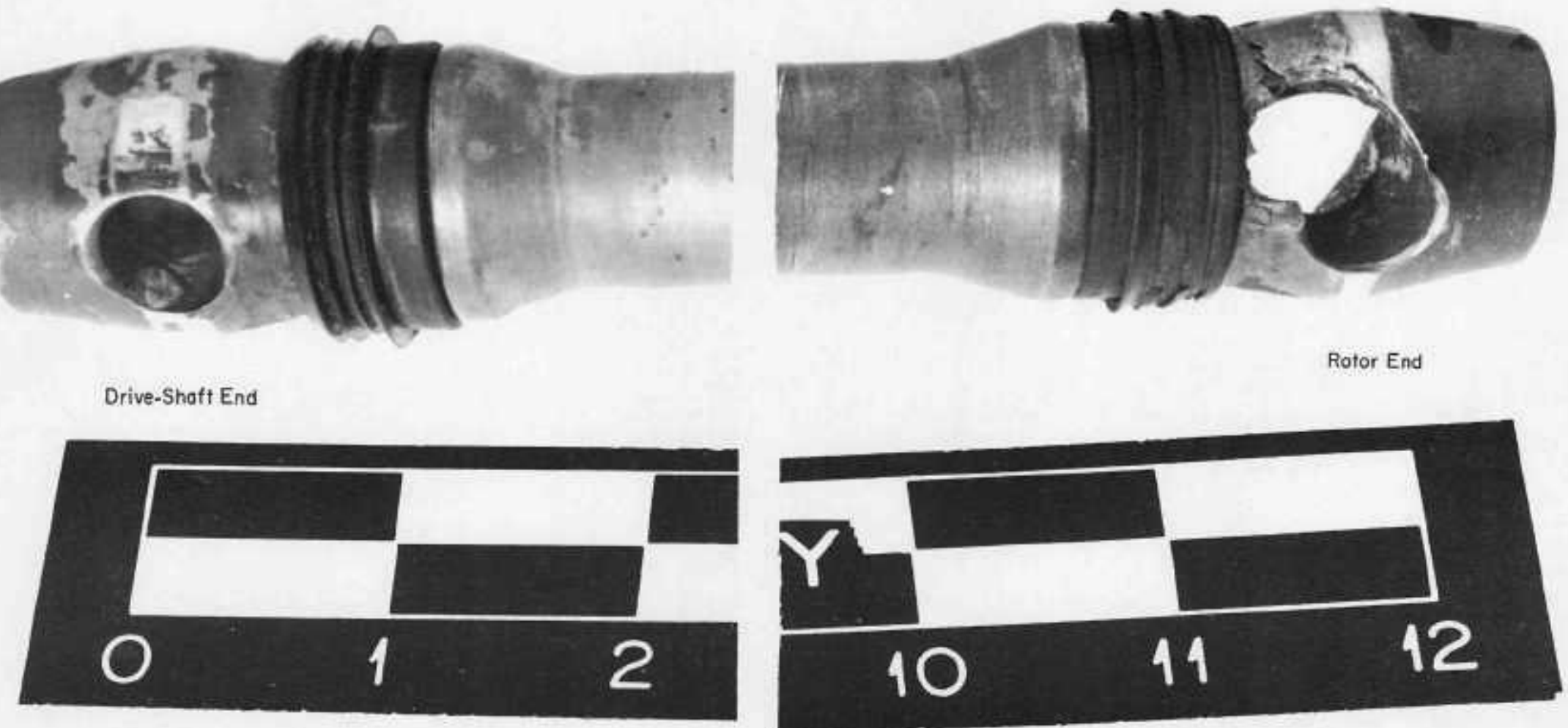

Rotor End

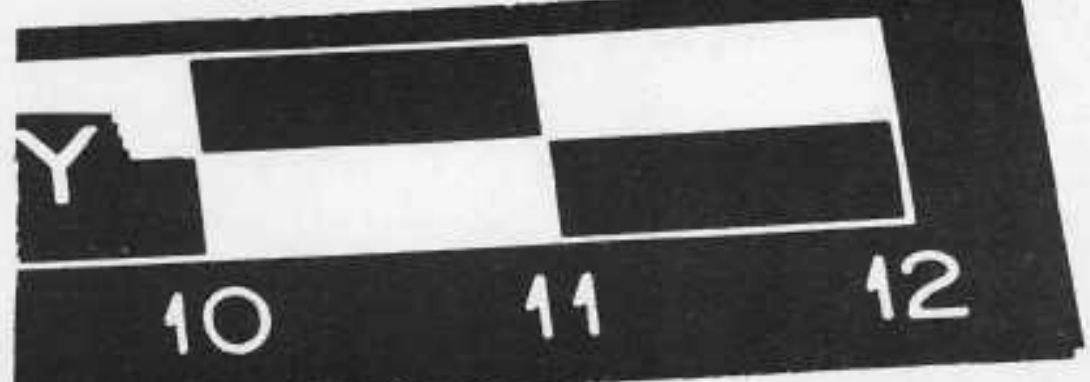

Fig. 11.5. Ends of Connecting Rod for Moyno Pump after 7000 -hr Service Time. 


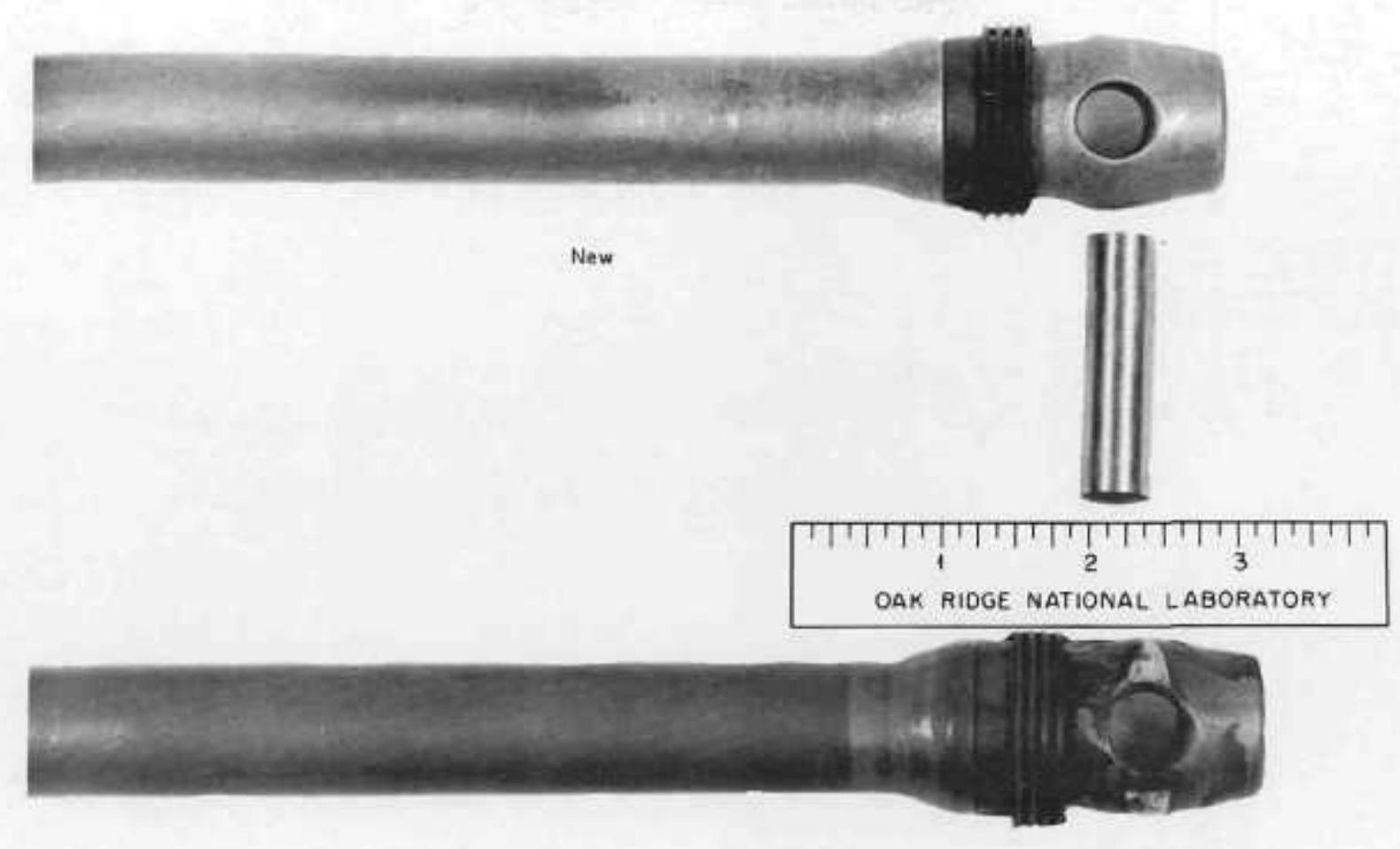

Used (-1200-hr Service Time)

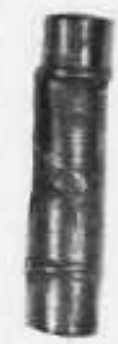

Fig. 11.6. Comparisons of New and Used Moyno Pump Parts:

Rotor-End and Corresponding Pin of Connecting Rods. 
11.4.5 Caustic Make-up Tank, FV-140; Caustic Make-up Agitator, FV-340; Caustic Transfer Bump, FV-440; and Caustic Drum Lift, FV-940

This caustic make-up equipment was adequate.

\subsection{Sumary and Conclusions}

Most equipment in the scrubbing system performed satisfactorily. Major problems requiring attention were: (a) scrubbing solution entering the vent lines, (b) apparent pressure-vacuum surges in the scrubber, (c) plug formation in the gas inlet line to the scrubber, and (d) near-failure of a connecting-rod. joint in the Moyno pump. Actions taken in solving these problems along with other pertinent data were discussed earlier.

\subsubsection{Scrubbing Tower Performance}

The scrubbing tower performance data were:

a. Handled $F_{2}$ flow rates up to 30 liters/min with $10 \mathrm{gpm}$ of $\mathrm{KOH}$ flowing through only the top three sprays.

b. The uranium appearing in the scrubber solution during operations was insignificant.

c. Fission product activity in the $\mathrm{KOH}$ solution was low. KOH solution concentration limits were: (a) 0.5 (minimum) to (b) 2.0 M $\mathrm{OH}^{-}$(maximum).

A series of developmental runs considered beyond the scope of this report is referred to.

Corrosion of the scrubbing tower was apparently nil. The only corrosion noticed was the very severe attack on the gas inlet liner in early work which was less severe later. A weld "fallure" on the gas inlet line apparently resulted from the poor design of that weld.

\subsubsection{Scrubbing Tower Modiflcations}

The Mark IB scrubbing tower was superior to Mark IA in that it contained remedies for earlier troubles:

a. Eight-foot jack-legs and surge tank FV-151 to keep KOH out of the vent line piping.

b. A second gas inlet line to avoid having to shut-down when the original tower inlet line plugged.

c. Altered PCV-39 design to prevent pressure-vacuum surges in the scrubber.

FE-9 and IE-4 adequately monitored the KOH flOT rate and surge tank liquid level. Trouble with the water purges at $\mathrm{FB}-4$ was experlenced. 
The surge tank was satisfactory and aufered insignificant corrosion.

The aurge tank agitator was suitable. This inftially unsafe installation was later corrected.

\subsubsection{Moyno Pump Pexformance}

Although the Moyno purp was suttable for pumping the KOH solution, the troubles which occurred and remedieg tried were:

-a. The packing gland orerheating was corrected by using Teflon washers, correctly placing the grease seal, and replacing the chevron-type packing with $3 / 8$-in. Bquare graphite-impregnated asbestos. A slow drip occurring later vas not corrected be. cause it wight reduce shaft scoring, compered vith worn ary packing.

b. Severe wear occurred on the rotor-end knuckle joint of the connecting rod. This wear may be inherent in Noypo pump. Iubrication evidently does not reduce this wesr because of the Btress concentration along a line vhlch tenda to shear the pin. Details are given for the inspection and repair of the pump after the first $\sim 7,000$ hours of service, and after an additional $\sim 1,200$ hours of servlce. A near failure occurred after the first $\sim 7,000$ hours of service. Although redion active operation was a deterrent to following the establiahed lubrication schedule, no trouble with the pump or motor occurred becalse of the lack of acbeduled lubrication.

The ceustic meke-up equipment operated astiafectorily.

\subsection{Fecommendat1ons}

It is recommended that the components of the scrubbing system continue to be ueed as described berein and further that:

a. A drained dxip pen be provided wider the Hoyno packing gland.

b. The knuckle joints of the Noyno pump be inspected efter every 2500 hours of operation, this inspection schedule be followed wotil sultable date are obtalied for formulating a better ore.

c. More work be done on eliminating gas inlet line pluge in the acrubbing tower with movling the discharge end of the line out of the KOH sprey to be congidered.

a. The rust and water pressure problems in FE-9 purges be solved.

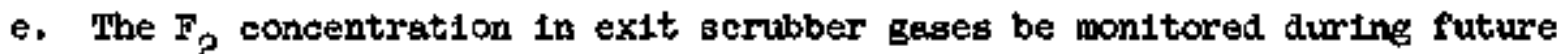
operation. 


\subsection{Apgendix}

11.7.1 Operating Procedure: Scrubber Meke-Do Procedure

Batch gin

$$
\text { (250 Galions) }
$$

Condition: Assume FV-152 hold tank is empty.

1. Close these valves near FV-140 in the gallery: Valves 19 24 and 21

2. Close these valve near FV-152 on the roof: Valves 1 and 15

3. Add water to FV-140 up to the ypper mark on the recirculation IIne (4" from the top of Fv-140).

4. Open valve 19

5. Turr on FV -440 pump.

6. Turn off $\mathrm{fV}-440$ efter solution has been pumped (Some heel wtll remain.).

7. After line to roof hes drained back to FV-140, close valve 19.

8. Record LR山 liquid level inches.

9. Add water to Fv-140 up to the upper merk, open valve 19, turn on FV 440 pump.

10. Turn off FV-440 pump after solution has been punped. close valve 19

11. Add water to FV $-140 \mathrm{up}$ to the widdle of the bottom ring (11" from bottom).

12. Hoist a arum of $45 \% \mathrm{KOH}$ (caugtic potash) into position above $\mathrm{FV}-140$,

13. Drain sufficient solution from the caustic drum into FV-140 to bring the liquid level up to the lower mark on the recirculation line (10* from the top of $\mathrm{FV}-140$ ).

14. Agitete the solution for two minutes on

15. Turn off the esitator and add water up to the upper mark on the recirculation line.

16. Open valve 19

17. Turn on $\mathrm{FV}^{\mathrm{V}} 4 \mathrm{40}$.

18. Turn off FV-440 pump after solution has been pumped. Close valve 19

19. Add water to By -440 up to the middle of the bottom ring.

20. Ho1st a drm of $45 \%$ KOH-into position above FV-140.

21. Drain sufficient solution from the caustic drum into FV-140 to bring the liquid lopel up to the lower mark on recirculation line.

22. Agitate the solution for two minutes on off

23.

Turn off the agitator and add water up to the upper mark.

Open valve 19

Turm on FV -440 .

Turn off FV-440 pump after solution has been pumped. Close valve 29

27. Add rater to FV -140 up to the upper mark on the rectrculation line.

28. Open ralve 19

29. Turn on $\mathrm{FV}-14 \mathrm{it}$ pump.

30. Turn off FV 440 after solution has been pumped. Close valve 19

31. Add water-to $r v-140$ up to the middle of the bottcm ring.

32. Pump this solution to FV-152, then close valve 19 and record LR.4

liquid level inches.

33. close these valves near Fv-450 on the roof 3 16 17 13 , 14 
34. Open valves 11 and 1 35. Turn on FV-450 agitator. on at 36. Turn on Fv-450. On at

37. Recirculate solution in FV-152 for 30 minutes.

36. Drain about 100 ce from sanple valve 14 and discard. Then collect two samples for koH analysis. Code sil - - 1,2.

39. Shut off FV-450. Close valve 11

40. Shut off ag1tetor.

41. Proceed to acrubber operation min sheet. (See Part B, Sec. 11.7.2).

MOT: : When FV-752 was not empty, enough KOH was added to bring its strength to $\mathrm{m} \mathrm{M}$. So strengthening the $\mathrm{KOH}$ was not recommended, however, as mentioned in item a. of sec. 11.3.2.

\section{7 .2 Operating Procedure: Development Operations of Scrubber Tower}

PART A: To prepare the $F_{2}$ supply aystem for operations:

OST

1. Shut off the air to FCV-1 and FCV-2 and open V-81.(This 1soletes nitrogen system from fluorine system $n$ To close FCV turn right-band knob FC counterclockwse until horizontal gage reads zero.

2. Record the reading on PR-10 (the $F_{2}$ supply) pressure than proceed to "Chenging Fiuorine Tanks".

3. Hove BwItch HX-1, near F'K-2 on the panel board to the (upper, lower) position. This will give the needed instrument sensitivity for this rum.

4. Close the followling valves on the panel (turn handle "across" the flow Iine. HX -8 $-\mathrm{HX}-20, \overline{\mathrm{BX}-32}$ and $\mathrm{HX}-34$ EXX-14 $\mathrm{HX}-16$

5. Open the following valves on the control penel (turn hendle perellel to the flow line). HX-12 HX -35 , and $\mathrm{HX}-36$

PAFT B: To prepare the scrubber for operation:

6. Record LR-4 liquid level. scrubber makeup sheet ( $50 \overline{\mathrm{gall}}$ ).

If less than inches, proceed to

7. Close the following valves nesr FV -450 on the roof: 11 13 and 68 14 16 17 22 25

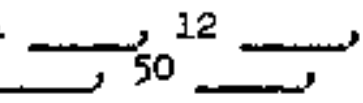

8. Open the following valves near FV-450 on the roof: 1 $3 \ldots$, $27, \ldots$ and 72

9. Turn on FV 450 pump.

10. Graduelly open each of the following valves checked "open" and adjust the velve position to give the indicated pressure readings. close velves checked "closed". 


\section{Open closed Gage Reading on}

$\begin{array}{ll}V-4 & \text { PI }-18 \text { is } \\ V-5 & \text { PI }-19 \text { is } \\ V-6 & \text { PI }-20 \text { is } \\ V-7 & \text { PI }-21 \text { is } \\ V-8 & \text { PI }-22 \text { is } \\ V-9 & \text { PI }-23 \text { is } \\ V-10 & \text { PI }=24 \text { 1s }\end{array}$

11. Connect the sampling apparatus to valve 25 .

12. Invert \& $(500 \mathrm{ml}, 1000 \mathrm{ml}, 1500 \mathrm{ml}, 2000 \mathrm{ml}$ or ml) Plask on tapered sample tip.

13. Open glass stopecek on sample flesk.

14. To start flow of $F_{2}$ to system, turn the right hand valve on FR-2 clockvise until the pen reaches aet point of - T1me pen reaches set point

15. Five minutes after time in step 14, open valve on either a1de of flask on off -gas sampling apparatus. Turn on vacuun pump to evacuate sample flask. Time on

16. Five minutea after vaculm pump vas started, close the valve between sample flask and vacuum purip. Time

17. Turn off the vacum pump.

18. Open valve 25 to let gas into flask.

19. Close valve 25 , close the glass stopcock on sample flask, and remove flesk from apparatus. Submit to lab. Code $O G$

20. Drein about $100 \mathrm{cc}$ from velve 50 (near $\mathrm{Fv}-150$ ) and discard in waste peil. Collect two enmples for laboratory enalysis. Code so $1,2$.

21. Shut off the output air frosil FR-2 by tuming the right hand wnob counter aclockwise until the horizontal gege reads zero.

22. Lrain about $100 \mathrm{cc}$ of sample frord valve 14 (near FV-450) and discard in wsste pail. Then collect two serrples for laboratory anslys1s. Coaje SI $1,2$.

23. Turn off FV -450 pump. 
12.0 Product Sarpling Sjstem . . . . . . . . . . . . . . 159

12.1 Introduction... ..................... 160

12.2 Equiprent . . . . . . . . . . . . . . . . . . . 160

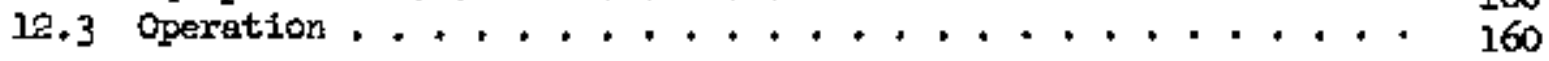

12.3 .1 Operating Procedure ............. 160

a. K-25 Samplex . . . . . . . . . . . . + 160

b. Minisampler ............... 167

12.3 .2 CrIt1cel operating Steps ............. 169

a. K-25 Sempler . . . . . . . . . . . . . . 169

๖. Minisampler ................. 169

12.4 Equipment Etaluation ..................... 170

$12.4 .1 \mathrm{~K}-25$ Sanpler . . . . . . . . . . . . . . 170

12.4 .2 Ninigampler ..................... 171

a. Sampler Dolly, FV-ge5 . . . . . . . . . . 172

b. Minisangler Sample Container .......... 171

c. Minteampler Chemical Trap, FV-125. . . . . . I I7l

d. Minisampler $\mathrm{N}_{\rho}$ Line Heeter, H-525 ...... . 17k

e, Mintsampler Vacuum Line Heater, FV-525A..... 171

12.5 Sumary and conclusions ................... 173

12.6 Recommendations . . . . . . . . . . . . . . . . 174

12.7 Appendix . . . . . . . . . . . . . . . . . 174

12.7.1 Operating Procedure: Sampling of Product in

K-25 Sempler . . ............ 174

12.7.2 Operating Procedure: Product Sampling Operation

in Minlsampler . . . . . . . . . . . 175 


\subsection{PRODUCT SAMPLING SYSTEM}

\subsection{Introiuction}

The $\mathrm{VF}_{6}$ in the product cylinder was sampled in the VPF by flowing a portion of it as liquid into a sample container. Barpling lose was reduced by freezine the liquid $\mathbb{F}_{6}$ in the sample container and thermally traneferring vapor to the cold container before sealln and disconnecting 1t. Chemical contamination wes avoided by adhering to strict cleanliness and by using controlled atmospheres, either a nitrogen blanket or a vacuun. Frincipal steps in the operation of this systen were:

a. Coupling the heated cylinder to the sempling rib.

b. Flowing l1quid $\mathrm{LF}_{6}$ into a tared sample container and freezing it therein.

c. Weighing the filled container, washing off external $\alpha$ radioactivity, and subritting for ansiyses.

Mask were worn whlle agmpling to protect persomel frou $\alpha$ radioet1rity.

\subsection{Equipment}

Two $\mathrm{UF}_{6}$ sampling syatems have been'used;

a. The K-25 rig show in $7 i g .12 .1$ in which one sagnple was obtained ranging in weight from 85 to 125 gxams. (Subsequently, thls sample was allquoted to obtain chemjeal, radiochemical, and isotopic semples.)

b. The Minisampler (developed by J, E. Bigelow of VPP), shown In Figs, 12.2, 12.3 , and 12.4 in which four samples vere taken varying in bize from 3 to 12 grams each. (The Minisampler was developed to take the allquots directly from the cylinder.)

The component pertis of both the $15-25$ rig and the Minisampler are described in Table 12.1.

\section{3 oxeration}

\subsubsection{Operating Procedure}

Steps in the operating procedures were:

\section{A. K-25 Sampler}

1. Welghing the product cylinaer on the Toledo scales checked by ss Accountability.

\footnotetext{
All evacuatine was done with FV-420 (Sec. 10.4.12). The sampling time exclusive of cylinder heat-up was a 2 hours.
} 


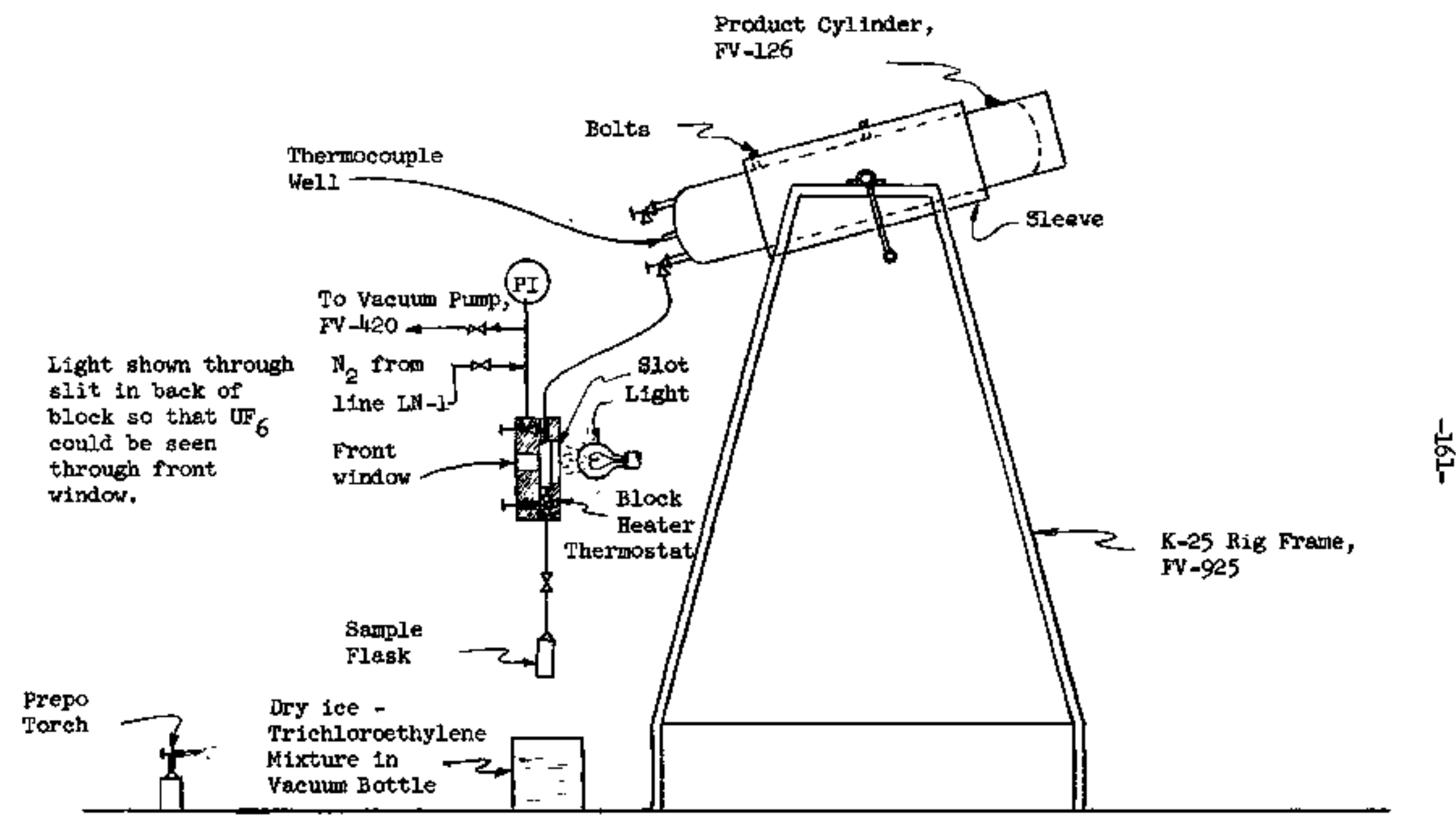

F1g. 12.1. Equipwent Arrangement in the Product Bampling Systen (K-25 Sampler) 


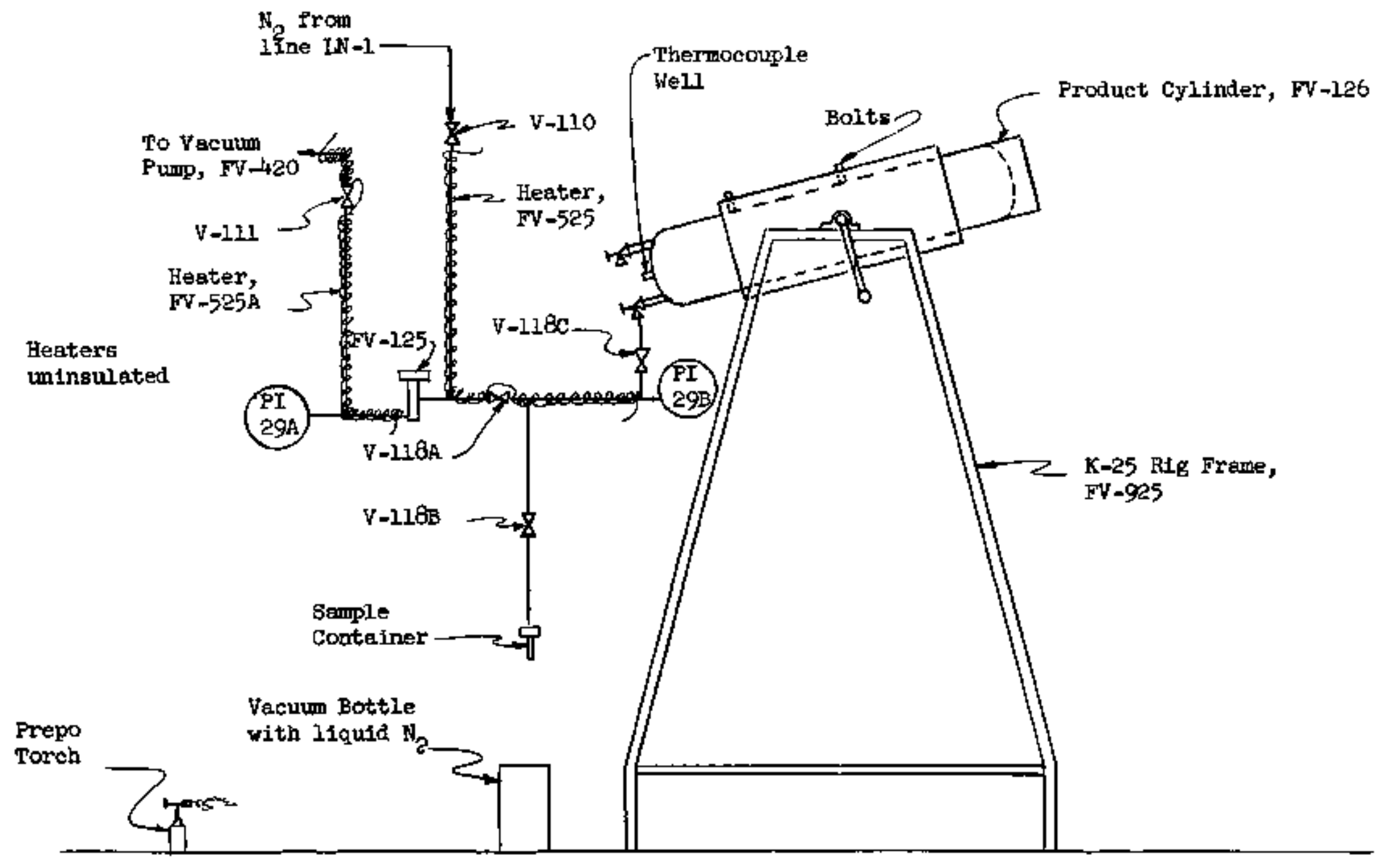

Fig. 12.2. Equipment Arrangement in the Product Sempling Syatem (Minisampler) 


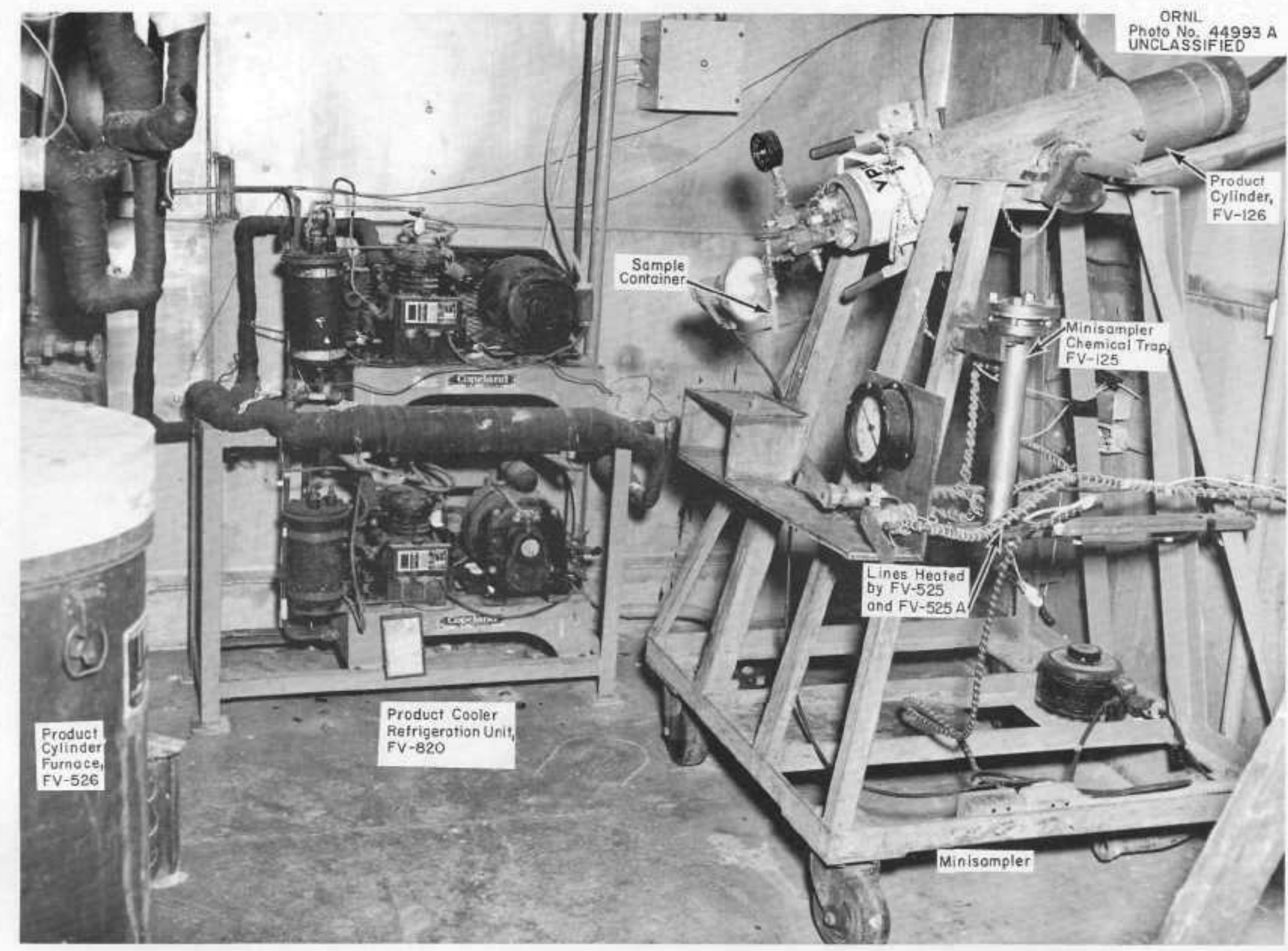

Fig. 12.3. View of Minisampler as Used in Cell 2. 


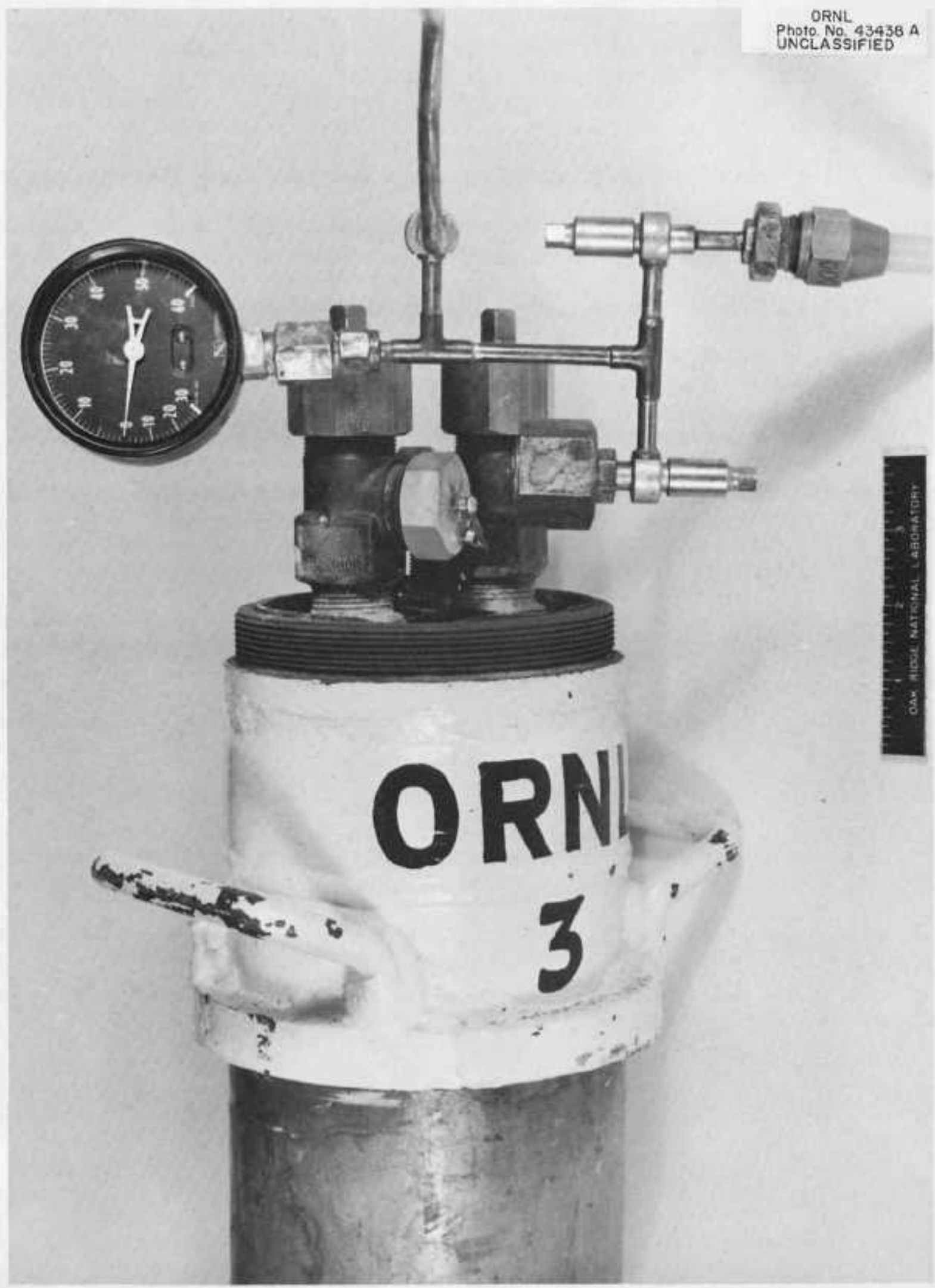

Fig. 12.4. Close-up View of Minisampler Manifold Connected to a Product Cylinder. 
Tuble 18.1

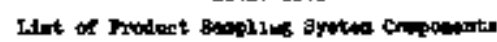

\begin{tabular}{|c|c|c|c|c|}
\hline \multirow{2}{*}{ 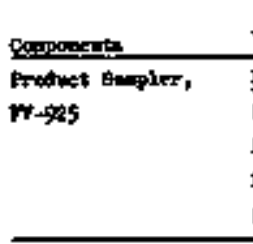 } & \multicolumn{2}{|c|}{ TG. } & Manelleneoun intarmation & Anteringess \\
\hline & 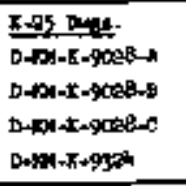 & 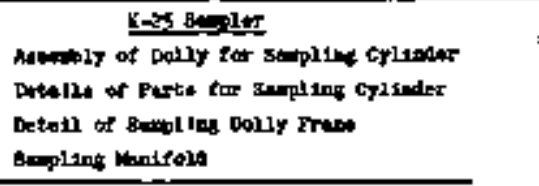 & 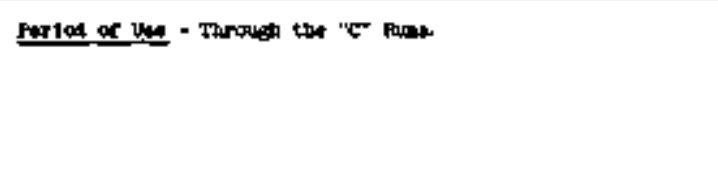 & 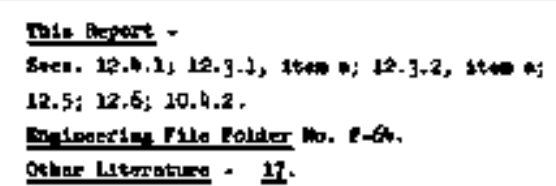 \\
\hline Conteples & 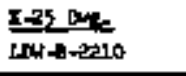 & Doproat suplo Crisinder & & \\
\hline 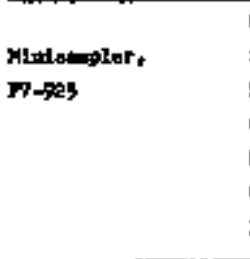 & 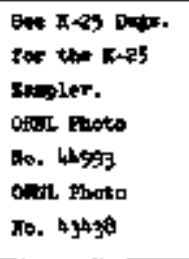 & 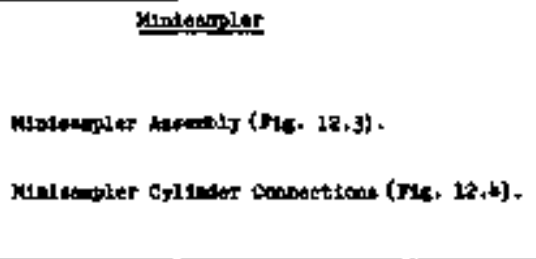 & 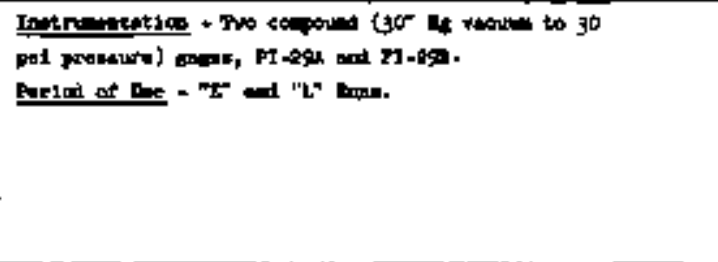 & 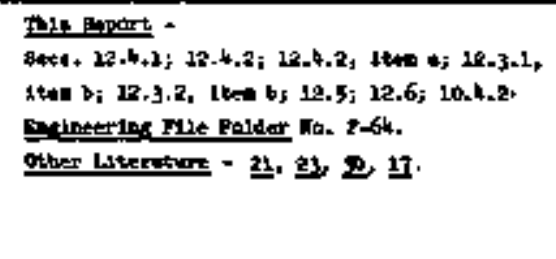 \\
\hline $\begin{array}{l}\text { Banplo } \\
\text { contalnty }\end{array}$ & 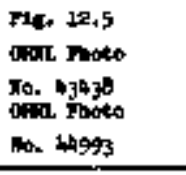 & 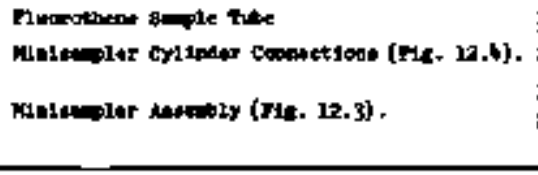 & 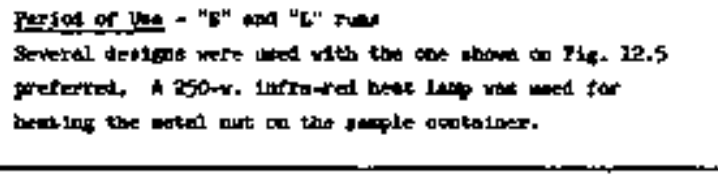 & 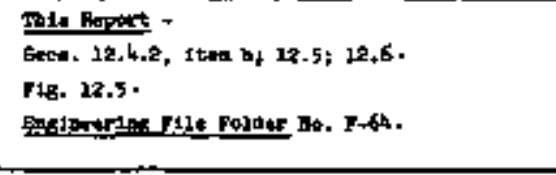 \\
\hline Trap, nites & $\begin{array}{l}\text { r.s. } 12.2 \\
\text { ofin. 20016 } \\
\text { Do. } 44939\end{array}$ & 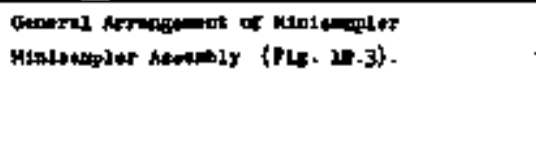 & 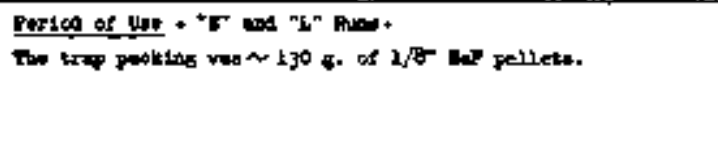 & 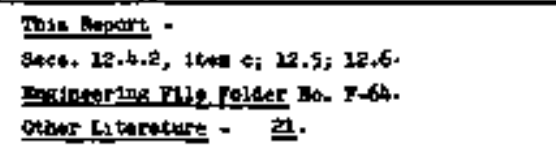 \\
\hline 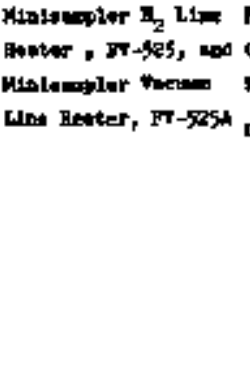 & 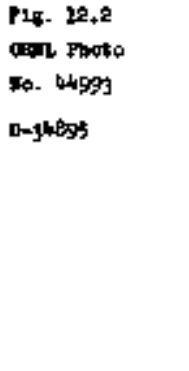 & 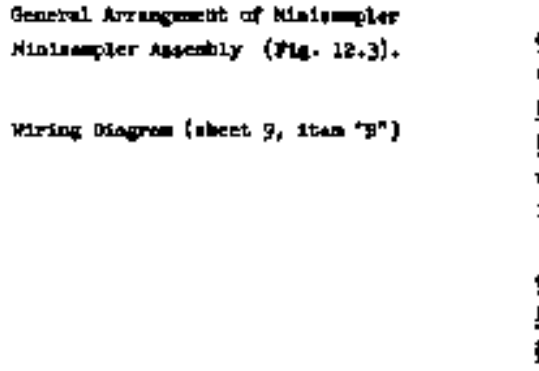 & 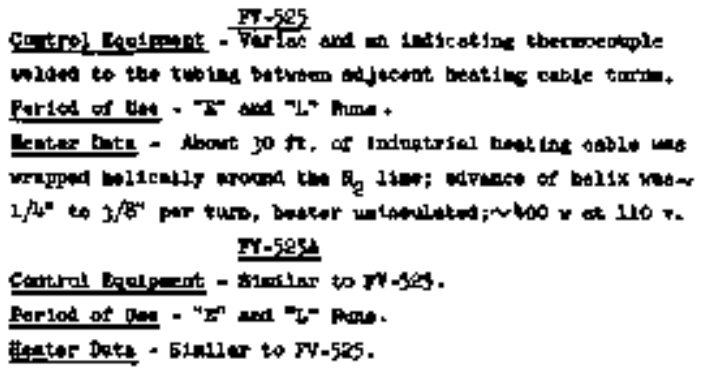 & 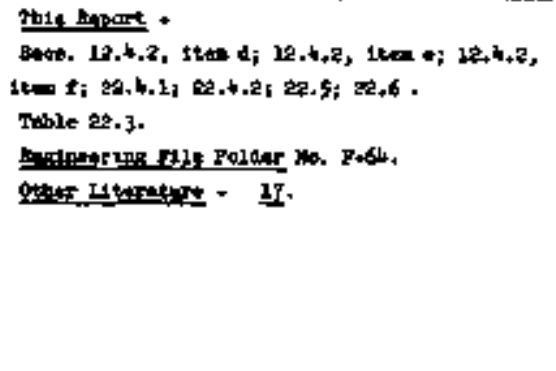 \\
\hline
\end{tabular}


2. Heating the cylinder to $100^{\circ} \mathrm{C} 1 \mathrm{1n}$ FV-526 and the block on the rig to $70^{\circ} \mathrm{C}[$ Items $(2)$ and $(5)$, Sec. 12.3.2E]. .

3. Having these items on hand prior to removing the sylinder from its furnace:

(a) A clean tered sample flask.

(b) A new'Teflon gagket for connecting the block to the cylinäer.

(c) Protective clothing and mesk for each man in the cell.

(d) Dewar flask conteining a ary see-trichlorethylene mixture.

(e) Prepo torch and wrenches.

4. Placing the cylinder in the sampler dolly, tilting 1t up and down four or five times, and then locking it with the valves down and Its axis declined at about $15^{\circ}$ to the horizontal.

5. Having the light turned on behind block; comecting the upper block line to the cylinder and the lower block line to the sample elask.

6. Leak-testing the asseribly by rate of racum fall when sJstem was evacuated to a $29^{+}$in of $\mathrm{HB}_{\mathrm{B}}$ vacuutu. (No change In $\sim 30$ seconds was acceptable. Leals greater then this were ellminated before proceeding.)

7. Heating the line between the block and the cylinder with the Prepo torch.

8. Evacuating the block, lines, and sample flask to a $29^{+}$in. of $\mathrm{Hg}$ vacuum.

9. Closing the lower block valve and valve on sample flagk.

10. Opening the cylinder valve about one-half turn, keeping valve open unt1l the receptacle in the block filled about helf-full of Ilquid $U_{F}$, and then closing the cylinder valte.

11. Heating the line between the block and sample flask with the Prepo torch.

12. Opening the lower block velve and the valve to the sample flask thereby allowing $U_{6}$ to run into the flesk.

13. Chilling the ample flask with the dry-ice bath. 
14. After sample had frozen in sample flask and residusl vapor thermelly transferred to the flask by playing the torch 1ightly on the lines (required 25 to 10 minutes), closing the valves on sample flask, evacuating residual $\mathrm{UF}_{6}$ from the block to a suttable chenical trap (FV-122, Sec. 10.4.9) and filling the aystem with $\mathrm{N}_{2}$.

15. Removing sample container, welghing, decontaminating external surfaces from $\alpha$ redioactiv1ty, and sending for analyser. (Subsequently, this sample was divided with allquots being sent to different laboratories for chemical, radiochemical, and lsotopic anelyses.)

16. Reweighing the cylinder on the Toledo scales.

NOTE: The detalled procedure used is presented in Sec. 12.7.1.

b. Minisampler ${ }^{a}$

1. Welghing the product cyllnder on the Toledo scales checked by is Accountability.

2. Heating the cylinder to be sempled to slightly $>100^{\circ} \mathrm{C}$ in the product cylinder fumace; having FV-125 filled with $130 \mathrm{~B}$ of $1 / 8-i n$. FaF pellets.

3. Having these 1 tems on hand prior to removing the cylinder from its furnace:

(a) Four clean tared anmple flaaks,"

(b) A new Teflon gasket for connecting the biock to the cylinder.

(c) Protective clothing and maks for eech man in the cell.

(d) Dewar flaek contalning liquid nitrogen.

(e) Prepo torch and wrenches.

All eracuating was done wth FV-420 (Bec. 10.4+12). The gampling time exclusive of cylinder heat-up was $\sim 4$ hours.

"F FV-125 was used only during the "L" rums. FV -122 was used to sorb residual UF, 6 during the "E" runs.

The sample tubes vere cleaned with an aqueoug Tide solution and aried with C. P. acetone. 
4. Placing the cylinder in the sampler dolly, tilting it up and down four or five tines, and then locking 1t with the valves down and 1ts axis declined at about $15^{\circ}$ to the horizontal.

5. Connecting the mentfold nut to one cylinder valve and attaching one of the sample containers to the mantfold.

6. Directing the heat lemp at the netal fitting on the sample tube.

7. Leak-testing the manifold by evacuating, noting the rate of vacuum fall, and eliminating any leaks. (An acceptable vacuum leak-test wes essentially no vacuum decrease inn3o seconds at a vacuun of $29^{+} \mathrm{in}$. of Hg. Greater leaks were eliminated before proceeding.)

8. Evacuating the esmpling system.

9. Drawlng enough ldquid $\mathrm{W}_{6}$ to belf-fill the tube by proper valiving and then closing the cylinder valve.

10. Inmersing the lower end only of the semple tube in liquid $\mathbb{N}_{7}$ unt 11 the 1iquid $\mathrm{WF}_{6}$ was frozen and vapor bed thermelly transferred (required bout 5 minutes).

11. Evacuating and filling the manifold vith $\mathbb{N}_{2}$.

12. Removing and plugging the sample tube and then installing a tube for the next sample except for the last ommle frors a cylinder.

13. Takfing three more semples using stepe 5 through 12 above,

14. Cleaning and weighing the sample tubes and then submitting for analyses. [Cleaning and decontaminating were done as indicated in 1tem (3) sbove]

15. After the cylinder cooled to room temperature, rewelghing it on the Toledo scales.

MOTE 1: Originally, the sanple for masa spectrometer snalyais was to have been collected in a glass tube. This was not done becaube of the dffriculty in adapting the equipment for such sampling, and because of the trouble involved in training operators for such an advanced analytical technique.

HONE 2: It was not necessary to empty and fill FV-125 (FV-122, Sec, 10.4.9, was used during the " $\mathrm{R}$ " runs.) after ench sampling. Therefore, ususily lt was changed after sampling every three or four cylinders.

NOTE 3: The actual procedure used is ahown as Sec. 12.7.2. 
12.3.2 Critical operating Stepg

a. K-25 Samplex

1. Having the aample flask scrupulously clean and the system leak-tight to avold contaminating the sample.

2. Having the cyllnder at $100^{\circ} \mathrm{C}$ immedlately before sampling to be certain that liquid $19 F_{6}$ would flow frow 1 t.

3. Tilting the cylinder back and forth before placing in the sampling position to aroid rapor-locking the valves.

4. Having the block at $70^{\circ} \mathrm{C}$ before flowing the liquid $\mathrm{UF}_{6}$ into it. (A lower temperature froze the UF; 6 ; higher temperature rapor-locked the block and prevented liquid UF 6 from flowing into the block.)

5. Using the Prepo torch to heat the lines to and from the block to $>65 \mathrm{C}$ because these lines were not otherwise heated.

6. Filing the block only half-full of liquid UF $6^{\text {. (Nore }}$ liquid JF $_{6}$ than ltbis reaulted in a larger cample than needed.)

7. Opening the eylinder valve wide enough so that liquid $18 F_{6}$ would slow.

b. Ninsagupler

1. Having the sample tubes scrupulously cleen and the systen leak-tifybt to avoid contaminating the semples. (This vas espectally important for the Minlsempler because of the amall size of the aamples collected.)

2. Having the cylinder at ellghtly $>100^{\circ} \mathrm{C}$ at the start of sampling. (Since sampling required about one and one-half hours time, the lagt of 4 samples was sometimes difficult to etet if the cylinder was not at the temperature of $>100^{\circ}$ c initially. Evidentiy no more samples could be taken after $\mathrm{UF}_{6}$ aterted to freeze in the cylinder valve.)

3. Tilting the cylfinder back and forth before placing in the sampling position to gvota vepor-locking the valves.

A ternperature of $70^{\circ} \mathrm{C}$ was high enough to keep the UF molten but low enough to prevent the formation of an excessive amount of UF 6 vopor. The triple polnt of $\mathrm{UF}_{6}$ was $64^{\circ} \mathrm{C}$ at $2 \mathrm{psia}(1,7, \mathrm{p} .4$ ). Also Secs. 12.3.20 and 12.4.1.

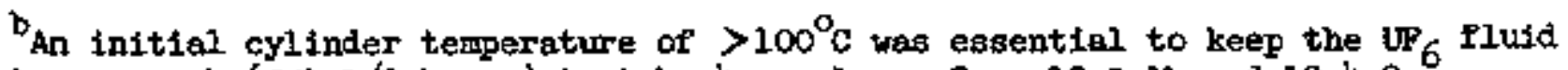
long epough ( $\sim_{1-1 / 2}$ hours) to take 4 sanples. Sec. $12.3 .1 \mathrm{~b}$ and 12.4 .2 . 
4. Using the Prepo torch to heat the cyldinder valve and/or cold sections of the mantfold and having FV -525 and $-525 \mathrm{~A}$ on to keep the lines $>65^{\circ} \mathrm{C}$.

5. Filling the sample tube only half-full of liquid UF ${ }^{\circ}$ (If more liquid than this were inltially drawn into the tube, the residual $\mathrm{UF}_{6}$ in the line between the tube and the cylinder would over-fill the tube.)

6. Opening the cylinder valve wide enough. (For the first sample, $1 t$ was necesaary to open the valve about one-half turn. Later and especlally for the last sample, the valve was opened about one full turn.)

7. Being certain to avoid contacting the brass nut on the sample tube with liquid $\mathrm{H}_{2}$ to prevent cracking 1 .

12.4 Equipinent Eraluation

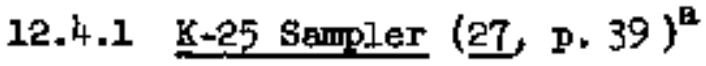

The K-25 sampling equipment and operating procedure were satis-
factory. Using the K-25 sampler had these advantages: (a) Less $\alpha$ contamination was released in Cell 2 than with the Minisampler because only one container was filled, and because the $K-25$ flask was valved off before Alsconnecting; (b) less sampling time (one-half hour versus one and onehalf hours for the Mindsampler) was required; (c) there wes less chance or chemically contaminating the sarple; and (d) the technique was easier for chemtcal operators to master. On the other hand, however, using the $K-25$ sampler offered these disadvantages: (a) Increased the sampling cost beceuse 1t was necessary to aliquot the sample and (b) took about $100 \mathrm{~g}$ from a cylinder compared with 30 to $40 \mathrm{c}$ for the Hinisampler.

The cylinder clamps on the sampler dolly would not hold sone of the cylinders in the dolly because the shoulders on these cylinders were not square all around. The potential seriousness of this situation was realized when a hot cylinder in the sampling position fell out of the dolly. The brtme of the fall was absorbed by one of the valves whose connection to the cylinder was bent. To prevent a recurrence of this, the sleeve which contalned the cylinder was drilled and tapped for 8 bolts to hold the cylinder firmly in place without using the clemps.

Records of the analyticel date for samples collected with the $K-25$ sampler are recorded elsewhere for kums $\mathrm{C}-3$ through $\mathrm{A}$ ( 25, p. 27; 27, p. 33; 36 , p. 21; and 31, pp. 30,31). Since the $\mathrm{UF}_{6}$ in Funs $\mathrm{C}-9$ through -15 was not sampled, the figure for the theoreticel $\mathrm{u}$ in $\mathrm{UF}_{6}$ was used (31).

\footnotetext{
AThe K-25 sampler was dismantled when the Hinlsampler was fabricated. Unused parts were moved to Bur1al Ground No. 3 (Sec. 23.4.16b).

"That is, analytical samples covla be obteined.
} 
12.4 .2 Minisgnplex

The disadvantages mentiomed in Sec. 12.4 .1 were: (a) $\alpha$ contemination of Cell 2 necessitating the wearing of ges masks and subsequently cleanlng of the cell, (b) one and one-half hours saupling time, and (c) sample contanination. A record and discussion of the samples collected are given elsewhere (로, 证 and 23 ).

a. Sampler Dolly, FV-925

The K-25 dolly was successfully used also for the Hintsampler. $A$ panel conteining $V-110, V-111$, and PI-29A was added. The bolts had already been added to the sleeve as described in Sec. 12.4.1.

b. Minisampler Semple Container

Several different designs were used with the one shown in Fig. 12.5 being the most satisfactory. Fille chilling the WF $_{6}$ sample with liquid $\mathrm{N}_{2}$ in this tube, inadvertently immersing the brass nut $1 n^{2}$ the liquid $N_{2}$ has caused the brass to crack.

c. Minisampler Chemical Trap, $\mathrm{Fv-125}$

This trap used only during the " $L$ " runs was falrly satisfactory. Operational characteristics were:

1. Its small diameter (1-3/8 in.) coupled with its length (11 in.) made discharging difficult except by disconnecting from the system.

2. Forty-nine grems of $U$ were collected while sampling nine cyllnders, an averege of five grams collected per cylinder sampied. (르).

3. Haf was changed after sampling four or tive cylinders.

Durting the "E" runs, residuel $\mathrm{UF}_{6}$ from the Minisampler was sorbed in FV-l2s as previously for the $K+25$ sampler. Seperate data for residual $\mathrm{UF}_{6}$ from sampling were, therefore, not kept prior to the "I" rung (sec. 10.4.9).

d. Ninisampler $\mathrm{H}$ Line Heater, FV $-525^{\mathrm{b}}$

e. Minisamplex Vacum Line Heater, Fv-525A

after the "L" runs, the Minisampler was dismantled and moved to Burial Ground No. 3 (Sec. $23.4 .16 \mathrm{~b}$ ).

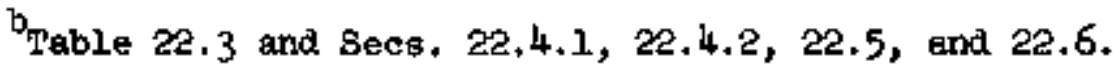


$1 / 2-1 n+0 . d \cdot x$ 5/16-in. i.d. Fluorothene Tube

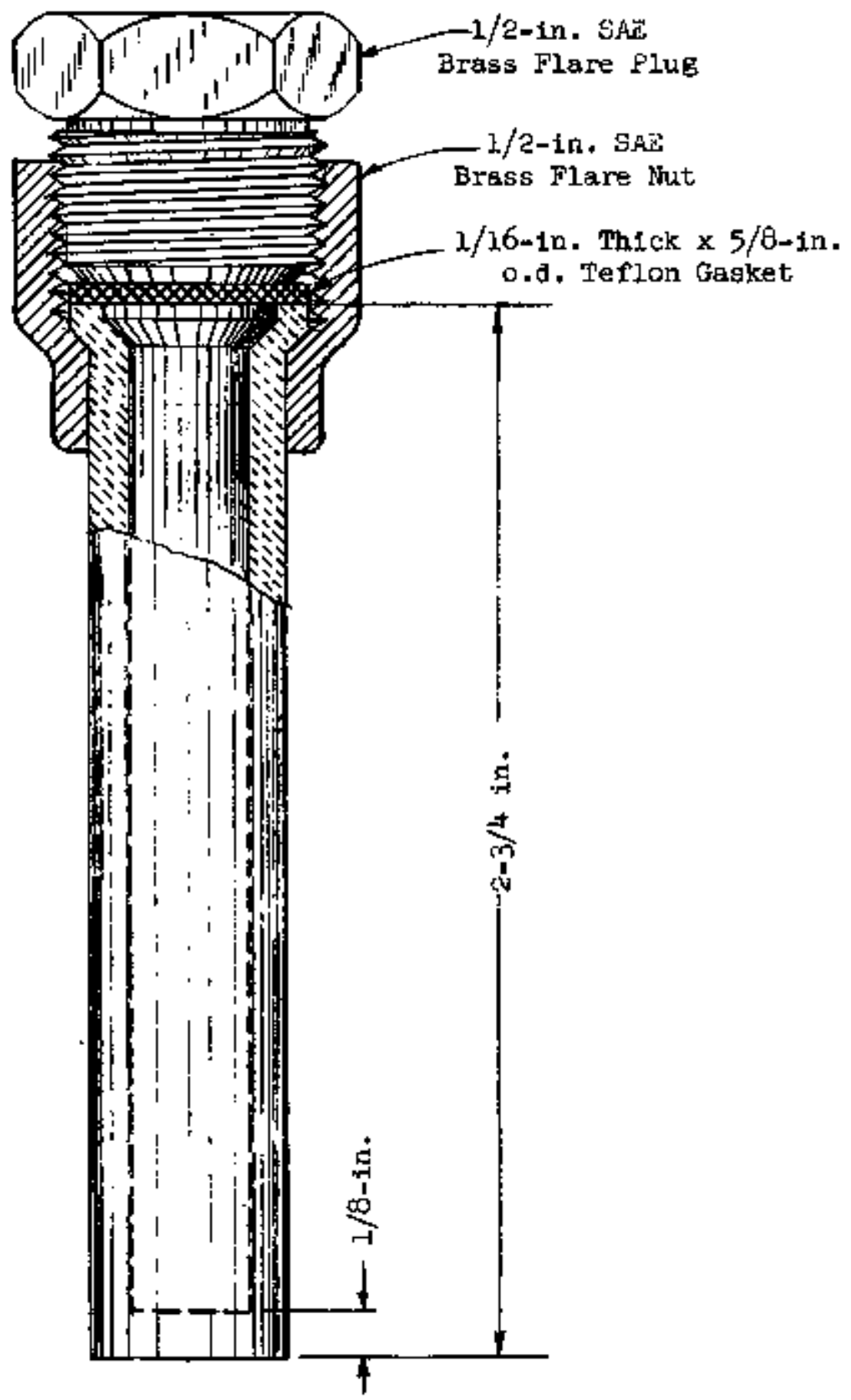

F1g. 12.5. Minisampler Sample Container 
These heaters operated satisfactorily requiring leas than one hour to heat their copper tubing lines to $>100^{\circ} \mathrm{C}$ wth Variacs set at $60 \mathrm{v}$.

\subsection{Summary and Conclusions}

Both the K-25 sempler and Minisampler were barely adequate. The sampling times were 2 hours in the $K-25$ sempler and 4 hours in the Minisampler. Cheracteristics of the heaters for these semplers are given.

The K-25 sampler was better adapted to sampling in VPP because:

a. Less $\alpha$ redionctivity was released in cell 2 .

b. The sarpling time was one-half that for the Mtingampler.

c. The technique was less aifficult for chemical operators to master.

d. The probabiltty of sample contamination was less.

In spite of these advantages, more experience was gained with the Mintaampler because:

a. Less UF (30 to $40 \mathrm{~g}$ compared with $\sim 100 \mathrm{~g}$ for the $\mathrm{K}-25$ sampler) was drawn from each cylinder.

b. One handing step, i.e., takth the $100 \mathrm{~g}$ senple, was avoided.

For the K-25 sampler, the critical opereting steps of utmost importance

vere:

a. Having the cylinder at $100^{\circ} \mathrm{C}$ prior to sampling.

b. Keeping the bloek at $7 \mathrm{o}^{+5^{\circ}} \mathrm{c}$. Other critical operating ateps are listed.

For the Minisampler, the critfcal operating step of primary iruportance was having the cylinder at allghtly $>100^{\circ} \mathrm{C}$. Other ariticel opereting steps were recorded earlier.

Two operating personiel and a Prepo torch were required with either ris.

Since $\alpha$ radioactivity was released from the Minisampler, wearting masks wss essentiel. Because masks were worn, communleation between the two operating personnel was difficult. This disadvantage also applied to the K-25 sampler although to a lesser degree.

After a cylinder fell from the dolly becauge the clamps were inadequate, bolts were added to the cylinder-containing sleeve to secure the cylinder.

The operation of the Minisampler chemleal trap during the " $L$ " mans vas cheractertzed by: (a) being hard to unload because of 1te 1 .d. to depth ratio, (b) picking up $5 \mathrm{~g}$ of Uf 6 per cylinder sampled, and (c) requiring unfobding about every four or five cylinders sampled. During the "C" and " $E$ " runs, residual UF' 6 from eampling was sorbed in FV-12?! 
Both the K-25 ampler and Minisampler aample containers were satiafactory. Of the several designs of the latter uaed, the one described was preferred, but it was possible to crack the brass nut by contacting it with liquid $\mathrm{H}_{2}$.

\subsection{Recoumendations}

It is recoramended that any product sampling in the future in the VPF be done by the K-2S method.

12.7 Appendix

12.7.1 Operating Procedure; Sampling of Product in K-25 Sampler

SOP

1. Place product cylinder to be sampled in FV-526 and set TIC-2B-1 controller on $100^{\circ} \mathrm{c}$. Gradually increase Voriac setting to this controller until automatic control is obtained.

2. Turn on switch to heater is aample manifold.

3. Turn on witch to atrip heaters on inlet and outlet lines to sample manifold, and racuum header.

4. Connect a sample flask to the ample menifold.

5. Record time fumace FV-526 (TIC-2B-1) reaches the Betpotnt

6. close or check to see if closed, valve $\mathrm{HX}-26$ on panel vacura line into Fv-420 in Cell 2

7. Open $\vee-30$ and 31 near cold trap FY -924 .

NOTE: Do not begin the next step unless you have time to complete the entire runsheet.

8. F1ll FV-924 with dry ice-trichloroethylene mixture.

9. Thirty minutes or more after the time recorded in step 5, using agbestos gloves and chain holet, lift product cylinder from the furnace and lower into the gampling dolly.

10. Connect the retaining clamps on sample dolly and also secure cylinder with bolts in cylinder sleeve.

11. Invert the product receiver five or six times, pause in the upside-donn position, and finally, connect the receiver into the sample manifold.

12. Open two valvea on semple menifold (blue baxdles).

13. Open the valve on line to vacuum pump (Tees in near v-30.)

14. Open valve into sampile rlask.

15. Murn on FV

16. Wait sbout 3 minutes, close vacuran valve on line from sample manifold.

17. Turn off vacurm pump.

18. Close lower velve (blue handle) on sempler manifold.

19. Partially open the valve on the product receiver and observe the Tepion window.

20. Fill the manifold to a depth elightly hlgher than the center of the Teflon window (approximately $100 \mathrm{~g}$ of produet). 
21. Close the valve on the product cylinder.

22. Open the lower valve in the sampler manifold (blue handle).

23. After solution drains to the semple flesk, lumerse the flesk in ary 1ce slush (Ralse a canful of olush into position eround rlask.) If difficulty is found in dreining, thaw lines with torch.

24. Let system stand with heat on lineg and flesk cooled for

25. Close valve on sample fiesk.

26. Turn on vacuun punp.

27. Three minutes later, close the valve on the line to the vacuut purp.

28. Shut off vacum purip.

29. Close two velves in sample tentoid,

30. Disconnect product recelver and rotate the recelver into its normal

upright position.

31. Turm off the heating swtches.

32. Submit sample to lab.

Code UP 1.

12.7.2 Operating Procedure: Product Bamping Operation in Minisampler

PSO

Time

Date

Oper.

1. Heat cylinder to be sampled to gust above $100^{\circ} \mathrm{C}$. Time to $100^{\circ} \mathrm{C}$

(Cylinder number

2. Continue to heat For 30 minutes.

3. Assemble the following 1tems before beginning to sanple cylinder:

a. Four tared sample tubes number

(1) es No $)$.

i b. Protective clothing and mask for each man in cell

c. New Teflon gasket

a. Dewar flesk full of ilquid $\mathrm{N}_{\mathrm{a}}$

e. Wrenches, etc.,

4. Place cylinder in semple dolly with left-hend valve (as you face top of cylinder) is pointed dowward. Then rotate cylinder clockise about 5

5. Clamp end lock cylinder in this position opposed are suffictent to hold).

- (Two clanpa $180^{\circ}$

6. Tilt cylinder up and down four or five times. Pause 5 sec in each posi* tion of maximum movement.

7. Lock cylinder in normal sampling position sampling tubes

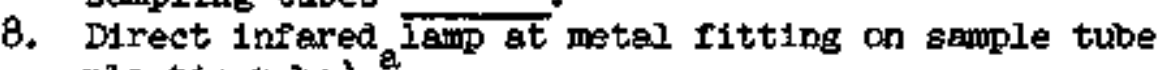
plastic tube).

9. Open three minlature valves (1.18 A, B, C)

10. Öpen $v-111$.

11. close $V-118 \mathrm{~A}$ 12. Gen $v$-llo to let in $\overline{\mathrm{F}_{2}}$ until pressure rises to $10 \mathrm{psig}$.

Watch PI-2CB

- If pressure is constant for 30

ase Pik. 12.2 for equipment numbers referred to below. 
13. Close V-110 and open V-Ill.

14. Close $v-111$ and repeat steps 12,13 three more times.

15. On $f^{\prime \prime}$ all evacuation, leave $\mathrm{V}-11 \mathrm{l}$ open and close $\mathrm{V}-118 \mathrm{~A}$ and $\mathrm{V}-118 \mathrm{C}$

16. Personnel should don masks.

17. Open (slightly) eflinder valve ( $1 / 4$ to $1 / 2$ turn is ugually a sufficlent opening).

18. close cylinder valve

19. Open V-118 c carefully. Watch PI-29B and level in sample tube. Close $\checkmark-118$ c in time to flil ample cylinder about half full.

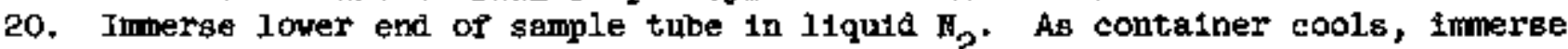
further; however, DO NOT LET BRASS FITWTNG DIP INPO THE LIQUID $\mathrm{N}_{2}$.

2l. Continue to cool sample tube until PI-2gB stops falling.

22. Then, open $V-118$ A to purp out inert gases.

23. Close $\frac{\mathrm{v}-111}{\mathrm{C}}$

24. close v-110 and gen $v-110$ to let in $\mathrm{H}_{2}$

Remove semple tube and cap of tube.

Install fresh sample tube as aoon as possible (Vapors are probebly HF).

27. Open $V-118 \mathrm{~A}$ and $\mathrm{V}-118 \mathrm{~B}$ procedure in steps 10-25.

28. On tinal sample, retighten closure of cylinder velve

, $V-118 \mathrm{~A}$, and $V-118 \mathrm{C}$

, $V-118 \mathrm{~A}$, and $V-118 \mathrm{C}$ - Then betin at step 10 and repeat

29. After pressure has fallen, open V-1 $\overline{18} \mathrm{~B}$

30. Close $\mathrm{V}-118 \mathrm{C}$ eylinder valve assconnect semple mifola

31. When cylinder $1 \overline{\mathrm{s} \mathrm{col}}$, rewelgh.

Cylinder No.

Rum No.

Final Gross tht kgs

32. To clean and dry semple tubes use an equeous Tide solution, tissue peper, and C. P* acetone. DO HOT CEI WATER THTO THFEADS.

33. Fewelgh semple tubes:

No. grems

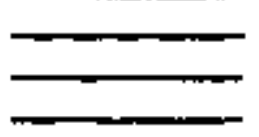

34. The seconi and fouth semples go to laing, the third sample to Feldman. The first we keep.

NorE: Samples for mass spectrometer:

35. If a sample is collected for mass spectrometer it will be drsined from the manifold into a glass tube prior to final purging of manifold. A bigh-temperature flame should be used to seal the neck of the tube. 
13.0 Weste salt System . . . . . . . . . . . . . . . 177

13.1 Introduction . . . . . . . . . . . . . . . . . . . 178

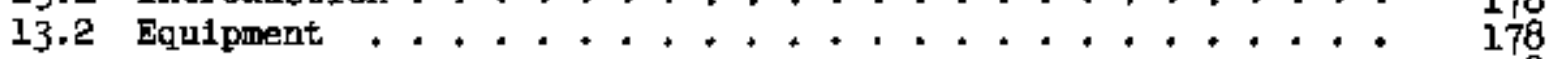

13.3 Operation ....................................... 178

13.3.1 Operating Procedure .............. 178

13.3 .2 Critical operating Steps.............. 185

13.4 Equipment Evaluation . . . . . . . . . . . . . . 186

13.4.1 Major Design Changes . . . . . . . . . . . . 186

13.4 .2 Waste Line, MS-100-1 to MS-106-1.......... 186

13.4.3 Vent LInes Heaters, FV-506 and FV-507 . . . . . . 190

13.4.4 Waste Container, fV -112 . . . . . . . . . . . . 190

13.4 .5 Waste Mozzle Heater, Fv-512 . . . . . . . . . 190

13.4.6 Waste Nozzle Vent IIne Heater, FV-512A. . . . . 190

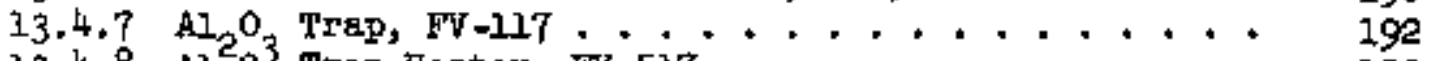

13.4 .8 Al $\mathrm{O}_{3}^{3}$ Trap Heater, FV-517 . . . . . ...... 193

$13.4 .9 \mathrm{Al}_{2}^{2} \mathrm{O}_{3}^{3}$ Trap Inlet Flange Heater, FV-517A . . . . . 193

13.4 .10 Waste Dolly, FV-902 . . . ............. . 193

13.4.1. Waste Weighing Device, FV-904. . . . . . . . . . . 193

13.4.12 Waste Nozzle, FV-906 . . . . . . . . . . . . . 193

13.4 .13 Waste Cerr1er, FV-912.............. . . . 194

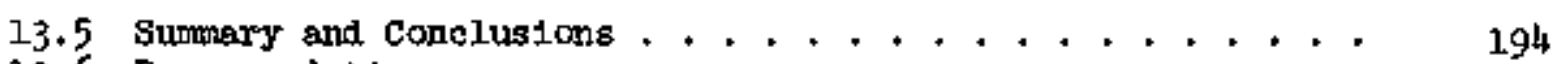

13.6 Recommendations. . . . . . . . . . . . . . . . . . . 197

13.7 Operating Procedure: Waste Salt Transfer. . . . . . . . 197 
13.0 WASTE SALT SYSTEMN

\subsection{Introduction}

Bssentially all high-activity level waste material (greater than ninety-nine per cent of the total activity) remained in the fluorinator after fluorination. This waste was elluinated from the process through the waste salt system. The principal steps in the operation of this system were:

a. Transferring the wolten salt from the fluorinator through a freeze valve into a waste recolver.

b. Removing from the cell (and disposing in the burlal ground) the fllled waste receiver.

Radiation exposure was minimized by shielding the waste receiver and venting the vapors.

\subsection{Eguipment}

The flowsheet of the waste salt systen with the Mark I waste line and the Mark II freeze velve is shown In F1g. 13.1. After the "E" runs, the system was modifted to eliminate major difficulties. The revised gystem with the Mark II waste line and Mark $\mathrm{V}$ Ireeze valve is shown In F1g. 13.2. The components of the vaste salt systen are liated and described in Table 13.1.

\subsection{Operat1on}

\subsubsection{Operating Procedure}

Steps in operating the vaste salt system vere:

a. Positioning the waste can and activating the weight recorder to nonitar the flow into the waste can.

b. Mainteining the waste salt temperature at $\sim 600^{\circ} \mathrm{C}$ in the fluorinator.

c. Heating the entire molten salt line including FV-106, vent lines saddie jolnts, and waste nozzle to $\geq 570 \mathrm{c}$.

d. Establishing fluorinator Instrument and vent lines purges at one cfh.

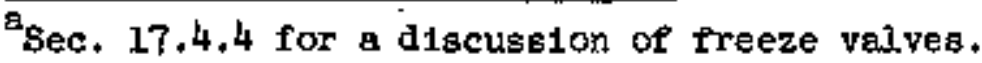

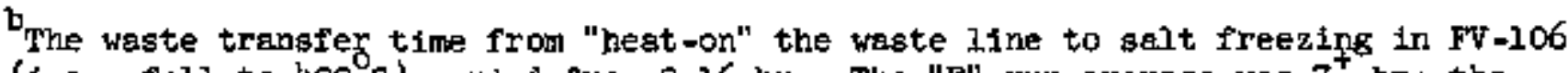
(i.e., fell to $400^{\circ} \mathrm{C}$ ) varied from 2-16 $\mathrm{hr}$. The " $\mathrm{E}^{\prime \prime}$ run average was $7^{+} \mathrm{hr}$; the average in the last five "L" runs was 11 " hr.

rinat $1,3, \geq 50^{\circ} \mathrm{C}$ above the melting point of the salt. The composition of most of the salt used was approxtmetely $\mathrm{C}-30^{\circ}$ having an m.p. of $520^{\circ} \mathrm{C}$ (11). 


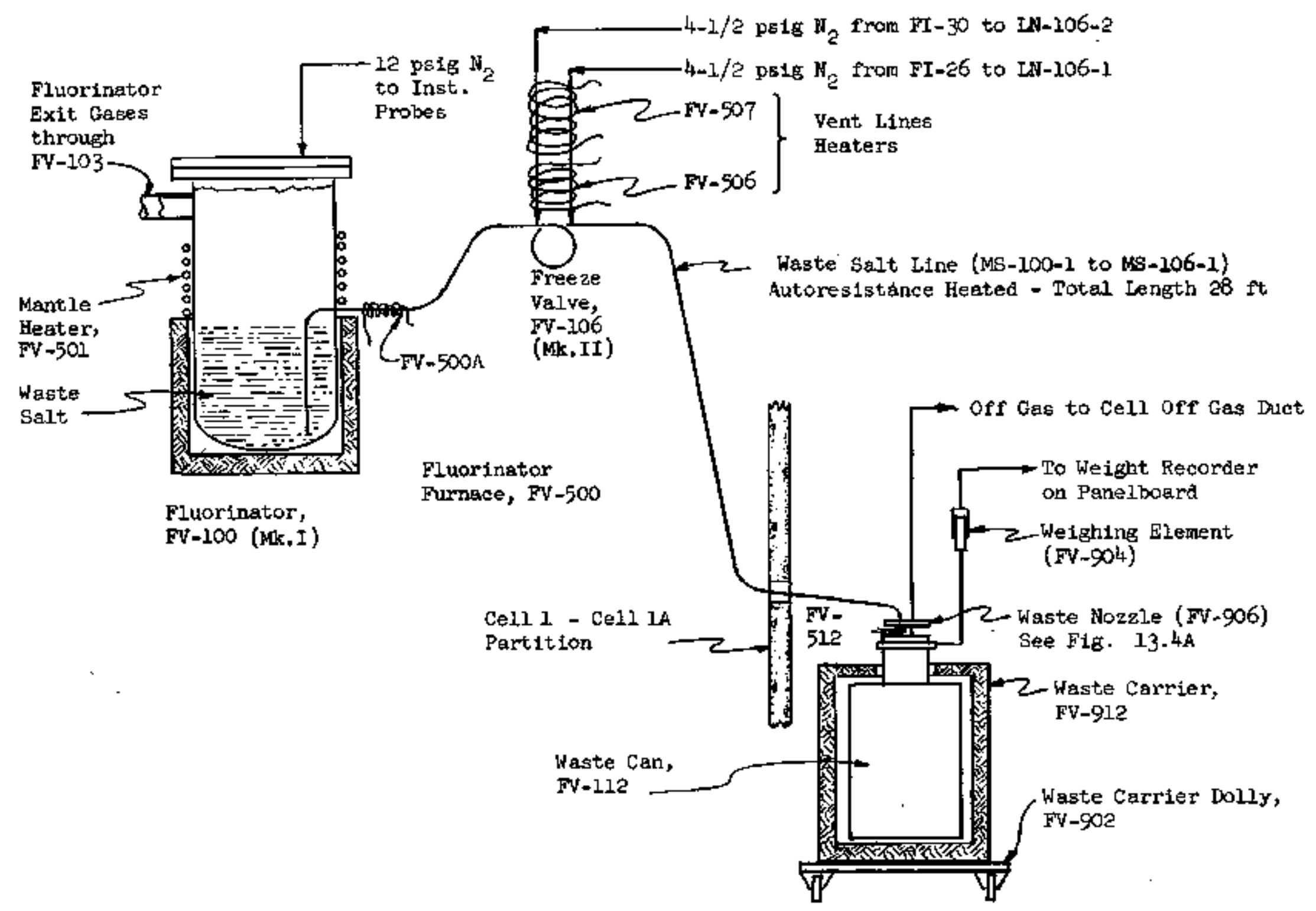

F16. 13.1. Equipment Arrangement in the Haste Salt System (Mark I Waste Line) 


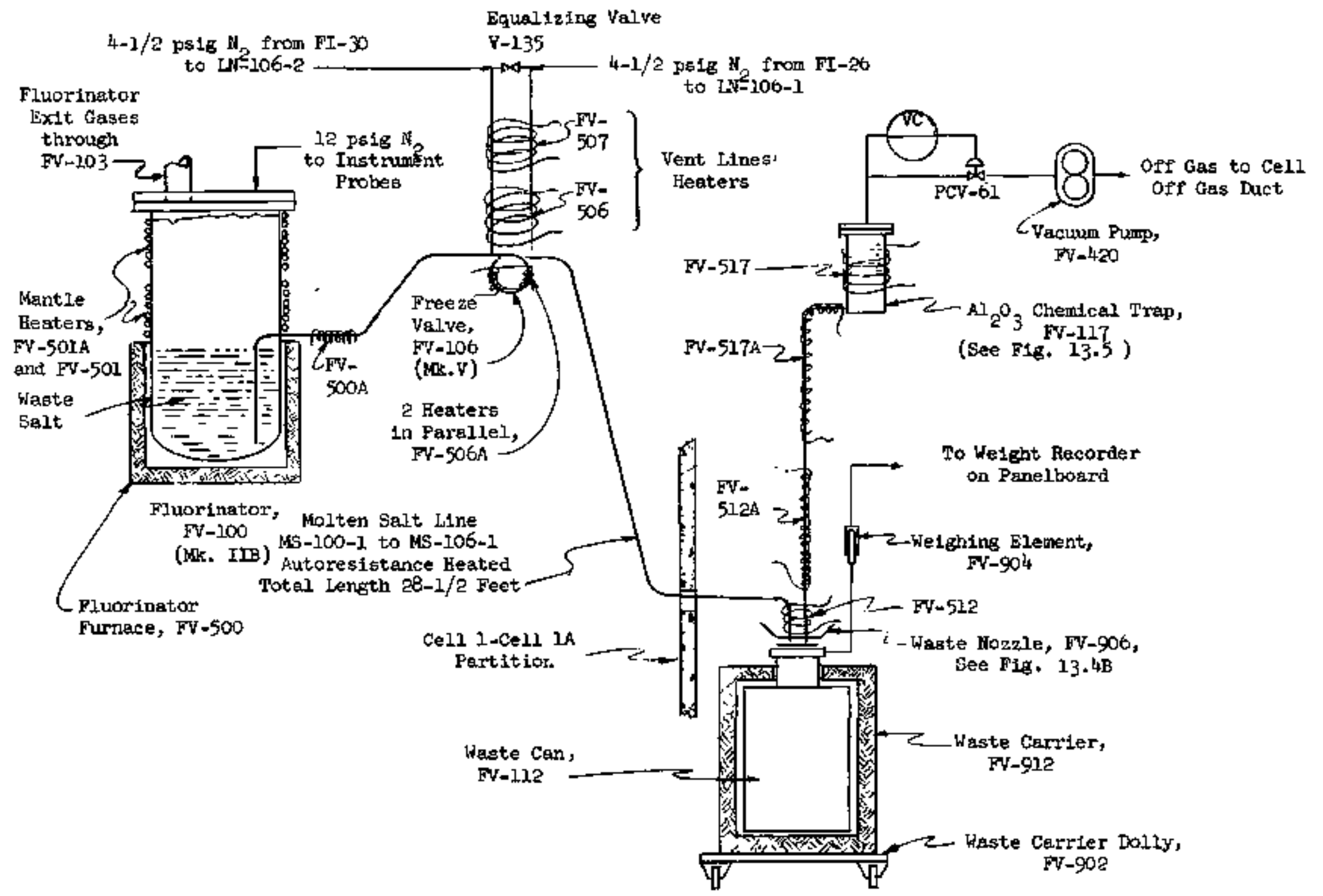

Fíg. 13.2. Equipment Arrangement in the Waste Salt System (Mark II Waste Line) 
Tnola 19.1

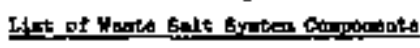

\begin{tabular}{|c|c|c|c|c|}
\hline \multirow{3}{*}{ 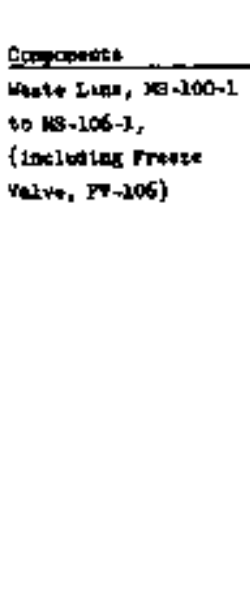 } & \multicolumn{2}{|c|}{ 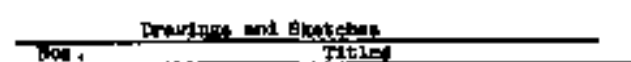 } & 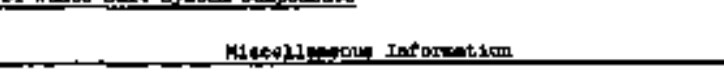 & \multirow{3}{*}{ 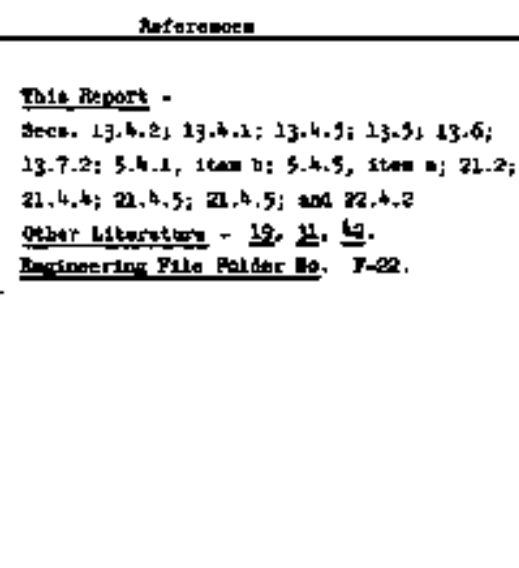 } \\
\hline & 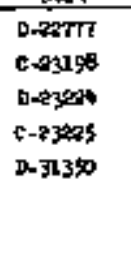 & 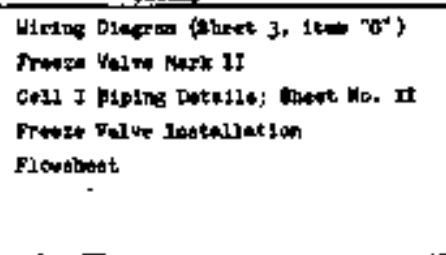 & 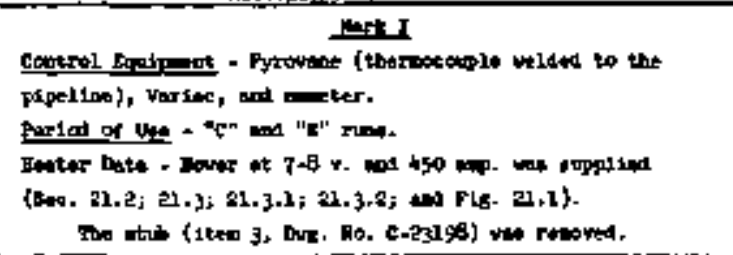 & \\
\hline & 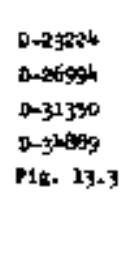 & 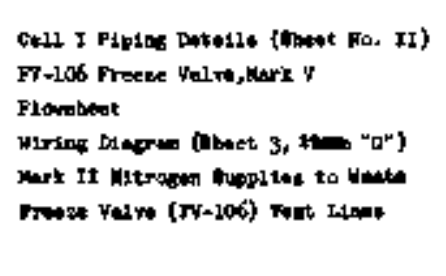 & 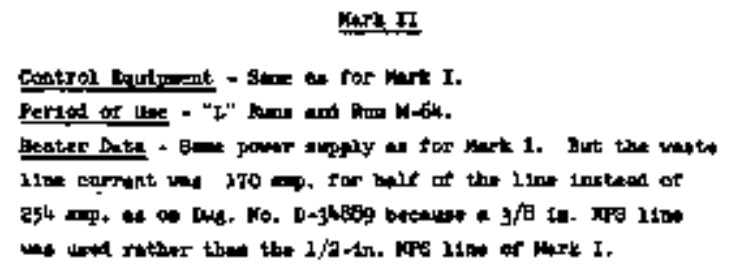 & \\
\hline 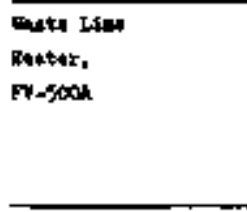 & $\begin{array}{l}0=31350 \\
0 \times 34686\end{array}$ & 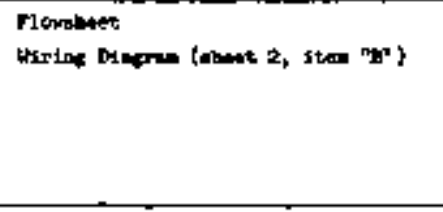 & 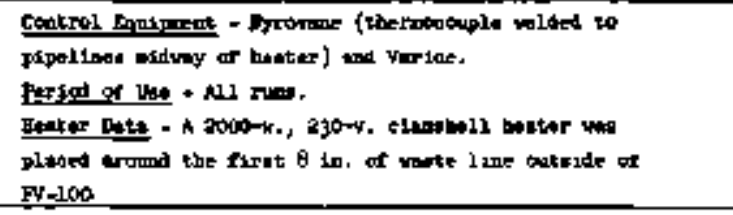 & 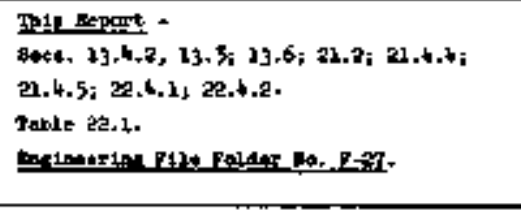 \\
\hline 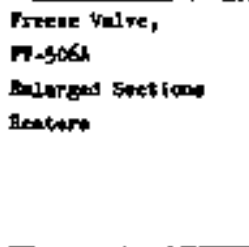 & $0-32350$ & 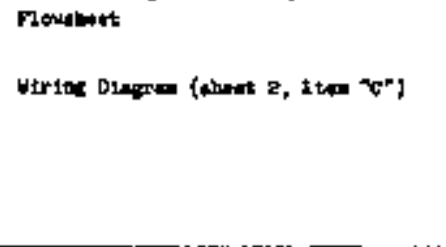 & 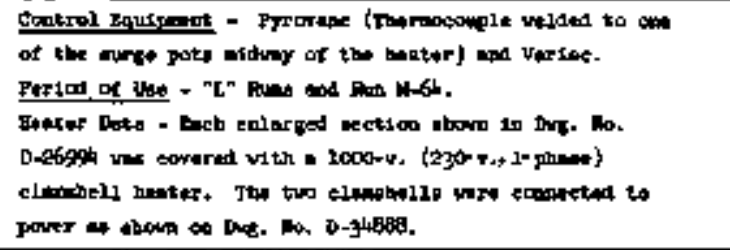 & 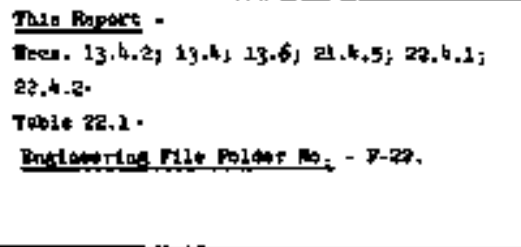 \\
\hline
\end{tabular}


Town 1 j.1 (caltinum)

\begin{tabular}{|c|c|c|c|c|}
\hline Cospanats & 7.52 & and latelent & 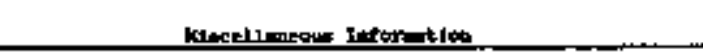 & 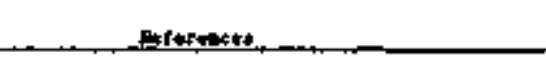 \\
\hline 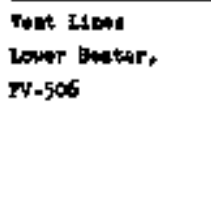 & $\begin{array}{l}0.4270 \\
0-32950\end{array}$ & 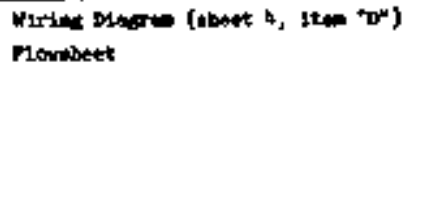 & 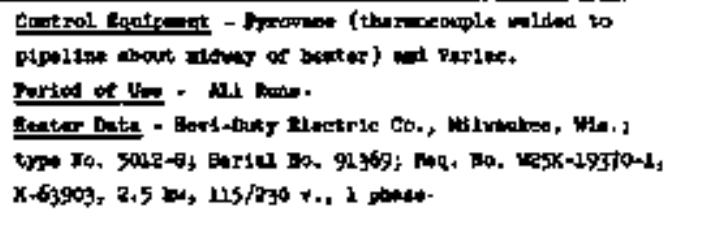 & 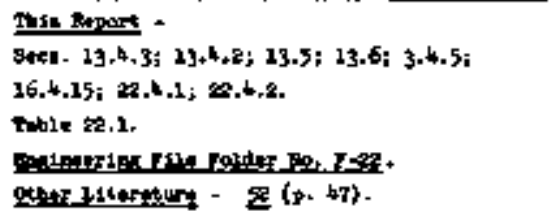 \\
\hline 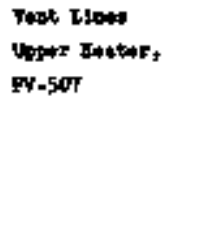 & 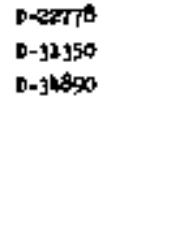 & 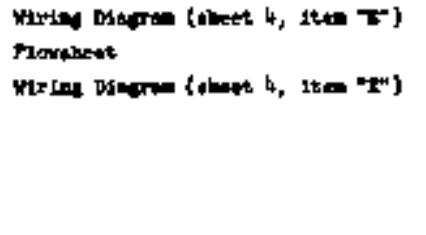 & 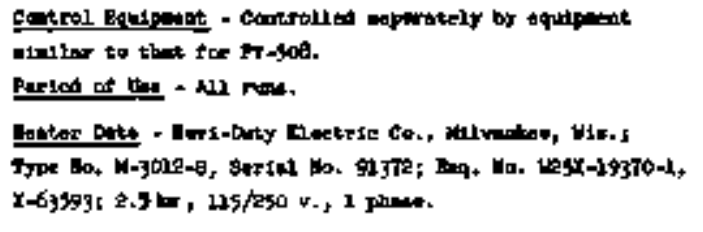 & $=0$ tor Fr-X16. \\
\hline 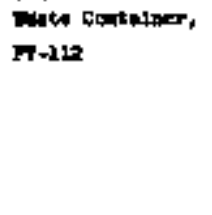 & 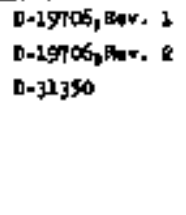 & 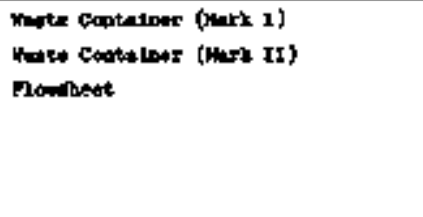 & 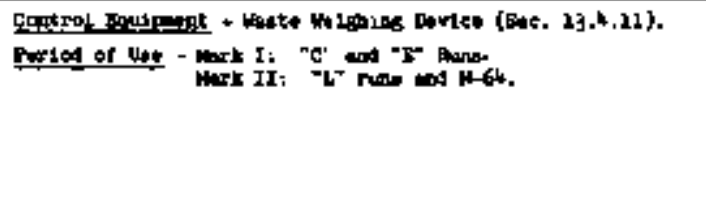 & 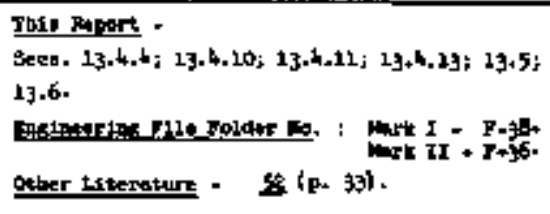 \\
\hline \multirow[t]{2}{*}{ Inote Hoesle } & $\begin{array}{l}0-31350 \\
0-31369 \\
\text { DSt. } 13.4\end{array}$ & 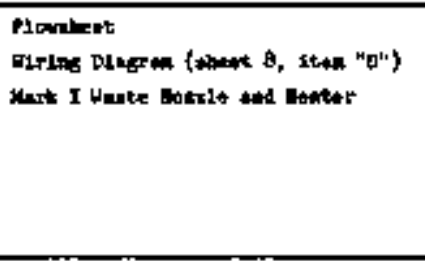 & 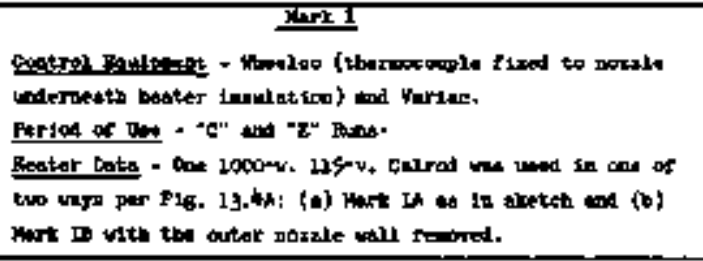 & 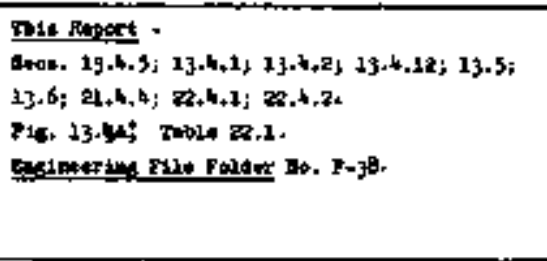 \\
\hline & 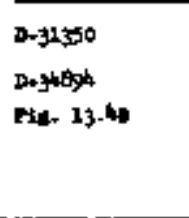 & 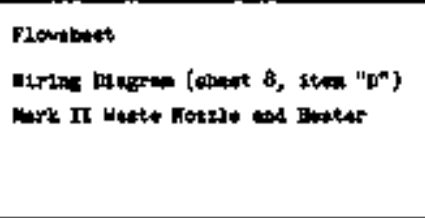 & 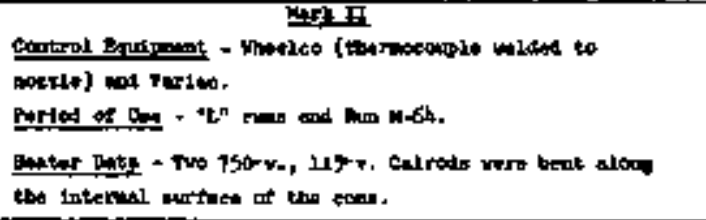 & 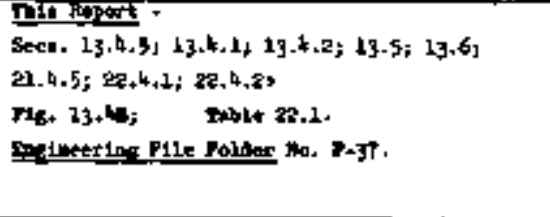 \\
\hline
\end{tabular}


Table 13.1 (Ocationed)

\begin{tabular}{|c|c|c|c|}
\hline Coveroonte & Fon. & 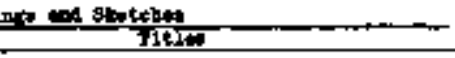 & 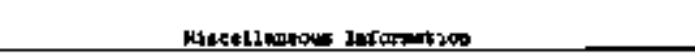 \\
\hline 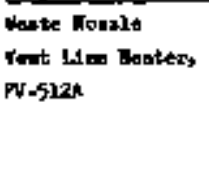 & 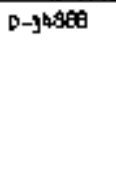 & 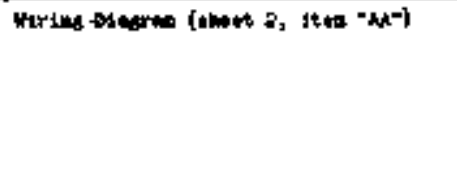 & 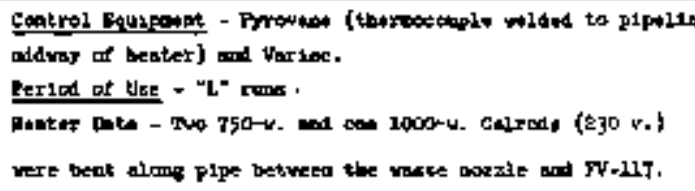 \\
\hline 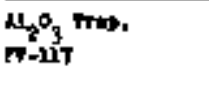 & $748+13.5$ & $\mathrm{~N}_{2}{ }_{3}{ }_{3} \mathrm{~m}$ & 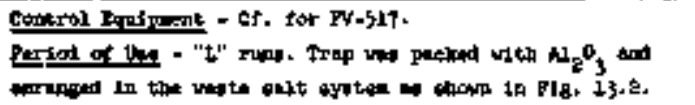 \\
\hline
\end{tabular}

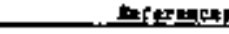

Mats Mapre -

Seck. 13.4.51 13.4.6; 13.5; 13.6; 22,4,

tect 4.2

Table ati.

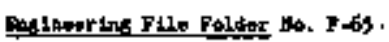

Than Figont: -

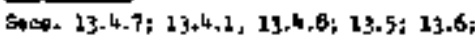

29.4.9; 23.4.101 T1E. 13.2.

Entneerirp File Folder Ho. P-6s.

Gaber kiteratirat 49.

\begin{tabular}{|c|c|c|c|c|}
\hline 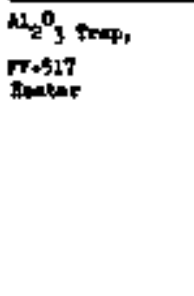 & D-94les & 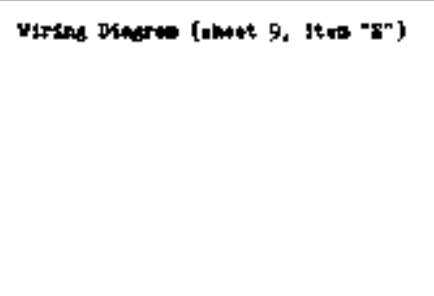 & 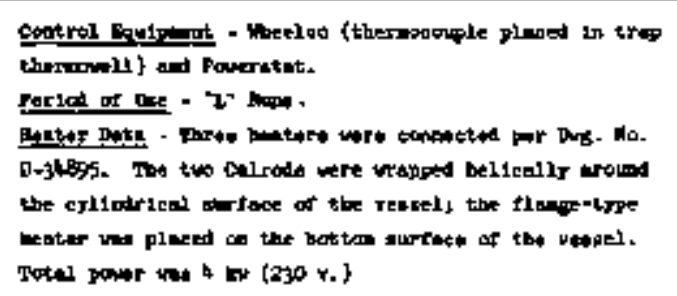 & 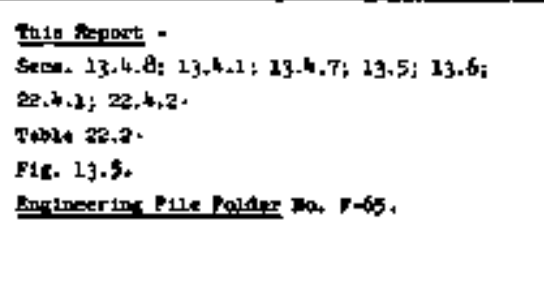 \\
\hline 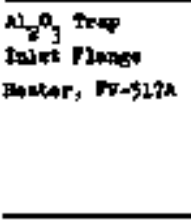 & D-3hed & 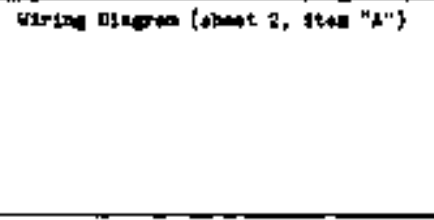 & 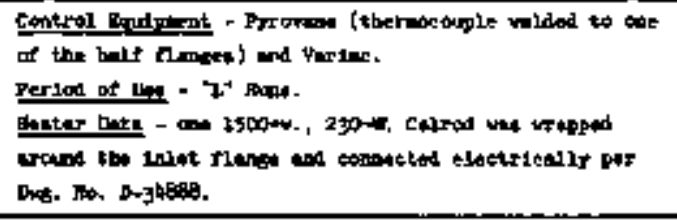 & 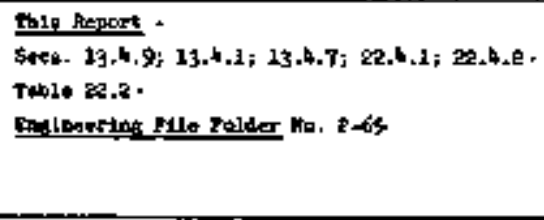 \\
\hline $\begin{array}{l}\text { Wrote nally, } \\
\text { Fr-9ce }\end{array}$ & 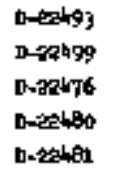 & 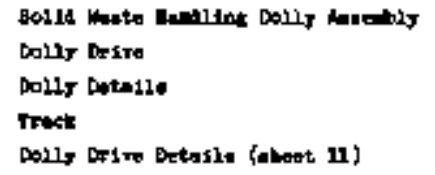 & 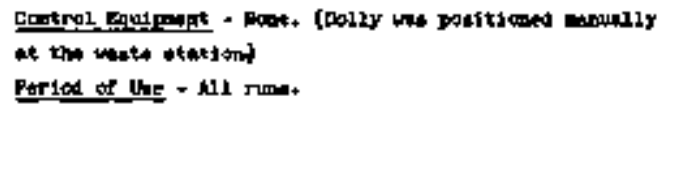 & 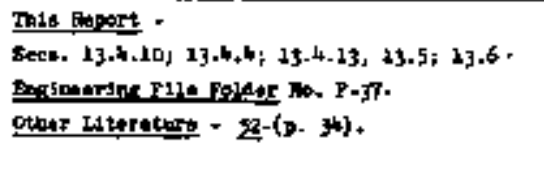 \\
\hline
\end{tabular}

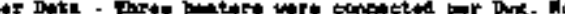

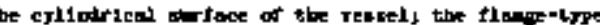

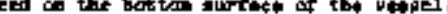

4.9; 13.4.1; 13.4.7; 22.6.1; 20.4.e.

Talole 22.2 .

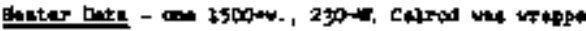

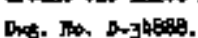


Trob 23.2 (Contirued)

\begin{tabular}{|c|c|c|c|c|}
\hline Expconst: & Gat & 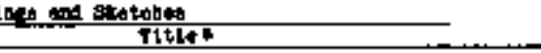 & 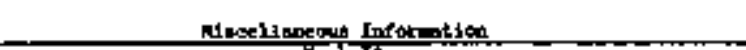 & Petertice \\
\hline \multirow[t]{2}{*}{$\begin{array}{l}\text { Wate We Lefoine } \\
\text { Deplet, FP-904 }\end{array}$} & 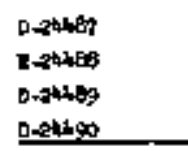 & 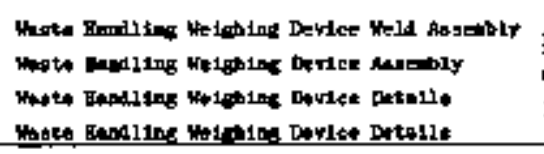 & 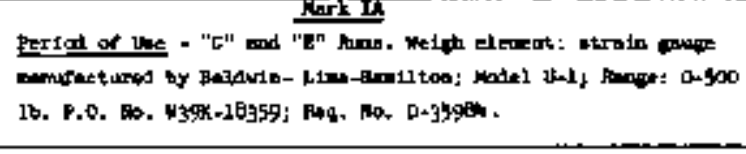 & 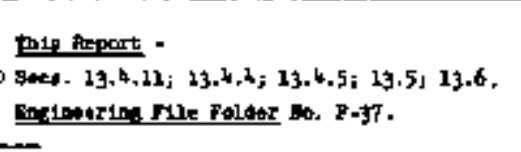 \\
\hline & D-84490, Bay. 1 & 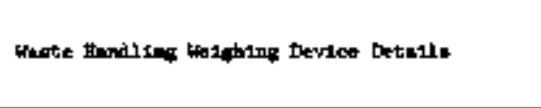 & 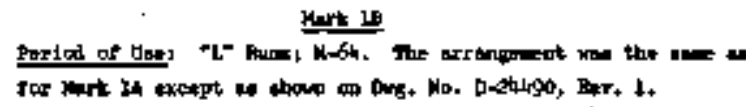 & 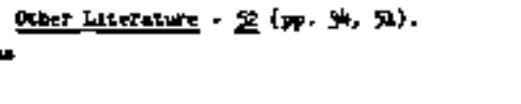 \\
\hline \multirow[t]{2}{*}{ 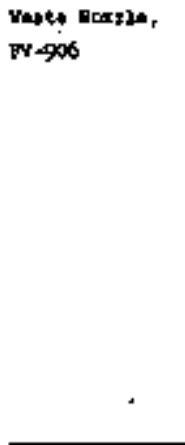 } & 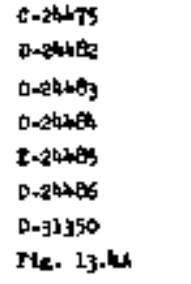 & 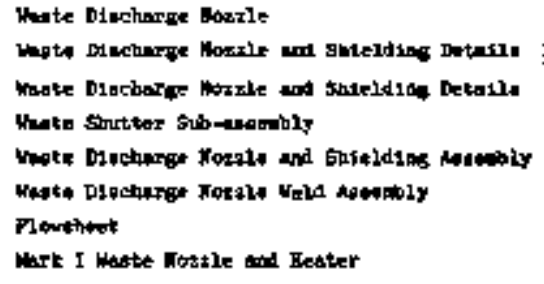 & Friat of uns - " $\mathrm{c}$ " and & 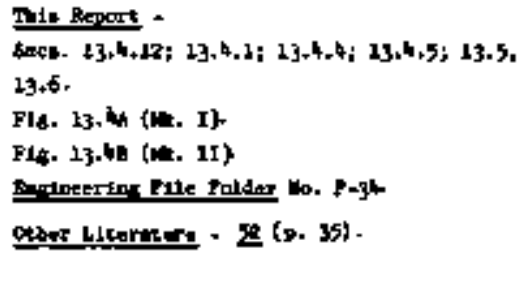 \\
\hline & 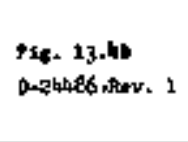 & 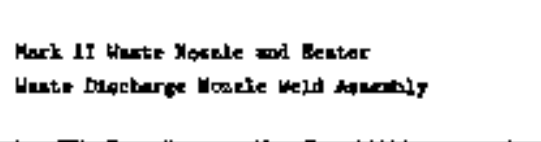 & 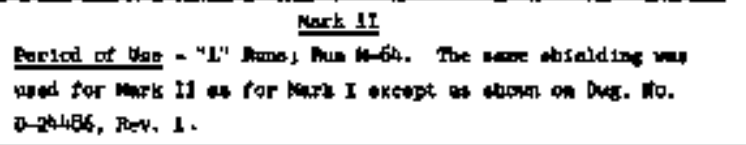 & \\
\hline \multirow[t]{2}{*}{ 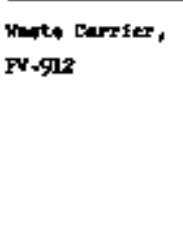 } & $\begin{array}{l}=1970^{4} \\
E=26184\end{array}$ & $\begin{array}{l}\text { Mate Contsiner farrier } \\
\text { thor closing Jis }\end{array}$ & 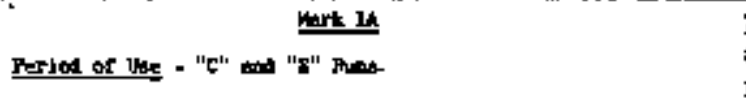 & 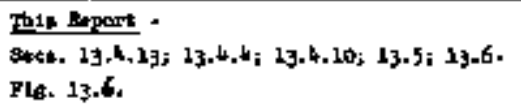 \\
\hline & E-19704, Ray. 3 & 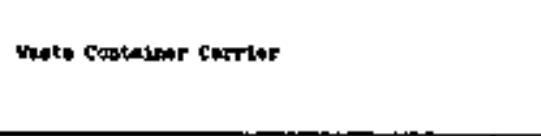 & 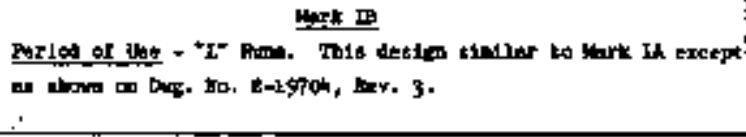 & 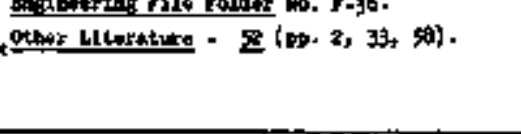 \\
\hline
\end{tabular}


e. Closing HCV-11 to pressurize the waste out of FV-100.

f. Transferring until the $L R-\hat{z}$ reading was 2 to $4 \%$ below the desired FV-100 heel value, then stopping the transfer.

g. Re-establishing nitrogen parges through the freeze valve vent lines, and heating the vent furmaces to $\sim 650^{\circ} \mathrm{C}$ to melt regidual salt from the vent ines.

h. Shutting off heat (about one hour later) to solidify the selt in the freeze valve.

With the Mark I veste Ifne, nitrogen was contimuously purged through the fluor fnator instrument purges (step d. above) resulting in a pressure trensfer which was stopped by opening HCV-11. In adattion, the FV-106 freeze ralve plirges were continued during the transfer to prevent forcing waste salt into the vent lines. W1th the Mark II waste line, the freeze valve vent lines vere kept closed furing transfer, resulting in siphoning; HCV-1l was opened when siphoning started; the transfer was stopped by introducing nitrogen into the froeze valve vent lines.

System modirleations necessitated additional minor ateps in the procedure. For the complete transfer procedure, see Sec. 13.7 .

\section{3 .2 Critical Qperating Steps}

a. Naintalning the molten salt at $\sim 600^{\circ} \mathrm{C}$ and the ent 1 re waste pipeIine at $>570^{\circ} \mathrm{C}$ to permit flowing the salt through the line to the waste can. The salt transfer usually presented no difficulty when the specified salt and line temperatures were wained.

b. Stopping the salt trangfer at the appropriate time to retaln adequate salt for a fluorinator heel and for bealing the waste freeze valve. Froviding a fluorinator heel and a freeze valve seal efter each transfer permitted batch measurement, waste line purglng, and leak-testing. Stopping the tramsfer was afficult uith the Mark I waste ine. The troubles encountered are discussed in Sec. 13.4.2.

an most cases, a 2 to $4 \%$ increase 1 the IR-2 reading occurred after aiscontinuing the transfer because of salt run-back.

batch measurement could also be done by woste salt weight. 
13.4 Equigment Evaluation

\subsubsection{Major Design Changes}

a. Haste salt line and freeze valve: The $3 / 8-i n$. HPS schedule 40 line in Mark IT requared about $20 \%$ less autoresistance power than aid the 1/2-1n. NPS Schedule 40 line in Mark I (Table 21.1 and Secs. 13.4.2, 1.7.4.4, 21.4.4, 21.4.5).

b. Waste nozzle and heater: The Mark II nozzle was easier to fit with a Calrod than Mark $I$. In ddd1tion, better contact between the conleal surface of the nozzle and waste can in Mark II reduced the salt spsttering problem (Sec. 13.4.5 and 13.4 .12$)$.

c. Waste can vent line equipment: In the Mark I nozzle design, waste can venting was inadequate because of the car neckwaste nozzle gecmetry. In Mark II, the better waste-can-tonozzle fit enabled exhausting the off-gas from the can through a heated $\mathrm{Al}_{2} \mathrm{O}_{3}$ chemical trap designed to scrub out the $\mathrm{ZrF}_{4}$ vapor (Secs? $3.4 .7,13.4 .8$, and 13.4.9).

13.4.2 Waste Line, $\mathrm{MS}-100-1$ to $\mathrm{ks-106-1^{2 }}$

a. A siphon transfer was nore diffieult to stop in Mark I than in Mark II. (Sec. 13.4.1). For example, one siphon transfer in Mark I resulted in completely emptying the fluorinator and the freeze valye, thereby eliminating the fluorinator heel and the freeze valye seal. Thus, it was necessary to add barren salt in order to seal the ireeze valve before making another run. This siphon us not stopped by opening HCV-11, the usual control measure, and was so fast (5 to 10 sec) that there was Insuffictent time to break 1t by adding nitrogen through the vent lines. All siphon transfers in Mark II were 1nterrupted easily.

Waste salt trangfer stadies were made in the tinit Operations section with equipment slmulating a $3 / 8-i n$. HPs schedule 40 pipe system (later installed in the volatility Pilot Plant) (42). Findings were:

1. A siphon trensfer could always be interrupted by increasIng the nitrogen purge rate to the freeze valve vent lines.

2. With the design chenge discussed below, sufficient liquid to seal the freeze valve could be retained even when completeiy emptying the fluorinetor nock-up in an uncontrolled pressure transfer.

aecs. 17.4.4, 21.4.4, and 21.4.5; Table 21.1. 
The recommended design change consisted of surge pots in the vertical sections of the freeze valve and a slope toward the freeze valve at each vent-line sadde foint. In operation, liquid was retalned by setting the n1trogen purge rates at the end of the trensfer. Subsequently equalizing the presaures in the two vent lines by opening V-135 shown in Fid. 13.3 allowed the retained ilquid to seek its level.

The surge pots in the Mark V Fv-106 (Sec, 17.4, 4) required heating by both autoresistance and res1stance (FV-506A). a Autores1stance beating alone was insufficient despite careful wall thickness design per Bec, 2l.2. Cold spots evidently resulted from uneven current distribution in the surge pots wall or from overly thick valls at the welds.

The vaste transfers made in the Mark II waste line were of the siphon variety. The only difficulties arose from aalt plugs in the freeze valve vent lines, near the FV-100 wall, and at the waste nozzle. The vent line plugs resulted from molten salt being sucked into cold sections of these lines by the $10 \mathrm{in}$. of $\mathrm{Hg}$ vacum created during waste transfer.

D. Freeze valve vent lines and the vaste line at or near the fluoringtor wall were susceptible to plugging in both designs. Item $b_{n}$ wa related to item $a$ in that siphoning was accompanled by a vacurm uhich carried molten salt up into the vent lines (42).

Two techniques to prevent vent line plugs durting waste salt transfer have been proposed. F1rst, keep a sufficlent length ( $110 \mathrm{ft})$ of the vent lines at $600^{\circ} \mathrm{C}$ to ensure that galt never freezes in these lines. Second, mesntatn only the first foot of the vent lines at $600^{\circ} \mathrm{C}$ using the vent furneces. Selt frozen in the vent lines sbove the $600^{\circ} \mathrm{C}$ section would be subsequently melted.

In general, pluge near the FV-100 wall were caused by inadequate heating to maintain the line at $\geq 570^{\circ} \mathrm{C}$ although one incident of $\mathrm{NiF}$, precipitation ( cult to heat: (a) above the melt level instde the fluurinator, and (b) in the first 1/2-in. to 2-in. of the vaste line just outs1de the fluorinator shell. The gipe in both of these regions was nickel pipe.

The unhested section of plpe above the melt level inside the fluortnator caused trouble as evidenced by the frozen salt annulus above the interface, Indicating that the wate line at this level was below control temperature. To reduce the tendency for anmulus formation, heater FV-501 was redesigned as described in Sec. 5.4.5a. The ilmited data avallable after this change indicated that this messure was partially effective.

Table 22.1 and Secs. 22.4 .1 and 22.4 .2 .

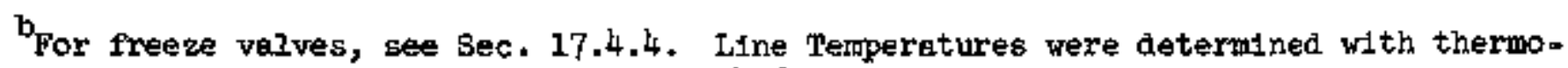
couples placed as described in Sec. 21.4.6.

cf. Sec. 5.4.1c and later in this section. 


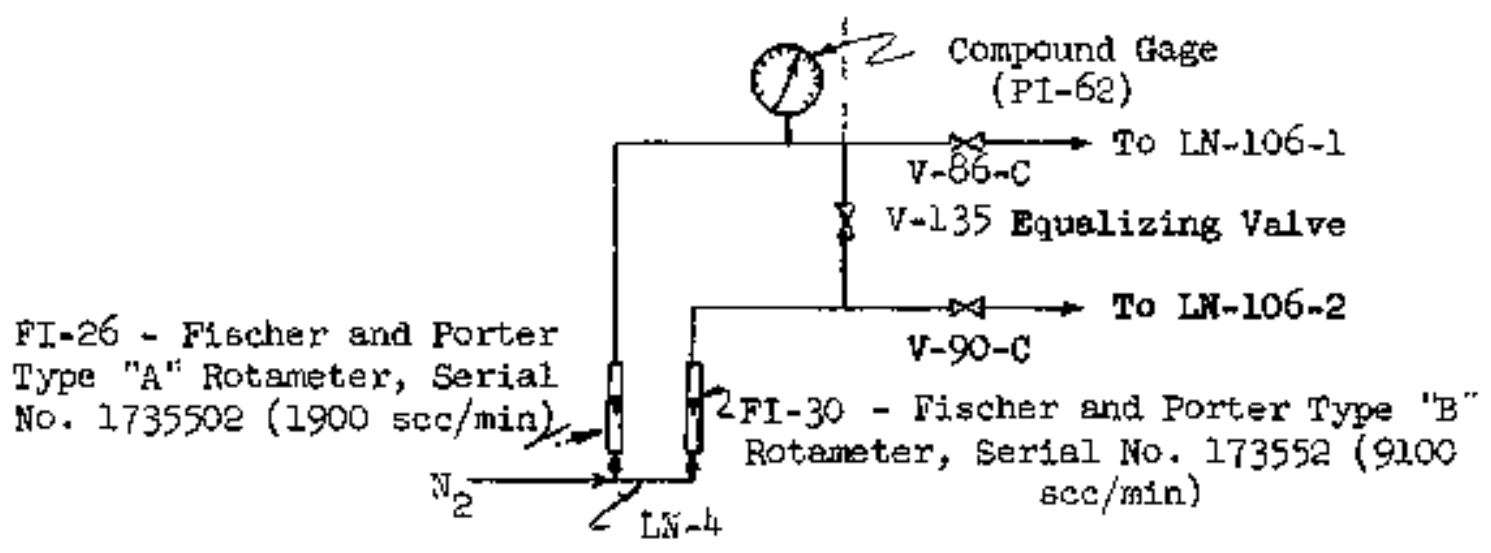

Fig. 13.3. Mark II Nitrogen Supplies to Waste Freeze Valve (FV-I06) Vent Lines

Hote: Heaters are not skown.

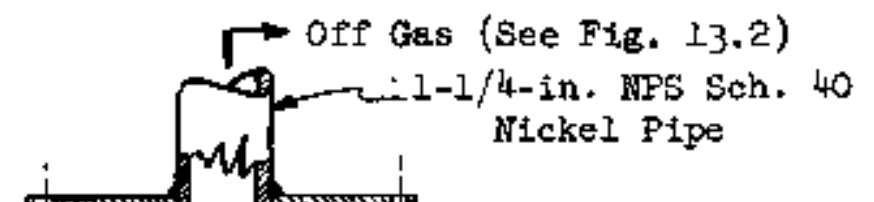

See Fig. 13.2

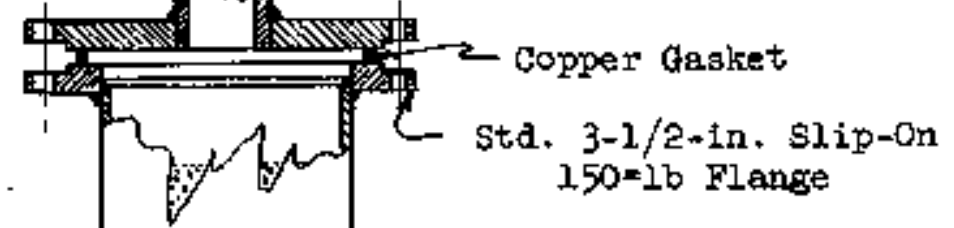

$1-1 / 4-1 \mathrm{n}$. MPS Sch. 40 Nickel Pipe

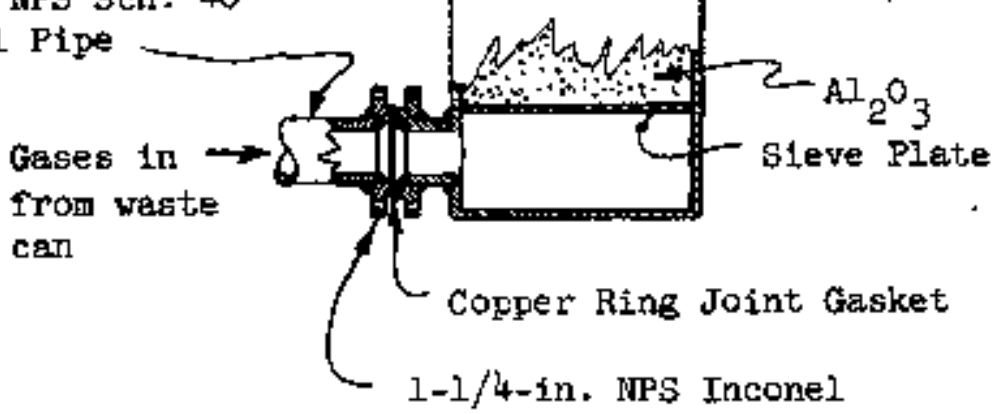

Ring Joint Flange

Fig. 13.5. $\mathrm{Al}_{2} \mathrm{O}_{3}$ Trap $(\mathrm{FV}-117)$ 
The first $1 / 2-1 n$. to 2-In. ${ }^{2}$ of the waste salt line outside of the fuoxinator vessel wall vas nickel. Frozen salt piugs formed in this section of the line because lower-registance nickel was heated to a lower temperature by autorealatance than wes Inconel. At $550-600^{\circ} \mathrm{C}$, for example, the resistance of nlckel is about one-third that of Inconel (Sec. 2l,2). Theae plugs were eliminated by adding the clenshell heater, FV-500A. ${ }^{b}$ This difficulty was anticipated with the heater addition beins preferred over making a diasimllar metal weld (nickel-Inconel) at the ressel vall.

The placement of autoresistance electrodes for the wate line Is delineated in Secs. 21.4 .4 ; 21.4 .5 , and 21.4 .6 . Although not determined conclusively, the effect on FV-100 wall plugs of moving the FV-100 electrode from the waste IIne to the FV-100 flange was belleved to be beneficial. Ho disadvantage to flange plecement has been found. However, placing the nozzle-end electrode on the nozzle or nozzle vent line did not elintrate the necessity for FV-5.12 (Sec. 13.4.5).

Most of the waste line pluga were caused by inadequate heating. At least one plug, however, was due primerily to the precipitation of ibspurities in the salt. This plus (at the end of Pun L-4) vas caused by $\mathbb{N 1 F}$ which was present both as a corrosion product and as an inpurity approaching the solubility limit in the feed. This bith-uelting waste salt mixture could not be trenaferred because all dip tubes were plugged. Consequently, rewoval required jack-hanmering and chipping which vere very costly, and which resulted in mechanlcal damage to the fluorinator as described in Sec. 5.4.3c. In a very radioactive operation, such manual methods of taste removel would be imposstble.

During the fun $\mathrm{C}-8$ waste transfer, a crack occurred in the nickel aection of the Mark $I$ raste line about $1 / 4+1 n$, awey from the fluorinator. It wes essential to repair the line before resuning operations. Two factora contributing to this failure were: (a) approximately a half-inch fall of the vessel huring prior maintenance work and $(b)$ thermal cycling of the waste line and fluorinator (31, p.34).

c. Insulation was essertial since, when uninsulated, the line reached only $\sim 300^{\circ} \mathrm{C}$ at full power of 4200 watts.

The Mark I waste Line was removed after the "E" runs and taken to the burial ground (Secs, $21,4,4$ and $23,4,160$ ).

Corroston of the Nark II waste line was not severe except near the waste nozzle. The 2l-mil attack at the waste nozzle might be attributed to the external hesters FV-512 and -512 A vich probably augruented the line temperature near the waste nozzle (19).

\footnotetext{
Two inches in the Mark I fluorinator and I/2-in. In the Mark II vessel.

biale 22.1 and Secs. 22.4.1 and 22.4.2.

"The waste line in this reference is termed "Mark II-B." After the corrosion specimens were removed from the Mark II waste line, the waste line and auxlliary equipment were discarded in Burlal Ground Ho. 3 (sec. 21.4.5, 22.4.3, and 23.4.16b). The specimens tested were decontenulusted per Sec. 23.4.15b.
} 


\subsubsection{Yent Lines Beaters, FV-506 and FV-507}

The vent lines were difflcult to heat near the sadile joints because the metal walls at the welds were thicker, and because of the chimney effect and conduction of heat to cold portions of the vent lines. Therefore, the lower vent lines heater was placed as close to the top of the freeze valve as possible to adequately heat the lines near the saddle joints. In edd1tion, any opening between the freeze valve insulation and the bottom of the lower furnace or between the two furneces was eliminated to evoid cooling. The vent lines were electrically ingulated from each other to prevent unnecesfary autoresistance power leaks. The t1memto-650 $\mathrm{C}$ was about one hour.

\subsubsection{Waste Container, FV-112}

The salt spattering problem was reduced but not completely eliminated in the Mark II degign. This was attributed to the venting and the better seal between the waste nozzle and the can neck in the Mark II design (Secs. $13.4 .10,13.4 .11$, and 13.4 .13$)$. See sec. 23.4.16a for ectivity of the " $\mathrm{E}^{\mathrm{N}}$ and "L" run waste containers.

\subsubsection{Waste Hozzle Heater, Fv-512}

The Mark IA and IB designs differed in that for Mark IA the doublewall of the nozzle was retained whereas for Mark IB the outer nozzle wall was removed as Indiceted on Fig. 13.4A. Both the Mark IA and IB designs wore inadequate, however, for heating the Mark I waste nozzle for two reasons: (a) Pitting a heater to the nozzle was difficult and (b) placing the heaters close to the end of the nozale made them very susceptible to contact with the corrosive molten salt.

The Mark II design (shown in Fig. 13.4B) was cepable of keeping the nozzle at $650^{\circ} \mathrm{C}$ with a $120 \mathrm{v}$ setting on Vardac PC-11. The time-to$650^{\circ} \mathrm{C}$ wes $<3 \mathrm{hr}$. In adation, this heater seemed to be capable of rating a nozzie piug.

\subsubsection{Waste Nozzle Vent Line Heater, FV-512A ${ }^{c}$}

This heater was satiafactory. The tire-to-temperature data we re similar to those for Mark II FV-512 (sec. 13.4.5).

The sttuation at FV -508 and -509 was similar (Sec. 3.4.5), but that at FV-50lt and -505 was dissimilar (Sec. 16.4.15).

bill three waste nozzles were heated both by autoresistance and resistance (Table 22.1 and Secs. 13.4.1, 13.4.2, 13.4.12, 21.4.4, 21.4.5, 22.4.1, and 22.4.2).

Table 22.2 and Secs. 22.4.1 and 22.4.2. 


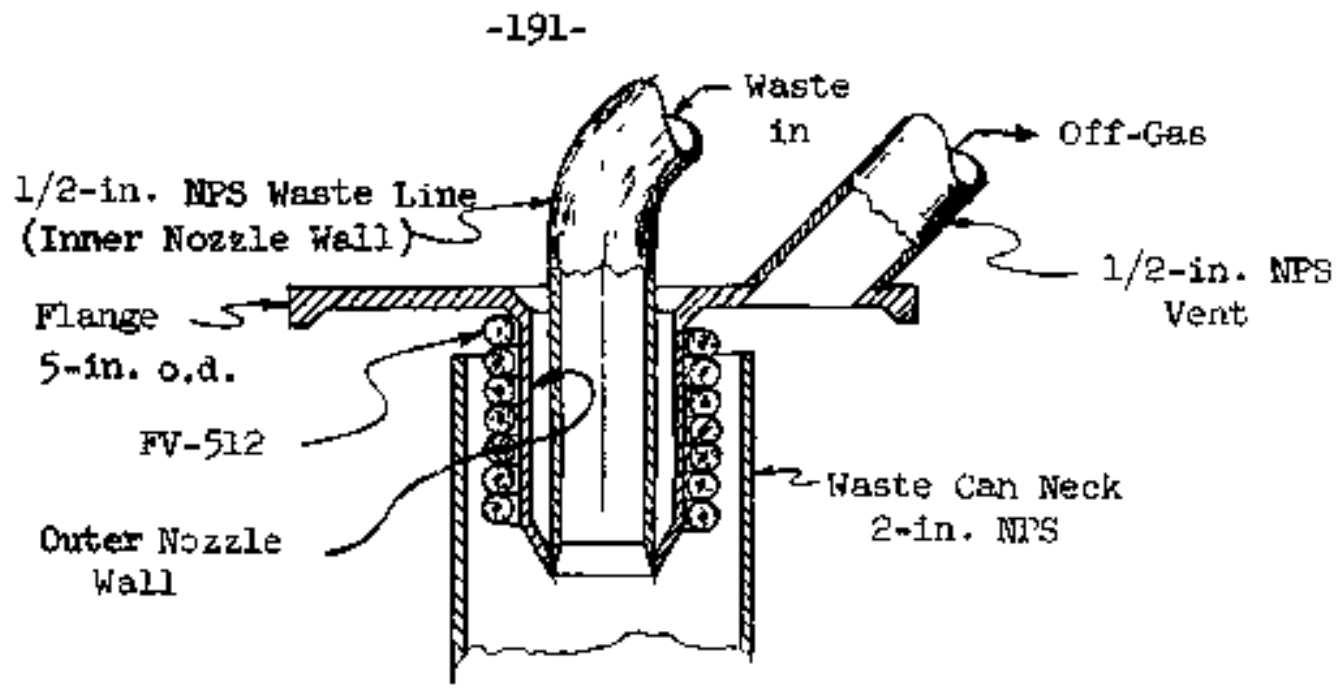

Mark IA Heater: As Showt

Marik IB Heater: Outer Nozzle Well Removed

insulation is not shown on heater.

The $\mathbb{N}_{f}$ line adjacent to tip for purging tip during waste trangfer is not shown.

Fig. 23.4A. Wark I Waste Nozzle and Heater

Insulation is not shown on heater.

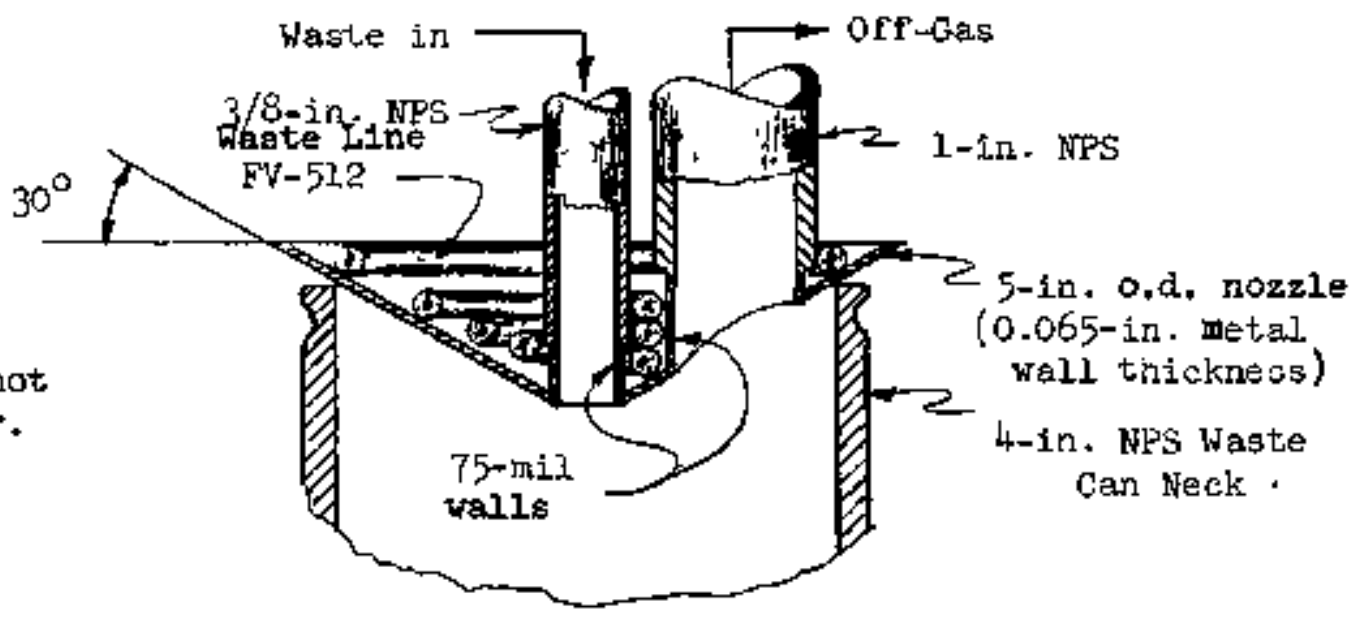

Fig. 13.4B. Mark II Waste Hozzle and Heater 
13.4.7 Al 0 , 3 Trap, FV-117

The purpoge of this trap showm in F1. 13.5 (on same page as Fig. 13.3) vas to remove radioective $\mathrm{ZrF}_{4}$ vapor vented from the waste can (Sec. 13.4.1). The trap vas packed with $1 / 4-\mathrm{in}$. $\mathrm{Al}_{0} \mathrm{O}$ and maintained at $700-800 \mathrm{C}$. The line between the vaste nozzle and the trap was kept at $400^{\circ} \mathrm{c}$.

Despite the fact that the $700-800^{\circ} \mathrm{C}$ operating temperature was reportedly low for the $\mathrm{Al}_{2} \mathrm{O}-\mathrm{ZrF}_{4}$ react $10 \mathrm{n}$, this temperature was selected because of the sheath limitation $\left(815^{\circ} \mathrm{C}\right.$ or $1500 \mathrm{~F}$ ) for Calrods (43). "The nocessity for using readily avallable Calrods to heat iv-117 resulted from the limited construction time before the " $\mathrm{L}$ " rins. runs were:

Anelytical data for samples taken from the $\mathrm{Al}_{2} \mathrm{O}_{3}$ trap after the "L"

$$
\begin{aligned}
& \text { a. Activity of } \mathrm{Az}_{2} \mathrm{O}_{3}:^{\mathrm{c}} \\
& \alpha: \text { None } \\
& \text { 0-7: At inlet }-\sim 18 \mathrm{mrem} / \mathrm{hr} \\
& \text { At outlet - } 4 \mathrm{mrem} / \mathrm{hr}
\end{aligned}
$$

Eesentially no $\mathrm{2rF}_{4}$ in the $\mathrm{Al}_{2} \mathrm{O}_{3}$ bed.

About 1.2\% $\mathrm{ar}$ in every light whtish deposit on top flange.

(This material passed the trap.)

From these analytical data, the trep apparently performed no clearcut function during the " $L$ " runs. In addition, the vapors vented from the approximately equimolar $\mathrm{NaF}: \mathrm{ZrF}_{4}$ waste in the " $\mathrm{L}$ " runs evidently presented no serious radioactive hazard although the activity of this waste was -10 $\mathrm{rem} / \mathrm{hr}$. Despite the fact that the trap wes not needed for the " $L "$ runa, two considerations for future work eeem pertinent. First, higher-activity salt nixtures might result in hazardous amounts of radioactive $\mathrm{Zr}$ in the gapors. second, the $700-800^{\circ} \mathrm{C}$ operating temperature for the trap and the $400^{\circ} \mathrm{C}$ operating temperature for the vent line should be increased.

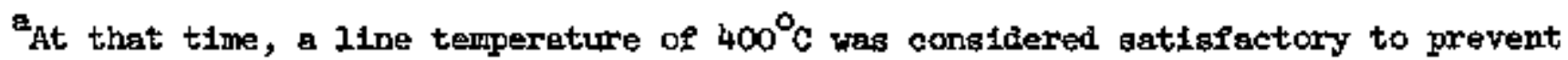
$\mathrm{ZrF}_{4}$ vapor deposition. Since that time, however, experimental work on entrainment and ${ }^{4} \mathrm{KF}_{4}$ vapor in the fluorinator exit gases (Runs $\mathrm{M}-62,63$ and 64 ) indiceted thet $2 \pi \mathrm{F}_{4}$ vapor will condense on a $400^{\circ} \mathrm{C}$ surface.

blso of. Sec. $13,4,8$.

Alpha activity was deternined with an alphs survey meter (Sec. 23.4.9) and $\beta-\gamma$ activities with a cutie ple (Sec. 23.4.10, 16.4.16). 
$13.4 .8 \quad$ Al $_{2} \mathrm{O}_{3}$ Trap Hester, FV $-517^{\mathrm{a}}$

This heater was satisfactgry for keeping the $\mathrm{Al}_{2} \mathrm{O}_{3}$ trap bed at the opereting temperature of $700-800^{\circ} \mathrm{C}$. Tine-to-750 $\mathrm{C}$ was $<3$ hours with a 60 $80 \mathrm{v}$ setting on Variec, TC-117.

$13.4 .9 \mathrm{Al}_{\mathrm{Q}} \mathrm{O}_{3}$ Trap Inlet FIange Heater, $\mathrm{FV}-517 \mathrm{~A}^{\mathrm{a}}$

This heater was adequate for maintaining the flange at $400 \%$. The time-to-400' $\mathrm{C}$ was $<3$ hours wth a $100-\mathrm{v}$ setting on Var1ac, TC-110.

13.4 .10 Waste Dolly, FV -902

The principel disadventage with the FV-902 design was that recesses existed in which spattered ant could collect. These recesaes included holes in the chein as well as a number of hard-to-get-at places in the chain support and the can base-plate.

A can of redicective salt which dropped from the cerrier in Fun $\mathrm{L}-\mathrm{B}$ bent the base-plate. For the one remaining mu, the waste system was used without the carrier since the bent base interfered with properly positionsing the can-cerrier assembly. (Sec. 13,4.1.3.)

13.4.11 Weste Weighiog Device, Fv-904t

The Mark IA and Mark IB waste weighing devices differed only in the size of waste container neck each would accomodate. This instrument was uee principally to qualitatively monitor the waste transfer from start to finish. In adiftion, it was weful in batch measurement.

13.4 .12 Waste Hozzle, FV $-906^{\mathrm{d}}$

The two waste discharge nozzles are show in Figs. 13.4A and 13.4B. The Mark I nozzle was unsatisfactory because: (a) the nitrogen flow aggravated the plugging tendency by cooling the nozzle; (b) the tip of the nozale could not be heated to $550-600^{\circ} \mathrm{c}$ by autoresistance even wthout nitrogen $f(10 \%$ and (c) a suitable calrod or clamshell heater could not be fitted to the nozzle design.

Although the Mark II design was superior to the Hark I in that it could be meintained at $650^{\circ} \mathrm{C}$, some nozzle plugs still formed. In addition, the poor seal (although better than in Maris I) achleved between the nozzle and the can neck allowed salt to spatter during a transfer.

Table 22.2 and Secs. 22.4.1 and 22.4.2. Also Seck 13.4.1 and 13.4.7.

b

Sec. 13.4 .4 and 13.4 .13 .

e

Sec. 13.4.4.

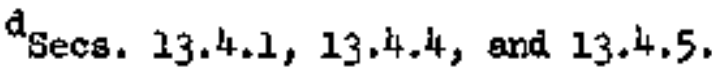


Two aspects of Mark II waste nozzle plugging are pertinent here. First, it was possible by proper operating technique to prevent plug formation following a waste transfer. This could be done by flowing nitrogen through line 18 -106-2 and thence through the waste nozzle long enough after a transfer to ensure the freezing of all residual salt. This prevented a sufficient accumulation of galt to form a plug. Fowever, a plug in line IN-106-2 upstrean from the freeze valve would prevent uslag this technique. Second, the heating of this nozzle was adequate in some cases to melt the nozzle plugs, although experience with the Msrk II nozzle was insufficient to determine whether a plug once formed might pregent a major difficulty.

\subsubsection{Weste Carrter, Fv $912^{a}$}

The waste carrier contained the waste container while filling and until burial.

The Mark IA waste carrier accommodated a larger-neck can than the Mark IB carrier. Two troubles with the waste carrier were experienced. First, the recessed holes in the carrier top tended to collect spattered or spilled salt. Such salt was difficult to remove and, if radioactive, presented a distinct hazard to personnel.

Second, a waste can of radioactive aalt was dropped in Fun $L-8$. Before making the next rui, the faulty door-closing device causing the incident was altered to prevent recurrence. The equipment flas which trisgered this incident was the inadequate provision for retaining the securing bolt on the door-closing device. "The before-and-efter-the-indient views of this device in F1B. 13.6 show that the lip added to the upper steel strap was the difference between a safe and unsafe situation. The arrow in the beforehend view shows the direction in which an applied force would cause the cen to drop from the carrier.

\subsection{Summary and Conclusions}

The waste salt system was operable. The siphon transfer (Mark II) was preferred to the pressure transfer (Mark I). The everege waste tranafer tine wes $7^{+}$hours in the "B" runs and 17 hours in the "L" runs. Sources of magor troubles were:
a. Plugs in the piping.
b. Blowing the freeze valve seal and eliminating the fluarinator heel.
c. Splattering of salt at the waste can.

secs. 13.4 .4 and $13.4 .10 ; 23.4 .16 \mathrm{~b}$.

bThe "as-built" design differed from that shown in ORKL drawing No. E-19704. 


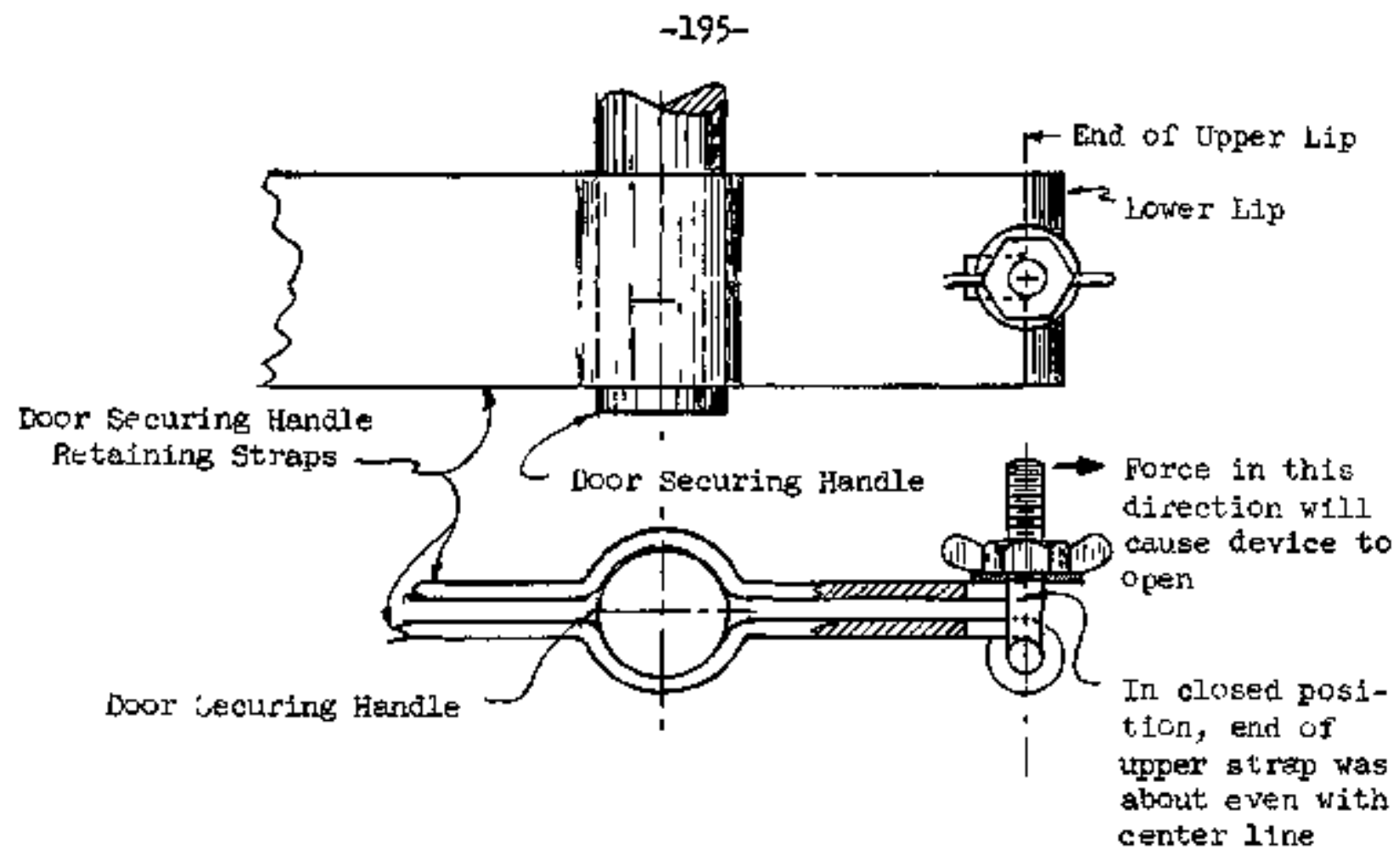

BEFORS THE WWCIDERT

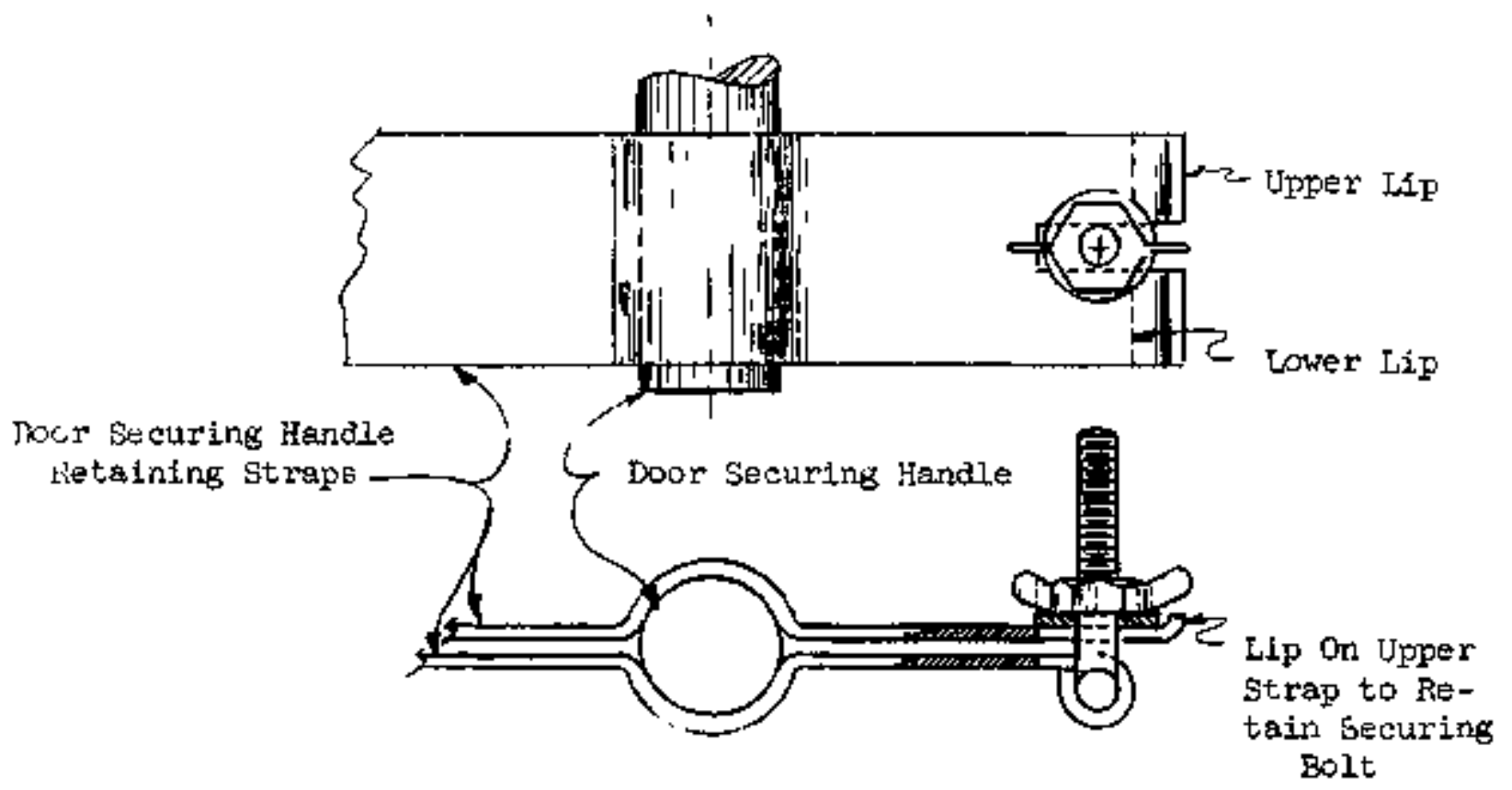

AFTER THE INCIDENS

Fig. 13.6. Before- and After-the-Incident views of the Waste Carrier Door Senuring Device 
d. Unsafe door-closing derice on the wagte carrier.

e. Crack in weste line during Run $\mathrm{C}-8$ waste trensfer.

Plugs formed in almost all cases at cold gpota. Therefore, the uavel romedy was heating the pipe at the plus to $\geq 570 \%$.

Although plug formation occurred in nearly every part of the waste line, the three folloring regions were particularly sueceptible to plugs; (a) waste line adjecent to the FV-100 well, (b) maste nozzle, and (c) freeze valve vent 11nes. The flow blocks occurring in the waste line just outalde of the FV-100 wall resulted from alt freezing in the ahort run or nickel pipe at thila location because this section of the waste line was incompletely heated by autoresistence. This sitwation wes corrected by adding FV-500A in both the Herk I and Mark II weste lines, Although not assessed, the effect on well plugs of moving the FV-100 eutoresistance eround lug from the waste line to the FV-100 flange wes believed to be beneficial. And no dibadvantage to the flange locetion has been found. In addition, sonte trouble resulted from plugs in the internal portion of the weste line in FV-100 above the melt level. This altuation was improved by redesigning FV-50l.

Even though the waste line aurge pots were carefuly designed for autoresistance heating, FV-506A was also required to inerease temperetures $<570^{\circ} \mathrm{C}$.

At the waste nozzle, two complementary means of plug elimination were used; (a) flowing nitrogen through the nozzle at the end of each transfer to prevent plug formation and $(\mathrm{b})$ heating the wate nozzle (witb FV-512) elther to prevent plug formation or to melt a plug which had already formed. This two-fold means of ellminating plugs was more effective in the Mark II destgn. Placing the ground electrode on the nozile did not elininate the neceseity for FV-5i2.

In the freeze valve vent lines, pluge were reduced by avoiding highpresiure $\left(1, \theta_{0},>4\right.$ to $6 \mathrm{psig}$ ) on high-racum (1.e., $>10$ in of $\mathrm{Hg}$ ) conditions during transfer and also py weltiog at the end of the trangfer any plugs formed In the vent linee during the transfer. The Mark II design was slightly better in reducing vent line plugs than was Nark $I$.

The extent of vaste line corrosion was determined only on the Mark II wate line. Resuits indicated corrosion to be severe (21-011 attack) only near the waste nozzle.

Although blowing the freeze valve seal and ellminating the fluoringtior heel occured infrequently, corrective measures vere tiwe-consuning. This problem was virtually solved in the Kark II design rith the 3/8-1n. HPS sehedule 40 wagte ant line and the newly devezoped method of waste tranifer.

Salt spattering at the weate stetion was not elininated.

The faulty design of the waste cerrier door-closure triggered the accidental droppling of the waste cen.'In.Run $L-8$. The remedy was the bolt-retaining lip described.

The etudy of the vent-ayatem conteining the $\mathrm{Al}_{2} \mathrm{O}_{3}$ trap for $\mathrm{ZrF}_{4}$ vapor removal ylelded inconclusive results. 


\subsection{Recompendations}

It is recominended that:

a. Autoresigtence heating continue to be used in waste salt trangfer lines with the FV-100 electrode on the vessel flange and the nozzle-end electrode on the nozzle.

b. 3/8-in. NPS Schedule 40 plpe be used for sazt transfer lines.

c. The use of the siphon transfer be cont1nued.

d. The freeze valve vent lines be redesigned (elther to prevent plug formation or to enable the melting of plugs once formed).

e. There be no section of nickel pipe between the fluorinator well and the Incorel wate line in bew-design waste aystem.

f. The fluorlnator heater be so designed that cold apota cannot occur in the raste line within the fluorinator.

g. The waste nozzle and surge pots in the freeze valve be heated both by autoresiatance and by reslstance heaters such as Calrods.

h. Means be found to ellminate or significantly reduce the spattering problem.

i. The wate carrier be redesigned to eliminate recesses in which spsttered salt might collect and to provide a safe bottom clobure.

j. The waste dolly be redealgned to include a power drive with remote control and to avold recessea in which alit might collect.

k. The use of unit shjelding at the waste station be continued.

1. Additional stuiy be done to determine the need for a chemical trap in the waste vent ine.

13.7 Opereting Procedure: Waste Salt Trangfer (Reviaed June 24, 1958)

Wag
Dete
Time
Operetor

1. Check that waste container is properly in place and ready for use.

2. The following valves in the penthouge should be open: V-27

$v-72$

$v-113$

and $v-223$ or $\mathrm{V}-124$

3. The following valves in the Pentbouse should be closec: v-87c $v \_88$

4. The following valves on the panelboard should be open: $H X-11$ HX -35 $\mathrm{Ex}-36$ 
5. The folloring valves on the penelboand should be cloged: $5 \times-8$ $\mathrm{HX}-12 \ldots, \mathrm{XX}^{2}-14, \mathrm{HX}-16, \mathrm{HX}-32, \ldots, \mathrm{HX}-34$

6. The foilowing yalves in the gallery should be open: $V-70$ $\mathrm{V}-78$ $V-79$ $v=81$

7. The following valves in the gallery shourd be closed: $v-74 \mathrm{C}$

$$
v=75 \mathrm{C}
$$
and $\mathrm{V}-91 \mathrm{C}$

8. Set regulator $P V-8$ at 1 psig

9. Set regulator PV-ly4 at 4.5 psig

10. Set the following purges:

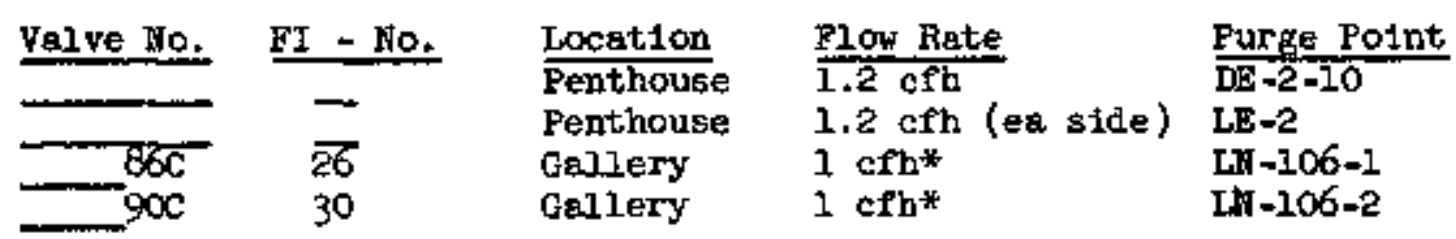

*Enough to raise bob in rotameter.

NOFE: If any of these lines is plugged, notify supervisor.

11. Switch TX-1B $\mathrm{EX}-1 \mathrm{~B}-4$ , and TX-1B-7 to position " $A$ ".

12. Do not proceed beyond this step without signature of Froblen Leader:

'Problem Lesder

13. Do set these controllers on the setpoints given below:

Controller Setpoint TIC $-1 B-3 A$

TIC-1B-7A

PIC - 1B-4A

TIC -11

TIC-108

TIC -110

TIC -111

TIC-112

TIC-113

TIC -FV -517

$500 \circ$ indicate and control

$650^{\circ} \mathrm{C}$ indicate only

$650^{\circ} \mathrm{C}$

$650^{\circ} \mathrm{C}$

$250 \% \mathrm{C}$

$400 \%$

$400 \mathrm{C}$

$600^{\circ} \mathrm{C}$

$620 \%$

14. Adjust these Variacs to setpoints shown. ADVANCE TO ABOUT $1 / 3$ OF THE VOLTAGE SHOWN -- WAIT 10 MINUTES -- THEN INCREASE SETPOINT ANOTHER 1/3-WAIT 5 MTNUITS AND EESET TO VALUE SHONN BELON.

\begin{tabular}{cr} 
ET-1B-4 & 314 enps \\
\hline TC -11 & 120 volts \\
\hline$T C-108$ & volts \\
\hline$T C-120$ & 100 volts
\end{tabular}

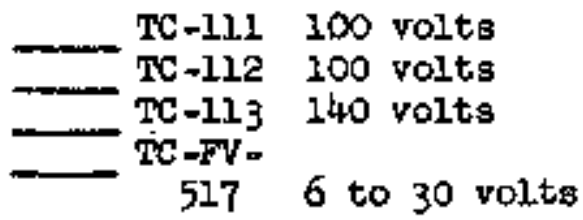

15. When transfer line and freeze valve are up to temperature, record the following dats:

Time

TR-1B-2

TR-1B-4A

TR-IB-5A

WR-IA

LR-2

PR-33

DA -2

16. Get epproval of shift supervisor before proceeding further. 
17. Open V-99 and valve on vacuum line to Cell 1.

18. Have 1nstrument men set vacunm controller on 5 in. water.

19. Set WB-lA between 20 and $30 \%$ (adjuat hydraulic lifting device on weste receiver).

20. Clobe V-86A

21. Open V-86C $\mathrm{V}-86 \mathrm{~B}$ and $v-90 \bar{C}$ , $-90 \mathrm{~A}$ $\mathrm{V}-90 \mathrm{~B}$

\section{Close equais $\overline{12 e x}$ valve between V-86C and V-90C.}

23. Close ECV -11

; when transfer beging watch PI-62 on FI-26 purge line. When this gage reading reaches $10 \mathrm{ln}$. of Hg vecunum the siphon has started -. oper HCV-ll

24. A6 soon ag $\overline{\mathrm{HX}-\mathrm{Il}}$ is closed and until the transfer is complete, record the folloring dete every two to five minutes.

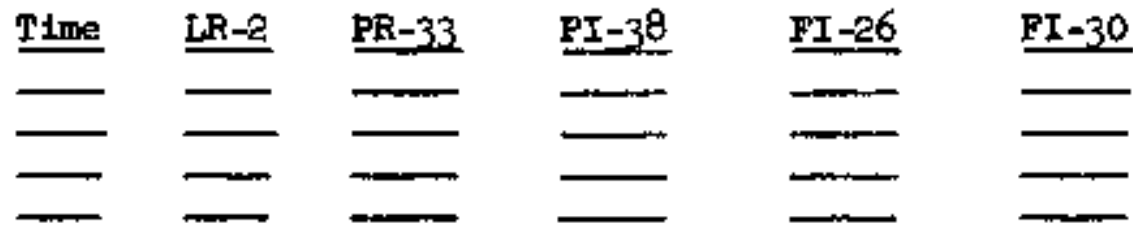

25. To Interrupt aiphon open V-90A fully and then cloge to give $30 \%$ on FI-30

26. Immediately, open $\mathrm{V}-86 \mathrm{~A}$ fully

27. Wait untis LR-2 levele out and then close V-90A

28. Decrease flow throuteh PI-26 to $8 \%$

$\forall-86 c$ and $v-90 C$

29. Increase setpoint on TIC-1B-3A and TIC-1B-7A to $650^{\circ} \mathrm{C}$

30. One hour later, shut off toste loop heaters.

31. After line cools to $\cong 150^{\circ} \mathrm{C}$, close $\mathrm{V}-90 \mathrm{C}$

32. Record th-2

33. Open V-74C $\longrightarrow$ V-75C

$\checkmark-75 c$

$\overline{\mathrm{V}}-8 \mathrm{CC}^{\circ}$ and $\mathrm{v}-9 \mathrm{IC}$

35. Set the following purges at $150 \mathrm{cc} / \mathrm{min}$ : FI-14 FI-26* FI $-30^{*}$ and PI-31

$\mathrm{FI}-15$ (also FI-27),

* Just enough for float to rise of botton retalner.

36. When TR-1B-2 cools below $400^{\circ} \mathrm{C}$, close $\mathrm{BX}-11$. Time

37. When PR-33 ahows 4 psig, open tx-11. Tye 
I4.0 Hitrogen Syotem . . . . . . . . . . . . . . . . . . . 200

14.1 Introduction ...................... . . . . . . . . . . . .

14.2 Equiptinent. . . . . . . . . . . . . . . . . . . . 201

14.3 Operation......................... . . 201

14.3.1 Operating Procedure .................. . 201

14.3 .2 Critical Operating steps ............ 204

14.4 Equipment Evaluetion . . . . . . . . . . . . . . . . 205

14.4 .1 Cylinders . . . . . . . . . . . . . . 205

14.4.2 Manffold.................... . . 205

14.4 .3 Dryer, FV-146.................. 206

14.4 .4 Water Analyzer ................... 207

14.4 .5 Transmitter Racks . . . . . . . . . . . . . . 207

14.4 .6 General Information............... 209

a. Specifications and Procurement of Nitrogen . . 209

b. Materials of Construction ........... . 210

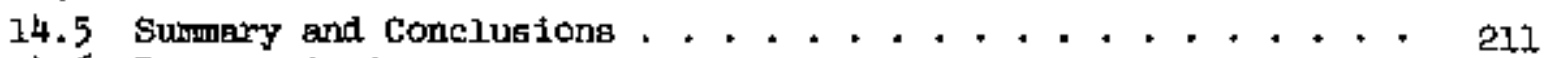

14.6 Recommendations .................... . . 212

14.7 Operat1ng Procedure: Chenging Nitrogen Cylinders . . . . . 212 


\subsection{NITROGEN SYSTMM}

\subsection{Introduction}

The nitrogen system provided the inert gas required for the vessels, instrument purges, and piplng in the VPP. N1trogen instead of air was used as the purge ges for pneumatic-type instruments, and a blanket of nitrogen was maintained in process vessels and pipes at all times as needed. The principal steps in the operation of this system:

a. Keeping full nitrogen cylinders on the two manifold banks.

b. Mointaining the nitrogen dryer.

\section{4,2 Equipipent}

The nitragen syatem equiprent was arranged as shown in Fig. 14.1. Information regerding components is given in Table 14.1.

\subsection{Operation}

\subsubsection{Operating Procedure}

a. Changing eppty nitrogen cylinders (sec, 14.7.1),

1. Keeplng date es required such ss cyl1nder pressures, cyltnder numbers, and mentfold pressure (after putting on full cylinders) on $\mathrm{H}_{2}$ Cylinder Log.

2. Closing cyllnder and manifold valves and moving empty and tułl cylinders as required.

3. Crecking the valve on each full cylinder for an inatent to blow dust out of the valve body.

4. Ogening velve supplying purge nitrogen to the manifold at 5 psig.

5. Coupling each cylinier in turn by first opening the corresponding mantfold and then with $\mathrm{N}_{2}$ flowing through the pigteil connecting the tubing to the cyIInder.

6. Opening all four manifold valves wide, closing the valve on purge line, and lowering the low-pressure regulator to zero.

\footnotetext{
$\mathrm{a}_{\text {"Empty" }}$ cylinder should heve $>75 \mathrm{psig}$ of $\mathrm{N}_{2}$ to avoid contamination from the stmosphere (Sec. 14.4.1).
} 


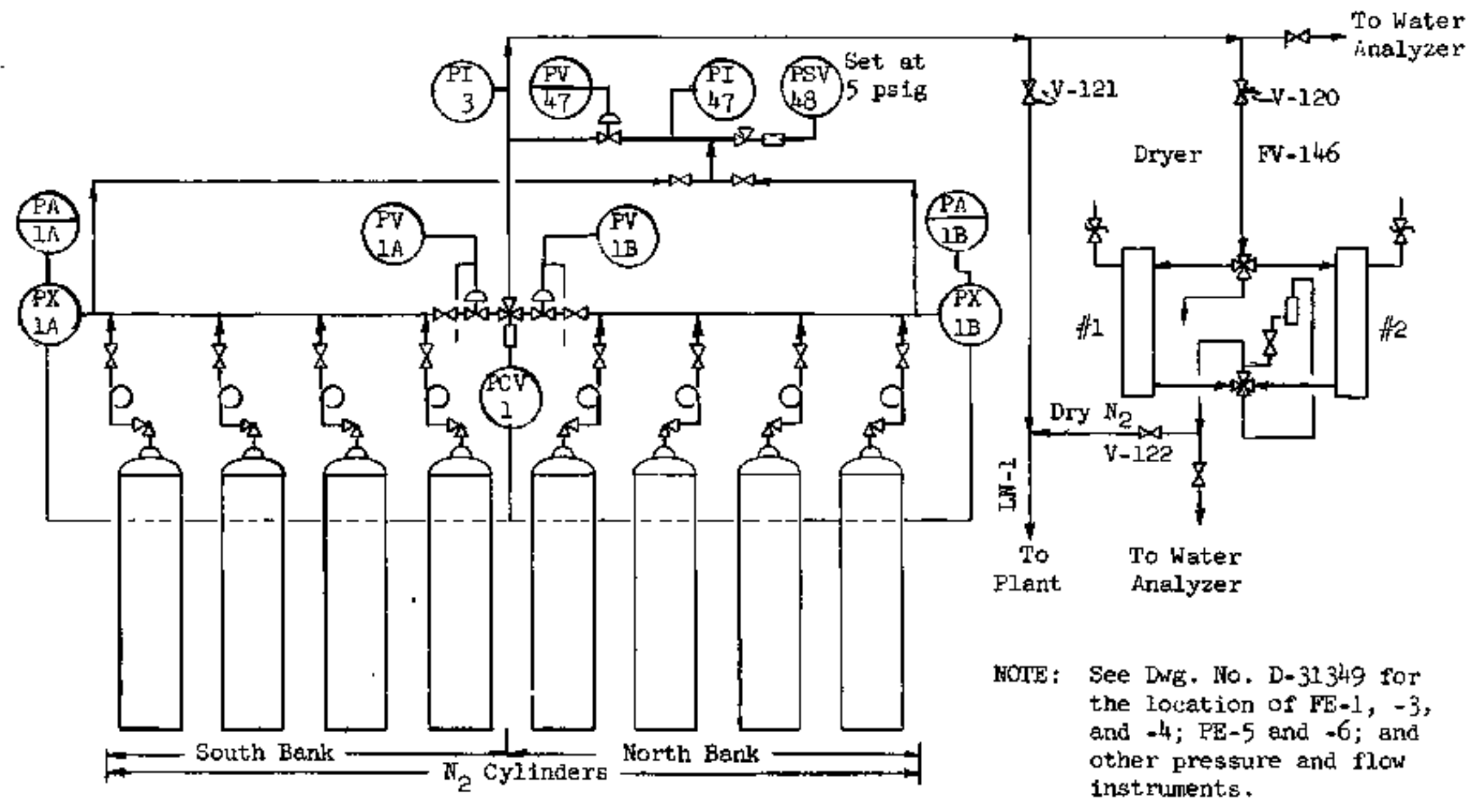

Fig. 14.1. Equipment Arrangement in the N1trogen System 
tatie 1t.1

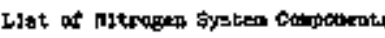

\begin{tabular}{|c|c|c|c|c|}
\hline Cormosente & nonser & 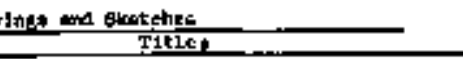 & 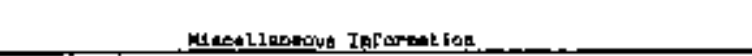 & Anterameas \\
\hline Grlineri & $n-313^{49}$ & MItroged Flowabett & 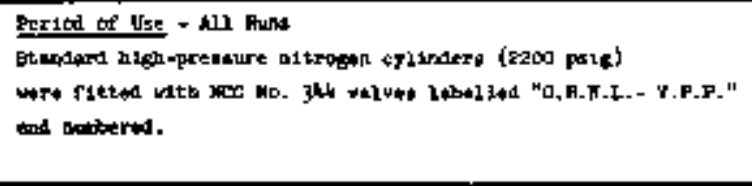 & 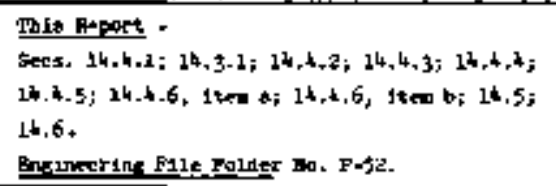 \\
\hline Wintfold & 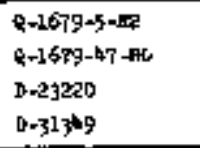 & 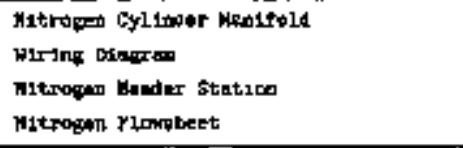 & 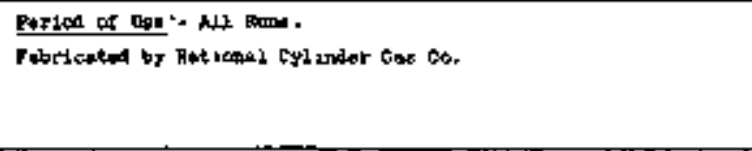 & 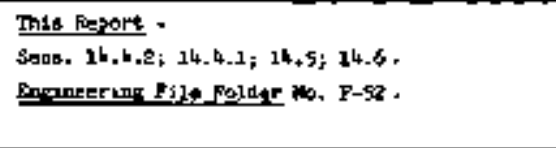 \\
\hline Dryer, $\overline{x y-166}$ & $\begin{array}{l}\text { Yosctors Dug. } \\
30055-7 \\
\text { Bulletio No. } \\
\text { D-200 } \\
0.9409\end{array}$ & 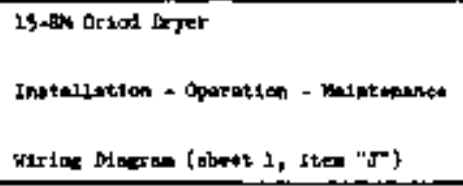 & 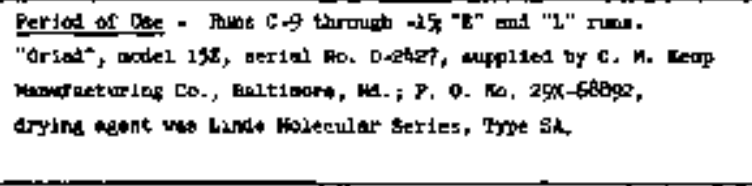 & 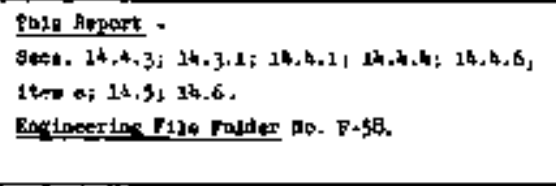 \\
\hline Woker dinelyer & 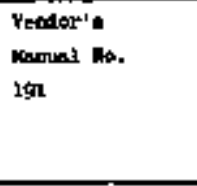 & 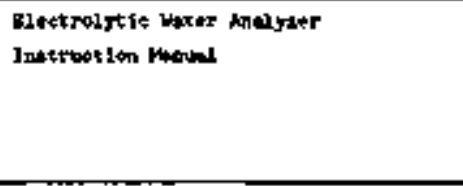 & 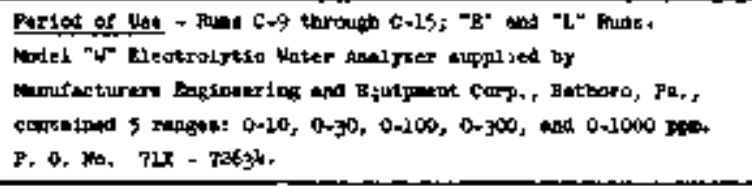 & 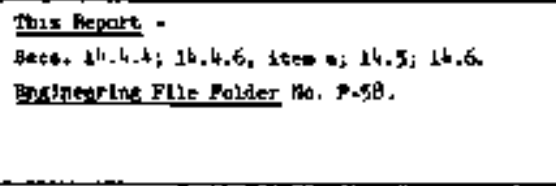 \\
\hline $\begin{array}{l}\text { trmenititer } \\
\text { Panelx }\end{array}$ & $\begin{array}{l}Q-1679-14-102 \\
R=1679-13 \\
8-1679-16\end{array}$ & 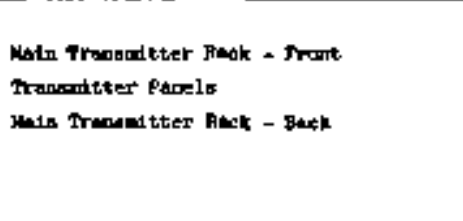 & 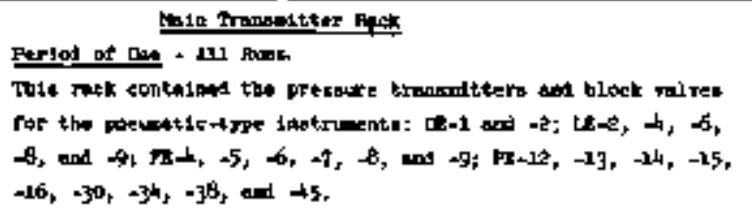 & 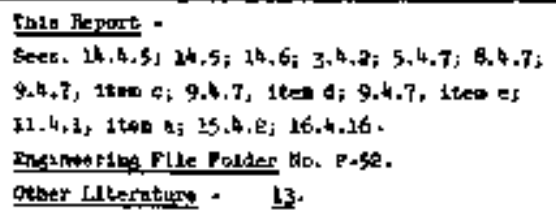 \\
\hline & 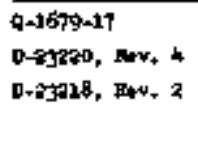 & 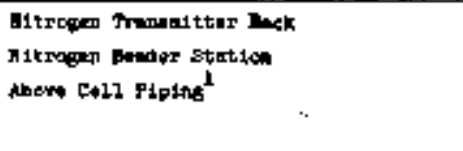 & 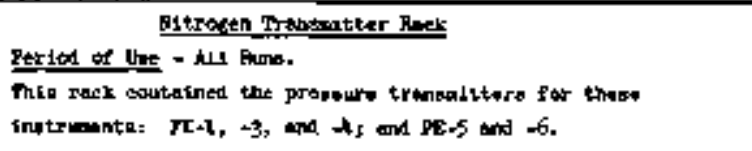 & 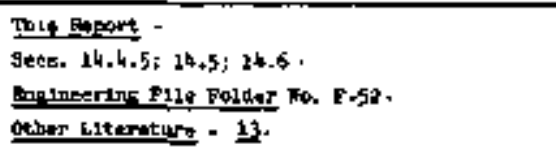 \\
\hline
\end{tabular}

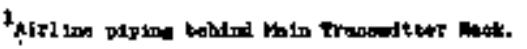


7. Opening each oplinder valve in turn by first cracking the valve until the pressure equalized and then opening the valve fully.

8. Checking to see whether the red panelboard light was out. See Item e., Sec. 14.3.2.

b. Regenerating Oriad Type Dryer

1. Switchling main ralte slowly from Un1t A to thit B (This put Unit $B$ "on-stream" and Unit A "off-strean" for regenereting.)

2. Turning beat on Jinit $A$ and setting the thermostat to maintain a maximum temperature of $400 \mathrm{~F}$. (Maintain a low $\mathrm{N}_{2}$ flow through the unit being regenereted end, if not in use, also on the spare unit at all times to prevent moist air from getting into the unit.)

3. Cutting off heat to Unit $A$ after 4 to 6 hours.

See Sec, 14.7 for the conplete procecture for ahanging empty nitrogen cylinders and Kemp Manufecturing Company's Bulletin No. D-200 - Book Ho. 10,033 (corrected) for the electric reactiration of the Oried type aryer.

\subsubsection{Criticel Opereting Stens}

a. Momenterily crecking the valve on each full cylinder to blow out dust.

b. Purging the plgtell with $\mathrm{s}_{2}$ while connecting to the cylinder to avold getting aix into the nitrogen system.

c. Cracking each oylinder valve (after connecting) to equalize the pressure before openting the valve fully.

d. Narking each cylinder bled to $<75$ psig wo that the nitrogen Bupplier will know to pump out the cylinder before refilling.

e. Checking to gee whether the red light at penelbond hed gone off after changing a bank of cylinders. (If it is not out, the manifold will not bwitch automaticaliy to the full benk when the other bank becomes empty.)

Sec. $14.4 \cdot 3$.

bingineering File Foldar Ho. F-58. The procedure for the water analyzer which is not recorded here 1s in Nenufacturerg' Engineering and Equipunent Corporation' $B$ instruction manual in Englneering File Folder Ho, F-58. 
14.4 Equipment Evaluation ${ }^{\mathrm{a}}$

14.4 .1 Cylinders (느)

Nitrogen was orlginally obtained through the ORNL Purchasing Department from National Cykinder Gas Division of Chemetron Corporation (ICG) in Knoxville. 'By speclal arrangement, VPF cylinders (identified by painted numbers and markings) to be refilled were bled by $K C$ to sesure that they had a positive nttrogen pressure in them before being refilled. Cylinders that were depleted to $<75$ psig were marked by VPF operators for evacuation, purging, drying and pressure testing by ICG before refilling. The NCG flling manfold (Sec. 14.4.2) was checked for positive pressure by bleeding before any VPP cylinders were connected to it. N1trogen was bled frow this manifold and from each cylinder as it was connected to the menifold to prevent entry of alr and/or molsture. A similar procedure was followed in changing cylinders at the VPP manifold; pressure reducting valve PV-47 and relief valve PSV -48 allowed low pressure $\mathrm{N}_{2}$ from full cylinders to purge the section of manifold while cylinders were being changed.

In August, 1958, the nitrogen contrect was let to the Weldine Gas Products Company in Chattanooga, Tennessee. The handing procedure was unchanged.

A covered outdoor storage area for full and empty nitrogen cylinders was prowided on the east dock of Bullding 3019 near the VPP nitrogen supply manifold. No difficulty wes encountered by exposure of this system to out-door temperatures. However, the nitrogen dryer, (Sec. 14.4.3), water analyzer (Sec. 14.4.4), transmitter rack (Sec. 14.4.5), valves and purge rotameters (Sec. 14.4.6b) were housed in the heated operating gallery (Dws. D-23220).

\subsubsection{Mantrold}

Two banks of four cylinders each supplied nitrogen at en initial pressure of $\sim 2000 \mathrm{ps} g$ to the manifold through flexible copper tube "pigtalls" and high-pressure valves." only one bank of eyllnders was used at a time. Each bank was provided whth a pressure-reducing valve (FV-IA or PV-1B, uslally get at 20-30 psiE), a pressure swttch (PX-LA or PX-1B) and a lowpressure alaris (PA-1A or $P A=1 B$ ). When the pressure in the bank of cylinders In use fell to $100 \mathrm{psig}$, the pressure switch automatically actuated the alarn and a 3 way solenold valve (PCV-1) mounted at the junction of the two halves of the manifold. The solenoid valve then closed the depleted bank of cglinders and opened the full bank to the nitrogen header. This system worked quite satisfactorily unt1l the last two weeks of operation, when a worn coil tn the alart annunctator circuit prevented the switch-over. This coil had been in service two years, making some 500 switch-overs.

Bfter the "L" runs, the nitrogen system equipment downstream of the dryer was dismantled and moved to Burial Ground No. 3 (Sec. 23.4.16b). The remalning equipment vas retained for future processing.

becs. $14,3.1$ and $14,4,6 \mathrm{e}$.

sec. 14.4 .1 . 
The nitrogen eupply system was organized as follows (flowsheet

D-31349): Main supply hesder LN-1 from manifold to:

a. Coolant line LN-510-1 for FV-510 fan.

b. Blanket heeder IN-2 for:

1. Salt charging system (LN-102-1 and -2 ; Lis-108-1 and -2 ).

2. Waste nozzle FV-112 (LN-112-1)(I1ne abandoned).

3. Product collecting and sampling systems (LN-126-1).

c. Blanket header LH-4 (originally operated at a higher pressure than otber blankets because of waste dip leg in $F v-100$ ) for:

1. FV-103 inlet purge (LN-100-1).

2. FV-106 purges (LN-106-1 and -2).

d. Penthouse supply header ( $\mathrm{L} / \mathrm{H}-3)$ for;

1. Fv-100 sampler blanket (IN-955).

2. Fing-joint flange lekk-detecting system (LAl-FLD).

3. Main inetrument transmitter rack (LAH-MRR).

e. Vacurm rellef gas to vacurum promp FV 420 (1,N-420-1).

f. No $-F$ supply to fluorinator $F-100$ and absorbers FV-120 and 121 (1N-12I-1).

g. Purge for $F_{2}$ syotem (LW-FTR-1).

14.4 .3 Dryer, FV-146

The oriad type dryer was bat1sfactory. It maintained the water content of the nitrogen supplied to the VPP at $<$ one ppm under these conditions.

a. Rate of regenerstion - once a reek (Sec, 14,3,1b).

b. Average moisture content of $\mathrm{H}_{0}$ to the dryer - probebly between 10 and $50 \mathrm{ppm}$ (Sece. 24.4 .4 and 14.4.6a).

c. Rate of $\mathrm{N}_{2}$ usage - about 1000 standard cuble feet per day."

\footnotetext{
The water content of the $\mathrm{N}_{2}$ was determined with the Model $W$ Electrolyt1c Water Analyzer (Sec. 14.4.4). No oxygen anelyses were reade of the $\mathrm{N}_{2}$ in VPP (Sec. 14.4.1).

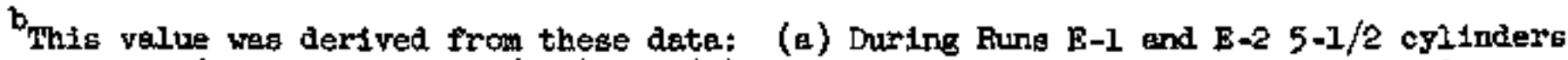
were used ( $\sim 1100$ std cu $t /$ /asy) and (b) during kuns $L-5$ through -9 five cylinders were used ( $\sim 1000$ std cu $\mathrm{ft} /$ day).
} 


\subsubsection{Water Analyzer}

The water analyzer apparently worked satisfactorily. This instrument was calibrated by the Instrument Division. It consistently showed that the dried $\mathbb{N}_{2}$ had a lower moisture content ( $<1 \mathrm{ppm}$ ) than did the cylin$\operatorname{der} \mathrm{N}_{2}(10-50 \mathrm{ppm}$, Sec. 14.4.6a), as would be expected. The instruction manual is in Engineering File Folder No, F-58.

\subsubsection{Transmitter Racks ${ }^{\mathrm{a}}$}

The main transmitter and nitrogen transmitter racks were satisfactory (Sec. 15.4.2).

The main transmitter rack (in Penthouse, Fig. 14.2) contained the pressure transmitters, block valves, and " $C$ " clamp rotameters for the pneumatic-type instruments: DE- 1 and -2 ; LE-2, $-4,-6$, and -8 ; FE-5, $-6,-7$, b -8 , and -9 ; and $\mathrm{PE}-12,-13,-14,-15,-16,-30,-33,-34,-38$, and $-45(13)^{\mathrm{b}}$. Nitrogen was the purge gas for all instruments requiring purges (except $\mathrm{FE}-9$ ) and was supplied to this rack from line LN-3. Minor alterations were made in this transmitter rack from time to time. Major troubles were:
a. $F_{2}$ and/or $\mathrm{UF}_{6}$ getting into the pressure transmitters and purge rotameters. Three measures in addition to those normally exer- cised in operations were taken to prevent this: (a) installed Hoke No. 413 valves in the instrument lines between the cells and main transmitter rack to give purge shut-off as required; (b) permanently capped off instrument purge lines for FE-5, -6 , and -7 ; $\mathrm{PB}-12,13,14,15$, and -38 , after Run $\mathrm{E}-3$ (Secs.

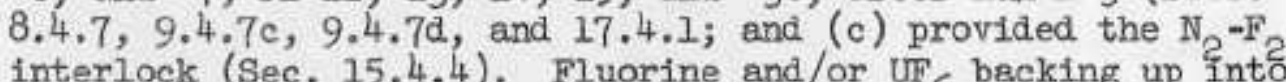 interlock (Sec. 15.4 .4 ). Fluorine and/or UF backing up into
instrument purge lines damaged and/or contaminated lines, rota- meters, and instruments. An example of what could happen was demonstrated when $F_{2}$ initiated a fire in one of the plastic tubing lines. (Plastic tubing was used extensively in instrument lines carrying air or nitrogen. The plastic tubing was both cheaper and easier to install than copper tubing.)

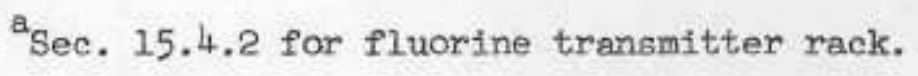

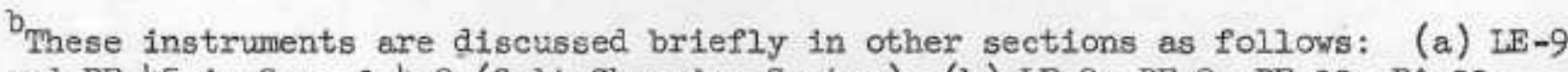
and PE-45 in Sec. 3.4.2 (Salt Charging System); (b) LE-2, DE-2, PE-33, PA-33, $\mathrm{PX}-33 \mathrm{~A}, \mathrm{PX}-33 \mathrm{~B}$, and $\mathrm{PA}-57$ in Sec. 5.4.7 (Fluorinating System); (c) FE-5, PE-12, $\mathrm{PE}-34$, and $\mathrm{PE}-38$ in Sec. 8.4 .7 (Absorbing System); (d) FE-6, -7, -8; PE-13, -14, -15 , and -16 in Secs. 9.4.7c, 9.4.7d, and 9.4.7e (Cold Trapping System); (e) $\mathrm{LE}-4$ and FE-9 in Sec. 11.4.2a (Scrubbing System); and $(f)$ DE-1, LE-6 and PE-3O in Sec. 16.4.16 (ARE Charging System). 


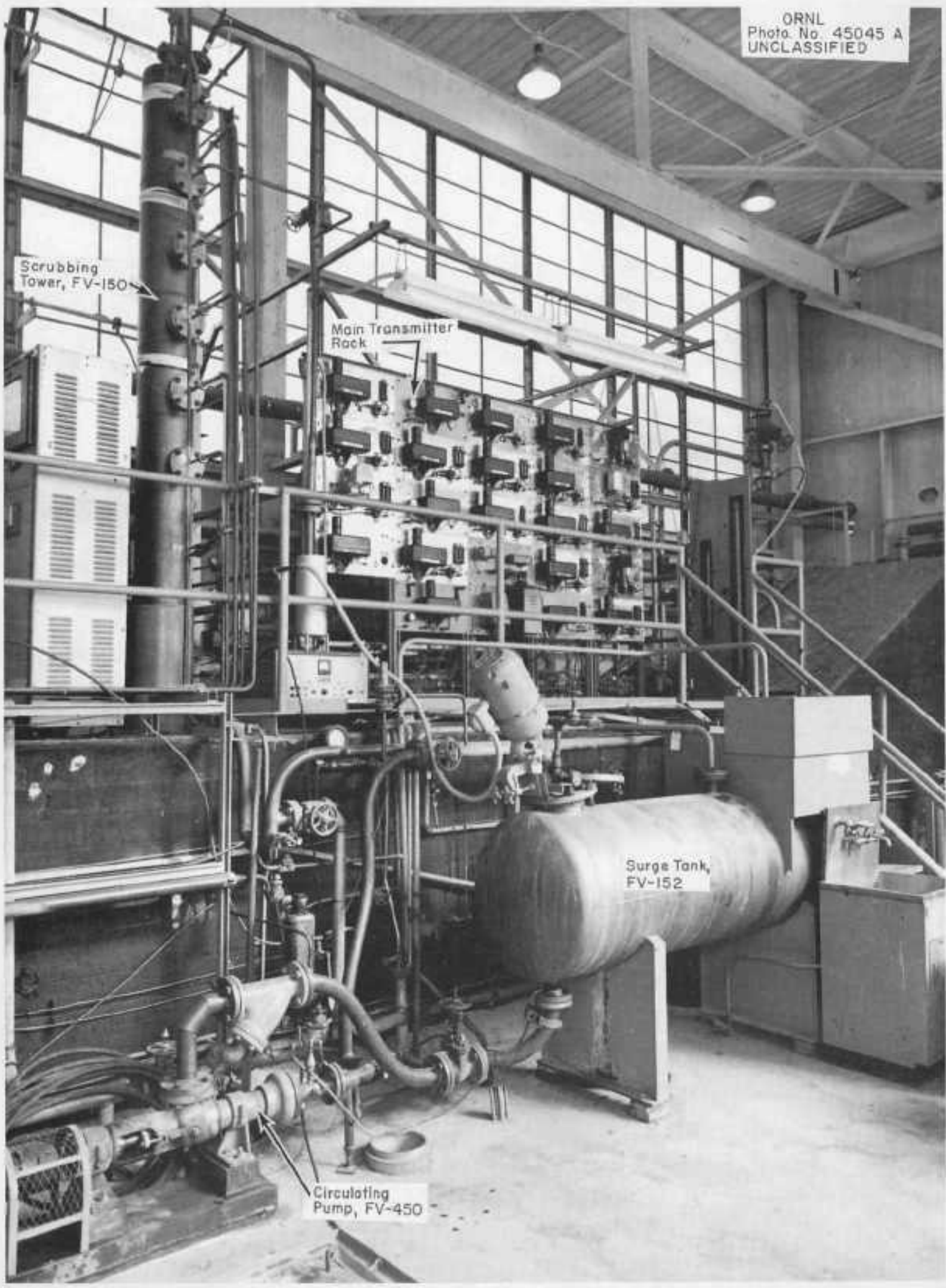

Fig. 14.2. Main Transmitter Rack and Scrubbing Equipment in the Penthouse. 
b. Instruments not being removed from service resalting in transmitter bellows damage. This occurred with DI -1 (Sec. 16.4.16). Correctly removing an instrument for service required opening the by-pass valve on the "block" before clostng the high- and low-presgure purge line valves on the "block". (Then, correctly putting an instrument into service was done by opening the purge line valves before closing the by-pass valve.)

The nitrogen transmitter rack (1n Gallery) fecelved nitrogen from line $\mathrm{LH}-1$ and conteined the presalme transmitters for instruments FE-1, -3 , and -4 ; and PE-5 and -6 (13). Two additions were made:

a. FI-33 to provide a continuous purge through line LN-121-1 when FCV-1 was not in use to prevent $F_{2}$ from entering the FR-1. pressure transmitter. (This system still required that FCV-l be opened slightiy.)

b. FI-34 to meter $\mathrm{H}_{2}$ in the $0-37$ liters/min range since the FR-1 range was 80 great $(0-200$ liters/min). (After the range of FK-1 was changed to $0-22$ SIM, FI-34 was no longer needed.) Aside from the fact that the range of the first FR-l was too great, all of these instruments were satisfactory.

\subsubsection{General Information}

a. Specificetions and Procurement of Nitrogen

The 11quid-pumped nitrogen stacked in cylinders at ORIL carried only the specification "bone-dry". Over a pertad of severel months in 1957, the following data on this altrogen were collected:

$\begin{array}{lcc}\text { Anelytical Laboratory } & 0_{8} \text { (pom) } & \mathrm{H}_{2} \text { (pm) } \\ \text { Reed Division (J. Leonard) } & 20 & 3 \\ \text { K-25 } & 100 & 10 \\ \text { Analytical Chemistry Div. (Laing) } & 175 & 70 \\ \text { Y-12 Mass Spectrometer } & 195 & 50\end{array}$

It was suspected that the higher impurities reparted vere caused by sample contemination either in collecting or transferring operations. Although no $o_{2}$ removal equipment was installea, no difficulties were encountered that could be assigned to $0_{2}$ in the $\mathrm{N}_{2}$. A dryer and continuous water analyzer were installed, mainly to scavenge water entering the system from en occasional cylinder with high water content or from careless purging during cylinder changing (Secs. 14.4.3 and 14.4.4). The water analyzer readings on $\mathrm{H}_{2}$ sampled downstream from the drier consistently read $<1$ ppm $\mathrm{H}_{2} \mathrm{O}$ (Sec. $14,4,4$ ). 
b. Materials of construction

Nitrogen aeemed to be compatible at the VPP temperatures ( $-60^{\circ} \mathrm{C}$ to $750^{\circ} \mathrm{C}$ ) and pressures (maximum $50 \mathrm{pgig}$ ) with all the meteriala used in the Volatility Process. No nitriding of metale vas observed. It was considered auperitor to helism and argon for VPP use because of its lower cost and essier contalnment.

The original serewed ftttings in $\mathrm{H}_{3}$ aervice (2000 peis forged steel) were difficult to make leak-tight agajnst gas pressure $(0-60$ psig); so most were back-welded. Copper tubing and Swagelok fittings were found more astiafactory then ateel pipe and встеwed fittings for $\mathrm{N}_{2}$ Bervice. Thes were easier to install and to alter in arrangentent and were more leak-tight. Standard llanged joints wlth Teflon gaskets were originaliy used in the cells and on the sleeves through cell walls. Most of these flanged joints were elininated after ome was inadvertently left loose, causins a $10 \mathrm{~s}$ of $\mathrm{UF}_{6}$ from the fluorinator in Run E-2 (22, p. 21) ; copper tubing with swagelok ani/or silverbrazed fittings tere gubstituted for some steel pipe and flanged joints in cells. ${ }^{2}$ Swagelok fittings vere easier to make leaktight than screwed plpe rittings; silver-brazed fittings were ueed to minjmize the number of joints that could be opened by wrenches $(45)$.

The small purge rotemeters ( $150 \mathrm{cc} / \mathrm{m}$ in capeclty), several larger rotameters ( 2 scfm cepecity), and pecked valves (Sec. 17.4.1a) were satisfectory in $\mathrm{N}_{3}$ service. These had pipe fittings where Swagelok, fittings were preferred. However, this fact caused no major difficulty. The slass tubes in several rotameters frosted upon accidental contact with $F_{2}$ and/or tF caused by operational errors. The rotemeters acted as reatrictions to $\mathrm{N}_{2}$ flow and caused the pressure in vessels, dip lines, and piping downstream from them to be several psis lower than the pressure indicated on the $N_{\text {}}$ blanket heeder gauges. This pressure differential increased the difficulty of maintaining penumatic balance in the process systen durins certain selt transfers. Bypass valves were, therefore, Installed around the $\mathrm{N}_{2}$ blanket rotameters to reduce the presgure drop. Hoke Ho, 1 ig7 bellows. gealed valteg were installed downtream frow the rotameters and tbeir bypasses to provide e means of 1solating the $\mathrm{H}_{2}$ system from the process system during leak test5. This was the "c-velve" arrangement shown in line LN-1,08-2 and in other lines on Dwg. D-31350.

sec. 19. 
Troubles with $\mathrm{N}_{2}$ valves as delineated elsewhere were:

a. Check valve near PI 433 was never satiafactory (Sec, $17,4.1$ ).

b. Safety valves (Sec. 17.4.1) and packed valves (Bec. 17.4.1) were bources of insignificant continuous leaks.

c. Pressure regulators such as FV 8 were hard to adjust to low gas pressures because the range was too preat (Sec. 17.5).

\subsection{Summary and Conclugions}

Nitrogen having $\sim 10$ to 50 ppm of $H_{2} 0$ and $\sim 100$ ppm of 0 wes obtained at an initiel cylinder pressure of $2,000 \mathrm{psig}^{2}$ in VPP cylinders. The pressure of this gas was reduced to 20 to $30 \mathrm{psig}$ before entering the plant. The nitrogen then flowed through en oriad type dryer and into the VPF. A continuous water analyzer irdicated that the $\mathrm{H}_{0} \mathrm{O}$ content was maintained at $<1$ ppm. The oxygen was not remoyed, however. ihls nitrogen was evidently compatible at VPP temperatures $\left(-60^{\circ} \mathrm{C}\right.$ to $750^{\circ} \mathrm{c}$ ) and pressures (max of $50 \mathrm{psig}$ ) with all materiale of construction.

The manifold upstream of the dryer conteining two 4-cylinder banks of nitrogen was fitted with an automatic switch-over from an empty ( $<100>75$ psig) bank to a full bank. This manifold was virtually trouble-Iree. The oriad type aryer and water analyzer evidently operated satiafactorily.

The nitrogen transmitter rack conteining pressure transmitters for FE-1, FW-3, FE-4; PE-5 and PE-6 required only minor design changes such as afing FI -33 and FI -34 .

The main transmitter rack containting preseure transmitters, "C-clakp" rotameters, and "block" valves for most of the remajning pneumatic-type lngtruments vas aat1sfactory. Mejor troubles arose from $\mathrm{F}_{2}$ and/or WF $_{6}$ backing up to the reck and froul inproperly removing instruments from sêrvice.

Leaking joints comprised the major difficulty with the nitrogen system, To eliminate some leaks the original screwed fittings were back-welded. In other leaking joints, steel pipe and flanges were replaced vith copper tubing and Swagelok flttings as for the loose flange through which the UF 6 leak in Run $\mathrm{B}-2$ occurred. Generaliy, using copper tubing with swegelok joints eliminated leaks originally occurring in screwed pipe fittings and standerd flanges with flat gaskets.

Rotameters were subject to smell continuovs leaks as well as to some attack by $\mathrm{F}_{2}$ and $\mathrm{UF}_{6}$. These leaks were considered 1nsigaificant. After Run E-2, the "C-valve" arrangenent was installed to 1solate the $\mathbb{H}_{2}$ system from the cell. plping. The check valve near PI-43 vas never satisfactory. The safety valves exhibited insignificant continuous leaks as did the pecked valves. The pressure reducing valves such as FV.8 were difficult to adjust to low gas pressures. 


\subsection{Recormendations}

It is recommended that;

a. Ali $N_{2}$ piping in the Gellery downstrean from the $\mathrm{N}_{\mathrm{f}}$ aryer be removed and replaced vith suitably sized copper tublng contalning Bwagelok joints except where flow orif1ces, pressure reducing valves, and other essential devlces require pipe. Tubing should be properly supported to avold sagging and to protect the joints. A centrelly loceted penelboerd for mounting purge rotameter should be provlded. Access to the rear of this panelboard is required. A rack to support all $N_{2}$ etetion instrutrent transmitters should be provided.

b. A means for keeping $F_{2}$ out of $i_{2}$ lines be provided. The best of these destgns should be used: (a) separete $\mathrm{N}_{2}$ supply for the $F_{2}$ station, (b) more reducing stages in a system similar to the exfating one, and (c) $\mathrm{H}_{2}-F_{2}$ interlock similar to that deacribed in sec. 15.4 .4 .

c. The by-pass around FI-34 and V-93 be altered to 1nclude the by-passing of FCV-1. In eddition to FI-33, this by-pass should include a suit. able manually operated valve. Thle arrangement would make it posstble to keep $N_{2}$ pressure at all times in line $L N-121-1$, thereby helping to prevent molten salt plugs in the $F$ F-100 $F_{2}$ filet live wheh HCV -8 is opened while no $F_{2}$ is flowing (sec. 5.6 ).?

d. Commerctal nitrozen be tried as a substitute for "VPP" nitrogen described herein. "Commerctal nitrogen" referg to that atocked in ORAL Stores which differed from VPP nitrogen in two ways; (a) not contained in special cyllnders and (b) filled without extra precautions.

e. The preseure reducing valve $\mathrm{PV}-8$ and others as needed be replaced with valves having a lower output pressure range to facilitete setting lov line pressures.

\subsection{Operating Procedure: Changing Hitrogen Cylindexs}

Initial

When Complete

1. Record whether north or south benk of manifold is being changed.

2. Record nitrogen pressure on that bank: bigh-presiure gage: Psig; low-pressure gage: psis.

3. Record cylinder numbers (left to right): VPP

4. Close all four cylinder valves.

5. Close the four manifold valves connecting to the cylinder pigtails.

6. Using line lever (to prevent twisting tubing) and open-end or crescent wrench, disconnect cyilnders.

7. Put caps on used cylinders and teg each cylinder. Tegs should show (1) VPP cylinder number, (2) pressure, (3) date, and (4) operator's neme. 
8. Hove empty eylinders to north end of storage reck and strap in place.

9. Place four full cylinders of nltrogen in manifold rack. Record cylinder numibers: VPP -

10. Open valve supplying purge to the manifold at 5 psig.

11. Before connecting each cylinfer, crack the cylinder vaive for an instant to blow dust out of the valve body.

12. Comnect each cylinder In turn by firgt opening the corresponding mantfold, and then while the nitrogen flows through the pigtail, connect the tubing to the cylinder.

13. Open all four manifold valveg whde after first cracking to equalize pressures. 14. Close valve on purge line, and lower low-presaure regulator to zero. 
15.0 Eluorine System , , ......., , , , , , .......

15.1 Introduction

15.2 Equipment .............................

15.3 Operation...........................

15.3.1 Operation Procedure ............... 215

15.3.2 Critical Operating Stepg . . . . . . . . . . . 220

15.4 Equipment Evaluation . . . . . . . . . . . . . . . 221

15.4.1 Tank Trallers, Fv-161 and -162. . . . . . . . . 221

a. General Information ............... 221

b. Autometic High $\mathrm{F}_{\mathrm{z}}$ Flow Shut-of ....... 223

15.4.2 Pluorine Transidtter kack . . . . . . . . . . 225

a. Traller Switching Device............ . 225

b. Renote Manual Shut-off ............ 225

c. Orifice-3elector Device . . . . . . . . 226

d. Other Instruments............. 226

e. Fluorine Detection............... 227

15.4.3 FV-163, HF Trap and Heater (FV-563) . . . . . . 227

a. General Informat1on ............. 227

b. HF Removel by HF Trap ............. 22?

$15.4 .4 \mathrm{~N}_{2}-\mathrm{F}_{2}$ Interlock . . . . . . . . . . . . . . . 929

в. Purpose . . . . . . , . , . . . . . , 229

b. Componenta..................., 229

c. Operation ................... 231

d. Discubsion ..................., 231

15.4.5 Materials of Construction . . . . . . . . . . 232

a. Valves and Piping. ..............2 232

b. Other Materials............. 233

15.5 Stmmery and Conclueions.................. 235

15.6 Recolmendations . . . . . . . . . . . . . . . . 237

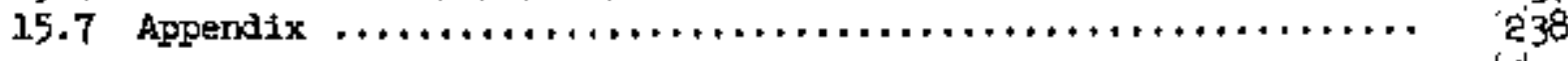

15.7.l Operating Frocedure: Chenging Fluorine Tanks . . . 238

15.7.2 Operating Frocedure: Furging Fluorine Line $\# l$. . . 239

15.7.3 Operating Frocedure: HF Trap Operation 240

15.7.4 Operating Procedure: Fluorine Conaltioning Procedure 242 


\subsection{Introduction}

Fiuorine was used in the Volatility Process as an oxidizing agent for comverting WF $_{4}$ in the molten salt to UF which passed from the salt as a gas subsequently collecting on FaF in the absorbers. Fluorine was also used to desorb UF from NaF in the absorbers and to leak-test joints. The principal steps in operating the fluorine systen were:

a. Maintaining an adequate supply of fluorine in the tank trailers.

b. Flowing fluorine at controlled flow rates through the HF trap from the trailers into the VPP.

c. Scrubbing fluorine from the vaste geses.

\subsection{Bquipment}

The general arrangement of the fluorine system is shoun in Fig. 15.1. Details of the individual conponents are given in table 15.1 .

\subsection{Operation}

\subsubsection{Operating. Procedure}

Steps in operating the fluorine system were:

a. Hooking up the $F_{2}$ Tank Trailers and flowing $F_{2}$ into the VPP.

1. Connecting the copper pigtails to the tratler mentiolds, tekins adequate precautions ageinst residual $\mathrm{F}_{2}$ which might be releesed.

2. Making certain the serubber is operating and hes sufficlent $\mathrm{KOH}$ to react with the $\mathrm{F}_{2}$ to be flowed to the Plant (Sec, 11.3 .1$)$.

3. Purging the trailer manfolds and all connecting lines with $\mathrm{N}_{2}$

4. Shutting off the air to FCV-2; nearly shutting off the alr to FCt 1 and starting a slow purge of $N_{2}$ through FI-33; and opening $V-81$. (This isolated the $\mathrm{N}_{2}$ end $\mathrm{F}_{\mathrm{q}}$ systems and provided a low $\mathrm{N}_{2}$ purge through FCV-l to prevent $F_{2}$ from enterIng tbis talve, )

\footnotetext{
Condtioning (Part e) was necessary only in Part a as indicated. In parts a, b, and $c$, the syrtem was either not opened or opened coly momentarily to atr while being blanketed with nitrogen, in which case reconitioning vas unnecessary.
} 


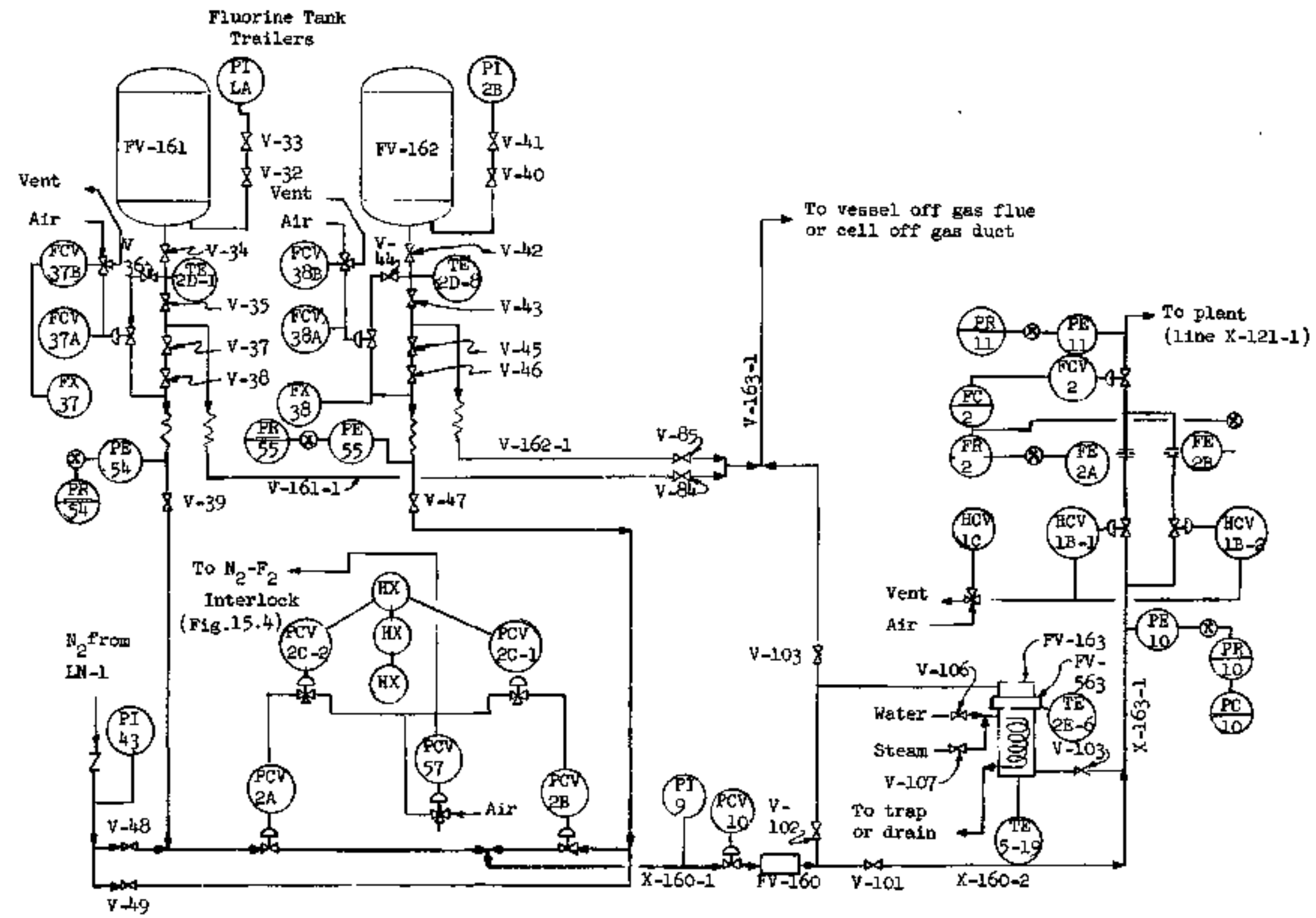

Fig. 15.ג Egulpment Arrangement in the Fluorine Sy日tero 
Table 15.1

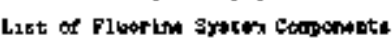

\begin{tabular}{|c|c|c|c|c|}
\hline Con ponent & Lrevt & and Gxatohns: & Mlonellanecose Infornotion & 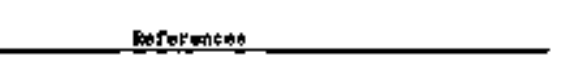 \\
\hline 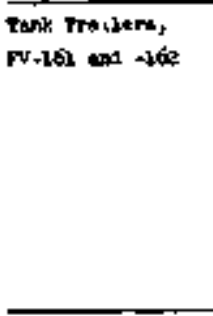 & 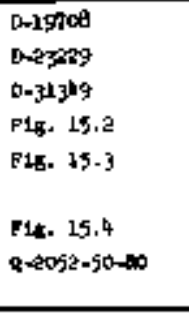 & 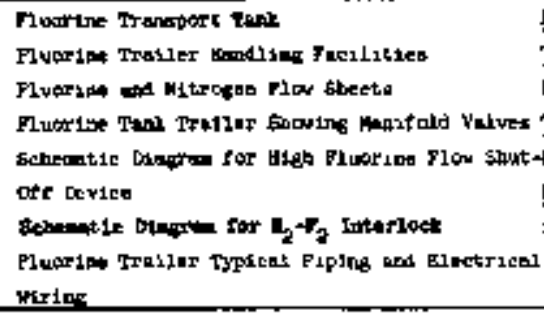 & 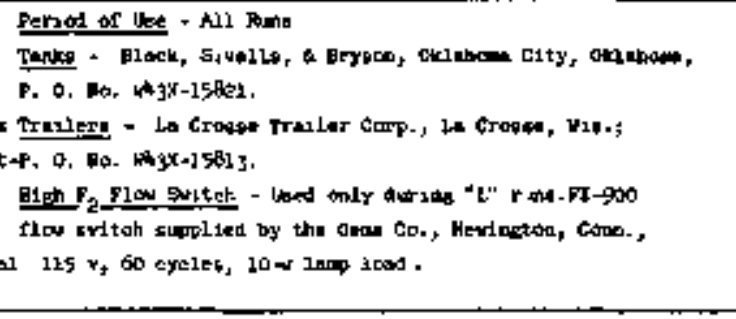 & 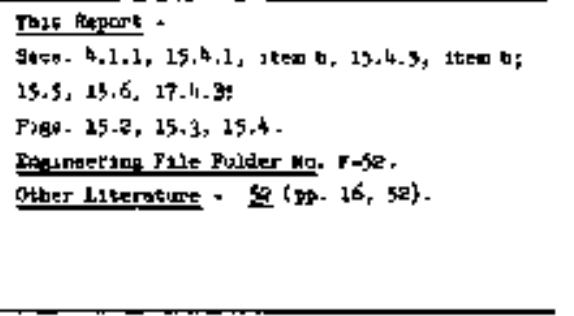 \\
\hline $\begin{array}{l}\text { Flworint } \\
\text { Trananitar Reth }\end{array}$ & $\begin{array}{l}Q=1679-16-10 \\
Q-1679-19-160\end{array}$ & 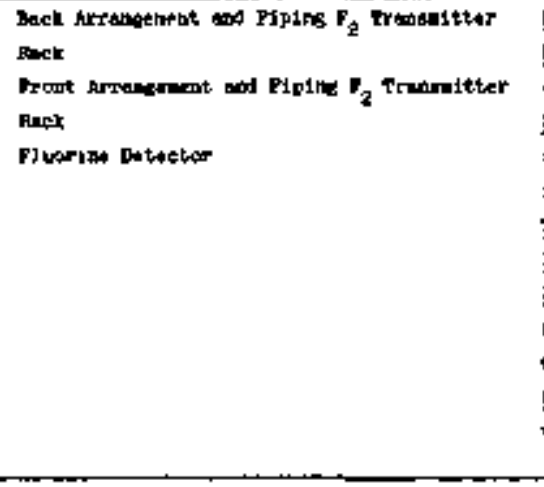 & 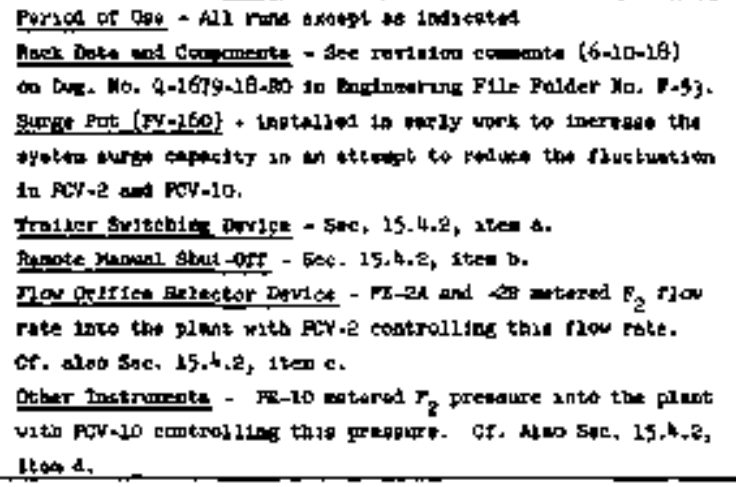 & 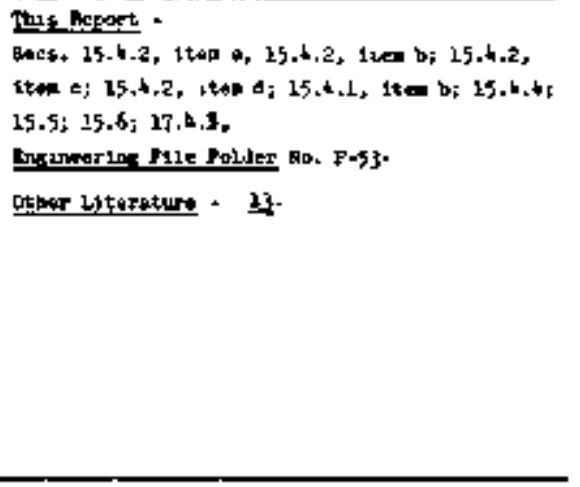 \\
\hline 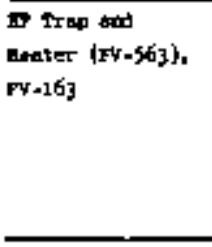 & 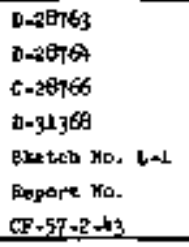 & 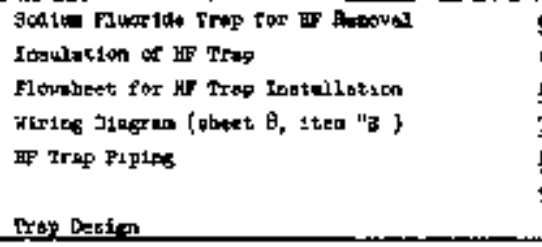 & 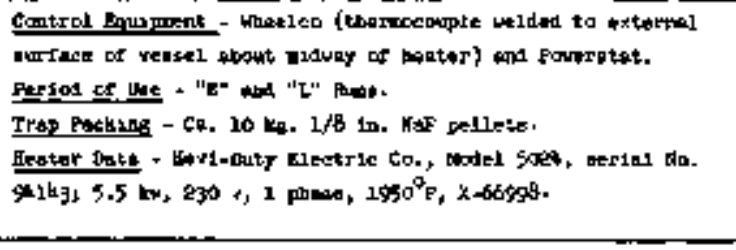 & 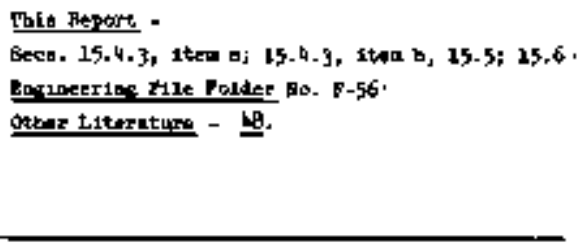 \\
\hline $\begin{array}{l}n_{2}-P_{2} \\
\text { Inter10xx }\end{array}$ & $\begin{array}{l}\text { D-34687 } \\
\text { P28. 154 }\end{array}$ & 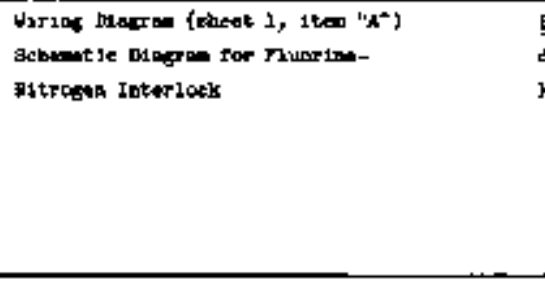 & 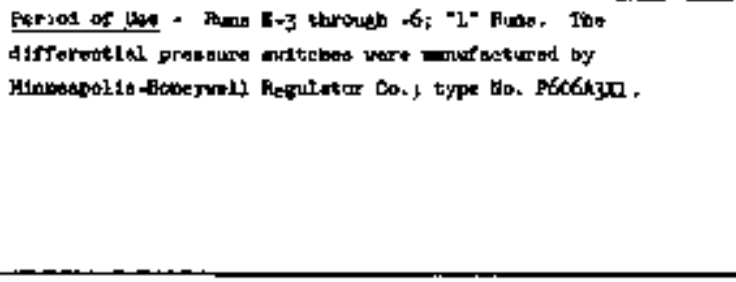 & 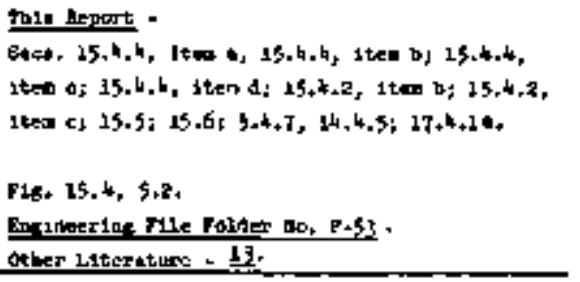 \\
\hline
\end{tabular}


5. Selecting a trailer to use which has more then 15 psig of $\mathrm{F}_{2}$; otherwise, the autcmatic switch-over would switch to the other trailer.

6. Setting the trailer manifold and other valves for the oelected trajler. (Assume that the ortfice selector device no longer existed since this was the case in the latter part of the VPP work. Otherwise, it would be necessary to select the orifice for use.)

7. Energizing the bigh $F_{2}$ flow shut-off device, throwing the $F_{2}$ menual emergency ohut off awitel to "on," and opening PCV-16

- and FCV-2. (Usually PCV-10 was set at 4-I/2 psig with FCV-2 being set at the desired flow rate, )

8. Preparing the other traller for guttch-over by aetting the trailer manfold and other valves and energizing the high $F_{2}$ flow shut-off device.

9. (When the presaure in a trailer was reduced to $15 \mathrm{psig}$, the automet 1c trailer sultching device took it "of $t^{-s t r e a m " ~ a n d ~}$ put the other treiler "on-gtrean,") Preparing the 15-poig treiler for shipment by closing tratler mantfold valves, de-energizing the bigh $F_{2}$ flow shut-off device, purging tratler mancfoid valves, dieconnecting the copper pigtalls, capping the tubing connectors on manifold, and closing the tratler doors.

10. Cutting off $F_{2}$ flow es required by shutting off PCV-10, FCV-2, and then throwing the $F_{2}$ menuel emergency shut-off switch to "off."

1I. In an energency, throwing the $F_{2}$ wenuel emergency shut-off swltch to "oft" gtopped $F_{2}$ elow.

b. Using the BF trap。

1. Setting the necestary valves.

2. Maintaining the center of $\mathrm{HaF}$ bed at $100-105^{\circ} \mathrm{C}$ with $\mathrm{FV}-563$.

3. Adjusting the weter supply to trap heat exchanging coil to meintein the bottom of the NaF bed at $25^{\circ} \mathrm{C}$ (TR-2E-12).

c. Regenerating the HF Trap

MOIE 1: During operstions, the HF trep was regenerated after ebout every 5 runs. Tests with $\mathrm{N}_{2}-\mathrm{HF}$ mixtures indiceted that vas still essentially complete at an HF loeding of $>714$. on $9.7 \mathrm{~kg}$ of NaF pellets as delineated in Sec. 15.4.3.

NOTE 2: Because of the piplng arrangement, FV-1.63 regeneration wes done only when $F_{2}$ wes not being ueed. 
1. Adjusting valves at $F_{2}$ 8tation, in Penthouse, and at Main Panelboard es required.

2. Throwing the $F_{3}$ manus] emergency shut- $\alpha$ ff switch to "on" and Betting PCY $-10^{2}$ et 4 psig.

3. Adfusting flow rate of the $\mathrm{N}_{2}$ supplied to $\mathrm{F}_{2}$ transmitter rack by setting FI-29 at $25 \%$.

4. Setting TIC-2F-6 to obtain temperature of $350^{\circ} \mathrm{C}$ at top of MaF bed (TR-2F-1) and noting the time this temperature was attained.

5. Stoppling $\mathrm{N}_{2}$ flow one hour after item $d$ was cotgpleted.

6. Reducing Ner bed temperature at the center to $100^{\circ} \mathrm{C}$ (TR-2E-6) by adjusting TIC-2E-6 and the gas outlet temperature to $25^{\circ} \mathrm{C}$ (TR-2E-12) by cutting of steam and starting watex through heat exchanging coil to prepare for using trap.

7. Setting valves as needed in system.

d. Filling the HF Trap

NOTE: The frequency of trap charging has not been established, Trap Charge $=10 \mathrm{~kg}$ of $1 / 8-1 \mathrm{n}$. NaF peilets.

1. Removing top flange, adding the NaF and replacing lid.

2. Leak-testing lid by soap-bubble test with vessel containing about 15 pgis of $\mathrm{N}_{2}$.

3. Conditioning $\mathrm{NaF}$ bed with internal surfaces of trap with $\mathrm{F}_{2}$ by using $F_{2}$ to slowly gweep out the $\mathrm{N}_{2}$ (Part e).

4. Leak-testing lid joint by KI-starch test with vessel containing $F_{2}$ at 10 psig.

e. F-Conditionins

1. Making certain that the entire system is clean, leak-tight and at essentially roor temperature, that the scrubber has adequate (Bec, 11.3.1) capactty for the $F_{2}$ to be flowed ind that the instrumentation is in service.

2. Starting the heated duct heaters and blower and the scrubber.

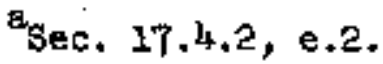


3. Flowing nitrogen through the various $\mathrm{N}_{\text {g }}$ supply headers, instrument, purges, and FT-34 at a combined rate of $\sim 15$ slm ( $\sim 5$ through supply headers and 210 through $\mathrm{FI}-34$ ).

4. Cutting off FI-34 one hour later but keeping $\mathrm{N}_{2}$ flowing through the supply headers and 1pstrument purges.

5. Turning on $F_{2}$ and adjusting the $F_{2}$ flow rete to 4 sim (The resulting $\mathrm{N}_{2}-\mathrm{F}_{2}$ wixture contained $\sim 50 \% \mathrm{~F}_{2}$ )

6. Then by valving properly, flowing this $\mathrm{N}_{2}-\mathrm{F}_{2}$ mixture for periods of a balf-hour each through successively greater portions of the system until it was flowing through the entire system. For exemple, the first part ( portion A) included FV-100, -103, -120 , and -124 ; portion $B$ included portion A plus $F-121$, -220 , and -ezc; and ao on. In this say, each such portion was contacted first with a mixture of very low $F_{2}$ concentration which gredually increased as the residual $\mathrm{N}_{2}$ was swept out, and which finally becene $\sim 50 \%$ in $\mathrm{F}_{2}$.

7. Next, flowing the $\mathrm{N}_{2}-\mathrm{F}_{2}$ mixture through the entire system for 4 hours or less depending on the judgent of the supervisor.

8. Then, turning off the $F_{2}$ and again flowing $\sim 15 \mathrm{sim}$ of $\mathrm{N}_{2}$ for 20 oninutea.

9. Finally, turning off FI-34 and leaving the header and instrument purges on intil the next operation.

Ninor changed were prade in the operating procedures from time to time, and the necessary recoxda were kept. The actusl procedures used are shown as Secs. 15.7.1, 15.7.2, 15.7.3, and 15.7.4. " The procedure used for stert. ing $\mathrm{F}_{2}$ flow was incorporated in other procedures such as Secs. 5.7 and 8.7 .

15.3 .2 Critical Operating Steps

a. Exercising extreme care at all times when work1ng around $F_{2}$, espectally while making or breaking connections. (All lines were purged with $\mathrm{H}_{\text {( }}$ before breaking a connection $1 f^{2}$ there was any doubt as to whêther this had elready been done.)

b. Assuring that the scrubber was operating and had required scrubbing capacity before starting $\mathrm{F}_{2}$ flow.

c. Throwing the $F_{2}$ manual emergency shrt-off switch in Penthouse, at $\mathbb{F}_{2}$ station, ${ }^{2}$ or at Nain Panelboard in an emergency.

sec. 15.7.1 was the original rmsheet prepared for changing fluorine tanks. Iater the procedure for the purging phese of Tenk Ho. 1 was prepared which is shown here as Sec. 15.7.2. A corresponding runsheet for purging Tank No, 2 was never made. 
d. Keeping the gas exit bed temperature of FV-163 at $25^{\circ} \mathrm{C}$ and central bed temperature at $100^{\circ} \mathrm{C}$.

e. Using the sense of smell to establish the presence of $F_{2}$ in an ares and being careful about entering such an area unless the true situation was known.

f. Using acetone around $\mathrm{F}_{2}$-handling equipment cautiously (Sec. 15.4.50). 15.4 Equipment Evaluation $^{\text {a }}$

\subsubsection{Tank Trailers, FV-161 and -162}

a. General Information (44, 46)

Gaseous fluorine was obtained from the K-25 fluorine plant in steel tank trailers at $\sim 55$ psig. Fig. 15.2 is a photograph of the two trailers with doors opened showing manifold valves. Each trailer held 650 standard cubic feet of gas. b The K-25 typical composition was 90-98\% $\mathrm{F}_{2}$ (usually 95\%), 3-8\% HF (usually 5\%), and $1-2 \% \mathrm{~N}_{2}$ and/or $\mathrm{O}_{2}$ as determined from a flowing stream sample taken once per day. ${ }^{2}$ No difficulty in the VPP was experienced that could be directly assigned to impurities in the fluorine, although the HF content was believed troublesome in FV-103 (Sec. 6.4.1b), -120 , and -121 (Sec. 8.4.1b). The HF was removed with an NaF trap installed prior to the " $\mathrm{E}$ " runs (Sec. 15.4.3).

The VPP Fluorine Station was located outdoors on the south side of Building 3019. The two fluorine tank trailer bodies were not protected from weather although the tank valves and connections were housed in a cabinet on the end of the trailer. The $\mathrm{F}_{2}$ control instruments, valves, and fittings were installed under the Sample Gallery, which afforded some protection from rain. The main difficulty encountered with this system because of weather was the freezing of steam and water lines to the HF trap during one week of severe cold in February, 1958.

The tank trailers were backed into position and parked with their rear wheels against a curb stop and their small front parking wheels resting in steel chocks partially buried in the asphalt pavement. Painted lines on the pavement aided the truck driver

after the " $L$ " runs, the equipment downstream of the fluorine transmitter rack was dismantled and moved to Burial Ground No. 3 (Sec. 23.4.16b). The remaining equipment was retained for future processing.

Prailer volume is $137 \mathrm{cu}$ ft (R. P. Milford, personal communication) standard conditions: $14.7 \mathrm{psia}$ and $70 \mathrm{~F}$; average pressure and temperature of trailer = $55 \mathrm{psig}$ and $70^{\circ} \mathrm{F}$. 


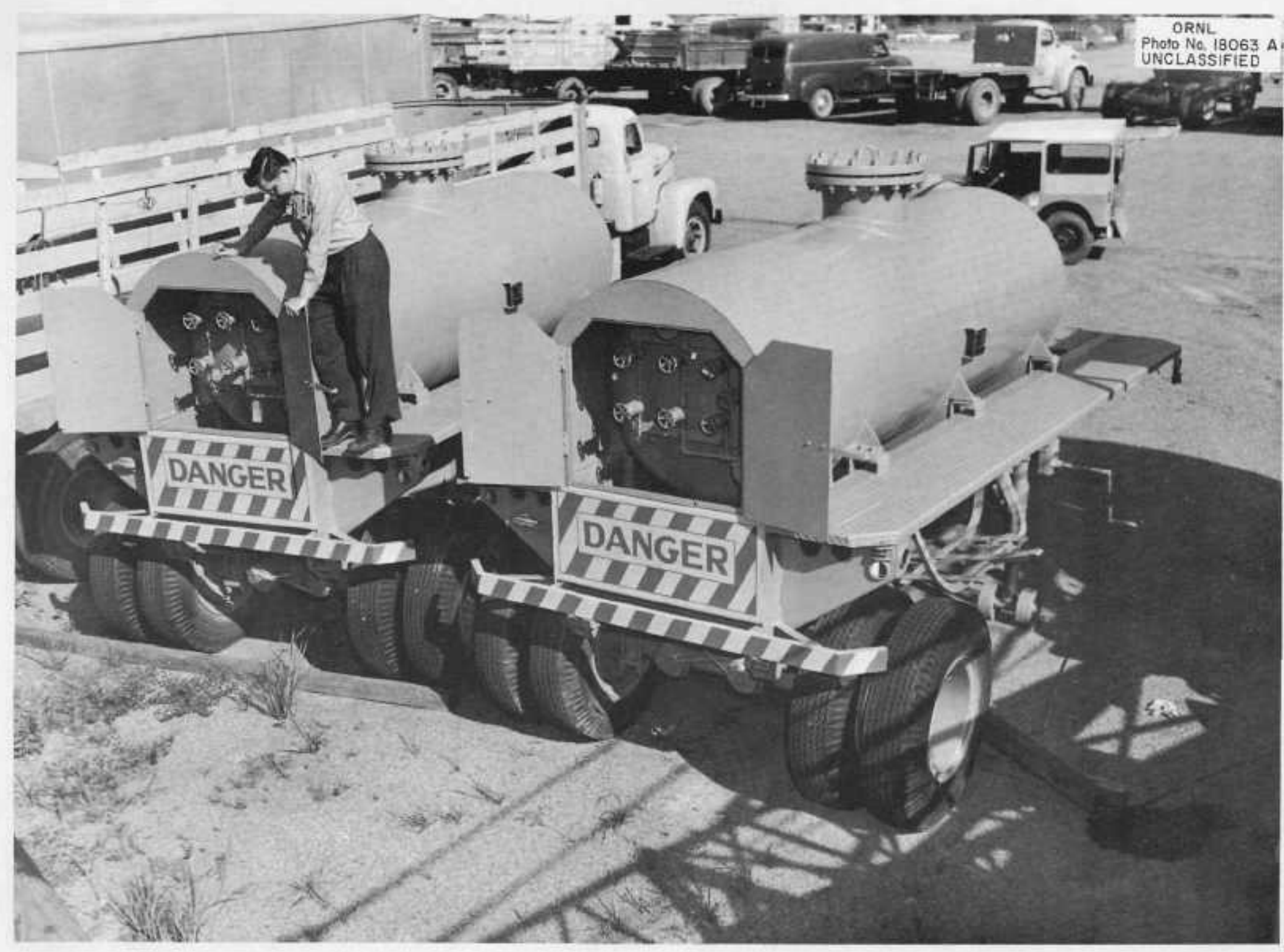

Fig. 15.2 Fluorine Tank Trailers Showing Manifold Valves. 
in positioning the trailers. No difficulty was experienced in handling the tank trailers. Copper pigtails made from $3 / 8$-in. o.d. tubing formed flexible connections from the tank trailers to the VPP Fluorine Station; a similar arrangement was used at K-25 fluorine filling station (Sec. 15.4.5b). Two copper pigteils, one for the $\mathrm{F}_{2}$ flow to the process and one for venting the trallers and plping to the $F_{0}$ disposal system, were provided for each trailer at the VPF Fluorine Station. Flaretype fittings with freshly annealed inserts were used for connecting the pigtails to the trailers. After a near-accident because of a worn flare fitting, these fittings and the copper tubing were frequently inspected and replaced every four months during operations. In September, 1957, the trailers were repainted because the original paint had partly deteriorated. At that time, the original paint was about 3 years old.

\section{b. Automatic High $\mathrm{F}_{2}$ Flow Shut-Off}

An arrangement actuated by high $F_{2}$ flow from the $F_{2}$ trailers was installed after approximately half a trailer of $F_{2}$ was discharged to the atmosphere because a Teflon gasket burned on a temporary HF trap near the $F_{2}$ trailer (Sec. 15.4.6; 47). Since the emergency remote manual shut-off (Sec. 15.4.2b) depended on PCV-2A and PCV-2B which are located a conslderable distance downstream from the $F_{2}$ trallers, no remote or automatic means of shutting off $\mathrm{F}_{2}$ at the trailers existed at that time. Some difficulty was encountered in designing such an automatic high $F_{2}$ flow shut-off that met these $K-25$ Safety Department and the K-25 Fluorine Plant specifications: (a) no alteration of trailer valves and piping was permitted and $(b)$ no change could be made that would affect the K-25 trailer filling procedure.

The automatic high $\mathrm{F}_{2}$ flow shut-off, mounted on both $\mathrm{F}_{2}$ trailers, is illustrated Fy Fig. 15.3. Flow switches FX $-37^{2}$ and FX-38 actuated $F_{2}$ shut-off valves FCV $-37 \mathrm{~A}$ and FCV $-38 \mathrm{~A}$ whenever the flow through ${ }^{2}$ the swltches exceeded $2 \mathrm{cfm}$. The shut-off was accomplished by means of relays and solenoid valves in the air supply to the shut-off valves. The entire installation was added to the existing piping on the $F_{2}$ trailers without modifieations to the piping or to the K-25 filling procedure. The electrical circuit for the remote manual shut-off system was extended to serve the automatic safety system.

This $F_{2}$ safety system worked satisfactorily. Although no emergency arose to actuate the system, its functioning was demonstrated every time $\mathrm{F}_{2}$ flow was started into the empty $\mathrm{F}_{2}$ piping, as the flow would ${ }^{2}$ exceed the $2 \mathrm{cfm}$ setting of the flow switch, causing it to shut off the $F_{2}$ flow. To avold having an operator hold the re-set button during $F_{2}$ start-up, the flow switch was manually bypassed until sufficlent back pressure was built up in the piping down-stream from the switches to reduce the $F_{2}$ flow to normal. In subsequent operations, the change in- 


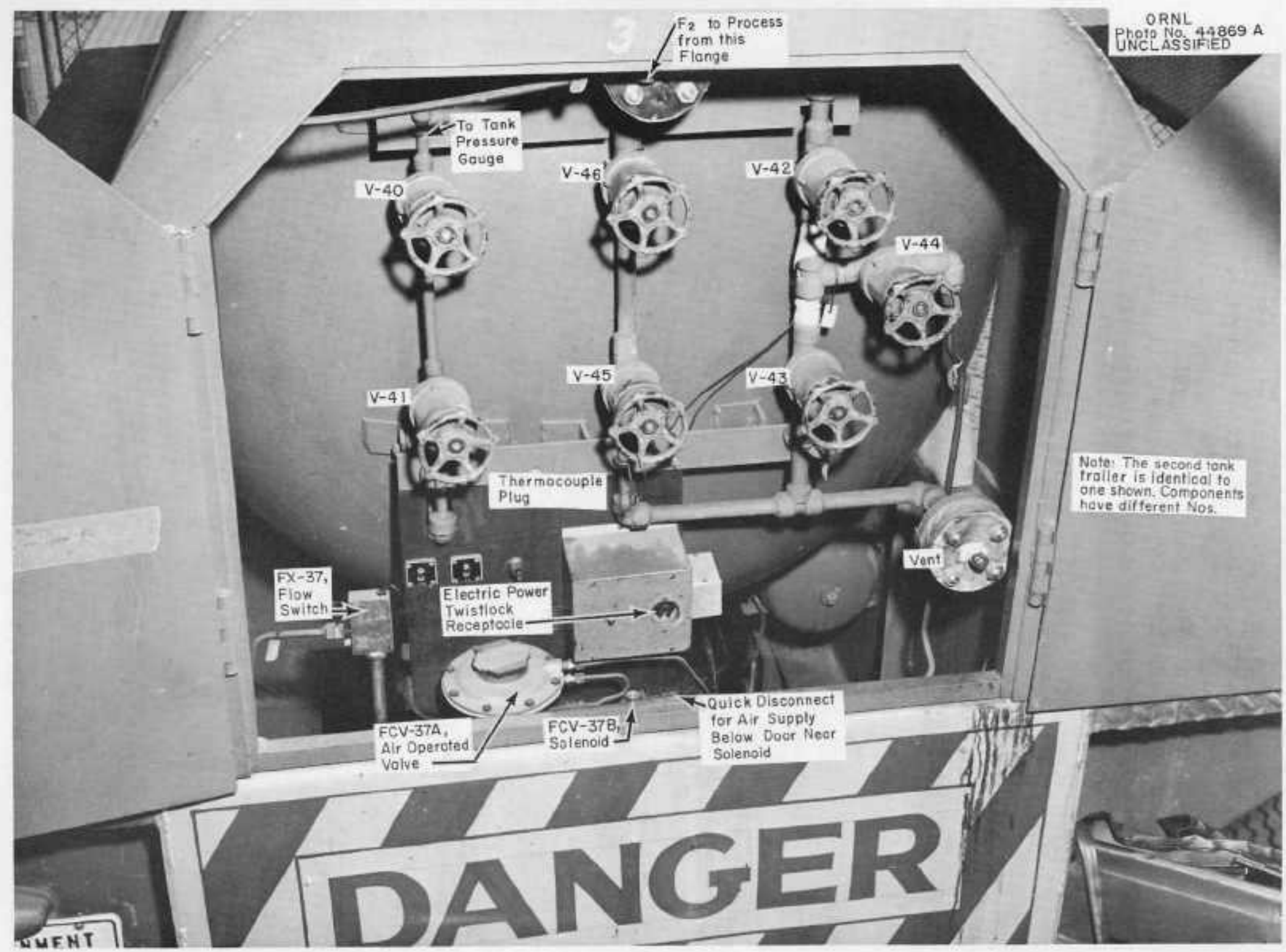

Fig. 15.3 Fluorine Tonk Trailer, FV-161, Gas Manifold Showing High $F_{2}$ Flow Shut-off Equipment. 
dicated at the reset button on Dwg. Ho, Q-2052-50-RO Will eliminate such flow interruptions. The reset button will be held in manually at the trailer until the pressures equalize, and until the $F_{2}$ flow rate is too low to actuate the high $F_{2}$ flow shut-off. Then, the desired $\mathrm{F}_{2}$ flow can be set.

One flow switch (FX-37) developed a leak through 1ts setting adjustment and bad to be replaced after several months' service. The Teflon gaskets on botb switches tended to creep loose and had to be retained in a spectal recessed fitting. One, gasket was destroyed by $F_{2}$ after $1 t$ had worked loose as wentioned In See, 17.4.1. Both awitches were subject to the spindle stickIng in the "open-circuit" position. The remedy for this was sharply rapping the switch with a small tool.

\subsubsection{Fluorine Transmitter Rack ${ }^{9}$}

\section{a. Trajler Switching Device}

The $F_{2}$ trailer switching device eutomatlcally changed the $\mathrm{F}_{2}$ feed from a nearly depleted tank traller to a ful trailer when the pressure fell to 15 psig. This was accomplished by pressure switches $\mathrm{FX}-\mathrm{2C}-2$ and $\mathrm{PX}-2 \mathrm{C}-1$, relays and solenotd velves FCV-2C-1 and PCV-2C-2 in the air supply to atr-operated $F_{2}$ alpply valves PCV-2A and PCV-2B. This device was satisfactory, although later control circuit modiflcations or additions to the $F_{2}$ system apparently caused the switch-over to be actuated unnecessarily. The reagon for this was obscure, and therefore, needed further study. The tratler, switchlng almost always upset the FCV-2 and FWV-10 combination. Such fluctuationg scatimes continued for as nuch as one-half hour and required close attention to eliminate (Sec. 15.4, ad and 17.4,1).

b. Remote Manuel shut -Off ${ }^{b}$

Three hand-operated switches (HX's) were provided for emergency remote manual shut off of $F_{2}$. One switch was mounted on the Main Instrument Panelboard, one in the Penthouse near the maln Instrument Transmitter Rack, and one at the $\mathrm{F}_{2}$ stetion. These switches were wired in series so that all had to be "on" to flow $F_{\text {}}$ to the process, The switches actuated solenold valves PCV-2C-I and FCV-CC-C in the air supply lines to $F_{2}$ shutoff valves PCV-2A and PCV-2B. This arrangement was sat1Bfactory, and the switches were used for convenience in addition to emergency.

Sec, 14.4 .5 .

${ }^{b}$ Sec. 15.4.1b for automatic hlgh $F_{2}$ flow shut-off. 
c. Orifice-Selector Device

Originally a device wes instelled at the $F_{2}$ station to allow fluorine flow meter FE-2 to operate on two ranges of flow, a low range of $0-2$ sefm at 10 psig and a high range of $0-10$ scfm at 10 psig. Two sets of orifice flanges (FE-2A for low range and $\mathrm{FE}-2 \mathrm{~B}$ for higb renge) and an air-opereted shut-off valve for each (HCV-IB-I and HCV-IB-2) were installed in the main $\hat{F}_{a}$ supply header at the $F_{2}$ station. A switch (HX-1) on the Kain Panelboard actuated 3+Way solenoid valve HCV-1C in the alx supply to $H C V-I B-1$ and HCV-IB-2, opening one and closing the other to select which ortfice to flow $F_{2}$ through. Simultaneously HX-1 actusted 3-way solenold valve HCV-LA, whose position deternined which gignal (that for $\mathrm{FB}-2 \mathrm{~A}$ or $\mathrm{FE}-\mathrm{CB}$ transmitter) was sent to flow recorder FR-2 so that the flow was properly recorded.

The high-range orifice was not needed because a much lower $F_{p}$ flow rate was used than was first anticlpated. A new lowrange orfflee was substituted for the high-range orifice in the FE-2B flangea. It was later discovered, however, that HCV-1B-1 allosed $F_{2}$ to leak through its seat and through $\mathrm{FE}-2 \mathrm{~A}$ so that more $F_{2}$ reached the process than $\mathrm{Fk}-2$ recorded from FW-2B. A blank instailed in the FE-2A flanges corrected this difficulty but trapped $\mathrm{F}_{2}$ that leaked through HCV-1B-1, interfering with the $\mathbb{N}_{2}-\mathbb{P}_{2}$ interlock operation (Soc. 15.4.4). The situation was flnally corrected by providing separate, temporary air supply lines to the orifice selector valves to keep HCV-1B-2 open and HCV-1B-1 closed at all times. The air outlet from solenoid valve HCV-1C was capped and EX-1 was removed from the Maln Panelboard.

\section{a. Other Instruments}

All purge-type instruments depending on $f_{2}$ bleeding into the $F_{2}$ lines were changed because $F_{9}$ diffused or surged back into the instrument transultters, defeating the purpose of the $\mathrm{H}_{0}$ purge. Transmitters capable of betng exposed to $F_{2}$ were substituted for the originals (FT-2A, FT-2B, PT-10, and PT-11), and proved satisfactory. A muber of instruments (PE-54, PE-55, FX-2A, PX-בB, otc.) were exposed to $F_{F}$ internally at 60 psig, without incident. It was considered hazardous design to mount PX-2A and PX-2B in the "Black Box" control center on the fluorine transmitter rack with all the electrical wiring exposed to $F_{2}$ In the event che of the plping connections leaked. No harm came from this, however.

The instruments tended to cycle because of pressure surges in $F$ piping, which seemed to have too small a capacity. Instaliation of aurge pot FV-160 ( $2-1 / 2$ in.NFS pipe, 6 -ft long) improved this situation, but a larger surge capacity was stil1 needed. 
e. Fluorine Detection

The utilty of this inatrument was reduced by:

1. The difficulty of determining which of the three sampling points (Penthouse, Cell 1 , and Cell 2) actueted the alarm at the Hain Panelboard. Since the signal from each of the sampling points was sent to the Main Penelboard through a cowaion circult, the source of the high sample could not be deteralned at the Nain Panelboard. This necessitated going to the Penthouse. Even then, positive proof could not be establiahed because the instrument had already awitched to another adopling point (The instrument remained on a samplIng point for two minutes before switehing to the next.). In some cases, buch follow-up consured considerable time, especially when the sensing element was "poiconed."

2. The ease with which the senaing element became "polsoned." Because of the high sensitivity of the sensing element, considerable recovery time was required after recelving a concentrated sanple of fluorine.

\subsubsection{FV-163, HF Trap and Hester $(F V-563)^{b}$}

a. General Information

The hl trap and its furnace operated satisfectorily. The only difficulty arose when the steam and water supply lines to the trap burat during a period of wevere cold weather. Before the trap was installed, $\mathrm{UF}_{6}$ broke through the absorber beds promaturely. Calculations Indicated that the $3 \%$ IF in the $F_{0}$ supply from $K-25$ would cause th $1_{1} \mathrm{UP}_{6}$ break-through (Sec. 15.4.1b), this fact initiating the design and inetallation of the HF trap. After the trap was 1nstalled, no UF ${ }_{6}$ break-through was experienced, possibly indlcating successful HF removal by the trap. The trap was packed with ca. $10 \mathrm{~kg}$ of $1 / 8$-in. NeF pellets.

b. HF Removal by HF Trap

During the last " $L$ " rums, attempts were made to determine the amount of $H F$ in the fluorine entering the VF. The fluorine both upstream end downstream of FV-163 was passed through a copper coil chilled with a ary ice-trichloroethylene mixture. The material collected in the coli was subsequently titrated with a standardized $\mathrm{KOH}$ solution. The data were erretic presumabiy because of the large volume of solution required for ringing the coll, and because of the uncertainty of whether HF was lost while

\footnotetext{
The fluorine detector was located at the nain transmitter rack in the penthouse.

Trap design (48, 29, p. 9 ).
} 
rinsing. Both weight change and titrating data indicated that some HF had been collected. After the " $L$ " rung, this work was continued using $\mathrm{N}_{2}$ containing up to 10 volume of $\mathrm{HF}$. $\mathrm{HF}$ concentration in the gas streans entering and leaving FV-1.63 were determined in equipment simliar to that uged in the Reich teat for atr -50 , mixtures. ${ }_{2}$ The data showed that:

1. A negligible HF concentration $(<0.00 \mathrm{e}$ ) downtreem of the trap could be obtalned unker these conditions:

(a) Inlet gas HF concentration - 2 to $10 \%$

(b) Gas flow rate - 15 liters/min

(c) Bed temperature near trap exit (TI-5-19) - var1ed from $2 c^{\circ}$ to $70^{\circ} \mathrm{C}$.

(d) Bed temperature near center of bed $(\mathrm{TR}-2 \mathrm{~F}-6)-\sim 100^{\circ} \mathrm{C}$.

(e) HF loading of bed $-7 \mathrm{lb}$ of HF on $9.7 \mathrm{~kg}$ of NeF pellets (determined by weight differences of $\mathrm{HF}$ cylinders).

2. An HF concentration of $\sim 0.045 \$$ could be obtained under the same conditiona except thet the bed teriperature near exit was held at $150^{\circ} \mathrm{C}$. Thus, the temperature dependence of the HF concentration as vell as the negligible fF concentration attainable were demonstrated,

Subsequently the trap ras opened to Inspect the bed, and this inspection was followed by attempts to regenerate and then a final inspection. The pre-regeneration inspection revealed that the top thermowell was firmly beld in plece by the bed. After the lid vas finally removed, the upper part of the bed was a solid cake containing biow-holes and cracks and evolving HF, indicating it to contain polyfluorides. The trep was then covered with a blenk flange, and regeneration was atarted. The regeneratIng perlod was October 31. - November 7, 1958 under these conditions:

1. $\mathrm{N}_{2}$ flow rate -15 slw

2. Bed temperature near center of bed - varied from $120-320^{\circ} \mathrm{C}$.

3. Exit gages HF concentretion - varied from 12 to $2-1 / 2 \%$.

NOTE: Trap wes plugged, presumebly with polyfluorides, for about one-fifth of regeneration period.

Instead of the standardized lodine solution with a starch indicator for $\mathrm{sO}_{2}$, $\mathrm{a}$ standardized KOH solution with a phenolphthalein indicator was used.

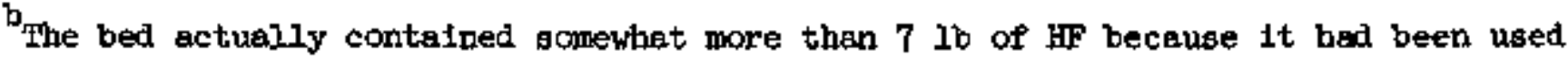
prior to this test-work. 
Stnce the IIF concentration of the exit gases was $2-1 / 2 \%$ after the week' 8 regeneration perlod, all of the HF was not removed: The final bed Inspection revealed that:

1. The top one-foot of materiel was a solid mass in which the individual pellets had lost thelr identities.

2. The remainder of bed contained individualy identifiable pellets sticking together but easily broken up and some fines.

15.4.4 $\mathrm{H}_{2}-\mathrm{F}_{\mathrm{e}}$ Interlock

a. Furpose

The purpose tas to prevent entry of $F_{2}$ into $F_{0}$ lines

( $\mathrm{H}_{2}$ blanket aystem and instrument $\mathrm{N}_{2}$ supply) by shutting off $F_{2}$ flô: :

1. When $F_{2}$ (or $\mathrm{UF}_{6}$ ) pressure rose to within 0.5 psi of $\mathrm{N}_{2}$ pressufe.

2. When preasure in the fluorinator exceeded s set ralue (usually $4.5 \mathrm{psig}$ ).

b. Components (F1G. 15.4)

1. Pressure swttch PX-33B, rounted behind the main inatrument panelboard and connected to FV-100 vepor spece through $\mathrm{PB}-33$, set for actuation at $4.5 \mathrm{psig}$.

2. Differential pressure swtich PX-57, mounted behind the Main Penelboard, 1ts high-pressure side connected to $\mathrm{N}_{o}$ supply header IN-12l-1 (to the fluorinator and ebsorbers') through $\mathrm{PE}-6$; 1ta low-pressure side connected to $F_{3}$ supply neader X-160-1 through PE-10 (set for 0.5 pot dffferential pressure).

3. Differential presaure switches FX-58, PX-59, and PX-60, mounted in the gallery, their high-pressure sides, respective$1 \mathrm{y}$, connected to $\mathrm{N}$, blanket headers LN-172-1 and LN-4 and N supply header If -MFR-1 (to the Math Instrument Trensmitter Reck, Sec. 14.4.5); their low-pressure stdes ell connected

A The solid mass evidently resulted from incouplete regeneretion of the top of the bed because of the low tenmerature in the top one foot of bea.

bsec. I4.4.5.

sec. 5.4.7. 


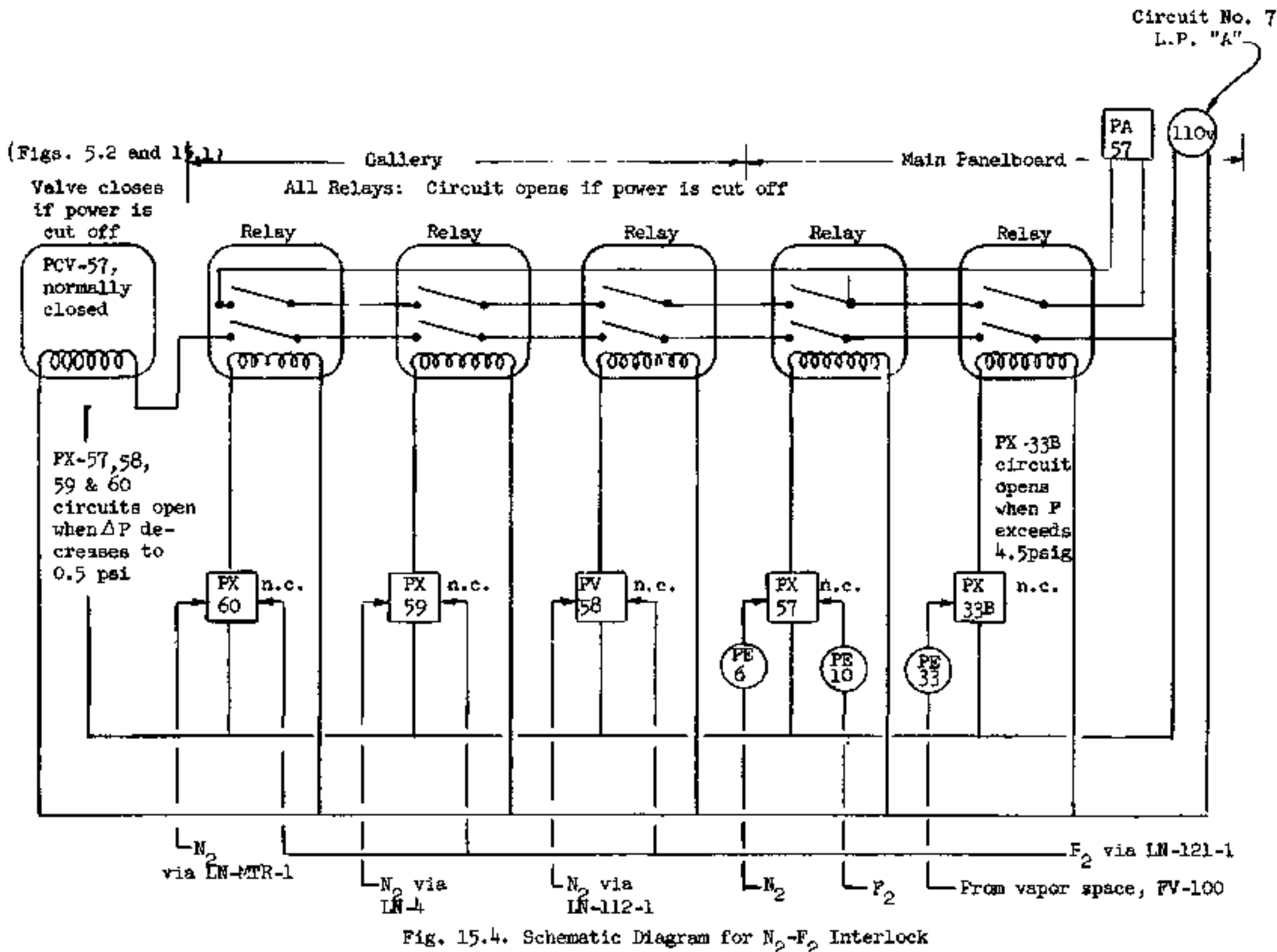


to the $F_{2}$ supply header $X-121-1$ through $V-1.28$ in the $\mathrm{H}_{2}$ line LII-F21-1 that connects to the $F_{2}$ supply (jet for ${ }^{2}$ 0.5 psi differential pressure).

4. Fluorine Bhut-off valves $P C V-2 A$ and $P C V-2 B$ (alr-to-open, Kel-F disk, bellow-Bealed), mounted at the $F_{2}$ station.

5. Air supply shut-off velve PCV -57 (3-way solenold, powerto-open mounted on the $F_{2}$ transmitter rack.

6. Pressure alarm PA-57 (ectivated by open relay circuit), mounted on panelboard.

7. Relays for pressure switches and alarm (power-to-close).

c. Operation

When the $\mathrm{N}_{2}$ pressure on any of the pressure aritches fell to no more than 0.5 psi above the $F$ pressure on the switeh, current flowed to a relay, which opened the circuit to PCV-57, shutting off afr to PCV-2A and PCV-2B, closing them, and shutting off $\mathrm{F}_{2}$ flow. The alarm sounded simultaneously.

\section{d. Discussion}

The $F_{m}-F_{0}$ interlock was installed after $F_{0}$ had entered the No system ¿everal timea through vessels and pipes having connections to both gas systems. Instrument purge rotameters and plastic tubes were damaged by $F_{2}$ on these occasions. The interlock was effective in preventing recurrence of such incidents. But it could not prevent $\mathrm{F}_{\text {s }}$ at full trailer pressure ( 55 psis) from entering the entire $\mathrm{N}_{2}^{2}$ system through a $\mathrm{H}$ purge velve (V 48 at the $F_{2}$ tratlers) that ${ }^{2}$ once was exronecusis left open. A check ralve in this $\mathrm{N}_{\text {, }}$ purge line failed to keep the $\mathrm{F}_{2}$ frow backing into the $\mathrm{N}_{2}$ supply ( $\mathrm{sec}$. 17.4.1).

The interlock required that the blanket $N_{\text {p }}$ pressure be raised from the 4.5 paig previously matntasned to 8-12 psig. This was desirable from the atandpoint of protecting the $\mathrm{N}_{2}$ system from $F_{2}$ but undesirable in that gas pressures needed to be kept as low as possible to minimize surges, which tended to force molten salt into unheated areas (e.g., the dip-les in the fluorinator, Sec. 5.4.7).

The installation of the interlock proved to be arkward, although it pointed up changes needed in the $F$, system. As an exanple, start-up of $\mathrm{F}_{2}$ flon or switching of $\mathrm{F}_{2}^{2}$ trailers was aiffi-

${ }^{a}$ Secs. 15.4.20 and 15.4.2c. 
cult because the interlock frequently shut off the $F_{2}$ flow at these times. The reason was found to be a $F_{2}$ pressure surge caused by FCV -2 ahutting suddenly to reduce $F_{\text {, flow, that }}$ tended to be high (1,e, , $>2$ cfil) when the $F_{2}$ was adifitted to the empty piping. The surge raised the $F_{2}$ pressure above the $\mathbb{N}_{\text {, }}$ pressure, properly actuating the lnterlock to shut off $F_{2}$ flfow. The difficulty arose because PCV-57 was installed to shut off air to the flow meter (FR-2) orifice selector valves (HCV-1B-1 and HCV-1B-2) as well as to the $F_{2}$ shut-off valves PCV-2A and FCV -2B. This arrangement caused $\frac{2}{6}$ reversal in the setting of the

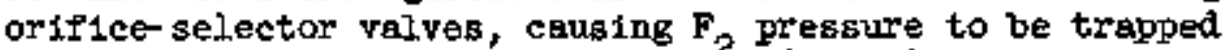
against the blanked low-flor oriftee (FE-2A). The $F$ pressure could then be relleved only by leakage or by releasing $F_{2}$ through the $F_{\text {g }}$ station vent, This situstion was corrected temporarily by providing 1ndependent air supplies to the orifice-selector valves to hold HCV-lB-I closed and HCV-1B-2 open all the time (see Dwg. Ho, Q-1679-19-RQ revised to June 10, 1958, in Engineering File Folder No. B-53).

The operating pxinciple and the busic need for the $\mathrm{N}_{2}-\mathrm{F}_{2}$ interlocik are velid. However, a study of it is needed to ${ }^{2} 1 \mathrm{~m}^{2}=$ prove its performance.

\subsubsection{Materials of Construction}

\section{a. Valves and Piping (49)}

Piplng as originally specified vas satisfactory. Teflonpacked hand valves became very difficult to operate after britef $F_{2}$ service. Packless valves proved satisfactory as follows.

velve Types

Crane Co., types SMND, SSD, and SMD

Hoke, Inc., types 471,413 and 415

Hoke, Inc., types 480 (HGP) series
1/4-In, and 3/8-in. $0, d$. tube
Słzes

1/4-1n., 1/2-1n., and $1-1 / 2$ in. NPS

1/4-in, and $3 / 8-i n$. o.d. tube.

\section{Duty}

$F_{\text {}}$ supply and vent plping, scrubber $F_{\text {, inlet, vacum }}$ piup.piping, etc.

$F_{2}$ sampling, $F_{2}$ inlet to instrument transmitters, $\mathrm{H}_{2}$ supply to molten salt sampler, shutoff between process end instruments.

$\mathrm{F}_{2}$ sampling, $\mathrm{N}_{2}$ supply to ring joint leak test system, HF sampling from $F_{2}$ supply.

See Sec, 15.4.2e.

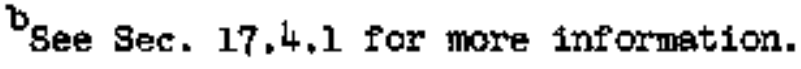


Valve Types

Hoke, Inc., types

440 series (1197)

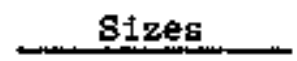

1/4-1n, o.d. tube
Duty

Shut -off valvea between process and $\mathrm{H}_{2}$ system, $F_{2}$ inlet to tnstrumênts.

A atandard brass sulng-check valve in the $N_{2}$ purge line to the $F_{0}$ station falled to prevent back-flow of $F_{2}$ into the $\mathrm{N}_{2}$ systef on one accasion when the SMMD valve (v-48) was erroneously left open. The check valve was not examined to determine why it failed to operate, but it is suspected that this type of valve is senerally unsuitable for ges service and espectally $F_{2}$ service (Sec. 17.4.1).

b. Other Materials

Monel, nickel, Inconel, ateel, stainless steel, (types 316 and 347), bress, end eppper gave satiafactory aervice in contect with $F_{2}$ below $150 \mathrm{C}$. Nickel and Inconel only were exposed to $F_{g}$ above $150^{\circ} \mathrm{C}$. At elevated temperetures, widely varying amounts of attack occurred on the component materials in the VPP by process gases (). Specific troubles occurring were:

1. A cast brass tee brazed to a trailer and a cast brass coupling on FV-2e2 (Sec. 9.4.4) cracked. Becalse of this, most cast brass fittings were replaced by Bwagelak fittings of brass, Monel, or stainless steel (type 316) bar stock, which were suitable for tubing connections in $F_{p}$ sexvice except in places where the $K-25$ use of flare fittings (on tank trailers and $\mathrm{UF}_{6}$ sample lines) required flares at the VPP. On the tank tratler pigtails, freahly annealed copper 1nserta were used when remaking the flare jolnts to ensure leak-tightness.

2. Brasa Swegelok flttings on a Hoke No. 413 valye eracked after about $81 x$ weeks exposure to $F_{2}$ and $U F_{6}{ }^{*}$

A variety of joints were used succesafully:

1. Tubing - Sragelok, s1lver brazed, and flare with the first two preferred.

2. Pipe and vessels - Welds and ring-joint flanges with annealed copper ringa.

aec. $17.4 .1,(\underline{50}$, p. $5 ; 1)$.

ber spectfications in (21). Also see (52-pp.42-44). 
Tefion and Kel- $F$ were partly satisfactory for valte disks and geskets where soft materials were desirable. The disadvantages of these plastics were their tendencies:

1. To creep or cold-flow wnder pressure, wbich resulted in gaskets and wheners becoming loose after several weeks of service (several incidents).

2. To burn to a fine ash if the slightest amount of grease (e.g., a fingerprint) was left on them (sec. 15.4.10; 17.4.2, 1.4 ; and 17.4 .3$)$.

These difflculties were surmounted by designing confining chambers in flenges to prevent besket creep and $b y$ mintaining scrupulous cleanliness on Teflon and Kel-F surfaces to avoid fire danger,

All metals, Teflon, and Kel-F subjected to $F_{0}$ were found to be more resigtant to $F_{2}$ ettack if they bad been "conditioned" by exposure to gredually Increasing concentrations of $F_{2}$ [secs. $17.4 .2,1.3$; and $\left.17.4 .2, f^{1.4}(37)\right]$. Before condtioning, all surfaces (metal and nonmetal) to be exposed to $F_{0}$ were weshed carefully with acetone or other solvent and driec. Incidents occurring while using acetone were:

1. $F_{2}$ contacted liquid acetone which had not completely evaporeted from a new installation of copper tubing becaupe of severe cold weather. The copper tubing beceme red hot, and a deposit of soot was spread through the $\mathrm{F}_{2}$ station piping.

2. Fesidual $F_{\text {e }}$ on a metall1c surface ignited an ecetone-soaked eloth beine used to wipe the surface.

Methylene chioride, although not as widely used as acetone, had two advantages over acetone: (a) less iusgeptible to fire danger from $F_{2}$ and (b) lower bolling point $\left(40^{\circ} \mathrm{C}\right.$ to $58^{\circ} \mathrm{C}$ for acetone). Although insufflcient work with methylene chloride was done to prove that it would not initiate a fire with $F$, no case is known where such a fire occurace. Danger from using methylene chloride in poor ventilation might occur because of its narcotic nature (mpc = $220 \mathrm{ppm}$ of air) (53). Trichloroethylene has also been used although its boiling point is high $\left(87^{\circ} \mathrm{c}\right)$.

VPP practices required that the following be "conditioned" before use with $\mathrm{F}_{2}$ end/or $\mathrm{UF}_{6}$;

For preconditioning Kel-F disks for HCV's, see Sec, 17.4.2, f.4. Also see below for conditioning of other materials. 
1. Hew equapment.

2. Used equipment.

(a) After performing maintenance or operational steps such as recharging with NaF'.

(b) After being washed out with water or aqueous solutions. Drying out of water was dome with the VPP heating equipment.

(c) After being opened to the air for more than about an hour.

Troubleg occurxing which were believed to be assocfated with poor cleanliness control and/or insufficient conditioning were:

1. Disintegration of Kel-F and Teflon valve parts (Sec. 17.4.2, 1.3 and 17.4 .3 ).

2. Destruction of a Teflon gasket (Sec. 15.4.1b).

3. Disintegration of an absorber diffuser ring (Sec. 8.4.1b). The diffuser ring in FV-120 apparently falled when $F_{3}$ was suddenly admitted to the veasel, which was being held at $600^{\circ} \mathrm{C}$. The gas distribution ring of $1 / 8-1 \mathrm{n}$. thick Inconel melted over 5 inches of Its length. Because the resiel had recently been opened and exposed to the atwosphere, it was suspected that some impurity, probably grease, on the ges distribution ring started the raaction with $F_{2}$. The sudden exposure to $F_{2}$ was also thought to have sontributed to the failure, as no faifure in othor instances occurred at $600^{\circ} \mathrm{C}$ ugon gredual increase of $\mathrm{F}_{2}$ concentration to a maximum of $100 \%$.

\subsection{Summary and Conclustons}

In general, the entire $F_{2}$ system worked satisfactorily. Most difficulties tbat arose were caused by hurried installation and were corrected. Ho trouble except perhaps from the HF content could be directly assigned to Impurities in the F.

Fluorine was recieved in steel tank tratlers filled to $\sim 55$ psig at the K-25 generating plant. The typtcel $\mathrm{F}_{2}$ andysis recelved from $\mathrm{K}-25$ was: $95 \% \mathrm{~F}_{2}$, $<5 \% \mathrm{HF}$, and 1 to $2 \% \mathrm{~N}_{2}$ and/or $\mathrm{O}_{2}$.

The $F_{2}$ station was outdoors on the south side of Building 3019. The two trailers were unprotected from the weather, but tank valves, $F_{\beta}$ control instruments, valves, $\mathrm{HF}$ trap, piping and fittings were under the Sample Galiery which afforded some protection from the rain. The only trouble with the weather arose frow the freezing of water and steam lines of the HF trap during the severe cold in February, 1958. The trailers were coupled to the Fluorine Transmitter Rack through copper pigtalis. 
The trailers were repalnted in September, 1957 at which time the original paint tas 3 years ola.

An automatic high $F_{0}$ flow shut-off device was installed after about half a trailer was accidentally discharged to the atmosphere. Although no subsequent emergency arose to actuate this device, high $F_{2}$ flows at times when starting $F_{2}$ flow proved tts efficacy. Severel minor troubies occurring with this device afe delineated.

The automatic trailer switching device was satisfactory. The difficulties met with it are discussed. One trouble was the cycling of the FCV-2 and PCV-10 combination following trailer switching. Subsequent eddition of surge pot FV-160 improved this situation very ilttle.

The remote manual $F_{2}$ emergency shut-oft which enabled cutting off $F_{2}$ at the Fluorine Transmitter Rack, in the Penthouse, or at the Main Panelboard ${ }^{2}$ worked satisfactorily.

The orifice-selector device ras not needed because a much lower $F_{2}$ flow rate was used than anticipsted. Later, it was necessary to blank off the valve not in use (HCV-IB -1) because it leaked.

The trangmitters on all purge-type instruments depending on nitrogen bleeding into $F_{2}$ lines had to be replaced with transmitters capable of $F_{2}$ service.

Fluorine detection was harpered by: (a) the difficulty of deternining the source of $h i g h F_{2}$ and (b) poistoning of the sensing element.

The HF trep and 1 ts furnace operated satisfactorily. Its installation apparently prevented $\mathrm{VF}_{6}$ from prematurely "breaking-through" the absorber beds. Attempts to establish the effictency of the trep by freezing out $\mathrm{HF}$ in the $F_{2}$ both upstream and downstreem of FV-163 produced erratic results. Later, using $\mathbb{N}_{2}-\mathrm{HF}$ mixtures, the HF concentration downstrean of the trep was essentially nil at $a^{2} 15$ literg/min Plow rate of the $\mathrm{N}_{0}-\mathrm{HF}$ wixture contalning 2 to $10 \% \mathrm{HF}$. During th1s work, the $9.7 \mathrm{~kg} N \mathrm{NaF}$ pellet cherge containing $>7 \mathrm{lb}$ of $\mathrm{FF}$ was held at an exit temperature $\sim 60^{\circ} \mathrm{C}$. Subsequent bed inspection revealed much sintering of pellets and probable polyfluoride formation.

Regeneration of this bed showed that after $\sim 6$ days the exit stream still contained $2-1 / 2 \%$ HF. Finel bed inspection indicated scme pellet asglomeration.

Data indicated that even a heavily loaded (7 Ib HF in $\sim 10 \mathrm{~kg}$ of $\mathrm{MeF}$ ) $\mathrm{MF}$ trap will exhaust a gas of negligible HF concentration, and that such a heavily loaded trap required a long period for complete regeneration. In addition, the dependence of the exit gas HF concentration on bed exit temperature was shown.

After Installing the $\mathrm{N}_{2}-\mathrm{F}_{3}$ interlock, the number of purge rotameters and plastic tubing damages with $F_{2}^{2}$ were reduced. Although this advantage and the pointing up of changes needed accrued, the interlock was awkward. It required raising the $\mathrm{N}_{2}$ blanket pressure from 4-1/2 to 8-12 ps1g wh1ch increased molten salt plugs in line $X-100-1$ to the fluorinator. In addition, starting $F_{2}$ flow or switching of trailers was affficult because the interlock frequently shutoff $F_{2}$ at these \#imes. 
The valves suitable for $F_{0}$ were Crane's SMDD, SSD, and SMD; and Hoke"s Hos. $411,413,415,480$ (HCP), and 440 (No.3197). The check valve near PI-43 was unsatisfactory. Piping as originally apecified was satisfactory other materials of conatruction included Monel, nigkel, Inconel, steel, atainless steel types 316 and 347 , brasf and copper below $150^{\circ} \mathrm{C}$. Nickel and Inconel only were exposed to $F_{\theta}$ above $150 \mathrm{c}$, Corrosion of these metals cecurred above $400 \mathrm{C}$ as probebly experilenced for Inconel with the FV-120 diffuser ring et $600^{\circ} \mathrm{C}$. All metals and Kel-F were more reskatant to $F_{2}$ attack if previously "conditioned" by exposure to gradually increasing concentretions of $\mathrm{F}_{2}$.

Several fatlures of brass parts in $F_{2}$ occurred; (a) a cast brass tee brazed to a trailer flange and cast brass coupling on FV-222 by cracking after several weeks of $\xi_{2}$ service and (b) Swagelois flttings on a valve by cracking after six weeks' exposure to $F_{2}$ and $\mathrm{UF}_{6}$.

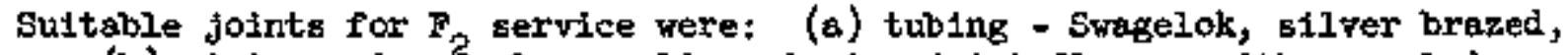
and flare; (b) piping and vessels - welds and ring-jolnt flanges with axnealed copper rings.

Teflon and Kel-F were partly satisfactory for yelve disks and gaskets where soft materials were desirable. Disadvantages were:(a) cold flow under pressure and (b) burning when not scrupulously clean. The effect of cold-flowing was reduced by confining in metallic fremework. The fire hazard was dintnished by cleanliness and conditioning.

Cleanfing agenta used on both plastics and wetals were acetone, uethylene chloride, and trichloroethylene. Of these, wethylene chloride was safest although it is a varcotic. Acetone was a flre hazard, and the high bolling point of trichloroethylene made it inattractive.

\subsection{Recommendations}

It is recommended that:

a. The $F_{2}$ station piping be altered to remove unused sections (FE-CA, HCVIB-1, fCV-1C and HCV-LA as shom on Dwg. Q-1679-18-k0 conments in VPP Finginering File Folder No. 53) and to make permanent the temporary atr supply line to HCV-1B-2; a larger surge capecity be built into the piping.

b. A study of the $\mathbb{N}_{3}-F_{2}$ interlock be mede to retain its alvantages but remove $1 t s$ disadfanfages. See recomendations $j$, and $k$. in Sec. 5.6 .

c. A siudy be made to determine the reason for the unecesaary actuation of the trafler switch-over at times.

d. Two $\mathrm{N}_{2}$ cylinders with pressure reducers be provided at the $\mathrm{F}_{2}$ station for purging the plping (The original design provided this arrangement.)

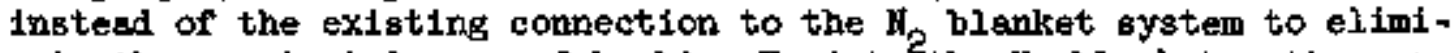
nate the greatest danger of backing $\mathrm{F}_{2}$ into the $\mathrm{N}_{2}$ blanket spktep; $a$ low pressure switchaover and alarn defice be provided on these $\mathrm{H}_{2}$ cylinders to assure an adequate supply at all times; e restriction in the $N_{2}$ line be provided to prevent blasting $N_{2}$ through the $F_{2}$ system 
during purging. (A back pressure on the fluorinator vas sometimes ob. served during $\mathrm{F}_{2}$ station purging, caused by excessive quantities of $\mathrm{F}_{0}$, which flowed through $V-68, V-72, F V-124$ and all cell 2 piping to FV-16o.)

e. The thermocouple wells in the FV-163 top Plange be moved or an NaF fill line be added to facilitate $\mathrm{HaF}$ charging and discharging.

f. Braas be re-evaluated as a material of construction for $\mathrm{P}_{2}$ service.

g. More work be done on FV-163 to determine maximum HF loading of NaF, the permissible exdt bed temperatures, and effictency using $F_{2}$-HF mixtures of about 5\% HF. (thatil this work is done, the bed loeding should not exceed $7 \mathrm{lb}$ of fF and the exit gas bed temperature be kept $<70^{\circ} \mathrm{Cr}$.

h. The $F_{2}$ trailers be painted about every 3 years or more often if needed.

15.7 Appendix

15.7.1 Gerating Procedure: Changing Fluorine Tanks

CFI

When $F_{2}$ low-pressure alarm sounds, do the following:

Remoral Operation

1. Open valves $32,33,40,4$, , and 41 at fluorine supply tanks. This wili give readings on pressure gages, PI-2A and PI-2B.

2. Record PI-2A and $\mathrm{PI}-2 \mathrm{~B}$ and the time

3. The lower resing on the two gages indicates which tank to remove from the system. Record whether $\$ 1$ or $\# 2$ tank reads the lower pressure

4. Close valves $32, \ldots, 33 \ldots, 40 \ldots$, and 41

5. Check to be sure valve 67 , near vent header on the Foor, is open

6. If tank il is to be removed from the bystem atart with 6 tep 7 ; omjit steps 12-16 lnclusive. If tank th is to be removed from the syotem stert with step 12; onit steps 7-11, inclusive.

7. For tank 11 , elose values 34

8. Open valves 37

8. Open valves 37 Ad JuBt $P V-40$ regulator to reed 60 psis. and 35

10. Open valve 48 for 1 second, close valve 48 , reopen for another second, and close. (Th1s to more effective then one opening for 2 seconds.)

11. Close velves 37,38

12. For tenk \#2, cloae valvea 42

13. Open valves 45

Open valves 45 , 46 , 39 and 43 and 84

14. Adjust PV -40 regulator to Tead 60 psig.

15. Open valve 49 for 1 second, cloge velve 49, reopen for another second, and close. (This is more effective than one opening for 2 seconds).

16. Close valves $45,46,47$, and 85

17. Disconect $F$ tank from he eder and notify transportation for removal if they are not ${ }^{2}$ on a routine schedule. 
Reinstallation Operation

18. When replacement tratler arrives froal $\mathrm{K}-25$ comect it into the $F_{j}$ header,

19. If 1 tank is the unit being connected to the system, start with ${ }^{2}$ tep 21; omit steps 29-37, Inclusive. If th tank is the unit being connected to the system start with step 29; ondt steps 2l-28 1nciubive.

20. To install \#1 tank, open valves 37

21. Adjust FV 40 regulator to read $60 \mathrm{psig}$. 38 39 and 84 and close.

23. Clobe valves 37 check to be sure valve 36 is closed.

23. Clobe valves 37 check to be sure vaive 36 is closed.

23. Close valves 37 Check to be sure vaive 36 1s closed.

Open valves 34

close valves 32 35 32 and 33

\section{Record PI-2A reading \\ 26.}

27.

Arenuncistor 33

Amunciator panel light for "low fluorine pressure" should be off now that the first unit is on "standby". If not, check valving on drawing D-22759.

29. To install. \#2 tank, open valves 45

30. Aijust $P Y-40$ regulator to read $60 \mathrm{p} \overline{\mathrm{sig}}$.

31. Onen valve 49 for 1 second, close valve 49, reopen for another second, and olose.

32. Close valves 45

46

, and 85

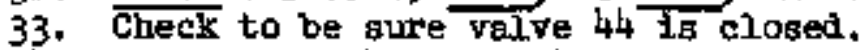

34. Open ralues 40

35. Record PI-28 reading

36. Cloge valves 40 41 42

anâ 43

37. Annunc1ator panel l1ght for "10 fluorine pressure" should be off now that the second unit 18 on standby. If not, check valving on drasing D-22759.

\subsubsection{Operating Procedure: Purging Fluorine Lfne \# 1}

PFI,

1. Check to be sure $\mathrm{V}-67$, near vent header on roof is open

2. Open $v-77$

3. Open $\mathrm{V}-32$

4. Record PI- $\overline{\mathrm{AA}}$

5. Close V-32

6. Close V-34

2A $v-33$ and the tise

$\longrightarrow$ and $v=33$ , -35

7. Open V-37 $\vec{v}-38$ and $v-36$

8. Open $v+8 \overline{\text { for } I}$ second, close $v-48$, reopen for another second, and cloge. (This is more effective then one opening for two seconds.)

9. Open $v-35$ enci $v-36$

10. Repeat step"

11. Close $v-35$ $v-84$ $v-36$ , $\mathrm{V}-37$ $v-38$ $v-39$ and 
15.7.3 Operating Procedure: HF Trap Operation

HTO

Dete

Time

oper

Part A: Charging NaF Pellets to HF Trap

1. Turn off heater TIC-2E-6

close $V-107$

2. Check that $\mathrm{Y}-1061 \mathrm{~g}$ open and low FV -163 to cool enough for safe handling.

3. Close V-77A, 39, 47, 102, 84, 85, 67, BCV-2. (Check off each one.)

4. Open $v-48,101,103,105,68$. (Check off each one.)

5. Open $F_{2}$ supply suttch and set PC-10 to 4 paig.

6. Set $F I^{2}-29$ ( $V-T T B$ ) for $\mathrm{H}_{2}$ flow at $25 \%$ of seale. Time done

7. After 30 minutes close $F I-29$ (V-7TB), V-103, 105. Time done

8. Remove top Ilange of FV-163, vacum out spent NaF pellets and obtaln welght. Gross ks, Tare kg, Het

9. Charge about $10 \overline{\mathrm{kg}}$ of fresh HaF pellets to a level 4 to $5 \mathrm{ln}$. bejow gas inlet line. Record welght. Gross

10. Reples top flange, taksing care to work thermocouple-well into pellets ks, Tare ks, without crushing thew.

11. Open V-103, 105 , gnd set FI-29 for $25 \%$ of scale. Thme done

12. After one hour shut FI-29. TIme done

13. Froceed to part B, for conditioning of WaF.

Part E: Condtioning Hap Pellets and Trep

1. Close V-102, 67, 84, 85, 39, 47, 77A, FCV-1, FCV-2, (Check off each one.)

2. Open $v-48,101,103,105,68$. (Check off each one).

3. Dpen $\mathrm{F}_{2}$ supply swttch.

4. Set PCt -10 at 4 psig and put on automatic.

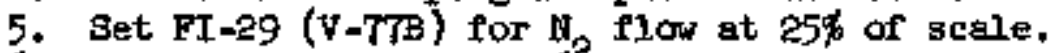

6. Close water valve $V-106^{2}$ and gpen steam velve $V-107$ wide, silowdy.

7. Set TTC-2J-6 to reed $100-105^{\circ} \mathrm{C}$ on TR-2E-6.

8. Record time 100-105 $\mathrm{C}$ is reached on TI-5-19 TR-2B-? , TR-2E-1.

9. One hour after $100-105^{\circ} \mathrm{C}$ is reached In item $\mathrm{B}$, adjust $\mathrm{FE}-6$ purge rotameters to give $65 \%$ reading on $\mathrm{FR}-8$.

10. Crack $F_{2}$ valve $v-39$ to obtain an inerease to $87 \%$ on FR-8. T1me done - $F R \rightarrow 8$ reajing

11. Fifteen minutes after Item 10, adjust $\mathrm{FE}-6$ purge to reduce FR-8 to $85 \%$ done then adjust $V-39$ to ratse $F R=8$ to 87 of again - Time

12. Immediately after Item 11, decrease FI-29 to $20 \%$ of scale.

13. Fifteen minutes after Item 11 , repeat Item 11. Time done

- 14. Irtsediately after Item 13, decrease FI-29 to $15 \%$ of acale.

15. Fifteen minutes after Item 13, repeat Item 11. T1me done

ㄴ. Decrease FI-29 to $10 \%$ of scale. 
17. Fifteen minutes after Item 15 , repeat Item 11. Time done

18. Decrease FI-29 to $5 \%$ of scale.

19. Five minutes after Item 17, close FI-29 (V-77B), Time done

20. Fifteen minutes after Iters 19 , close $\mathrm{V}-39$

Plow at $25 \%$ of scale

$\checkmark-107$ whde, slowly

- Set TIC-2E-6 for $350 \%$

- Set FI-29 for $\mathrm{H}^{2}$ - Tine done

2I. Record time $300-350^{\circ} \mathrm{C}$ is resched on: TI-5-19, $\mathrm{TR}-2 \mathrm{E}-7$ TR-2E-1 , TR-28-12

22. One hour after reaching $300-350^{\circ} \mathrm{C}$ in Item 21, atop $\mathrm{N}_{2}$ flow through FI -29 (V-778). Time done

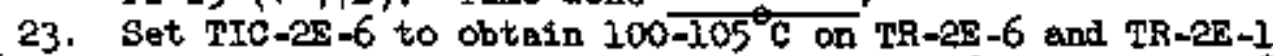

cloae V-107 and T-5-19

and adjust $v-1,06$ to obtain $25^{\circ} \mathrm{C}$ on $\mathrm{TR}-2 \mathrm{E}-12$

24. Close V-48, Tol, 105, 68, PCV-10. (Check of exech one.)

25. Open V-39, 47, 102, 67, FCV-1. (Check off each one.)

26. Hold temperatures os set in Iten 23 for use in next pilot untt run.

Part C: Regeneration of HF Trap (Revised April 1, 1958)

1. Close these valves at the $F_{2}$ trailers: v-39 B5 102 and 106

2. Qpen these valvea at the $F_{3}$ tratlers: ${ }^{*}-48$ 105 and 107 (slowly)

3. Close V-67 close FCV -2 in Penthouse. Open v-68 at penelboard.

5. Open $F_{2}$ eupply switch "auto"?.

6. close V-TTA end eet FC-10 on 4 psig , 47 , 84 , 101 103 In Penthouge.

. Ra1se setpoint on TIC-2E-6 to attain $350^{\circ} \mathrm{C}$ on $\mathrm{TR}-2 \mathrm{E}-1$.

8 . When TR-2E-1 reached $350^{\circ} \mathrm{C}$, record time

9. One hour after time in previous step, stop $\mathrm{N}_{2}$ flow through FI-29.

Due off

- Actual time flow stopped TR-2E-12, TR-2E-1, TIC-2E-6, TR-25-6 - Record TI-5-19 (and

10. Reduce setpoint on TIC-2E-6 to give $100^{\circ} \mathrm{C}$ on TR-2E-6. Ad just $\mathrm{V}-100^{*}$ to obtain $25^{\circ} \mathrm{C}$ on TR-25-12

11. Close these valves at the $F_{2}$ trailers: V-48 and 105

12. Open these valves at the $F_{2}$ trallers: $V-39$ 102

13. Close $\overline{\mathrm{V}-68} \mathrm{~S}^{\circ}$

in the Penthouse. Open $V-67$

14. Shut off the $\bar{F}_{2}$ supply swltch and close PCT-10 , 101 , 47 and close valve.) 
15.7.4 Opereting Procedure: Fluorine Condit1oning Procedure

(Revised ñovember 1, 1957)

FCP

Dente

Time

By

1. Check that the following pleces of equipment are installed and leakand Fy-126.

2. Purn on EX-FV -522 and EX-FY -650 Fv-303 side flange FV -1.14

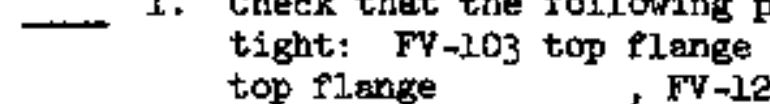 \\ -1. Check that the rollowing p
tight: Fv-103 top flange
top rlange

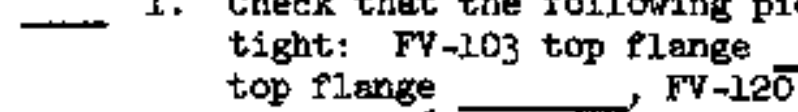

— 3. Set the following aitrogen redueing atations on 4.5 psis. PI-4

\section{PI 6} PI-7 and $\mathrm{P} \overline{\mathrm{I}}-5 \overline{3}$ (on $15 \mathrm{ps} \overline{\mathrm{Sg}}$ ) PI -44 PI -50 FV-100 sampler.)

4. Close all HCV's on Instrument panels (except HCV-7 which will be open when HCV -8 is closed).

5. Cloge ell "B" and "C" valves around $\mathrm{H}_{2}$ purge rotameters.

6. close $v-88$ on samplex.

7. Open the following valves near the nitrogen supply header: V-69

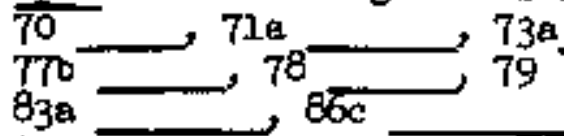
$79 \longrightarrow \frac{79}{900}$

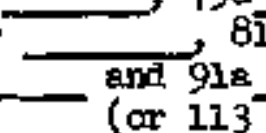
$8 \overline{1}$ $76 \mathrm{a}$

Open $\mathrm{V}=27$

lines. close $\mathrm{V}-\mathrm{25}$

9. Start up Bcrubber side inlet In oft-gas saxplor.

Check that the following Instruments are in service and theis purges

flowing: $\mathrm{DR}-1$

FR 6

PR-16 LR=6 PR $-3 \overline{3}$ , LR. 2

Read the following rotameters on nitrogen supply lines FI -13

11. Read the following rotan 15 $30 \ldots$ 6 and 33 27 eft or $150 \mathrm{cc}$ min witchever is applicalle.

12. Open $\mathrm{HCV}-8$

13. Öpen TCV-1 to 11

14. One hour later at paig. 14 15. Check that fluorine traller valves are open

16. Set PC-10 on "Auto" and adjust set point to 4 psig , FR-5 82 in of $-\mathrm{gas}$ - Open valve to top Pluorine Inlet or

17. Move orlfice-selector switch to "up" position - Turr on fluorine supply swtteh - Time on - Adusti flow to give $10 \%$ on FR-2

18. If fiuorinator, or FV-103 has been opened since the last run, proceed to next step - If not proceed to step 20

19. Thirty minutes after step 18 go to atep 20.

20. Open HCV -12 13 14 15 16 30 and 34

21. Opea $\mathrm{HCV}-12$ - close $\mathrm{HCV}-8$ - Time 
22. Twenty minutes later open HCV-18 Close HCV-15 34 . TMme

19 32 23. Twenty minutes iater open product receiver valves HCV -22 $23 \longrightarrow 24$ 24. Open $\mathrm{HCV}-23$ - Time

25. Twenty minutes later open all HCV's except HCV +7

26. Reduce fluorine flow to 5 on 10 ocelle Time

27. Continue up to four hours or whenever requested to stop fluorine flow by superviston.

28. Open fluorine supply switich (stop flow) - Trme

29. Close PCV -10

30. Open Fev-1 to 5 psi.

31. Open V -93 to give $25 \%$ on FI -34

32. Close fluorine tra1ler valves.

. (PI-6 on 4.5 psis

33. Thenty minutes after step 31 , close valve 93

- 34. Leave purges on until. time for next operation. 35. Time completed 
16.0 ARE Charging System ........, .............. 244

16.1 Introduction . . . . . . . . . . . . . . . 245

16.2 Equipment , . . . . . . . . . . . . . . . . . 245

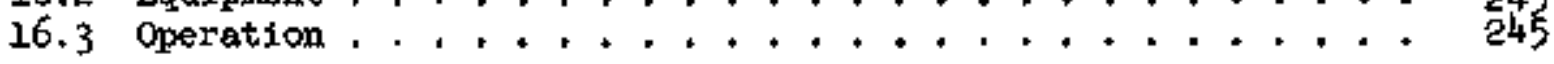

16.3 .1 Operating Procedure . . . . . . . . . . 245

16.3.2 Critical Operating Steps ............. 251

16.4 Equpment Evaluation . . . . . . . . . . . . . . 2 252

16.4.1 Late Deaign Work . . . . . . . . . . . . . 252

16.4.2 ARE Dump Tank, FV-1.10 ............. 254

16.4.3 ARE Dump Tank Retort, FV-111 . . . . . . . . . 258

16.4 .4 ARE Dump Tank Furnace, FV-510............ . 258

16.4.5 ARB Dump Tenk Furnace 0utlet Heater, FV-510A . . . 259

16.4.6 Molten \$alt tine Heaters Between FV-110 and -114,
FV-511 and -511A . . . . . . . . 259

16.4.7 Molten Salt Line Heaters Between FV-110 and -114,
FV -513 and $-513 \mathrm{~A}$. . . . . . . . . 259

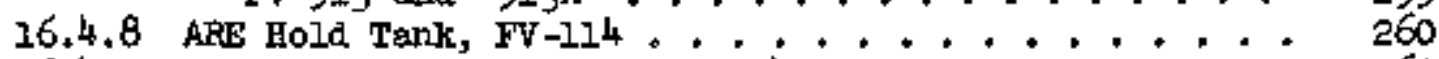

16.4.9 ARE Bold Tant Furnace, FV-514 . . . . . . . . . . 260

16.4.10 ARE Hold Tank Irlet Teater, FV-514A . . . . . . . 260

16.4.1.1 AKE Bold Tank Outlet Heater, FV-514B . . . . . . . . 260

16.4.12 Are Bnow Trap, FV-115 . .............. . 261

16.4.13 AFE Hold Tank Vent Iine Heaters, FV-515A and -515 . . 261

16.4.14 AFE Chaxging Line. . . . . . . . . . . . . . . 263

16.4.15 Vent IIne Heaters, FV-504t and -505 . . . . . . . 266

16.4.16 ARE Charging System Instrumentation. . . . . . . . 866

16.5 Sumary and Conclusions . . . . . . . . . . . . . 267

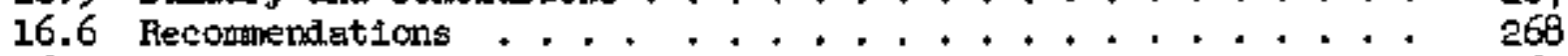

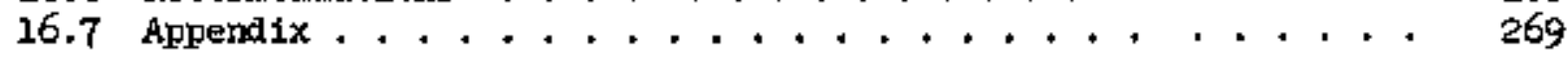

16.7.1 Operating Frocedure: Charging the Hold Tank . . . . 269

16.7.2 Operating Procedure: AFE Feed Salt Tranifer , . . . 270 
$-245-$

16.0 ARE CHARGTNG SYSTBM (2, 22, 23)

\subsection{Introduction}

The ARE fuel vas stored in the dup tank (FV-ilo) until it was processed in the Polatility Filot Plant in Fiscal Year 1958. This material was removed from the dimit tank and fed to the fluorinator batch-wIse from the ARE charging syster. The principal steps in the operation of this syatem were:

a. Transferring the entire molten ARE fuel charge into the hold tank (FV-174).

b. Flowing batches of the fuel as required to the fluorinator (FV-100) for processing.

Radiation exposure was reduced by remote operation.

\subsection{Equipment}

The generel arrengement of equiptent for this system is shown in Fig. 16.1. Each piece of equiprent is described in Table 16.1 .

\subsection{Operetion}

\subsubsection{Gpereting Frocedure}

Steps in the operation of the ARE Charging System were: ${ }^{\mathrm{A}}$

a. Demonstrating Utility of FV-104 Crosg-Over and Loop and Sealing Cross-Over ( 24$)$, b

1. Heating to and maintaining at $600^{\circ} \mathrm{C}$ the FV-114 injet line, outlet line and rent line and FV-114.

2. Flowing twelve cans of barren ealt into FV-114 through the FV-ll 4 inlet line with $\mathrm{N}_{2}$ purges on.

3. Heating to and holding $\geq 570^{\circ} \mathrm{C}$ the three autoresistance heated sections of the charge line (F1g. 36.1).

4. Filling the FV-104 cross-over with salt by having autoresistance sections $A$ and $C$ at $\geq 570^{\circ} \mathrm{C}$ and then sealing the cross-over by shutting off eircuit A.

\footnotetext{
${ }^{2}$ Radiological safety practices inclined using the meens listed in Sec. 16.4.16.

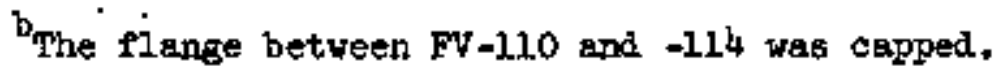




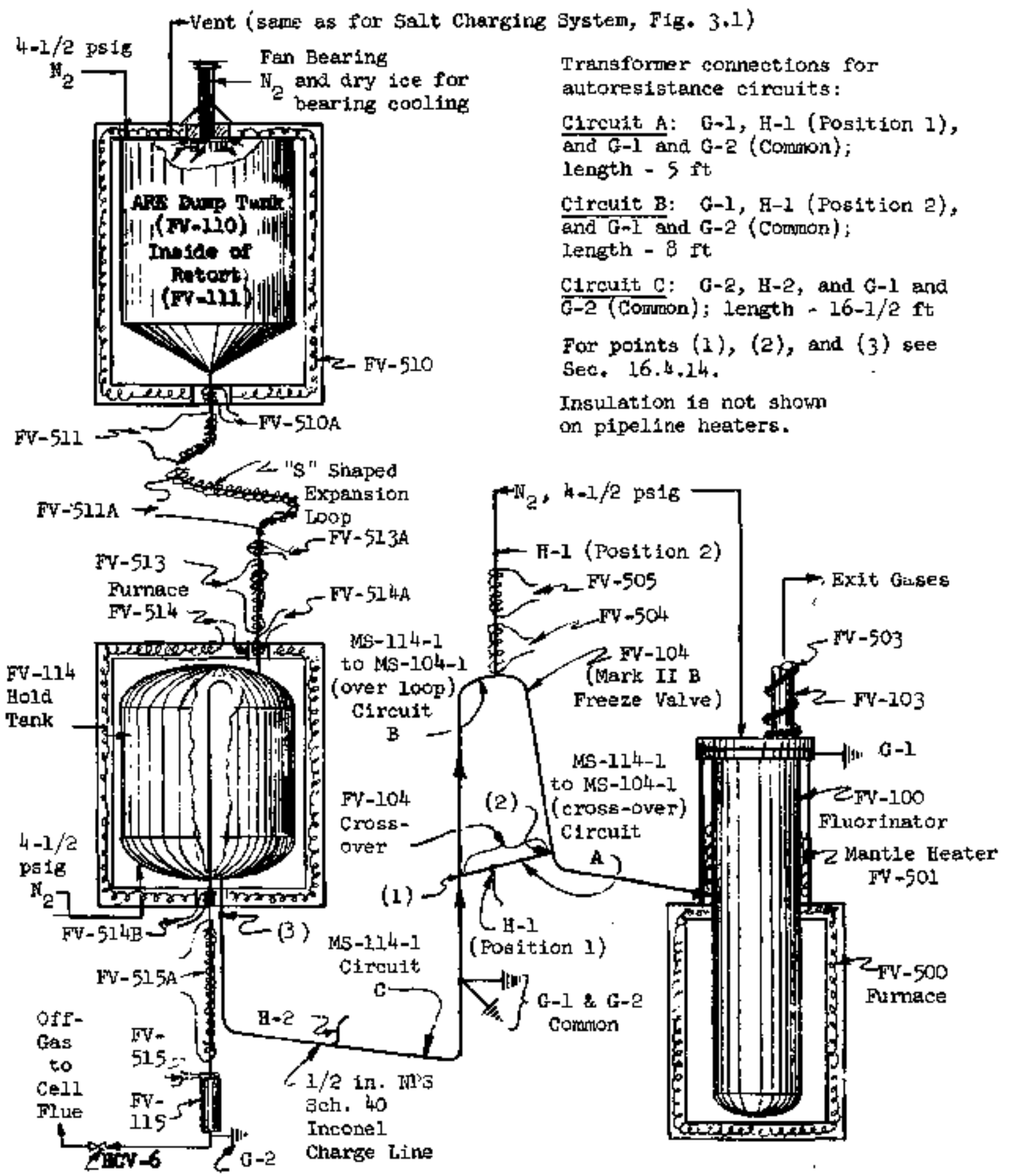

Fig. 16.1. Equipment Arrangerent in the ARE Charging System 
totio 16.1

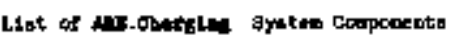

\begin{tabular}{|c|c|c|c|c|}
\hline Coppopent| & Fon. & 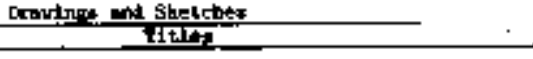 & 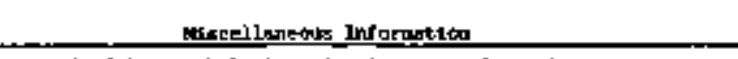 & Bofertented \\
\hline 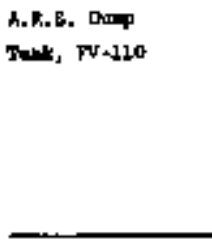 & 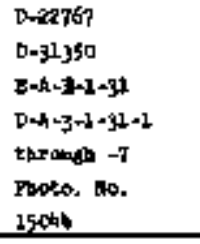 & 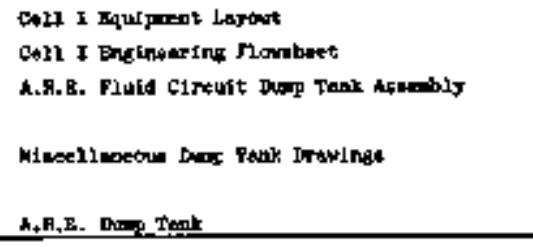 & 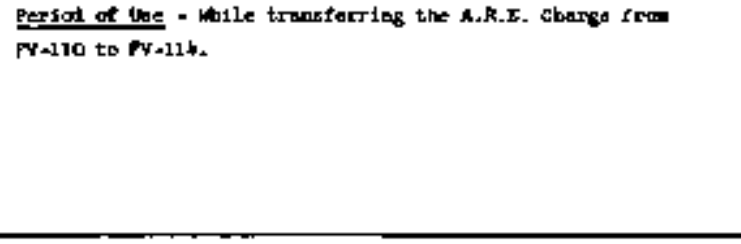 & 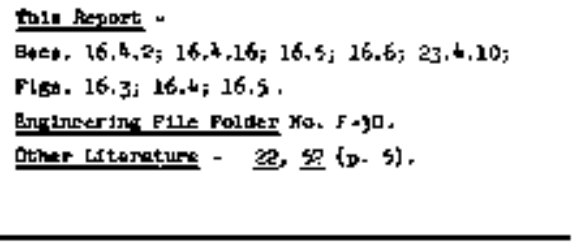 \\
\hline 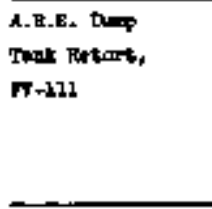 & 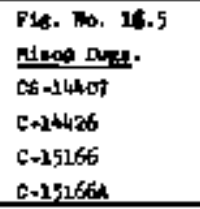 & 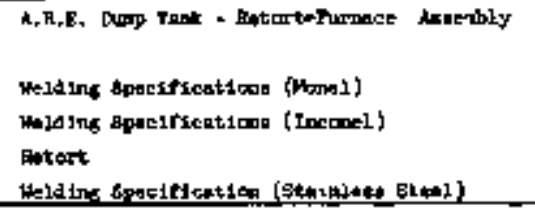 & 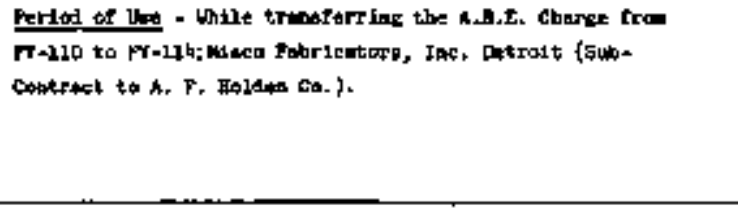 & 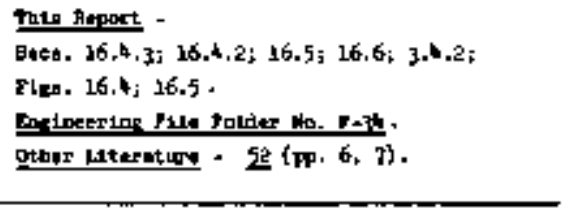 \\
\hline 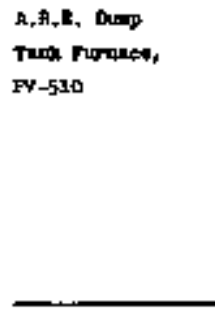 & 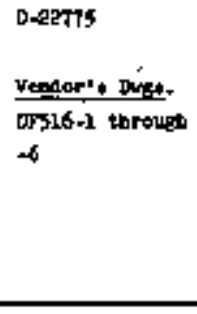 & 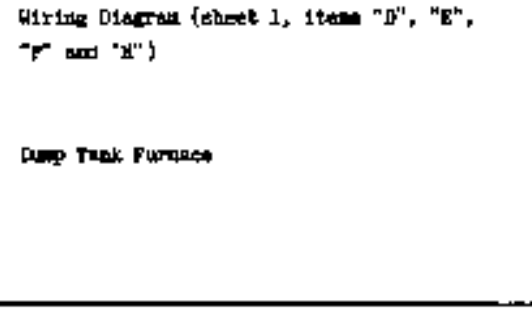 & 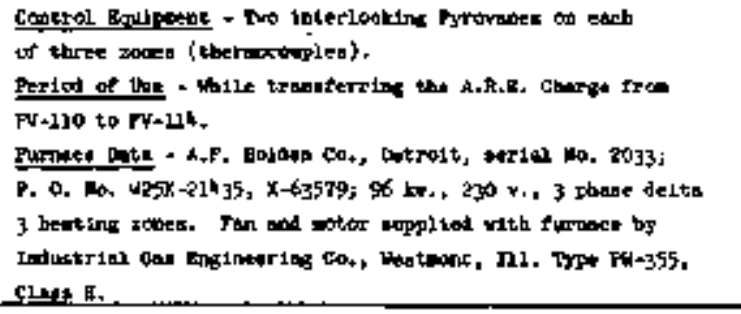 & 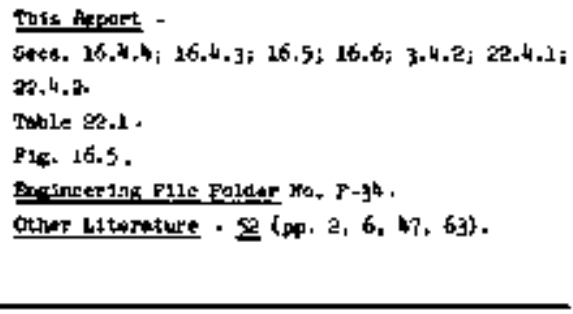 \\
\hline 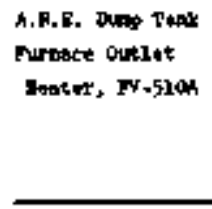 & 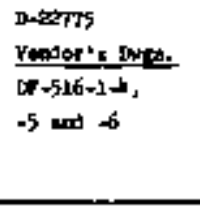 & 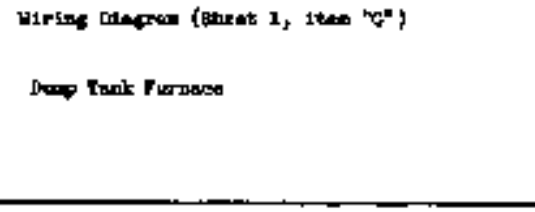 & 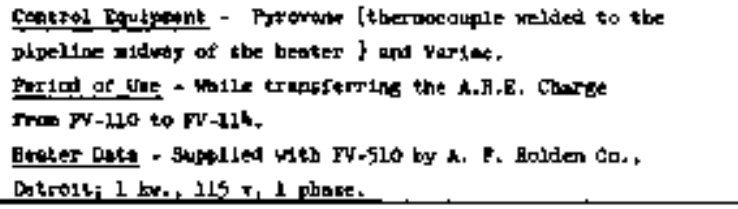 & 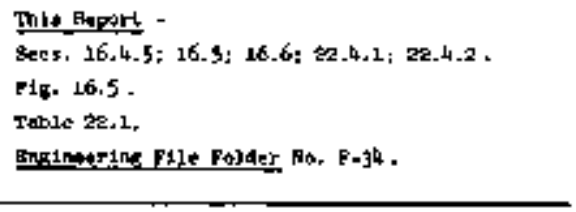 \\
\hline 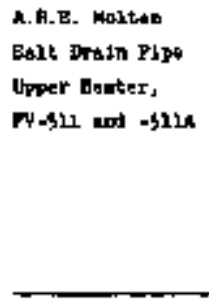 & 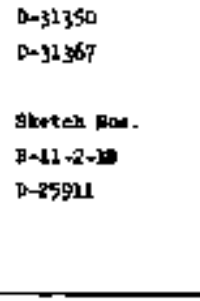 & 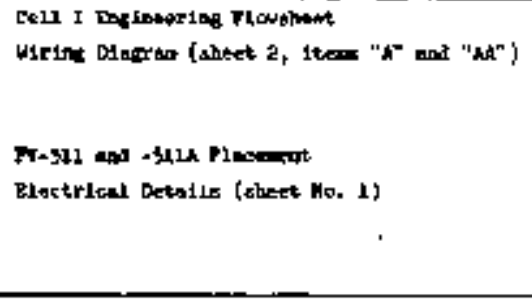 & 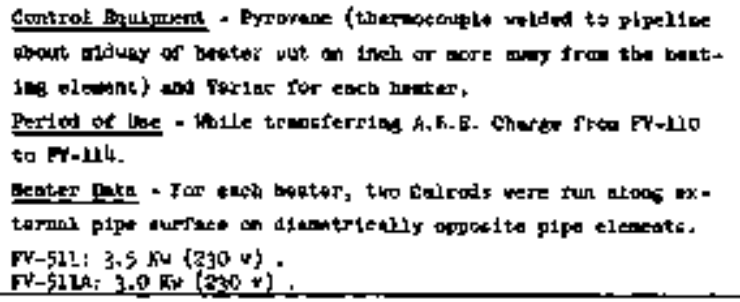 & 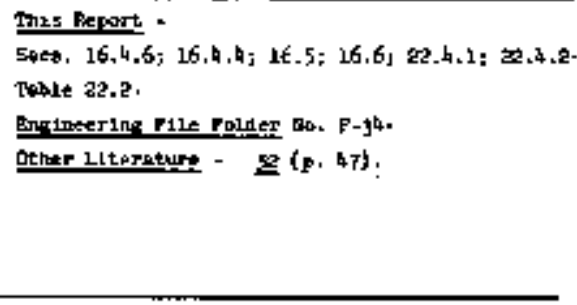 \\
\hline
\end{tabular}


Tatile 16.1 \{teat1onod $\}$

\begin{tabular}{|c|c|c|}
\hline & \multicolumn{2}{|c|}{ 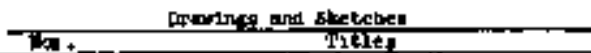 } \\
\hline A.R.E. Holten & 0.85911 & 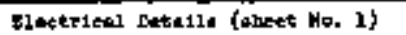 \\
\hline Eant Drald & 0.91350 & Cell I Eng1neryine howapet \\
\hline P1p* vower & 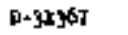 & 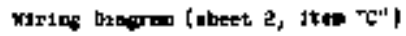 \\
\hline Batater, $\mathrm{NH}-513$ & Steted Fa. & \\
\hline & B-11-5-15 & $F V-513$ on -51 jh PLgeand \\
\hline
\end{tabular}

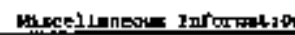

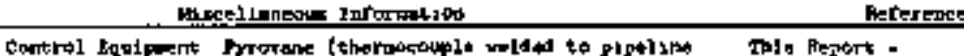

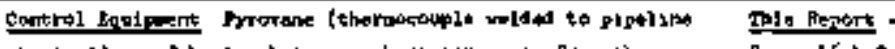

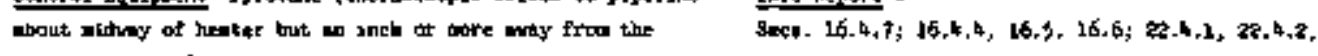

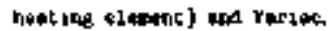
Tote Re.?.

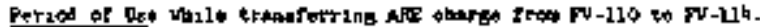

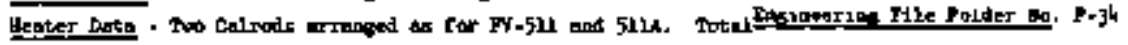

power ves 4.0 bu, (230 $r$ )

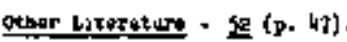

\begin{tabular}{|c|c|c|}
\hline 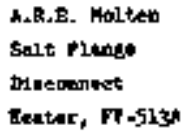 & 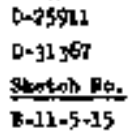 & 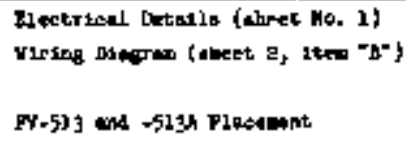 \\
\hline $\begin{array}{l}\text { L.R.t. Fold } \\
\text { Tank, N N-11 }\end{array}$ & $\begin{array}{l}0-15713 \\
0-23194\end{array}$ & $\begin{array}{l}\text { Boid Tank } \\
\text { hrotedity } \mathbf{N}-114,-115, \text { and sit }\end{array}$ \\
\hline
\end{tabular}

Conkrol Iquilemint - Bin11er to toot tor Fr-S13

tame an for $\mathrm{r}^{\mathrm{N}}-513$

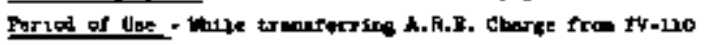

to $5 y-24$.

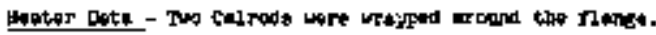

Tutal poner vas $1,5 \mathrm{kv},(230 \mathrm{c})$.

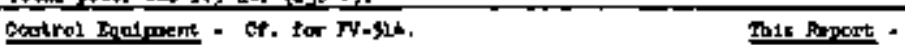

Periad of USEE - 's mpe.

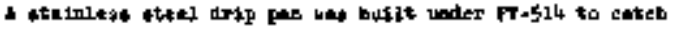

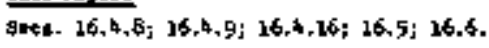

the salt lo ereat of weberel tablure.

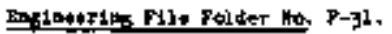

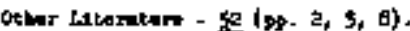

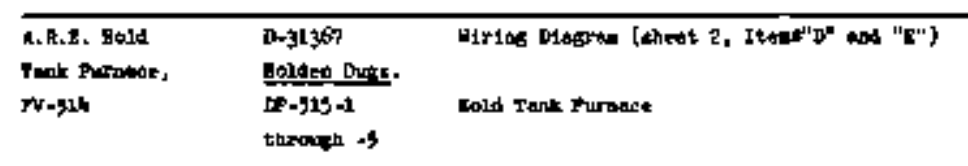

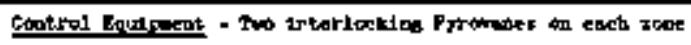

this Beport .

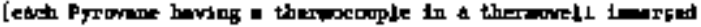

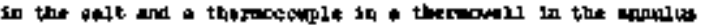

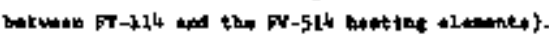

Per iod of che - "E" Pand.

5059, $16.4 .9 ; 16.4 .8 ; 16.5 ; 16.6 ; 22.4 .1$

$2,4,2$.

Toble 22.1.

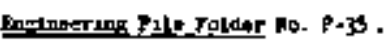

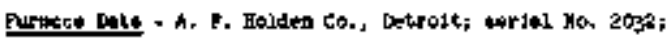

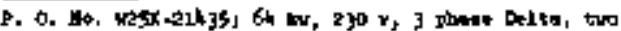

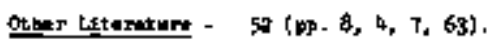

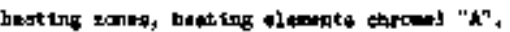

\begin{tabular}{|c|c|c|c|c|}
\hline 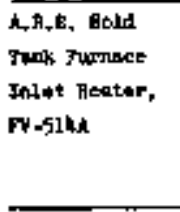 & 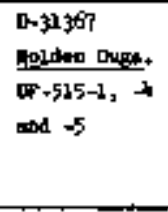 & 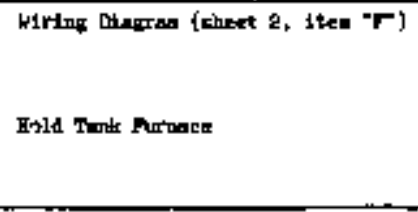 & 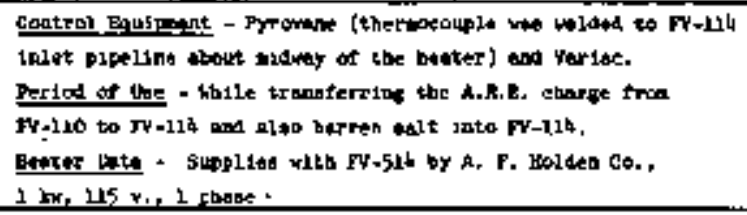 & 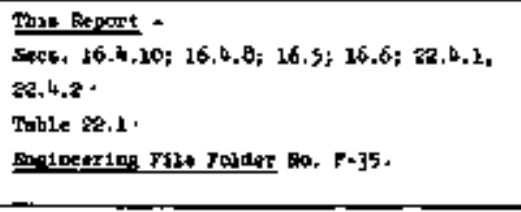 \\
\hline 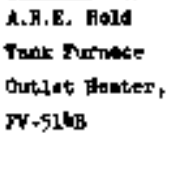 & 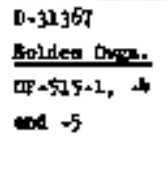 & 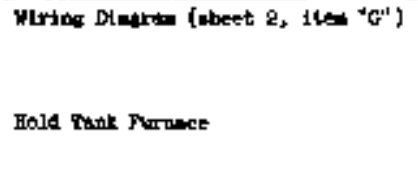 & 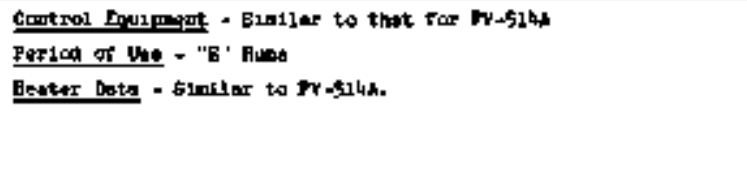 & 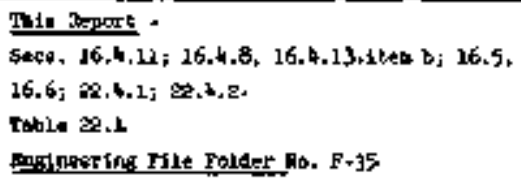 \\
\hline
\end{tabular}


Tuble 16.1 \{Continowd\}

\begin{tabular}{|c|c|c|c|c|}
\hline \multirow{2}{*}{ 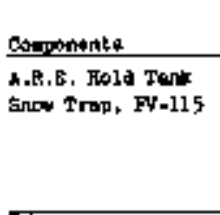 } & \multicolumn{2}{|c|}{ 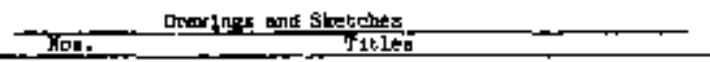 } & 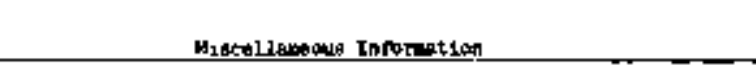 & Beferemsit: \\
\hline & 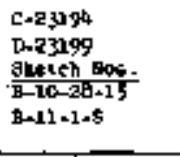 & 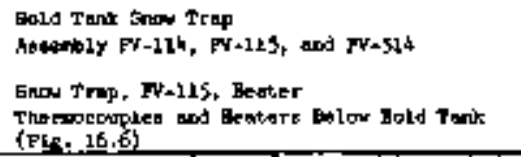 & 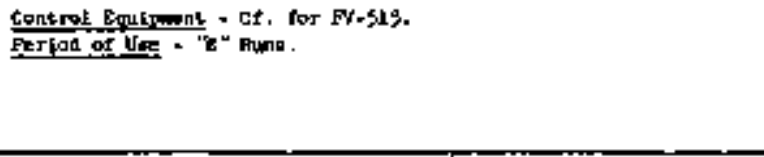 & 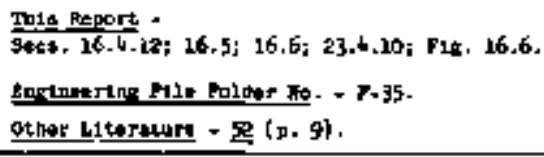 \\
\hline 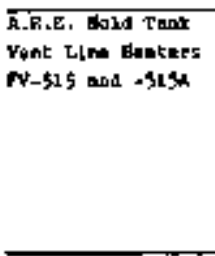 & $\begin{array}{l}0.22780 \\
118.16 .6\end{array}$ & 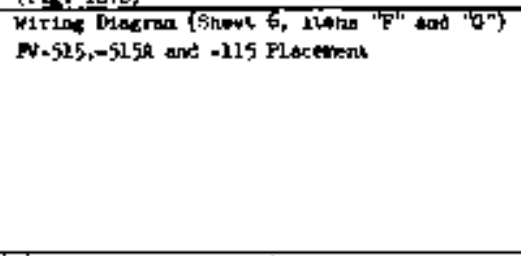 & 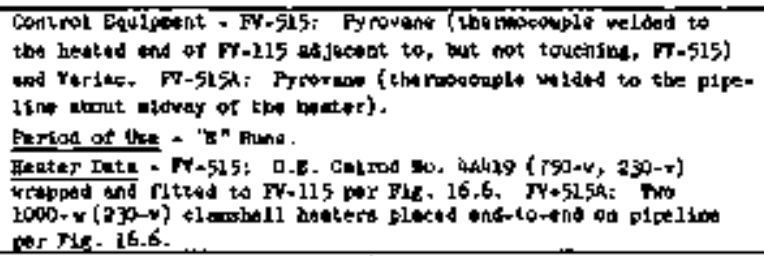 & 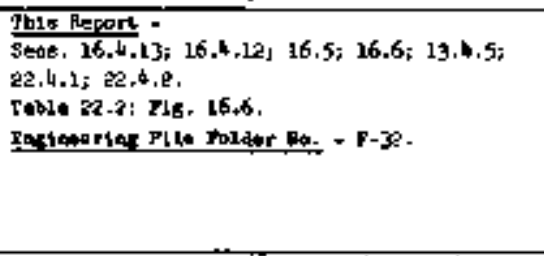 \\
\hline 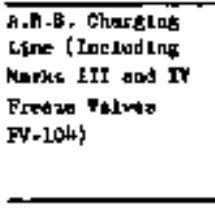 & 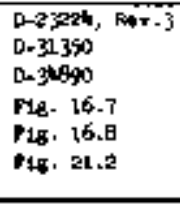 & 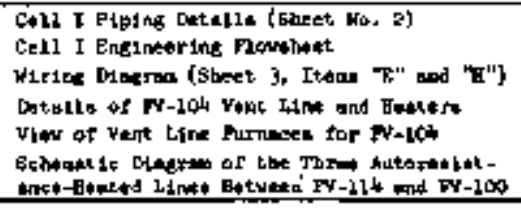 & 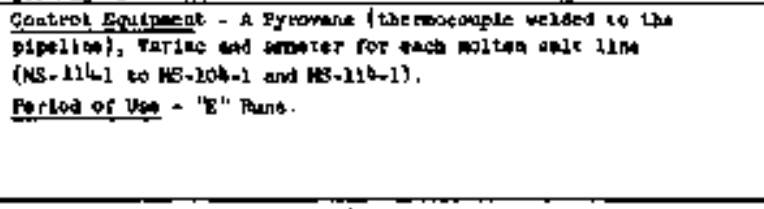 & 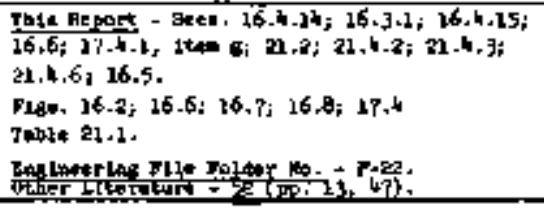 \\
\hline $\begin{array}{l}\text { Wast Liae lover } \\
\text { Fontur, FY-s, }\end{array}$ & $\begin{array}{l}0.227 \times 8 \\
0.31300\end{array}$ & 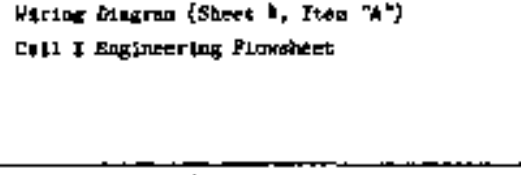 & 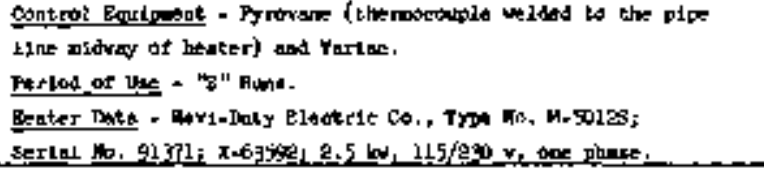 & 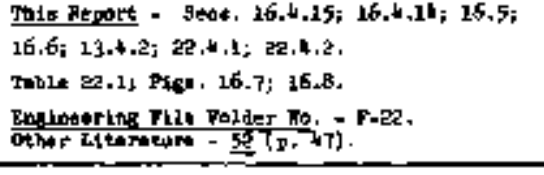 \\
\hline $\begin{array}{l}\text { Yont Lin* } \\
\text { Upper Deater, } \\
\text { fv-sos }\end{array}$ & $\begin{array}{l}0-22 \pi 6 \\
0-31350\end{array}$ & 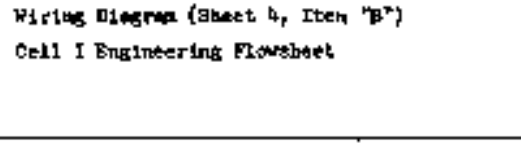 & 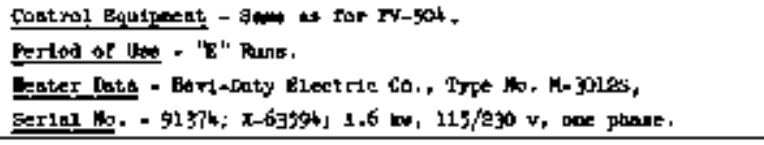 & sace e sor PY-904. \\
\hline 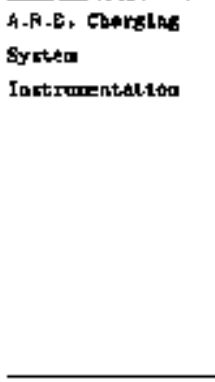 & $0-31350$ & 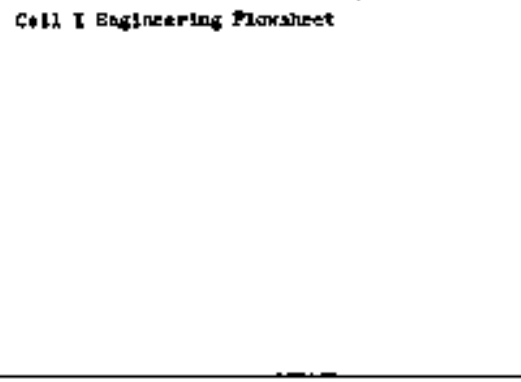 & 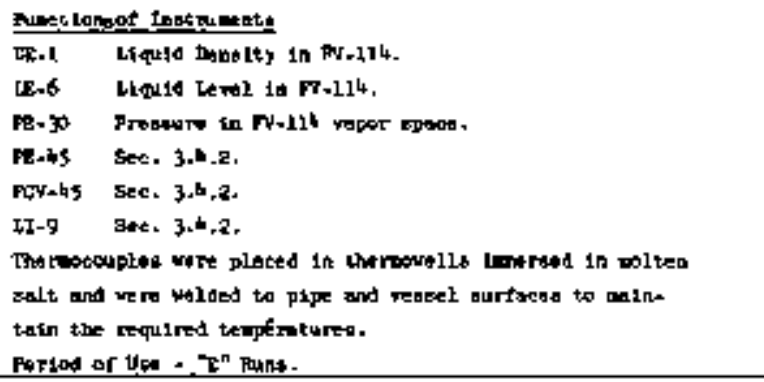 & 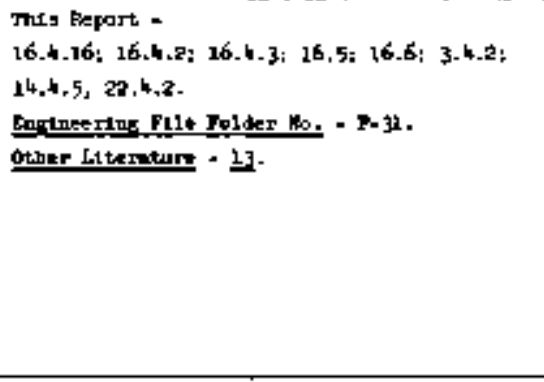 \\
\hline
\end{tabular}


5. Trensferring molten aalt across the loop by having eutoresistance sections $\mathrm{B}$ and $\mathrm{C}$ at $\geq 570^{\circ} \mathrm{C}$ and then sealing tbe charge line at its lowest point by cutting off autoresistance power.

b. Charging FV-114 with the ARE fuel Charge

1. Having already performed item 1 in Part A and having connected the flange between FV-110 and -1.14.

2. Weighing 5\%-210 and then placing FV-110 dintorFvinll.

3. Putting 11d on Fv-510.

4. Adjust1ng the necessary valves, setting purges, ant continuing the purges for 28 hours to remove ail atr before starting to melt the salt.

5. Turning on the FV-510 fan and maintaining $\mathrm{H}_{2}$ flow and addition of dry 1ce to keep fan bearing cool.

6. Putting necessary instruments into serrlce and synchronizIng the charts.

7. Adjusting set-polnts on temperature controllers to $600^{\circ} \mathrm{C}$ and setting Verlacs on furnaces and heaters to prepare for AFE charge melt-down.

8. Malntaining temperatures of vessels and l1nes at $\sim 600^{\circ} \mathrm{c}$.

9. Wetching liquid level recorder (LR-6) in Fv-114,

10. When LR -6 reading reached the maximum, heat Ing FV-510 to $650^{\circ} \mathrm{C}$ and holding it at $650^{\circ} \mathrm{C}$ for 15 hours to assure entire drainge of AFE cherge to FV-i1l.

11. Tuming off power to the FV-510 fen and all heaters above FV-514 (including FV-514A).

12. Resetting vilves and purges.

13. Then AFE charging equipment had cooled essentialiy to room tempereture, difconinecting and discarding this equipment and then capping the flange above FV-1.14 (FV-110 was agein weighed before discarding.)

NOTE: The degree of FV-110 dratnage was determined in three ways: (a) weighing before and after, (b) activity readings, and (c) IR-6 reading. See Sec. 16.4.2 for more detail. 
c. Transferring $\sim 150-\mathrm{kg}$ Batches of Feed Salt from $r V-114$ to -100 .

1. Having AFs fuel at $600^{\circ} \mathrm{C}$ in FV-1.14; FV-514B, -515 , and $-515 \mathrm{~A}$ et $600^{\circ} \mathrm{C}$; HCV -6 open; and the charge line sealed.

2. Heating the charge line circuits $\mathrm{B}$ and $\mathrm{c}$ to $\geq 570^{\circ} \mathrm{C}$ and FV -100 to $600 \mathrm{c}$.

3. Closing vent yelve (HCV-6) and pressurizing FV-114 to $\sim 10$ psig with $\mathrm{N}_{2}$.

4. When IR-2 reading in FV-100 reached the desired value, openlng HCV-6 to stop the transfer."

5. Adjusting velves and maintainfing the required tenperatures, (Autoresistance circuits $B$ and $C$ were sbut off; all other power was left on.)

d. "Washing-Out" FV-114 and the Charge Line after Run E-6 Charging.

1. Having vessels and lines at tenperatures indicated in items 1 and 2 in Part $c$ and $\mathrm{F}-514 \mathrm{~A}$ at $600^{\circ} \mathrm{C}$.

2. Transferring $39 \mathrm{~kg}$ of barren salt "flush" into FV-114 through the capped flange above ritlly.

3. Transferxing more than half ( $\sim 25 \mathrm{~kg}$ ) of this flush over the FV-104 loop.

4. Then, after alsconnecting clfcult B and connecting clrcust A, completing the "wash-out" salt transfer to FV-100 through the Fv-1.04 cross +over.

5. Shutting off power to circuits $A$ and $B$ to seal charge line at its lovest point.

6. Shutting off all power except for IV-100.

Operating procedures prepared for Parts $b$ and $c$ are show as sees. 16.7.1 and 16.7.2. Methods used for Parts a and d were variations of these procedures.

\subsubsection{Critical Operating Steps}

a. Denonstrating the operabllity of the FV-lol loop and cross-over and a tight seal at the crose-over.

\footnotetext{
an contrast to the aalt run-back obtained in waste salt transfers (Sec. 13.3.1),
} essentially no run-back occurred in the ARE work.

$b_{\text {Run }}$ E- 6 charging exhausted the AFE fuel. At that time, the salt level was at about point (3) on Fig. 16.1 . 
Prior operating experience cast doubt on the advisability of using the molten lead-sealed disconnect flange botween FV-110 and -114 snstesd of a positively gealed joint. Using the original flange design would have made it passible to flow the entire ARE salt charge into Cell 1 should a plug occur in the inlet to FV - 114 before the salt tranaferred to FV-134. Such a mishap would have presented a severe radiation hazard and a complicated uraniun recovery problem. Therefore, the molten lead-sealed flange was replaced with a ring-gasketed flanged joint. This joint was easily broken after the aalt transfer and capped to provide the desired seal whth a gas and/or molten salt connection to FV-1.24."

b. Deaigns unflnished which required obtaining.operating data and/or avallable manpower for completion.

The pipeline between FV-110 and -114 was fitted wth an " $\mathrm{S}$ " sheped expansion loop as ghown in Fis. 16.2. Also incorporated in this scheme was the four-section heater comprising Fv-5ll, $-5.11 \mathrm{~A},-513$, and $-513 \mathrm{~A}$.

The shape of the vent line vith the placement of FV-115 and associated heaters, FV-515 and -515A, was determined as shown in Fig. 16.1.

\subsubsection{ARE DuIP Tank, Fv-110}

The AFE dum tank contalning the radioective ARE salt fuel (reading 10 rem at $5 \mathrm{ft}$ eway) was tranaferred by truck and mobile crane from Building 7503 to Cell 3 in Building 3019 on July 28, 1955 (Fig. 16.3,22). This glove being very carefully planined was me without difficulty or axceasive persannel exposure to radiation. An attempt was made to mainta1n a nitrogen atmosphere about the eglt in the Inverted dump tank during its storege in Cell 3. However, the rubber stoppers closing the drain holes fell from the the tank after a few months. So this idea was abandoned. Nevertheless, no difficulty fron aiv or water vapor in the salt was experienced during processing. The dump tank wes losded 1nto 1te furnece on Decerdber 2, 1957 without trouble or excessive personnel radietdon exposure (Fige. 16.4 and 16.5). The dump tank wes weighed ( 4,370 1b) by means of a strein gauge before being lowered into its furnace and again after the selt had been drained from it to the hold tank $(2,275 \mathrm{ib})$.

The trengfer of salt from the dump tenk to the hold tank was made on Degember 5, 1958 without incident. The transfer required 5 hours at $\sim 550^{\circ} \mathrm{C}$ for the bulk of the salt to drain by gravity. The furnece was heated, however, to $650^{\circ} \mathrm{C}$ for an edditional 15 hours to assure that all of the salt had drained. The level of rodiogctivity at the surface of the dump

\footnotetext{
This flanged joint also required the expansion loop described below in Item $b$.
} 


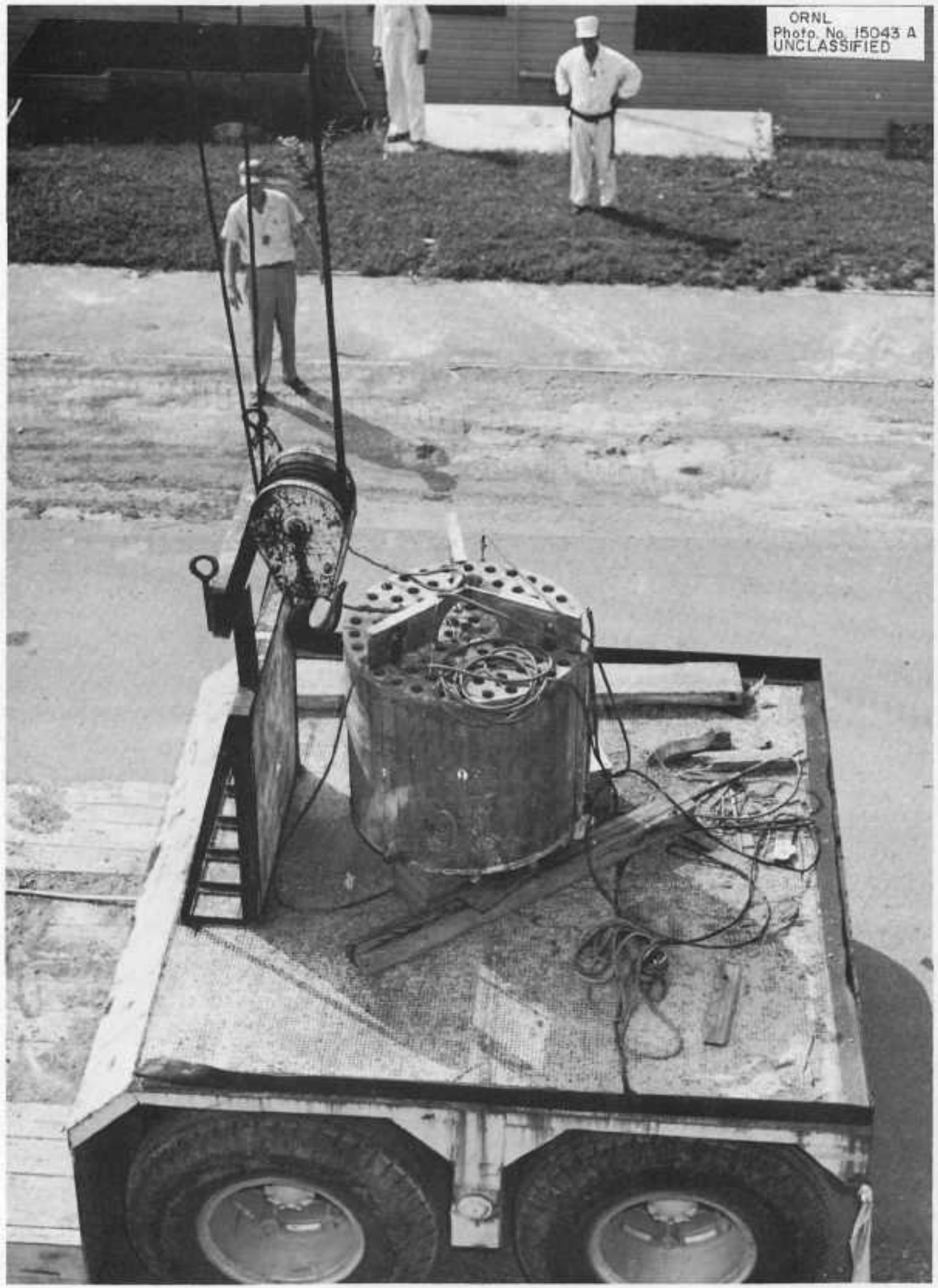

Fig. 16.3. ARE Dump Tank, FV-110. 


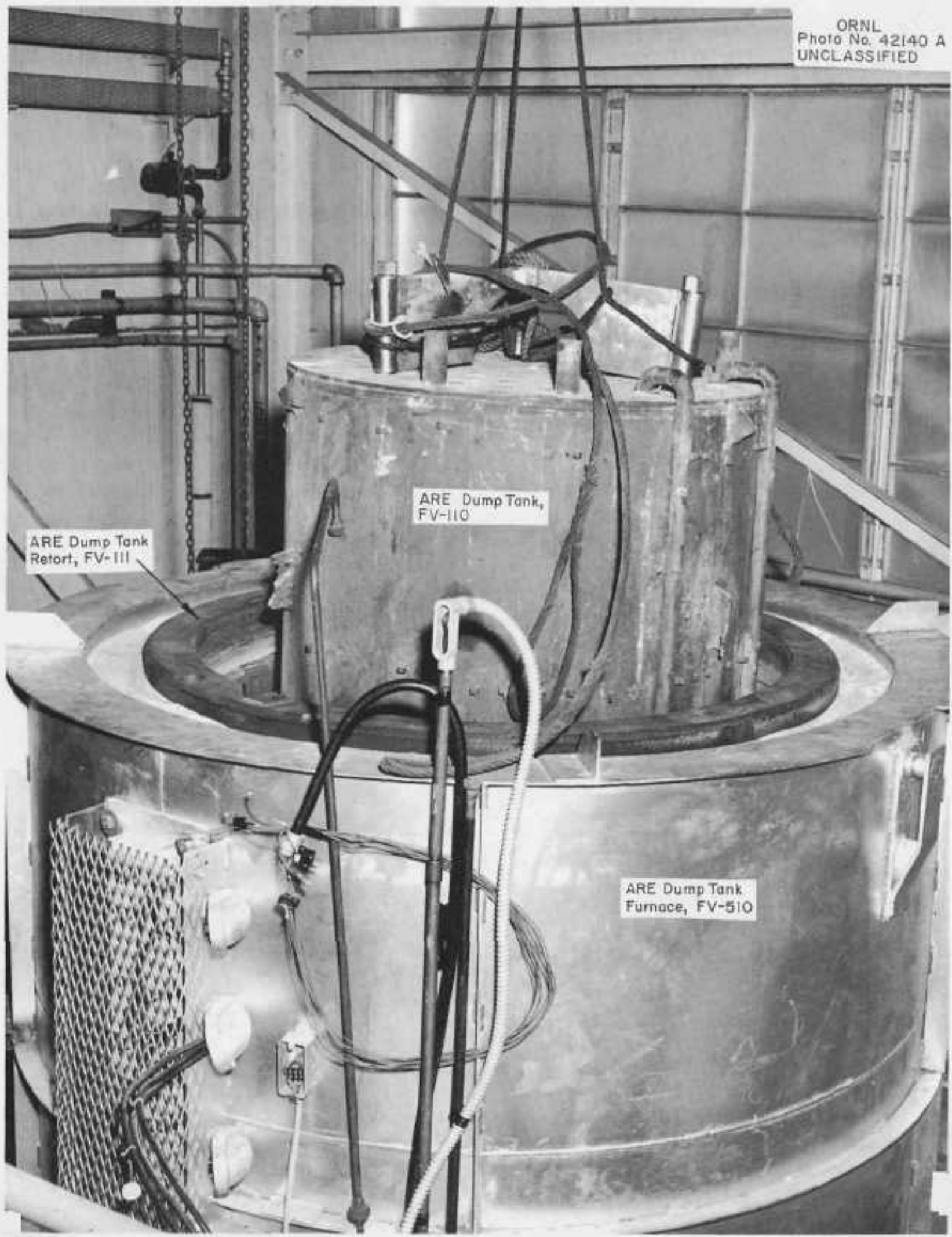

Fig. 16.4. ARE Dump Tank Being Lowered Into the Retort and Furnace. 


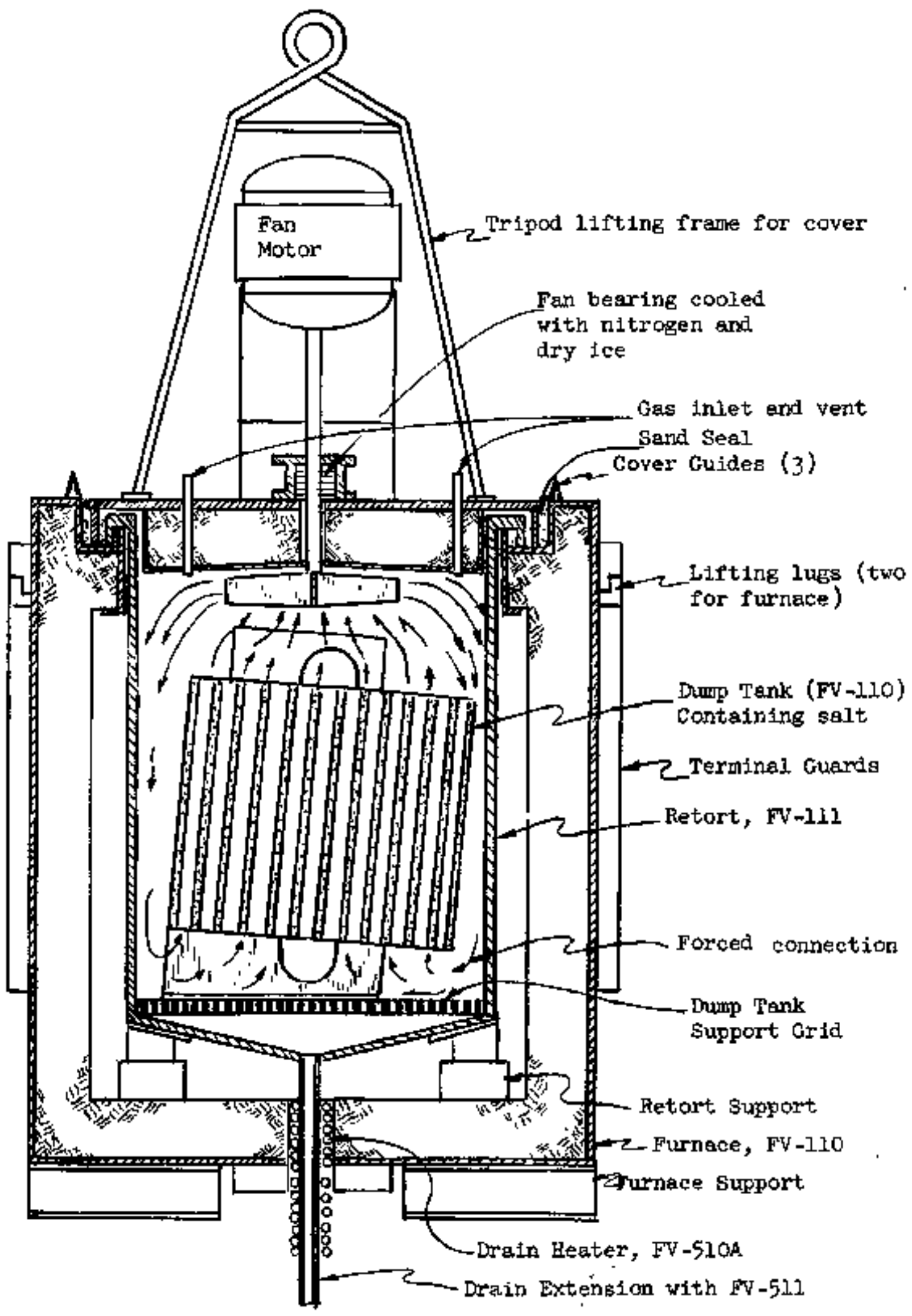

F1g. 16.5. ARE Dump Tank-Retort-Furmece Assembly 
tank furnace decressed from $60 \mathrm{mrem} / \mathrm{hr}$ (firnace top) before the transfer to $\sim 2$ mrew/hr after the transfer, indicating complete remoral of the ARE salt. The completeness of the trengfer was in doubt before the activity measurementa were made because the liquid level (I. -6; Sec. 16.4.16) in FV-114 indiceted approximately $10 \%$ less salt than was expected from preliminary calculations. The highest activity reading on the dump tank itself decreased from $1500 \mathrm{mrem} / \mathrm{hr}$ at contact before the transfer to $30 \mathrm{mrem} / \mathrm{hr}$ after the transfer.

\subsubsection{AFE Dump Tank Retort, FV-11}

This vessel contained the dump tank whtle trensferring the AFE charge to FV-114 (Sec. 16.4.2). A thin coating of dark brown scale covered the statnless steel surfaces of the ARE retort (FV-lll) despite $N_{2}$ purging of the system for 18 hours prior to heating. (A hygrometer had been instaried in the retort vent to determine when all of the rater vapor wes removed.) Because of this scale 1t was feared that all of the air in the dump tank bad not been removed by the purging. Wo difficulty was experienced, however, during operation becaupe of $\rho_{2}$ or watex vepor in the salt. The seme vent arrengement described in Sec. 3.4 .2 was used for the ARE dump tank (16.4.16). After the dump tank and $i t a$ furnace were removed from Cell 1 , the vent system was reinstalled on Fy-loe.

\subsubsection{ARE Dump Tank Furaace, EV-510}

were:

The ARE dump tank furnace wes satisfectory. Time requirements

a. Time to $550^{\circ} \mathrm{C}$ (Pyrotane set-point at $600^{\circ} \mathrm{C}$ ) - $27 \mathrm{hr}$. $^{\mathrm{c}}$

b. Time et $550^{\circ} \mathrm{C}$ to drain bulk of galt by gravity - $5 \mathrm{hr}$.

c. Time from $550^{\circ} \mathrm{C}$ to $650^{\circ} \mathrm{C}-3 \mathrm{hr}$.

d. Time at $650^{\circ} \mathrm{C}$ to assure conplete aalt removal - $15 \mathrm{hr}$.

The send seal on the dump tank furnace isd held effectively (as indicated by PR-45) both for the ARE salt tranafer and for a preliminary trial transfer of berren aalt from 20 cana (Secs, 16,4,3 and 3.4.2),

Difficulty was experienced in keeping the FV-510 fan bearing cool (i.e., below $100^{\circ} \mathrm{C}$ ). Since the $\mathrm{H}_{2}$ flow for this pirpose wes inadequate, dry

Activitios were determined with a cutie pie (Seca, 23.4 .10 and 16.4 .16 ).

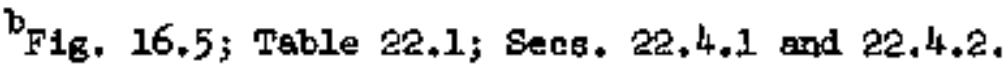

This Included the curing time of the furnace as well as the time required to heat the dump tank to $550^{\circ} \mathrm{C}$. The time to melt the Afrs fuel was $\sim 10$ houra. 
Ice was packed around the bearing to cool 1t. The effective draining or the dump tank, which was a heat exchanger having 90 two-in. diameter tubes vertically through 1t, indicated that the FV-510 fan spread the heat evenly through the tubes as intended.

16.4.5 ARE Dump Tank Furmace Outlet Heater, FV-510A

After the salt was thought to be molten and before the salt transfer to FV-134 had begun, the power to this heater was set at nearly the maximum since this heater was located near the transition point betweed the retort and the molten salt pipeline, a point found to inhibit trangfer in the salt charging system. Actually, several hourg elapsed between the time the salt was presumed to bo molten and the time the selt level in PV-114 began to rise. Therefore, concern had developed over whether this or aome other heater on the line between FV-510 and FV-114 was inadequate.

Operational data were: Pyrovane set-point $-600^{\circ} \mathrm{C}$ and vartac setting $-240 \mathrm{v}$.

16.4.6 Molten Salt Live Hegters Between FV -110 and -114, FV -5.11 and $-5,21 A^{D}$

These heatera were satisfactory.

Operational data vere:

a. Pyrovane set-point6:

FV -51] - $600^{\circ} \mathrm{C}$

b. Variac settings FV-51] - $140 \mathrm{v}$

FV $-511 A-140 \mathrm{v}$

Heat-ug times were leas then the $\sim 10$ hours $c$ required to melt the salt in Fv-110.

16.4.7 Nolten Selt Line Heatere Between FV-110 and -114 , FV -513 and $-513 \mathrm{~A}^{\mathrm{b}}$

These heater's were setisfactory.

Operational data were:

a. Pyrovane set -pointe

$F V-513=600 \%$
$F V-513 A=600 \%$

b. Variac settings

FV $-513-70 \mathrm{~V}$

FV-513A $-140 \mathrm{v}$

Heat-up $c$ times were less than the $\sim 10$ hours required to melt the aalt in for-j10.

Fig. 16.5; Table 22.1; Secs. 22.4.1 and 22.4.2.

Table 22.2 and Secs. 22.4.1 and 22.4.2

Eatimate based on 27 hrs required to cure furnace and melt the ARE charge (Sec.16.4.4). 


\section{4 .8 ARE Hold Tank, FV - 114}

FV-114 was a Btalnlegs steel tank heated by Fv-514 (See. 16.4.9). This vessel withstood the additional time-at-temperature of about one month after Fun No. B-2 with no spperent BIBns of fallure. This vessel has not been visually or otherwise inspected since the ARE recovery runs. In order to assure that no loss of selt would occur in the event of vesiel fatlure, a stainless steel drip pan was bujlt under FV-Jil.

The instrumentation on FV-114 (DE-1, LE-6, and PE-30) Is discussed in Sec. 16.4.16. The technique of bringing the ingtrument purge lines through the bottom of FV-114 was considered less desirable than bringing them through the top. Not only did this aubject a greater length of purge line to the corrosive salt mixture but it also mede maintenance work on the probes impossible.

16.4.9 ARE Hold Tank Furnace, $\mathrm{FV}-514^{\mathrm{b}}$

This funsec satiefectorily heated FV-114 (Sec. 16.4.8). To malntain the ARS fuel charge at $600^{\circ} \mathrm{C}$, its Pyrovane was set at $600^{\circ} \mathrm{c}$.

During installation, it was necessary in order to obtain a proper fit to redrill some of the holes in the base provided for pipelines and instrument purge lines.

16.4.10 ARE Hold Tank Inlet Beater, FV-514A

This heater was gatisfactory.

Operational data were:
a. Pyrovane set-point - $600^{\circ} \mathrm{c}$
b. Variac setting $\quad-70 \mathrm{~T}$

This heater was used only when transferring selt into FV-1l4 (Sec. 16.4.8). Its heat-up time was less than that required to melt the salt to be charged (See. 16, 4,4$)$.

16.4.11 ARE Bold Tank Outlet Heater, FV - $514 \mathrm{~B}^{\mathrm{b}}$

Th1s heater was satisfactory.

Operational data were:
a. Pyrovane aet-point
$-600^{\circ} \mathrm{C}$
b. Variac setting
$-70 \mathrm{v}$

The salt was maintalned at $560^{\circ} \mathrm{c}$, about $40^{\circ}$ above the melting point, duriag the one month's period whereas normally it was kept at $600^{\circ} \mathrm{C}$ while operating. bable 2e.1 and Secs. 22,4.1 and 22.4.2. 
Since this heater vas kept hot while the ARE charge was molten in FV-1.14 (Sec. 16.4.8), 1ts heat-up t1me was not operationally algnificant.

\subsubsection{AFi Snow Trap, FV-115}

"Snow" removal data included the followlng: (a) the activity of the mesh varled from $120 \mathrm{Jurem} / \mathrm{hr}$ at the inlet to $10 \mathrm{mrem} / \mathrm{hr}$ at the point half-way along the axis, remaining 10 mrem/hr along the rest of the axis; (b) the deposit was very thin on the flrit hale of the wesh and virtually nonexlstent on the second half; (c) the deposit when scraped off the mesh had a graylsh cast and read $400 \mathrm{mrem} / \mathrm{hr}$; and (d) there was insufficlent material for identification anelyaes," These data point toward the conclusion that the anow problem was not serious enough either to form plugs or to render the vent line bighly radioactive. (Sec. $16.4 \cdot 13$ ).

See Fig. 16.6 for location of this trap which was neated by FV -515 16.4.13 AFE Hold Tank Vent Line Heaters, FV-515A and $-515^{b}$

The clamshell heater, FV-515A, was satisfactoxy,

Operational data were:
a. Pyrovane set-point $-600^{\circ} \mathrm{C}$
b. Variac setting - $140 \mathrm{v}$

FV-515, a tightly bent Calrod heating FV-115 (Bec. 16.4.12) failed twice. Since no other calrod feilures under reasonebly good conditions of Bervice occurred," the reason for trouble with thls heater was belleved to have been the tight bend requixed. The usual precautions with bending were taken. However, in spite of these precautions, the final required outside diameter of the bent calrod was hand to achleve wthout exceeding the recominended ininimum redius of bend. Fyrovane set-point was $600^{\circ} \mathrm{c}$.

Since these heaters were kept hot while the AFE charge wes in FV-114, heat-up times were not operationaliy signticant.

Activity data vere obtainea with a custe pie (Beca. 23.4 .10 and $16,4,16$ ).

FIg. 16.6; Sees. 22.4.1 and 22.4.2; Table 22.2

'Some trowble with the waste nozzle Calrod, FV-512, was also experienced as cited in Sec. 13.4.5. In this case, however, service conditions were severe, especially since molten selt contacted the calrod. 


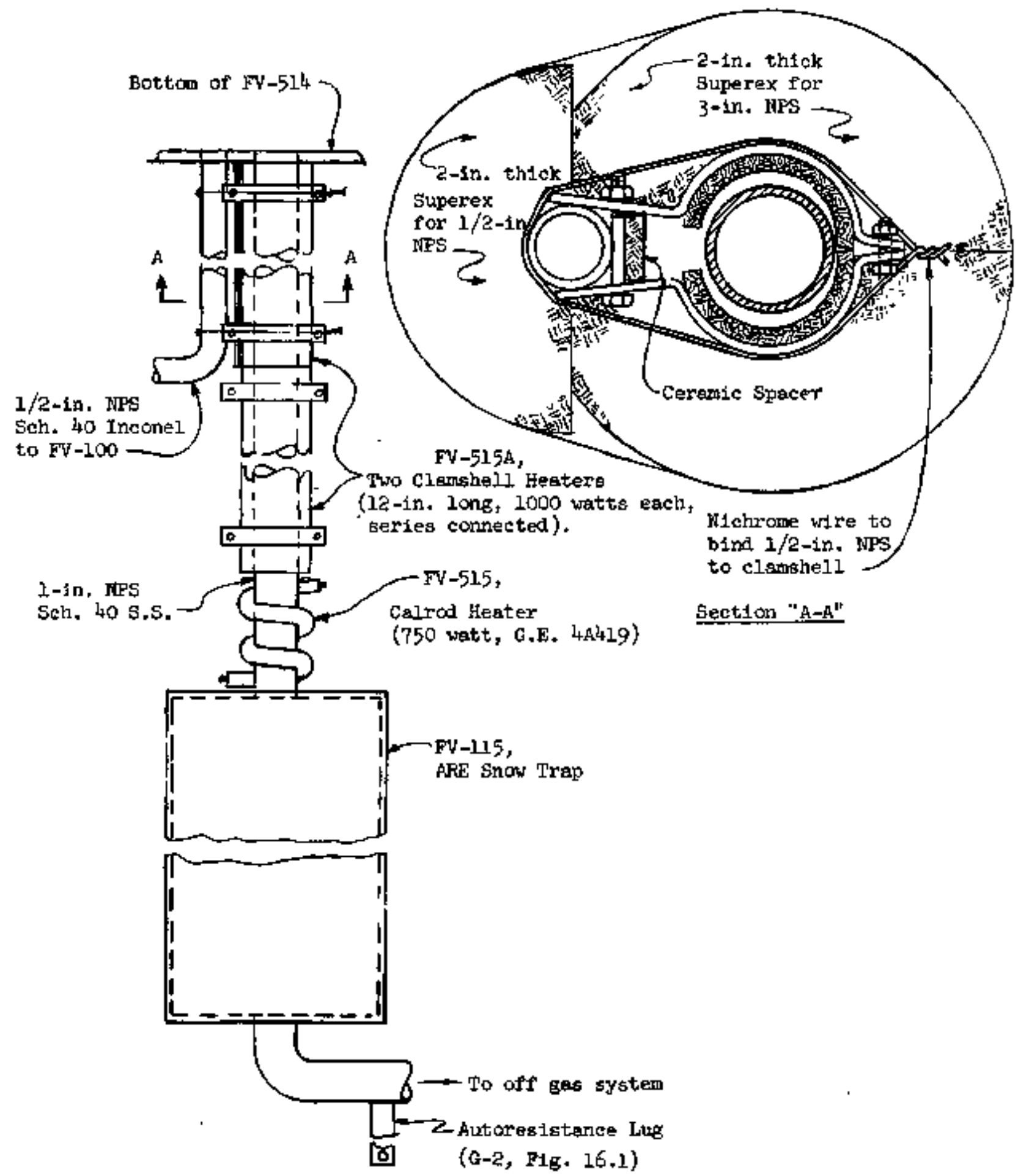

Fig. 16.6. Placement of FV-515, -515A, and -115 


\subsubsection{ARE Charging Line}

The new-deatgn charge line including the Mark III (no FV number) and IV (FV-104) freeze valves show in Figs. 16.2 and 17.4 replaced the original design to facilitate "washing-out" FV-114 after the last ARE feed transfer (Part d, Sec. 16.3.1 and Sec. 17.4.4).

The placement of electrodes on the MS-114-1 and MS-114-1 to MS-104-1 transfer Iines is delineated in Secs. 21.4.2; 21.4.3; and 21,4.6. The satia. factory placements of two ground electrodes on the corresponding molten salt lines are of specteic interest here:

a. The Fv-114 extremity electrode for NS-114-1 on the vent line.

b. The Fv-100 extremity electrode for MS-114-1 to $\mathrm{MS}-10 \mathrm{H}-1$ on the vessel flange.

In addition, the off-molten-selt-line placement of the "hot" electrode on the FV-lol nitrogen line was satisfectory as indicated in the two following paragraphs and in sec. 16.4.15.

Essential technical deargn features of FV-104 were:

a. Placement of the nitrogen line at the top of freeze talve loop equidistant from points (1) and (2) (Fig. 16.2) so that the loop "hot" electrolde (H-1) could be placed on the nitrogen Iine.

b. At this nitrogen line, proper seddle-joint formation to assure an epproximately even split of autoresistence current and adequete heating of the "tee." [This also included the correct wall thickness of the nitrogen line (n1ckel) for guffictent autoresistance heating at the "tee" per Sec. 2l.2]

c. Point (2) being placed slightly below point (3) so that the line segment (3)-(2) could stand full of salt wh FV-124 empty.

d. Iine segment (1)-(2) being sloped upwerd toward FV-100 so that pressure would be required to transfer salt from the filled line segment (3)-(2) to FV-100.

The operation of the charge line was without incident except that full current( $\sim 500 \mathrm{amp}$ ) in Run $\mathrm{E}-6$ was required to transfer the "wash-out" salt to FV-100 through the cross wover. The reason for this was presumed to be cold spot (s) occurring at cracks in the line insulation. The transfer time was normally $\sim a$ half-hour, belng somewhat longer in the Fun $E-6$ "wash-out."

Figs, 16.6, 16.7, 16.8; Becs. 21.4.2 and 21.4.3; and Table 21.1. Ifne temperatures were measured with thermocouples placed as delineated in Sec, 21,4.6. 


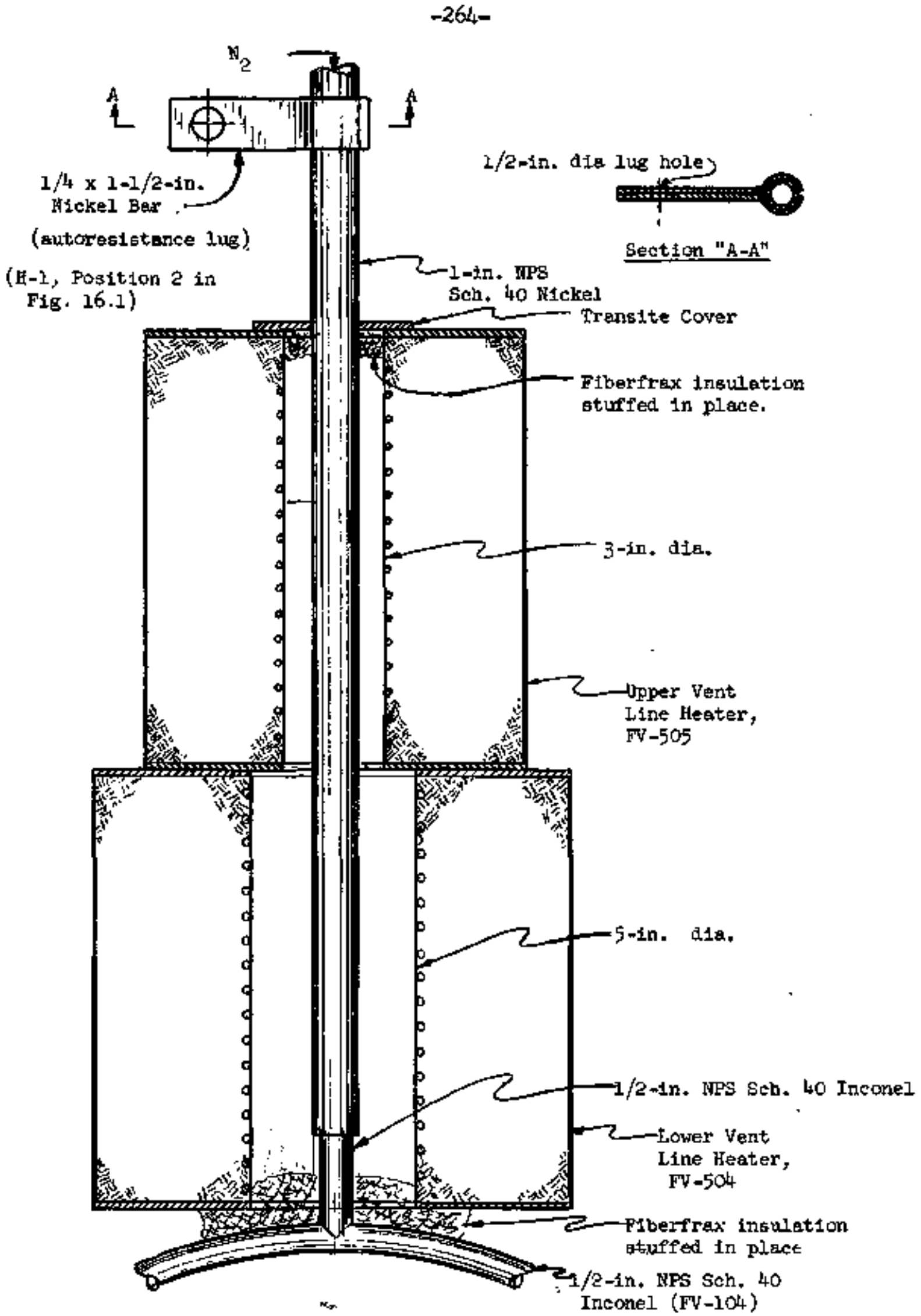

Pig. 16.7. Details of Fi-104t Vent Line and Heaters Placement 


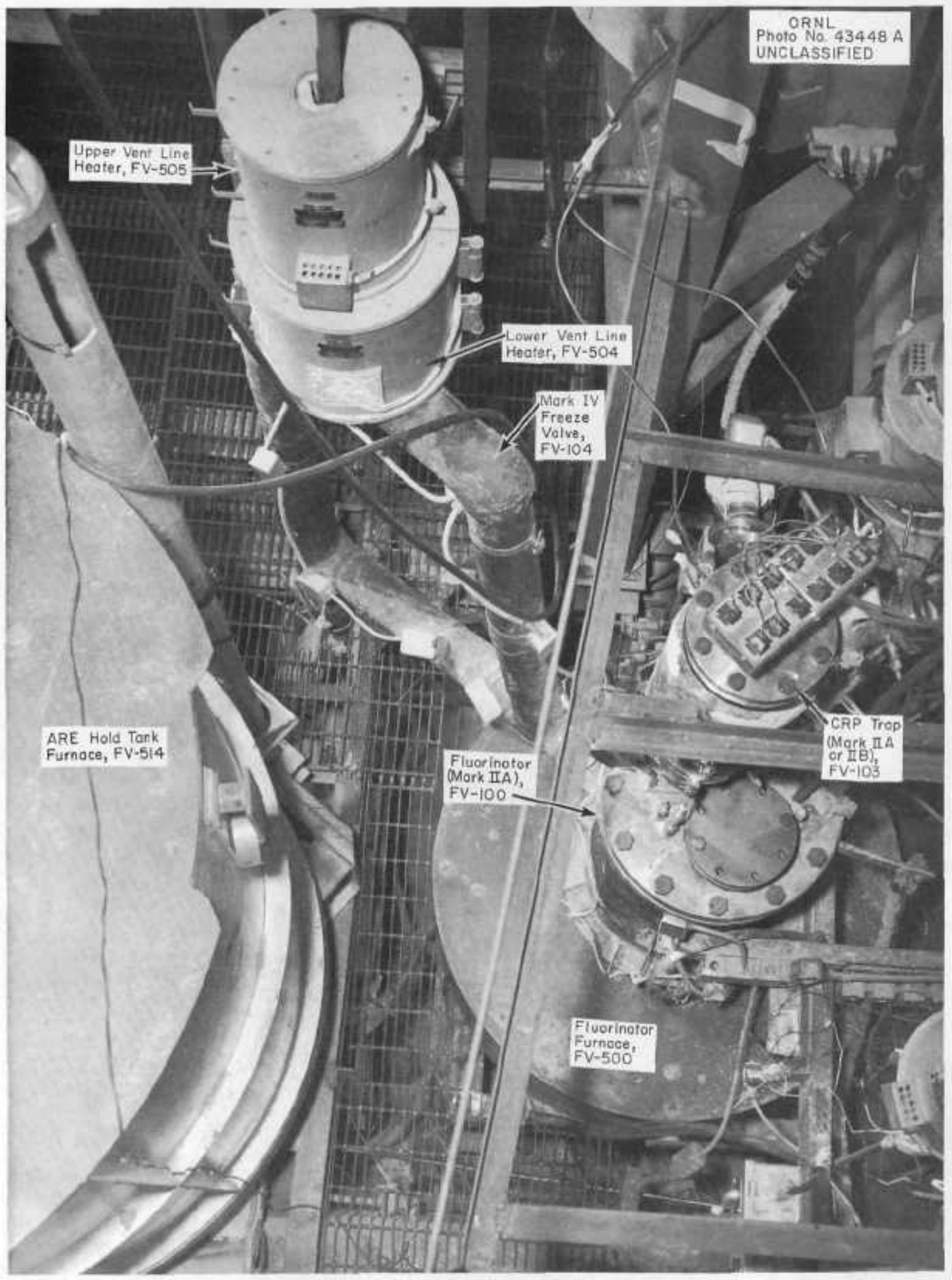

Fig. 16.8. Vent Line Heaters for FV-104 and Other ARE Equipment in Cell I. 
Autoresistance circuits on $1 / 2$-in. NPS schedule 40 Inconel were run at 435 amperes (Table 21.1).

Because of the severe corrosion of the Mark II waste line heated both by autoresistance and resistance (Sec. 13.4.2), four specimens from the ARE charging line were to be tested. These specimens disappeared, however, during the eleaning of Building 3019 following the explosion in November, 1959.

\subsubsection{Vent Line Heaters, $\mathrm{FV}-504$ and $-505^{\mathrm{a}}$}

For conventional freeze valves, the joints between the freeze valve and the nitrogen and/or vent lines were the most likely cold spots as delineated in Sec. 13.4.2. This situation was not encountered for FV-104 presumably for the two following reasons: (a) that this joint was autoresistance heated as well as being partially heated by the resistance heater FV-504, and (b) the wall thickness of the 1/2-in. NPS nickel was correct to ensure autoresistance heating (Sec. 16.4.14); and (c) great care was taken in placing the furnaces, FV -504 and -505 . Pyrovane set-points used. were $600^{\circ} \mathrm{C}$.

\subsubsection{ARE Charging System Instrumentation (13)}

The instrumentation for $\mathrm{FV}-174$ (DE-1, LE- 6 , and PE-30) worked satisfactorily. The indication of $10 \%$ less salt in FV -114 than expected (Sec. 16.4.2) apparently resulted from a misestimation of the ARE charge rather than an error in LE-6. In Run E-6, the common probe for LE-6 and DE-1 plugged. After this, these Instruments could not be used. The resulting high differential pressure across the bellows wall ruptured the density transmitter bellows. This occurrence led to the practice of taking a density instrument from service when the high-pressure probe was thought to be plugged, and when salt was frozen in the fluorinator (Sec. 14.4.5 for procedure of removing an instrument from service).

The same vent arrangement described in Sec. 3.4.2 was used for the ARE dump tank (Sec, 16.4.3).

Means used to detect the presence of radiochemicals were:

a. Constant air monitor (Sec. 23.4.2).

b. Portable disk sampler (Sec. 23.4.3).

c. Alpha hand monitor (Sec. 23.4.6).

d. Quintector (Sec, 23.4.6).

a secs. 16.7.3, 16.7.5, 22.4.1, 22.4.2 and Table 22.1 
e. Band-foot counter (sec, 23.4 .6 ).

f. Beckground secorder (Sec, 23.4.7).

g. $\alpha, \beta$ smears (sec. $23,4,8$ ).

h. Alpha survey meter (Sec, 23.4,9).

i. S-y probe meter (Sec. 23.4.9).

3. Cutie pies (Sec. 23.4.10, 16.4.2, 16.4.12, 13.4.7).

k. Montron (Sec, 23.4.10).

1. Film badges (Sec, 23.4.11),

m. Dose meters (Sec, 23.4.12).

n. Urine and fecal samples (Sec, 23.4.13).

Protective devices (Sec, 23.4.14) and decontamination practices (Sec. 23.4.15) were used as required. The UF, leak during Fun E-2 accelerated the frequency of monitoring for radiochemficals and the use of protective devices. Personnel exposures and afr activities dirting subsequent operation vere recorded (Sec, 23.4.1).

\subsection{Shumary and Conclusions}

The ARE salt system operated smoothly and effectively with only minor difficulties. All furnaces and heaters were satisfactory. Heating and cooling times are recorded.

Late desfgn work included:

a. Chenging the location of FY-114 relative to FV-100 to eneble transferring batches against a 5 $\mathrm{ft}$ instead of a 15- $\mathrm{ft}$ head. (This also necessitated moving FV -510 and designing another charge line with the Nark III and IV freeze valves.)

b. Replacing the molten leed-sealed disconnect flenge with a bolted flange to eliminate the possibility of flowing the ARB charge into Cell 1 in the event of a line plug below the flange.

c. Designing the pipeitne between FV-110 and -114 , Including the expersion joint.

d. Determining the shape of the FV-114 vent line and the placement of FV $-115,-515$, and $-515 \mathrm{~A}$.

Dump tank deta included: (a) noved to Cell 3 on July 28, 1955, (b) placed 1n FV +510 on December 2, 1957, and (c) selt drained out on December 5, 1957. 
The bulk of the salt transferred in 5 hours with FV-110 being held at $550^{\circ} \mathrm{c}$. Subsequently, the temperature of $F V-510$ was resised to $650 \mathrm{C}$ and kept at that temperature for 15 hours to ensure complete drainage. The completeness of removal was assured by: (a) tank welghts, (b) activity readings, and (c) the salt level in FV-114. Although a thin brown scale forned on FV-lll during the AFE melt-down, no later trotble was experlenced with oxygen or water vapor in the salt.

The nitrogen flow for cooling the FV-510 bearing wes inedequete. Additional sooling was accomplished with dry ice.

The hold tank successfully held the ARE charge during procesaing and the one month shut miown between Rums E-2 and -3 . Evidently the cosmion instrument probe for LE-6 and DE-1 falled in Run E-6. Otherwise, the FV-114 pneumatic-type ingtruasents (LE-6, $\mathrm{FE}-30$, and $\mathrm{DE}-1$ ) were satiafectory. Redrilling for pipelines and Inetrument lines was required to obtain the proper fit for the FV-514 installatiton.

FV-115 data 1ndicated that the "snow" problem in the FV-114 vent line was mor both regarding plug formation in the line and the radioactivity of the line. The FV-515 Celrod failed twice, apparently because of the close bending required. These Calrods and the earlier one at FV-512 were the only Calrod failures In VPF.

Operation of the cherge line and two freeze valves was satisfactory. Ho plugs formed at the rent line joint similar to those at the FV -106 and -108 vent lines joints. This vas attributed to the better design of FV-104. Three eutoresistance electrodes were successfully placed off the molten salt ilnes: (a) on the FV-134 vent line, (b) on the FV-lol nitrogen line, and (c) on the FV-100 Ilange.

\subsection{Recojmendations} and thet:

It is recommended that future salt charges like the AFe be handled similarly

a. Subsequent pressure-type salt transfers be made against as low a head ea posalble, preferably 5 ft or less.

b. Bolted flanged joints be used in salt tranafer lines instead of molten lead-sealed flanges.

c. The expansion joint necessary with bolted flanges (item $b$ above) be an "S" bend es for the ARE work.

d. Vent lines on future freeze valves be designed as for Fv-lol to elfminate cold spots at seddle joints.

e. No gas-cooled bearing be used in the future unless absolutely necessary and then only if its adeguecy is double-checked.

f. All pno umatie-type Instrment probe lines enter through the top of a vessel. 
B. Either autores1stance or resistance (clamshell, Calrod, or furnace) heating be used, the choice being based on the item being heated.

h. Off-molten-salt Iine placement of autoresiatance ground and hot electrodes as described herein (Sec. 2l.4.6) continue to be used.

\subsection{Appendix}

16.7.1 Operating Procedure: Charging Hold Tank (Revised Hovember 1, 1957)

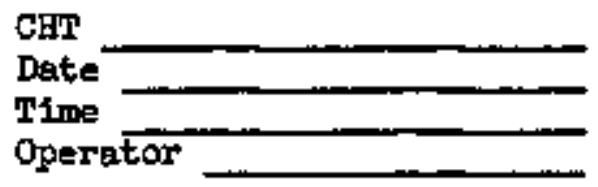

This musheet ia to be started after the bold tank is partially charged with barren salt; the FV-104 loop is successfulily used; and the cross-over is sealed.

1. Close HX-6

; open FCV-45.

on vent system.

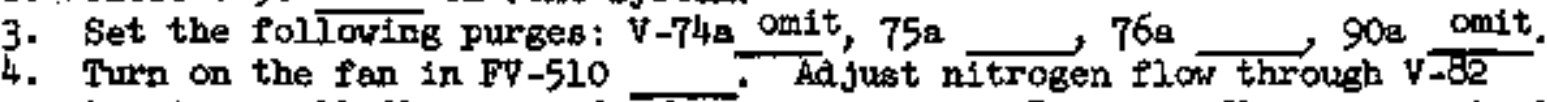
to give amali flow over fan bearing. Increase flow as required to meintain low bearing temperature, and add dry ice to bearing surface.

5. Check that these Instruments are in sexvice, purges on, and chart aynchronized. DR-1 IR-6 and $P R-30$

6. Go to INV, do steps $\overline{16-31}$ remembering that FV-111 has replaced FV-102, and that the system should be purged w1th $\mathrm{N}_{2}$ for 18 hours prior to melting the salt, After the 18-hr purge time, open ${ }^{2} \mathrm{HX}-6$.

7. Tuxn on the following controllers and set for $600^{\circ} \mathrm{C}$ :

TIC -1

TIC -2

TIC-J10

TIC-102

TIC-103

TIC-105

TIC-106

TIC-107

TIC-108

Time

8. Set the following Variacs:

Variac - TC Set point 108

109

110

113
TIC-109

TIC-110

TIC-13].

TIC-1.12

TIC-113

TIC-IA-9

TIC-IA -10

TIC-1A-1]

TIC-1A-12

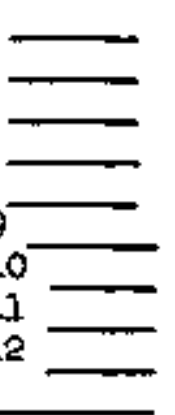


9. Three hours after time in 7 , reset the Herlacs to these settings:

\begin{tabular}{lc} 
TIC & Set Point \\
\hline 108 & 70 \\
109 & 70 \\
110 & 140 \\
111 & 140 \\
112 & 140 \\
113 & 140 \\
$1 \mathrm{~A}-12$ & 140
\end{tabular}

Time

10. Two hours after time in-d, aet the $V$ ariacs only as high as is necessary to maintain $600^{\circ} \mathrm{C}$ on the ine. Time

11. Record data on the appropriate aheets.

12. Watch LR-6 for maximum I1quid level. Wast twenty minutes, then record final liquid level reading

13. Turn off the following controliers: - NOTE: FV-510 was subsequently

TIC-101

TTC-102

TIC-J.03

TIC -105

IIC-106

TIC -107

TIC-108
TIC-109

TIC $-\$ 10$

TIC-1]

TIC -112

TIC-113 heated to $650^{\circ} \mathrm{C}$ and held at $650^{\circ} \mathrm{C}$ for $15 \mathrm{hr}$ to insure draining entire charge into Fv-114. This was not contemplated when the runsheet was written (Becs. $16.3 .1 \mathrm{~b}$ and 16.4 .2$)$.

14. Lower the following Variacs to zero: $\mathrm{NC}-108$
15. When fumaces hes eooled off tern off fen in FV-510

Time

16. Riggers will remove dum tank and furnace from cell area. cold run, see log for additional ingtruetions.

\subsubsection{Operating Procedure: ARE Feed Salt Transfer (Revised November 1, 1977)}

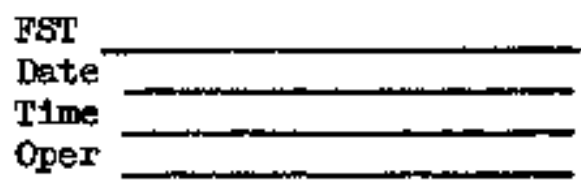

1. Open the following valves on the control panel: $\mathrm{HX}-6$
2. Close the following valves: $\mathrm{HX}-8 \ldots$, $\mathrm{HX}-12 \ldots$

1. Open the following valves on the
2. Close the following valves: ix -8

1. Open the following valves on the
2. Close the following valves: ix -8 HX -34

3. Valves $v-27$ HX-12 HX-11 open near the Earubioer. and fluorine inlet valve HX -14 $\mathrm{HX}=16$

4. Sw1teh BX-1B-4 to "C" porit1on.

5. Adjust the setpoints on the following temperature controijers;

\begin{tabular}{lll} 
Controller TIC & $6 \mathrm{At}$ Potnt & Thme set \\
\hline $1 \mathrm{~A}-5$ & $660 \mathrm{C}$ & \\
$1 \mathrm{~A}-6$ & $610 \mathrm{C}$ & \\
$1 \mathrm{~A}-8$ & $650 \mathrm{C}$ & \\
$1 \mathrm{~B}-4$ & $650 \% \mathrm{C}$ & \\
$1 \mathrm{~B}-8$ & $650 \% \mathrm{C}$ & \\
$1 \mathrm{~B}-10$ & $650 \% \mathrm{C}$ & \\
$1 \mathrm{~B}-11$ & $700 \mathrm{C}$ &
\end{tabular}


6. Set the following Veriecs:

\begin{tabular}{l} 
Variac $-\mathrm{TC}$ \\
\hline $\mathrm{B}-4$ \\
$1 \mathrm{~B}-8$ \\
$1 \mathrm{~B}-10$
\end{tabular}

Set Potint
(about 170$)$
about 140
about 70$)$

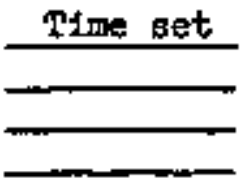

7. Check these ingtrument purge rates to be correct, then record these readings $\mathrm{DR}-1$ DR-2 , LR-C LR-6 FR -30 PR -33

8. When all these points are above $600^{\circ} \mathrm{c}$, go to the next step. TR-1A-5 TR-1A-6 TR-1A-8 TR-1B-4C TR-1B-10 , and TR-IB-Il

9. Record pertinent data on rinsheets provided.

10. Set PI-8 on 10 psis

11. Close $\mathrm{HX}-6$.

12. Watch LR-2 closely. When LR-2 raches

\$, open $\mathrm{HX}-6$

13. Wait 5 minutes, then lower these set points to zero: TIC-1B 4 and TIC-1B-8

14. Reduce these Variacs settings to zero $\mathrm{TC}-1 \mathrm{~B}-1$

15. Reduce the aet point on TIC-1B-10 to and $\mathrm{TC}-1 \mathrm{~B}-8$

16. Record these reading when TR- $\mathrm{TE}-4 \mathrm{C}$ and $5 \mathrm{C}$ fali below $200^{\circ} \mathrm{C}$ : $\mathrm{DR}-1$ 17. Reset PI-8' to $4.5 \overline{\text { Psig. }}$. $\mathrm{LR}=2$ LR -6 , PR-30 and PR -33 Time

18. Proceed to "Feed Salt Fluorination" runsheet. 
17.0 valves....................... 272

17.1 Introduction ................... 273

17.2 Equipment . . . . . . . . . . . . . . . . 273

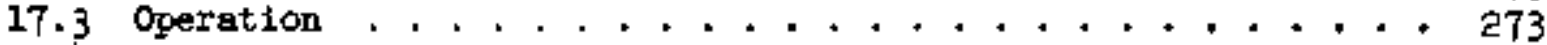

17.4 Equipment Performance - Process Valves . . . . . . . . 273

17.4.1 Conventional Manualiy Operated Valves , . . . . 273 17.4.2 Remotely Operated "On-0ff" Valves (HCV's). . . . . . 281

a. Description of HCV's ................ 281

b. Good Design Features .............. 281

c. Poor Design Features .............. 281

d. Initial Installation of $\mathrm{HCV}^{\prime} \mathrm{s} \ldots . . . . . .283$

e. Developing and Malntalning HCV's ...... 284

1. Inftial Period . . . . . . . . . 284

2. Later Perlod . . . . . . . . . . . 288

f. Tests with Kel-F and Monel Disks in HCV's . . . . 291

1. Test Conditions and Procedures . . . . . . 292

2. Test Results and Discussion . . . . . . 29'

3. Monel and Kel-F Disks in a Variety of Service 299

Conditions . . ...........

4. Preconditioning of Kel-F Disks with Fluorine. 299

8. Additional Coments on HCV's ......... 302

17.4 .3 Remotely Operated Control Valves . . . . . . . 303

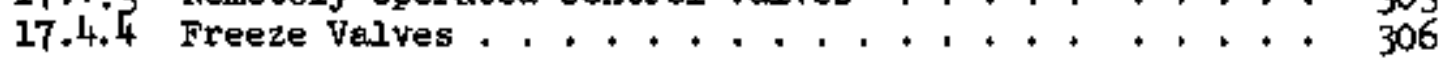

17.5 Equipment Ferformance - Service valves ......... 309

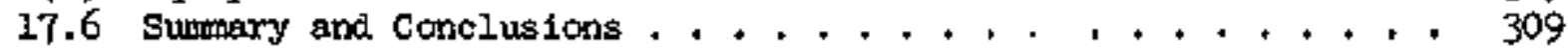

17.6.1 Conventional Manually Operated Valves ........309

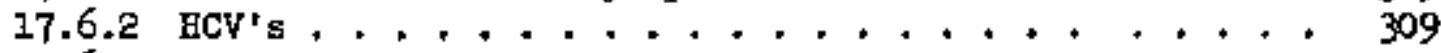

17.6.3 Renotely Operated Control valves ......... 313

17.6 .4 Freeze velves . . . . . . ....... 314

17.6 .5 Service valves .................... 314

17.7 Recormendations. . . . . . . . . . . . . 3 314 


\subsection{Introduction}

The manualily and autowatically operated talves in the Volatility Pilot Plant provided desired "on" or "off" conditions in pipelines and gave suitable controlied flow in both process and kervice plping.

This treatment lists the valves used under various service conditfons, troubles encountered, tests and developmental work, and finally a liat of valves reconmended for future work. In sowe cases, advantages and disadvantages of widely used valves are Given.

\subsection{Equipment}

Process valves compriged four categories:

a. More than one hundred conventional manually opereted valves to give shut-oft and controlled flow.

b. Twenty-six remotely operated "on-off" velves (coumonly called HCV's) to tiolate sections of the process plping.

c. Ten remotely operated control valves to control nitrogen and fluorine Ilow rates as well as line pressures.

d. Freeze valves in wolten salt lines - an ORL Innovation - to seal molten selt lines.

The treatment of remotely operated control valves is limited to the valves themeelves. The mechanica of each control velve aystem is discussed in the appropriate eygtem. Service valves were used in air, water, and nitrogen lines, Velve specifications were drawn up prior to VPP operations (49).

\subsection{Operation}

The operations of specific valves were parts of the plant operating procedures.

\subsection{Equipment Performance - Process Velves}

\subsubsection{Conventional Manually Operated valves}

Table 17.1 is a compilation of the dealgn features and service conditions For the bulk of the process valves. The valves listed under each service notation were successfully used in the specified service conditions. Detalled descriptions of the design features for these velves ere avallable in existing valve literature. Noteworthy Items from experlence in the Volatility Pilot Plant follow. 
Table 17.1

MANUAJLY OPERKTED VALVES USED IN VPF PROCESS WORK

\begin{tabular}{|c|c|c|c|c|c|c|c|c|}
\hline \multicolumn{3}{|c|}{ Identification Data } & \multicolumn{3}{|c|}{ Materials of construction } & \multirow{2}{*}{\multicolumn{2}{|c|}{ Usedilused }} & \multirow[b]{2}{*}{ Remarks } \\
\hline Designation & Type & Nenufactures & Body & Disk & Stem Seg & & & \\
\hline \multicolumn{9}{|c|}{ Service: $\mathrm{UF}_{6}, \mathrm{~F}_{2}$, and $\mathrm{N}_{2}$ Mixtures (Temperature $=\sim 66-150^{\circ} \mathrm{C}$; Pressure $=15-25 \mathrm{pa} 1 \mathrm{a}$ ) } \\
\hline $\operatorname{simD}^{5}-4140$ & Globe & Crane & Monel & Monel & Bellowts & $\begin{array}{r}10 \\
24 \\
3\end{array}$ & $\begin{array}{l}1 / 4 " \\
1 / 2^{n} \\
1\end{array}$ & $\begin{array}{l}\text { Inner Bellows, Phosphor bronze } \\
\text { Outer Bellows, 80-20 Brass; Used } \\
\text { principally with } F_{2}-\mathrm{H}_{2} \text { mixtures } \\
\text { near room temperature. }\end{array}$ \\
\hline 10. 5665 & $\begin{array}{l}\text { Angle } \\
\text { Cylin- } \\
\text { der } \\
\text { velve }\end{array}$ & Superior & $\begin{array}{l}\text { Bridge } \\
\text { port } \\
\text { Alloy } \\
\text { a } 3712\end{array}$ & Monel & $\begin{array}{l}\text { Peflon } \\
\text { packed }\end{array}$ & 15 & 1 & 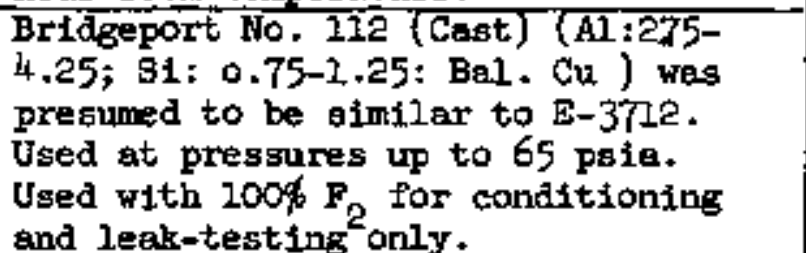 \\
\hline Ho. 411 & $\begin{array}{l}\text { Globe } \\
\text { Angie }\end{array}$ & Boke & Monel & $\begin{array}{l}\text { Dura- } \\
\text { Nickel }\end{array}$ & $\begin{array}{l}\text { Inconel } \\
\text { Diaphragm }\end{array}$ & 4 & $1 / 4^{\prime \prime}$ & $\begin{array}{l}\text { Singll ports were subject to } \\
\text { plugging in } \mathrm{UF}_{6} \text { service. }\end{array}$ \\
\hline IO. 1193 & GIobe & Hoke & Brass & Brass & $\begin{array}{l}\text { Asbestos } \\
\text { Packed }\end{array}$ & $\overline{1}$ & $1 / 4^{\pi}$ & $\begin{array}{l}\text { Bmald ports were subject to } \\
\text { plugsing in UF } 6 \text { service. }\end{array}$ \\
\hline Wo. 1197 & GIobe & Eoke & 5.5 & Teflon & $\begin{array}{l}18-8 \text { S.S. } \\
\text { Bellowa }\end{array}$ & 8 & 174 & $\begin{array}{l}\text { Used at room temperature to isolate } \\
\mathbb{N}_{2} \text { portion of system from process } \\
\text { portion and not for flowing } \mathrm{UF}_{6} \\
\text { and } \mathrm{F} \text {. }\end{array}$ \\
\hline No. 1199 & Globe & Hoke & 316 & Teflon & \begin{tabular}{|l|}
$18-8 \mathrm{S.S}$ \\
Bellows
\end{tabular} & 1 & $17 e^{\pi}$ & $\begin{array}{l}\text { Used et room temp. to fsolate } R_{2} \\
\text { portion of system from process portion } \\
\text { and not for flowing } U_{6} \text { and } F_{2} \text {. }\end{array}$ \\
\hline $\begin{array}{l}\text { Fig. } \\
1300\end{array}$ & Gate & Jenkins & S.S. & 5.5 & Packed & $\overline{3}$ & $1 / 2^{n}$ & \\
\hline No. 1103 & Angle & $\begin{array}{l}\text { Discon- } \\
\text { timued } \\
\text { Eoke }\end{array}$ & Monel & Monē & $\begin{array}{l}\text { Aonel } \\
\text { Bellows }\end{array}$ & 3 & $1 / 8^{11}$ & $\begin{array}{l}\text { Used with } 100 \% \mathrm{~F}_{2} \text { for conditioning } \\
\text { and leak-testing only. }\end{array}$ \\
\hline Ho. 413 & Globe & Hoke & Monez & $\begin{array}{l}\text { Dura- } \\
\text { Nickel }\end{array}$ & $\begin{array}{l}\text { Inconel } \\
\text { Diaphragm }\end{array}$ & 14 & $1 / 4 "$ & $\begin{array}{l}\text { Suall ports were subject to } \\
\text { plugging in } \mathrm{UF}_{6} \text { service. }\end{array}$ \\
\hline
\end{tabular}


Table $1 ? .1$ (Continued)

MAMUALLY OPERATED VALVES USED IN VPP PROCESS WORK

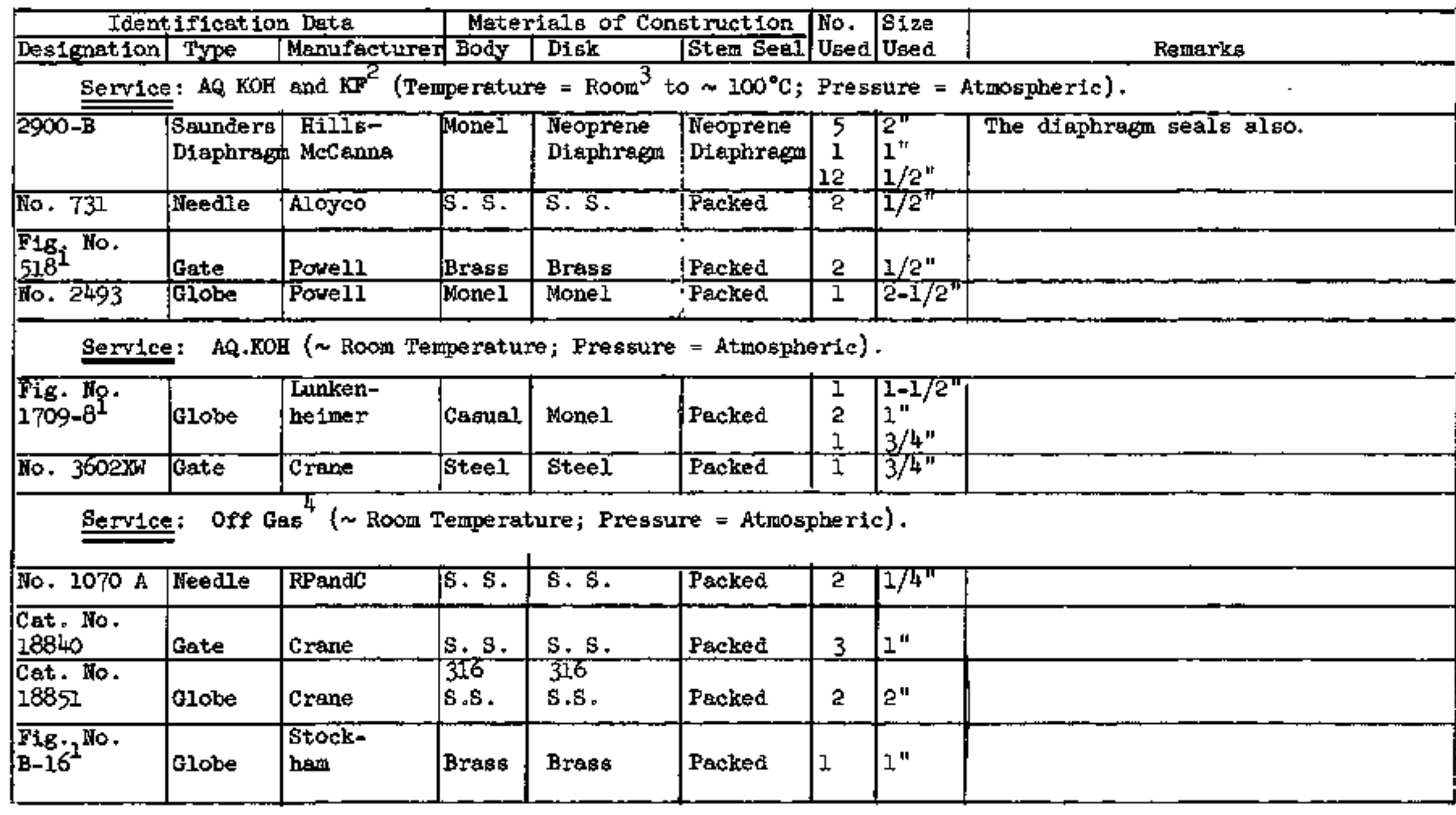


Table 17.1 (Continued)

MAPUALIY OPERATED VALVES USED IN VPP PROCESS WORK

\begin{tabular}{|c|c|c|c|c|c|c|c|c|}
\hline \multicolumn{3}{|c|}{ Ident, ification Data } & \multicolumn{3}{|c|}{ Materials of Construction } & \multirow{2}{*}{$\begin{array}{l}\text { No. } \\
\text { Used }\end{array}$} & \multirow{2}{*}{$\begin{array}{l}\text { Size } \\
\text { Used }\end{array}$} & \multirow[b]{2}{*}{ Remarks } \\
\hline \multicolumn{2}{|c|}{ Desisnation Tyye } & Mamufecturer & Body & Disk & Stem Seal & & & \\
\hline \multicolumn{9}{|c|}{ Service: Vacuum ( Room Temperature; Pressure $=5-15$ psia) } \\
\hline SSD & Globe & Crane & Fteel & Tefrion & Betlows & $\begin{array}{l}7 \\
4\end{array}$ & {$\left[\begin{array}{l}1-1 / 2^{H} \\
11\end{array}\right.$} & $\begin{array}{l}\text { Inner Beliows Phos } \text { Bronze } \\
\text { Outer Bellows, } 80-20 \text { Brass }\end{array}$ \\
\hline No. U-0.28 & Gate. & Fairibanks & Brass & Brass & Packed & 3 & $1 "$ & Vaculum Service Lines for \\
\hline Cat. $\mathrm{No} .4 \overline{3}$ & Gate & Crane & Brass & Brass & Packed & 1 & $1 / 4^{\pi}$ & Discharging Chemical Traps \\
\hline \multicolumn{9}{|c|}{ Service: $\mathrm{N}_{2}$ (Room Tempersture; Pressure $=0.40$ psis) } \\
\hline No. 90417 & Globe & $\begin{array}{l}\text { Fulton } \\
\text { Sylphon }\end{array}$ & Honel & Tefion & \begin{tabular}{|l|} 
Phos.B̈ron \\
Bellows \\
\end{tabular} & 20 & $1 / 4^{t+}$ & \\
\hline Fiz. No.150 & IGate & Powe11 & Brass & Brass & Pecked & 3 & $1 / 2^{\prime \prime}$ & \\
\hline$F 1 z .2608$ & Globe & Powell & Brass & Brass & Facked & 2 & $1 / 8^{\prime \prime}$ & \\
\hline F.g. 1708 & Globe & Powell & Bress & $\overline{\mathrm{B}} \mathrm{ras}$ & Packed & 15 & $1 / 4 \pi$ & \\
\hline Fig. 708 & Giobe & Potrell & Bress & Brass & Pecked & 6 & $1 / 2^{\prime \prime}$ & \\
\hline 170. 11 & Globe & Walworth & Brass & Brass & Packed & 4 & $1 / 2^{\prime \prime}$ & \\
\hline 10.704 & Gate & RPende & 8rass & Brass & Packed & 4 & $1 / 4^{11}$ & \\
\hline No. $212 P$ & Gate & Crane & Brass & Brass & Packed & 1 & $\begin{array}{l}1 / 2^{11} \\
1 / 4^{\prime \prime}\end{array}$ & \\
\hline Ho. $108 \mathrm{ED}$ & 4-Way & Inpertal & Brass & Brass & Packed & 1 & $2 / 4^{11}$ & \\
\hline Fig. $556^{1}$ & Globe & Jenkins & Bress & Brass & Packed & 1 & $1 / 4 "$ & \\
\hline No. $73 \mathrm{P}$ & Globe & $\begin{array}{l}\text { Lunken- } \\
\text { hetmer }\end{array}$ & Brass & Brass & Packed & $\overline{1}$ & $1 / 2^{11}$ & \\
\hline No. 0501 & Globe & Fairbanka & Brass & N3ckel & Packed & 1 & $1 / 4^{11}$ & \\
\hline 110.1193 & Globe & Hoke & Brass & 18-8 S.S. & Packed & 20 & $1 / 4^{\prime \prime}$ & 1 \\
\hline Ho +333 & Globe & Fat1. Cyl. & Brass & Brass & Plast1e & 10 & $1 / 2^{n}$ & Pressure $=0-2000$ psig \\
\hline No. 334 & Globe & Gas Co. & Brass & Brass & Gasket & -60 & $3 / 4 \pi$ & $\begin{array}{l}\text { Jbed on all }{ }_{2} \text { cylinders. } \\
\text { Pressure }=0-2000 \text { psig. }\end{array}$ \\
\hline No. $173^{4}$ & $\begin{array}{l}\text { 4-Way } \\
\text { Lub. } \\
\text { Plug }\end{array}$ & Walworth & $\overline{s t e e l}$ & Steel & Packed & 2 & $1 / 2^{11}$ & \\
\hline
\end{tabular}


Table 27.1 (Continued)

MANUALLY OERRATED VALWES USED IN VRP PROCESS WORX

\begin{tabular}{|c|c|c|c|c|c|c|c|c|}
\hline \multicolumn{3}{|c|}{ Identification Dats } & \multicolumn{3}{|c|}{ Materials of Construction } & & \multirow[b]{2}{*}{ Remarks } \\
\hline \multicolumn{2}{|c|}{ Destanation Type } & \multicolumn{2}{|c|}{ Mamufacturer Body } & Disk & Stem Seal U $_{\text {Bed }}$ Used & & & \\
\hline \multicolumn{9}{|c|}{ Service; $\mathrm{H}_{2}$ (Room Temperature; Pressure = $0-40 \mathrm{psig}$ ) (Continued) } \\
\hline $150^{1}$ & $\begin{array}{l}\text { Pressure } \\
\text { Safety }\end{array}$ & Seott & Brass & Brass & $\begin{array}{l}\text { Metal to } \\
\text { Metal }\end{array}$ & 2 & $1 / 2^{n}$ & \\
\hline $\begin{array}{l}\text { P18. } \\
10201\end{array}$ & $\begin{array}{l}\text { Pressure } \\
\text { Safety }\end{array}$ & Farris & Bras 8 & Brass & $\begin{array}{l}\text { Metal to } \\
\text { Metal }\end{array}$ & 2 & $1 / 2$ & \\
\hline Kodel Kir & $\begin{array}{l}\text { Pressure } \\
\text { Safety }\end{array}$ & Loneghan & Brass & Brass & $\begin{array}{l}\text { Metal to } \\
\text { Metal }\end{array}$ & 1 & $1 / 2^{+1}$ & \\
\hline $\begin{array}{l}\text { Sho-Rate } \\
\text { "50" }\end{array}$ & $\begin{array}{l}\text { Flo- } \\
\text { Mite } \\
\text { (Rota- } \\
\text { meter) }\end{array}$ & Brooks & $\begin{array}{l}\text { Anodize } \\
\text { Alumimu }\end{array}$ & s. 8 . & Teflon & 30 & $1 / 8^{\prime \prime}$ & Maximum Pressure vas 10 psig \\
\hline 150.132-G & $\begin{array}{l}\text { Flor }= \\
\text { Rator }\end{array}$ & $\begin{array}{l}\text { Fischer: } \\
\text { Porter Co. }\end{array}$ & Remak & S.S. & $\begin{array}{l}\text { Plastic } \\
\text { Gasket }\end{array}$ & 11 & $1 / 8 "$. & 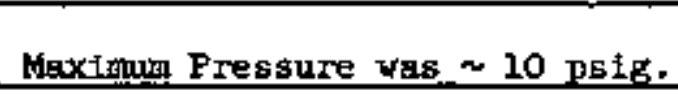 \\
\hline \multicolumn{9}{|c|}{ Servlce: Freon-1l (Temperature $=\sim-60^{2}$ to $120^{\circ} \mathrm{C}$; Pressure $=15-35 \mathrm{ps} 1 \mathrm{a}$ ). } \\
\hline Mio. 2031 & Globe & Ḧenry & $\begin{array}{l}\text { Bronze } \\
\text { Alizoy }\end{array}$ & $\begin{array}{l}\text { Bronze } \\
\text { Alloy }\end{array}$ & Packed & 4 & $1-3 / 8$ & \\
\hline 190.6261 & DHaphragi & Henry & Bronze & $\begin{array}{l}\text { Spauldite } \\
\text { or Micart, } \\
\text { Insert }\end{array}$ & $\begin{array}{l}\text { S.\$. } \\
\text { Disphragn }\end{array}$ & 1 & $1 / 4^{\prime \prime}$ & \\
\hline Ho. R-2402 & Diaphrags & Kerotest & Bronze & Bronze & $\begin{array}{l}\text { S.S. } \\
\text { Disphragm }\end{array}$ & $\overline{2}$ & $1 / 4 \pi$ & \\
\hline
\end{tabular}

1 Available catalogs in the pilot plant do not show this figure number.

2 Fron $2 \underline{K}$ KOH to $1 M$ KOH and $1 M K F$.

3 Room temperature varied from $\approx 5^{\circ} \mathrm{C}$ to $35^{\circ} \mathrm{C}$.

4 Off Ges: $H_{2}$ with $<100$ ppm $F_{2}$ 。

5 (46, $\mathrm{pg} .16,51)$. 
a. Crane SMMD $(22$, p. 16) and SSD

These velved were used extensively, SMM's in fluorine service and SSD's in nitrogen end vecuun service. The only difficulties with them arose because the gas stream contalned NaF f1nes.

1. Difficulties

(a) In one SMUD ( $V-72)$, NaF fines eroded the disk sufficiently to necessitate replacement. Repair involved replacing the entire stem assembly because of the integral construction of the atem essembly.

(b) Seat leakage in an SSD resulted from NaF fines depositing internally so as to prevent normal valve closure. The deposit vas removed by vacuuming out the fines. Proper valve orientation to avold recesses subject to deposits would bave prevented this happening.

2. Advanteges

(a) Excellent for gas and vacuum service.

(b) Amenable to lapping digk into seat to reduce learage. a (BMD disk could be used whereas ssD would require an auxiliary $\mathrm{d}=\mathrm{ak}+$ )

3. Disadvanteges

(a) Socket-weld ends.

(b) Replecing either the disk or bellows would require changing the entire bonnet assembly.

(c) Subject to closure interfering deposits if misorlentated.

b. Hoke No. 1197

One of these valvea did not pass gas even in the fully opened position. Inspection revealed that no opening through the valve existed because one of 1 ts ports had been incompletely drilled at the factory.

Ao maximum permissible leak-rate standard was established for these valves al-

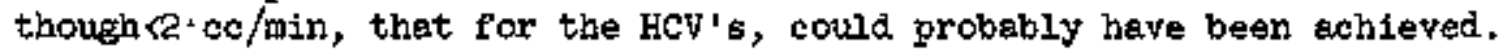

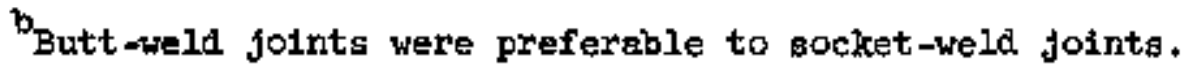


c. Cbeck Valve Near PI -43

Th1s valve was on the nitrogen supply to the fluorine station and was aupposed to prevent fluoxine from entering the nitrogen system. A tight shut-off of such a valve cannot evidently be expected at the low $\triangle P^{\prime} B(\sim 5-50 \mathrm{psig})$ existing across the valve. Consequently, another means to obtain tight shut-off should be tried. In late work, manually operated "on-off" valves were used In this line in addition to the check velve. This scheme gave the desired tight-shnt-off- but did not offer the versatility of a check valve.

d. Safety Valves in Mitrogen service.

A amall leak in these valves could never be eliminated, So far, the smali leak hag been considered economically insigniflcant. It is probeble, however, that a more elaborate and consequently more expensive sarety valve would give a tighter clobure if a nearly no-leak situation were neceseary.

e. Valves on Nitrogen Purge Line Rotameters

These valves were Inadequate in that they (1) did not afford a nearly no-leak shut-off, and (2) were unsultable for both t5 6 and fluorine. The experiences with these purge line rotameter valves sre given here as a record only since nelther a no-lesk shut-off nor competibility with Uf 6 and fluorine was expected.

All cages in which $\mathrm{UF}_{6}$ and/or fluorine flowed tnto purge rotameter resulted from maloperation and necessitated replacing the rotameter. In fact, at one stage of the operation early in the " $\mathrm{B}$ " runs such occurrences were so prevalent that control measures were taken to eliminate them. The first such step was installing Hoke No. 413 valves at the Penthouse floor on the process-side of the purge rotameters which could be used as needed to prevent process gases from reach1ng the purge rotameters. since this step proved to be less positive than that required, certain instrument connections were capped of in the heated duct.

f. Valve on a $\mathrm{WF}_{6} \mathrm{Cylinder}$ (Superior No. 5665)

One of these valvea developed a leak after fliling with Uf 6 . The Teflon packing in this valve was successfully replaced using two precautionary measures: (1) the cylinder was maintained cold with dry

Private communication.

Probably $<5 \mathrm{cc} / \mathrm{min}$.

Failures occurred in leaded yellow brass fittings used to Install these valves as delineeted in $(20,7)$.

Instruments put out-of -service were: $\mathrm{FE}-5,-6$, and $-7 ; \mathrm{PE}-12,-13,-14,-15$, and -38 (Secs, 9.4.7c end 9.4.7d). 
Ice to reduce the vapor pressure of $\mathrm{UF}_{6} ;(2)$ the vold space above the $\mathrm{UF}_{6}$ in the cylinder was fllled with nifrogen to reduce the contact of UF 6 with ast.

In severel ceses, closing the $\mathrm{UF}_{6}$ cylinder velves was prevented by If 6 solidifying internaliy in the valve. These situations were remedied by heating the valves. In early work, heat was supplied with a torch. In later work after the situation bad been establiahed as a chronic one, heating was done with heat lamps (Sec. 10.4.4).

g. Four Valves Developing Plugs in $\mathrm{UF}_{6}$ Service

1. A Hoke No. 413 valve in the product pigtails plugged. This valve developed a port plus during product collection in the early stages of pilot plant, work even though the cemperature of the velve was kept above $65^{\circ} \mathrm{C}$. The plus was probably caused by the deposition within the valve of reaction products of UF, with air and/or water vapor. very likely the amall diameter of the Hoke No. 413 opening rendered. this valve particulariy amenable to such a plug. Further study of this aituation, however, was not made.

2. A Hoke No. $413(\forall-126)$ valve in the FV-103 bypess also plugged. This valve presumably became plugged with $\mathrm{UF}_{6}$ reection products and/or nonvolatile fluorides during fluorination in the early "L" rums. In this case, the conditions of use were sonewhat uncertain because the early "L" runs had frequent operational troubles. As for the Boke No, 413 in the product pigtails the valve plugged in spite of being meintained above $65^{\circ} \mathrm{C}$ with industrial heating cable." The probable remedy was to replace this valve with one having $a$ larger opening. Consequently, a l/4-in. SMD valve was substituted for it. However, the SMMD valve had not been aervice-tested because no aubsequent occaston to use the FV-I03 bypass arose.

3. Both a Hoke Ho, 1193 and a Superior Ho. 5665 valve developed plugs during the cold trap and absorber studies. Little information exists regarding these plugs. Observations included, however, three noteworthy iters: (a) the plugs could not have been pure $\mathrm{UF}_{6}$ because the valvea were kept above $65 \mathrm{c}$; (b) more than 75 pounds of $\mathrm{UF}_{6}$ had already been transmitted through both of theae valves before the plugs formed; (c) once plugsing started the flow of $\mathrm{IF}_{6}$ from that cylinder was never again successfully maintatned although several attempts were gade to do so. These observations seen to point toward one conclusion, that the $\mathrm{UF}_{6}$ cylinder contalned $\mathrm{UF}_{6}$ reaction products and/or forelgn materials. Two likely sources of the extraneous materials were the cylinder "as rece1ved" from K-25 and water vapor from air entering the cylinder and forming $\mathrm{vO}_{2} F_{2}$ durlng temperature cycling while the flrst 75 pounds of $\mathrm{WF}_{6}$ we $^{2}$ being used.

That is, safely above the sublimation point of $\mathrm{UF}_{6}\left(57^{\circ} \mathrm{C}\right.$ at $\left.14.7 \mathrm{ps} 1 \mathrm{a}\right)$ (17, p. 4). 
The packed valves in $\mathrm{N}_{2}$ service were sources of insignificant continuous leaks. Although these were considered economicaliy insignificant in VPP, they might become signifleant at a higher mantfold pressure or in a systen containing more valves.

After the "I" runs, nost of the conventional manually operated valves were taken to the burial ground glong with associated pleces of equipment (Bec. 23,4,16b).

17.4.2 Remotely Operated "On-Off" Valves (HCV's)

a. Description of HCV's

Eighteen 1/2-In, and eight 1-1n. HCV's were used in the VPP". These valves were manufactured by the Associated Valve Engineering Company, Chicago, Ill1nols. Since the designs of the $1 / 2-1 \mathrm{n}$, and 1-in. wexe similar, the cross-sectional view of the $1-i n$, valve shown in Fig. 17.1 gives the essential design features. Certain good and poor design ttems are apparent.

b. Good Design Features

1. All Monel construction provides for corrosion resistance in $\mathrm{UF}_{6}$ and fluorine.

2. The disk-seat closure is metal-to-metal and of the line-contact varlety. Line contact between disk and seat is capable of providing low leak rates in gas service.

3. The bellow eliminated using gtem packing which might be attacked by $\mathrm{IF}_{6}$ or fluorine.

\section{c. Poor Design Features}

1. Disk and seat of the same materiel. On closure one would not deform the other, a situation which may tend to aggravate the tightclosure problem.

2. Inadequate provision for guiding the stem. Th1s may allow the valve disk to contact the seat in a varlety of positions. Such a situation can produce a number of leak-rates, one in one position, another in a second, and so on.

3. Undesirable main bonnet joint 5eal and unnecessery additional joints. The majn bonnet seal scheme involved tightening threenis to provide contact between a circular reised face and a flet annulus. This design was considered less desirable than bolted flanges with a suitable

A See Drewsings Nos. D-33761 and D-31350 for locattom of HCV's and VPF Engtneering File Folders tos, F-13 end F-14 for other pertinent information. (52, p. 51 ). 

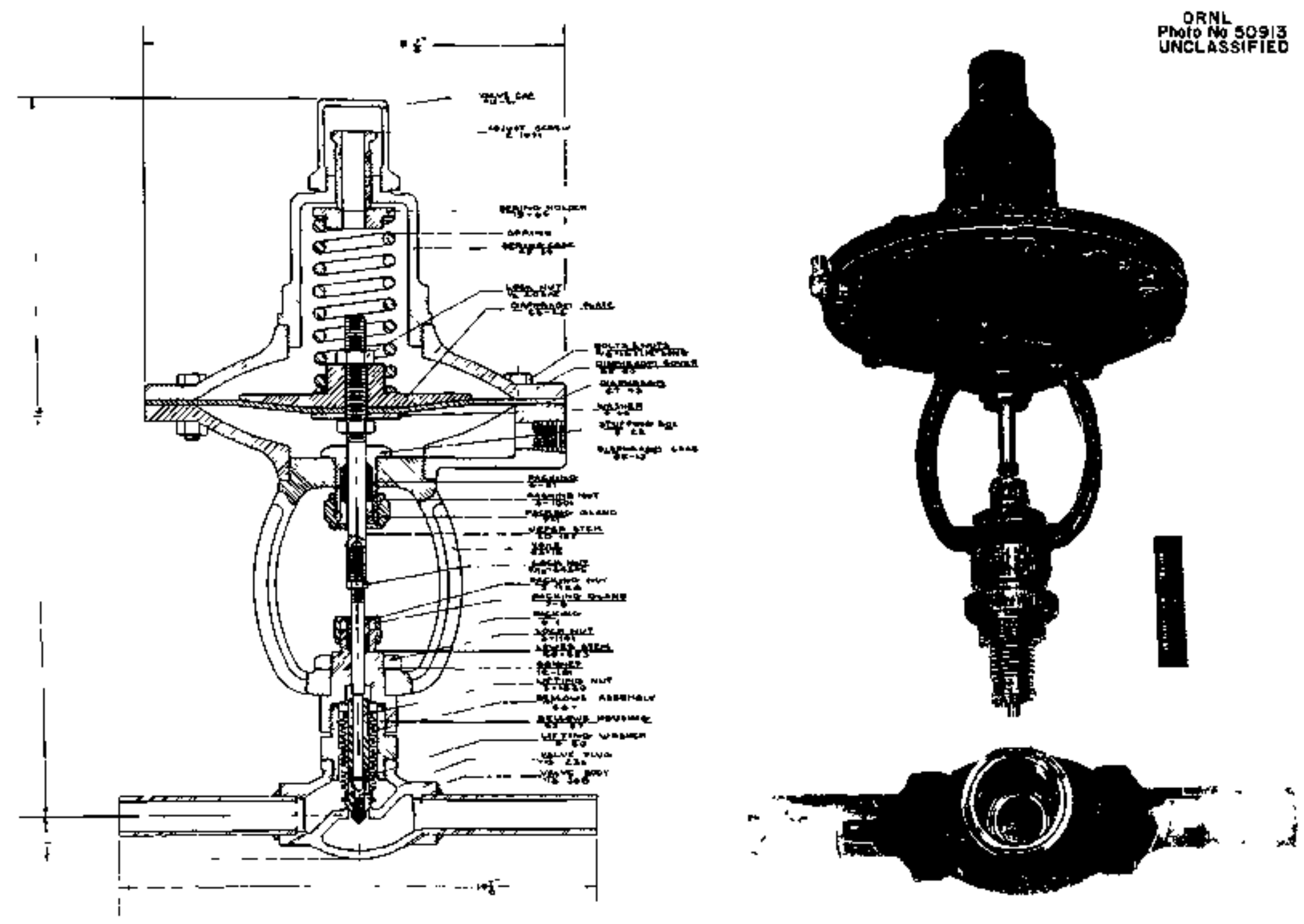

Fig, 17.1. Cross Section of t/2-in. Remate-Operated Valve (HCV) and a I-in. HCV Disossembled. 
Gasket such as copper. ${ }^{2}$ In sddition to the maln bonnet aeal, a joint above the bellows also existed, the seal for which depended on tight contact of flat annulf. Thia seal could probably have been more positively mede by welding.

4. Cast body. Because of the notorlous porosity of castings, ber stock 1s preferred for body conatruction.

5. Valve welded 1nto the pipeline. Welding the valves into the system is superior to flenging from the leek-possibjlity stand point. But welding in this case forced body end seet maintenence in the field because of the difficulty and expense involved in removing and replactiog the valves. Therefore, the desirability of welding the valves in place is questionable.

6. Threaded joint between disk and stem with no locking mechanism. The threaded joint between the disk and the stem is a poor metbod of fastening the two together. Such a foint may work loose during operation. Then, after working loose, any subsequent valve operation may result in the dikk striking the seat in a variety of ways, In such seating, either a variety of contact rings is worn on the disk or uneven wear of the seat may effect seat leskage.

\section{d. Inftial Installation of HCV's}

The initial installation of HCV's brought some unexpected problems:

1. Several valves leaked either through the seat or through the body. The cause(s) of the seat leakage was not readily ascertained, on the other hand, however, body leakage resulted from the porosity of the cast bodies.

2. Welding the ralves Into the system was thought capable of warping the valve because of the heat developed in welding. Such warpage might ruin the entire valve. Therefore, the following two precautions were taken in welding: (a) the bonnet asgembly was removed and (b) the valve body was cooled with dry ice or a damp cloth. Since all of the valves were later rendered leak-free, these precautions were apparently effective in eliminating valve warpage from welding-in-place.

Kel-F or Teflon are not specified because both reacted with pure fluorine under ORW tent conditions, (For a description of these tests, see $17.4 .2, \hat{1}, 3$, and $15.4 .1 \mathrm{~b}$.

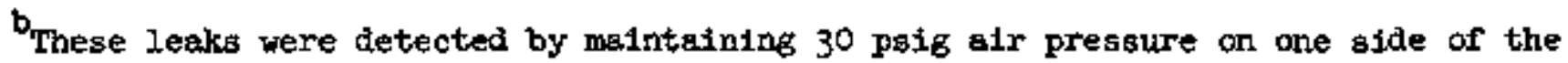
valve with the valve closed and inmersed in weter. 
3. The anticipation of seat leakage resulting from the expected oradual loosening of the disk was responsible for the decision to weld the disks to the stem. This step was deened risky in view of the posible concomitent disk werpage. In spite of this disedvantage, however, and since Mr. Schubert of Aveco reported satisfectory experience with welding the disks, this welding wes done (25).

\section{e. Developing and Maintaining HCV's}

HCV maintenance work was divided into two parts beged on the crafts performing the maintenance. Initialiy, for the first half-year, meintenance was done by a machiniat and a pipefitter. Later end until the present, these valves were serviced by a second machinist and an instrument mecharic.

The work in these periods was to some extent developmentel. During the first period, there was 1ittle experience at OFNL with this particular remotely operated valve. During the second period, although a few of the earlier maintenence prectices were contimued, independent thinking and somewhat different techniques were used in order to gain a wider experience with the valves.

1. Initial Period

In the inftial maintenance work, three schemes were tried more or less aimultaneously to render the valves leak-free and to lengthen the leak-free period:

(a) The disks whlch had been welded to the stems were cut off, turned to the original confcal shape on a lathe, and fastened to the stem as before velding. Th1s step tas taken because the warpage occurring in the conical surface during welding was apparently effecting seat leakage.

(b) D1sks vith integral bottom goides (B. and F. in F1g. 17.2) were used. Such a disk kept the stem axis nearly on a vertical stralght line as the valve opened and closed by the action of the guides in the raire seat. In this way, the disk alweys contacted the seat in very nearly the same way thereby eliminating a number of different alak-seat contact lines. This technique tended to eliminate one of the original objections to the valves, that is, the inadequacy of the "as recelved" stem gulding.

Care was exercised in designing the gulded disk to prevent an excesaive pressure drop through the valve. This was achieved by cutting out passageweys through the guides as for B. in Fig. 17.2. The pressuredrop lintt per valve was arbitrarily set at $1 / 2$ psi for both $1 / 2$ " and l" valves. At these pressuxe drops, the flow retes indicated in Table 17,2 were obtained. The flow rate of about 5 scfm obtalned with 


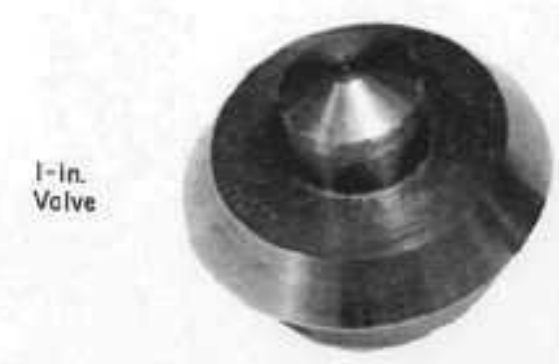

A

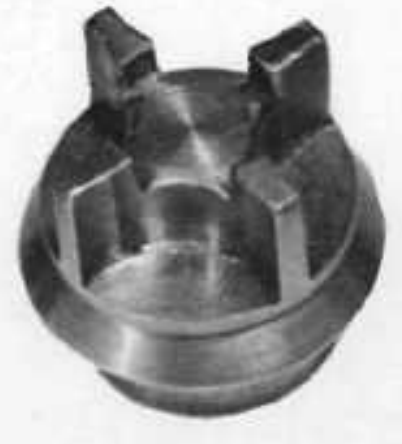

B

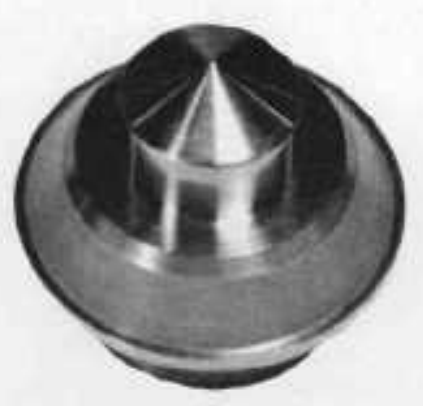

c

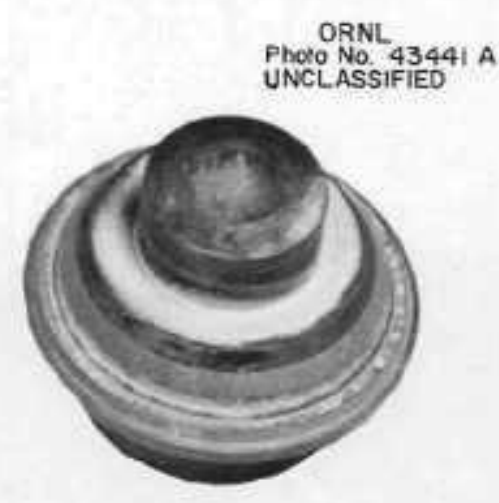

D

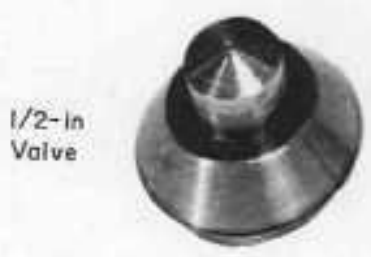

E

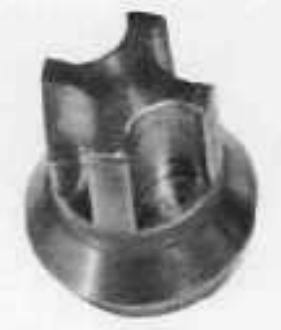

F

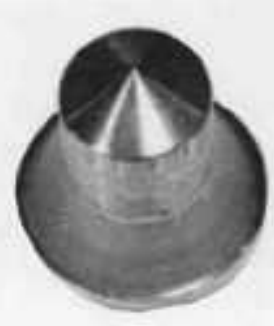

G

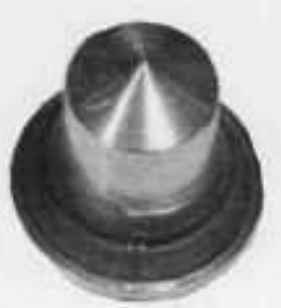

H

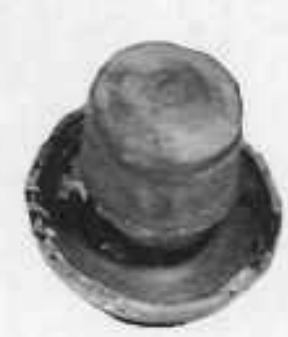

I

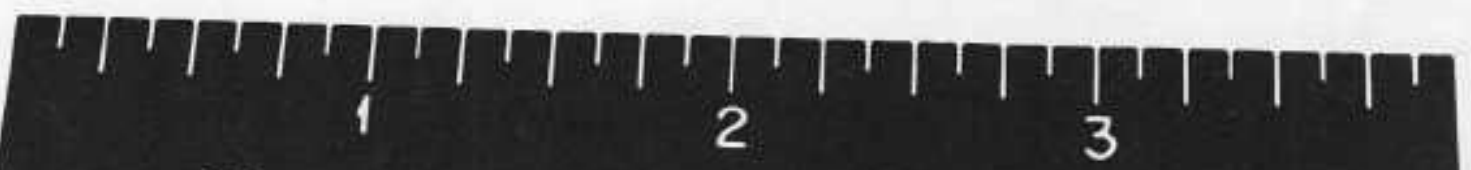

OAK RIDGE NATIONAL LABORATORY

Fig. 17.2. HCV Disks. 
$-286-$

Table 17.2

Flow Rates Through $1 / 2-1$, and 1-in. HCV's w1th a 1/2-psi Pressure Drop Flow Rate, scfm

\begin{tabular}{|l|c|c|c|}
\hline Gas Flowing & Disk with no Guide & Disk with Cut-Out Guide & Disk with Solid Guide \\
\hline $\mathrm{N}_{2}$ & $20^{1}$ & $\frac{1^{\prime \prime} \mathrm{HCV}^{\prime} \mathrm{s}}{11}$ & 7 \\
$\mathrm{UF}_{6}{ }^{2}$ & Not determined & 6 & 4 \\
$\mathrm{~N}_{2}$ & 12 & $\frac{1 / 2^{\prime \prime} \mathrm{HCV}^{\prime} \mathrm{s}}{8}$ & 8 \\
$\mathrm{UF}_{6}{ }^{2}$ & 6 & 4 & 4 \\
\hline
\end{tabular}

1. With no $\triangle P$.

2. The data were obtained with nitrogen. To obtain $\mathrm{UF}_{6}$ data, $\mathbb{N}_{2}$ data were converted to $\mathrm{UF}_{6}$ data by calculation. 
the guided d1sks in both the $1 / 2 "$ and 1 " HCV' $B$ was adequate by several -fold factor for use in the plant; therefore, the presaure drop through one valve during normal operation (<l sefm) would be much less than the selected P1gure of $1 / 2$ pai.

(c) Line contact between the d1sk and the seat was re-established each time a valve wes lapped. In this method, two fluted cutters for heavy cuts and two grades of lapping powder for the finlshing work yere used, one of the cutters contalned cutting edges at $30^{\circ}$ to the horizontal while the other contalned $45^{\circ}$ bledes. The lepping procedure was;

(1) By using the two fluted cutters properly centered with a jig, a circular edge was made on the valve seat.

(2) The Monel disk retained on a shaft centered by a jig as for the cutters was lapped lightly into the seat usting the cosise compourd, 400 -mesh diamond dust compounded with a suitable vehtcle.

(3) The disk was relapped similarly Into the seat using the fine compoumd 600 -mesh diamond dust tolxed with a suritable carrier.

(4) The excess lapping compound was wiped off the seat and disk with acetone.

(5) After the residual acetone had been allowed to vaporize, the valve was reassembled.

(6) The spring-tensign, $14 \mathrm{pgig}$ for $\mathrm{l}^{\text {" }}$ valves and $12 \mathrm{pgig}$ for $1 / 2$ " valves," was set, and the valve wes leaktested in place in the plant.

Valve leak-testing consisted of two parts: (a) The seat-leakage was determined. (b) After seat-legkage was satisfactory, bonnet leakage was investigated.

For both tests, arbitrary specificetions were established. For seat-leakage, this specification wes $\angle 2 \mathrm{cc} / \mathrm{min}$; for bonnet-leakage, the criterion wss that no Freon could be detected with the Freon flame detector while the valve contained Freon at $30 \mathrm{psig}$.

\footnotetext{
"Eoth compounds were labeled "Dymo" as prepared by the Abrasives DAvision of the Elgin National Watch Comany, Elgin, Illinois. Both were avallable in ofit Btores.

bower spring tenslons seemed to be incapals of giving the desired seat leak rate. Spring tengion was that pressure of alr supplied to the diaphragm required to completely open the valve.
} 
The seat-leakage test was performed whth the valve closed as follows:

(1) Witrogen at a predeterifnod preseure was epplied agalnit one side of the valve while the other side of the velve was at atwospheric pressure.

(a) A soap film was placed on a $1 / 2^{\prime \prime}$ or $3 / 8^{*}$ tubing nipple connected to the atrospheric pressure side at some convenient location.

(3) The stze of bubble blown by this tube in a given length of time was noted.

(4) The valve was opened to allow $\mathrm{N}_{\text {o }}$ escape through the nipple to confirm that $\mathrm{N}_{2}$ presidure had actually been ageinst the valve seat diring the test.

(5) Ieak rate was caleulated from bubble diameter and time date.

Although Step (4) might seem unnecessary, it was deemed necesaary as a check bectule of the complexity of the plant piping. In fact, on several ocessions teat data vere aiscarded when th1s check revealed that no pressure had been ageinst the valve seat.

The frequency of HCV maintenance during this pertod can be determined only through data taken between serles of mans because valve maintenance was done only between rum series. Usually each series covered flve to ten rums, and each sertes was started with all of the valves leak-tIght by the spectfication given above. After the serles of runs and before water-washing the system, generally about half of the ralves would leok. After weter-washing, usually a fes more of the valves leaked then before. In a fer cases during a series of runs, valves were suspected of devoloping leaks. Therefore, some of the velves which were found to leak at the end of run series apparently developed leaks before the end of the serles.

\section{Later Period}

During this geriod, the HCV developwent and mointenance program was altered. Changing the program was an effort to ut1lize the experience of instrument Division personnel in developing and maintaining the HCV's. Several innovations and alteretions were initiated:

An" $T^{\prime \prime}$ connections were provided at seversl points in the system so that the ralves could be leak-tested in place. 
(a) The gutided disk was repleced with an unguided one, and a new deatign disk having Kel-F contalned in Konel frantework as for disks $C$ and $G$ in Fis. 17.2 wes used extensively.

(b) The lapping procedure was eltered, Materlals enployed during lapping were: flrst, an HCV stem and bellows subassembly for supporting and centering the disk; second, a Monel disk for the lepping surface. (This disk was the one to be subsequently used in the valve when the valve contained a Monel disk, or this disk was a Monel disk with e relatively smooth conical surface when the valve contained a Kel-F diak.); and finally, lepping compounds - for roughing No. 303-1/2 and for fintshing No. 39-1200, both compounds being manufactured by united States Products Company, 518 Nelwood Avenue, P1ttsburgh, Penngylvenie.

The lapping procedure was:

(1) The bonnet was removed with the valve open to avold seatdisk damage.

(2) Both seat and disk were cleaned, usually with acetone but sometimes with methylene chloride to reduce the fire hazerd existing when rubbling a fluorinated surface with an acetone-soaked cloth (Sec. 15.4.5b).

(3) The Monel disk was fixed onto the stem and bellows subassembly and then a smell amount of roughing ecimpound was smeared on the conteal surface of the disk and on the surface of the seat.

NOIS: The roughing compound was used only on valves having badly scored seats.

(4) This atem-bellows aisk subassembly was fitted to the valve body as usual by engaging the bonnet threads.

(5) Then, by placing one hand on top of the valve stem to hold the disk against the seat, the seat and disk surfaces were rubbed agajnst each other by moving the atem back and forth with the other hand through an angle of ebout 1.5 to 30 degrees. Decsistonally, to get evenness in lapplng, this back-and-forth motion was stopped and the stem was lifted and moved through an angle of from 45 to 180 degrees.

Rel-F disk designs were avalleble as OFWL Drawing No. Q-1679-44-RO for 1/2" HCV'B and $\mathrm{Q}-1679-45-\mathrm{Rl}$ for I" $\mathrm{HCV}$ 's.

Detther of these preparations was avallable in offl stores. 
Then, the lapping was resumed as before. To determine the progress of lapping, the excess lapping compound on the seat was removed with the solvent. At this time, the machinist declded whether to resume the roughing operation or to proceed to the finlshing step. The length of roughing time depended primarily on the judgment of the machinist.

(6) In finishing, the same general method was used as in roughing.

(7) Following the finlshing operation, the seat and disk were cleaned as before. It wes very important, moreover, that this cleaning be scrupulous beceuse if the valve did not leak after assembly it was then conditioned with fluorine and put into fluorine aervice, (Sec. 15.4.5b).

(8) The valve wes then reassembled and the spring tension set at $12 \mathrm{psig}$. Before sssembly, the Monel disk was replaced with a preconditioned Kel-F disk if the valve vas to contain a Kel-F inatead of a Monel disk. On the other hand, if the valve was to contein a Monel disk, the lapped-in disk was used. See Sec. 17.4.2,e.1, for the definttion of epring tension. Extrese care during lapping was exerctied to avoid enclosing forelgn materials in the system. The term "foreign materlals" embraced any substance such as cellulosic metter, finger printe, greasy spots, metal turnings, and the like. The two wain reasons for this precaution were: first, fluorine reacts violently with many materials, especially thase of orgenic origln and second, any hard material, for example, metal turnings, might be blow through the syetem and possibly at some time interfere with valve elosure and/or scone valve seats. (At least one case in which metal turnings have acored a valve disk has occurred.)

(c) The $k$-starch method of leek testing was used on the valve bonnet.' The prosedure was:

(1) A fresh KI-starch solution wes made by diseolving ebout one-third of 8 teaspoon of soluble starch and the same anount of C. P. KI erystals in a half-pint of demineralized water. (Wote: The water should not contain free chlorine or other substances which liberate Iree iodine frow $\mathrm{KI}$; otherwise, the color of the solution till be mid. night blue. Such a coloration reniers the solution useless since it indicates a positive test.)

(2) The valves for bonnet checking were opened, and the pertinent portion of the system was pressurized dymami-

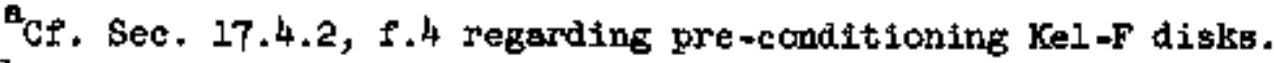

b

This method was developed by G.I. Cathera and $s$. Bann for use generally with joints in the VPP. The necessary care to avold the false indication by Fe ${ }^{3+}$ reacting with KI should be exercised.
} 
$\operatorname{caz} 1 y^{\theta}$ to 10 to 15 pgig with fluorine.

(3) A strip of soft tissue paper such as Kleenex long enough to entirely cover the bonnet joint and wetted with the KIstarch solution was placed on the joint.

(4) After this strip had been in place for about a minute, it wes removed. A midnight bluish coloration of the paper Indicated a leak. In the event that the plece of tissue was not entirely discolored, a leak existed only over a portion of the joint. In Buch cases, the exact location could be fatrly well ascertalned. No work directed at determining the sensitivity or this test has been attempted. It was found, however, to be as sensitive as the soap bubble method with 100 psig $\mathrm{N}_{0}$ (Sec. 19.4.2). The joint to be tested should be clean to avold the interference of extraneous matersals with the test.

The frequency of lapping was on the order of every 6 to 9 runs during the second maintenance perict. The wear on the Kel-F disks in 6 to 9 runs was about half-ray through the Kel-F or as Indicated by disks $D$ and $B$ in Fig. 1T.2.

It vas necessary to replace a bellows in only one HCV valve. The bellows fallure evidently resulted from poor malntenance practice sucb as trying to remove the bonnet with the valve shut. The repair work necessitated replacing the entire stem assembly with that from another valve.

HCV-22 developed a bonnet leak in Run E-2 (Bec, 7.4.2), This leak was eliminated by 11 ghtly dressing the bonnet contact surfaces and then replac1ng the bonnet.

f. Tests with Kel-F and Monel Disks In HCV's

Several tests using HCV's $18,3^{4}$, and 36 fitted with Kel-F disks were made during the later pertod of valve meintenance and testing. The purpose of this work was three-fold: f1rst, to determine the expected life of Kel-F assks; second, to determlne whether a Kel-F fitted valre will start to leak as the Kel-F wears, and third, to determine whether Kel-F disks would self-heal by cycling the valve.

aymamieally Instead of statically to avoid pressure leek-off while leak-testing. otherwise, the system should be monitored continuously while testing.

${ }^{b} \mathrm{cf}$. Sec. 17.4.2f for details of the wear obtained during Kel-F disk test-work.

CThe results of the first endurance tests on Zel-F aisks which were made by

L. H, Chase of the Instrument Division are not reported here. 
1. Teet Conditions and Procedures

The following endurance tests were made:

(a) Test $l_{\mathrm{e}}$ was performed at room temperature with unconditioned disks.

(b) Test 2 was performed at normal heated duct temperatures with

(c) Test 3 was performed at normal beated duct temperatures with
preconditioned disks.

The valves tested at room temperature simalated conditions for valves outside of the hested duct and those tested at normal heated duct temperatures simulated conditions in the heated duct. A test at room temperature with preconditioned disks was not made because wear under guch conditions was considered less severe then that for preconditioned disks at normal heated duct temperatures.

The procedure fn all endurance tests was:

(a) The valves were fitted whth Kel-F disks and rendered leaktight at the temperature of the test and at the specifled. test pressures.

(b) Each valve was fully opened and cloged, or cycled, 100 tímes and retested for seat-leakage.

(c) Each valve was cycled 100 more times and asaln tested for seat leakage.

(d) Bach valve was disasgenbled for alsk and seat inspection. A seat inspection was done only in Test 1 .

One self-bealing test (Test 4) was mede by cyciling leaking HCV'a fitted with Kel-F disks. Periodically, the cycling was stopped to check the seat leakages.

2. Test results and discussion, The results of the valve tests are presented in Tables $17.3,17.4,17.5$, and 17.6 .

That is, d1sks without preconditioning vith fluorine,

borthal average hested duct temperature date were: (2) $150^{\circ} \mathrm{C}$ near HCV -34 , and (3) $145^{\circ} \mathrm{C}$ near HCV -36 .

(1) $130 \%$ near $\mathrm{HCV}-28$,

CPreconditioning was done per procedure given in Sec. $17.4,2,1.4$. 
Table 17.3

ENDURAHCE TESTS OF WCCODIIIONED KEL-F DISKS AT ROOM TEMTERATURE ${ }^{*}$

Teat 1

Spring Tension: 9 paig

Detes: $9-18,-19,1957$

$\longrightarrow$ Valve Data $\longrightarrow$

Test

Preasure $\leftarrow$ Leak Rate, cc/min,, at Indiceted $\rightarrow$

HCV No. Size psig Number of Cycles

\begin{tabular}{|c|c|}
\hline$\frac{18^{c}}{18^{d}}$ & $1 / 2^{\prime \prime}$ \\
\hline 34 & $1^{\prime \prime}$ \\
\hline 34 & \\
\hline $\overrightarrow{36}$ & $1 / 2^{\prime \prime}$ \\
\hline
\end{tabular}

$\begin{array}{ccr}\text { Zero cycles } & \frac{100 \text { ayclea }}{4} & \frac{200 \mathrm{cyc}}{4} \\ <2 & <2 & 9 \\ <2 & <2 & <2 \\ <2 & <2 & <2 \\ <2 & <2 & <2 \\ <2 & <2 & <2\end{array}$

Appearances of Disks After Test 1

The actual wear was alfficult to assess, probably belig $<1 / 64^{\prime \prime}$; little cracklng, splintering, or peeling of Kel-F was apparent. Disk photographe were sade as follows: HCV-18, OKNL No, 41723 and No. 41724; HCV-34, OKNL No. 41721 and No. 41722; and HCV-36, ORNL No. 41725 and No. 41726.

Appearances of Seats After Teat 1

HCV -18 bad a rough seating surface but not as rough as for HCV -36 ; $\mathrm{HCV}-3^{4}$ had amooth seating surface; and HCV -36 had a rough seating surface vith nicka, Photographs of the seats were not made.

Room temperature: $\sim 10-30^{\circ} \mathrm{c}$.

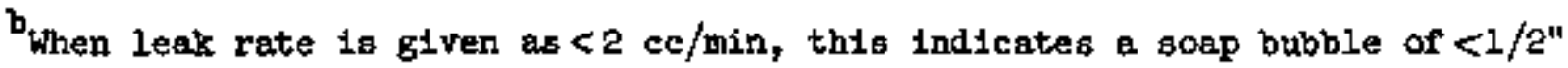
diameter formed in $30 \mathrm{sec}$.

c

18 indicates that leak-test was made in same direction as arrow on HCV-18 valve actuator at Mein Panelboard polnted when valve was open. A similar scheme was used for the other valves.

d.

I8 indicates that leek-teat was made in the reverse direction to that which arrow on HCV-18 valve actuator at Main Penelboard pointed when valve was open. A similer scheme was used for the other valves. 
$-294-$

Table 17.4

ENDURAMCE TESTS OF UNCONDITIONED KEL-F DISKS AT MOFMAL HEATED DUTT TEMPERATURBS

Teat 2

Spring Tension: 9 paig

Date: $10-16-57$

\begin{tabular}{|c|c|c|c|c|c|c|}
\hline \multirow[t]{2}{*}{ HCV HO. } & \multirow[t]{2}{*}{$\begin{array}{l}\text { Size } \\
\text { of } \\
\text { Valve }\end{array}$} & \multirow[t]{2}{*}{$\begin{array}{c}\text { Test } \\
\text { Pressure } \\
\text { psiz }\end{array}$} & \multirow[t]{2}{*}{$\begin{array}{l}\text { Temperature } \\
\text { in Vicinity } \\
\text { of Valve, } \\
\text { o }\end{array}$} & \multicolumn{3}{|c|}{$\begin{array}{l}\text { Leek Rete, cc/min, } \\
\text { At Indicated Number } \\
\text { of Cycles }\end{array}$} \\
\hline & & & & Zero & 100 & 200 \\
\hline $\overrightarrow{2^{\mathrm{c}}}$ & $1 / 2^{\prime \prime}$ & 50 & 130 & $<2$ & $<2$ & $<2$ \\
\hline $28^{\mathrm{d}}$ & & 50 & & $<2$ & $<2$ & $<2$ \\
\hline $\overrightarrow{3^{4}}$ & $1^{*}$ & 10 & 150 & $<2$ & $<2$ & $<2$ \\
\hline 4 & & 10 & & $<2$ & $<2$ & $<2$ \\
\hline $\overrightarrow{36}$ & $1 / 2^{1+}$ & 10 & 145 & $<2$ & $<2$ & $<2$ \\
\hline$\sqrt[5]{36}$ & & 10 & & $<2$ & $<2$ & $<2$ \\
\hline
\end{tabular}

\section{Appearances of D1aigs After Test 2}

Wear was much worke than in Test 1 , being $1 / 16 \mathrm{ln}$. with some evidence of cracking, aplintering, or peeling of Kel-F. Disk photographs made were: HCV-18, ORAL HO, 41889; HCV-34, ORHL Ho. 41890; and HCV-36, ORNL No. 41891 . Appearences of Seat; After Test 2 were not determined.

PNormal average heated duct tempergture data were: (1) $130^{\circ} \mathrm{C}$ near $\mathrm{HCV}-18$, (2) $150^{\circ} \mathrm{C}$ near $\mathrm{HCV}-3^{4}$, and (3) $145^{\circ} \mathrm{C}$ near $\mathrm{HCV}-36$.

When leak rate is given as $<2 \mathrm{cc} / \mathrm{min}$, this indlcates a soep bubble of $<1 / \mathrm{C}^{\text {t }}$ diameter formed in 30 sec.

c $\overrightarrow{18}$ indicates that leak-test was made in seme direction as arrow on HCV-18 valve actuator at Main Panelboard pointed when valve was open. A slwilar scheme was used for the other valves.

d 88 indicateg that leak-test was made in the reverse direction to that which arrow on HCV -18 valve actuator at Main Panelboard polnted when valve was open. A similar gcheme wes used for the other valves. 
Teble 17.5

ENDURANCE TESTS OF PRECONDITIONED KEL-F DISKS AT NOFMAL HEATED DUCT TEMPERATURES

Test 3

Spring Tension: 9 psig

Dates: $10-29,30-57$

\begin{tabular}{|c|c|c|c|c|c|c|}
\hline \multirow[t]{2}{*}{ HCV No. } & \multirow[t]{2}{*}{$\begin{array}{l}\text { Size } \\
\text { of } \\
\text { Valve }\end{array}$} & \multirow[t]{2}{*}{$\begin{array}{c}\text { Test } \\
\text { Pressure } \\
\text { psLs }\end{array}$} & \multirow[t]{2}{*}{$\begin{array}{l}\text { Temperature } \\
\text { in vicinity } \\
\text { of Valve, } \\
\text { o }\end{array}$} & \multicolumn{3}{|c|}{$\begin{array}{l}\text { Leak Rate, cc/min, } \\
\text { at Indicated Number } \\
\text { of Cycles }\end{array}$} \\
\hline & & & & Zero & 100 & 200 \\
\hline $18^{\circ}$ & $1 / 2^{\prime \prime}$ & 50 & 130 & $<2$ & $<2$ & $<2$ \\
\hline $18^{\mathrm{d}}$ & & 50 & & $<2$ & $<2$ & $<2$ \\
\hline $\overrightarrow{34}$ & $1^{*}$ & 10 & 150 & $<2$ & $<2$ & $\angle 2$ \\
\hline 3 & & 10 & & 42 & $<2$ & $<2$ \\
\hline $\overrightarrow{36}$ & $1 / 2^{\prime \prime}$ & 10 & 145 & $<2$ & $<2$ & $<2$ \\
\hline 36 & & 10 & & $<2$ & $<2$ & $<2$ \\
\hline
\end{tabular}

\section{Appearance of Disks After Test 3}

Wear was probably a little worse than In Test 2 , belng $\geq 1 / 16 "$ with truch more evidence of cracking, splintering, or peeling of Kel-F than in Test 2 , especially for $\mathrm{HCV}-18$. Disk photogrephs mede vere as follows: HCV -18 , ORNL No. 41935; HCV-34, ORNL No. 41936; and BCV-36, ORWL Ho. 41937.

Appearances of Seats After Test 3 were not determined.

Mormal average heated duct tempergture data were:

(2) $150^{\circ} \mathrm{C}$ near ACV -34 , and (3) $145^{\circ} \mathrm{C}$ near HCV -36 .

(1) $130^{\circ} \mathrm{C}$ near $\mathrm{HCV}-18$,

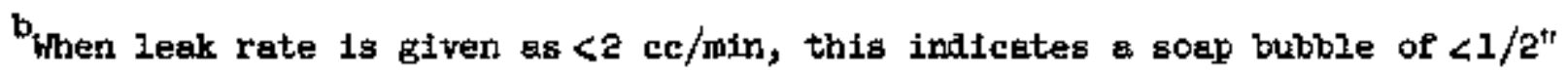
alameter formed in $30 \mathrm{sec}$.

c $\overrightarrow{18}$ indicates that leak-test was made in same direction as arrow on HCV -18 velve actuator at Main Panelboard pointed when valve was open. A similar scheme was used for the other valves.

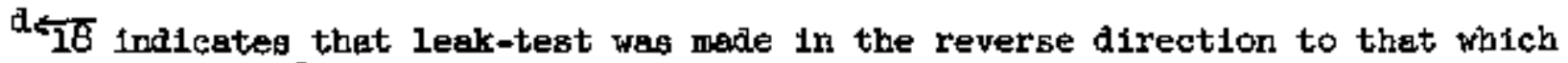
errow on HCV-18 valve actuator at Maln Panelboard polnted when val ve was open. A similar scheme was used for the other valves. 
Table 27.6

SELF-HEALING DATA AY ROOM MZAMPERATIRE ON LEAKIYG HOV'S FITTED WITH WANCONDITIONED KEE-F DISKS

Test 4

Sprsing Tenaion: 9 psig

Disks: thconditioned

Date: $9-18-57$

\begin{tabular}{|c|c|c|c|c|c|c|c|c|c|}
\hline HCV Ho, & $\begin{array}{l}\text { Size } \\
\text { of } \\
\text { Velre }\end{array}$ & $\begin{array}{c}\text { Teat } \\
\text { Pressure, } \\
\text { palg }\end{array}$ & $\longleftarrow$ & Leak $F$ & $\begin{array}{l}\text { ate, } \\
\text { Numbe }\end{array}$ & $\begin{array}{l}\mathrm{c} / \mathrm{min} \text {, } \\
\mathrm{r} \text { of } \mathrm{C}\end{array}$ & $\begin{array}{l}\text { at Ir } \\
\text { reles }\end{array}$ & Icated & $\longrightarrow$ \\
\hline & & & Zero & 5 & 10 & 20 & $\underline{40}$ & 80 & 160 \\
\hline $14^{2}$ & $1 "$ & 50 & 26 & 51 & 51 & 51 & 51 & 17 & 26 \\
\hline $14^{d}$ & & 20 & 2 & 51 & 0 & 0 & 0 & 0 & 0 \\
\hline $\overrightarrow{18}$ & $1 / 2^{n}$ & 50 & 17 & 15 & 26 & 15 & 15 & 21 & T.D. \\
\hline 18 & & 50 & 34 & 34 & 26 & 34 & 34 & 34 & N.D. \\
\hline $\overrightarrow{22}$ & $1 / 2^{11}$ & 20 & $\approx 300$ & 170 & 170 & 170 & 170 & 170 & 170 \\
\hline t22 & & 50 & $>500$ & $>500$ & 170 & 170 & 170 & 170 & 64 \\
\hline
\end{tabular}

aroom temperature: $\sim 10-30^{\circ} \mathrm{C}$.

b. W. D. = Not Determined.

c $\overrightarrow{18}$ inalcates that leak-teat was made in same direction es errow on HCV-18 valve actuator at Main Panelboard pointed when valve was open. A similar echeme was used for the other valves.

d 18 Indicates that leak-teat wag made in the reverse direction to that which arrow on HCV-18 valve actuator at Kain Panelboard pointed when valve was open. A similar scheme was used for the other valves. 
(a) Results of Teat 1,2 , and 3

In hot and cold tests with both conditioned and unconditioned Kel-F disks, $1 / 2-i n$, as well as $2-i n$, valves remained leak-tight for 200 cycles with one exception. This exception was HCV-18 in Test 1 , which was not leak-tight inttlally and which leaked worse after cycling.

The wear on the disks was most severe (probably $\geq 1 / 16-1$. deep) for the preconditioned disks in the hot test, Test 3 . In splte of the weer suffered by these disks, no disk failure occurred. Some cracking, splintering, or peeling of the Kel-F did take place, hovever, this spalling of the disks was apparently worst for the preconditioned disks in the hot teat. The desired leak rate of $<2 \mathrm{cc} /$ min was achieved with both amooth and rather rough-looking seats in test 1 .

\section{(b) Results of Test 4}

The eelf-healing test results from Test 4 were erratic. For instance, HCV -14 exhlbited healing in the reverse direction only. In addition, HCV-a2 seemed to show a tendency to heal whereas HCV 18 showed no tendency to heal.

(c) Discussion of Test Results and Additional Information

The results of Teats 1, 2, and 3 indicated that both 1/2in, and l-in. BCV's with elther preconditioned or unconditioned diaks uaed at room temperature or at $\sim 150 \mathrm{C}$ will remain leakfree for more than 200 valve cycles. The wear on the Kel-F during 200 valye cycles was most setrere for the preconditioned disks at $\sim 150 \%$. Even at this worst wear rate, the useful life of a disk should probably be several times the 200 cycles uaed in these tests.

This expected life is based on the $\sim 1 / 16$ " wear in Test 3 and on the thickness of the Kel-F at the point of vear whlch Is 1/8" for both 1/2-in. and 1-1n. disks. In this projection of wear, it was assumed that:

(1) Wear raries linearly with the number of valve cycles.

(2) Wear would not exceed one-half of the Kel-F thickness avaliable for wear.

(3) The valve would not leak before this "half-thickness" of Kel-F avallable for wear was worn through.

In prectice durlag an aterage gerles of about nine runs, the worst wear on Kel-F disks was about the sease es thet in Teat 3 as shown by disks $D$ and $H$ in P1g. 17.2. This fact might Indicete that the most 
used valve was cycled about 200 times during a run series. But a cross-check from runsheets revealed that the maximun number of cycles during a sertes of nine rums wound be about 80 (w1th 100\% excess cycling). Thus in a 9-run series to obtain vear equivalent to 200 eycles would require efther a greater wear rate in practice or about soof excess cycling. Either of these explanations is possible. But the main consideration here is that data obtained both through endurance testing and experience Indicated the adequacy of the Kel-F disks for a 9-run ser1es.

The cracking, peeling, or aplintering of the preconditioned disks alght effect seat leakage earlier than otherwise because fissures night form across the seat contact line. There was no concrete evidence during operetions, however, that spalilng reduced disk life.

The conditions of the valye sests in Test 1 might lead to the conclusion that uaing Kel-F diaks would enable obtaining leak-free valves with both smooth and rough seats. Th1s conclusion has not been substantiated.

The data in Test 4 most likely indicated that valves with Kel-F diaks which leeked orisinaliy would not heal on cycling. In spite of the fact that little work along this line has been done, additionel effort is not recommended because the test results were not encouraging.

The variability of soine of the data in Tests 1 and 4 may cause a question of the reliability of the leaktesting procedure. The point werits mention when the two following factors wilich may influence the results are considered: (1) the possiblilty of unknown sources of bas flow in such a complex piping system and (2) the difference in technique used by different operators. Even though the exiatence of either of these two factors may produce spurious results, only the second ractor is believed to be of any significence in these four tests. The effect of this factor is difficult, if not inpossible, to essess. The reason that the adverse effect of urknown ges sources on the leek-rate deta is discounted here is that such gas aupplies usuelly produced abnornally high leak rates which were not observed in these tests. 
3. Monel and Kel-F Disks in a Variety of Service Conditions

During the pilot plant operations, the HCV's with either Monel or Kel-F disks were maintained leak-free in a variety of service conditions. The service variables were: material handled, temperature, and time. The materials handled were $\mathrm{UF}_{6}$ (in solid, liquid, or gaseous state) $\mathrm{F}_{2}$, and $\mathrm{N}_{2}$; the temperatures varied from ambient cell temperatures of around $10-30^{\circ} \mathrm{C}$ up to about $150^{\circ} \mathrm{C}$; the exposure time ranged from about $35 \mathrm{hr}$ to $150 \mathrm{hr}$.

Both Monel and Kel-F valve disks were used in all combinations of the service variables with one exception. This exception concerned using Kel-F disks at heated duct temperatures ( $150^{\circ} \mathrm{C}$ ) in pure fluorine supplied at room temperature. In HCV-12 which was exposed to pure $\mathrm{F}_{2}$ at times, for instance, two Kel-F disks have disintegrated. The first such occurrence initiated the preconditioning of the disks with fluorine prior to installing in the system. At first such preconditioning was thought to be the remedy. However, subsequent operating experience in which a supposedly preconditioned Kel-F disk was destroyed in HCV-12 led to the conclusion that Kel-F was unsuitable for pure $\mathrm{F}_{2}$ service regardless of whether preconditioned. A qualification is necessary because it is possible that the preconditioned. Kel-F disk might have had some foreign material on its surface which reacted with fluorine, thereby initiating the reaction between fluorine and the Kel-F. At any rate, in the VPP work, replacing the disintegrated preconditioned disk was costly enough to take no further chances. In future work, only Monel disks were used in pure fluorine service.

4. Preconditioning of Kel-F Disks with Fluorine

While preconditioning the first batch of Kel-F disks, several disks disintegrated when contacted with fluorine as soon as the temperature of the disks reached $100^{\circ} \mathrm{C}$. To avoid this, it was necessary to hold the disks a length of time at the preconditioning temperature of $100^{\circ} \mathrm{C}$ before exposing them to fluorine. The necessary length of the holding time was never determined exactly. Practice revealed, however, that 1 to 2 hours was adequate. Figure 17.3 shows the effect of preheating conditions on the reaction of Kel-F disks with fluorine.

astimated exposure time during a 9-run series for little used HCV's such as HCV -34 and for more frequently used HCV's such as HCV-18 or 19, respectively.

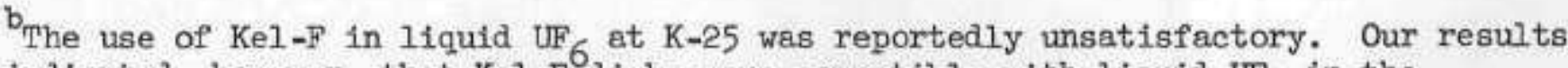
indicated, however, that Kel-F disks were compatible with liquid $\mathrm{UF}_{6}$ in the Volatility Pilot Plant.

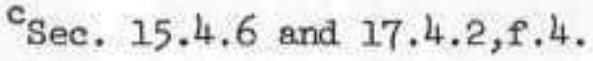




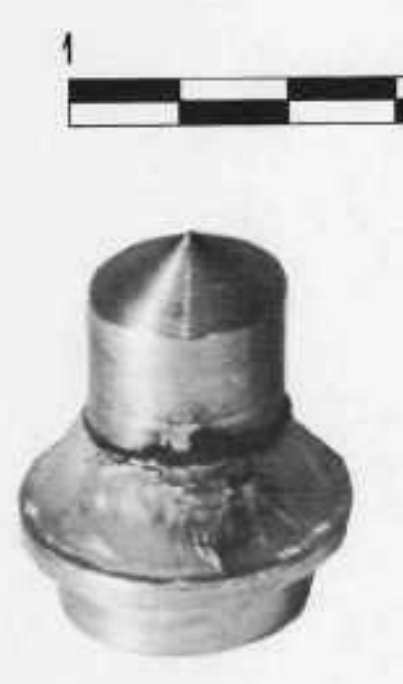

\section{0}

SCALE IN INCHES

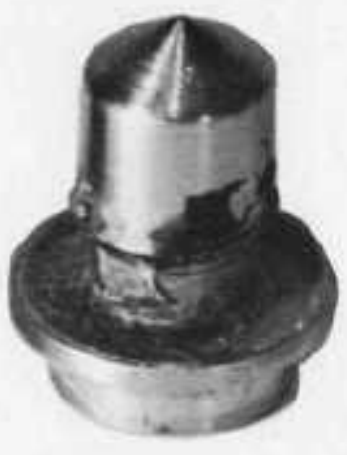

Preheoting Prior to $\mathrm{F}_{2}$ Addition: on Attaining $100^{\circ} \mathrm{C}$.

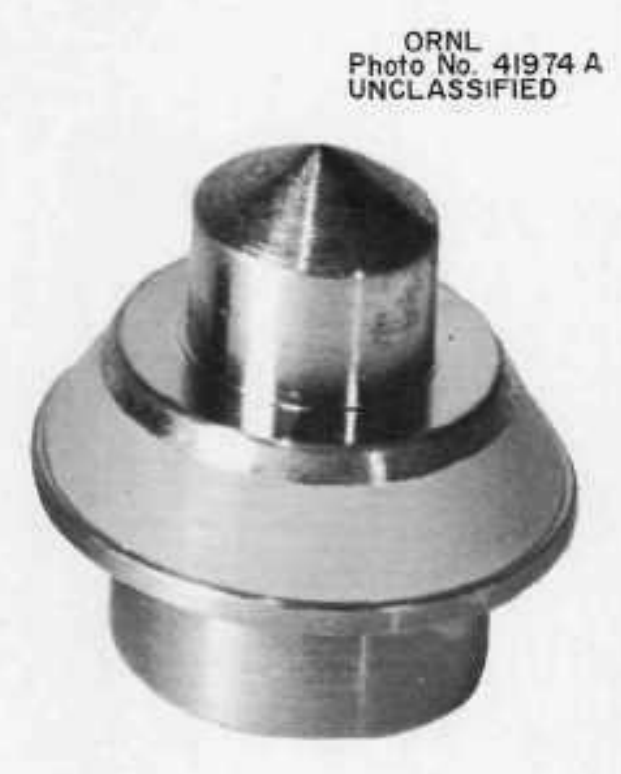

\begin{tabular}{l}
1 \\
\hline \\
\hline
\end{tabular}

Fig. 17.3. Effect of Preheating Conditions on the Reaction of Kel-F Disks with Fluorine.

Preheating Prior to $F_{2}$ Addition: 2 or more hours at $150^{\circ} \mathrm{C}$. 
The initial reection leading to the disintegration during preconditioning was apparently that of fluorine and the plasticizer in the Kel-F. This reaction, in turn, produced sufflelent heat to cause the fluorine and Kel-F to react. Regardless of wether the reaction partly or completely deatroyed the Kel-F portion of the diak, the disk was useless. Probably the reason that the holding time at $100^{\circ} \mathrm{C}$ rendered the disk compatible with fluorine was that a ameller amount of the plasticizer was retalned at the surface to reect with fluorine.

Although the optimu preconditioning scheme has not been worked out, the following procedure has been used successfully:

(a) Degrease disks briefly with C. P. carbon tetrachloride and allow excess solvent to vaporize.

(b) Place disks in a container suitable for use with fluorine and start an inert pas such as nitrogen bweeping across the disks and thence to vent.

(c) Heat container to $100^{\circ} \mathrm{C}$ and hold it at this temperature for 1 to 2 hours.

(d) Wrile contimuing to maintain the container at $100^{\circ} \mathrm{C}$, shut off $\mathrm{N}_{2}$ flow gradualy while starting $\mathrm{F}_{2}$ flowing through the container at alow rate.

(e) Maintain fluorine flow and the container at $100^{\circ} \mathrm{c}$ for onehalf hour.

(f) Shut of heat allowing container to cool to room tempersture while maintalning the fluorine flow.

(g) When conteiner is at room temperature, cut off fluorine and sweep chamber with $\mathrm{N}_{\mathrm{a}}$ for one hour before removing diaks.

(h) Remove disks whth cere to avold contaminating Kel-F surfaces with foreign materials or fingerprints. Store disks in a ary place at room temperature untsl ready for use. Subsequent banding of disks ahould be with the name care as durIng unloading disks.

Preconditioning the dikkg as recommended apparently produced taxpage or uneven shrinkage of the Kel-F. This warpage caused the confcal surface of the Kel-F to depart from that of a right cone. This aftuation can best be described through the following test made on a lathe. With the disk mounted on the lige center, the atak was rotated such that a feeler gage would describe a circle on the conteal surface of the Kel-F if the Kel-F surface were truly contcal. The described circle was near the place at thich the seat would normally atrike the aisk. The results of this test indieated 
that a true circle could not be described on many of the preconditioned disks. In fact, the deseribed ofrcle for some of the disks failed to contact the Kel-F sumface by 68 mach as 7 to $10 \mathrm{mils}$.

This situation was remedied by truing the conjeal surface on a lathe without any lubricant; otherwse, if a lubricant had been ured, the disk vould have had to be preconditioned again after machining.

Before warpage of the Kel-F was found to be the difficulty, much concern was expresend regarding the inability of preconditioned Kel-F disks to bive a tight shut-off. And, since this difficulty ceme chronologically after tight shut-off with Kel-F disk had lnitially been attained, this problem was one of the most puzzling encountered in the HCV program.

The following factors in preconditioning Kel-F dishs seem to be important: rinsing in carbon tetrachloride, time and temperature of preconditioning, and surface machining. The exposure to carbon tetrechloride should be brief so as to decrease the anount of this solvent sorbed by the Kel-F. This is important because both sorbed carbon tetrachloride and plesticizer must be removed during preconditioning. The time end temperature of precondtitioning govern the depth of conditioning, the degree of surfece varpage, and the emount of mechining necessary to "true" the conical surface. The envisioned goel in preconditioning is to render the disks conlpatible with fluorine so that little or no machining is required. Such a scheme would necessitate minimal rinsing in carbon tetrechloride, timent-temperature, and preconditioning temperatire.

\section{B. Aditional Comments on HCV's}

In the future, the following three considerations regarding HCV's might become very important:

1. Heplacement of body or body components to elfminate leak(s). The ECV's lend themselves reasonably well to any type of replecement except for body replacement if spare parts are stocked. The body replacement would be difficult because ingtalling the new body would require making two fully inspected Hell-arc welds.

2. Further attenpts to prevent deposits on internal parts and salt backflow such as heve jecurred In HCV -7 and -8 . Just whet form future attempts to reduce the internal deposition of materials and/or to prevent salt backflow might taice is unlnown. Installing the CRP trap and water-washing the system periodically were atternts at decreasing the internaldeposition of solids in the systen generally. Various fluorinator design charges as well as perfecting operating techniques were aimed at preventing salt backflow near the fluoringtor. 
3. Replacement of HCV's with other $\mathrm{val}$ ves. Whether to replace the HCV's with different velves is the nost important decision in the field of remotely operated "on-off" control valves. The following turee factors are of prine inportence in making this decision:

First, whether the future experience with $\mathrm{BCV}$ 's can be expected to parallel the past experience. Past experience with HCV's Indicated that reletively satisfactory plant operation has resulted through a large expenditure of money for developuent and malntenance. The "relatively sat1afactory" qualification refers to the fact that some valves developed leaks during a given run serles, and that the "integraz" nature of the valve made it more desirable to operate with the leaks rather than repair or replace the valves. In addition to the troubles in pagt experiences with HCV's, some of the poor desten features not yet causing trouble migbt cause airficulties in the future.

Second, whether the advanteges of maintedning valves in a shop rather than in the fleld would make replacing all HCV's attractive. New valves might be flanged into the system and, therefore, could be handled as unfts.

Third, whether the combined initial and maintenance costs for replacement ralves would be less than that for mainteining the HCV'B in the future. To resolve this consideration depends on the enswer to the first factor, and on the maintenance requirement of the new ralves.

The above considerations involved in replacing the HCV's have been raised without resolution because that decision is beyond the scope of this report.

After the " $L$ " runs, the HCV's were decontaminated and delivered to the Instrument Division for reuse, (Sec. 23.4.15a and Table 23.4).

\subsubsection{Remotely Operated Control Valves}

Remotely operated control ralves were used in the Volatility Pilot Plant to control $F_{2}$ and $H_{2}$ flow rates and also to control pressures at several points In the systefr. Table 17.7 Iists construction date and service conditions for bach control valve as well as an operational evaluation. The mechanics and design of each control mechenism are covered in the description of the VPP system containing that control mechenism.

Most of the remotely operated control valves were left in place after the "L" runs. If any are removed with equipanent in the futune, decontamination as for the HCV's (Sec. 23.4.15a) Ia planned along with subsequent delivery to the Instrument Division. 
Table 17.7

REMOTELY OPERATED COMTROL VALVE DATA ARD REQQUIRED OPERATTONAL ATTEMTION (46, p. 51)

\begin{tabular}{|c|c|c|c|c|c|c|c|c|c|c|}
\hline \multirow[b]{2}{*}{$\begin{array}{l}\text { Falve } \\
\text { Halmer }\end{array}$} & \multirow[b]{2}{*}{ Size } & \multirow[b]{2}{*}{ Manufacturer } & \multicolumn{4}{|c|}{ Materials of Construction } & \multirow{2}{*}{$\begin{array}{l}\text { Dase of } \\
\text { Oper- } \\
\text { ation }\end{array}$} & \multicolumn{3}{|c|}{ Service conditions } \\
\hline & & & Body & Disk & Stem Seal & $\begin{array}{c}\text { Bonnet } \\
\text { Seal }\end{array}$ & & Temp -, ${ }^{\circ} \mathrm{C}$ & $\begin{array}{c}\text { PSIG } \\
\text { Pessure }\end{array}$ & $\begin{array}{c}\text { Chemicel } \\
\text { Component }(s)\end{array}$ \\
\hline FCV $=1$ & $1 / 2^{11}$ & $\begin{array}{l}\text { Research } \\
\text { Controls }\end{array}$ & $\begin{array}{l}\text { Forged } \\
\text { Steel }\end{array}$ & 316 & $\begin{array}{l}\text { Monel } \\
\text { Bellows }\end{array}$ & $\begin{array}{l}\text { Tefion } \\
\text { Gesket }\end{array}$ & 6001 & 10 to 30 & $0-20$ & $H_{2}$ \\
\hline $\begin{array}{l}\text { Fiv-2 } \\
\text { Nodel No. } \\
\text { F-79 }\end{array}$ & $1 / 2^{\prime \prime}$ & $\begin{array}{l}\text { Research } \\
\text { Controls }\end{array}$ & Monel & Monel & $\begin{array}{l}\text { Mone1 } \\
\text { Bellows }\end{array}$ & $\begin{array}{l}\text { Tefion } \\
\text { Gesket }\end{array}$ & Poor & -10 to +30 & $10-30$ & $\mathbf{F}_{2}, \mathbf{H}_{2}$ \\
\hline $\begin{array}{l}\text { FCV-37A } \\
\text { and -38A } \\
\text { Model Ho. } \\
3919 \text { ABS }\end{array}$ & $3 / 16^{\prime \prime}$ & Femmel Dahl & Brass & $\mathrm{Kel-F}$ & $\begin{array}{l}\text { Brass } \\
\text { Bellows } \\
\text { with Tef- } \\
\text { lon Gasket }\end{array}$ & $\begin{array}{l}\text { Teflon } \\
\text { Gasket }\end{array}$ & Good & -10 to +30 & $15-60$ & 2 \\
\hline $\begin{array}{l}\text { PCV-2A } \\
\text { end-2B } \\
\text { Hodel No. } \\
3919 \text { ABS }\end{array}$ & $1 / 2^{11}$ & Hammel Dahl & Brass & Kel-F & $\begin{array}{l}\text { on one end } \\
\text { and other } \\
\text { end weided }\end{array}$ & $\begin{array}{l}\text { Teflon } \\
\text { Gasket }\end{array}$ & Poor ${ }^{b}$ & -10 to +30 & $15-60$ & $\mathbf{F}_{2}$ \\
\hline $\begin{array}{l}\text { Fx-37 } \\
\text { and -38 } \\
\text { Model } \\
\text { FI-900 }\end{array}$ & $3 / 8^{\prime \prime}$ & $\begin{array}{l}\text { The Gems } \\
\text { Co. }\end{array}$ & Brass & Brasa & None & $\begin{array}{l}\text { Teflon } \\
\text { Gesket }\end{array}$ & Good & -10 to +30 & $0-55$ & $F_{q^{\prime}} \bar{F}_{2}$ \\
\hline $\begin{array}{l}\text { PCV-10 } \\
\text { Model Ho. } \\
\text { F-7 } 7 \mathrm{y}\end{array}$ & $1 / 2^{\prime \prime}$ & $\begin{array}{l}\text { Resesrch } \\
\text { Controls }\end{array}$ & Honel & Hone1 & $\begin{array}{l}\text { Monel } \\
\text { Bellows }\end{array}$ & $\begin{array}{l}\text { Teflon } \\
\text { Gesket }\end{array}$ & Poor & -10 to +30 & $0-60$ & $\mathrm{~F}_{2}$ \\
\hline $\begin{array}{l}\text { PCF-39 } \\
\text { FiE. } \\
3978 \text { ABP9 }\end{array}$ & $1-1 / e^{1}$ & HanmeI Dahl & Monel & Honel & $\begin{array}{l}\text { Bonel } \\
\text { Bellows }\end{array}$ & $\begin{array}{l}\text { Teflon } \\
\text { Geselset }\end{array}$ & Cood & $\sim 30$ to 50 & $\sim 0$ & $\begin{array}{l}\text { Scrubber } \\
\text { Off Gases }\end{array}$ \\
\hline $\begin{array}{l}\text { PCV } 45 \text { FIC } \\
3978 \text { ABPg }\end{array}$ & $1-1 / 2^{1}$ & HagmeI Dahl & None1 & Monel & $\begin{array}{l}\text { Monel } \\
\text { Bellows }\end{array}$ & $\begin{array}{l}\text { Tefilon } \\
\text { Geskat }\end{array}$ & Good & 10 to 30 & $\approx 0$ & $\mathrm{H}_{2}$ \\
\hline $\begin{array}{l}\text { PCV-61 } \\
\text { Type Ho. } \\
\text { V-4 }\end{array}$ & $3 / 411$ & Foxboro & $\begin{array}{l}304 \\
5.5 .\end{array}$ & $\begin{array}{c}18-8 \\
304 \\
5.84\end{array}$ & $\begin{array}{l}\text { Tefion } \\
\text { V-Ring } \\
\text { Packed }\end{array}$ & $\begin{array}{l}\text { S.S. } \\
\text { Gesket }\end{array}$ & Good & -50 to 100 & $\begin{array}{l}5^{\prime \prime} \mathbf{E}_{2} 0 \\
\operatorname{Vac}^{2}\end{array}$ & $\begin{array}{l}\text { Waste Can } \\
\text { Off Goses }\end{array}$ \\
\hline
\end{tabular}

aycling of the FCV-2 and FCV-10 combination caused constderable flow variation most of the time.

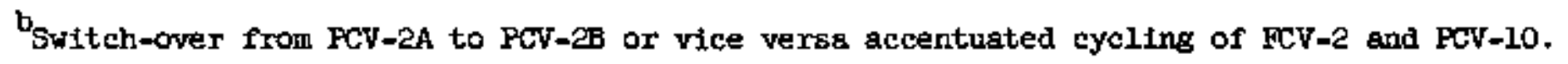


Operational difficulties oceurring were:

a. Components' failures in PCV-10 and FX-37. The two components' failures in FCV -10 and FX -37 are evidence that fluor-1ne will react with both Kel-F and Tefion although the conditions existing in these cases cannot be specified. ${ }^{a}$ At any rate, the Kel-F disk of PCV-10 was destroyed by fluorine. In addition a Teflon wagher in FX-37 disintegrated when a leak developed timrough a faulty seal in the switch. In both situations, pure fluorine was beling handled. For PCV-10, the valve was replaced with one of all Monel construction. For FX-37, aince the switch was replaced with a spere, Teflon wes successfuliy used of ter the 1ncident. In nefther case has further trouble been experienced.

Another difficulty with both $\mathrm{FX}-37$ and -38 was that a sudden high flowrate of fluorine caused the switch spindie to stick in the "opencircuit" position. In such a case, fluorine flow could not be resumed until the spindle was freed by rapping the switch sharply with a small tool. This situation wes principally annoying but also potentially t1me consuming. For inscence, without knowing thet this might happen, much operating time might have been lost while investigeting other possible causes of fluorine flos interruption.

b. Undue cycling of the PCV-10 and FCV 2 cowbination. The cycling of the FCV -10 and FCV-2 combination wes a problem during the entire processing period. Since there were elways unsolved instrumentation problems of a more gerious nature, this condition was never corrected. Early in the pilot plant work (i.e., before the "C" $\mathrm{CunB}$ ) a surge pot (FV-160) was added to the system in an attenpt to reduce the fluctustions by adding surge capacity. This was a step in the correct direction in that it seemed to diminish the fluctuations. The effect was slight, however, and subsequentiy no further remedies were tried.

The eutometic trailer switch-over through the sction of PCV-2A and PCV-2B usually disxupted the operation of the FCV-10 and FCV-2 combination and almost invariably necessitated re-establishing the desired readings on FCV-10 and FCV-2. In mapy cases, leveling out the FCV-1O and FCV-2 readings required almost constant attention for a half-hour or more.

c. The KOH backilow through PCV -39 was countered in two ways. First, fack-legs, an over-flow drug ( $5 \mathrm{~V}-151)$, and a slope in the vent gases line were incorporated in the system es described elsewhere. "Second, a

a See Secs. 15.4.1b, 15.4.6, and 17.4.2,f.4 for other cases of Kel-F or Teflon reacting with fluorine. Detalla for the Kel-F fitted PCV-10 are not given in Teble 17.7.

${ }^{b}$ cf. Sec. 17.4.2f relat,ite to using Kel-F disks in pure fluorine service.

SEec, $11.4 .1 b$. 
modified PCV-39 system destgned to control the vent line pressure was installed (Sec. 11,4.1b). The relative merits of one of these actions are unknown. But another KOH backflow has not occurred since these chengeg were made.

\subsubsection{Freeze Valves}

A freeze valve was a loop or bend in elther $3 / 8-1 n$, or $1 / 2-1 n$. Schedule 40 RPS Inconel pipe with the seal being achieved by freezing salt in the low portion of the loop. The valve was "opened" by melting the salt, that is, by heating the entire autoresistance line in which the freeze valve was located to $\geq 570^{\circ} \mathrm{C}$ (Sec. 21.3 .2 ). The valve "shut" by discontinutng flow and freezing the entrapped molten salt by cooling the entire autoresistance heated line to room temperature. The four different designs used with indicated regions of sealing are shown in $\mathrm{Fig}$. 27.4. In addition to autoresistance heating, the $3 / 8$-in. NPS valve (Mark $v$, Sec. 13.4.2) also required resistance heeting to maintain the expanded sectloms at the deatred temperature. The expanded sections were added to this valve to increase liqutd retention for sealing purposes. as discussed under sec. 13,4,2.

The Mark I (pot-type) freeze valve design tested in the Unit operations section was never used in the VPP. The Mark II (Bull Noose) design, however, was thoroughly tested in the Unit Operations section and was used as both FV-106 and -108 in the VPP. One valve of this type has been tested through 225 cycles of freezing and thswing with a gas pressure of $20 \mathrm{psib}$ applied after each cycle without leakage (determined by gas collection) or dimensional chenge (determined by microneter). Leakage wes also monitored wth a halogen leak detector and Freon ges with no leskage being found even at pressures up to 100 psis (56). Three other Bull Mose valves were tested 15 times each using 20 peis gas pressure without leakage (determined by gas collection) (57). The "fin" of the Bull Moose valve was removed in VPP (Bec. 21,4.1). No leakage tests except those done In the VPF and described below have been mede for the Nark III, IV, and V freeze valves.

Two difficulties with freeze valves found in the Unit Operations section were: (a) having vents which are too small and (b) plugging of the venta vith salt forced up into them (56). Having the vents too small resulted in siphoning which sometimes completely emptled the freeze valve. In only one case in the VPP, however, did the Bull Moose valve completely expty itself (Sec. 13.4.2). Siphoning in the Mark $v$ freeze valve could be stopped (See. 13.4.2).

Operationally, two aspects regerding freeze valves vere of prime importance in the VP:

a. The valve should have an unobstructed flow path when open. The normal time required to flow a eluorinator batch (about 52 liters) through a freeze valve varled from about a minute to an hour or more. The fast transfers (pressure or siplion types) were made through the freeze valves $\mathrm{FV}-104$ (Sec. 16.4.14) and -106 (Sec. 13.4.2). In both types of transfers, the rapidity and/or success of the transfer depended largely on whether all of the salt throughout the entire transfer line was molten.

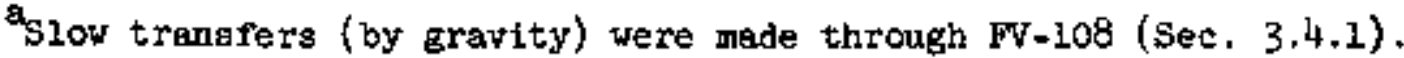




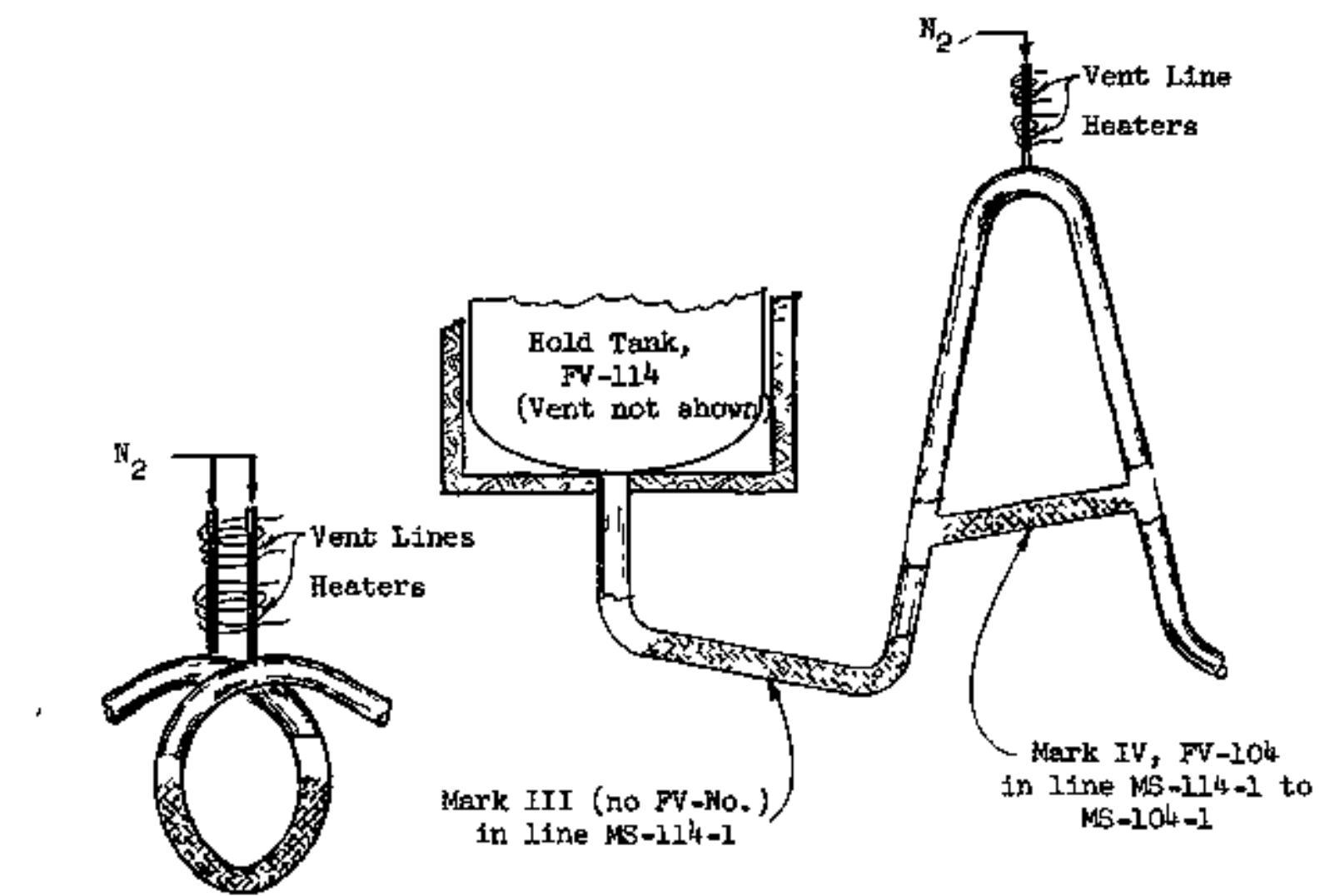

Nork II, FV-106 \& 108

in lines WS-100-1 to MS-106-1 and

MS-102-1 to MS-106-1

(Bull Moose) tortes: PIping insulation 1s not shown. All piping is exaggerated.
SXbzog Region of sealing

by frozen salt

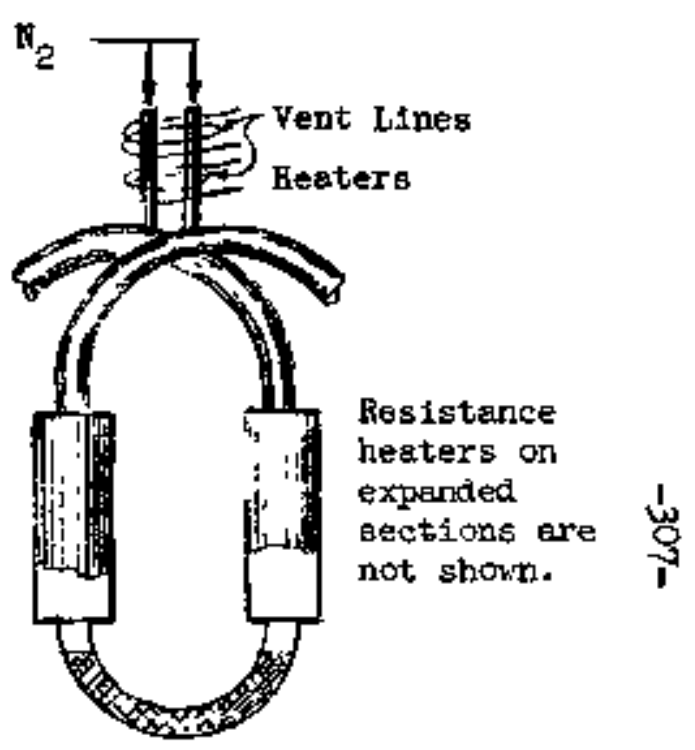

Mark V, FV-106

in line $\mathrm{MS-100-1}$ to $\mathrm{MS}-106-1$

Mark I was UNop model which

was never used in Pilot plent.

Fig. 17.4. Four Freeze Valve Designs whth Approxlmate Regions of Sealing 
b. It was essentiel that a tight shut-off be achieved. Leak rete data for a freeze valve alone were never obtalned in the Volatility Pllot Plant because of system complexity. The evidences of tight shut-off of the three freeze valves bounding the fluoringtor were as follows:

1. The fluorinetor leak-test which wes run prior to feed salt fluorination alnost always indicated a leak rate less than the alnimm arbitrarily set.

2. There was no evidence of $F_{2}$ leakling through FV-104 or FV-108 during a feed salt fluorination nor during descrption of product.

The fluorinator leak-test mentioned in 1tem 1 . abovs actually teeted for leak tightness the Mark III (no FV number), FV-104, -106 , and -108 Ireeze valves as well as $v-88$, HCV -7 or $-8, \mathrm{HCV}+1 \mathrm{l}$, the $\mathrm{FV}-100$ top flenge, and the FV-103 top flange. The leak rate found was the aggregate leak rate through these valves and flanges. Because of the sundry possible leak sources, the arbitrary criterion that the total leak rate should be less than $125 \mathrm{cc} /$ min with a syatem pressure of 4.5 ps 1 s seemed reasonable. From measurements made during runs, the ageregate leak rate was less then $125 \mathrm{cc} /$ nlln, an Indication that the leak rate through any one freeze valve was wuch less than $125 \mathrm{ec} / \mathrm{min}$.

This type of leak-test in wich the leak rate of one item is presumed from the aggregate leak rate of a mumber of items is nonspecific and at best a rough indieation of the leak rate. Consequently, almost sinultaneously with this type of leak-testing another sensitive type of leak-testing was performed during every feed ast fluorination and during many of the product desorption steps. This type of leaktesting utilized the odor of fluorine as the criterion. For example, small quantities of $F_{0}$ leaking through the FV al.08 freeze valve or through the fluorinatis or snow trep flange would have probably been detected by personnel in Cell 1 and/or the Penthouse.

Although objections might be raised to the two types of leak-tedting used for freeze talves In VPP, the resulte Indicated very little, if any, leakage -as a leak rate consistent with the "no leak" found in Unit Operations tests.

After the "B" runs, the Marks II (FV-I06), III, and IV (FV-104) freeze valves were removed from the plant and sent to the burlal ground.

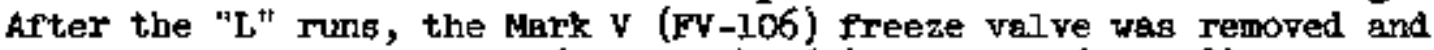
sent to the burtal ground (Bec. $23.4 .16 \mathrm{~b}$ ); Mark II (FV-108) was left in cell I.

Thet 1s, for the runs in which HCV-ll was left open during desorption of product.

beter the two flanges were incorporated into the flange leak-detector system described in Sec, 18. 


\subsection{Equipment Ferformance - Service Valves}

The various service valves such as those used on water and air supplles were satiafactory. Iro tabulation of these valves is needed here because a wealth of expertence already existo.

The pressiure regulators used in the nitrogen supply system are listed in Table 17.8. The regulators given vere satisfactory for the specified pressure range and presented no:known leakage problems. In some cases, however, such a for PV-8 (Mason-Neilan Kodel No. 33-22), the range of 0-20 pai was so large that 1t was difficult to get a pressure of 5 pal as was sometimes deaired.

\subsection{Sugumary and Conclusions}

A list of valves which were suitable for indicated service conditions in the Volatility F1lot Plant is given in Table 17.9. The llst given 1ncludes all Volatility velves except service valves on water and alr lines. The criterion for selection was that several velves of a particular kind had been successfully used in the Ilsted service conditions. Since the over-all perfornance of several valves was assegsed instead of only one, there 16 reasonable asaurance that each valve is auitable eq indicated.

\subsubsection{Conventional Manueily Operated Valves}

Recesses in the bodiea of both SMMD and SSD valvea trapped Nar fines when placed in certain politions in lines carrying NaF-laden gasea. Because of the integral neture of the SMMD and SSD stem eagemblies, replacing elther the disk or bellowa required changing the entire stem easembly.

The ports in Hoke Valve No. 413 and 1193 plugged in UF 6 eervice presumably with the reaction products of $\mathrm{UF}_{6}$ with extraneous aateriels. Valves with larger ports appeared wore promiatng for UF 6 eervice, but similar plugs in the Superior No. 5665 valve indleated that a Iarge port valve will also plug with $\mathrm{UF}_{6}$ reaction products.

valves.

In VP, an insigniflcant quentity of $\mathrm{N}_{2}$ epparently leaked through packed

\section{6 .2 HCV's}

The HCV'B were. successtuly used In opereting the Volatility Pilot Plant with no major difficulty whlch covld be assigned directly to these valves.

The frequency of repair paralleled the lengthe of the different run series; that 1s, valve repair cceurred between Beries of rune. In fact, after a series of runs, usually 6-9 rms, approximately one-half of the $26 \mathrm{HCV} / \mathrm{s}$ leaked through the Beats. Just when these valves started leakin during the run aeries wes not ascertained although evidences of leaking velves were found during a run series. These leaks were never aerlous enough to cause shut -down, even though in some cases leaking valves reduced the versatiltty of the plant. A bonnet leak in fun $\mathrm{E}=2$ was repased without aifficulty. 
Table 17.8

PERTINERT DATA FOR PRESSURE REDUCING VALVES USED TN THE VPP NITROGEN SYSTRM

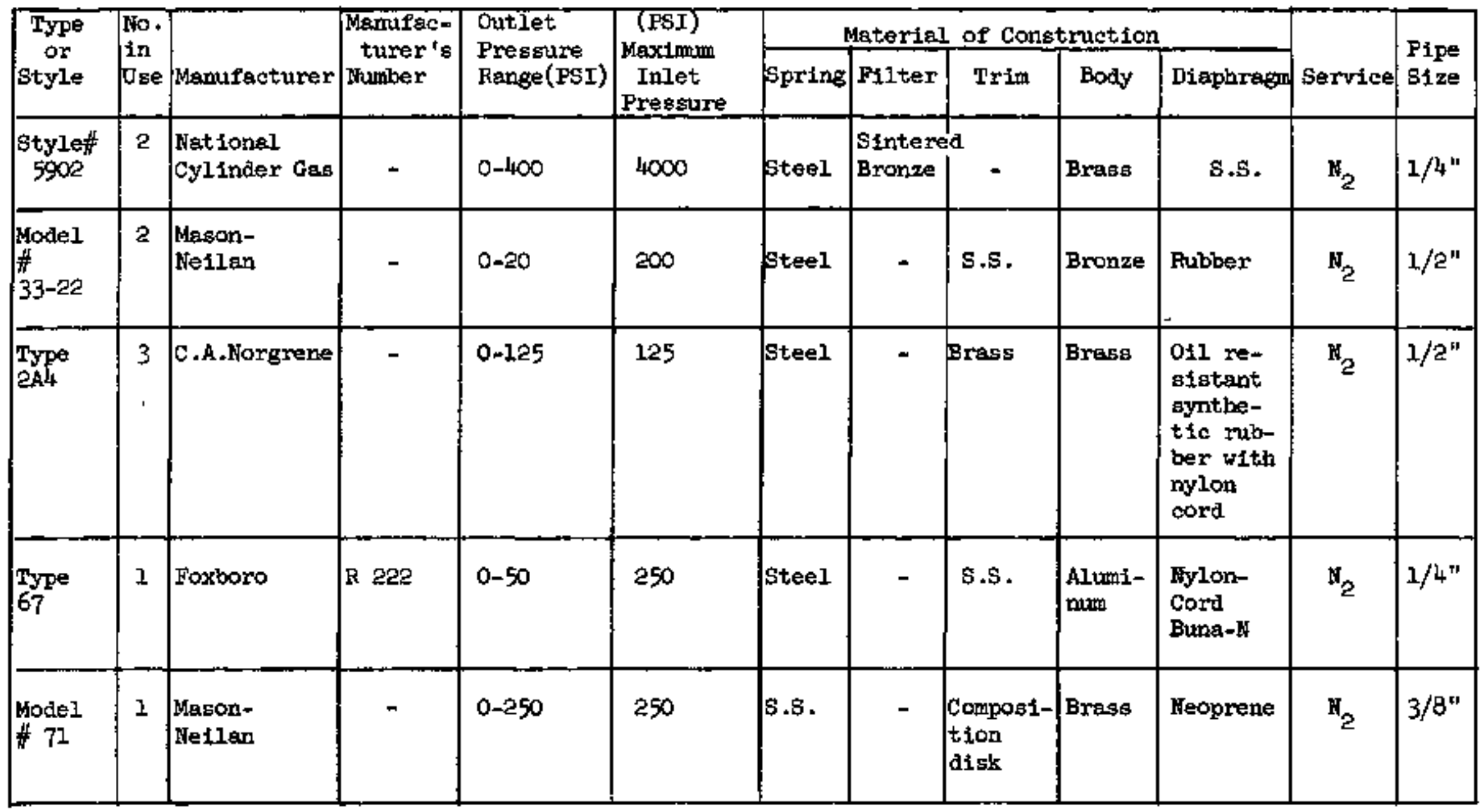


Table 17.9

RECOMENDED VALVES FOR VARIOUS SERICE COADITIORS IM THE VOLAIILITY PILOT FLART

\begin{tabular}{|c|c|c|c|c|}
\hline \multicolumn{3}{|c|}{ Service Conditions } & \multirow[b]{2}{*}{ Fecormended Valves } & \multirow[b]{2}{*}{ Remarks } \\
\hline Chemical Components & $\begin{array}{l}\text { Pressure, } \\
\text { psig }\end{array}$ & $\begin{array}{l}\text { Tenperature, } \\
\text { c }\end{array}$ & & \\
\hline $\begin{array}{l}\mathrm{UF}_{6}, \mathrm{~F}_{2}, \mathrm{~N}_{2} \\
\text { mixtures in all } \\
\text { proportions } \\
\left(\text { except } 100 \% \mathrm{~F}_{2}\right)^{\mathrm{a}}\end{array}$ & $15=-25 x$ & $66-150$ & $\begin{array}{l}\text { Crane and Hoke No. } 411 \text {, } \\
413,1197,1198 ; \text { Jenkins No. } \\
1300 \text {; HCV's with elther } \\
\text { Monel or Kel-F disk } \\
\text { - }\end{array}$ & 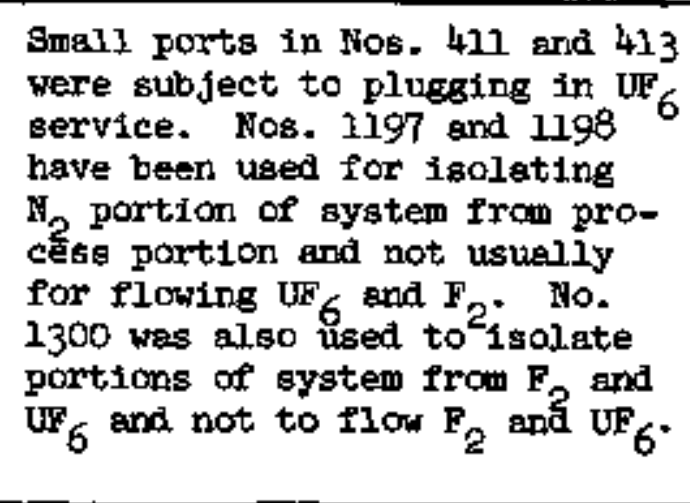 \\
\hline$\left|\begin{array}{lll}F_{2} \text { and } \mathrm{N}_{2} \text { mixtures } \\
\text { if atl } \\
(\text { except } 100 \% & \left.\mathrm{F}_{2}\right)^{\text {proportions }}\end{array}\right|$ & $20-25$ & $0-150$ & $\begin{array}{l}\text { Crene SMMD; HCV'a with } \\
\text { etther Monel or Kel- } 7 \\
\text { disk; FCV-2, PCV-10, } \\
\text { PCV-2A and -2B. }\end{array}$ & \\
\hline$F_{2}$ & $15-30$ & $0-150$ & $\begin{array}{l}\text { Crene soud; HCV with Monel } \\
\text { dIsk }\end{array}$ & \\
\hline$F_{2}$ & $15-30$ & 0.40 & $\begin{array}{l}\text { FCY }-2 ; \text { FCV }-10 ; \quad F X-2 A \text { and } \\
-2 B\end{array}$ & $\begin{array}{l}\text { PCV-2A and }-2 B ; F C V-37 A \text { and } \\
-38 A \text { are not recommended be- } \\
\text { cause of Kel-F disks. }\end{array}$ \\
\hline $\begin{array}{l}\mathrm{UF}_{6} \text { and } \mathrm{N}_{2} \text { in all } \\
\text { proportions }\end{array}$ & 0.65 & $66-150$ & $\begin{array}{l}\text { Superior No. 5665; HCV's } \\
\text { with Monel or Kel-F disk }\end{array}$ & $\begin{array}{l}\text { Small ports in Hoke Ho. } 411 \text {, } \\
413 \text {, and } 1193 \text {, would be sub- } \\
\text { ject to plugging with solid } \mathrm{WF}_{6} \text {. }\end{array}$ \\
\hline
\end{tabular}

Uaing Kel-F or Tefion parta in contact with pure $F_{2}$ ia questionable. 
Table 17.9 (Continued)

\begin{tabular}{|c|c|c|c|c|}
\hline \multicolumn{3}{|c|}{ Service Conditions } & \multirow[b]{2}{*}{ Recommended Valves } & \multirow[b]{2}{*}{ Remarks } \\
\hline Chemical Components & $\begin{array}{c}\text { Fressure, } \\
\text { psia }\end{array}$ & $\begin{array}{l}\text { Temperature, } \\
\mathrm{C}\end{array}$ & & \\
\hline $\begin{array}{l}\text { Equimolar } \mathrm{NaF}-2 \mathrm{rF} \\
\text { with or without } \\
\text { up to } 5 \mathrm{M} \phi \mathrm{UF}_{4}\end{array}$ & $15-25$ & $550-600$ & $\begin{array}{l}\text { Inconel freeze valves Mark I, } \\
\text { II, or III }\end{array}$ & See Sec. 17.4 .11 \\
\hline Freon 1$]$ & $\sim 15-35$ & -55. to +100 & $\begin{array}{l}\text { Henry No. } 2031,6261 ; \\
\text { Kerotest No. R-2402 }\end{array}$ & \\
\hline $\begin{array}{l}\mathrm{Aq} \text {, soln. of } \mathrm{KOH}+ \\
\mathrm{KF} \text { (from } 2 \mathrm{MOH} \text { to } \\
\text { M } \mathrm{KOH} \text { and } \mathrm{M} \mathrm{KF} \text { ) }\end{array}$ & $\sim 15$ & $\sim 20$. to 60 & Saunders No. $2900 \mathrm{~B}$ & $t$ \\
\hline Aq. soln. of $2 \underline{\mathrm{M}} \mathrm{KOH}$ & $\sim 15$ & Room Temp. & Lunkenhelmer Ho. $1709-8$ & \\
\hline 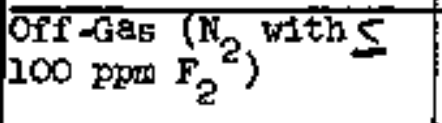 & $\sim 15$ & Room Temp. & $\begin{array}{l}\text { Crane No. } 18840, \text { Ho. } 18851 ; \\
\text { PCV-39, FCV-61 }\end{array}$ & \\
\hline$\pi_{2}$ & $15-50$ & Room Temp. & 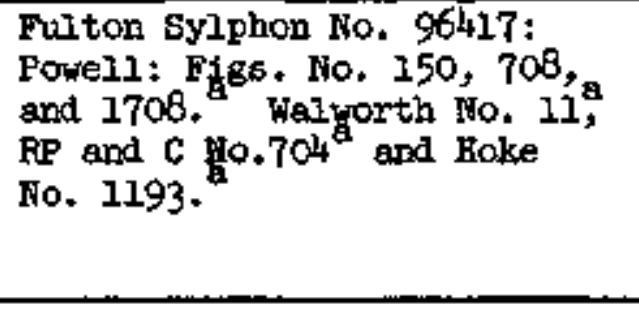 & $\begin{array}{l}\text { A variety of packed velves were } \\
\text { used setisfactorily but probably } \\
\text { leatsed at packing; two types of } \\
\text { rotaneters were used setisfactorily } \\
\text { but tended to leak through joints } \\
\text { and seats; all safety valves tried } \\
\text { leaked slightly. }\end{array}$ \\
\hline 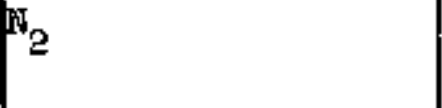 & $15-2000$ & Roon Temp. & $\begin{array}{l}\text { National Cylinder Gas Co., } \\
\text { Wo. } 333 \text { and } 334\end{array}$ & \\
\hline
\end{tabular}

These were the nost frequently used packed valves, especially the Hoke No. 1193. A small leak through the packing was suspected. Since the leak tf existing at all was negigible in our work, these valves were considered setisfactory for F, service in the nouprocess poxtion of the plant. In the process portions, Hoke No, 411, 413, or 1197 with a1aphragms or bellows seals were suttable. 
Water-washing the syatem between series of runs increased the number of leaking valves.

A leaking HCV was defined as one which when closed passed nitrogen through its seat at $>2 \mathrm{cc} / \mathrm{min}$. During leak-teating, the upstream pressure applied to the valve varled from 10 to $50 \mathrm{psig}$ of nitrogen depending on location in the VPF; the downstream was at atmospheric pressure. other deteils are given for leak-testing and repair. No trrepairable valve was encountered.

The lapping procedures and the various disk designs discussed were atisfactory in both periods of malntenance.

Both Monel and Kel-F disks were suitable for a varlety of service conditiong with one exception: The Kel-F disks were not always ured successfully in pure $F_{\mathrm{P}^{\prime}}$

Both unconditioned and preconditionet Kel-F disks tere capable of sustaining the naximian wear Imposed on a disk in a 9-run series.

Kel-F digks which leaked showed signs of healing on cycling the valve, but auch healing was never succesafully demonstrated.

Preconditioning Kel-F disks should have reduced the probubility of fluorye attacking the disk in the system although preconditioning aid not eliminate the possitility of subsequent alsintegration in pure $F_{2}$ even though using the preconditioned disks in all other plant service conditions was safe.

A sixtable procedure for preconditioning Kel-F disks has been given, a treatment which shoula be followed by "truing" the Kel-F surface as discussed. Whether "truing" the Kel-F surfece might render the diak unconditioned by removing the external layer of precondltioned Kel-F is unknown. Although not demongtrated, using the proper minimal combination of surface degreasing and time and temperature of preconditioning might renter the Kel-F surface gafe for use in fluorine without warpage.

\subsubsection{Remotely Operated Control. Valven}

Most of the valves and assoclated control systems were satisfactory as designed and, therefore, would require no change before further proceasing. The particular service conditiona in which opeciflc remotely operated control valves were auitable are given in Teble 17.9 .

The disintegration of fluorineted plastics in PCV-10 and FX -37 corroborated the experience with some Kel-F HCV disks in pure fluorlte service. This is further evidence that netther Teflon nor Kel $-\mathrm{F}$ is autable for pure fluorine although exceptions to this generalization are on record.

Sticklng of the $\mathrm{FX}-37$ or $\mathrm{FX}-38$ spindle in the open-circult position could be remedied by rapping the flow switch sharply with a small tool. 
The sycling of the PCV -10 and FCV -2 combtnation was troublesome and time consuming as was the effect of a trailer awitch-over on this valve combination,

No $\mathrm{KOH}$ colution entered the F-150 off-gas line after modfying the PCV -39 system and altering the piping.

$17,6,4$ Freeze Velveg

In onel freeze valves of the Mark Ii, III, IV, and V types were suitable for transferring molten galti encountered in the Volatility Pilot Plant as indicated in Table 17.9. Since there were differences in the configurations of these types of freeze valves, probably other configurations would work as welt depending prinsipally on whethor the entre valve could be walntained at $2570^{\circ} \mathrm{C}$ and whether sufficient liquid could be retained to form a seal after using the valve. Tests stade in the Unit Operations section on the Mark II valve showed that nc leakage occurred uaing $20 \mathrm{ps} 1 \mathrm{~g}$ gas pressure, and that the valve could withstand 225 freezing and thawing cycies without dimenstonal change. VPP leak-tests with the Mark II, III, IV and $V$ valvea in combination vith other valwes and flanges were apparently consistent with the tolt Operationa work. Size of vents and plugging of vents were also mentioned.

\section{6 .5 Service Valves}

Service valvea on water and air lines vere gatfafactory. In sone cases, the ranges on preasure regulators vas too great.

\subsection{Recomprendations}

It is recommended that:

a. The valves liated in Taule 17.9 be used within the apecified service conditions as needed in future Volatility procesaing.

b. Coreideration to be given to replace the existing HCV's with fianged valves dosfened to avoid as many as possible of the design flews in the existing vsives with mointenenee being done in the shop rather than in the field. f'inges on these valves should probably be incorporated into a flange leakdetestion systern as described. in Sec. 18.)

c. Ar even more elaborate systel of plant leak-teating cornections for testing aCV's be installed for future work than in past rork.

d. Disiss made of Kel- $F$ and Teflon not be used in pare fluorine service,

e. SMD and SSD valves be placed so as not to trap solid particles; steps be taken to replace SMD and SSD disks and bellows without heving to change the ertire stem ascemblies or equivalent ralvee of other makes be found in which this can te done. 
f. Valves with small ports such as Hoke Hos, 411 and 413 not be uged in $\mathrm{UF}_{6}$ service.

g. All Kel-F disks for HCV's be preconditioned and, if necessary, be "trued" by mechining before use.

h. Steps be taken to eliminate the cycling of the PCV-10 and FCV-2 combination and the adverse effects of a traller suitch-over on these valves.

i. In new freeze yalve design, empheat be placed on maintaining the entire valve at $\geq 570^{\circ} \mathrm{c}$ and on retaining sufficient liquid to seal the valve after $1 \mathrm{t}$ is opersted. 
18.0 Flange Leak-Detecting system . . . . . . . . . . . 316

$18: 1$ Introluction ................... 317

18.2 Equipment .............................. 317

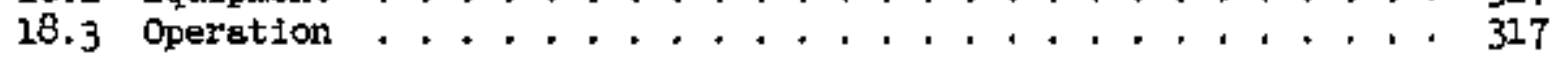

18.3.1 Operat1ng Procedure ............. 317

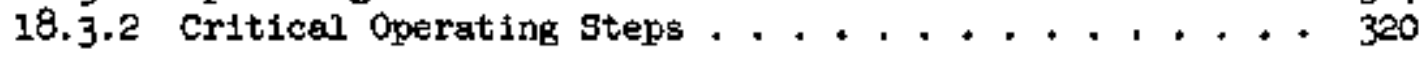

18.4 Equipment Evaluation . . . . . . . . . . . 320

18.4 .1 Flange Leak Rate Data ............ 320

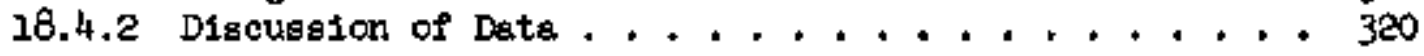

18.5 summary and Conclusions . . . . . . . . . . . . . . 322

18.6 Recommendations . . . . . . . . . . . . . . . . . . 322 28.7 Operating Procedure: Operation of Flange Leak-Detecting

System .................... 322 


\subsection{Introduction}

In the flange leak-detecting systew, the leak rates of ten ring-joint rlenges were determined. In addition, the grooves of leaking fianges could be dynemically pressurized with nitrogen to ensure in-leakage rather than outleakage. The design and operation of this system were pattemed after the one conceived by HFT personnel.

\subsection{Equipipent}

A schematic alagram of the nitrogen header and the list of ring-joint flanges monttored are given in Flg. 18.1. The changes necessary in a pair of flanges and itg ring gesket are shown in Fig. 18.2. As show, only one of the flanges required altering.

After the "L" Runs, the nitrogen header and tubing lines were removed from the plant and taken to the burial ground (Sec. $23.4 .16 \mathrm{~b}$ ).

\subsection{Operation}

\subsubsection{Operating_Procedure}

Steps in operating the flange leak-detecting system were:

a. Insturing the leak-tightness of the flange leak-detecting manifold and the tubing man to each rlange.

b. Determining the $M$ value for each flange which depended on the length of the tubing run.

c. Closing ralve $B$ and opening valve $A$.

d. Adjusting the nitrogen aupply pressure by setting the appropriate pressure reducing valve and observing gage $X$.

e. Cracking ralve $c$ and filling the tubing run for the flange to be tested until the desired preagure vas indicated on gage $Y$."

Fig. 18.1 for locations of valves and gages.

bec. 18.7 .

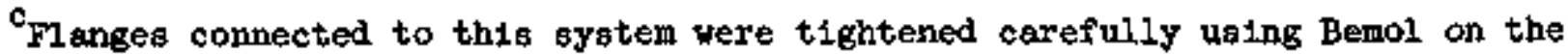
threads and a torque wrench, The finel torque varied with the bolt atze, being $150 \mathrm{ft}-1 \mathrm{~b}$ for the $3 / 4-i n$, absorber bolts and less for smaller bolts. 


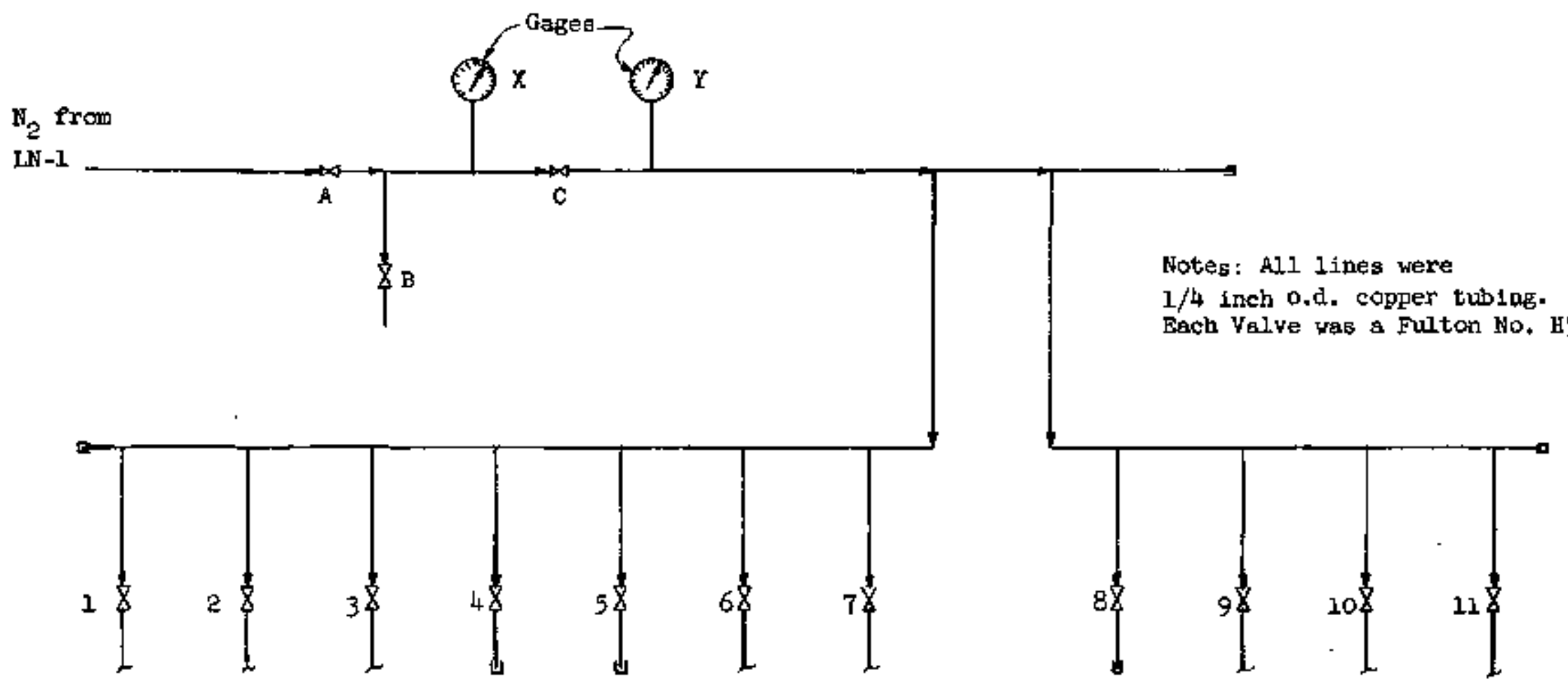

Legend

1. FV-l2l (Inlet, Outlet and Top Flanges). (Secs, 8.4.1a and $8,4,1 \mathrm{~b}$ )

2. FV-120 (Inlet, Outlet and Top Flanges). (Secs. 8.4.1a and 8.4.1b).

3. Leak-Test (Penthouse)

7. FV-103 Top Flange (Sec, 6.4,1)

8. Spare

9. FV-103 Exit Flange (sicc. 6.4.1)

10. FV-100 Hand-Hole Flange (Sec. 5.4.1 b)

11. Fy-100 Top Flange (Sec. 5.4.1b)

4. Spare

5. Spare

6. FV-103 Fill Line Flange (Sec, 6.4.1).

F1g. 18.1. Equipment Arrangenent in the Flange Leak-Detecting Syatem 


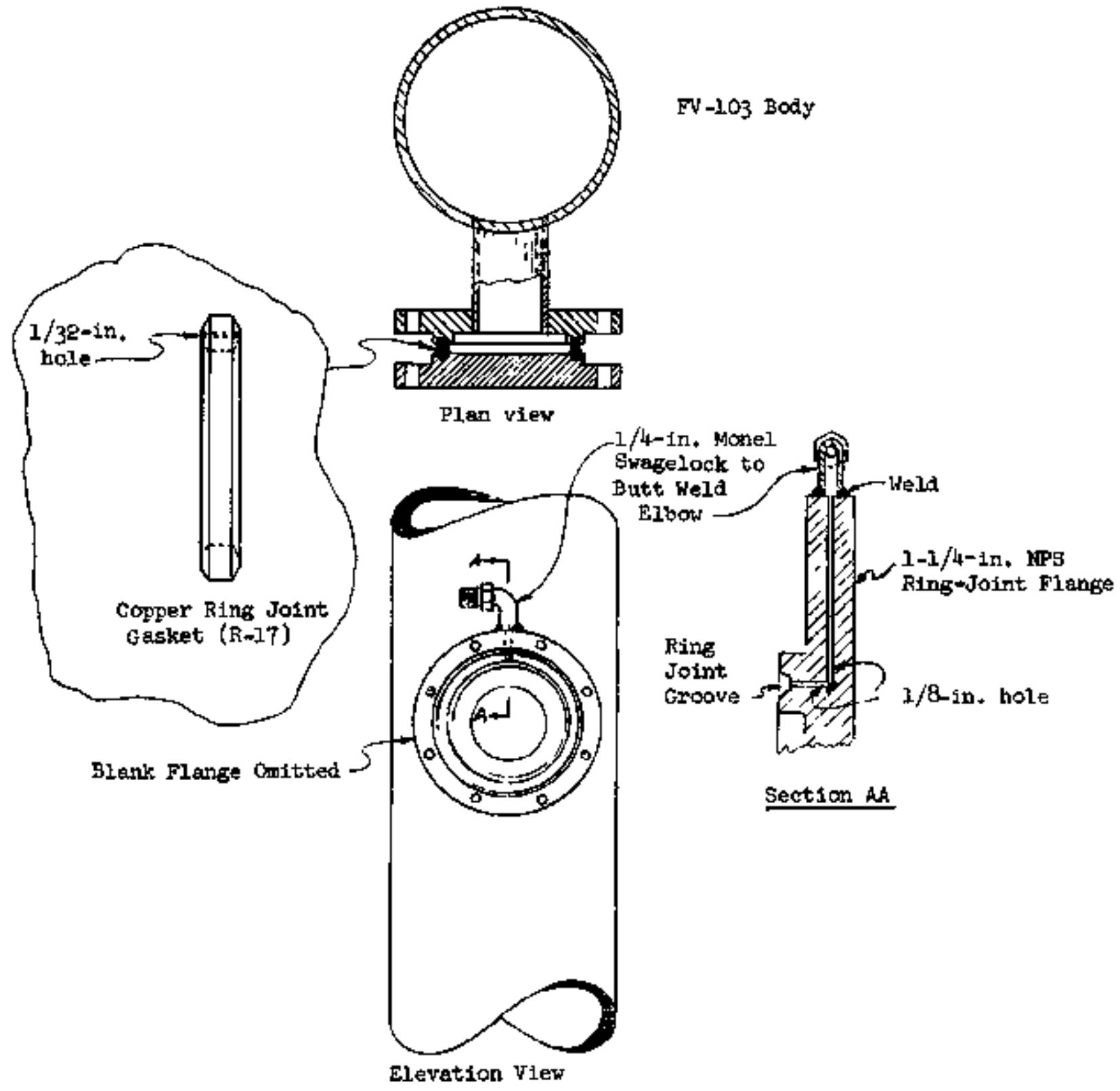

Fig. 1B.2. Detalls for Incorporating the First Flange in Line $H=103-1$ into the Flange Leak-Detecting 5ystem 
f. Closing valves $A$ and $C$.

g. Opening valve $B$ to vent gage $X$ and then closing palve $B$.

h. Recording reedings on gages $X$ and $I$ perlodicaliy.

Operating detalls including $M$ values for the tubing rms and the equation for calcuiatins the leak rate are shom in Sec. 18.7 .

\section{3 .2 Crttical operating Stegs}

a. Being certain that the leak-detecting manifold or tubing runs did not leek.

b. Kaking certein that the ring-joint gasket was in good condition and contained a pressure equilizetion hole; that the flange bolt threads were lubricated with Bemol; and then that the bolts were tightened properly using a torque wrench.

c. Bnsuring that the manifold section contalning gage $X$ was bled to atmospheric pressure and then valve $B$ closed to make it possible to monttor leeks in valves $\mathrm{A}$ and $\mathrm{C}$.

18.4 Equilpmeat Evaluat1om

\subsubsection{Flenge Leak Rate Data}

The dats avallable are shown in Table 18.1. These data are not necessarily listed in chronological order and should not be used to prove that the leak rete changed noticeably with small temperature changea (1.e., $\left.\sim 50^{\circ} \mathrm{C}\right)$. It is true, however, that the leak rates of the absorber top flanges were greater near room termperature than at $400 \%$.

\subsubsection{Discussion of Date}

Flange leak rates ranged from zero on severel flanges to $40 \mathrm{cc} / \mathrm{hr}$ on the FV 121 top Plange. The leak rates of the absorber top flenges were greater near room temperature than at $\sim 400 \mathrm{C}$. All attempts to reduce high leak rates by retorquing the bolts failed. Therefore, for those exhibiting high leak rates, 30 psig of $N_{\text {, wag }}$ dynemically applied to ensure leakage into rather than out of the system. No perzisissible leak rate wes esteblished.

Accounts of joint and over $-a i l$ system leak-testing are recorded in Secs. 19 and 20, respectively. 
Table 18.1

FLANGE LEAK-DETECTING SYSTEM DATA

\begin{tabular}{|c|c|c|c|c|}
\hline $\begin{array}{l}\text { Test } \\
\text { Point }\end{array}$ & Pressure & $\begin{array}{l}\text { Leak Rate } \\
\text { cc } / \mathrm{hr}\end{array}$ & $\begin{array}{l}\text { Duration } \\
\text { of Test }\end{array}$ & $\begin{array}{c}\text { Vesael } \\
\text { Tempgrature } \\
\mathrm{C}\end{array}$ \\
\hline $\begin{array}{l}\text { FV-120 Inlet } \\
\text { (Sees, } 8,4,1 \mathrm{a} \\
\text { and } 8.4 .1 \mathrm{~b} \text { ) }\end{array}$ & $\begin{array}{l}30.2 \\
30.0 \\
30.0 \\
30.0\end{array}$ & $\begin{array}{r}0 \\
.12 \\
<3.4 \\
1.7\end{array}$ & $\begin{array}{l}\text { I } \mathrm{hr} \\
\mathrm{l} \mathrm{hr} \\
1 \mathrm{hr} \\
1 \mathrm{hr}\end{array}$ & $\begin{array}{l}\sim 100 \\
\sim 100 \\
\text { RoO11 } \\
\sim 100\end{array}$ \\
\hline $\begin{array}{l}\text { FVulzo Outlet } \\
\text { (Secs. 8.4.1. } \\
\text { and } 8.4 .1 \mathrm{~b} \text { ) }\end{array}$ & $\begin{array}{l}30.0 \\
30.0 \\
30.0 \\
30.0\end{array}$ & $\begin{array}{r}0 \\
0 \\
<3.4 \\
<3.4\end{array}$ & $\begin{array}{l}1 \mathrm{hr} \\
\mathrm{l} \mathrm{hr} \\
\mathrm{l} \mathrm{hr} \\
\mathrm{l} \mathrm{hr}\end{array}$ & $\begin{array}{r}\sim 100 \\
100 \\
\text { Roon } \\
\sim 100\end{array}$ \\
\hline $\begin{array}{l}\text { FV-120 Top } \\
\text { (Secs. 8.4.1a } \\
\text { and } 8.4 .1 \mathrm{~b} \text { ) }\end{array}$ & $\begin{array}{l}30.0 \\
30.0 \\
30.0 \\
30.0 \\
24.0\end{array}$ & $\begin{array}{l}3 \\
0 \\
10 \\
<4.1 \\
30\end{array}$ & $\begin{array}{l}l \mathrm{hr} \\
\mathrm{l} \mathrm{hx} \\
\mathrm{l} \mathrm{hr} \\
\mathrm{l} \mathrm{hr} \\
\mathrm{l} \mathrm{bx}\end{array}$ & $\begin{array}{r}400 \\
430 \\
\text { Rocm } \\
400 \\
100\end{array}$ \\
\hline $\begin{array}{l}\text { FV-121 Top } \\
\text { (secs } 8,4,1 \mathrm{a} \\
\text { and } 8,4,1 \mathrm{~b})\end{array}$ & $\begin{array}{l}30.2 \\
24.2 \\
30.0 \\
30.0 \\
24.0\end{array}$ & $\begin{array}{c}1 \\
10 \\
4.3 \\
4.3 \\
40\end{array}$ & $\begin{array}{l}1 \mathrm{hr} \\
\text { Not Available } \\
1 \mathrm{hr} \\
1 \mathrm{hr} \\
1 \mathrm{hr}\end{array}$ & $\begin{array}{c}400 \\
\text { Wot Available } \\
\text { Room } \\
400 \\
100\end{array}$ \\
\hline $\begin{array}{l}\text { Fvalel Inlet } \\
\text { (Secs. } 8.4 .1 \mathrm{a} \\
\mathrm{axd} 8.4 .1 \mathrm{~b} \text { ) }\end{array}$ & $\begin{array}{l}30.0 \\
30.0 \\
30.0\end{array}$ & $\begin{array}{l}0 \\
<3.6 \\
1.8\end{array}$ & $\begin{array}{l}l \mathrm{hr} \\
1 \mathrm{hr} \\
1 \mathrm{hr}\end{array}$ & $\begin{array}{r}\sim 100 \\
\text { Room } \\
\sim 100\end{array}$ \\
\hline $\begin{array}{l}\text { Fr-1.21 ond let } \\
\text { (Sec. } 8.4 .1 \mathrm{a} \\
\text { and } 8,4.1 \mathrm{~b})\end{array}$ & $\begin{array}{l}30.2 \\
30.0 \\
30.0 \\
30.0\end{array}$ & $\begin{array}{c}0 \\
.2 \\
<3.6 \\
1.8\end{array}$ & $\begin{array}{l}1 \mathrm{hr} \\
1 \mathrm{hr} \\
1 \mathrm{hr} \\
1 \mathrm{hr}\end{array}$ & $\begin{array}{l}\sim 100 \\
\text { Not Available } \\
\text { Room } \\
\sim 100\end{array}$ \\
\hline $\begin{array}{l}F V-10_{3} \\
(\sec 6,4,1)\end{array}$ & $\begin{array}{l}30.0 \\
25.2 \\
30.0 \\
30.0 \\
25.0\end{array}$ & $\begin{array}{c}0 \\
0 \\
<2.4 \\
<2.4 \\
<2.4\end{array}$ & $\begin{array}{l}1 \mathrm{hr} \\
\text { Pot Available } \\
1 \mathrm{hr} \\
1 \mathrm{hr} \\
1 \mathrm{hr}\end{array}$ & $\begin{array}{c}390 \\
\text { Not Ava1lable } \\
\text { Room } \\
390 \\
1,00\end{array}$ \\
\hline Al1.1 Lnes open & $\begin{array}{l}50.0 \\
30.0\end{array}$ & $\begin{array}{l}2.3 \\
1.08\end{array}$ & $\begin{array}{l}1 \mathrm{hr} \\
1 \mathrm{hr}\end{array}$ & $\begin{array}{l}\text { Room } \\
\text { Operating } \\
\text { Temp., cf. } \\
\text { above }\end{array}$ \\
\hline
\end{tabular}

"Bifect of amblent temperature change wes nil.

HOIR: Date are not avallable on these flanges; (a) FY-103, Bec. 6.4.1; (b) Fv-103 Exit Line, Sec. 6.4.1; (c) Fv-100 Hand-Hole, Sec. 5.4.1b; and (d) FV-100 Top Flange, Sec. 5.4.1b. 


\subsection{Sumary and Conclusions}

No operational difficulty wag met with the flange leak rateg obtalned which ranged from zero to $40 \mathrm{cc} / \mathrm{hr}$. The leak rates of the absorber top flanges were greater near room temperature than at $\sim 400^{\circ} \mathrm{C}$. Retorquing lesking flanges failed to reduce the leak rates. Dynamic $N_{2}$ at $\sim 30$ psig was applied to leaking slanges to engure in-leakege rather then out-legksge. No permissible leak rate was established.

\subsection{Recommendations}

It is reconmended that:

a. A flange leak-detector be used in VPF during future work vith all process flanges being incorporated therein.

b. Permlssible leak retes for flanges be specified.

\subsection{Operating Frocedure: Ogeration of Flange Leak-Detecting System}

NOTE: frage and valve notations may be found on FIg. 18.1.

a. To fill leak-detector system:

1. Close valve B.

2. Open valve A.

3. Observe gage $X$. If $\mathrm{N}_{2}$ supply pressure is equal to, or greater than the desired test pressure, proceed to step 4. Otherwise adjust PV-IA or PV-IB to give the desired pressure.

4. Crack valve $\mathrm{C}$ and fill leak test system until desired pressure is indicated on gage $Y$.

5. Close valves $A$ and $C$.

6. Open valve $B$ to vent gage $x$.

7. Close valye $B$.

b. Tò meke test:

1. Observe gages $X$ and $Y$ at least once each shift. An indication of pressure on gage $X$ shows valve $A$ or valve $C$ leaks. Pressure arop on gage $Y$ may be correlated vith leak rate from the flange system:

$$
\text { leak rate }=\frac{\Delta P}{\text { thit time }} \times M=\text { std cc/unit time }
$$




$$
-323-
$$

where $M$ is a mutiplier characteristic of each leak-test line. The multipliers for ali lines for which the valves are open should be added together in computing the leak rate.

M VALUES FOR FLAMGE TIAKK-DETECTIIG SYSTEM

\section{Manifold}

PV-103

PV -120

$\mathrm{FY}-121$

$$
\begin{aligned}
& M=3 \\
& M=9 \\
& M=13 \\
& M=0.7 \\
& M=0.7 \\
& M=3.6 \\
& M=18 \\
& M=15 \\
& M=0.7 \\
& M=0.7 \\
& M=3.6 \\
& M=20 \\
& M=50
\end{aligned}
$$


CONTYMTS

Page

19.0 Jo1nt Leak nesting . . . . . . . . . . . . . . . . . . . . 34

19.1 Introduction . . . . . . . . . . . . . . . . . 325

19.2 Equipment. . . . . . . . . . . . . . . . . . . . 325

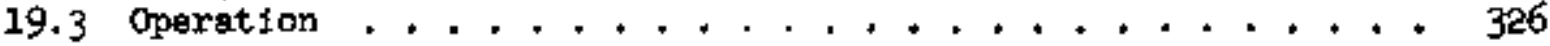

19.3.1 Operating Procedure . . . . . . . . . . . . 326

a. Inftial Leak Tests . . . . . . . . . . . 326

b. Later Leak Tests . . . . . . . . . . . . 326

19.3.2 Critical Operating Steps . . . . . . . . . . . 327

19.4 Equipment Eveluation . . . . . . . . . . . . . . . 327

19.4.1 Preliminary work . . . . . . . . . . . . . . . 327 19.4.2 Joint Leak-Tests - Red Tag System . . . . . . . . 328

19.5 Sumbary and Conclusions . . . . . . . . . . . . 328

29.6 Reconmendations .................. . . 329 


\section{$-325-$ \\ 19.0 JOTNT LEAK-TESTTING}

\subsection{Introduction}

Following the Uf 6 leak in Fun $\mathrm{E}-2$ and before $\mathrm{Run}$ E-3, joints in the VPF were catalogued and confirmed to be leak-free (22).

\subsection{Equipment}

Before joints were catalogued, as many semipermenent joints ag posaible in the process portion of VPP were made into permanent jointa, $b$ A "semipermenent joint" was one which could be broken and remede in a short time such as a flanged or a screwed foint. A "permanent joint" was one which required more than merely screwing or bolting the parts beck together to remake such as welded or silver brazed jointa. Not all joints could fessibly be mede permenent because of the expense involved for some jolnts as well as the fact that normal operations required the frequent making and breaking of other fointa.

In the jolnts catalogue, VPP was divided into aix areag. Each area was assigned a series number such as 1000, 2000, etc. Where possible the first digit of the series number for an area wag the same as the second digit in the equipment numbering system thich indlcated locationa lnside or outalde of Building 3019 (8). In each series, one thousand joints could be assigned numbers in sequence starting with the series number. The aress, series numbers, and numer of joints in each seriea were:

\begin{tabular}{|c|c|c|}
\hline Area & Series Humber & Number of Jointa \\
\hline $\begin{array}{l}\text { Cell } 1 \\
\text { Cell } 2 \\
\text { Main Trangmitter Rack }\end{array}$ & $\begin{array}{l}1000 \\
2000\end{array}$ & $\begin{array}{l}66 \\
73\end{array}$ \\
\hline $\begin{array}{l}\text { (Penthouse) } \\
\text { Nitrofen Tranamitter Rack }\end{array}$ & 3000 & 133 \\
\hline $\begin{array}{l}\text { (Operating Gallery) } \\
\text { Penthouse }\end{array}$ & $\begin{array}{l}4000 \\
5000\end{array}$ & $\begin{array}{l}227 \\
\text { These joints were grouped } \\
\text { with those in the } 3000 \\
\text { serles. }\end{array}$ \\
\hline Fluorine Transmitter Rack & 6000 & 89 \\
\hline
\end{tabular}

A total of 588 semipermanent joints vere catalogued. This included all process and some nomprocess joints.

\footnotetext{
"Leak-fxee" meant that the $1 /$-starch teat wea negative (Sec, 19.3.3.a, Test 2 ).

"The "process" portion of VPP Included equipment and piping in Cells 1 and 2 , in the Penthouse, and at the Fluarine station. The procesa portion ended on the $\mathrm{N}_{2}$ lines at the " $\mathrm{C}$ " valves in the Operating Gallery and at FE-8 in the Penthouse. All othex perts of VPP were termed "nonprocess."
}

Flanges incorporated in the flange leaklitetector system were not included. See F1g. 18.1. 
19.3 Operation

19.3.1 Ogereting Procedure

a. Inttial Ieak Tests

Two tests were made on the catalogued joints by:

1. Test 1: Soap-buble Test

(a) Pressurizing the portion of the system containing the joint to -30 psig with $\mathrm{F}_{2}$.

(b) Applying bubbles from a soap solution with a leak being indiceted if the number of bubbles increased.

HOIS: Joints were tested, repaired, end retested unt1l a "no-leak" test was obtained by this method before proceeding with Test 2 .

2. Teвt 2: KI -Stereh Test

(a) Fressurizing the portion of system containing the joint to 10 to 15 psis with $F_{2}$.

(b) Making KI-ztarch test es deseribed in Sec. 17.4.2,e.2.

Leak-test datn were kept on all of the catalogued joints (Sec. 19.2). Before plant start-up, it was necessary that the final test on each of these joints be negative.

b. Later Leak Tests

After start-up, a red tag system for all openings into the system thas set up. Under this system, when it wes necessary to break a joint, a joint tag was filled out for that joint. The original tag was tied to that foint, and its carbon copy was filed in the shift supervigors' office. Before the original tag could be removed from the joint, it was essential that the joint be remade, and that a negative test by the KI-starch method be obtained. Upon its removal, the tag was inftlaled by the person making the test and clipped to the carbon copy. Then, both were filed. No VPP operating work was to be done while any of these red tags was tied to a joint in the system.

\footnotetext{
At times, pressuredrop data while the system was pressurized with $\mathrm{N}_{2}$ were taken to determine sections of the plant leaking bacily.

bInitially, the halide (Frecn-flame) leak-detection nethod was used. But that method was more time-consuming that the KI-Etarch method developed by G.I. Cathers and $\mathrm{S}$. Mamn.
} 


\subsubsection{Criticel Operating Stepge}

a. Malring certain that the required systen pressure was in the system during the test. (This was done by monttoring with appropriate pressure instrumenta the ayatem preasure during the test, and observing the fell of the system pressure on subsequently bleeding down the system.)

b. Bnsuring that forelgn materials such as dirt or grease did not interfere with the KI atarch teat.

c. Being careful to avoid being burned by $F_{2}$ while doing the KIstarch test by placing the hand over a leak, or by attempting to tighten a leaking joint whth $\mathrm{F}_{2}$ in the system.

d. Keeping the red tag system up-to-date as specified.

19.4 Equipment Evaluation

\subsubsection{Preliminary Hork}

Prior to the leak-tests made before Run $\mathrm{E}-3$ was started, the following were done:

a. Welded joints were tested as made elther by dye-checking or by both dye-checking and $X$ - or gamma-ray testing.

Three classes of velde? joincs were encountered: (1) those in non-critical sections of the plant (These were dye-checked only.), (2) those in eritical sections but so located as to be inpossible to $\mathrm{X}$ - or camma-ray test (These were also dye-checked only), and (3) those in eritical sections whth good accessibility (These were dye-checked and $x$ - ar bampa-ray tested.). Weld test data were recorded, and copies were filed in VPP bissineering File Folder No. 62 ( 58$)$. In most cases, flaws appearing in $\mathrm{X}$ - or gomms-ray tests were eliminated by remaking the welds. But in some cases this was not feastble. Such situations were handled individuelly, and some of these welds were accepted with the flaws. None of the welds accepted with flaws gave trouble, hovever.

b. Some semipernanent Joints were replaced with permanent joints, that is, etther welded or silver brazed joints. Most of these joints vere on $\mathrm{N}_{2}$ lines on the process-side of the' " $\mathrm{c}$ " valves.

c. Silver brazed foints were dye-checked. Bince $X$ - or gamma-raying these jointa was virtually impoasible because of their Inaccessibility, these were dye-checked. Although dye-checking silver brazed jolnts had not been cominon practice, lt was apparently successfully done here, Teat data are contained in VPP Engineering File Folder No. 62 .

aec. 19.2. Stlver brazing spectfleations for various jolnts were made in (2). 


\subsubsection{Joint Legk. Tests - Red Tag System}

The 588 joints were tested first by the soap-bubble method and then by the KI-starch method. Leaking jointa were repaired and reteated until no joint leaked. This work required approximately four days. Pertinent records were filed in VPP Engineering P1le Folder Tho. 68.

The only work done on the sensitivity of the KI-starch test ind cated that a joint leak giving a moderate indication by that method could also be detected with the soep-bubble test using $\mathrm{N}_{2}$ at $100 \mathrm{paig}$ although not at lower $\mathrm{N}_{2}$ pressures.

After the plant was cleared of leaking joints, the over-all aystem test as described in Sec. 20.3 was made.

Although some flanges were leak-tested by the KI -atarch method, most of the ring-joint flanges were tested with the flange leak-detecting systen as bet foxth in Sec. 18.3 .

The red tag system (Sec. 19.3.1b) was satisfectory. Complete reconds were kept in the shift superv1sors' files.

It is significant that after incomporating the varioug leak-tests and the red tag system no serious $U_{F}$ leak as in Run E-2 occurred, and that the frequency of minor $U_{6}$ leaks was reduced aharply.

\subsection{Summary and Conclustomg}

Prior to the leak-tests made before Run E-3, permanent joints (welded and silver brezed) had all been dye-checked and some $\mathrm{X}$ - or gamma-rayed. Resulta of dye-checking and $x$ - or gamma-ray teats were f1led.

A total of 588 semipermanent joints were catalogued. These joints were in both the process and nomprocess portions of the VPF. The cataloguing system was patterned partially after that for vessel numbering.

Leaks in the catalogued joints were checked by both the soap-bubble and KI-starch methods. Leaks so found were repaired until all joints showed no leak by the KI-stareb method. The sensitivity of the KI-starch nothod was of the same order as that obtained with the soapmbuble test using $100 \mathrm{psig} \mathrm{N}_{2}$. A complete record of $K I-s t a r c h$ tests were kept.

After the catalogued joints were leak-free, the red tag system debcrtbed wes set up for controlling subsequent openings into the syretem. Under this system, additional openlngs into the system were closed and shown to be leak-tight by the $\mathrm{KI}$-sterch method before any subsequent processing was done.

Some flanges were leak-tested by the KI-starch method. But, generaIly, leak-detection on ring-jolnt flanges was performed as described in Sec. 18.3. 
After ellminating all jolnt leaks detectable by the KI-starch method, overall aystem test delineated in sec. 20.3 were made.

In stibsequent processing, no large $\mathrm{UF}_{6}$ leak occurred. The frequency of small UF 6 leaks was reduced sharply.

\subsection{Recomendations}

It is recomended that all process joints in the VPP pass the KI - starch test before any future work ia done. 
20.0 System Leak- Detecting . . . . . . . . . . . . . . . . 330

20.1 Introduction ..................... 333

20.2 Equipment . . . . . . . . . . . . . . . . . . . . 331

20.3 Operation........................ 331

20.3.1 Operating Procedure . . . . . . . . . . . . 331

20.3.2 Critical Operating Steps ............. 331

20.4 Equipwent Eraluation ...................... 333

20.5 Summery and Conclusions . . . . . . . . . . . . . . 333

20.6 Recommendations . . . . . . . . . . . . . . . . 333 


\subsection{Introduction}

Before Run E-3, leak rate data on the system were made to determine whether the system was sufficiently leak-free for start-up.

\subsection{Eguiponent.}

The portion of the VPF systen leak-tested wes that shown in Fig. 20.1. This portion was isolsted from connecting lines by indicated velves (HCV' $\mathrm{a}$, FCV's, manual valves, and freeze vaives).

The leak rate was determined from the change in the PR-26 or -33 reading using 240 liters es the estimated volume of the syatem.

\subsection{Operation}

20.3.1 Operating Procedure

Ma.jor operating steps were:

a. Isolating the system ${ }^{a}$ as shown In Fig. 20.1 with all bounding valves shut off except those on the $\mathrm{H}_{2}$ feed line.

b. Putting PE-26 or PE-33 in service.

c. Pressurizing the system to 30 psig with $\mathrm{H}$, and then closing the bounding valves (FCV-l and $V-93$ ) on the $\mathrm{N}_{2}$ feed line.

d. Noting the change in PR-26 or in FR-33 and in ambient temperature with time.

20.3.2 Criticaz Operating Steps

a. Ensuring the leak-tightness of bounding valves and system jolats.

b. Mon1toring the amblent temperature so that its effect could be assessed.

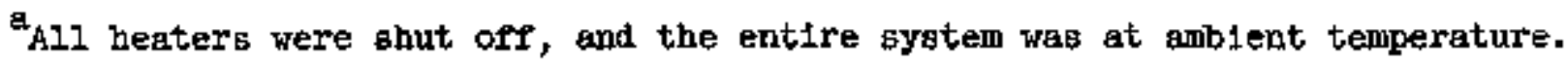

bcf. Sec. 17.4.2, e.1 for methods of leak-teating valves and sec. 19.3 for the methods of leak-testing joints. 


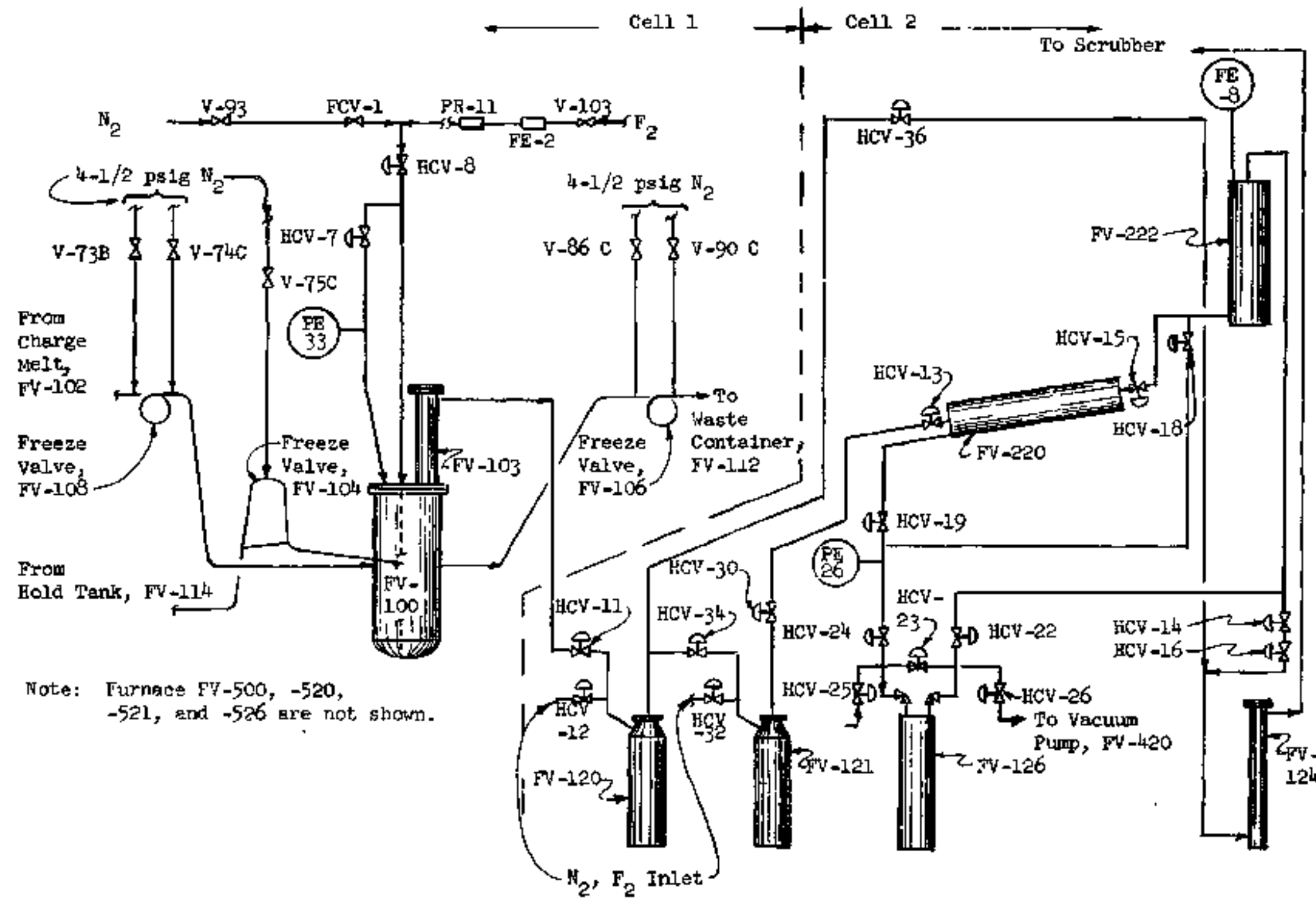

Fig. 20.1. Portion of VPP Equipment Used in System Leak Detecting 
20.4 Equipment Evaluation

Prior to over-all syatem leak-tests, joint leak-tests were made ab delineated in Sec. 19. These joints included some of the flangea. Ten ring-joint flanges were leak-tested as described in Sec. 18.

The test made from February 22-24, 1958, Indicated a leak rate of $8.4 \mathrm{cc} / \mathrm{min}$. The portion of the syetem tested is shown in Fig. 20.1 with these bounding velves: Freeze valves $\mathrm{FV}-104,-106$, end -108 ; " $\mathrm{C}$ " valves $\mathrm{V}-7 \mathrm{l} \mathrm{C}, \mathrm{V}-75 \mathrm{C}$, and $\mathrm{V}-86 \mathrm{C}$; $\mathrm{HCV}$ " s $-12,-14,-16,-25,-26,-35$, and -36 ; memual valves $V-93$ and $V-1.03$; and FCV -1 , The pressure-drop was determined with PE-26. On February 22 at midnight, the PE26 reeding was 20 psig. At midnight on February 24, the PR-26 reading was 18.5 psig. The uncerteinty in reading PR-26 was $\pm 0.1 \mathrm{psi}$.

This leak rate of $8.4 \mathrm{cc} / \mathrm{min}$ was believed to be pessimistic because it included the seat-leakage of all the valves blocking off the system. The temperature change during the test was insignificant. Becsuse of the meny bounding valves in the system, this value should not be compered with the standard ( $\sim 0.1 \%$ of the conta1ned volume per day) for reactor-contalnment vessels (29).

The effect that a temperature change can have in short-time testB, however, is a serious limitation to using this method. Consequently, long-time teste (i.e., 48 hours duration or longer) are preferred. But economic considerations associsted with an idle plant become important in long-time tests.

Al though there was no suitable standerd with which to compare the regult obtained, the work done 18 important because:

a. The result is a check against the joint leak-testi ,possibly showing that no large leak was overlooked.

b. It pointed up just how difficult such tests are.

20.5 Burmary and Conclusions

The leak rate of $8,4 \mathrm{cc} / \mathrm{min}$ obtained on the equipment in Celds 1 end 2 was conaldered pesatmiatic and should not be compared with the standard for reactor-containment vessels. The mechanics of the test and scme of the 11mitations are discussed.

Flange and Jotnts leak-tests were made as described in Secs. 18 and 19 respectively.

20.6 Recommendations

It is recomended that system leak-tests be made, and that the rates obteined be compared with an established permissible leak rate before every proceasing seriea in the futire. 
21.0 Autoresistance Heat1ng $\ldots \ldots . \ldots . \ldots . \ldots 34$

21.1 Introduction ................... 335

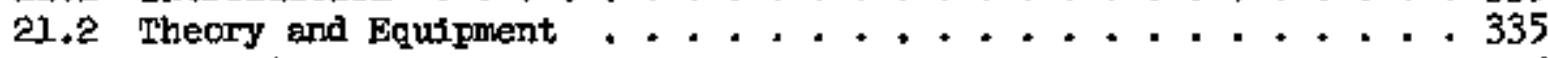

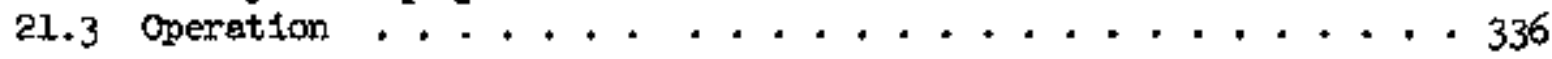

21.3.1 Balancing Procedure . . . . . . . . . . . 336

21.3 .2 Henting Procedure . . . . . . . . . 336

21.4 Equipment Evaluation ... . . . . . . . . . . 339

21.4 .1 NS-102-1 to MS-108-1 . . . . . . . . . . 339

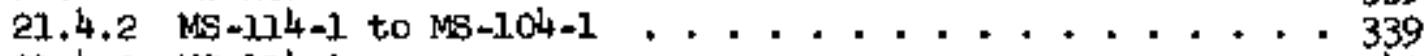

21.4 .3 MS $-114+1 \ldots . . . . . . .340$

21.4 .4 MS-100-1 to MS-106-1 (Marit II FV-106) . . . . . 340

21.4 .5 MS-100-1 to MS-106-1. (Nark v FV-106) . . . . . 341

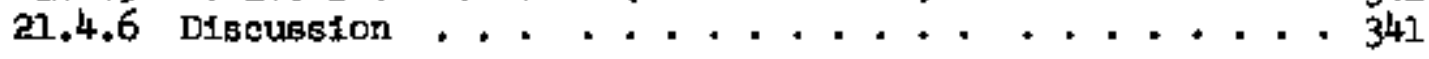

21.5 Sunmary and conclustons ............. $344_{4}^{4}$

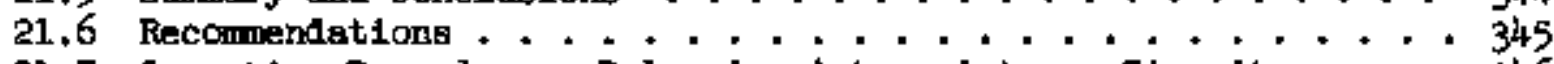

21.7 Operating Procedure: Balancing Autoresistance c1rcuits ... 346 


\subsection{Introduction}

Five molten salt transfer lines in VPP have been heated by autoresistance.

\subsection{Theory and Equipment}

In autoresistance heating, the item to be heated is the current carrier end, therefore, the resistance in the electrifeal circult. Heat is generated in the resistance by the relationship, heat $=1{ }^{2}$ rt where:

$$
\begin{aligned}
& i=\text { electrical current } \\
& \mathbf{r}=\text { electrical resistance } \\
& t=\text { time }
\end{aligned}
$$

The heat produced elther heats the resistance or escapes by rediation, conduction, or convection. Therefore, the frection of beat available for heating the resistance can be increased by thermally insulating the resistance. Since the resistance of a conductor depends upon its cross-sectional area, the temerature attained by the thaterial can be changed by altering the cross-sectionil area. Congequently, different materials in a given circust can be heated to a umiform temperature by suitably aljusting the cross-sectional areas. This $\mathrm{P}$ act wes successfully used In the design of MS-114-1 to MS-104-1 because the molten salt line wes made of Inconel and the vent line at the top of FV-iol was of nickel (Secs. 16.4.14 and 21.4.6).

In the VP, all autoresistance heating was of pipelines insulated with 2-in. Superex to reduce hest losses. The jolnts between pieces of Superex were sealed with asbestos cement. Usually the entire outer surface of the insulam tion was covered with Thermatex "B" to minimize the slaughing off of powdery material. Sometimes, then, a layer of aluminum foil was put over the Thermatex "B" to further reduce heat losses (sec, $21,4,6$ ).

\begin{tabular}{|c|c|c|c|}
\hline & $0^{\circ} \mathrm{C}$ & $20^{\circ} \mathrm{C}(61)$ & $600^{\circ} \mathrm{C}(61)$ \\
\hline $\begin{array}{l}\text { "L" Nickel } \\
\text { Inconel. } \\
\text { INOR-B }\end{array}$ & $8.3(60)$ & $\begin{array}{l}120^{\mathrm{a}} \\
120^{\mathrm{a}}\end{array}$ & $\begin{array}{r}39^{\mathrm{a}} \\
120^{\mathrm{a}} \\
120^{\mathrm{a}}\end{array}$ \\
\hline
\end{tabular}

Spectfic resistances in microhm per em of the three pertinent materials of construction at temperatures of interest are:

Memorandum from A. P. Litman to \#. W. Miles, "Electrical Resistivity of Nickel, Ineonel and INOR-8", 10-23-59. 
A wiring dlagram of a typical electrical circuit is presented in Fig. 21.1 . Power at $480 \mathrm{vac}$ is supplied through a 20 contactor to a $460 \mathrm{v}$ Varlac with a 10-ang capacity. The output of the Varlac, which was mounted on the panelboard, was fed into two step down tranaformers located in the P1pe Tunnel just outalde Cell 1. These transformers having a turns ratio of $400 / 6$ were each capable of carrying 450 emp in the seconfary winding. The low-voltage, bigh-current output of the step-down trangformers wes directiy impressed upon a length of process piping. The "hot" sides of the transformers were connected by two $500 \mathrm{MCM}$ cables to the center leg on the heated line (point $x$ in Fig. 2l.1). "The "ground" sides of the transformers were connected to pointa $J$ and $I$ by one $500 \mathrm{KCM}$ cable each, comected as neer as possibje to the ends of the pipe. The secondary winding of the step dow trensformers was grounded at the transformers in the design. However, in Instajlation it was found more conventent to connect together the pointa $J$ and $\mathrm{L}$ (shown by dotted line in Fis. 2l.1) and elso connect ground there.

The efve molten selt lines sketched In Figs. 3.1 (MB-102-1 to Ms-108-1), 16.1 (MS-114-1 to MS-104-1), 13.1 (MS-100-1 to Ms-106-1 with Mark II FV-106) and 13.2 (MS-100-1 to MS-106-1 with Mark IV FV-106) heve been used. Pertinent data are presented in Table 21.1 .

\subsection{Operation}

\subsubsection{Balancing Frocedure}

The balancing procedure for each of the three autoreslatance circuits given in Sec. 2l.7. Is typicel and, therefore, yald for all wuch eutoresistance lines. The critical operating step was welding the hot electrode at the center of the line to obtain an even current split. Fine edjustments could be made in the adjustable electrodes. There wes, however, no coerse adjustment short of cutting off the not electrode and rewelding it on the line. Baking coarse adjustments wes avolded because of the expertence with removing a heat-bleed lug described in sec. 21.4.1. Lug destors are show on drawings Hos. D-26999 and D-27536.

\subsubsection{Heating Procedure}

Curing the insulation prior to use was done as for restatenceheated lines described in Sec. $22.3 \mathrm{~b}$.

The procedures for beating autoresistance lines are incorporated In the procedures for the systems involved. Generally, optimus practice dictated gradually rather than abruptly increasing the current (B.I-IB-it readins for MS-102-1 to $\mathrm{kS}-108-1$, $\mathrm{MS}-1 \mathrm{l} 4-1$ to $M$ S-104-1, and $M S-100-1$ to is-106-1 and E- $1 \mathrm{~B}-8$ reading for $\mathrm{N}-1,14-1)$. Any insulation eracks required

It was essential to heve a nearly equal current split at the center leg so that the two halves of the process plpe would be heated to nearly the seme temperature. The roltage drop in each half was 7 to 8 volts.

And also Ms-124-1. 
$480 v$

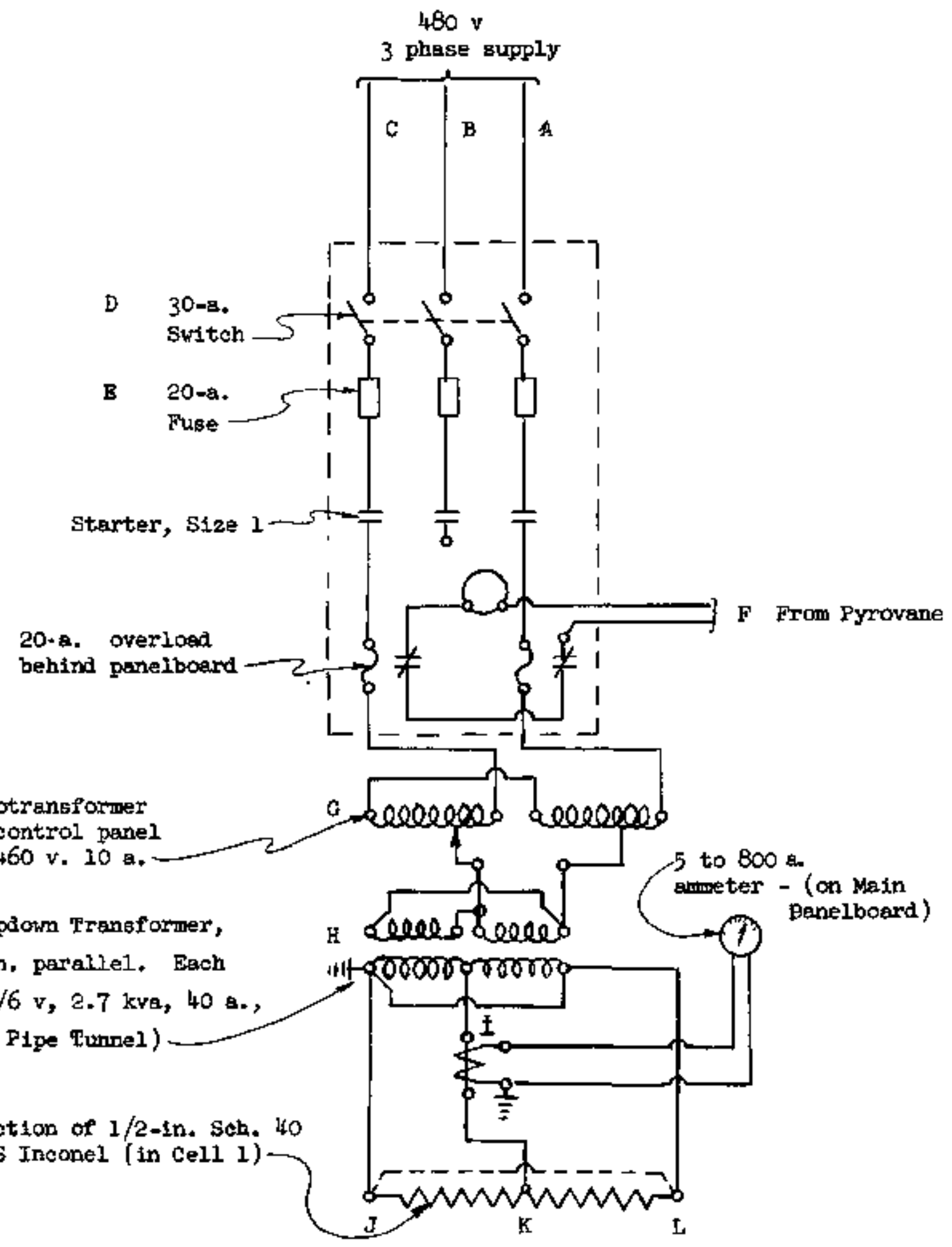

Fig. 21.1. Autoresistance Heating Circuit 
Table 21.1

DATA FOR AUTORESISTANCE-HEATED MOLTEN SALT LTIES

\begin{tabular}{|c|c|c|c|c|c|c|c|c|c|c|}
\hline $\begin{array}{l}\text { Wolten } \\
\text { Salt } \\
\text { Ine }\end{array}$ & References & $\begin{array}{l}\text { Freeze } \\
\text { Valve }\end{array}$ & $\begin{array}{l}\text { Length } \\
\text { (ft) }\end{array}$ & $\begin{array}{l}\text { Normal } \\
\text { Voltage } \\
\text { (Volts) }\end{array}$ & $\begin{array}{c}\text { Oogexating } \\
\text { Current } \\
\text { (Amps) }\end{array}$ & $\begin{array}{c}\text { Data } \\
\text { Power } \\
\text { (Whtts) }\end{array}$ & \multicolumn{4}{|c|}{$\begin{array}{l}\text { Operating Temperature Extremes } \\
\text { (Average Extrene Temperatures } \\
\text { during Salt Transfer) }\end{array}$} \\
\hline $\begin{array}{l}\text { us-102-1 to } \\
\text { Ms-108-1 }\end{array}$ & $\begin{array}{l}\text { Secs. } 21.4 .1 ; \\
17.4 .4 ; 3.4 .1\end{array}$ & $\begin{array}{l}\text { Mhk.II } \\
\text { (FV-108) }\end{array}$ & $14 \mathrm{ml} / 2$ & H.A. & 435 & $=-\infty$ & $\begin{array}{l}\frac{\text { Molten Salt }}{\text { Maximim }} \\
690 \\
\text { (Note: Dats }\end{array}$ & $\begin{array}{l}\frac{t \text { Line }}{\text { Minimm }} \\
\text { S70 } \\
\text { a are for }\end{array}$ & \begin{tabular}{|}
$\frac{\text { Freeze }}{\text { Maximum }}$ \\
630 \\
Rums I-1
\end{tabular} & $\begin{array}{l}\text { ve Valve } \\
\frac{530}{1 \text { inimum }} \\
\text { and }[-7)\end{array}$ \\
\hline $\begin{array}{l}\text { Ws-114-1 to } \\
\text { Ns-104-1 } \\
\text { (Over loop) }\end{array}$ & $\begin{array}{l}\text { Sees. } 21.4 .2 ; \\
17.4 .4 ; \text { and } \\
16.4 .1 .4\end{array}$ & $\begin{array}{l}\text { Mk.III } \\
\text { (no FV } \\
\text { Dimber) }\end{array}$ & 8 & N.A. & 435 & $=--$ & $\begin{array}{c}600 \\
\text { (Note: Date }\end{array}$ & $\begin{array}{l}550 \\
\text { a are for }\end{array}$ & $\begin{array}{c}780 \\
\text { Runs E-1 }\end{array}$ & $\begin{array}{c}680 \\
\text { and } E-5)\end{array}$ \\
\hline $\begin{array}{l}\mathrm{Ms}-114-1 \text { to } \\
\mathrm{MS}-10^{4}-1 \\
\text { (Cross-over) }\end{array}$ & $\begin{array}{l}\text { Seca. } 21.4 .2 \\
17.4,4 ; \\
16,4.14\end{array}$ & $\begin{array}{l}\text { Mk.III } \\
\text { (no FV No.) } \\
\text { Mk. IV } \\
\left(\mathrm{FV}-1 \mathrm{OH}_{4}\right)\end{array}$ & 5 & N.A. & 435 & -0.0 & $\begin{array}{c}640 \\
\text { SNote: Data }\end{array}$ & $\begin{array}{l}620 \\
\text { e are for }\end{array}$ & $\begin{array}{c}570 \\
\text { Rung } 8-7 \\
\end{array}$ & $\begin{array}{c}550 \\
-2, \stackrel{3}{\&}-3)\end{array}$ \\
\hline MS -114-1 & $\begin{array}{l}\text { Secs. } 21.4 .3: \\
17.4 .4 ; \\
16.4 .14\end{array}$ & $\begin{array}{l}\text { Mk. III } \\
\text { (Mo FV } \\
\text { number })\end{array}$ & $16-1 / 2$ & $N_{*} A_{t}$ & 435 & $-\infty$ & $\begin{array}{c}590 \\
\text { (Note: Data }\end{array}$ & $\begin{array}{l}560 \\
\text { are for }\end{array}$ & Ruan E-1, & $-2,8-3)$ \\
\hline $\begin{array}{l}\text { is }-100-1 \text { to } \\
\text { MS-106-1 }\end{array}$ & $\begin{array}{l}\text { Secs. } 21.4 .4 ; \\
17.4 .4 ; \\
13.4 .2\end{array}$ & $\begin{array}{l}\text { Mk.II } \\
(\text { Fv-106) }\end{array}$ & 28 & $7-8$ & 435 & $-3300^{\circ}$ & $\begin{array}{c}770 \\
\text { (Note: Data }\end{array}$ & $\begin{array}{l}660 \\
\text { are for }\end{array}$ & \begin{tabular}{|c|}
610 \\
Ruma E-1.
\end{tabular} & $\begin{array}{r}580 \\
\text { and }-5) \\
\end{array}$ \\
\hline $\begin{array}{l}\text { WS-100-1 to } \\
\text { MS-106-1 }\end{array}$ & $\begin{array}{l}\text { Secs. 21.1.5; } \\
17.4 .4 ; \\
13.4 .2\end{array}$ & $(\mathrm{k}, \mathrm{v}-106)$ & $28-1 / 2$ & $7-1 / 2$ & 340 & 2600 & $\begin{array}{c}620 \\
\text { (Note: Deta }\end{array}$ & $\begin{array}{l}550 \\
\text { are for } 1\end{array}$ & $\begin{array}{c}620 \\
\text { Runs L-1 }\end{array}$ & and $\begin{array}{l}540 \\
-71\end{array}$ \\
\hline
\end{tabular}

"The current was approximately divided into two equal parts at the "hot" electrode.

$\mathrm{b}_{\mathrm{N} . \mathrm{A} .}=$ Iot Available.

Based on $7-1 / 2$ volta, 
patching, and current legks needed to be minimized. The goal was to heat the entire line to $\geq 570^{\circ} \mathrm{C}$, a temperature setisfactory for transferring fused salt compositions 30,31 , and 108 (11), Normal operating currents are given in Table 21.1 .

\subsection{Equipment Evalustion}

\section{$2.1,4,1$ MS-102-1 to MS-108-1}

Th1s molten salt 1ine Included the Mark II freeze valve FV-108 (Bec. 17.4.4) and is show in PIg. 3.1; operational data are given in Table 2l.1. Ita operation was satisfactory although sore difficulties occurred. Temperature extrenes were: (a) molten galt line maximun, $690^{\circ} \mathrm{C}$ and minimum, $570^{\circ} \mathrm{C}$ and (b) freeze valve - meximum, $630^{\circ} \mathrm{C}$ and winimu, $530^{\circ} \mathrm{C}$. Th1s $530^{\circ} \mathrm{C}$ value was lower than the $570^{\circ} \mathrm{C}$ deslred. It is not known whether transfers could be made at true line temperatures of $\sim 530$ to $540^{\circ} \mathrm{C}$ or whether the indicated temperatures were lower than the true ine temperatures. Ine temperatures were determined with thermocouples placed. as described in sec. 21.4.6.

Slow transfers resulted in part from the gravity-type transfer uged but mainly from cold spots at the vent ines joints and Insulstion breaks as mentioned in sec. 3.4.1. $\mathrm{a}$ One of the plugs (Sec. 3.4.1) wes caused by Zircom ore falling into the molten salt line. The removel of the heatbleed lug from the Mark I freeze valve elfmineted a cold spot at that point. While cutting off this lug with frozen selt in the freeze valve, a hole formed in the pipe wall. This necessitated replacing the entire freeze valve and indicated the difficulty of perforwing work at cutting or welding temperatures on lines contgining selt. Flacing the ground lug at the vessels for both $F V-100$ and FV-102 avolded troubles as delineated in Secs. 5.4.1a and 3.4.1, respectively. See Sec. 21.4 .5 for placement of other electrodes. This molten selt line was left in place after the " $\mathrm{L}^{\text {" }}$ runs.

\section{4 .2 MS-114-1 to $M B-104-1$}

This molten salt line Included the Mark III (no FV number) and Mark IV (FV-104) freeze valves (Sec. 17.4.4) and 1s shown in Fig. 16.1. operational data are given in Table 2l.1. Two flow paths were possible: (a) over the freeze valve and (b) through the cross-over. The operation of both was ant 1 ffactory and much less troublesome than for MS-102-1 to MS-108-1 or NS-100-1 to MS-106-1. Note that the ground electrode at the FV-100 extremity was welded to the vessel flenge (Fig. 16.1 and Sec. 16.4.14), and that the "hot" electrode for FV-lolt was placed on the nitrogen line (Fig. 16.1 and Secs. 16.4.14 and 16.4.15). See Sec. 21.4 .6 for placement

a "cold spot" was a polnt below a temperature of $570^{\circ} \mathrm{C}$ (Sec. 21.3 .2 ). 
of other electrodes. Temperature extremes for the path over the loop were: (a) molten aatt line - maximu, $600^{\circ} \mathrm{c}$ and minsmu, $550^{\circ} \mathrm{c}$ and (b) freeze valve - maximm, $780^{\circ} \mathrm{C}$ and minimum, $680^{\circ} \mathrm{C}$. Temperature extremes for the path through the crosg-gver were: (a) molten sajt line - maximum, $600^{\circ} \mathrm{C}_{\mathrm{o}}$ and inlofmum, $530^{\circ} \mathrm{c}$ and freeze valve - maximum, $740^{\circ} \mathrm{C}$ and minimum $650^{\circ} \mathrm{C}$. Line temperatures were determined with therwocouples placed as described in Sec. 21.4.6.

The cold spot trouble at the vent line joint was absent. The cold spots at the insulation crecks were fewer than for MS-102-1 to MS-108-1, WS-100-1 to MS-106-1 (Mark II FV-106), or WS-100-1 to MS-106-1 (Merk V FV-106). It vas necessary to inarease the current to 500 amperes to flow salt through the cross-over in Run E-6 (sec. 16.4.14).

This molten salt line was removed from the plant after the " $E$ " runs and taken to the burlal ground (Secs. 16.4 and $23.4 .16 \mathrm{~b}$ ).

\section{$21.4 .3 \quad \mathrm{HS}-114-1$}

This molter alt line included the Mark III freeze valve (no FV number) (Sec. $17,4,4$ ) and is shown in F18. 16.1. Operational date are given in mable 21.1 . Tempereture extremes were: maximum, $590^{\circ} \mathrm{c}$ and alnImum, $560^{\circ} \mathrm{C}$. Fote that the ground electrode at the FV-114 extremity was velded to the rent ine (F1g. 16.1 and Sec. 16.4.14). Bee Sec, 21.4.6 for placement of other electrodes. Line temperatures vere measured with thermocouples placed as described in Sec. 2l.4.6. The low potnt in the line retained liquid and served as the freazs talve in this molten salt line. Operational troubles whth this line were nearly nonexigtent.

This molten salt line was removed from the plant after the "E" runs and taken to the burisl ground (Secs. 16.4 and $23.4 .16 \mathrm{~b}$ ).

\section{4 .4 MS-100-1 to $\mathrm{MS}-106-1$}

This molten salt line included the Mark II freeze valve FV-106 (Sec, $17,4,4$ ) and is shown in F1g. 13.1. Operational data are given in Table 21.1. Its operation was satiffactory. Temperature extremes were: (a) molten salt line - maximum, $770^{\circ} \mathrm{C}$ and minimu, $660^{\circ} \mathrm{C}$ and (b) freeze valve - maximum, $610^{\circ} \mathrm{C}$ and minimum, $560^{\circ} \mathrm{C}$. Line temperatures were megsured with thermocouples placed as described in sec. 2l.4.6. Although its configuration was sinllar to that of MS-102-1 to is-108-1, transfers were made under pressure or by alphoning instead of by gravity. These transfer techniques resulted in rapid trensfers at times and in one case an uncontrolled transfer (Sec. 13.4.2). In addition to this difficulty, the line wes subject to cold spots inside the fluorinator, at the vent lines joints, at breaks in the 1nsulation, and at the waste nozzle. As for Ms102-1 to MS-108-1, the heat-bleed lug vas removed, and the ground electrode

acoment on temperatures in sec. 21.4.1. 
at FV-100 was put on the vesgel (sec, 13.4.2). See Sec. 21.4.6 for the placement of other electrodes. Insulation vas neceagary for this line since when uninsulated it heated to only $\sim 300^{\circ} \mathrm{C}$ (Sec. 21,4.5). Auxillary heaters (FV-50OA of Sec. 13.4 .2 and FV-512 of Sec. 13.4.5) were necessery for satisfactory line temperaturea.

In two Instences, Incomplete heating of this line resulted from accldentally grounding a vent line:

a. A vent line flange was Ioproperly Ingulated.

b. A ladder had been placed so as to ground a vent line to other piping. The Mark I waste line was removed from the plant after the "E" rung and taken to the burtel ground (Sec. 13.4.2 and 23.4.16b).

\section{4 .5 MS-100-1 to Ms-106-1}

This molten selt line Included the Maxk $\mathrm{V}$ freeze valve fV-106 (Sec. 17.4.4) and is shown in Flg. 13.2, Operational data are given in Table 2l.1. Temperature extremes were: (a) molten salt line-maximum, $600 \%$ ard minimum, $550^{\circ} \mathrm{C}$ and (b) freeze valye - maximum, $620^{\circ} \mathrm{c}$ and minimum, $540^{\circ} \mathrm{c}$. Line temperatures were determined with tbermocouples pleced as described in Sec. 21.4.6. Although 1ts operation was superior to the $1 / \mathrm{e}-1 \mathrm{n}$. NPS line previously used (Sec, 13.4.2), cold spots retalned were: (a) inside the fluorinator, (b) at breaks in the insulation, (c) at the vent lines joints,

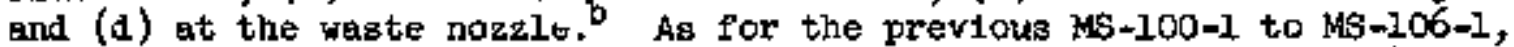
the FV-100 ground lus was placed on the vessel flange (sec, 13.4.2). See Sec. 21.4 .6 for the placenent of other electrodes. Insulation was essential for this line since, when uninsulated, it alao attained only $\sim 300^{\circ} \mathrm{C}$ (Sec. 2i.4.4.). As anticipated, the power requirement of $\sim 2600$ watts for this 3/8-1n. WPS line was less than that ( $\sim 3300$ watts) for the $1 / 2-1 n$. NPS line. This lower power requirement coupled with good operating character1stics resulting from an an advanced design made thig line superfor to the 1/2-in. HPS line discussed in sec. $21,4,4$.

The Mark II waste i1 ne was removed from the plant after the "I" runs and taken to the burial grownd (Sec. 13.4 .2 and $23.4 .16 \mathrm{~b}$ ).

\section{4 .6 D1scussion}

Designs of suitable autoresiatance electrodes for $3 / 8-1$, and $1 / 2$. in. NPS Inconel are shom on dravings to. D-26999 and D-27536. Welding and installation detaflo are elso included. These bave been satisfactorily used in both 3/8-in, and 1/2-1n. Schedule to Inconel. Although these electrodes have never been used on INOR $-B$ autoresistance heated lines the resistance of Inconel relative to INOR-8 indicates Inconel electrodea to be atisfectory for THOR -8 plpelines (Sec. 2l.2).

Comment on Temperatures in Sec, $21,4,1$

b An auxiliary waste nozzle heater (FV-5l2 of Sec. 13.4.5) was necessary for satia. factory temperatures. Other auxiliary heaters required were FV-500A and FV $-506 \mathrm{~A}$ of Sec. 13.4.2. 
Electrode placement on gutoresistance lines were determined during balancing (Sec. 2l.3,1). While some of the electroles were welded to the monten salt lines, others were put in off-the-line locations integral with the corresponding lines. Vsually such electrode placement avoided salt plugs at vessel wills and pipeline tees. Bxamples were:

a. For autoresistence lines starting at or ending at an equipment piece or vessel such as FV-100, FV-102, FV-112, or FV-114, the "ground" electrode at that extremity of the line was welded to a convenient flange integral with the equipuent piece (Secs. $21.4 .1,21.4 .2,21.4 .4$, and 21.4 .5 for FV-100, FV-102 and FV-112), ${ }^{\text {, b }}$ or to a vent line (Sec. 21.4.3 for FV-114).

b. For MS-114-1 to MS-104-1 with an $\mathrm{F}_{2}$ line "teed" 1nto FV-104, the "bot" electrode was welded to the $\mathrm{N}_{2}$ line about three feet frox the tee (sec. 21.4.2). d

The current distribution in the two halves of a balanced autoresistance line was usually such that the currents in the two halves differed by ebout $10 \%$.

The only study of corrosion in autoresistance-heated lines was made on the Mark II waste sajt line (Sec. 13.4.2). Results Indicated that:

a. Relatively instgoificant corrosion occurred on most of the Iine.

b. Severe attack took place near the waste nozzle, the attack befing attributed to the expected higher ine temperatures effected by FV-512 and -512A.

A fallure occursed in MS-100-1 to MS-106-1 (w1th Mark II FV-106) near the fluorinator wall, (sec. 13.4.2), This fatlure apparently resulted frow stresses rather than from corrosion.

The one case In whtch dissimilar metals were used in an autoresistance heated line was in the vent line of the Mark IV freeze velve. The freeze valve and molten salt line were made of Inconel; the vent line was made of nickel. The thickness of nickel pipe requlred was deternined using the equation in Sec. 21.2. In addition to properly sizing the wall of this line, it vas heated vith vent line furnace FV-504. This arrangement worked satisfactorily.

aecs. $5.4 .1 \mathrm{a}$ and 13.4 .2 .

bhe waste nozzle also required resistance heater (Sec. 13.4.5).

sec. $16,4.14$.

$\mathrm{d}_{\text {Secs, }} 16,4,14$ and 16.4 .15 . 
Thermocouples were indispensable on autoresistance-heated lines. Both of the methods used for attaching themocouples to eutores1stanceheated pipes were satisfactory. The preferred method was welding the hot junction to the externel pipe surface. In this method, the insuleted leads were run along the pipe and strapped to it for several inches before being brought through the Superex insulation to avotd unduly stressing the thermocouple pipe joint. The other method utilizing a atrap-on thermocouple has been very ilttle used. Therwocoyples atteched in both ways evidently gave readings of the desired $\pm 10^{\circ} \mathrm{C}$ accuracy. $\mathrm{AB}$ to chotce of method, the welded joint was preferred because of more experience with it, and because good contect with the pipe wes almost always ensured. In addtion, some of the teuperatures obtained with strap-on thermocouples have been low. This possibly indicated inadequate contact of the thermocouple hot junction with the pipe. Other methods of placins thermocouples in VPP are given in Bec, 22,4,2.

Three difficulties have been met with welded thermocouples:

e. Current leaks from the line through thermocoupleg which touched the outer eluninum fotl wrepping. Such leaks reduced the line temperature and startled nearby personnel at times, thereby being possible safety hazards. The remedy was to prevent the thermocouple wire from touching the aluminum foil.

b. Interference with Pyrovanes. The trouble wes from AC pick-up by the Pyrovane thermocouple which affected the Pyrovane reading. The remedy was to tie a cepecitor across the leads Instice the Pyrovane case and then to groumd one of the leads.

c. Low temperature readings. Low temperatures usually inilcated that the welded joint between the thermocouple and the pipe was crecked, or that the thermocouple was partially shorted. Vse of auch a thermocouple was discontinued.

Although no work on the variability in the wall thickness of autoresistance-heated lines has been done, no trouble directly assignable to thin or thick walls bas occurred. Care has alwajs been exerclsed to select pipe appearing to be good by visual examination, to avoid unduly thinning or thickening pipe walls in bends, and to prevent weld depasits of elther extreme.b In the future, however, tests of "as-received" stack and "asbent" configurations may be essential to prevent elther variability in wall thickess or ovality of pipe.

This accuracy was established by comparing the recorder reading with the melting point of the molten salt mixture. AlBo $\mathrm{cf}$. Sec. 22.4.2.

Weld inspection has included: (a) dye-checking and (b) $x$ - or gamm-ray testing (Sec. 19.4.1). Cr. (58)for examples of weld inspections and (52). 
21.5 Summary and Conclusions

The following were found to be essential for the operation of autorealatance-heated molten salt lines with Compositions 30,31 and 108:

s. Sufficient power to maintain the entire pipeline at $>570^{\circ} \mathrm{C}$ although succegsful transfers have been made with line temperatures as low as $\sim 540^{\circ} \mathrm{C}$. For $1 / 2-1$. If. Inconel about 28 feet long, power required was $\sim 3300$ watts. For $3 / 8-1 n$. NPS Inconel about $28-1 / 2$ feet long, power required was $\sim 2600$ vatts,

b. Continuous ${ }^{a}$ 2-in. thick superex 1naulation covered with Thermatex " $\mathrm{B}^{\text {" }}$ to prevent sloughing off of fine material.

c. Avolding the plpeline touching itself or other objects.

d. Adequate heating of joints at any vent or nitrogen ilne.

e. Proper baiancing of two halres of clreutt such that the currents in the halvea were within $10 \%$ of each other.

1. Adequate plac1ng of autoresistance electrodes on the line where positile or off-the-1ine as discussed to arota salt plugs at vessel. walls or plpeline tees.

夰. Either avolding a heat sink such as the waste nozzle or providing additional resistance heating for the heat sink.

h. Either avolding dissimilar metals in the molten salt line or suitably adjusting the wall thicknesses of dissimilar metals.

1. Froper electrade desion to avold a cold opot on the line at the electrode connection.

3. Absence of protruding lugs such as the heat-bleed lugs on early design freeze valves.

The extent of corrosion on Inconel sutoresistance-heated lines is probably minor except possibly in bigh-temperature zones. The one fellure occurring evidently resulted from stresses rather than from corrosion.

Cutting off a heat-bleed lug from fv-108 with the line conteining frozen salt necessitated replacing the entixe freeze valve. This occurrence raised a question as to the advisability of dolng work at welding or cutting tempratures on Inconel lines contasing frozen selt.

That is, containing no eracks to cauke plugs at cold spots. 
Themacomples attached to the pipe both by welding and by strappingon have evidently given temperatures within the desired $+10^{\circ} \mathrm{C}$ variability. The welded foint was preferred since only three minor atfficulties with welded joints have been experienced.

Intensively ingpecting pipe "as-recejved" and "as-bent" has never been done. Molten salt lines fabricated without such inspection have performed adequately although cere has been exercised in selecting and bending plpe to avoid abnormal wall thicknesses. In addition, welding inspection included visual examination as well as dye-checking and X-raying. This inspection avoided poor welds and elther thick or thin weld-metal deposits.

\subsection{Recommendations}

It is recommended that:

a. Insulated autoresistance-heated molten galt lines of either 1/2-in. or $3 / 8-1 n$. Schedule 40 NPS Inconel with welded thermocouples continue to be used.

b. Balancing of such lines continue to be done as described herein.

c. Vent or nitrogen lines be redesigned to provide adequate heating at joints with the molten salt line.

d. Electrodes continue to be placed as described herein.

e. A heet sink at elther end of a molten salt line be avolded or, if It cannot be avolded, be heated also with resistance heating.

f. Sultable wall thlekness design be worked out for any lines of Aissimiler metals built in the future.

g. Electrodes as designea be used on Inconel and probabiy on InoR-8 lines.

h. No beat-bleed lugs be incorporated in future freeze valve or molten salt line designs.

1. No future molten salt line be extended unheated into a vessel as the waste line in the two fluorinators bullt to date.

j. Corrosion study in progress be followed up as needed.

k. Welding Inspection of molten salt ine joints be continued as described herein.

1. The inspection of pipe "as-recelved" and "es-bent" be studied and appropriate recomendations be made. 


\subsection{Operating Procedure: Balanc1ng Autorestatance Clrcuits}

WVE: Prior installetion of power leads in correct lengths was assumed. Four 500 MCM copper power cables were required for each autoresiotance meated 11ne. Two of these cables were "hot" leads and the other two "cold" leads. As shown on Fig. 2l.1, the "hot" leads were connected to polnt $K$, one "cold" lead to point $J$, and the other to point $L$. To arold a significant affference in the valtage drop in e1ther the "hot" or "cold" leads, the lengths of the "hot" leads were made within a foot of each other and likewlise for the "cold" leads. The difference in voltage drop so imparted in either the "hot" or "cold" leads was insigniflcent because the ratio of the resistance of Inconel pipe to the $500 \mathrm{MCM}$

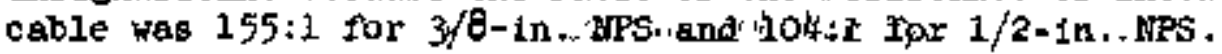

The three sections of line Ms-114-1 to $\mathrm{MS}-104-1$ were balanced separately, See F1g. 2l.2.

To balance ilne ABCDS, one ground lead of the double circult was connected to the lug (type $\mathrm{C}$ on arawing Ho. D-27536) welded to the fluorinatior at point $\mathrm{E}$, and a double hot lead to the lug (sketch $A R-3$ ) velded to the freeze valve vent pipe at point $c$. One "tuning fork" electrode was then clamped to the Inconel plpe at point $A$ eccording to item No. B-I on drawing No, D-27536 and with the adjusteble clamp set in midposition. The circuit was then turned on to about 100 amp. Amprobe readings were taken on lines $\mathrm{BFD}, \mathrm{BC}$, and $\mathrm{CD}$. The current on line BFD should bave been zero. If it was not zero, the electrode et point $A$ was moved along the pipe as follows. If the current in CD was greater than the current In BC, the electrode et point $A$ was moved closer to FV-100. If the current in $B C$ war greater than the current in $C D$, the electrode at point $A$ was moved away from FV-100, closer to FV-114. Mext, a check was made to see that no current was flowing through LN-104-1. When the circult was sufficientiy vell belanced that with 100 amp flowing to the hot lead BD = CD, and BFD $=0$ within the precision of the Amprobe, the cycle was repeated at currents of 200 , 300, and 400 amp. When the circutt was balanced at $400 \mathrm{amp}$, the electrode was welded in plece as shown for type B on drawing No, D-27536. Then another "tuning fork" electrode was welded directly opposite point $A$, and the adjustable clanp was set in midposition.

To balance line ABFLE, the bot lead was removed from $\mathrm{C}$ and connected to the lug (type A on drawling No. D-27536) festened at polnt $F$, midway between $B$ and D. With 100 amp flowing to the hot lead, the currents in lines BF, FD, and $\mathrm{BCD}$ were measured. The current in line BCD should have been zero. If it was not zero, the electrode at point $F$ was moved along the pipe as for the corresponding electrode for line $A B C D$ above. When the circult wes sufficlently well balanced thet with 100 amp flowing to the hot lead, BF = FD and BCD $=0$ within the precision of the Amprobe, the cycle was repeated at currents of 200,300 , and 400 amp. When the circult was balanced at 400 amp, the electrode at point $F$ was welded in place as shown for type $A$ on drawing Fo. D-27536.

To balance ikne AJK, a "tuning fork" electrole (item B-1, drawing No. D-27536) with adjustable clamp set in midposition was welded at point $K$, The hot lead (type A on drawing No. D-27536) was clamped to this line at point $J$. 


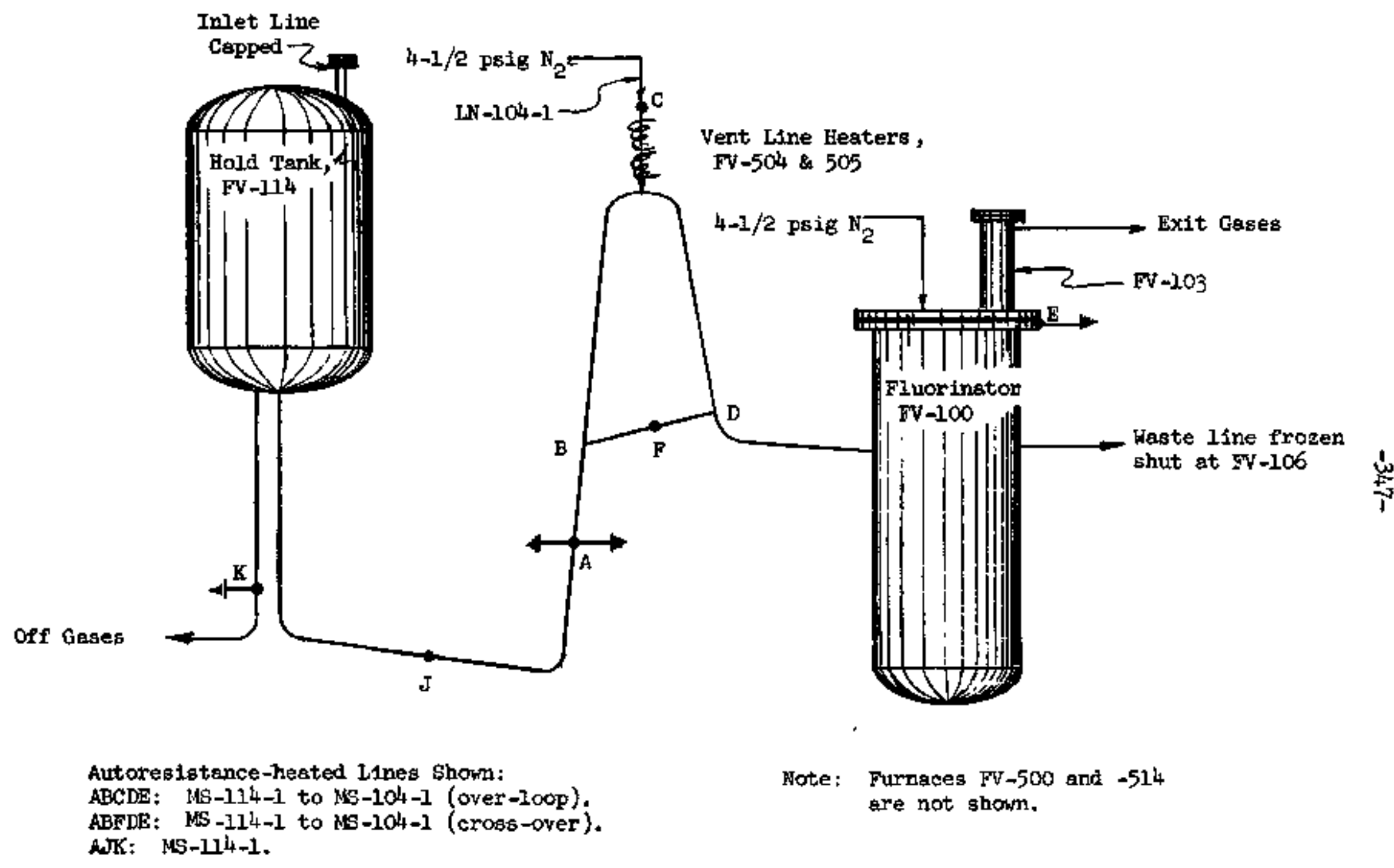

F16. 21.2. Schematic Diagram of the Three Autoresistance-Heated Lines Between FV-114 and FV-100 
With $100 \mathrm{amp}$ flowing to the hot lesd, the currents in lines AJ and JK in the vicinity of the hot electrode were measured. If the currents were not equal, the electroie at point $J$ was moved along the pipe as for corresponding electrodes for lines $A B C D E$ and $A B F D$. When the circuft was sufficiently vell beined that with 100 amps flowing to the hot head $\mathrm{AJ}_{\mathrm{J}}=\mathrm{JK}$ within the prec1sion of the Auprote, the cycle should be repested at currents of 200,300 , and 400 amg. When the circuit was balanced at 400 amp, the electrode was welded in place as shown for type $A$ on drawing No. D-27536.

After the line was 1ngulated and allowed to cure, fine adjustments were made in the "tuning forks" at, points $\mathrm{A}$ and $\mathrm{X}$ to equalize line terperstures. 
$-349-$

CONTENTS

Page

22.0 Resistance Heating . . . . . . . . . . . . . . . . . . . . 349

22.1 Introduction . . . . . . . . . . . . . . . . . 350

22.2 Equipment . . . . . . . . . . . . . . . . 350

22.3 operation ........................ 350

22.4 Equipment Evaluation . . . . . . . . . . . 354

22.4 .1 Watt Density Deta . . . . . . . . . . . 354

22.4 .2 Heater Construction............... 355

22.4.3 Corrosion ................. 357

22.5 Sumnary and Conclustons . . . . . . . . . . . . . . 357

22.6 Recommendations . . . . . . . . . . . . . . . 357 
22.0 RESISTANCE HEATING

\subsection{Introduction}

All of the heated vessels and most of the heated pipelines in the VPP were heated by resistance beaters to temperatures varying from 100 to $750^{\circ} \mathrm{C}$. This heating equipment was arbitrarily divided into two clesses: (a) heater (wattage $<5 \mathrm{kw}$ ) and (b) furmace (wattage $>5 \mathrm{kw}$ ).

\subsection{Equipment}

Pertinent data for the resistance beaters are recorded in Tables 22.1, $2 e, 2$, and 22.3 .9 Table 22.1 contains heaters which were not in contact with the heated surfaces, and which heated these surfaces to $400^{\circ}-650^{\circ} \mathrm{C}$. Teble 22.2 includes heaters which were in contact with the heated surfaces, and which heated these surfaces to $400^{\circ}-750^{\circ} \mathrm{C}$. Table 2.3 gives heaters which wefe in contact with the heated surfaces, and which hested these surfaces to $\sim 100^{\circ} \mathrm{C}$.

Disposition of heaters after use was:

a. Removed from the plant and taken to the burlal ground after the "E" russ: Fv $-510,-510 A,-514,-514 A,-514 B,-511,-511 A,-513,-513 A$, $-515,-515 \mathrm{~A}$ (Sec, 16,4 ).

b. Removed from the plant and taken to the burial ground after the "L" runs: $\mathrm{FV}-500,-504,-505,-506,-507,-508,-509,-501 \mathrm{~A}, \mathrm{E}-503,-512 \mathrm{~A}$, $-517,-517 \mathrm{~A},-500 \mathrm{~B},-503 \mathrm{~A},-525,-525 \mathrm{~A},-520 \mathrm{~A},-521 \mathrm{~A},-520 \mathrm{~B},-521 \mathrm{~B}$.

c. Sold to J. A. Martin, Technical Services Dept, , Bullding K-1401 at $K-25$ after the "I" runs: FV -520 and -521 .

d. Left in the plent after the "L" runs: FV -502, $-502 A,-527$, and -563 .

See also appropriate report aection indicated in Tablea 22.1, 22.2, and 22.3 and Sec. $23.4 .16 \mathrm{~b}$.

\subsection{Operation}

Heater operating procedures were incorporated in sections of this report devoted to the pertinent systems. The procedures given presupposed that the heater and 1ta insulation had already been cured. Curing in VPP might be arbitrarily divided into three classes:

\footnotetext{
FV-522 did not fit into any of these tables; ef, Sec. 7.4.3., Also cf, Fngineering File Folder No. P-75.

${ }^{\mathrm{H}} \mathrm{gt}$ enough to prevent the condensation of $\mathrm{UF}_{6}$, sublimation point of $\mathrm{VF}_{6}$ was $57^{\circ} \mathrm{C}$ at 14.7 psia $(\underline{17}, \mathrm{p} .4)$.

c And also FV-50l.
} 
Table $22.1^{\text {a }}$

VESSEL OR PIPB HOT IN CONPTACT WITH HRATTER: OPBRATING TEMPRRATURE $=400-650^{\circ} \mathrm{C}$

\begin{tabular}{|c|c|c|c|c|c|c|}
\hline $\begin{array}{l}\text { Heater } \\
\text { Number }\end{array}$ & $\begin{array}{l}\text { Report } \\
\text { Section } \\
\text { Number }\end{array}$ & $\begin{array}{l}\text { Approximate } \\
\text { Operating } \\
\text { Temperature, }{ }^{\circ} \mathrm{C}\end{array}$ & $\begin{array}{l}\text { Surface Ares } \\
\text { Seeing } \\
\text { Heating Element } \\
\text { (so. It.) }\end{array}$ & $\begin{array}{l}\text { Container Fv Ho. } \\
\text { or Pipe Line } \\
\text { Number }\end{array}$ & Wattage & $\begin{array}{c}\text { Watt } \\
\text { Density } \\
\text { (Watts } / \mathrm{ft}^{2} \text { ) }\end{array}$ \\
\hline$F V-500$ & 5.4 .3 & 650 & 8.18 & $F V-101$ & 30,000 & 3665 \\
\hline FV -502 & 3.4 .3 & 600 & 14.45 & FV -102 & 36,000 & 2500 \\
\hline $\mathrm{FV}-502 \mathrm{~A}$ & 3.4 .4 & 650 & 0.234 & MS-10e & 1,250 & 5000 \\
\hline $\mathrm{EV}-50^{k}$ & 16.4 .15 & 600 & 0.344 & $\mathrm{LN}=10_{4}^{4}$ & 1,600 & 4650 \\
\hline FV -505 & 16.4 .15 & 600 & $0.3^{44}$ & LN -104 & $m$ & $-\cdots$ \\
\hline $\mathrm{FV}-506$ & 13.4 .3 & 600 & 0.688 & $I+106$ & 2,500 & 3630 \\
\hline FV-507 & 13.4 .3 & 600 & 0.361 & LN-106 & 2,500 & 6925 \\
\hline$F V=508$ & 3.4 .5 & 600 & 0.688 & $1 \mathrm{~N}-108$ & 2,500 & 3635 \\
\hline $\mathrm{FV}-509$ & 3.4 .5 & 600 & 0.361 & $L N-108$ & 1,600 & 4430 \\
\hline$F=510$ & 16.4 .4 & 650 & 45.57 & FV -111 & 96,000 & 2100 \\
\hline $\mathrm{V}-510 \mathrm{~A}$ & 16.4 .5 & 650 & $0.3^{44}$ & WS-111 & 1,000 & 2900 \\
\hline$F V-514$ & 16.4 .9 & 600 & 39.42 & $F V-114$ & 64,000 & 1625 \\
\hline$F V-514 A$ & 16.4 .10 & 600 & 0.344 & $M S-111$ & 1,000 & 2900 \\
\hline$F V-514 B$ & 16.4 .11 & 600 & 0.615 & $M S-114$ & $1, \infty 00$ & 6060 \\
\hline FV -520 & 8.4 .2 & 400 & 8.941 & FV-120 & $1.5,000$ & 1675 \\
\hline$F V-52.1$ & 8.4 .2 & 400 & 8.941 & FV-1D1 & 15,000 & 1675 \\
\hline $\mathrm{Fv}-563$ & 15.4 .3 & $100-350$ & 1.767 & Fv- 163 & 5,500 & 3110 \\
\hline
\end{tabular}

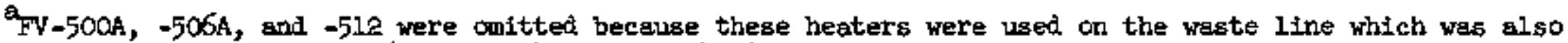
beated by autoresistance (Secs. 13.4.2 and 13.4.5). 
Table $22.2^{a}$

VESSEL OR PIPE IN CONTACT WITH HEAIER: OFERATING TEMPERATURE $=400-750^{\circ} \mathrm{C}$

\begin{tabular}{|c|c|c|c|c|c|c|}
\hline $\begin{array}{l}\text { Heater } \\
\text { Number }\end{array}$ & $\begin{array}{l}\text { Report } \\
\text { Section } \\
\text { Number }\end{array}$ & $\begin{array}{l}\text { Approximate } \\
\text { Operating } \\
\text { Temperature, }{ }^{\circ} \mathrm{C}\end{array}$ & $\begin{array}{l}\text { Surface Areg } \\
\text { Seeing Heating } \\
\text { Element, Sq. Ft. }\end{array}$ & $\begin{array}{l}\text { Container } \\
\text { Number or Pipe } \\
\text { Line_Number }\end{array}$ & Wattage. & $\begin{array}{c}\text { Watt } \\
\text { Density } \\
\text { (Watts } / \mathrm{Ft}^{2} \text { ) } \\
\end{array}$ \\
\hline $\mathrm{FV}-501^{b}$ & 5.4 .5 & 600 & 4.88 & Fv-100 & 9,500 & 1950 \\
\hline FV-501A & 5.4 .6 & 600 & 4.88 & FV -100 & 9,500 & 1950 \\
\hline FV -503 & 6.4 .2 & 400 & 3.40 & $\mathrm{EV}-103$ & 6,000 & 1750 \\
\hline FV -511 & 16.4 .6 & 650 & 2.064 & MS-III & 3,500 & 1700 \\
\hline $5 V-511 A$ & 16.4 .6 & 600 & 1.767 & MS-111 & 3,000 & 1700 \\
\hline$F V-512 A$ & 13.4 .6 & 600 & 0.868 & v-112 & 2,500 & 2890 \\
\hline $\mathrm{FV}-513$ & 16.4 .7 & 600 & 1.032 & MS-111 & 4,000 & 3875 \\
\hline$F V-513 A$ & 16.4 .7 & 600 & 1.245 & Ws -111 & 1,500 & 1200 \\
\hline FV -515 & 16.4 .13 & 600 & 0.239 & $V-115$ & 750 & 3135 \\
\hline$F V-515 A$ & 16.4 .13 & 600 & 0.688 & $v-1,15$ & 2,000 & 2900 \\
\hline$F V-517$ & 13.4 .8 & 750 & 1.758 & FV $-11 ?$ & 4,000 & 2275 \\
\hline$F V-517 A$ & 13.4 .9 & 650 & 0.295 & $\mathrm{v}-112$ & 1,500 & 5000 \\
\hline
\end{tabular}

av-520C and $-521 \mathrm{c}$ were omitted because of ineffectiveness (Sec. 8.4.5). Fv-500A was omitted because of the difficulty in determining the surface area.

$b_{\text {Both Marks } I \text { and II. }}$ 
Table $22.3^{\mathrm{a}, \mathrm{b}}$

VESSEL OR PIPE II CONTACT WIIH HEATER: OPERATIMG TEMTPERATURE $=\sim 100^{\circ} \mathrm{C}$

\begin{tabular}{|c|c|c|c|c|c|}
\hline $\begin{array}{l}\text { Beater } \\
\text { Number }\end{array}$ & $\begin{array}{l}\text { Report } \\
\text { Section } \\
\text { Number }\end{array}$ & $\begin{array}{l}\text { Surface Area } \\
\text { Seeing Heating } \\
\text { Element, Sq.Ft. }\end{array}$ & $\begin{array}{l}\text { Container FV } \\
\text { Number or Pipe } \\
\text { Lifne Humer }\end{array}$ & Wattage & $\begin{array}{c}\text { Watt } \\
\text { Density } \\
\text { (watts/ft }{ }^{2} \text { ) }\end{array}$ \\
\hline FV $-500 \mathrm{~B}$ & 6.4 .4 & 0.742 & $\mathrm{H}-100-2$ & $\sim 400$ & 540 \\
\hline $\mathrm{FV}-503 \mathrm{~A}$ & 6.4 .3 & 2.170 & $\mathrm{H}-103$ & $\sim 400$ & 185 \\
\hline Fv-520A & 8.4 .3 & 1.30 & $E-103$ & $\sim 400$ & 300 \\
\hline $\mathrm{FV}-520 \mathrm{~B}$ & 8.4 .4 & 1.30 & $\mathrm{H}-120$ & $\sim 400$ & 300 \\
\hline FV - 521A & 8.4 .3 & 1.30 & $\mathrm{H}-120$ & $\sim 400$ & 300 \\
\hline $\mathrm{FV}-521 \mathrm{~B}$ & 8.4 .4 & 1.30 & $\mathrm{H}-1 \geqslant 1$ & $\sim 400$ & 300 \\
\hline FV $-525^{c}$ & $12.4 .2 d$ & 0.424 & LN -125 & $\sim 240$ & 560 \\
\hline FV $-525 A^{c}$ & $12.4 .2 \mathrm{e}$ & 0.530 & vs -125 & -400 & 750 \\
\hline$F V-526 A^{C}$ & $10.4 \cdot 3$ & 0.994 & $\begin{array}{l}\mathrm{H}-220-2 \text { and } \\
\mathrm{V}-126\end{array}$ & $\sim 400$ & 400 \\
\hline$F V-526 B^{C}$ & 10.4 .4 & 0.846 & $\begin{array}{l}\text { (P1gtails) } \\
\mathrm{H}-220-2 \text { and } \\
\mathrm{v}-126\end{array}$ & $\sim 400$ & 475 \\
\hline $\mathrm{FV}-527$ & 9.4 .3 & 0.688 & $\begin{array}{l}\mathrm{H}-121 \\
\mathrm{H}-220\end{array}$ and & $\sim 400$ & 550 \\
\hline
\end{tabular}

The heaters for FV-220 and -202 were omitted because of the difficulty in determining the surface areas (Secs. 9.4 .3 and 9.4 .6 , respectively).

$b_{F V-526}$ was onitted because F-126 did not contact the heating elements (Sec. 10.4.2).

Geater was uninsulated. 
s. Curing $400-600^{\circ} \mathrm{C}$ furnacea such as FV-10e. This procedure was to keep at:

1. $400 \%$ for the first 8 hours or overnight,

2. $700^{\circ} \mathrm{g}$ for the next 6 hours or overnight,

3. $1000 \mathrm{~F}$ for the next 4 hours, and

4. $1300^{\circ} \mathrm{F}$ for the next 4 hours;

then use at any temperature up to $1600^{\circ} \mathrm{F}$ maxtmum. ${ }^{a}$ such alow curing prevented crackling the furnace lining.

b. Guring 2-1n. Syperex Insulation joined with asbestos cement on IInes heated tg $600^{\circ} \mathrm{C}$. Usually stach lines were heated for 16 to 24 hours at $\sim 200 \mathrm{C}$ to dry out the water. Sowetines during this curing holes opened in the insulation which required patching before the line could be heated to operating temperature. Fiberfrax, alumimm silicate vitreous ceramic fiber, was used for such patchwork.

c. Curing 2-in. Superex insulation joined with asbestos cement on lines heated to $-100^{\circ} \mathrm{C}$. Such lines needed little or no curing.

22.4 Equipment Eraluation

22.4.1 Watt Denaity Data

Operating characteriatics of the heaters are given in pertinent sections of this report.

From Tables $22,1,22,2$, and 22.3 , the following generalizations about the heaters are mode:

a. Veasel or pipe not in contact with heater (Table 22.1). The dealgn watt density varled from 1625 to 6925 watts per square foot. The valuea over 4000 were primerily for heaters on small diameter pipel1nes auch as FV-507 and FV-514B. Values for the large furmaces were between 1625 and 4000 . Two of the large furnaces' (FY-500 and -510) heated materlal through a double wall. In addition to FV-500 heating through a double wall, this furnace fitted around only about half of FV-100, possibly explainIng why its watt density of 3665 was the highest for the large furnaces. Although no detalled atudy was intended from these watt density data, the figures compare favorably with those for ORtL-desfgned heetera listed in Table 22.2 :

\footnotetext{
As recommended by the Herd Duty Electric Compeny.

bohne -Manville No. 450 Inswilating eement.

confl stores cat, No. 15-002-3000.

dret is, pipelines less than 1-1n. kPS.
} 
b. Vessel or pipe in contact with heater (Table 22.2). The watt density for these heaters varied from -1200 to 5080 . Those with the higher values were more than double the accepted design criteron of 1500 watts per square foot. One heater (FV-5i7) heated its vessel to $750^{\circ} \mathrm{C}$ with a watt density of 2275 .

All of the heating elements used to heat vessel walls or pipelineg to temperatures in the $400-750^{\circ} \mathrm{C}$ range were $G$. E. Calrods with $1500 \mathrm{~F}$ shesths. The only trouble with this brand of tubular heater occurred with FV-512 and FV-515 as described in Secs. 13.4.5 and 16.4 .13 , respectively.

c. Vessef or pipe in contact with heater at operating temperature of $\sim 100^{\circ} \mathrm{C}$ (Table 22.3). These values are given primarily as a contrast to those in the other two tables. The watt densitles were nuch lower varying from 185 to 750 watts per square foot. All of these heaters were fabricated of industrial heating cable as described in Sec. 22.4.2.

Pertinent design factors which have not been considered here are: (a) amount of insulation, (b) heat losses, (c) materials of construction of heated surfaces, and (d) the diatance between the heated surface and the heating element.

\subsubsection{Heater Construction}

The deslgn and construction of the heaters listed in Table 22.1 were perforthed by the suanufacturer. All of these beaters were satisfactory end trouble-free.

For heaters in Tables 22.2 and 22.3 , the design and fabrication were done at ORNL. The chief design and construction eriteria for heaters in Table 22.2 were: (a) using watt density of $\sim 1500$ watts $/ \mathrm{sq} \mathrm{ft}$, (b) attaching element firmly to the heating surface, (c) ingulating with 2 -in. Superex with joints being filled with osbestos cement, and (d) oovering outside surface of insulation with Thermatex " $B$ ".

Calroda were covered or "cenned" w1th stainless steel shimstock before Insulating. This "canning" allowed dissipation of heat from the Calrods whereas permitting the insulation to touch the calrods would inhibit heat removal -- a situation effecting Calrod burn-out. All of the Table 22.2 heaters were satisfactory and reletively trouble-free.

\footnotetext{
The TMK and Calrod tubular heaters used in FV-522 were satiofactory in that service (Sec. 7.4 .3 ).

bohns-Manvilie No. 450 insulating cement.

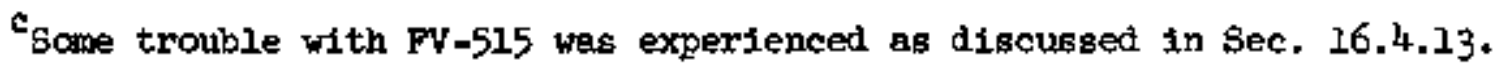


The major desibn criteria for Table 22.3 heaters were: (a) wrapped 30-to 50-ft lengths of industrial heating cable helically around line to be heated wth the advance of the belix being $1 / 4$ to $3 / \theta$ in. for $3 / 8-1 n$. o.d. tubing and $3 / 8-$ to $1 / 2-1 n$. for $1 / 2-$ to $1-1 / 4-i n$. MPS and (b) inswlated only lines over $1 / 2-i n$. HPs as in item $c$. for Table 22.2 heaters folloved by the Thermatex " $B$ " covering in item $a_{b}{ }^{\circ}$ All of these heaters were satisfactory and trouble-free.

Thermocouples were Indispensable in the VPP. Chromel-Alumel thermocouples were used in the $20^{\circ}$ to $800^{\circ} \mathrm{C}$ range and those of copperConstantan in the $-60^{\circ}$ to $0^{\circ} \mathrm{C}$ range. The accuracy of temperatures ind1cated wth Chromel-Alumel thermocouples was belleved to be $\pm 10^{\circ} \mathrm{C}$. This accuracy value was arrived at by comparing the recorded temperatures at Which UF 6 stayed in the gaseous state in the heated duct (Sec. 7.4.3) with the sublimation point of $\mathrm{UF}_{6}, 1 . e,, 57^{\circ} \mathrm{C}$. " The accuracy of copper-Constantan thermocouples was not determined.

Therwocouples for resistance-heated equipment vere usually welded or silver brazed to the surfeces of ressels ( $\mathrm{rV}-501$ in Sec. 5.4.5b), pipel1nes (FV-511 in Sec. 16.4.6), or tubing (product plgtails in Sec. 10.4.4). When the calrod temperature was also used for control as with FV-501, the controller thermocouple was welded to the Calrod, Other satibfactory placements of thermocouples vere:

a. In thermowells for protecting from nolten salt (FV-100 melt, Sec. 5.4.1), $\mathrm{NaF}$, or gaseous mixtures of $\mathrm{F}_{2}$ and $\mathrm{UF}_{6}$ (FV-120 and
-121 , Sec. 8.4 .1 ),

b. In contact (alloy-sheathed thermocouples) with NeF or geseous mixtures of $F_{2}$ and $\mathrm{LF}_{6}(\mathrm{FV}-103$, Sec. 6.4 .1$)$.

c. In the heated duct alr strean (bere thermocouplea, \$ec. 7.4 .2 ). d

Thernocouples on unheated equipment were also velded or silver brazed to the surfaces of vessels (FV-150, Sec. 11.4 .1 ) or pipelines ( $F_{2}$ trailer mentfold, Sec. 15.4.1).

\footnotetext{
Thirty feet for 3/8-1n. o.d. tublug and 50 ft for $1 / 2$ to 1-1/4-in. MPS. Fifty feet was the 1degl length for $120 \mathrm{v}$ supply. Heating cable data: G. E. No. CMCH-58758 Induatrial Ceble, No. 20 solid N1chrome wire wth Monel shlelding and asbestos sheath; resistance $=0.635 \mathrm{ohm} / \mathrm{ft}$.

BV -520A, $-5208,-521 \mathrm{~A}$, and $-521 \mathrm{~B}$ were cenned in stainless steel shimstock before insulating as described in Table 8.1 (Secs. 8.4.3 and 8.4.4).

${ }^{\mathrm{c}}(\underline{17}, \mathrm{p} .4)$. Also Sec. 21.4 .6 .

$\mathrm{d}_{\text {Sec. }} 21.4 .6$ for thermocouple placement on autoresistance-heated IInes.
} 
'22.4.3 Corrosion

Corrosion data were obtained on the following heated surfaces:

a. FV-100 (Sec, 5.4.1d).

b. The heated duct piping (Sec. 7.4.2).

c. The Mark II vaste ilne (Sec. 21.4.6).

\subsection{Sumisary and Conclusions}

All of the heaters were satisfactory. Observations made on the three classes of heaters used were:

a. Those ngt in contact with vessel or pipe (operating temperature = $400-650^{\circ} \mathrm{C}$ ). Watt densities varied from $\sim 1625$ to 6925 watts per square foot with those of large furnaces ranging froin w 695 to 4000 . These heaters were designed and built away from ORWL.

b. Those in contact with vessel or pipe (operating temperature = $400-750^{\circ} \mathrm{C}$ ). Watt densitied varied from 1200 to 5000 . These heaters were ORkL designed and fabricated using 1500 watts per square foot as the sialn deatg eriterion. Construction details are given. G. $B$. Calrods with $1500^{\circ}$ sheaths were satisfectory. The only trouble vith these heaters occurred at FV-512 and FV-515.

c. Those in contect with the vessel or pipe (opereting temperature $=$ $\sim 100^{\circ} \mathrm{C}$ ). Watt densities ranged from 185 to 750 . These heaters were deslgned and built at ORHL. Construction detajls are given.

Corrosion studies tere made on some heated surfaces.

\subsection{Recommendations}

It is recommended that:

a. Watt densities of furnaces purchased in the future to heat vessels In the $400-650^{\circ} \mathrm{c}$ range be at least 2000 .

b. Design and construction criteria given herein continue to be used on ORML-built heaters in contact with the heated surfaces with $1500^{\circ} \mathrm{F}$ sheath G. Z. Calrods as the heating elements, for high temperatures $\left(400-750^{\circ} \mathrm{C}\right)$ and industrial heating cable for low temperatures $\left(\sim 100^{\circ} \mathrm{C}\right)$. 
23.0 Radiation Safety Including Criticality ............... 358

23.1 Introduction . . . . . . . . . . . . . . . . 359

23.2 Radionct1ve Hazerds and Detecting Equipment . . . . . . . 359

23.3 Operations........................ 367

23.3.1 OperatIng Frocedures . . . . . . . . . . . . . . 367

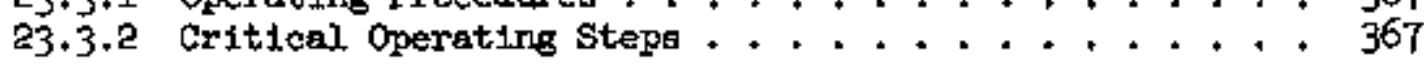

23.4 Equipment Performance . . . . . . . . . . . . . . . 367

23.4.1 Personnel Exposure and Air Activitles . . . . . . 367

23.4 .2 Constant A1r Monitor . . . . . . . . . . . . 367

23.4 .3 Portable Dlsk Sarpler ............... . 371

23.4.4 Alpha A1r Monitor . . . . . . . . . . . . . . 371

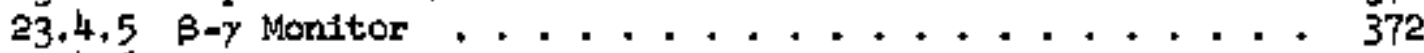

23.4.6 Monttors for Personnel and Clothing . . . . . . . . 373

23.4 .7 Background $(\beta-\gamma)$ Recorder ............ 373

$23.4 .8 \quad \alpha-\beta$ Smears .................... . . . 373

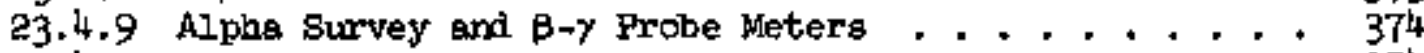

23.4.10 Cutie Pier and Monitron .............. 374

23.4.11 Film Bedges ......................... 375

23.4 .12 Dose Meters ......................... 375

23.4.13 Urine and Fecel Samples . . . . . . . . . . . . . . 375

23.4.14 Protective Derices .................... 376

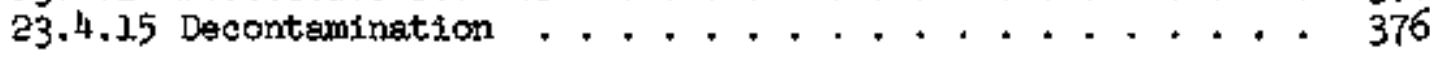

a. Surfaces not in Contact with Molten salt . + * 376

b. Small Metallic Surfaces Contacted by Molten seit. 379

c. Vessels. . . . . . . . . . . . . . 379

23.4.16 Waste Disposal Practices ............... 380

23.5 Sumary and conclusions ................. . 331

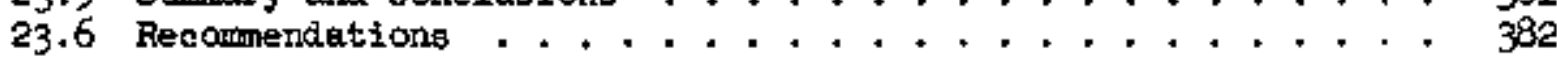




\subsection{RADIATIOH SAFETY INCLUDING CRITICALITY}

\subsection{Introduction}

In the VPP, radiation safety consisted of detecting rediation hazards, determining personnel exposures, decontaminating equipment and its enrivonment and preventing critical incldents. These efforts resulted in personnel exposures and atr activities below the permissible levels.

\subsection{Rad losct1ve Hazards and Detecting Equijinent}

The radioactive hazards in VPP were enriched urantum and fission products. Enriched uranium as UF ${ }_{6}$ was the moat serlous hazard because, being a gas, it was difficult to conta1s. The fission products were also serious hazards becsuse of their high activities (e.g., the waste contalner read as high as r lo ren/hr), but these were well contained within the equiprent.

The hazardous radiosctive operations to the VPP are liated in Table 23.1. Alr-borne $\alpha$ wes the most serious result of an operation because the tolerance in air was low, and because the aubsequent decontamingtion was so difficult and timeconsuming wearing assault masks. Contamination frow some of these operations was greatly reduced by design and operating technlques, but littile improvement vas realized in: (a) the salt spatter at the waste station, (b) the release of $\mathrm{UF}_{6}$ during product sampling, and (c) the spreading of dust while unloading FV-103.

Persomel exposure and atr activity dats are discussed in sec. 23.4.1, Details of the equipment and means used to detect radiation hazards and to deter mine personnel exposure are recorded In Table 23.2 and described in secs. 23.4.2 through 23.4.13. Protective devices, deconteminetion, and waste disposal are listed in Table 23.3 and in Secs. $23.4 .14,23.4 .15$ and 23.4 .16 , respect1vely.

Relative to a critical incident, three possible situations were considered:

a. Hold-up of a large mass of UF (several kilograns) In the cell 2 equipment. Th1s was prevented by comparing after each run the cumulative amount of product collected with the cumilative urenium fed into the system since the last system wash-out. The difference between these two figures was never breater than $5 \mathrm{~kg}$.

b. High comcentration of uranium in aqueous solution during system weshout. The aqueous wash solution draining from the cell 2 equipment into 30 gallon druns was analyzed for uranium periodically. A concentration of $10 \mathrm{~g} / 1$ was considered a sefe upper limit. The highest coneentration in the samples taken was $\sim 4 \mathrm{~g} / 1$ during the wash-out after the "L" runs.

c. Storage of product cylinders. Each Individual cylinder was stored in a critically safe container (Sec. 12,4.1).

\footnotetext{
"Radiation exposure and survey instrument data are given in "rem" throughout although it is recognized thet survey instruments read alrectly in "roentgen."
} 
$-360-$

Table 23.1

RADIOACTIVELY HAZARDOUS OPERATIOHS IH TEE VPP

\begin{tabular}{|c|c|c|}
\hline Operation & Hazardous Agent & Prineipal Radioactivity \\
\hline Produet Sampling & $\mathbf{v F}_{6}$ & Atr borne $\alpha$ \\
\hline Molten Selt Sampling & $\begin{array}{l}\text { Pission Products in } \\
\text { Salt } \\
\mathrm{UF}_{6} \text { (at times) }\end{array}$ & $\begin{array}{l}B-\gamma \\
\text { Air borne } \alpha\end{array}$ \\
\hline $\begin{array}{l}\text { Emptying chemical } \\
\text { Trap: } \\
\text { a. FV-103 } \\
\text { b. Fv-122 } \\
\text { c. FV-124 }\end{array}$ & $\begin{array}{l}\text { Fission Products } \\
\mathrm{W}_{6} \cdot 3 \mathrm{~N}_{\mathrm{a}} \mathrm{F} \\
\mathrm{UF}_{6} \\
\mathrm{UF}_{6} \cdot 3 \mathrm{NaF} \\
\mathrm{UF}_{6} \cdot 3 \mathrm{HaF}\end{array}$ & $\begin{array}{l}\beta-\gamma \\
\alpha \\
\text { Air borne } \alpha \\
\alpha \\
\alpha\end{array}$ \\
\hline Waste Removal $^{a}$ & Fission Products & $B-y$ \\
\hline $\begin{array}{l}\text { Malntenance } \\
\text { Around FV-100 }\end{array}$ & $\begin{array}{l}\text { Fission Products } \\
\text { UF }_{6}\end{array}$ & $\begin{array}{l}\gamma \\
\text { A1r borne } \alpha\end{array}$ \\
\hline Product Collecting & $\mathrm{UF}_{6}$ & $\begin{array}{l}\text { Alr borne } \alpha \\
\text { al. Inctident }\end{array}$ \\
\hline System Wash-dut & & al Incident \\
\hline
\end{tabular}

Apatter contaminated part of Cell IA (Sec. 13.4.4). 


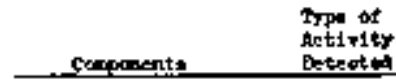

Gocotione Mle Mositios

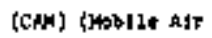

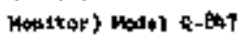
Ser1w Mo. $10_{j}$ OFol Jestrone bopt.
Detectine. Talozance for $\theta, 7$

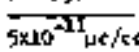
tor a Oto Eac. 23.4.2 ror Iostr. Rolorance

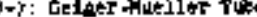
- Filter Dét 1s reod 10

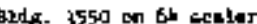
and Photooultipliter tuket

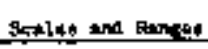

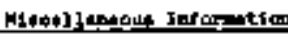

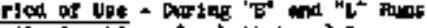

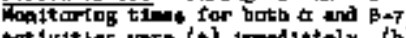

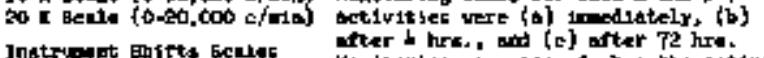
Inetrinonot Ehifts belle

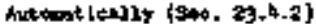

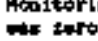

Thes bogra

STres. 23.4.2; 23.th.1; 27.5; 23.6;

12.3.2, 5tea b; 16.4.16

Medive Bapoled - A1r

Arr Bomilng Pute - 5 c.t.n.

Areat thed - Gelle I and II; Peathours and Aocen $\downarrow$ Lot.

\section{Portable Dsak} $a_{1} b_{2}$ and $\vec{r}$ bane an tor

eN.

Hede for halaing riltar digh wat courred in 3019 का th oosler and hotor. teltipliner toble torr a: con 6 scuer and and-vindor

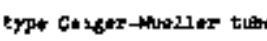
tor $\mathrm{B}=\mathrm{r}$.

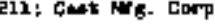
- Fotorultipler tone

Howe

Nipte his Moa1tor $a_{1} \beta_{2}$ and $r$ tren $a x$ for CWH. 2n 1nesturent Q.7 ean be counted as Meter \} Malil Q-1\$51; for partable disck Serist io, the complar if rectogery.

ans

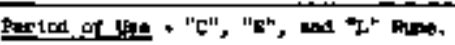

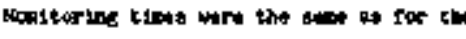

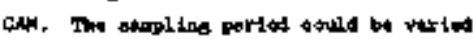
as desired, being unanlly

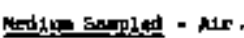

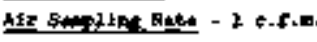

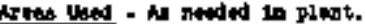

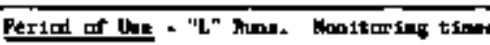

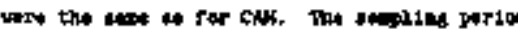
ocold be rerlod tro 5 mo, to $10 \mathrm{hro}$

vadile EnToled t A1r.

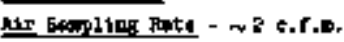

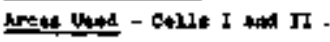

\begin{tabular}{|c|c|c|c|c|c|c|}
\hline 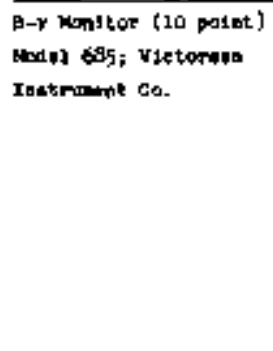 & $B-7$ & 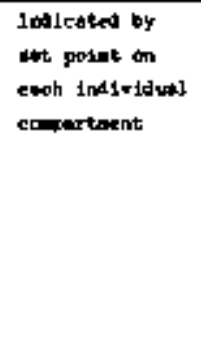 & 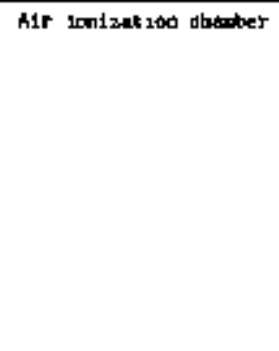 & 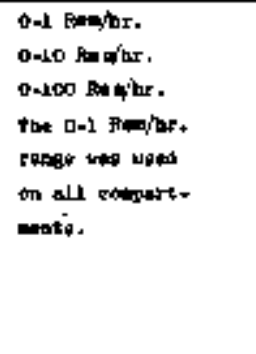 & 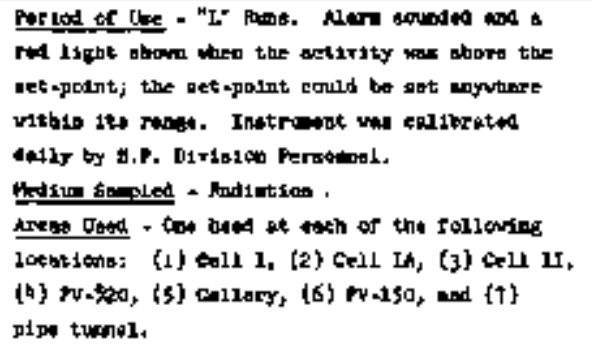 & 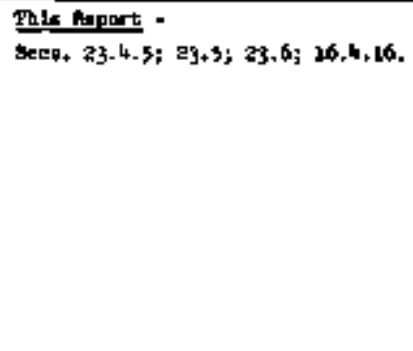 \\
\hline $\begin{array}{l}\text { Niphe fusd } \\
\text { Menitert }\end{array}$ & 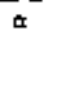 & 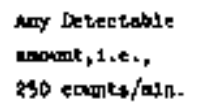 & 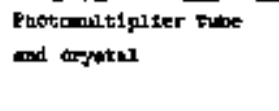 & 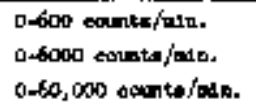 & 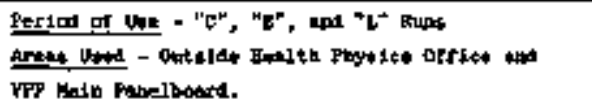 & 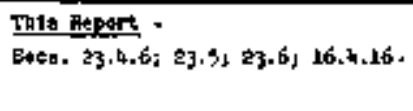 \\
\hline
\end{tabular}

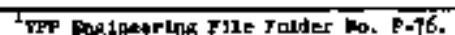


Table 23.2 (Cortsoned)

\begin{tabular}{|c|c|c|c|c|c|c|}
\hline Coaponwat: & $\begin{array}{l}\text { Type of } \\
\text { xctirity } \\
\text { Detercidi }\end{array}$ & Tolereoce & $\begin{array}{l}\text { Detrectsing } \\
\text { Cog prosent: }\end{array}$ & Frales and haness & 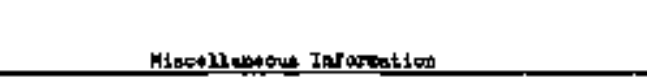 & Puforobest \\
\hline 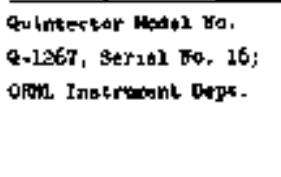 & 0.7 & 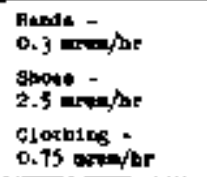 & 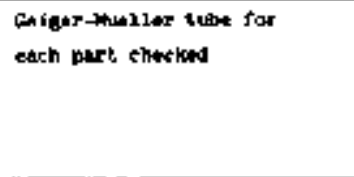 & $\ldots$ & 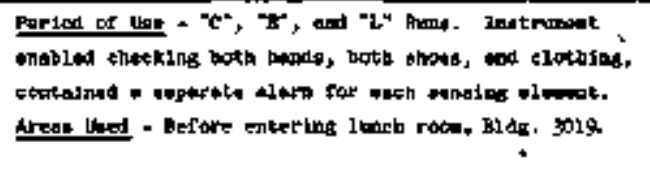 & 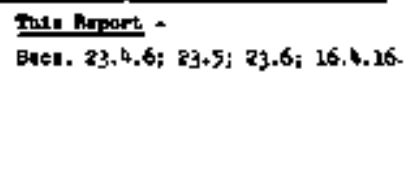 \\
\hline 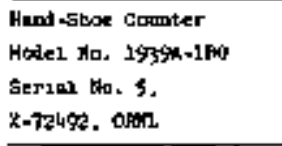 & $0-7$ & $\begin{array}{l}\text { Fanted at }- \\
\text { counter }\end{array}$ & 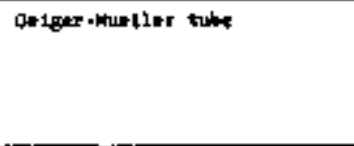 & . & 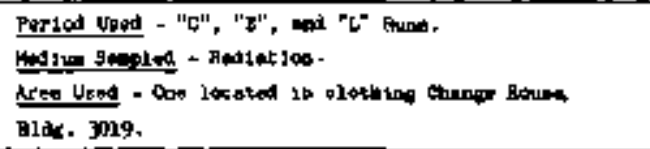 & 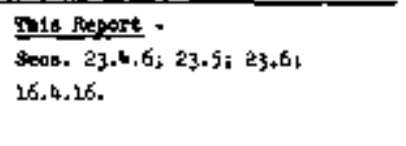 \\
\hline Sockgrowdil Reconder & 0.4 & 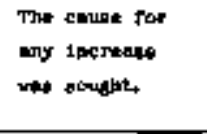 & Gorgerthellar vetest & 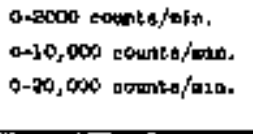 & 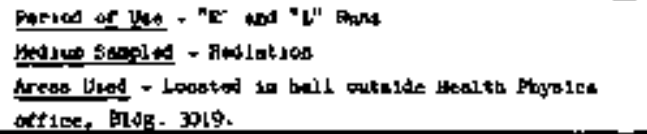 & 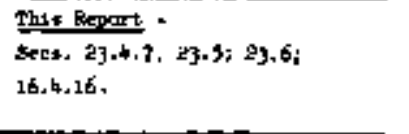 \\
\hline$t$, e garmin & a, $p$ & 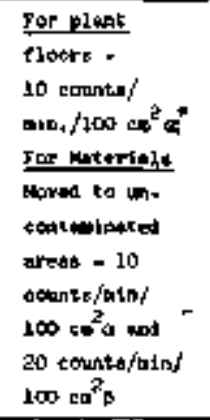 & 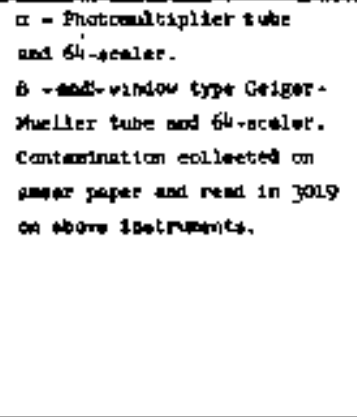 & $0 \rightarrow \infty, \infty \infty$ counts/en. & 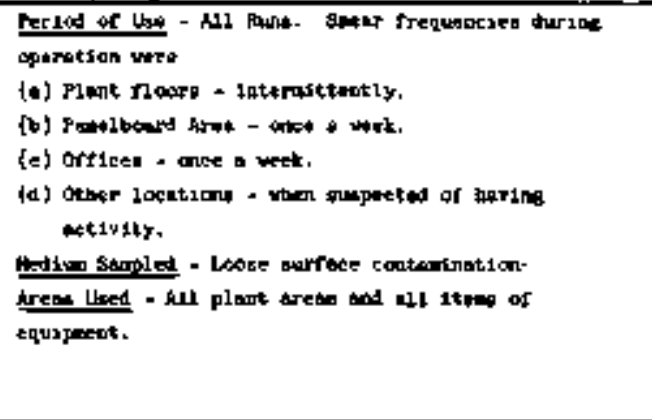 & 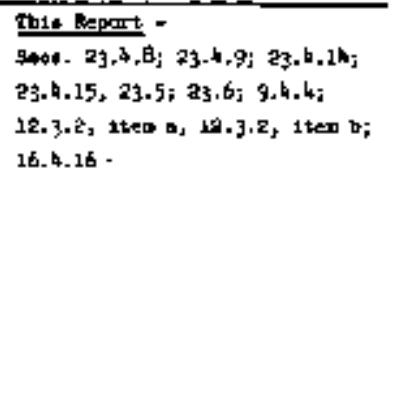 \\
\hline 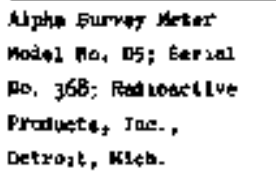 & $\pi$ & $\begin{array}{l}150 \text { coemts/oun. } \\
\text { per } 100<a^{*}\end{array}$ & 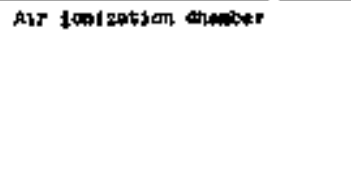 & $90-2000$ expors/osin. & 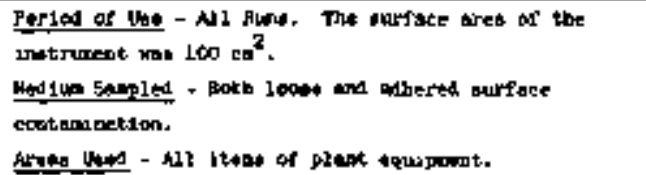 & 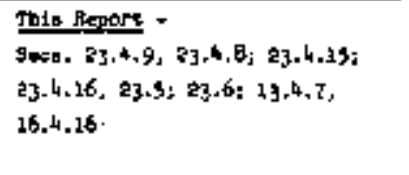 \\
\hline Q-4 Frobe & $\theta-7$ & $0.83 \Delta \times 10 / h t$ & 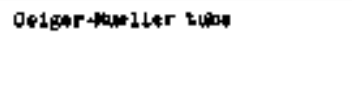 & 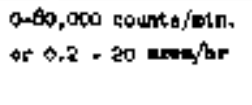 & 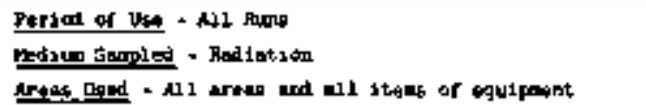 & 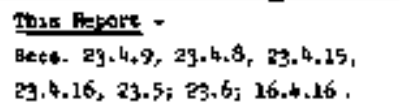 \\
\hline
\end{tabular}

TApl 100 exunts/ajn/100 $\sigma^{2}$ 
Tabue 23.2 (Cont 9uxed]

\begin{tabular}{|c|c|c|c|c|c|c|}
\hline \multicolumn{7}{|c|}{ 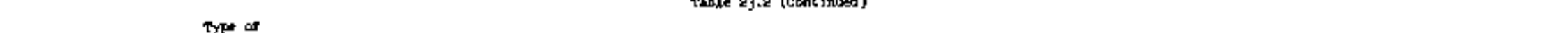 } \\
\hline comporiente & 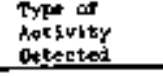 & Folerance & $\begin{array}{r}\text { Det.ect ing } \\
\text { colopinents } \\
\end{array}$ & 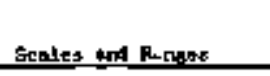 & 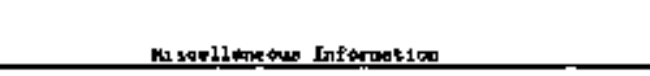 & Beferemast \\
\hline $\begin{array}{l}\text { Gotie P1e \{soft Stehl\} } \\
\text { outh Inutriment Dept. }\end{array}$ & All $\mathrm{a}$ and, & 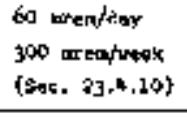 & A1s tinkzaticn chanter & 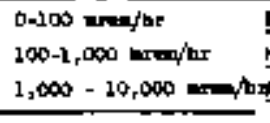 & 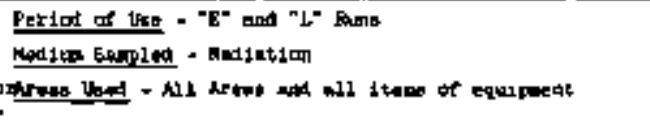 & 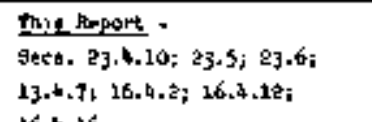 \\
\hline $\begin{array}{l}\text { Cutle Ple (Eard Sholl) } \\
\text { Wietoreen Iprotrument } \\
\text { Co. }\end{array}$ & 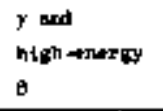 & $\begin{array}{l}\text { Salve ax for } \\
\text { sort shetil }\end{array}$ & Nor 10aisation chemer & 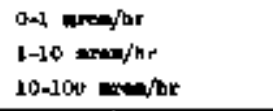 & & 16.4 .16 \\
\hline 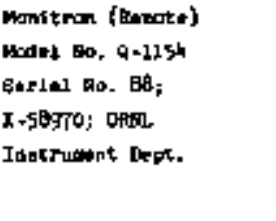 & $\begin{array}{l}\text { i wod } \\
\text { high }=0 \text { arrey } \\
\text { g }\end{array}$ & 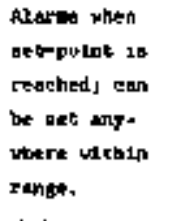 & A1r 2onilation clotaber & D-i25 andar & 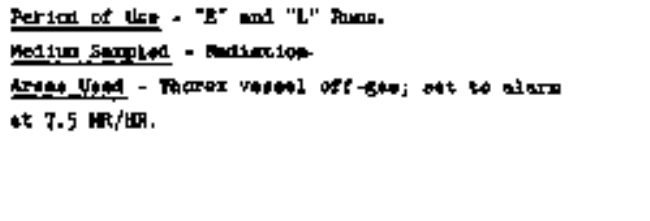 & $\begin{array}{l}\text { Th1s Regotet - } \\
\text { Sect. 23.4.10; 23.3; 23.6j } \\
16.4 .16 .\end{array}$ \\
\hline FIIL Bespen & 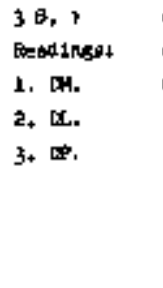 & 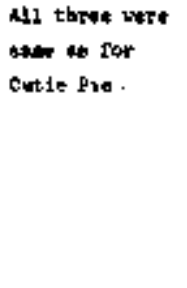 & 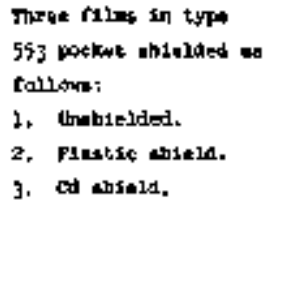 & 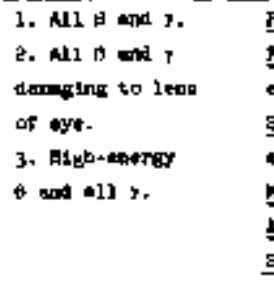 & 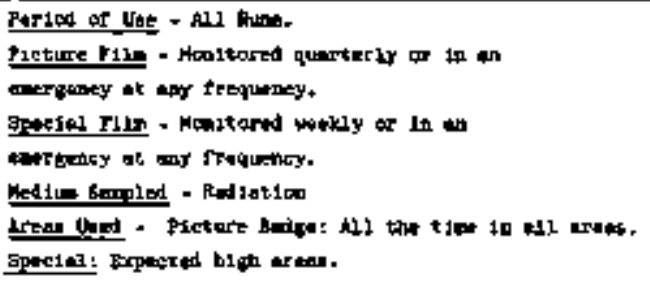 & $\begin{array}{l}\text { Th1s Raport : } \\
\text { Sect, 23,4.11; } 87.4 .1 ; 23,4,10 ; \\
83.5 ; 83.6 ; 16.2,16 . \\
\text { F14. } 23.1 \text {. }\end{array}$ \\
\hline Dowe Meteres & $\begin{array}{l}\text { Bigh: } \\
\text { Enere } \\
\text { B and } \\
\text { all } y\end{array}$ & 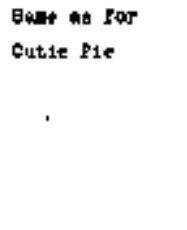 & AlY I onlest for thoser & 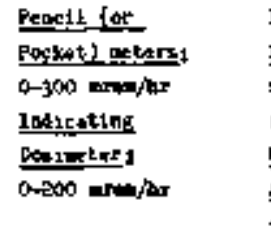 & 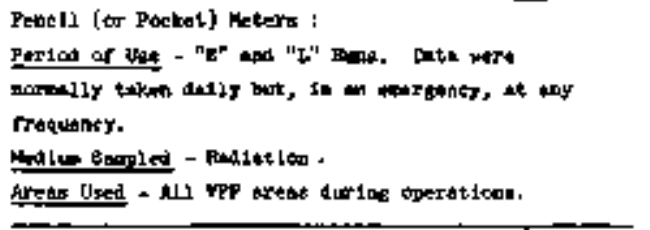 & 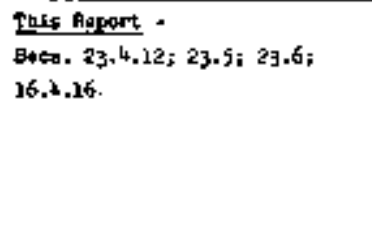 \\
\hline & & & & & 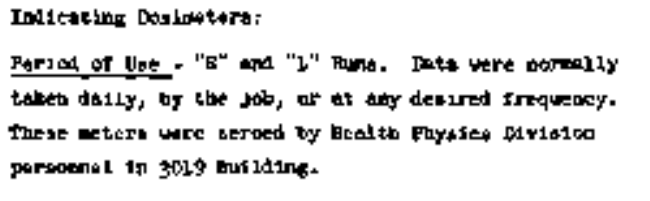 & \\
\hline & & $\cdot$ & & & 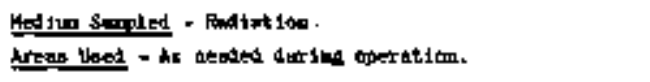 & \\
\hline
\end{tabular}


Table 23.2 (continuad)

\begin{tabular}{|c|c|c|c|c|c|}
\hline caponente & Furyose & couldetyoul Intervas & Fentep and Rangap & 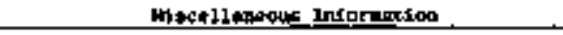 & Burergateds \\
\hline untor bexples & 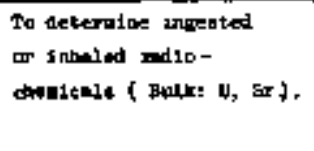 & 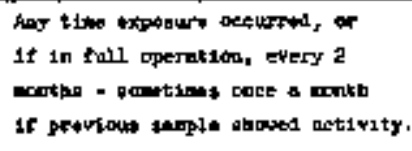 & $\ldots$ & 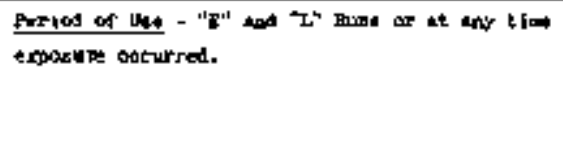 & 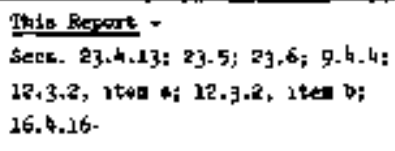 \\
\hline Pecenl 5ecplass & 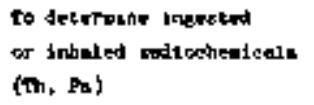 & 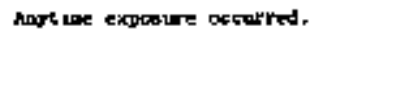 & --- & 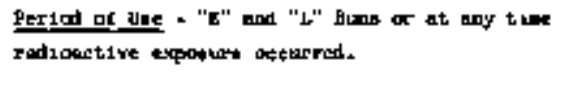 & 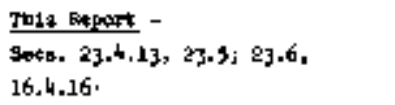 \\
\hline
\end{tabular}


Table 23.3

PROTECTIVE DEVICES, DECONTAMIMATION, AND WASTE DISPOSAL TNFOHMATION

\begin{tabular}{|c|c|c|}
\hline Item & Materials Used and/or Procedures & Remarks \\
\hline $\begin{array}{l}\text { Protective } \\
\text { Devices }\end{array}$ & $\begin{array}{l}\text { Unit shielding, lead bricks, assault masks, protective } \\
\text { clothing (1ncluding coverails, safety shoes, caps, and } \\
\text { gloves), and shoe covers }\end{array}$ & $\begin{array}{l}\text { Secs. } 23.4 .14,13.4 .4, \\
13.4 .13 .\end{array}$ \\
\hline \multirow[t]{5}{*}{$\begin{array}{l}\text { Decontani- } \\
\text { netion }\end{array}$} & $\begin{array}{l}\text { Surfacea Hot in Contact with Molten Salt } \\
\text { Floors \& Walls }\end{array}$ & \multirow[t]{4}{*}{$\begin{array}{l}\text { Sec. } 23.4 .15 a \text { for } \\
\text { activity data. }\end{array}$} \\
\hline & 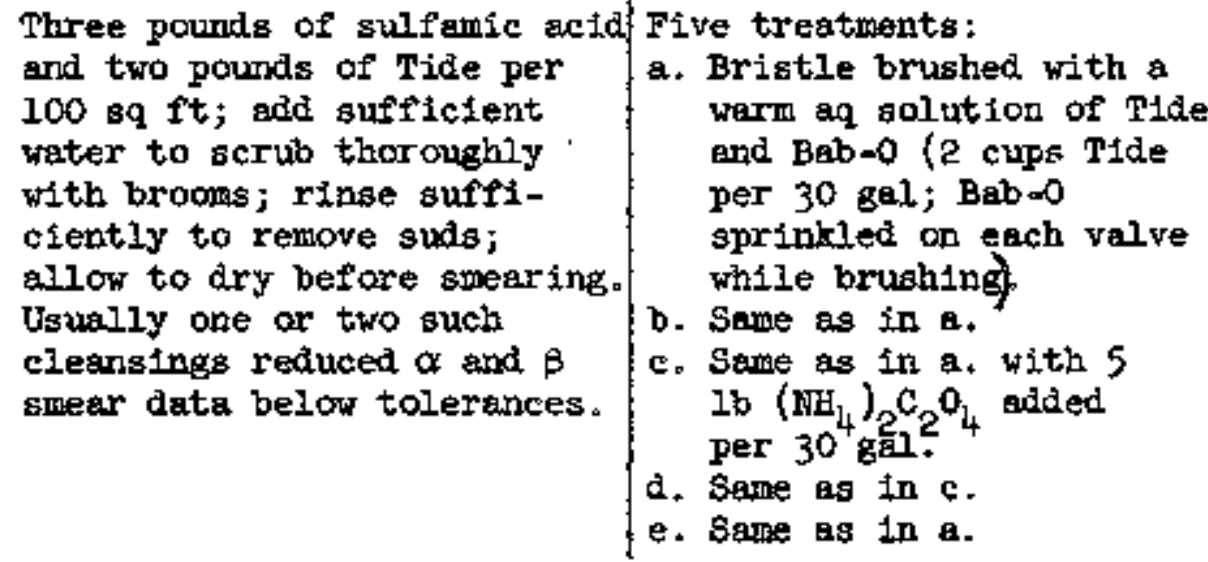 & \\
\hline & $\begin{array}{l}\text { Bmall Metallic Surfaces Contacted by Holten Selt } \\
\text { (Corrosion Specimens) }\end{array}$ & \\
\hline & Incanel Pipe & \\
\hline & $\begin{array}{l}\text { a. Removing as much fused salt as possible wechanically, } \\
\text { exercislng care not to scar the plece. } \\
\text { b. Gently boiling for one hour in } 0.3 \mathrm{H} \mathrm{aq}\left(\mathrm{NH}_{4}\right)_{2} \mathrm{C}_{2} \mathrm{O}_{4} \\
\text { solution. } \\
\text { c. Gently boiling for one hour in an } \mathrm{sq} 5 \% \mathrm{HMO}_{3} \text { and } \\
5 \% \mathrm{~A}\left(\mathrm{NO}_{3}\right)_{3} \text { solution. }\end{array}$ & $\begin{array}{l}\text { See Sec. } 23.4 .15 b \text { for } \\
\text { activity data. }\end{array}$ \\
\hline
\end{tabular}

These procedures were suggested by G. I. Cathers. 
Table 23.3 (Continued)

\begin{tabular}{|c|c|c|}
\hline Item & Materials Used and/or Procedures & Reitiariks \\
\hline $\begin{array}{c}\text { Decontami- } \\
\text { nation } \\
\text { (Contd.) }\end{array}$ & 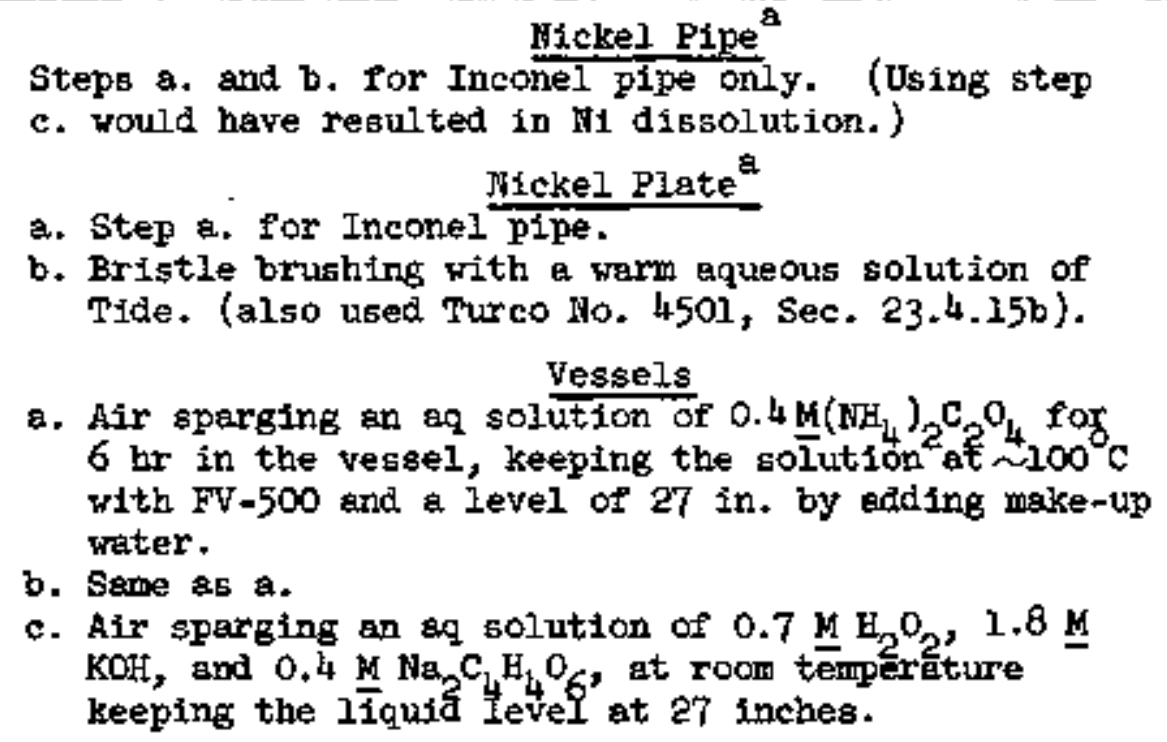 & $\begin{array}{l}\text { See Sec. } 23.4 .150 \text { for } \\
\text { ectivity data. } \\
\text { See Sec. } 23.4 .150 \text { for } \\
\text { activity data. } \\
\text { See Sec. } 23.4 .150 \text { for } \\
\text { activity data. }\end{array}$ \\
\hline $\begin{array}{l}\text { Wasto Dis- } \\
\text { posal }\end{array}$ & 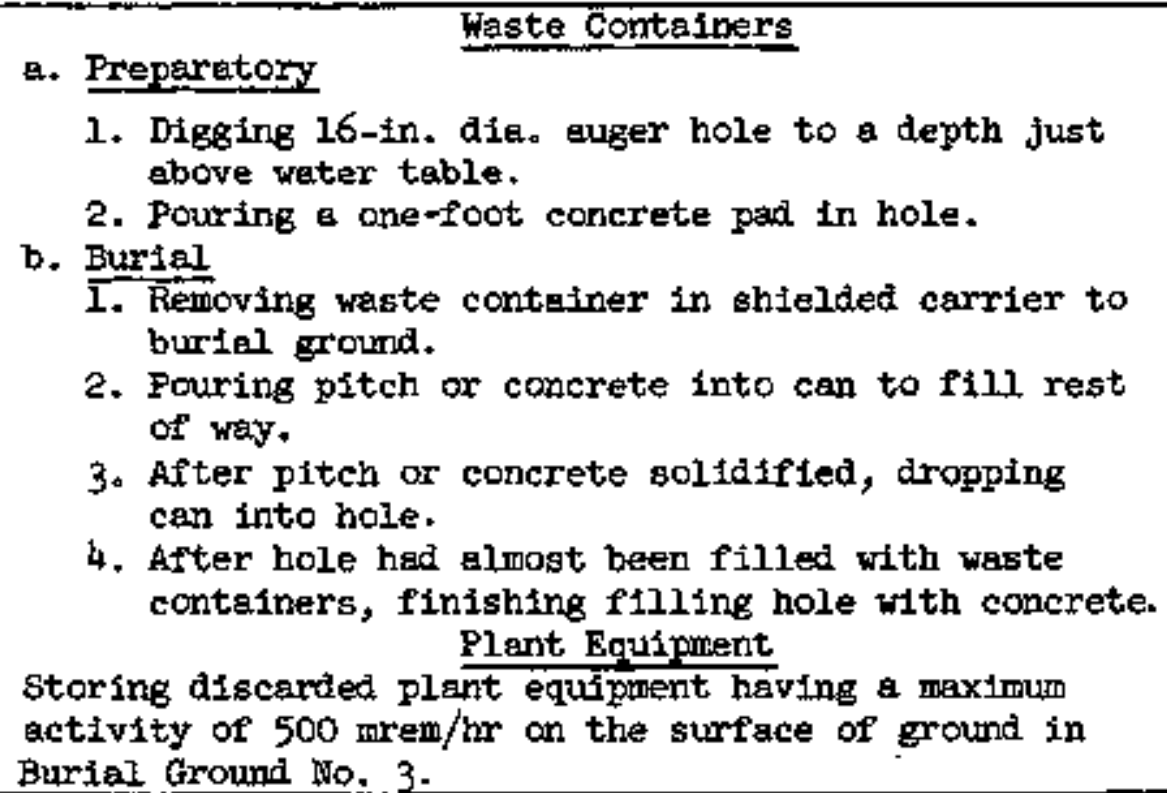 & $\begin{array}{l}\text { See Sec. } 23.4 .16 a \text {. } \\
\text { Sec. } 13.4 .13\end{array}$ \\
\hline
\end{tabular}

These procedures were suggested by G. I. Cathers. 


\subsection{Operations}

\subsubsection{Operating Procedures}

Since most of the equipment was operated and mantained by Health Physics Division personnel, the procedures used are beyond the scope of this report. Decontamination and waste disposal procedures, wich were done by VPP personnel, are given in Table 23.3 and in Secs. 23.4.15 and 23.4 .16 , respectively.

\subsection{2 critical Operatiag Steps} charge to:

Responsibility was essuned by the VPP Shift Supervigor in

a. Obtain the necessary assistance from Health Physics personnel.

b. Take the required precautions when doing work in hazardous areas.

\subsection{Equipment Performance}

\subsubsection{Fersonnel Exposure and Air Actirtties}

The average weekly $\beta-\gamma$ personnel exposure ia plotterd fron Runs E-3 through the last "L" run in Fig. 23.1. "The data are taken fron the Bpecial film badges (Sec, 23.4.11). The highest value of 49 mren/man-wk 18 below the weekly tolerance of 300 mrem (Sec. 23.4.10).

The average $\alpha$ ectivity in Room, 100 air is plotted in Fig. 23.2 from Run E-3 through the lagt "L" rum. The average $\alpha$ activity was contInuously below the tolerance value of $5 \times 10^{-11} \mu \mathrm{c} / \mathrm{cc}$.

The average $\beta-\gamma$ activity in Room 100 air is plotted In Fig. 23.3 for Run E-3 through the last " $\mathrm{L}$ " run. The average B-y activity was mainteined below the tolerance value of $i \times 10^{-8} \mu \mathrm{c} / \mathrm{cc}$.

23.4 .2 Constant Air Monitor

Constent eir monitors were used in Cells 1 and 2 during the " $\mathrm{E} "$ rums and in the Penthouse es needed during both the "$E$ " and " $L$ " runs (Secs. $12.3 .2 b$ and 16.4.16). This instrument primarily monitored air borne $\beta$ and $\gamma$.

These data were unavalable before Run E-3 becauge the speclal film bedges were not worn pritor to February, 1958 (Sec. 16.4.16).

bData collection started in February, 1958 or jugt prior to Run E-3 (Sec. 16.4.16). 


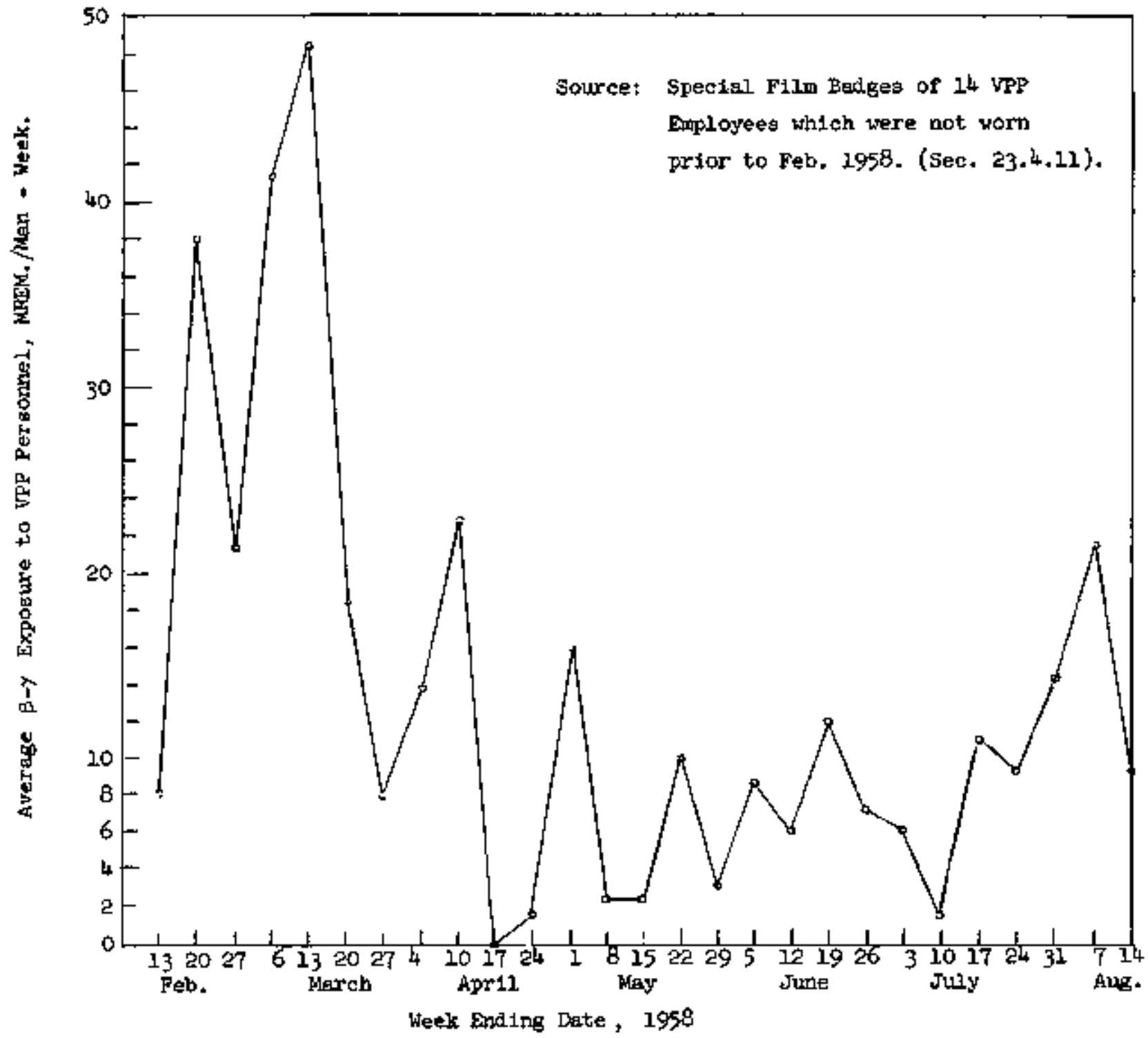

Construetion Corstruction Al1 "L" Rums

Roris E-3

through $\mathbf{E}=6$

Fib. 23.1. Flot of Average $\beta-\gamma$ Bxposure to VPP Personnel vo. Week Ending Date, 1958 


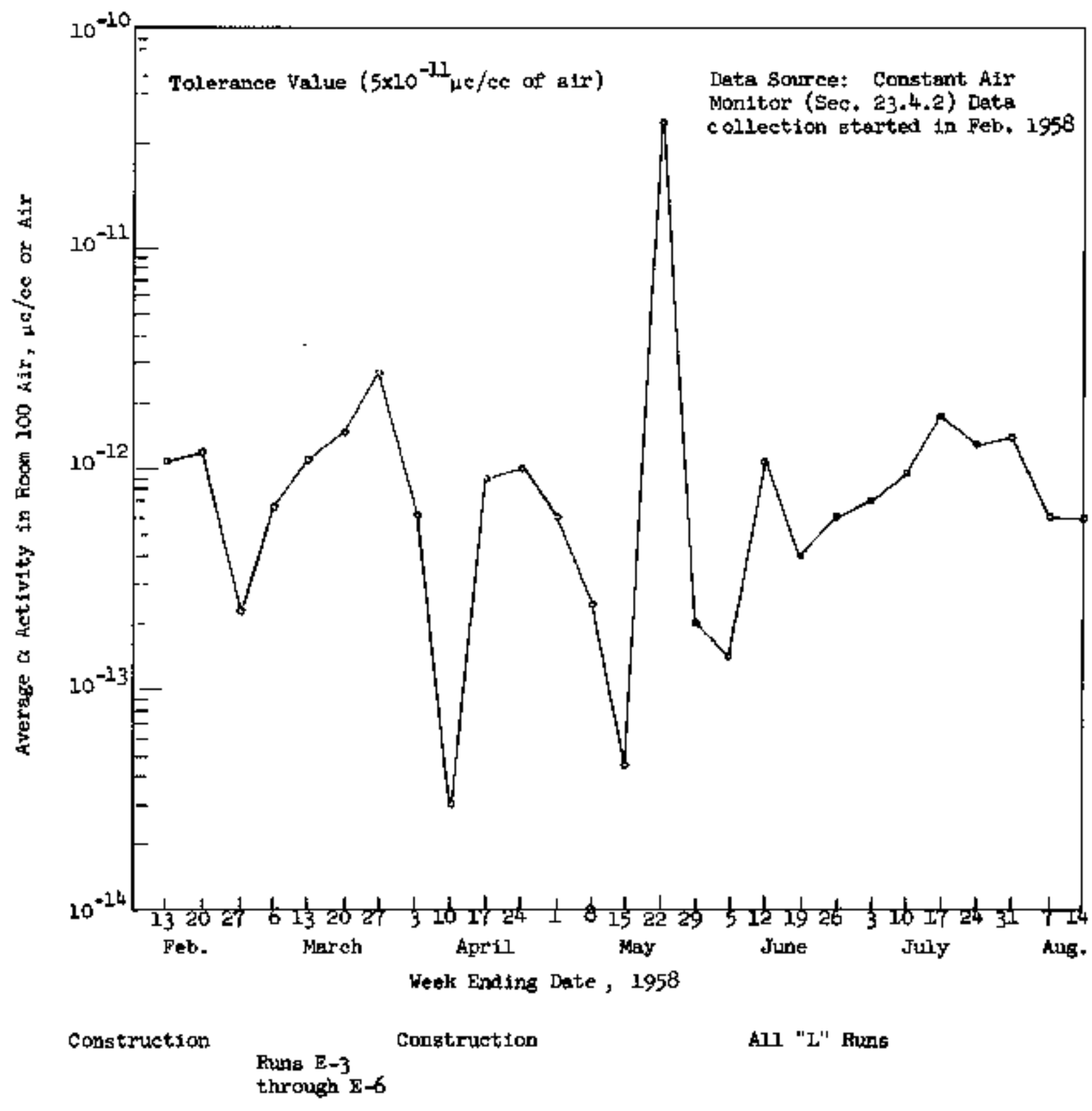

Fig. 23.2. Plot of Average $\alpha$ hetivity in Room 100 Air vs. Week Ending Dete, 1958 


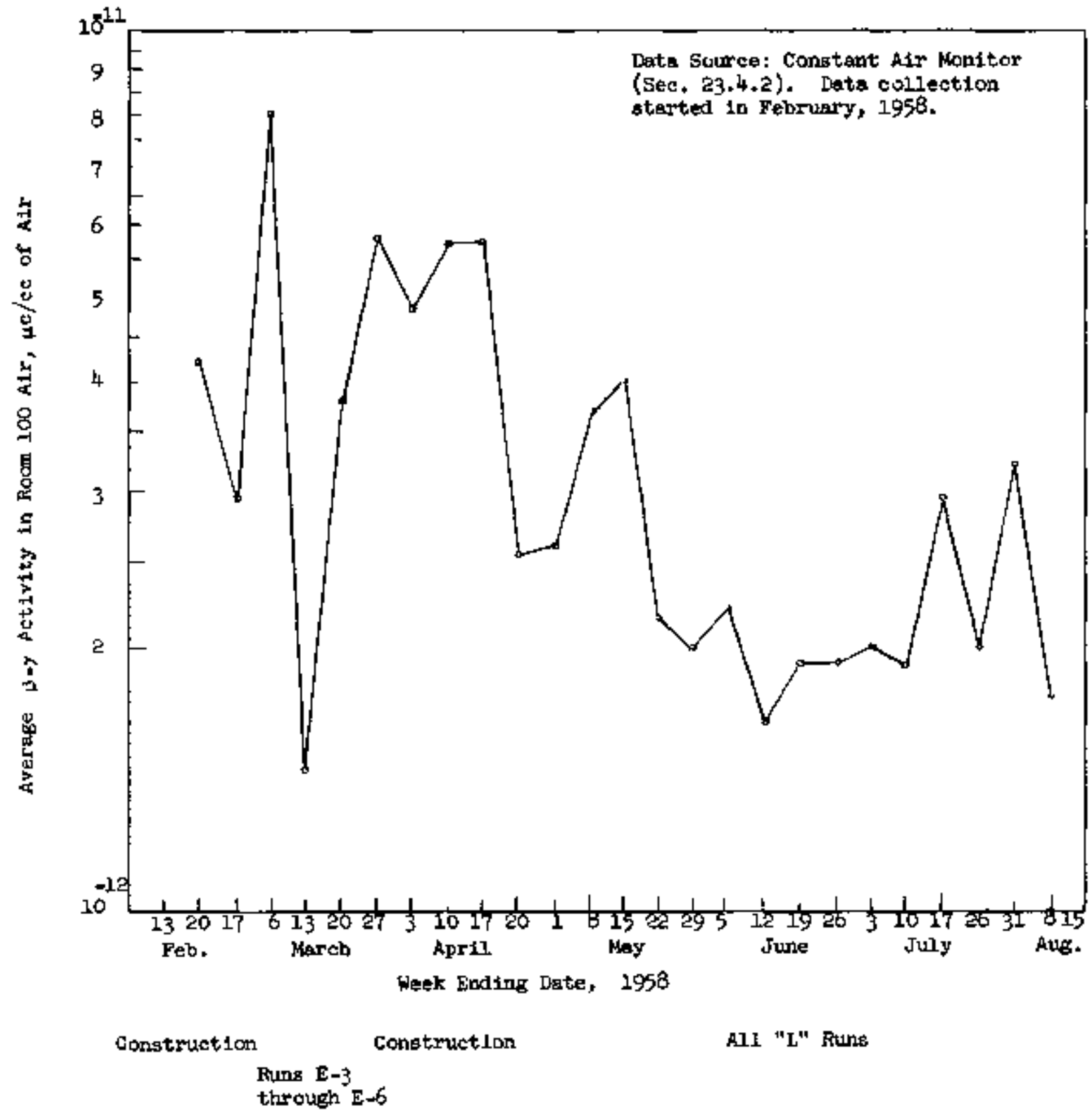

F1g. 23.3. P10t of Average B- $\gamma$ Activity in Room 100 Air vo. Week Enling Date, 1958 
Air was drawn through the filter in the instrument at a flow rate of 5 cfm. A continuous record in counts per minute of the $\beta-\gamma$ activity collected on the filter vas made. The instrument contained three activity acales:

(a) $2 \mathrm{~K}$ scale $(0-2000$ counts $/$ min $)$, (b) 10K scale $(0-10,000$ counts $/ \mathrm{min})$, and

(c) $20 \mathrm{~K}$ acele $(0-20,000$ counts/min). The $2 \mathrm{~K}$ scale was used when starting

the 1nstrument. Shifting of scales was automatic, 1.e., when the instrument indiceted full scale on the $2 K$ gcale it shifted automatically to the loK scale and when full scale on the loK scale was attalned the instrument shifted to the 2OK scale. On the $2 K$ scale, there was no flashing light or alarm. But an alarm sounded briefly when the 1nstripuent switched from the $2 x$ to the lok scele. And, while on the loK scele, a yellow light flaghed, on switching from the loK to the $20 \mathrm{~K}$ acale, an alarn sounded continuously until acknowledged. In eddition, a red light flashed while on the 2OK scale.

The Instrument tolerance varied with the calibration, the value being posted on the instrument when it was put in service. Thls value was a certain number of chart divisions (about 5 divisions or half-scale) on the $20 \mathrm{~K}$ scale. The tolerance was considered exceeded when, after bwitching to the zOK scele, the recorder pen reached the tolerance value in 30 minutes or less. Th1s signified that the B-y activity of the air being sampled was above the tolerance of $1 \times 10^{-8} \mathrm{\mu c} / \mathrm{cc}$. The filter was then removed by Fealth Physics pexsonnel and counted as follow: (a) immediately for $\alpha$ (tolerance $=5 \times 10^{-11}$ $\mu \mathrm{c} / \mathrm{cc})$, (b) after four hours for $\alpha$ and also $\mathrm{\beta}-\gamma$, and (c) after 72 hours egain for $\alpha$ and also $\beta-\gamma$. Whether this monitoring schedule was carrled the full 72 hours depended on the half life of the radiochemicals involved, i.e., the monitoring was stopped when the activities becane zero,

This instrument was useful for continuously monjtoring atr borne activities. The date in Figs. 23.2 and $23+3$ were obtalned with the constant air montior (Sec, $23,4,1$ ).

\subsubsection{Portable Disk Sampler}

The portable disk sampler wa used intermittently for monitoring air borne activities in the VPP especially during the " $\mathrm{E}$ " and " $\mathrm{L}$ " runs (Becs. 9.4.4, 12.3.2a, 12.3.2b, 16.4.16). This instrument pulled eir through a filter disk at a rate of one cfu. The sempling time was varied as desired, usually being about 30 minutes. After collection, the sample was monftore in Bullding 3019 for $\alpha$ and/or $\beta-\gamma$ activities. The $\alpha$ and $\beta=y$ data were obtained at the same time intervals and were referred to the same tolerances atated in Sec. 23.4.2. This instrument was useful for spotchecking plant areas and for confirming data obtained with the constant eir monttor or $\alpha$ aitr monitor.

\subsubsection{Alpha A1r Monitor (Linear Count Rate Meter)}

After the "E" runs, a 6em-cont1nuous $\alpha$ air monitor was used for Celis 1 and 2 . Permanent sampling lines vere run to this instrument such that either cell individually or both cells together could be monitored by proper valving. The sampling rate was $2 \mathrm{cfm}$, and the ampling period could 
be set as desired from $5 \mathrm{~min}$ to $10 \mathrm{hr}$. After a sample was taken, that sample was checked for $a$ while the succeeding sample was being collected. Alpha ectivities after 4 hours and after 72 hours and $\beta-\gamma$ date were determined as delineated in Sec. $23,4,2$.

The counting portion of the instrument had foux ranges: zero, 500 (500 counts/min), aK (2000 counts/min), and 5K (5000 counts/min). The range selecting knob was connected to a mill sammeter (0-1.0 mange) and a recorder. The milliameter hed three pointers: a red stationary pointer for eetting zero, a red stationary pointer for aetting the trouble alarm value, and a black indleatine pointer. The zero pointer was set at zero; the trouble pointer was usually aet at full scele (1.0 ma); and the black pointer indicated the machine tilliamps, a velue proportional to the count rate of the semple. On each of the three higher scale ranges (500, $2 K$ and 5K), both the milliammeter and the recorder were at fwll scale when the semple counted 500 , 2000, and 5000 counts/min, respectjuely.

The machine had both trouble end mochine faslure alarms connected. to Individual pilot lights. The ringing of either alarm was accompanied by the lighting of $1 \mathrm{ts}$ respective pilot $11 \mathrm{ght}$, making possible the lumediate determination of why the machine alarmed. In each circult, a toggle switch was provided to turn off the alarm. A common reset button enabled resetting the alarm. The trouble alarm indicated that the milliammeter reading had exceeded the setting of the trouble set-polnt. When the trouble alarm had been actuated, turned off, and reget, it was necessery for the black ind feating pointer to have been below the trouble set-point for several seconds before the trouble alarm sitich could be cut on agein without reactiating the alaris, The machine fallure alarn was actuated on machine failure and could be reset when the cause of fallure had been remedied.

Determining that tolerance had been exceeded depended on the longevity of the radiochemical species as well as the count rate value. Consequently, some time was required to make such a determination.

This Instrument was useful for continuously monttoring $\alpha$ ectivity in the cells, especially during product sampling as well as during plant disturbances (Sec. 12,3.2b). In addition, $\beta-\gamma$ data could be obtafned from the samples as destred.

\section{$23.4 .5 \quad 3-7$ Monitor}

Th1s ingtrument which was located at the Volatillty Panelboand rewotely indichted the $\beta-y$ radiation striking a senaling head at each of the seven locations indicsted in Table 23.2, Readings at lo locations were Indicated continuously. Eech individual compartment within the instrument contalned a dial, red light, and alarm. The dial had two pointers, one a set-point and the other an Indicating pointer. The set-point was placed at the acceptable railation background for that area. When the inalcating pointer exceeded this velue, the red light ceme on, and the alarm sounded. The light and alarm could be canceled by pushing a reset button. Each compartment was edjusted for a diel range of zero to one rem/hr but could have been set for other ranges. 
This instrument wes used only turing the " $L "$ runs. It enabled saving operating time and reducing personnel exposures because adequate precautionary measures could be taken prior to entering a $\beta-\gamma$ field.

23.4.6 Monitors for Personnel and Clothing

An $a$ hand monttor was located on the bench outside of the Health Physics offlce in Bullding 3019. This instrument vas useful in maintaining the acceptable hand tolerance of any detectable amount ( $\sim 250 \mathrm{cmm}$ ).

A Quintector wes provided just outbide the lunchroon in Bullding 3019 for $\beta-\gamma$ monttoring of hands, shoes, and clothing. The tolerances were: $0.3 \mathrm{mrem} / \mathrm{hr}$ for hands, $2.5 \mathrm{mrem} / \mathrm{hr}$ for shoes, and $0.75 \mathrm{mrem} / \mathrm{hr}$ for issued clothing. This instrument contained three alarms, esch of which was ectuated by an above-tolerance value in its category.

A hand and shoe counter for $\beta-\gamma$ monttoring wes located in the change room of Buslding 3019. The background and hand and shoe tolerance values were posted at the instrurent.

\subsubsection{Background $(\beta-\gamma)$ Recorder}

A continuous background $(\beta-\gamma)$ recorter was located above the bench outside of the Health Phyales offlce in Buflding 3019 (Sec. 16.4.16). This Instrument kept a continuous record of the $\beta-\gamma$ background in that vicinity and also indicated the background count rate by "pops" on its aulio system. The rate of "pops" increased with the background unt1l en alarm sounded. The alerm set-point was usually one mrem/hr.

\section{$23.4 .8 \underline{\underline{\alpha}-\hat{\beta} \text { Smaars }}$}

Smears wich were subsequently monitored for both $\alpha$ and $\rho$ contamination were taken on:

a. Surfaces in the operating areas, espectally floors and walls. These sheara helped to prevent the spread of radioactivity and to evold personnel exposure to $\alpha$ and $\beta$ activities. The protective devices mentioned in Sec. 23.4.14 also helped to accompliab these objectives. Decontamination was done as delineated in Sec. 23.4.15.

b. Piecea of equipment and samples, especialiy those to be bubsequently worked on in meonteminated areas. Decontamination practlces are diacussed in Sec. 23.4.15.

The $\alpha$ tolerance was 10 counta $/$ min $/ 100 \mathrm{aq} \mathrm{em}$ both for plant floora and for materials being moved to uncontaminated areas. Corresponding $\beta$ tolerances were 100 and 20 counts/min/100 aq.cm, respect 1 vely. Smears represented $\alpha$ and $\beta$ activitiea which could be ulped off surfaces while the total sctivities were detected as mentioned in sec. 23.4.9.

Sec. 16.4 .16 ,

becs. $9.4 .4,12.3 .2 a, 12.3 .2 b, 16.4 .16$. 
The criterion or frequency for making $\alpha-\beta$ smears was:

a. Plant floors - intermittently.

b. Penelboard area - once a week.

c. Offices - once a month.

d. Other ereas - when sugpected of containing activity.

e. Tools, samplea, and materlals - when moved to an uncontaminated place.

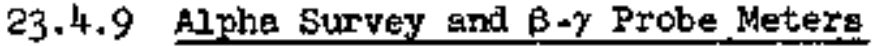

The $\alpha$ survey meter was used to detect the total $\alpha$ activity on toola, samples (Sec, 23.4.8 for sthear activities and Secs, 13.4.7, 16.4.16), clothIng, and pleces of equipment. In all cases, the a activity detected was that which could be removed by smearing plus that firmly adhering to the aurface. The tolerance was 150 counts $/ \mathrm{min} / 100 \mathrm{sq} \mathrm{cm}$. (The surface area of the meter was $100 \mathrm{sq}$ cm.) Materials survey 1 ng below tolerance could be moved to unconteminated areas, while those blove tolerence required additionel decontemination (Sec. 23.4.25) or burial (Sec. 23.4.16).

The beta-gamme probe data were taken on pieces of equipment and semples (ef. 1tem b. In Sec. 23.4.8 and Sec. 16.4.16). Subsequent decontemination practices are described in Sec. 23.4.15. The tolerance was $0.55 \mathrm{mrem} / \mathrm{hr}$. As for a surveying, materials below tolerance could be moved to uncontaminated areas. Those above tolerance required adattional decontomination (Sec. 23.4.15) or burial (Sec. 23.4.16).

\subsubsection{Cutie Fied and Monitron}

Both soft-and hard-shell cutie ples were uged es needed to detect $\beta-7$ activities (Sec. 13.4.7, 16.4.12, 16.4.16). Since these ingtruments were portable and were ased largely by operators, they were inmediately available and, consequently, the most useful $\beta-\gamma$ instruments. Cutie pie data were used to determine allowable working time such that a wan would recelve an exposure of no more than $60 \mathrm{mrem} / \mathrm{aay}, 300 \mathrm{mrem} /$ week, 3 $\mathrm{rem} / \mathrm{ar} \mathrm{yr}$, or $5 \mathrm{rem} / \mathrm{yr}$. In using the data for determining exposure, the next higher exposure rate takes precedence over the exposure for a given perlod, e.B., if an employee had already received $300 \mathrm{mrem}$ in a given veek, an additional 60 mem exposure in that week would overexpose him.

These data were obtalned from relationship, $5(n-18)=$ Total acceptable lifetime exposure in rem. 
A Monitron continuously surveyed the Thorex vessel off-gas line which runs behind the Main Transmitter Rack in the Penthouse (Sec. 16.4.16). The alarming device of this ingtrument was set at an activity of 7.5 mrem/hr.

\section{4 .11 F11m Badges}

Both picture film and special Iilm badges detected exposure to the three combinations of $\beta-\gamma$ radietions indicated in Table 23.2 The picture f1lm badge was worn continuously while in the $X-10$ area and was generally monitored quarterly by Health Physics personnel. Special film bedges were worn after February, 1958 by all operating personnel while procesaing radioactive materials in the " $E$ " and " $L "$ runs (Sec. 16.4 16). These badges were usually checked weekly by Heelth Physica personnel. The average veekly exposure data so obtained are plotted in Fig. 23.1 (Sec, 23.4.1). The tolerances observed are given in Sec. 23,4,10.

\subsubsection{Dose Meters}

Pencil meters were worn by all operating personnel while processing radioective materials (Sec, 16,4,16). These meters provided daily monitorIng of B- $\gamma$ radiation. The date were obtained and recorded by Hedith Physics personnel. At times, indicating dosimeters were also vaed to obtain immediate checks on personnel exposure to $\beta-\gamma$ radiation. Although these meters were zeroed by Health Physies personnel, the date were generally used only by operating persomnel and were valuable in limiting radiation exposure.

$23.4+13$ trine and Fecal Samples

Urine and fecal, samples were collected for these purposes and at these intervals:

a. Drine.

Purpose - To detect the presence of the bulk of ingested and inhaled radiochemicals such as $\mathrm{t}$ and $\mathrm{Sr}$.

Sampling Criterion and/or Frequency - Any time exposure occurred and also, if in full operetion, at least every two months.

b. Fecal.

$\frac{\text { Purpose }}{\text { and } \mathrm{Pa} \text {. To detect the pregence of Ingested and inhaled Th }}$ Sampling Criterion - Any time exposure occurred.

Gore frequent checking wes done where deemed necessary.

$b_{\text {Sec. } 16.4 .16 .}$ 
For both urine and fecal samples of VPP operating personnel, indications of radiochemieals were sowetines found. There were, however, never enough associated exposured to increase signiflcantiy the film badge exposures.

\subsubsection{Protective Devices}

Asseutt masks, protective clothing (including coveralls, safety shoes, caps, and gloves), and shoe covers were worn in contamination zones. Assault mask protected against air-borne activities and yere always worn when the air contained $>5 \times 10^{-11} \mu \mathrm{c} / \mathrm{cc}$ of $\alpha$ or $>1 \times 10^{-8} \mu \mathrm{c} / \mathrm{ec}$ of $\beta-\gamma^{b}$ Frotective clothing and shoe covers were always vorn along with the assault mssks. In addition, protective clotbing and shoe covers were worn when floors and surfaces in the area smeared higher than the $\alpha$ and $\beta$ tolerances (Sec. 23.4.8). For above-tolerance arees, shoe cover stations were provided to prevent spreading contamination. During operations, shoe cover stations were usually neceasary at each cell, in the Penthouse, and in the Pipe Tunnel.

For $\beta-\gamma$ radiation, both shielding and limited exposure time were used to control personnel exposure. Unit shield was either provided in the original design (e.g., the waste stetion) or lear bricks were stacked as required. The indicating dosineter was especially useful in limiting personnel exposure.

\subsubsection{Deconteminationc}

a. Surfaces not in contact with Molten Salt

Floors were washed as described in Table 23.3. Walls and externel surfeces of equipment were decontamingted simllarly (cf. Sec. 23.4 .8 for tolerances).

Seventeen HCV's were decontaminated and returned to the Instrument Division for subsequent distribution and credit to the VPP account (Sec. 17.4.2g). The five decontaminat1on treetaents elong with $\alpha-\beta$ smear data are 11sted in Table 23.4. Three $\alpha-\beta$ smears were made on each velve: (a) on body and on nipple ends, (b) on ster and underneath the valve operator, and (c) on top of the operator.

Minfampler semple tubes were decontaminated per Sec. $12.3 .1 b$.

aecs. 9.4.4, 12.3.2a, 12.3.2b, and 16.4.16.

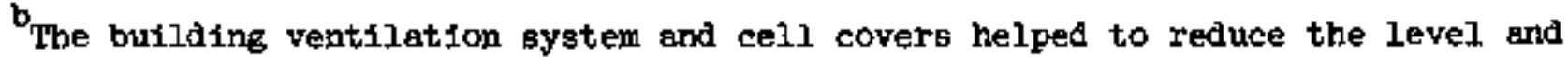
spreading of air-borme activity.

Sec. 16.4 .16 (6르).

The treatments ara also recorded in Table 23.3 . 
Table 23.4

DECORTAMINATION OF 17 HCV'S

HOIS: In1tial activities were not determined; B-y probe data were obtained only after the fifth decontamination. Alpha and beta smear tolerances were: $<10$ and $<20$ counts/min, respectively.

\section{a. First Decontamination and Survey}

Treatment - Bristle brushed with a varm aqueous solution of Tide and Bab-0. (2 cupfuls of Tide per 30 gel; Bab -0 sprinkled on each valve while brushing).

Q- $\beta$ Strear Data - All three amears on flve valves were below the $\alpha$ tolerance, ${ }^{a}$ Alphe smears on the other twelve valves averaged: (a) 290, (b) 18 , and (c) 36 counts/min. Suear date were essentially below B tolerance,

b. Second Decontamination and Survey

Treatment - Same as for the first decontamination.

$q-B$ Smear Date - More than half of the $\alpha$ date for the 12 contaminated valves in 1tem $a$, were belfow tolerance. Smear data were essentially below B tolerance.

c. Thyrd Decontamination and Survey

Treatment - Same as for the firat decontamination with about 5 Ib $\left(\mathrm{NH}_{4}\right)_{2} \mathrm{C}_{2} \mathrm{O}_{4}$ added per 30 gal of solution.

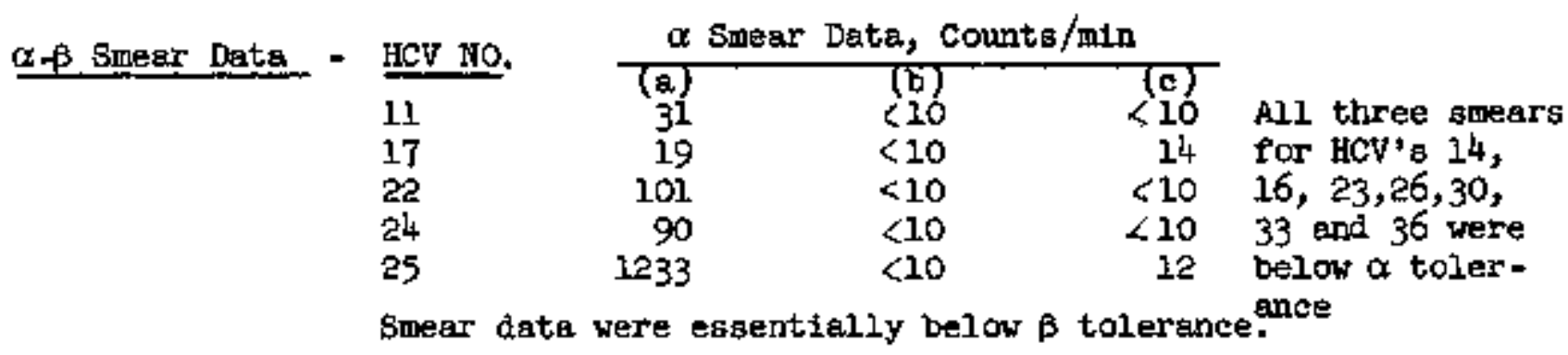

\footnotetext{
${ }^{8}$ The only further work on these valves were $\beta-\gamma$ probe tests whtch were approxtmately background, $1 . e,<0.25$ mrem $/ \mathrm{hr}$.

beanings of "a", "b," and " $\mathrm{c}$ " are given In Sec. 23.4.15a.

simear data on individual val ves were not arailable.
} 


$$
-378-
$$

Table 23.4 (continued)

d. Fourth Decontamination and Survey

Treatment - Same as for the third decontamination.

\section{$\underline{\alpha+\text { Smear Data }}-$ HCV No.}

11

25

\begin{tabular}{lll}
\multicolumn{4}{c}{$\alpha$ Smear Data, Counts $/$ min } \\
(a) & (b) & (c) \\
20 & $<10$ & $<10$ \\
35 & $<10$ & 410
\end{tabular}

All three smears for HCV's 17,22 , and 24 were below $\alpha$ tolerance.

Smear data were all below $\beta$ tolerance.

e. Fifth Decontamination and Survey

Treatment - Same as in the first decontamination.

$\alpha-\beta$ Smear Data - HCV No.

$\begin{array}{ccc}\alpha \text { Smear Dats, Counts } / \text { min } \\ \text { (a) } & \text { (b) } & \text { (c) } \\ 12 & <10 & <10\end{array}$

All three smears for HCV 11 were below $\alpha$ tolerance.

All valves probed background, i.e., <0.25 mrem $/ \mathrm{hr}$. 
b. Sraill Metallic Surfaces Contacted by Molten Salt (Corrosion Specimens)

Procedures for Inconel pipe, nickel pipe, and nickel plate are recorded in Table 23.3 .

Date for deconteminating corrosion specimens using these procedures were:

1. Inconel pipe speclmens required four procedures to dicontaminate to no a activity, 3 countg $/ \mathrm{min}$ of $\beta$, and $<0.25$ mrem $/ \mathrm{hr}$ probe reading (background).

2. A nickel pipe corrosion specimen (1/2" NPS, Schedule 40) required four procedures to decontaminate as follow: $\alpha=$ none, $\beta$ - none, and probe - <0.25 mrem $/ \mathrm{hr}$ (background).

3. Two nickel plate specinens ${ }^{c}$ required one procedure to decontaminate from 24 and 60 counts/min $\beta$ activity, respectively, and 0.5 and $14 \mathrm{mrem} / \mathrm{hr}$ probe reading, respectively, to no $B$ activity on either and 0.5 and $14 \mathrm{mrem} / \mathrm{hr}$ probe reading, respectively. Then, one procedure for nickel pipe produced no improvement in the probe reailing. Finally, treating the $14 \mathrm{mrem} / \mathrm{hr}$ epecimen with Turco 10.4501 at $100^{\circ} \mathrm{C}$ for $1-1 / 2$ hr reduced the probe reading to $10 \mathrm{mrem} / \mathrm{hr}$.

\section{c. Yessels}

Aqueous decontamination data are available only for the decontamination of FV -100 after Run $\mathrm{L}-4$. As mentioned in Sec. 5.4.1c, the bulk of the solidifled salt was removed by jack-hammering and chipping. Then the following work was done:

These specimens were seven 2-in. pieces of 3/8-in. NPS, Schedule 40 from the Merk II waste line. Activity data prior to decontaminating were not obtained. After two of the four procedures, activity data vere: 3 counts/min of $\alpha, 30$ counts/min of $\mathrm{B}$, and $<0.25 \mathrm{mrem} / \mathrm{hr}$ probe reading (background). See Sec. 13.4 .2 for corrosion results.

This spectuen was ebout a 3-in. section of the $F_{\text {a }}$ inlet line near the draft tube frow the Mark IIA fluorinator. Activity data werê not obtained prior to decomtamination.

These specimens came from the Mark IIB fluorlnator wal, $(3 / 8$-in. nickel plate originaliy). There was no inftial $\alpha$ activity.

Treatments are also recorded in Table 23.3 . 
1. Cutie pie survey of internel surfaces.

Point 1 (just below upper flange) - 1.5 rem $/ \mathrm{hr}$.

Point 2 (level of waste line exit) - $6 \mathrm{rem} / \mathrm{hr}$.

Point 3 (level of charge salt line entry) $-6.5 \mathrm{rem} / \mathrm{hr}$.

2, First decontamination and survey.

Air eparged an aqueous solution of $0.4 \mathrm{M}\left(\mathrm{NH}_{4}\right)_{2} \mathrm{C}_{2} \mathrm{O}_{4}$ for 6 hours in the vessel keeping the solution at tempreture of $\sim 100^{\circ} \mathrm{C}$ wth $\mathrm{FV}-500$ and a level of 27 inches by adding make-up water. After draining the solution and rinsing the vessel, the cutie pie survey was:

Point $2=0.9 \mathrm{rem} / \mathrm{hr}$.

Point 2 - $1 \mathrm{rem} / \mathrm{hr}$.

Polnt $3-1.5 \mathrm{rem} / \mathrm{hr}$.

3. Second decontamination and survey.

The some decontamination procedure deacribed in item $b$. was used after which the cutle ple survey was:

Point 1 - $20 \mathrm{mrem} / \mathrm{hr}$.

Point 2 - $40 \mathrm{mrem} / \mathrm{hr}$.

Point 3 - $40 \mathrm{mrem} / \mathrm{hr}$.

4. Third decontemination and survey.

Air eparged an aqueous solution $0.7 \mathrm{M} \mathrm{K} \mathrm{O}_{2}, 1.8 \mathrm{M} \mathrm{KOH}$, and $0.4 \mathrm{M} \mathrm{Na}_{2} \mathrm{C}_{4} \mathrm{H}_{4} \mathrm{O}_{6}$ at room temperature keeping ${ }^{2}$ the liquĩa level at 27 inchea. After draining and rinsing, the cutie pie survey was:

Point 1 - $40 \mathrm{mren} / \mathrm{hr}$.

Point 2 - $30 \mathrm{mrem} / \mathrm{hr}$.

Point 3 - $30 \mathrm{mrem} / \mathrm{hr}$.

Bottor of vessel - $80 \mathrm{nrem} / \mathrm{hr}$.

Some loosely adhering material still clung to the vessel wall, and some material vas still adhered tightly to the bottom.

\subsubsection{Waste Disposal Practices}

A. Waste Conteiners

Details of buriel ground preparation and can burial are given in Teble 23.3. The linit on the number of cans per hole was such that three to four feet of concrete was between the neck of the can top and the ground level.

The higheat activity of the waste containers for the " $E$ " and " $I$ " runs was $\sim 10 \mathrm{rem} / \mathrm{hr}$ as determined wlth a hard-shell cutle ple on contact with the contalner wall. 
Personnel exposure while burying waste containers was monitored by Health Physics gersonnel.

b. Plant Equipment

Discerded plant equipnent such as the two fluorinators, the AFE hold tenk, molten salt lines, and miscellaneous piping end tubing have been stored sove ground in Burial Ground Ho. 3. The maximum activity of this equipment was $2500 \mathrm{mrem} / \mathrm{hr}$ at the time of storage.

\subsection{Summary and Conclusions}

Enriahed uranium as UF 6 was the most serious hezerd in the VPP because, being handied largely in the gaseous state, it was difficult to contain. The fisaion producta, although at times producing activitieg up to $10 \mathrm{rem} / \mathrm{hr}$, were less hazerous because of better containmert and shielding.

The critical incident was potentially the most sertous congequence of VPP operations. Procedures used to evoid a criticel incident were listed in the previous sections.

A list of radioactively hazerdoug vPp operations is given. The worst consequence reswting from any VPP operations was alraborne $\alpha$ because of the low air tolerance and the difficulty of aubsequent decontemination. Although work could be done in an area having an air-borne $\alpha$ activity above tolerance by wearing assault masks, the work times for various operations were lengthened considerably. Solne reduction in the hazaris of some operations wes realized through better design and lmproved operating techniques, but little reduction occurred for: (a) the salt spatter at the waste station, (b) the release of $\mathrm{UF}_{6}$ during product sampling, and (c) the spreading of dust while unloeding FV-1 $b_{3}$.

Plots are glven showlng that the average weekly $\beta-\gamma$ personnel exposure and both the air-borme $\alpha$ and $\beta-\gamma$ in Room 100 were below eatablished A.E.C. tolerances for Runs E-3 through $\mathrm{E}-6$ and also for the " $L$ " runs.

Information pertinent to VPP personnel is given for all of the instruments and means used to detect radioactlve hazarda. These include: constant air monttor, portable disk sampler, $\alpha$ air monitor, $\beta-\gamma$ monitor, $\alpha$ hand monitor, quintector, hand and shoe counter, background recorder, $\alpha-\beta$ amears, $\alpha$ survey end $\beta-\gamma$ probe meters, cutie pies, Monitron, film bedges, doae meters, and urine and fecal samples. These instruments and nonitoring procedures were the responsibility of Health Physics Division personnel. Data obtalned vere evelueted largely by Health Physics Division personnel.

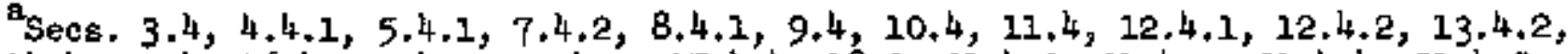
$14.4,15.4,16.4,17.4 .1,17.4 .3,27.4 .4,18.2,21.4 .2,21.4 .3,21.4 .4,21.4 .5$, and 22.2 . 
Protect1ve devices and practices are also discussed.

The decontamination procedures used are given for: (a) surfaces not in contact with molten salt, (b) metelilic surfaces contected by molten selt, and (c) vessela. Activity data indicated that the procedure for decontaninating floors and walls was sat1sfactory; that thoee for HCY's and metellic surfaces contacted by molten salt were too slow; and that the procedure for Fv-100 was falrly bat1afactory. The need for more work on decontamination is evident.

Waste disposal proctices were reconded in the final part of the section.

\subsection{Recomendations}

It is recommended that all past practices in rediation exposure and control delineated herein be continued in the future and that:

a. Effort be expended to eliminate the salt spatter at the waste station.

b. $\mathrm{UF}_{6} \mathrm{sempling}$ be done by the $\mathrm{K}-25$ method and preferably elsewhere than in Celi 2 to arold the posstble personnel exposure to $\alpha$ activity and also the contamination of cell 2 equiprent.

c. A better means of emptying FV-103 be devised.

d. Better deconteminating procedures for metalltc surfeces not contacted by molten salt and for Inconel and nickel pipe, nickel plate, and vessels contacted by molten salt be devised.

e. Waste disposal practices be reviewed to confirm their adequacy.

f. Two new radiation algrming dose meters, one for dose rate and the other for total dose, be tried in VPP.

g. Any new pleces of equipment be evaluated as criticality hazards. 


$$
-383-
$$

\subsection{ACKNOWLELXELENT}

For a report of this nature, the authors' desire to acknowledge the contribution of others must be tempered by the fact that a complete listing would be prohibitively long. The mejor contributors are 1isted in ORLL-2918 $(6, p .38)$, and the authors wish to acknowledge the contributions of all those listed in ORNL-2918. In addition, speciel thanks are due to J. C. Breser, F. N. Browder, J. E. Gibaon, Jr., R, B. Lindauer, R. B. Waters, C. L. Whitmarsh, and $A$. $V$. Wilder for Invaluable assistance in the preparation of the report. 


\subsection{FEFEREACES}

1. R. P. Milford, "Industrial and Mngineering Chemiatry," Vol. 50, No. 2, Pp. 187-191, February 1958, Same as "Engtneering Design Feetures of the ORNL Fluoride Volatility Pilot Plant," ORNL-CF-57-4-18.

2. G. I. Cathers, M. R. Bennett, R. L. Jolley, "The Fued salt-Fluoride Volatility Process for Recovering Urantum," ORNL-2661, Apri1 1, 1959.

3. A. M. Weinberg, et,al., "Nuclear Science and Engineering," vol. 2, pp. 797-853, (Supplement to November Issue). Seme as "Molten Fluoride Reactors," ORNL $=C F-57-6-69$.

4. G. I. Cethers et al., "Recovery of Uranilm from Highty Irradiated Reactor Fuel by a Fused-Salt Fluoride-Volatility Process," Proceedings of the Second United Fations International Conference on the Peaceful. Jaes of Atomic Energy, Vol. 17, Geneva: United Hationa, 1958. PP. 473-479.

5. W. H Cerr, "Wolatility Procesalng of the ARg Fued," Chemical Ingineerting Progreee Bymposius Series, Vol. 56, Book No. 28, Huclear Bngineering, Part 8, (1960). Similar to ORIL-CP $-58-12-60$.

6. C. I. Whitmarsh and W. H. Carr, "Fused salt Fuel Processing in the ORNL Volatility Pilot Plent," OFHL-2918, May 6, 1960.

7. A. P. Iftman and A. E. Goldman, "Corrosion Affilisted uith Fluorination of Fused Salt Fuels and Associated Operations in the ORNL Fluoride Volatility Process," OANL-2832, March, 1960.

8. R. P. Milford, "Volatility Pilot Plant - Homenclature Standarda for Equipment, Piping, and Instrumentstion on Engineering Flowsheets and P1ping Drawings," ORNL-CF-55-5-31, May 4, 1955.

9. M. C. Hill end H, C. Thompaon, "VPP Equipnent Code Iist," (Unpublished). (A copy is in Volatility Pilot Plant Engineering F1le Folder No. F-69.)

10. R. A. Cross and C. L, Whitmarsh, "Plutonium Behavior in the Finoride Volatility Process," ORLL-CF-59-9-5, Sept. 3, 1959.

11. C. J. Barton, "Fused Salt Compositions," ORNL-CF-57-6-81, June 20, 1957.

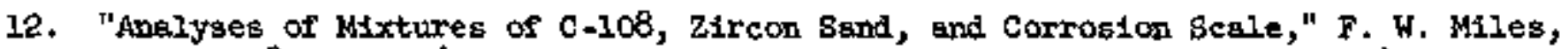
April 8, 1957. (A copy ia in VPP Engineering File Folder Ho. F-25.)

13. "Volatility Pllot Plant Instrument Specfficetion Sheets and Indices," compiled by Instrument Division Personnel.

14. R. W, Wolfe and R. O. Begley, Jr, "Volatility Sampling Problems," MIT Practice School File No. EPS-X-278, Nov, 12, 1956. (A copy is in VPP Fngineering File Folder No. F-2l.) 
15. C. L. Whitmarsh, "Reliability of the Salt Sampling Procedure in VPP," ORRL-CF-59-1-131, Jap. 30, 1959.

16. J. B. Ruch and S. H. Stainker, "VPF - Fluorinatior Degign, Effect of a Conical Bottom on Solide Circulation Rate," OFAL-CF-59-5-15, May 7, 1959.

17. J. W. Arendt, E. W. Powell, and H. W. Saylor, "A Brlef Guide to UF Gandling," K-1323, Feb. 18, 1957.

18. J. B. Fuch, "Voletility: Fluorinator Design FV-100 zr-U Fuel Element Processing Phase," ORAL-CF-59-5-89, May 28, 1959.

19. F. W. Fink (Battelle Memorial Inst.) to R. P. Milford, letter dated oct. 7, 1959 relative to a corrosion study made on sub-contract Fo. 988.

20. A. Goldman, "M-32, Inspection of the Volatility Pilot Plant Fluorinator, wark II, FV-100," ORHL-CF-58-9-94, Sept. 18, 1958.

21. C. L. Whitmarsh, "Uranium Recovery from Sodilam-Z1rconium Fluoride Salt Mixtures, Volatility Pil ot Plant Runs $I_{-1}$ Through L-9," ORNL-CF-59-9-2, Sept. 30, 1959.

22. C. L. Whitmarsh, "Reprocessing of ARE Fuel, Volatility Pilot Plant Runs E-1 and E-2," ORLL-CF-59-5-108, May 11, 1959.

23. C. L. Whitmarsh, "Reprocessing of ARE Fuel, Volatility Pllot Plent Fums E-3 Through E-6," ORHL-CF-59-8-73, Aug. 26, 1959.

24. "Short-Time Evaluation Test on Marinite Butt-Joint," F. W. M1les, Jen, 21, 1957. (A copy is in VPP Englneering File Folder No. F-61.)

25. C. L. Wh1tararsh, "Volat1lity P1lot Plant Run C-4," OFWL-CF-57-10-123, oct. $18,1957$.

26. "Inspection and Malntenance of Equipment in the Volatility Pilot Flant," W. J. Lee to $W$. H. Carr, March 29, 1960. (A copy is in VPP Engineering F1ld Folder $10, F-61$, )

27. C. L. Wh1tmarsh, "Voletility P1lot Plant Run C-3," ORIL-CF-5T-8-95, Aug. 15, 1957 .

28. G. I. Cathers, M. R. Bennett, and R. I. Jolley, "A Urantim Hexafluoride Volatility Process for Fused Salts," OFiL-CF-56-9-21 (BECRET), sept. 4, 1956.

29. C. I. Whitmarsh, "A Serles of Seven Flowshet Studies with Honradive Salt, Volatility Pilot Plant Runs C-9 through C-15," OFNL-CF-58-5-113, May 12, 1958.

30. "Substitution of $\mathrm{NaHF}_{2}$ for $\mathrm{HaF}, " \mathrm{~W}$. H. Cerr, late 1956.

31. C. L. Whitmersh, "Ylowsheet Demonstrations, Volat1lity Pilot Plant Runs C-6, $\mathrm{C}-7$, and $\mathrm{C}-8$," QRIL-CF-58-1-109, Jen. 6, 1958. 
32. R. A. Cross and C. L. Whitmarsh, "Uranium Recovery from Sodium Fluoride Beds in the Volatility Pilot Plant," ORNL-CF-59-8-98, Aug. 7, 1959.

33. "Volatility F1lot Plant Operating Log No. 6," p. 116.

34. "Installetion and Operating Instructiong for Tenmey Model Kolpak (Serial Nos. 2347 and 2348)," Tenrey Enstneering Inc. (A copy is in VPP Engineering File No. F-54.)

35. "The Second Performance Study of the Cold Trap System (Rum M-7)," R. B. Keely to W. H. Carr, Jan. 11, 1957. (A copy is in VPP Engineering File Folder No. $F-54$. )

36. C. I. Whitmarkh, "Yolatility Pilot Plant fun C-5," ORNL-CF-57-31-85, Nov. $18,1957$.

37. E. J. Barber and H. A. Bernhardt, "Passivation of Metale to Fluorine," K-1421 (Confidential), April 9, 1959.

38. Chemfeal Technology Division, "Unit Operations Section, Moptbly Progress Report," ORNL-CF-56-12-128, Sec. 8.2, Dec., 1956, pp. 50-56.

39. A. Seidell and W. F. Linke, Solubilities of Inorganic and Organic Compounda (Supplement to the 3rd, ed.; New York: D. Van Hostrand Co., Inc, 1952). pp. $292-294$.

40. L. R. Trotter and E. E, Foffman, "Progress Report on Volatility Pilot Plant Corrosion Problems to Aprid 2l, 1957," ORNL-2495, Sept. 30, 1958, pp. 29-35.

41. "Memo \#38: Inspection of Volatility Pilot Plent Process Vesse1s," A. P. Litmen, ORWE Metellurgy Division, to W. H. Carr, Nov. 18, 1958.

42. J. B. Ruch, "Volat1lity Pilot Plant - Waste-Balt Transfer Studies," ORNL-CF-58-5-62, May 21, 1958 .

43. M. H. Cooper, ANP Quar, Prog, Rept., ORNL-2274, March 31, 1957, pp. 60-61.

44. "Gases for Volatility Pilot Plant," W. H. Carr to C. D. Greenway, ORML Materials Department, May 29, 1956. (A copy is in VPP Engineering File Folder No, F-52, )

45. "M-29, Recommended Uaea for Silver Brazing Alloys," A, Goldmen, ORNL Metallurgy Division, to F. I. Brouder, Aus. 29, 1958.

46. "F Safety," D. W. Leigh to W. H. Carr, July 16, 1957. (A copy is in VPP Engineering File Folder No. F-53.)

47. "Fluorine Leak at Building 3019 on June 26, 1957," W. H. Carr to R. B. Lindauer, June 26, 1957. (A copy is in VPP Englneering File Folder No. F-53.) 
48. J. S. Watson, "VFP - Design of NaF Packed Tower for Removal of HF from Fluorine, "ORML-CF-57-3-43, Narch 7, 1957.

49. R. P. Milford, "Volatility Pilot Plant - Valve and Piplng Specifications," ORHI-CF-55-12-99, Dec. 12, 1955.

50. "Memo \#37 - Fajlure of Volat1lity P1lot Purge Line (PE-34) Valve F1ttings," A. P. Litman and C. Hays, ORNL Metallurgy Division, to R. B. Lindauer, Nov. $12,1958$.

51. W. D. Manly (ORHL and Staff), "Oak Ridge National Laboratory Reactor Material Specifications,"TID-7017, Oct. 28, 2958.

52. R. P. Milford, "Englneering Constderations on Volatility Bquipment," (Unpublished). (A copy is in VPP Englneerting File Folder No. F-69.)

53. Bervey B. Elkins, The Chemistry of Industrial Toxicology, 2nd. Ed., John W1ley and Sons, Inc., New York, 1959, $\bar{P}, 134$.

54. c, L. Whitmersh, "Equipuent Checkout Prior to ARE Procesaing, Volat1l1ty Pilot Plant Run B-1," ORWL-CF-58-5-112, May 29, 1958.

55. Wolatility Pilot Plant, Work Order A-5011, Repair of HC Valves," R. P. Milford to L. H. Chase, OFWh Instrument Diviakon, Ju2y 3, 1956. (A copy is in VPP Engineering File Folder No. F-ll.)

56. J. T. Long, "Engineering Developments in Fluoride Volatility, "Indugtrial and Engineering Chemistry, Vol. 51, Feb. 1959, pp. 169-173.

57. J. T. Long, "Unit Operations Montbly Progress Report for February, March 1956 (ANP), " ORNL,CF-56-3-116 (CONFIDEMTIAL), March 23, 1956, pp. 2-5.

58. "M-22, Volat1lity P1lot Plant Waste Salt Line," A. Goldman, ORNL Metallurgy Division, to F. W. Miles, May 13, 1958.

59. R. W. Bergstrom and W. A. Chittenden, "Reactor-Contalnment Engineertng --. Our Expertence to Date," Nucleonics, Vol. 17, Apr11, 1959, pp. 86-93.

60. "Bulletin No.T-13," International N1ckel Co., Jan. 1958.

61. "Electrical Reslstivity of N1ckel, Inconel, and Inor-8, " A. P. Litman, ORWL Metallurgy DLvision, to F. W. Miles, Oct. 23, 1959. (A copy is In VPP Engineering File Folder Ho. F-69.)

62. R. L. Jolley, R. D. Baybarz, D. O. Campbell, and G. I. Cathers, "Equ1pment Decontamination Methods for the Fused Galt - Fluorlde Volat1lity Process," ORWL-2550, Aug. 19, 1958. 


\section{DISTREATION}

1. D. E. Arthur

2. R. E. Blaneo

3. J. C. Bresee

4. R, E. Brooksbank

5. F. W. Browder

6. K. B. Brown

7. W. D. Bureh

8. W. A. Bush

9. W. H. Carr

10. G. I. Cathers

11. F. L. Guller

12. E. R. Dobyns

13. W. K. Eister

14. D. B. Ferguson

15. A. P, Freas

I6. H. E. Goellex

17. A. T. Gresky

18. W. J. Greter

19. C. E. Guthrle

20. R. W. Horton

21. H. H. Lewis

22. B. Lieberman

23. R. B. Lindauer

24. J. T. Iong

25. A. $P$. Litman

26. H. G. MacPherson

27. J. L. Matherne

28. S. Mann

29. F. W. Miles

30. R. P. MfIford

31. E. C. Moncrlef

32. R. O. Nicol

33. J. R. Parrott

34. J. B. Fuch

35. M. J. Skinner

36. M. E. Whatley

37. C. L. Whitmarsh

38. E. L. Youngblood

39.50. Laboratory Records

కI. ORHL-RC

52-53. Central Research Library

54. Document Reference Section

\section{BXTERHAL DISTRIBUTION}

55. J. E. Bigelow, AEC, Operattons Analys1s Division

56. F. W. Fink, Battelle Memorial Institute

5月. S. Lewrosk1, Argonne Hational Laboratory

58-72, TISE, ABC 